


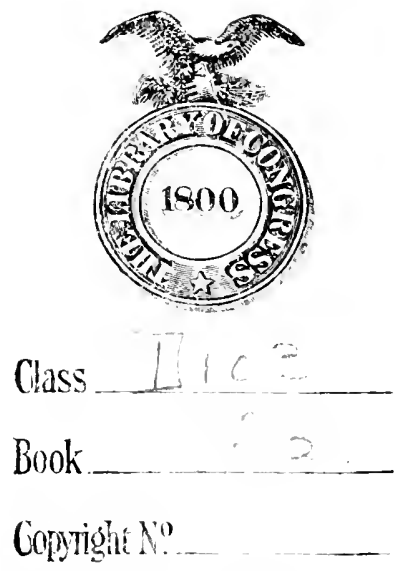

CORYHGHT DEPOST. 
I 



\section{,}






\section{EUROPEAN HISTORY}

AN OUTLINE OF ITS DEVELOPMENT 


\section{The $>$ X}





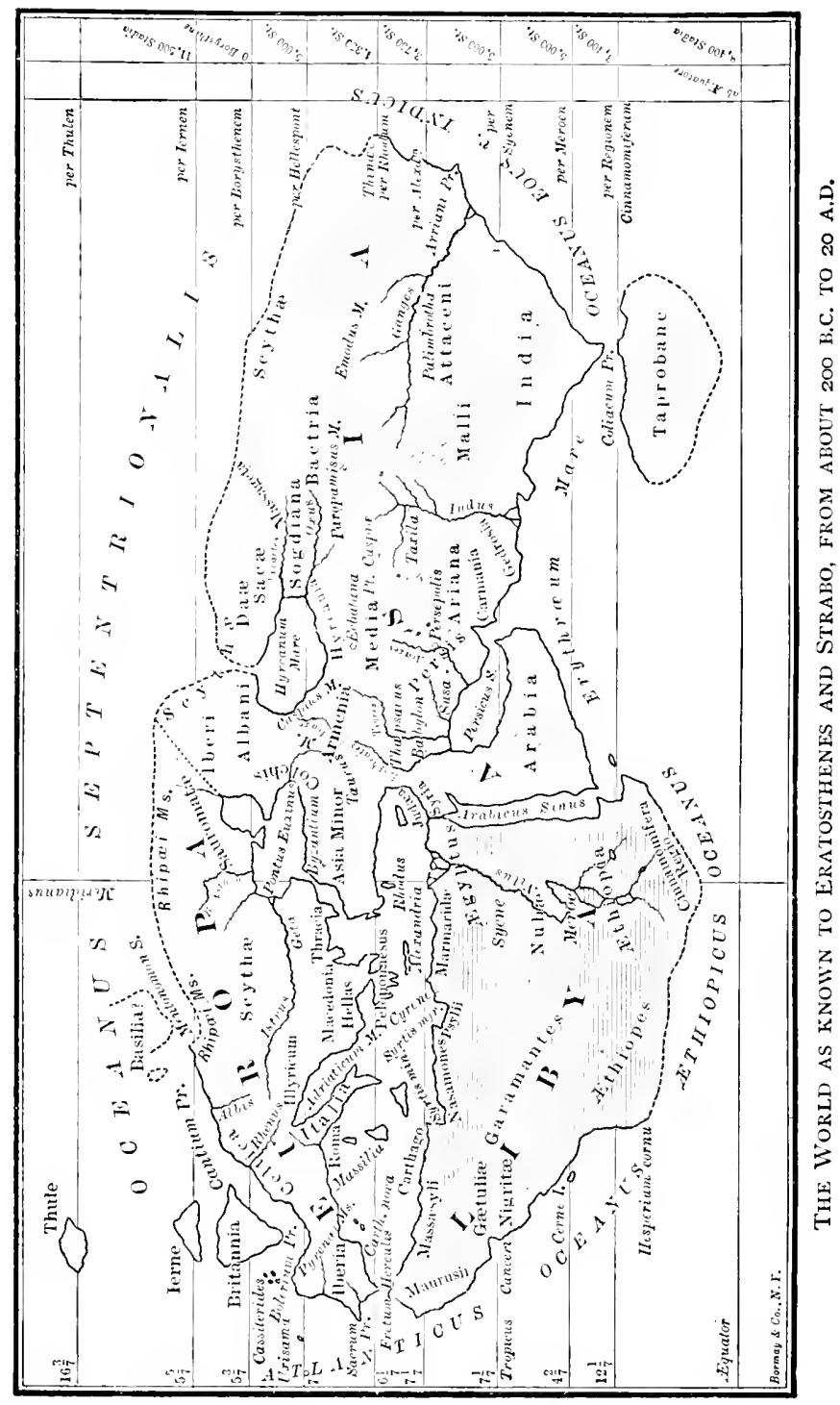




\title{
EUROPEAN HISTORY
}

\author{
AN OUTLINE OF ITS \\ DEVELOPMENT
}

BY

GEORGE BURTON ADAMS

PROFESSUR OF HISTORY IN YALE UNIVERSITY

WITH MAPS AND ILLESTRATIONS

Dิew 19ork

THE MACMILLAN COMPANY

LONDON : MACMILLAN \& CO., LTD.

I 899

All rights reserzed 
Copyright, I899,

By THE MACMILLAN COMPANY.
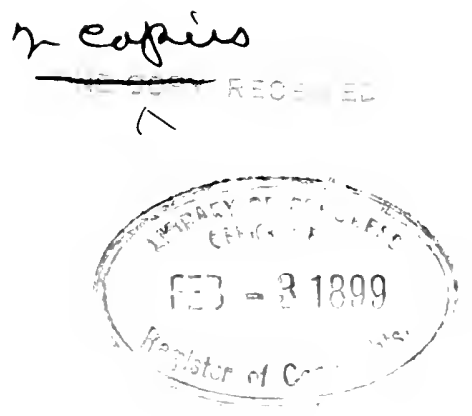

wormwood $3 \exists r e s s$

J. S. Cushing \& Co. - Berwick \& Smith Norwoud Mass. U.S. A.

0309 


\section{PREFACE}

IT is my hope that this book, while it may be used in any way, will be found of especial value by the teacher who has escaped from the bondage of set text-book recitations, as fortunately most teachers of history have now done.

In the preparation of the bibliographies and references I have had in mind both the needs of the teacher and of the pupil. Nothing adds so much to the interest of work in history as a more extensive knowledge of the subject on the teacher's part than the text-book gives, and an ability to fill it out and throw light upon it from various sources. The bibliographies give the names of many books not specifically referred to elsewhere. These are especially for the use of the teacher, and the intention has been to mention in each case the two or three best books. In the construction of the text also, while it has been my purpose to state as clearly as possible all the important facts, I have endeavored to make a text which would readily serve as the foundation for considerable expansion by both teacher and pupils. It will be noticed, possibly, that the stock historical anecdotes are lacking. These, if used at all, will have much more force and point coming from the teacher than if they stand in the text to be read and reread and repeated to the weariness of the bright pupil.

The specific references, while they may be of use to the teacher himself, are especially intended to be used with due judgment in the assignment of outside reading to the pupil and as the basis of reports to the class. At the close of each 
chapter two or three topics of especially assigned readings are given, but these are intended to serve as specimens rather than to furnish a complete list. The teacher can construct as many others as desired on the basis of the marginal topics and references. In the selection of the books, to which the specific references are made, I have been governed by the readiness with which the books can be procured. If a list of all those to which most frequent reference is made were drawn up, it would not exceed the limits of a good school library of European history. I believe that all the easily accessible sources in English have been referred to in most cases by specific references, and I have supplemented these by reference to two or three collections of sources in French and German which are readily obtainable and inexpensive.

In the preparation of the text I have endeavored to give especial emphasis to the different periods of history, and at the same time to make clear the continuous movement. If any fairly good conception can be gained from the study of history of the steady march of humanity up to its present level, one of its richest and most fruitful results has been secured, and it is a wish of mine, though one perhaps not easily realized, that the teacher should be able to make his class see in each lesson, or at least in each of the minor epochs of history, how the movement advances a stage in the given bit of time. I hope that the summaries prefixed to the different parts may be of service in this direction. It will be noticed also that the traditional divisions of general history have not been exactly followed, and that in a number of cases new names have been given to the divisions made. These names have been selected with a view to bringing out prominently the unity and continuous advance of history. The traditional divisions are, however, made clear enough in the text so that any one who prefers can make use of them. 
The book can readily be made the basis of a two-years course of study by a use of the references and assigned readings. If this is desired, I should advise a division at the end of Part IV, as the most logical and satisfactory, although it does not divide the text quite evenly. I hope the book may also be found to serve a good purpose in colleges as the "backbone book" of a wider course of study or as a book of review on the completion of such a course.

I have received suggestions of value in the preparation of the book from a number of correspondents, but I am under especial obligation for such suggestions to Professors Lucy M. Salmon of Vassar College and Fred Morrow Fling of the University of Nebraska.

It is impossible that in a book of this kind errors both of the pen and of the press, and even graver ones, should not have escaped attention. I shall be very grateful to those who will call my attention to any of these which they may notice.

GEORGE BURTON ADAMS.

DECEMBER 29, I898. 



\section{CONTENTS}

A Brief List of Books of Reference of Value to tile TEACHER . . . . . . . . . . xxvii

\section{PART I}

PRIMITIVE EUROPE AND THE ORIENT

Books for Reference and Further Reading . . . . . . I

I. The Earliest History . . . . . . . I

The Field of History - The Prehistoric Age - Succession of Historic Races of Men.

II. The Oriental Natiosis.

Egypt - Egyptian Civilization - Assyria and Babylonia - The Hebrews - The Phenicians - The Persian Empire.

\section{PART II}

\section{THE GREEK PERIOD}

\section{Books for Reference - Summary}

I. The EARLy History

Primitive Greek History - The Iegendary PeriodThe Homeric Age - The Spartans - A Military Communism - A Ruling Minority - Athens - The Great Reformers - Two Typical Greek Constitutions.

II. The Struggle of Greece with Persia and its Results

The Beginning of the Persian Wars - The First and Second Invasions - Xerxes' Invasion - Greek Lcadership' passes to Athens - Rise of the Athenian Empire - The Age of Pericles. 
III. The lebronnesian War aNi, its Results.

The Begmning of the War - The Sicilian Expedition The Last Period of the War, + $3-40+$ B... - Fall of Athens - Supremacy of syarta - The Invasion of Persia by Cyrus the Vounger - A New Persian War - The Decline of sparta.

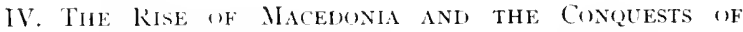
AlEXINIER . . . . . . . .

Philip's First Steps - The Sacred Wars - The Conquest of Greece - The Conyuest of Asia - The Fate of Alexander's Empire - Its Influence on Civilization - The Greek World between the Age of Alexander and the Roman Conquest - The Periol Intellectually-Condition of the Greek World at the Roman Conquest.

\section{PART III}

THE RLSE (OF TIL ROMANS

Rooks for Reforence-Summary' $\quad$. . . . . . . . 53

I. Beginvisgas and) Constitutumal Changes . . 56

The Relation of the Romans to the Creeks in IIistory - The (ieography and Peoples of Italy - The Founcling of Rome - The leriol of the Kings - Early Changes in the Constitution - The Early (onstitution of the Repul)lic - Rome begins her Conquests - Struggle of the Plebeians for Rights - I lelitors demanil I ess Severe Laws - Conflict for Equality in holeling Office.

II. The Struggle for EMpres . . . . . . 66

The First Samnite and latin Wars - War with the Greeks - The Roman Colonial System - Rome and Carthage, Rivals for Enpire - The lmportance of the Struggle - The First Pumc War - Ilannibal's Invasion of Italy Rome's Fortunes at their l.owest - The War carried into Africa - Effect of the War upon Rome. 
11I. The Empire completen. Its Efeect an Rome .

PAGE

Ten Years of Rapid Expansion-The Close of Greek IIistory - Abuses in Rome's Provincial Government The Abuses affect Rome herself - Tiberius (iracchus Caius Gracchus.

IV. Tile Fall of the Republic . . . . . .

No Patriotic Leadership in Rome - Jugurtha measures Rome's Corruption — The First German Invasion - Causes and Results of the Social War - The First Step towarls a New Nation - The Army lecomes a Political PowerCivil War and the "I'roscriptions."

V. The Beginning of tile Ceshes

The Rise of Pompey - Cesar and Cicero - The First Triunvirate - New Civil War - Nonarchy a Necessity Cosar's Measures - The Second Triumvirate.

\section{PART IV}

THE ROMAN WORLD-STATE WITH ITS FALI, AND ITS REVIVAL,

Books for Reference - Summary . . . . . . . IOI

I. The Enipire and its Decline . . . . . 105

Character of the Early Empire-Constitutional Forms - Economic and Literary Character of the Age - Provincial Administration - Augustus and the Germans - The Period of the Julian House - From Tiberius to NeroThe Flavian Dynasty - Growth of the Imperial Constitution - Five Good Emperors - The Roman I aw - Disorders of the Third Century-Reforms of Diocletian - Constantine the Great.

II. The Establishment of Christianity . . . . I20 Books for Reference and Further Reading . . . . . . I20

Christianity at the Death of Christ - Becomes a World Religion - Causes of Roman Persecution - Beginnings of Church Government - Christianity recognized by the State. 
III. The Last Age of Rome . • . • . . I 26

Character of the Fourth Century - Causes of the Fall of Rome - From slavery to Sierfdom - Attacks upon the Frontiers - Characteristics of the Germans - The Third and Fourth Centuries - The Goths cross the Danube Theodosius the Great - Invasions of Alaric - Breaking of the Rhine Frontier - Rome's German Defender sacrificed - Invasion of the Huns - End of the Western Empire.

IV. The FolNhing of the Gervan states • • .

A Second Period of German Conquests - Founcler of the Frankish Empire - Arian versus Catholic - Clovis adopted the Catholic Faith - The Last Years of Clovis' Reign - The ()strogoths conquer Italy - The Character of Theorloric's Rule - Growth of the Frankish Power Decay of the Merovingian lIouse - The Roman Empire of the East - The Keign of Justinian - Justinian's Work for Civilization - The Invasion of the Lombards - The Saxons in Britain - The Saxon States - No Roman Ele. ments in the Saxun states.

V. The Franks, the Arifi, and the PAPACY . . .

The Second Frankish 1)ynasty - The First Carolingians - Their liwer Fstablished - The fovernment Strengthened - Arahia before Nohammed - Mohammed and his Religion - A Religion of Conquest - Conquests of the First Century - The Revolution of 750 - Arabian Sicience - Coming in of the Turks - The Frankish Empire Restored - Iombards threaten the Pope's Independence - The Franks protect the Pope.

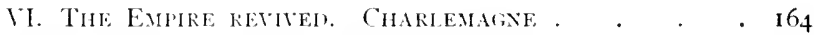

Books for Reforence and Further Reading . . . . . . . 164

The Way prepared for a Creat Empire-Conquest of Italy _- Of the Saxons - Charlemagne's ()ther Conquests - Revival of the Roman Empire - The Missi DominiciCharlemagne's Schools - Charlemagne's Place in History. 


\section{PART V}

\section{THE FORMATION OF THE NATIONS}

\section{Books for Reference - Summary}

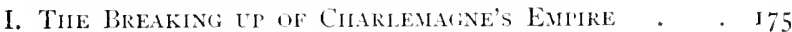

Causes of Division - Economic Condition - Louis I. the Pious - The Treaty of Verdun - End of the United Em. pire - New Barbarian Invasions - The Northmen - Rollo in Normandy and the Danes in England-Elfred the Great - The Second Lanish Invasion.

\section{The Feudal Sistem}

The Conditions which gave rise to Feudalism - Forms of the Feudal system - The Feudal System in FranceFeudal Rights and Obligations - The Serf Class - Ciradual Improvement in the Condition of the Serf.

III. Tile Rise of the New Nitions.

General Conditions - The lieginning in Gemany The Saxun Kings - The Empire revived by Otto I. Effect of the Revival - The Begrinning in France - Kings of Little Power - Norman Concuest of England.

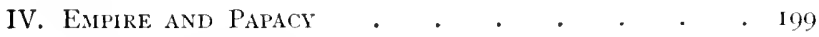

The Papacy Juring the Tenth Century - The Reforms of Cluny - Power of the Empire under Henry III. - The Beginning of the Conflict - Its Results - The Thirel (ierman Dynasty, the Hohenstaufen - I ranger to the l'apacy - The Cities of Northern Italy - Ciuelf and Ghibelline The Papacy at its Highest I'oint of Power.

V. Tire Crusades. . . . . . . . . . 209

Books for Reference and Further Reading . . . . . . . 209

Place of the Crusades in Histury - Motives of the Crusaders - The Beginning of the First Crusade - Results of the First Crusade - The Second and Third crusadesThe Later Crusades. 
VI. The Changes which fullowed the Crusades.

The Direct Results of the Crusacles - The Rise of the Third Estate - The Third Estate on the Sicle of Strong Government - Effect of the Increased Use of MloneyFall of the Feudal System - Changes affecting the Serf Class - Institutions of the Cities.

VII. The Forilation of the French Nation

General Conditions in France - Two (ireat Difficulties - The Work of Louis VI. - France threatened by the Angevin Empire - The First Great Advance - The Growth of the King's Power - The Salic Law - The First Period of the Great Struggle with England - The King of England becomes King of France - Joan of Are - The Final Triumph of France - Louis XI. and Charles the Bold.

VII. Exgland .

Books for Reference and Further Reading 236

General Character of English If Istory - Period of the Norman Kings - llenry Il. Abroad and at Home - England and Ireland - Henry's Two Sons - The Greatest of the Angevin Kings - The I Hundred Years' War - The House of Lancaster - The Wars of the Roses.

IX. The ()ther States of Errope

The Situation in Germany and Italy - The Foundation of Austria - A Period of Many Lynasties - The IIussite War - The Rise of Other German States - Italy - Spain - The Rise of the Ottoman Empire.

\section{PART VI}

\section{RENAISSANCE ANI) REFORMATION}

Books for Reference - Summary' $\quad$. . . . . . . . 257

I. The Revival of Learning . . . . . . 259

A Transitional Epoch - The Meaning of Renaissance - The Place of the Middle Ages in History - Learning in the Middle Ages - Medizeval Revivals - The Age of 
Scholasticism - The Founding of the Universities - The

PAGE Renaissance comes First in Italy - The Beginning in the Age of Petrarch - The Revival of Greek — Scientilic Method Recovered - The Invention of Printing and its Results - The Renaissance South and Nurth of the Alps - Erasmus.

11. The Imanedate Resclts of the Revhal . . .

Advance in Knowledge - The Commercial situation of the Fifteenth Century - Portuguese I iscoveries - Columbus and his Discoveries -- The Economic Results - The First Great Step in Ihysical Science-The End of the Renaissance - Art and Literature.

III. Revolution attemrted in the GovernMent of the Chukch . . . . . . . . . 283

The Papacy at Avignon - The Great Schism - The Demand for Reform - Wycliffe's Attempt at Reformation - Huss and the Ilussites - The Council of Constance The Council fails to reform Civernment or Concluet.

IV. The Political Changes of the Age. . . . . 290

Politics become International - The Condition of France - The Creation of Spain - Results of Ferdinand's Policy - England - Germany - Italy - France begins the Struggle - The First Invasion of Italy - A New French Claim on Italy - Rapid Changes in the Italian Situation - The Dominions of Charles V.-. The Imperial Election and its Results - France still seeks Dominion in Italy.

\section{The Reformation of Luther}

Luther's Theological Ieliefs - Indulgences - Luther posts his Theses - Luther gradually led to Open Rebellion - The Protestant Position in Regard to Authority The Diet of Worms - Events in Italy - The Treaty of Madrid - Enforcement of the Edict Delayed - Peace between France and Charles V. - The "Protestants" and their Strength-The Great Peasant War-The First Attack of the Turks - The Diet and "Confession" of Augsburg - The Emperor's Plans again Pustpuned. 
VI. The Later Age of the Reformation .

The Reformation in the North of Europe - Henry VIII. takes the Flace of the Pope - England becomes Protestant - Calvinism - The Reformation in France and Holland - The Counter Reformation - The Society of Jesus.

\section{PART VII}

THE STRUGGLE OF THE NATIONS FOR SUPRENACY ANL EXPANSION

Summary

I. The dge of Relirious Waks

The General Character of the Age - The Schmalkaldic War - Aldication of Charles $\mathrm{V}$. - The Power and Character of Philip II. - Philip anel Mary of England - England ayain Protestant - The Netherlands unler the llapslurgs - The beginning of Kesistance to Ihilip The Intepentence of the Lnited Netherlands - Engrand - Nary (gueen of scots - The Invincible Amada - Rise of the I'uritan Party - Opposing Parties in FranceHuguenot Civil Wars - The First of the IourbonsForeign I'lans of llenry IV. - Beginning of the Thirty Years' War - The Bohemian Period of the War - The I) anish l'eriod - Sweden and France-Richelieu centralizes France - Richelieu an! the Thirty Years' War Gustavus Adolphus in (iermany - The Ieath of Gustavus and Wallenstein - The French Period of the War - The Peace of West phalia - The Empire I sestroyed - The Other States of Europe in the Peace - The Sufferings of Germany - A New Era in English I Fistory - The Stuarts and the Puritans - The Keign of James I. - Charles I. and Parliament - Civil War Regun - The Great Rebellion and the Commonwealth.

II. FRANET TRIES IO IMMINATE ETROPE . . . . 365

The llapshurgs in 1660 - England and Holland - The situation in France - Charater of Louis $\mathrm{XIV}$ - Collert 
and the Finances - Colbert's Economic Measures - Preparing to annex Spain - Louis XIV.'s First War - Louis prepares to punish Holland - War against Holland - The Period of the "Reunions" - Revocation of the Edict of Nantes - Resources of France Declining - Charles II. in England - The Revolution of I6SS - The War of the League of Augsburg - The Question of the Spanish succession - The Partition Treaties - France annexes Spain - The War of the Spanish Succession - The War goes against Louis - The Peace of Utrecht - The Rise of England - The Beginning of Louis XV's Reign - The End of the Stuart Dynasty.

\section{HI. The Rise of Russia and Prussia}

The Position of Sweclen - The Early History of Russia - Russia in the Seventeenth Century - Peter the Great Russia against Sweden - The Fall of Charles XII. - The First Promotion of the Hohenzollern - Chief Steps in the Naking of Prussia - The Father of Frederick the Great - The Pragmatic Sanction of Charles VI. - The War of the Austrian Succession $(1740-1748)-$ Naria Theresa determined to punish Frederick - France abandons her Ilereditary Enmity - The Seven Years' War $\left(\mathbf{1} 75^{6-1} \mathbf{1}^{6} \mathbf{3}\right)$ - Prussia a Greal Power - Catherine II. of Russia (17621796) - The Condition of Poland - The First l'artition of Poland-Further Kussian Advance - The Rise of the Eastern Question - Poland at last Destroyed - A Revolution in the Political Situation of Europe.

IV. The Struggle for Colonial Empire . 406 Books for Reference and Further Reading. 406

The Dawn of the Age of World Politics - The First Modern Colonial Powers - Spain's World Power Threatened - The Rise of the Dutch Republic - The Beginning of the English Empire - The First English Colonies The Thirteen Colonies - Conflict between England and Holland - The Power of Holland broken by FranceThe Beginning of Rivalry with France - The Advantages 
of the English - Colonial Wars - The Situation in India - King George's War - The Interval of Nominal Peace The Great Colonial War $\left(175^{6-1} 763\right)$ - Its Ultimate Consequences-The English Ministry determines to tax the Colonies - Compromise not Possible - The War of the Revolution - The English Empire apparently broken up - The Revenge of France more Apparent than Real.

V. The French Revolution and Napoleon . . .

The Intellectual Leadership of France - The Deists Voltaire, Montesquieu, and Rousseau - Abuses existing in France - Financial Conclition of France - Attempts at Reform - The Danger of calling together the Estates General - The Struggle for One Chamber - The Struggle with the King - The King completely Overcome - Revolution Completed - The Rise of Opposing Parties - Financial Difficulties still Continue - Paper Money lased un Land - The Republic Proclaimed - The Beginning of a Long War - The First itep towards the Republic - The King Executed - War against all Europe - The Reign of Terror, followed by keorganization and success - The Wurk of the Convention - Bonaparte forces Austria to make Peace - Revolution within the Revolution - Bonaparte in Egypt - A Strong Government - Bonaparte turns the Tille of War - The Interval of Peace - The War Renewed - Napoleon stretches his Power too Far - The Beginning of the End - The First lestoration - The Charter of 1814 - The Congress of Vienna - The "Hundred Days" - The Second Restoration and the Congress of Vienna - Results of the Revolution in Europe at Large.

VI. EUROPE SINCE ISI5.

Books for Reference and Further Reading . . . . . 452

The Nineteentl Century an Age of Transition - Three Lines of Great Political ( hanges - The Alsolutist Reaction - Revolutionary Movements - The Monroe Doctrine - Further Reaction and a New Revolution in FranceThe Consequences of the Revolution in France - Preparation for Another Revolution - The Revolution of $\mathrm{IS}_{4} 8$ The Second Republic - Revulution in Austria and Italy 
- Unsuccessful Attempts in Germany - The Suppression of the Revolution - The second Empire established by Napoleon III. - Free Government indirectly Secured The Congress of Vienna and the ldea of Nationality The Independence of Greece-ittempts following the Two French Revolutions - The Spirit of Nationality growing Stronger - The Policy of Cavour - United Italy William I. and Bismarck - The Army made Realy - The New Prussia's First War — The Seven Weeks' War - The Results of the War for Germany - Results of the War for Austria - The Franco-I'russian War desired ly Both Govermments - The Pretext found for War - The Cinurse of the War - The Empire of Germany - Alsace-Lorraine and Rome - The Third Republic in France - Results of the Period in Furope at Large - The Eastern ( Juestion Rise of Egypt under Nehemet Ali-Preliminaries of the

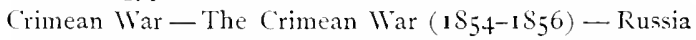
again attacks Turkey, $\mathbf{I} S_{77}$ - The Treaty of Berlin, $1 S_{7} \$$ - I ater I History of the Balkan States - Later Phases of the Eastern Question - The Greek and Turkish War.

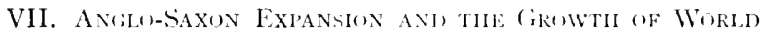
Poltics . . . . . . . . . $4 S_{7}$

Europe no linger the Stage of llistory - The ()ccupation of the Worlı - Australia the First Step - Its Early History - A New English Nation - England in the Wars of the French Kevolution - Napoleon's Attempt at Colonial Empire - The Expansion of the United States -- The English Empire in the Napoleonic Period - The Expansion of Canada - The struggle for Self-government Canada opens the Way- I Great Change in English Methods of Colonial Government $\rightarrow$ A Second Great Annexation by the United States - Gokl in California and Australia - A Theory of Imperial Dissolution - The Imperial Federation Movement - Expansion of English Dominion in India - Russian Expansion in Asia - The Results in Asia - The Occupation of Africa - The English Occupation of Egypt - The Insurrection of the Mahdi - The Anglo-Saxon Race in the World. 
VIII. The Growth of the ENGlish anN AMerican CONSTITLTIONS

Books for Reference and Further Reading

Importance of the llistory of our Institutions - The Absolutism of the First Jorman Kings - Our First Constitutional Document - The Beginning of our Judicial Institutions - The Iagna Charta - The Right of Civil War - The Right of Insurrection Applied - The Idea of a Limited Nonarchy - Origin of Representative Institutions - The First Case of Town Representation - P'rogress in the Thrteenth Century - The King recognizes the Right of Parliament to control Taxation - Parliament takes a New Step - Another Most Important Right Ciained - A Third Great Gain of Parliament's - The Exclusive light to Legislate - Kise of the Honse of Commons - Summary of Results - First Dangerous Attack on the Constitution - The Deposition of Edward 11., 1327- Right of Parliament to control succession - The Progress of the Fourteenth Century - The Yorkist Period - Peculiar Character of the Tulor Jeriod - Constitutional Change in the Position of the Church - Character of the stuart Periul - Reasons for the Attitude of the Kings-The Religious Parties - Slow Alvance towards War - The second Great Constitutional Document - Period of Rule without I'arliament - Concessions of King (harles - The King determines to Resist - The Constitutional Character of the Commonwealth - The Later Stuarts - The Revolution of I $68 S$ - Results of the Revolution - Constitutional (questions in the Colonies - Progress in the Eighteenth Century in England - The Constitution of the United States Tendency towards Democracy - Anglo-Saxon Institutions in Other States - The Common Work of England and America.

IX. Schentife AND ECONonic Alpance since the RENAISSANCE . . . . . . . 544

Books for Reference and Further Keating . . . . . . 544

The Close of the Renaissance - The Great Ige of English Literature - of Scientitic Work - The law of 
Gravitation - The Idea of the Reign of Law - The Eng-

PAGE lish Deists - Leaders of French Thought in England The Benevolent Despots - Character of Eighteenth Century science - Advances in Science - A New ScienceThe Age of Nachinery Begins - Its Effect on Manufacturing - On Labor - The Final Effect - Political Results The Accumulation of Wealth - Nineteenth Century Science-Advances in Pure Science.

List of Alibreviations Used in Referring to the Various Authorities Quoted . . . , , 559

Each chapter is followed hy a list of TOPICs - TOPICS FOR AsSIGNed Studies - and frequently by a list of Important Dates for Review. 


\section{LIST OF MAPS AND TABLES}

The World as known to Eratusthenes and Strabo, from about 200 B.C. to 20 A.D.

Frontispiece

PAGE

Greece at the Beginning of the Pelopunnesian War • facing 34

Empire of Alexander the Great . . . . . “ “ 48

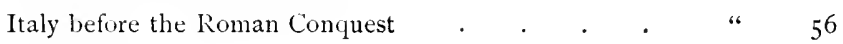

Roman Empire . . . . . . . . . between IIO-III

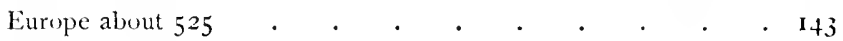

Charlemagne's Empire . . . . . between I68-169

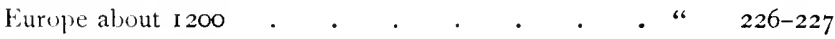

The Crusalles . . . . . . . . . 212,213

Europe about 1560 . . . . . . . betieen 334-335

The Battic Lands at the Beginning of the Eighteenth Century $\quad{ }_{3} S_{7}$

Europe about 1740 . . . . . . . between 392-393

Central Europe about I $\$ \mathbf{I} 2$ showing Battle-fields from 1792

between $446-447$

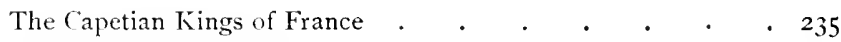

The Kings of England, 1066-I485 . . . . . . . 246

The (ienealogy of the Emperor Charles V. . . . . . . 302

The Kings of England, Tudors, Stuarts, and IIanoverians . . . $3^{6} 3$ 


\section{ILLUSTRATIONS}

Ruck-cut Figures at Aba-Simbul . $\quad . \quad$. $\quad$. 5

Fragment of the Rosetta Stone . . . . . . . . 9

Nebuchadnezzar . . . . . . . . . . 10

Section of the Black Obelisk of Shalmanezar . . . . 12

Darius and Attendants . . . . . . . . . . 14

Necropolis of Darius near Persepolis . . . . . . . $\quad{ }_{\mathbf{I}} 6$

Altar on the Acropolis, Pergamos . . . . . . $\quad 23$

The Acropolis restored, Athens . . . . . . . 25

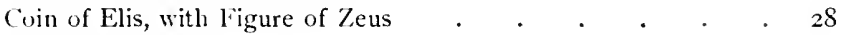

Pericles . . . . . . . . . . . 32

Greek Women decorating an Altar . . . . . . 33

The Parthenon as at Present . . . . . . . 37

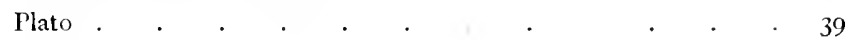

Pediment - Temple of Minerva, ligina . . . . . $4^{\mathrm{I}}$

Aristotle . . . . . . . . . . . . 44

Theatre of Dionysius .

Temple of Edfu, Time of the Ptolemies . . . . . . 49

Nask of the Otricoli Zeus, Naples . . . . . . 50

An Old Roman School . . . . . . . . 56

Roman Lictors . . . . . . . . . . 60

Ruins of the Aqueducts, kome . $\quad$. $\quad . \quad$. . $\quad .62$

A Ouadriga . . . . . . . . . 65

Roman Trireme, with boarding Brilge . . . . 7I

Rostra . . . . . . . . . . . 74

The Circus Maximus, Rome . . . . 75

Roman Chariot - a Triumph . . . . . . . 77

A Gladiatorial Combat $\quad$. $\quad$. . . . . $\quad$. 82

A Ballista, Time of Cæsar . $\quad . \quad$. . . . $\quad$. 84 
The Coliseum . . . . . . . . . . . 89

The Roman Forum, restored . . . . . . . 9 I

Ciesar's Bridge . . . . . . . . . . . . . 93

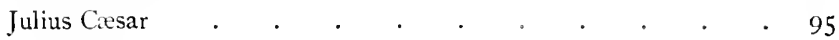

Cleopatra, with her Cartouche . . . . . . 97

A Street in I'ompeii . . . . . . . . . 105

Pretorian Guards . . . . . . . . 106

A Cameo - Portraits of Claudius, Agrippina the Younger, Livia, and Tiberius . . . . . . . . . . 109

Arch of Trajan . . . . . . . . . 112

Marcus Aurelius . . . . . . . . . . . 114

Constantine the Great . . . . . . . IIS

Christian Sarcophagus, with Labarum . . . . . . 123

(ierman Bodyguard, Column of Marcus Aurelius . . . . 128

German Settlement, Time of Tacitus . . . . . I30

German Weapons . . . . . . . . . . 136

St. Sophia, Constantinople . . . . . . . . 147

Fragment from the Digest of Justinian . . . . I5 1

The Kaaba at Mecca . . . . . . . . 154

Tomb of the Caliphs at Cairo . . . . . . . 159

Charlemagne . . . . . . . . . $\quad 167$

Signature of Charlemagne . . . . . . . . I70

The Cathedral at Worms . . . . . . . 179

Edinburgh Castle . . . . . . . . . . 187

Milan Cathedral . . . . . . . . 200

Ilarbor of Palermo . . . . . . . . 205

lapal Keys . . . . . . . . . . . . 207

Bird's-eye View of Khodes . . . . . . . . 21 I

Knight Templar . . . . . . . . . . 215

Saracenic Arms . . . . . . . . . 216

Grand Canal, Venice . . . . . . . . . 219

A Hanseatic Ship . . . . . . . . 222

Notre Dame, Paris . . . . . . . . 227

Canterbury Cathedral . . . . . . . . 230 
Tower of London

PAGE

The Great Seal of England .

241

Carving from a Muslem Screen

St. John's College, Oxford .

Dante Alighieri .

26.4

Gutenberg's Press

266

Armor of Columbus

268

Columbus

274

Cortes .

. 276

Lorenzo Magnifico

- $27 \mathrm{~S}$

The Duomo, Florence.

$28 \mathrm{O}$

The Emperor Charles V.

294

Luther

299

Bridge and Castle of S. Angeln, Rome

303

Ignatius Loyola .

309

Cannon of the Sixteenth Century

- 322

Philip II.

$33 \mathrm{I}$

William the Silent

$33^{2}$

Queen Elizabeth.

Soldier of the Thirty Years' Var.

Gustavus Adolphus

345

Richelieu

348

Swedish Leather Cannon

350

Holyrood Palace.

352

Charles I. of Englanci

- $35^{6}$

Cromwell

Louis XIV. .

- 359

- 360

I ouis de Bourbon, 'he Great Condè

368

Colbert

372

Gobelin Tapestry, T'me of Louis XIV.

375

A North View of Gibraltar

Peter the Great

382

Gigantic Grenadie of Frederick William I.

Stone Bridge at Prague 
PAGE

Frederick the Great . . . . . . . 40I

The Mosque at Delhi . . . . . . . . . 4IO

Villiam I'enn . . . . . . . . . . 4 II

Champlain . . . . . . . . . . . . $4 \mathbf{I 4}$

Dujleix . . . . . . . . . . . 417

The Declaration of Indepentlence. Facsimile (reduced) of the

tirst lines of Jefferson`s original traft . . . . . . $\quad 423$

George Washington . . . . . . . . facing 422

Versailles . . . . . . . . . . . . 429

Marie Antrinette. . . . . . . . . . . . . . 430

Taking of the Thastilie . . . . . . . . . . 434

Facsimile of an .ssignat (reluced) . . . . . . . 437

Lazare Carnot . . . . . . . . . 442

The Three Consuls . . . . . . . . . . 444

Naprilem . . . . . . . . . . . . 445

Iafayette . . . . . . . . . . . . 456

l'ople l'ius IX. . . . . . . . . . . . . 460

Count cavour . . . . . . . . . . . . . 466

Germania. Nillerwalı Nonument . . . . . . 474

M. Thiers . . . . . . . . . . . 477

Seloastoper . . . . . . . . . . . . . 480

The cimpress at berlin . . . . . . . . 483

Bird's-eye View of Mellowne, Australia . . . . . . 489

lurlan, Natal . . . . . . . . . . . . . 494

sutter's Mill. Where genll was first discovered in California . 499

Khartum . . . . . . . . . 506

lienjanin lianklin . . . . . . . fating 546

The cintun lin. . . . . . . . . . $55^{2}$ 


\section{A BRIEF LIST OF BOOKS OF REFERENCE OF VALUE TO THE TEACHER}

In French. - Lavisse et Rambaud, Histoire Générale du IV Siźcle d nos Jours. 12 vols. (I 44 francs.) Probably the best book of reference and for obtaining more full knowledge than the ordinary textbook gives on Medieval and Modern histury. Each epoch is treated by a specialist. - Rambaud, Histoire de la Civilisation Frangaise. 2 vols. (Paris; Colin; $S$ francs.) Deals chiefly with France from the beginning to the Revolution, but is of value for all Europe.

In German. - Leopold von Ranke, Weltgeschichte. 9 Parts. (I 58 marks.) Mainly political. - G. Weber, Lehrbuch der Weltgeschichte. 2 vols. (I 8 marks.) Will be found very useful by the teacher, as it takes up many sides of history.

In English. - George P. Fisher, Outlines of Unizersal History. (American Book Co.; \$2.40.) A very full single volume listory. Ilas some of the characteristics of Weber. This book and the same author's History of the Christian Church (Scribner's; \$3.50) will form a satisfactory reference library of the smallest size.- Arthur Hassall, Editor, Periods of European History. 8 vols. By different authors. (Macmillan; \$I.40 to \$I.75.) A very useful series covering the whole field of Medieval and Modern history. - The Story of the Nations Series (Putnam's; $\$ \mathbf{I} .5^{\circ}$ ) and the Epochs of History Series (Longmans or Scribner's; \$I.OO) approach the character of general histories in monographs. Volumes in each series will be mentionerl in connection with the different periods. - J. N. Larned, History for Ready Reference. 5 vols. (Subscription. Nichols, Springfield, Mass.; \$25.00.) A general history on the dictionary plan. It is especially useful because of the large number of unusual names and terms which are explained. - The American Historical Review (\$3.00) and the English Historical Review (20 shil.) are the standard periodicals in English. Teachers who can make use of French will probably find that the Revue Historique (Paris; Alcan; 33 francs) will keep them more nearly abreast of the new work in European history than any other single periodical. - Hassall, A Handbook of Europern History, 476-I S I (Macmillan; \$2.25), and Ploetz, Epitome of Ancient, Hedicitul, and Modern History (Houghton; \$3.00), are helpful manuals of chronology xxvii 
with genealogical and other tables. - Lorenz, Genealogisches Handbuih der Europäischen Staatengeschichte. (7 marks.) Very good and full tables. - George, Ginclogical Tables. (Clarendon; $\$ 3.00$.) The best in English. In atlases, the teacher should have at hand something better than any English school historical atlas. - Droysen, Historischer Hand-atlas (Leipzig; 25 marks), and Schrader, Atlas de Gécriathie Historique (Paris; 35 francs), are both very good. - The Oxford Historical Atlas, publishing in 30 parts (Clarendon ; \$1.10 each) is still better, but more expensive. 
Tartar nations, which have had so much to do with the history of Asia, and which may have a larger influence upon the future of the world than they have had upon its past.

4. The Succession of the Historic Races. - The centre of the ancient workd was the Mediterranean Sea. In lands bordering on it, or within easy reach of it, the earliest

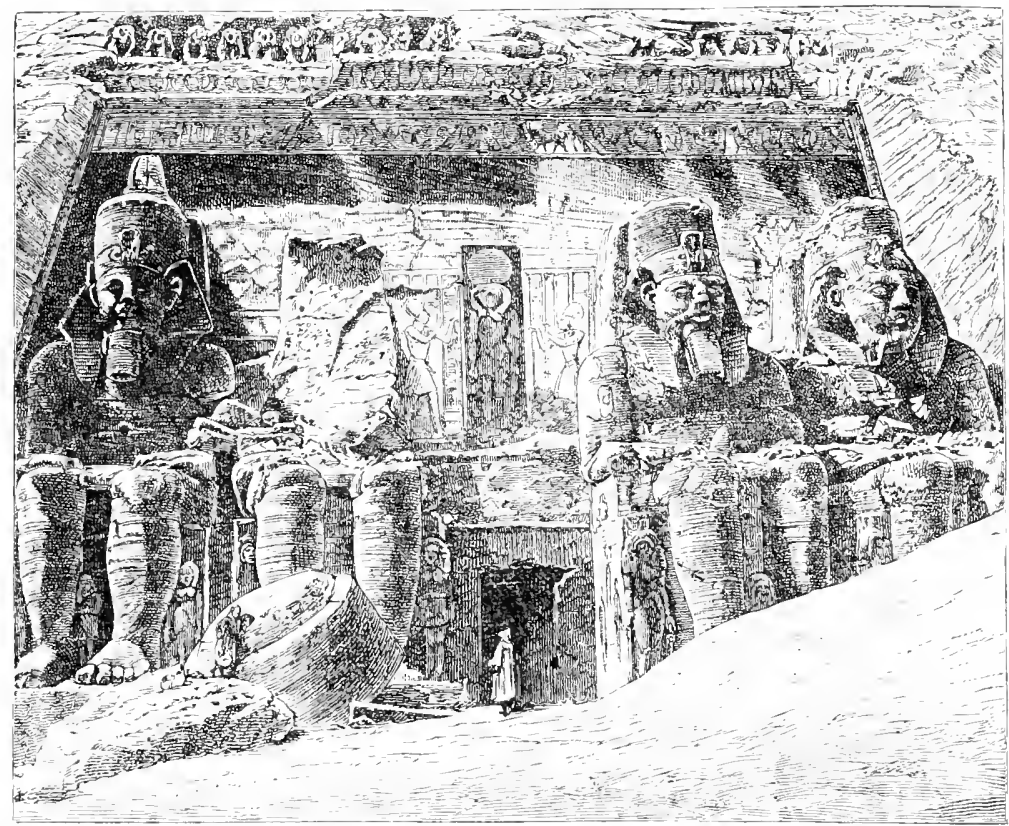

Rock-gL FIGURES AT ABA-SIMIUI,

civilizations of recorded history were formed. These were Recorded the Egyptian and the Assyrian in the valleys of the Nile and the Euphrates. Their successor in dominion and civilization was the great empire of the Persians, but many valuable additions were made to the common stock by some Oriental nations that did not found great empires, like the Phonihistory begins in the Mediterranean basin.

The Oriental cians and the Hebrews. From these Eastern nations the nations. 
The Greeks. line of our history passed to Europe and to the Greeks, who, borrowing some things from their predecessors, developed one side of our civilization, the intellectual, to the highest point which it was destined to reach for many

The Romans. centuries. The Romans followed the Greeks in time, and formed a great state which brought together into a common union all the lands of the Mediterranean basin, but in one sense they were the partners of the Greeks, for they filled ont a side of our civilization, the political, to which the other race had given little attention. The heirs of the The Ger- ancient world were the Teutonic tribes who broke up the man peoples. western half of the Roman Empire into the modern European nations, but in doing this they kept up something of the union which Rome had created, and so remained in close relations with one another. They gradually formed a new All mankind. uniform cryilization on the foundation of the classic, and in recent times this has begun to be world wide and to bring into close relationship) and under common influences all the inhabitants of the earth. 


\section{CHAPTER II}

\section{THE ORIENTAL NATIONS}

5. Egypt. - It was in Egypt that the first civilized nation of history was formed. This was no doubt because the favoring climate and the great fertility of the Nile valley, renewed every year by the inundation of the country, made it very easy to pass from the barbarous or nomadic stage into a settled agricultural life, and this change very soon made necessary a strong government to protect a peaceful laboring population. How early a government of this kind was formed in Egypt we cannot say with certainty, but it was several thousand years before the Greeks became a civilized people.

The history of Egypt is divided into dynasties, or families of kings, which serve the purpose of a chronology, since we have no date for the beginning of the history from which we can reckon. Of these dynasties there are about thirty, grouped into three or four larger groups. The first of these is of ten dynasties of kings who had their capital at Memphis in Lower Egypt, near the Mediterranean. The capital under the second group was changed to Thebes in Upper Egypt, far from the sea, and this group is divided into two, the first of which is called the Middle Empire, and the second the New Empire. With the last group the seat of the government returned to the Delta.

The earliest king of whom we are told the name is Menes, who is said to have founded Memphis, and to have united Egypt under one rule. In the early period the fourth The first Egyptian king.

The periods of Egyptian bistory. Rawlinson, Ancient Eirupt ( $\mathrm{Na}$ tions! dynasty is especially famous, for they were the builders of 
The pyramids.

The Middle Empire.

The New Limpire.

Ebers, lituda (novel).

The age of decline.

Connection with the Greeks.

the great pyramids of Gizeh, intended to be the tombs of the kings. The largest of these was built by King Cheops, or Kufu. Not much is known of the later dynasties of this group, and when we begin to learn more of the history Thebes is the capital.

The period of the highest civilization of ancient Egypt seems to have been that of the Middle Empire. It was a time of peace when great works of building and of internal improvement were undertaken. A king of the twelfth dynasty, Amenemhat III., transformed a great lake, called Mcris, or "the lake," into a basin to receive the waters of the Nile when too high, and to increase the inundation when it was not high enough. This period is closed by the invasion of the Hyksos, or Shepherd Kings, who ruled Egypt for about five hundred years. The New Empire is a period of great military glory and of conquests extending north almost or quite to the Euphrates, and south into the regions of the upper Nile under the great kings Thothmes I. and III. and Ramses II. and III. It was probably under the dynasty of the Ramses, the nineteenth, that the oppression of the Hebrews occurred.

Under the twentieth dynasty the power of Egypt began to decline, and the history of the last ten dynasties is filled with foreign invasions, and sometimes the country was ruled over by Assyrian or Persian kings who had conquered it. About the midlle of the seventh century a native king restored the independence of Egypt and founded the twentysixth dynasty. This was Psammetichus I., who made his capital the city of Sais near the sea, because the support of his power was his Greek mercenaries. This dynasty lasted until the conquest of Egypt by the Persians, and is characterized by interest in commerce and by its close connection with the Greeks. It was through this connection that the Greeks learned many of the things the Egyptians had to teach them, especially in philosophy and science, aithough they had in even earlier times learned much from the same source. After the conquest of Egypt by the Persians it was 
never again independent. It passed from the Persians to Alexander, and then to the Romans. White it was a part of the Roman Empire in the East, it was conquered by the Nohammedan Arabs, and afterwards by the Turks, who have kept possession of it, at least in name, until the present time.

6. Egyptian Civilization. - The Egyptians in nearly all periods of their history seem to have been very fond of

The end of Egyptian independener. Ebers, In istrition Princess (novel). The Egyptian records. making written records, or of constructing permanent monuments of some Ant ก.

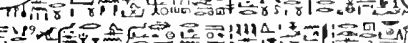

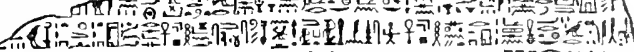

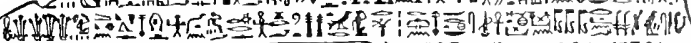

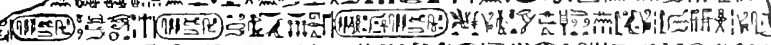

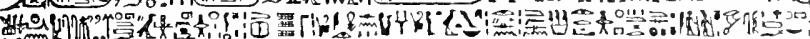
=for

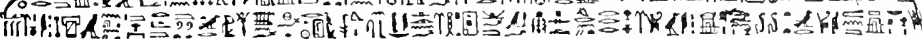

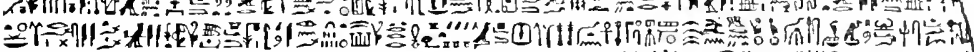

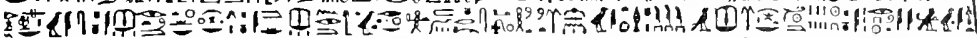

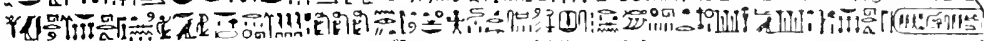

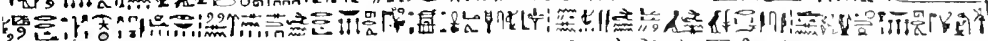

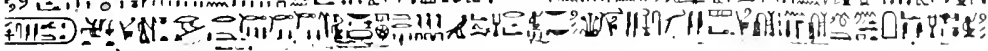

FRAGMENT OF THE ROSETTA SFUNE

Bearing the inscription by which the hieroglyphics were deciphered

kind which would preserve their memory to after times. The result of this is that we have a great deal of information not only about their history, but also about their ileas and their ways of life. Their forms of writing, which they had developed from a primitive kind of picture writing, were deciphered many years ago by a French scholar, who had an inscription to study which had been engraved in three forms of writing, one of which was Greek, so that the meaning was easy to determine.

The Egyptians were a very religions people, and the most characteristic features of their civilization, their wonThe religion of Egypt. derful buildings and monuments, their scientific knowledge, and their practice of embalming the dearl, are all connected with their religion. They had a great many gods. Almost 
every place or operation of nature had its divinity, and as they believed in the frequent incarnation of the gods in the bodies of animals, many animals among them were held sacred. They had a very strong belief in the immortality of the soul, and in a last judgment in which the future destiny of the soul was determined by the character of the life in this world.

The second civilization was in Asia. Ragozin, Assyria (Nations).

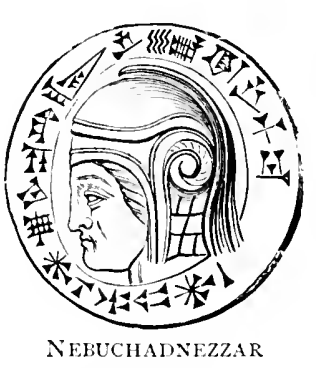

NEBUCHADNEZZAR

7. Assyria and Babylonia. - Probably it was some time after Egypt had become a highly civilized state that the lower valleys of the Tigris and the Euphrates, which present some of the same conditions favoring the formation of a settled community, became the seat of what we may call the second of the great states of ancient Oriental history, Assyria. Different kingdoms follow one another in this region in a series whose chronology is very uncertain. The earliest is a Chaldrean or old Babylonian kingdom, whose centre was towards the south, and which was contemporary with the earliest history of the Hebrews. Towards the end of the twelfth century B.c. there began to arise in the north the Assyrian kingdom proper. After a long struggle

The great period of Assyrian history. Babylonia was overcome and absorbed in Assyria. The great period of Assyrian history begins about the middle of the eighth century, and lasts for something more than a hundred years. The greatest kings are Sargon, who conquered the kingdom of Israel and carried the ten tribes into captivity, and Sennacherib, who defeated King Hezekiah and besieged Jerusalem. But the great period of Assyrian history was short. Her empire was too large for her resources, which were soon exhausted, and Assyria passed into a decline which was hastened by the rise, farther north, of a kinglom of the Medes, and to the south by the recovery of Babylonia. The new Babylonian kingdom was also short lived. It had its great period in the reign of Nebuchadnezzar, who sacked 
Jerusalem, and took the city of Tyre after a long siege. In the next reign the kinglom was swallowed up in the growing empire of the Medes and Persians under Cyrus.

'The civilization of the Chaldeans and Assyrians was very The records interesting and peculiar. They had a form of writing of their own which we call the cuneiform because of its wedgeshaped characters. In this they made very extensive records, historical, literary, and commercial. They wrote in soft clay tablets or bricks which were afterwards baked and so preserved. Large libraries of these have been found by the explorers in the ruins of their cities. Their buildings were extensive though not so grand or magnificent as those of the Egyptians, and they were often ormamented with interesting figures of huge winged beasts. In their literature we find stories corresponding in some ways with those recorded in the early chapters of Genesis, especially a story of the deluge. Their interest in the worship of the stars and their belief that they influenced the fate of men, led them to give much attention to the study of astronomy, and they laid the foundations of this science for other nations.

8. The Hebrews. - Before the fall of Babylonia the independent history of the Hebrews had come to an end. After the escape of the Hebrews from slavery in Egypt and their difficult conquest of the promised land, there followed a period in their history of local independence and separation, almost of anarchy, the time of the Judges, who were their leaders in almost continuous warfare with the neighboring tribes. From this condition they emerged in the time of the prophet Samuel by the choice of a king, Saul, who united all the Hebrew tribes into a nation and secured their independence from their more dangerous neighbors. He was succeeded by David, the great soldier and poetking, who so extended his kingdom that we may almost speak of a Hebrew empire. He made Jerusalem the capital of the monarchy. His son, Solomon, devoted himself to the encouragement of commerce and to the adorn-

Ward, The Whater of the Masicians (novel; 6th century B.C.).

Early Hebrew history. and civilizaAssyrians. Its periout of greatness. 
ment of his capital rather than to war. He built the beautiful temple at Jerusalem, and was famed through all that part of Asia for his own wisdom and for the luxury of his court. These two reigns cover the whole periorl of Its decline. Hebrew greatness. A great rebellion broke out on the

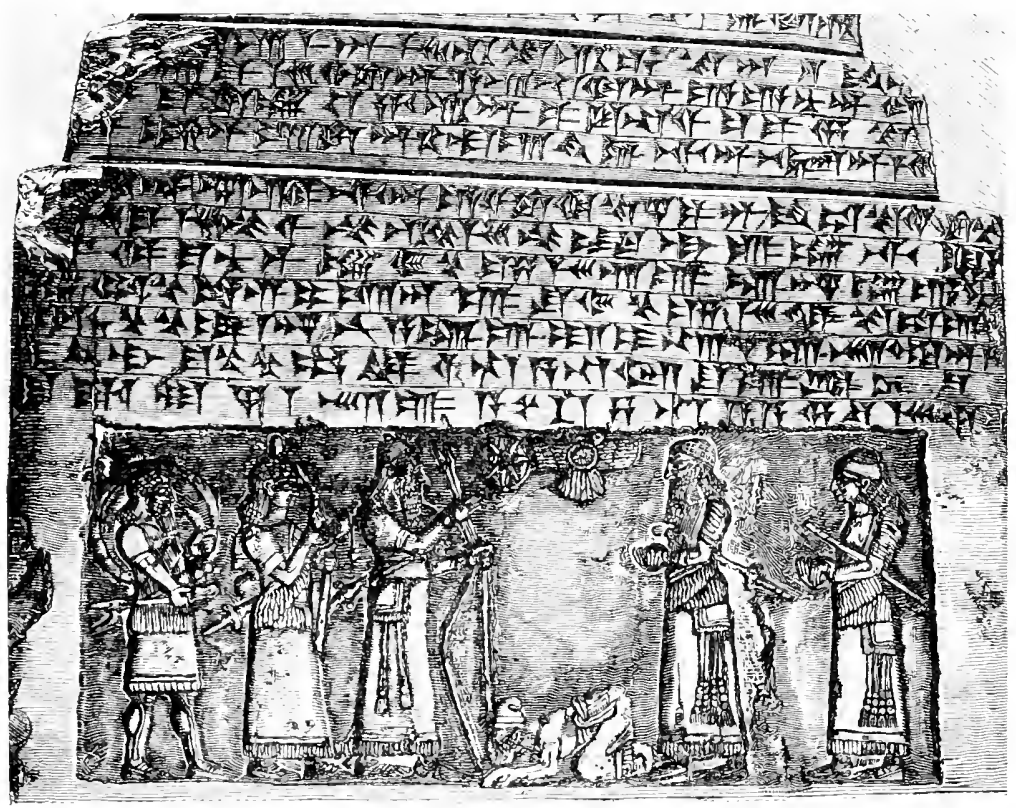

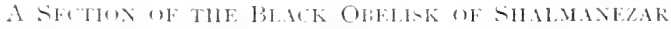

refusal of Solomon's son, Rehoboam, to reduce the heavy taxes, and the ten tribes of the north set up an independent state, the kinglom of Israel. The age which followed is that of the great prophets, who are continually striving to hold the people to the worship of the true Cod. 'Then came very soon the conquest of the country by the Assyrians and the Babylonians. From these, what was left of the Hebrew state passed under the rule of the Persians, then 
of the successors of Alexander the Great, and finally of the Romans, by whom the city of Jerusalem was almost destroyed.

Of the ancient Oriental states none has had so profound an influence upon the history of the world as the Hebrew. The most beneficent of the world religions, the Christian, rests upon the foundation of their religious experience, and their sacred writings, even considered independently of the divine truth which they recorl, are the most valuable contribution ever made to the world's religious literature.

9. The Phœnicians. - Along the seacoast of Palestine, shut in to a narrow strip of land by the mountains behind them, were the cities of the Phcenicians. Though they were really one people, Semitic in race, they never formed a state, but the separate cities remained independent like those of the Greeks. Their situation made them turn naturally to the sea, and they became the first of the world's great commercial powers. Siclon and Tyre are their greatest cities. In the first period of their history, before the rise of the Greeks, their ships visited all the coasts of the eastern Mediterranean and of the Black Sea, opening mines and founding trading-stations wherever they could. 'They rarely attempted to resist the great conquering nations of the continent, and submitted first to the Egyptians and then to the Persians, finding much profit in the commerce and carrying trade which was thus opened to them. In a later period they visited in the same way all parts of the western Mediterranean, and even ventured into the Atlantic. The greatest of their colonies was Carthage in northern Africa, which was destined to dispute for nearly a century the empire of the west with the Romans. In the arts and sciences the Phcenicians were the immediate instructors of the Greeks, and so of all the world. Our modern alphabets are probably all developed from the forms of the letters which they taught to the Greeks, and in shipbuilding and navigation, and many forms of manufacture, as well as in the fine arts, the Greeks, who were our teachers, learned from them.

The religion of the Hebrews and its results.

The Phoenicians.

Rawlinson, Phanicia (Nalions).

Their commerce,

and colonies.

Their services to civilization. 
Cyrus the Great, d. 529 B.C. Church, Storie's of the East, Chaps. V.-YIII. Herodotus, Bk. I. IO7 ff.

Invasion of Europe.
Io. The Persian Empire. - All these Oriental states were finally swallowed up in the last and the greatest of them, the empire of the Persians, the first empire established by any of the Aryan nations. Cyrus the Great, about the middle of the sixth century, was the founder of this empire, and conquered almost the whole of western Asia. Cambyses, his son, added Egypt. Darius I. conquered the valley of the Indus in India, and crossed into Europe with a great army, with which he subdued Thrace, made Macedonia tributary, and crossing the Danube invaded even modem Russia. Angered at the aid which the Athenians gave to the Greek cities of Asia Minor, which were in revolt against him, he began the great Persian wars of Greek history, and with the aid of the Phonician fleet landed 
a force near Athens, where it was defeated in the battle $490 \mathrm{k} . \mathrm{c}$. of Marathon. The reign of Darius $I$. is the highest point of the Persian Empire. Decline began immediately; and though the empire lasted for a century and a half, it made no further conquests, and fell easily on the attack of Alexander the Great towards the end of the fourth century. To the civilization of the world the Persians made no contributions in proportion to the size of their empire. They possessed the Aryan gift of political organization, and held their conquests under a firmer rule than had any of the earlier empires. 'Their government by satraps, or provincial governors, held to a strict accountability, has been often imitated in the East. Their great religious teacher was Zoroaster, and the fundamental idea of their religion was the existence of two great and eternal powers, one of good and the other of evil, continuousty striving for the possession of the universe in a never-ending conflict-an idea which influenced the belief of philosophers in more than one period of later history.

The history of these Oriental nations is rather preliminary to the history of our own civilization than a part of it. It is its introduction. They taught the nations of Europe many things, but the main body of our civilization is independent of theirs, and only slightly infuenced by it.

\section{Topics}

What is the object of the study of history? The periods of history, and the reasons for these divisions. The sources of linowledge of prehistoric times, especially language. Why did the parent race divide into separate nations? The three great races and their place in history. Name in order the great races which have made our civilization. Circumstances which favored an early civilization in Egypt. Characteristics of the early, middle, and later periods of Egyptian history. The connection of Egypt with Greece. The records of the Egyptians. Their religion. The second of the great Oriental states. The records and the civilization of the Assyrians. Early Ilebrew history. The great period of the Hebrew monarchy. Its ipuick lecline. The lleIntroductory

Zoroaster. Crawford, Zorouster (novel; $5^{\text {th }}$ century B.C.). history. 
brew religion and religious literature. In what ways are we indebted to the Phcenicians? 'The first great Aryan empire. Its relations with Europe. Its civilization and religion.

\section{Topics for Assigned Studies}

The primitive weaver. Mason, Woman's Share in Primilize Culture, Chap. III.

The houses of the primitive Indo-Europeans. Jevons' translation of Schrader, Chap. IX.

Egyptian ideas of the future life. Maspero, Dari'n of Cizilization, pp. $1 S_{2}-200$.

The private life of an Assyrian. Mlasperu, Life in Ancient Egypt and Assyria. Chap. XII.

Early Germanic weapons. Du Chaillu, The liking Age, Vol. II., Chap. VI.

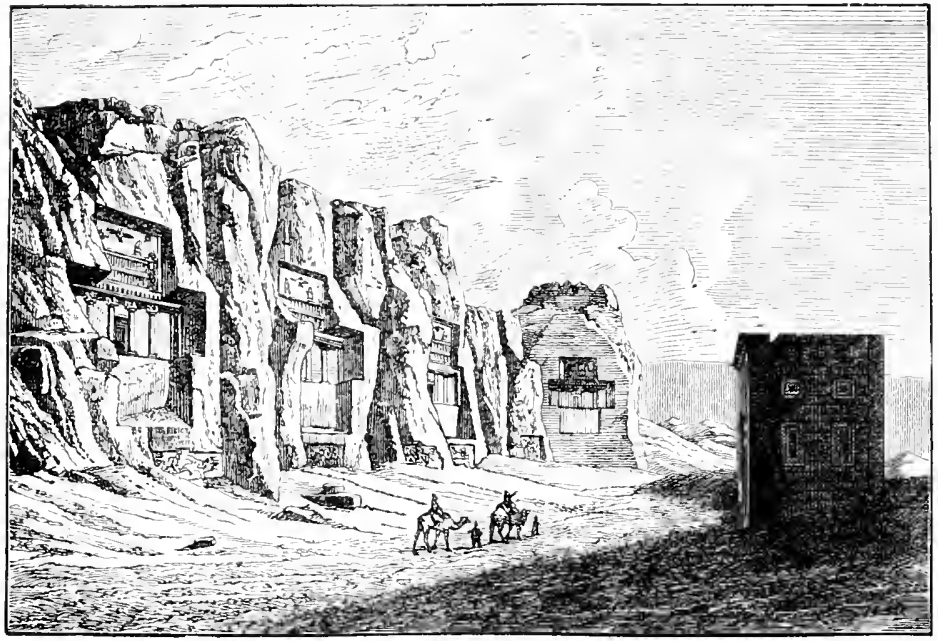

Necrofolis of DakiUs near Persepolis 


\section{PART II \\ THE GREEK PERIOD}

\section{Books for Reference and Further Reading}

Grote, History of Greece. 12 vuls. (1 Iarper; \$18.00.)

Curtius, Ifistory' of Grecice. 5 vols. (Scribner's; \$10.0o.) The standard histories. Very full and supplementing one anotler in many ways.

Ilum, History of Griece. 4 vols. (Nacmillan; \$IO.00.) To the completion of the koman conquest. Translation from the German. The most recent detailed history in English. Very satisfactory on the political side, and with very full bibliographical references.

Beloch, Griechische' Geschichte. 2 vols. (Trübner; Strasburg; Marks 16.50.) Very goud on the economic history.

Cox, Ilistory of Greces. (IIarper; \$1.25.) Probably the best onevolume history.

Reber, IIistory of Ancient Art. (IIarper; \$3.50.) Illustrated. All ancient art from Egypt to Rome.

Murray, Classical Greek Litcrature'. (Appleton; \$1.50.)

Mahaffy, History of Classical Greck Literature. 2 vols. (Macmillan; $\$ 4.50$.) - Social Life in Greve. (Macmillan; \$2.50.) - A Sur'ey' of Greck Cirilization. (Flood and Vincent; \$1.oo.)

Blümner, The Home Life of the Ancient Greeks. (Cassell; \$2.oo.)

Nearly the whole of Greek literature, including the historians, has been translated into English, and may be read in the Bohn Library (Nacmillan) or in Ilarper's Classical Library.

\section{SUMMARY}

European history was opened by the Greeks. They were a small people, and the land they occupied was not large. But their natural gifts were so high and were so stimulated by the beauty of their climate and of the land and sea around them that they were able to make a contribution to the permanent civiliza- 
tion of the world in literature, and art, and scientific thinking, which has never been surpassed by any of the greater nations that have followed them. Two leading divisions of the Greeks made their history, - the tribes of the Ionians and of the Dorians. The Dorians were less attracted by literature and art, and more by a military life. Their leading state was Sparta. The lonians produced the greater part of Greek literature and philosophy, and Athens was their leading state. After a long period of more or less legendary history, the Greek race first came clearly forward on the stage of history in a life and death struggle to prevent the absorption of their land in a great Asiatic empire the empire of Persia, which had already conquered the Asiatic Greeks. In the first attack of Persia the burden of the defence fell upon Athens, which gained the victory of Marathon. In the second. more of the Greek states were united, and the Spartans fought at Thermopyle. and the Heet, largely Athenian, gained the victory of Salamis, though Athens itself was taken and destroyed. The Persians abandoned the attack after this failure, and in the effort of the Greeks during the next few years to clrive their fleets and garrisons from the islands of the Egean the Confederacy of Delos was organized which Athens gradually turned into an empire of her own over other Greeks. Then followed the greatest age of Athenian history - the age of Pericles, brilliant in art and opening a great literary period in the works of the tragic poets. But in the meantime jealousy between Athens and Sparta had been increasing and they were now at the point of war. The great civil war of Greek history - the Peloponnesian War-lasted twenty-seven years and ended in the ruin of Athens. During its first period, gains and losses were about evenly balanced, but in the second the strength of Athens was exhausted by two great expeditions which she sent against the Dorian city of Syracuse in Sicily, which were both totally destroyed, and in the third, though she made a most heroic struggle, her last theet was surprised and captured, and the city fell into the hands of the Spartans. The age which followed is the unhappy period of Greek history. The rule of Sparta was harsh and selfish. Revolts and civil strife were frequent. Athens recovered something of her power. Thebes rose to a brief supremacy. But Greece was not strong enough to prevent the interference of Persia in her domestic affairs and lad to submit to her dictation. Toward the close of the period a half-Greek state - Macedonia in the north - suddenly rose to power, and under Philip confuered Greece and formed a military 
union of the Greek states. Philip's son, Alexander the Great. led the whole force of (ireece against the Persian Empire, and conquered for himself a still greater empire in Asia, Africa, and Europe. In Alexander's empire the language, literature. and science of Greece were made those of the whole Eastern world, and thus carried on into the permanent civilization of mankind, but in it also the history of Greece came to an end.

\section{CHAPTER I}

\section{THE EARLY HISTORY}

I I. Primitive Greek History. - Of the earliest history of the Greeks we know almost nothing. They were an offshoot of the Indo-European family, and must have separated from the parent stock while still in a primitive stage of advancement. At what date they entered their future home we have no means of determining, but it must have been at a time when Egypt was already highly civilized, and very possilly others of the Oriental nations as well.

Nor can we tell the route by which the Greeks entered. We find the same race occupying in historic times both sides of the Agean Sea and the islands between, but not the head of the sea to the same extent. This would seem to point to the fact that originally they passed down one shore or the other, and at a later time found their way across from island to island to the opposite side.

If we can trust the facts which language seems to give us, they had only just begun to till the soil in a rudimentary way when they separated from the original race. The broken and even mountainous character of Greece, however, would make it impossible to depend on flocks and herds for sustenance, and would force a more settled life and the development of agriculture.

The numerous plains separated by barriers of hills that form the surface of the country maile it easy, also, for the

Later than the Oriental civilizations.

The method of the Greek settlement.

Development of agriculture follows.

Holm, Vol. I., Chap. I. 
The physical race to separate, as population grew, into small groups becharacter of the land favored small states.

Legendary

history. tween whom would naturally soon grow up little differences of dialect and habits. As population became still more dense and permanent property increased, these groups of families, perhaps several of them together where communication was easy, began to form more definite political organizations, and so originated the later states of Greece.

12. The Legendary Period. - When the Greeks came, at a much later time, to reason about their own earliest history, they built up a great literature of myths and legends conCox, Taleref cerning it in which gods and demi-gods had as large a Ancient Greece. place as men. In many cases no doubt a germ of actual tranlition was at the beginning of these stories, but it is impossible for us now to separate the real from the imaginary.

Earlier The Greeks always called themselves Hellenes, and their inhabitants of the land. land Hellas. They tell us of a race which they seem to distinguish from themselves, called the Pelasgoi, and in Ifolm, Vol. I., some of the later Greek states we find a subject population Chap. V'l.

The three in a semi-servile condition, as if it had been conquered by the Greeks when they entered the country, like the Helots in Laceliemonia. But we cannot now be quite sure who the Pelasgoi were, nor in what relation they stood to the first Greek settlers.

great tribes.

The (ireeks divided themselves into three great tribes, the Ionian, the Dorian, and the Eolian, a division which we can trace, at least in general lines, in differences of speech and in tribal characteristics, for the Ionians are the most intellectual, the Dorians the most military, and the Aolians the most primitive and undeveloped of the Greeks. The great age of Greek history is made up chiefly of the deeds and the rivalries of the Ionians and the Dorians. Nearly all the great names belong to them. Almost the whole of Greek literature, science, and art is theirs, and indeed they are chiefly Ionian. And the sending forth of colonies, which were even more numerous and widely extended than those of the Phoenicians, and took possession 
of almost all the shores of the Mediterranean Sea, and even of the Black Sea, was mainly their work.

I3. The Homeric Age. - Of the events of Greek legendary history, the most interesting is that recorded in the Ilial of Homer, the ten years' siege of Troy by the allied Greek states. The events of the story we cannot be sure of, but we can draw from the Homeric poems a picture of the early civilization and governments of Greece which is all the more trustworthy because it is unconscious, but which perhaps represents the states in different stages of advancement. The states of the Homeric Age were small. Each had at its head a king who was at once general, priest, and judge, but whose power in the state was limited or was coming to be limited, by a council, a kind of senate of elders or nobles, and by a general assembly of the free men, which had, however, very little power. This is a constitution similar to that which we find in the early history of many of the Indo-European states.

Another event about which many legends gathered, but which we feel sure must have been a real occurrence, is the migration of the Dorians. From the north of Greece they passed south, and conquering the Greeks who divelt there in Homer's time, they became the ruling race in the Peloponnesus.

During the great age of Greek history, the Ionic people of Athens and the Dorian Spartans are the leading and most interesting states.

I4. The Spartans. - The Spartans ascribed their peculiar social and political organization, which was the real source of their power, to a half historical, half legendary lawgiver, Lycurgus. Their institutions were so well adapted to their situation, a small ruling class keeping in subjugation a much larger conquered population, that they were probably the result of experience and growth, though very likely the process was assisted by the genius of some statesman who may well have been Lycurgus.

In form the government of Sparta was a kingdom. It

The siege of Troy.

Church, The

Story of the

lliud.

Agnes M.

Clarke,

Familiar

Studies in

Homer.

Fling,

Studies,

No. I.

The early

government.

The Dorian migration.

The two great states.

Lycurgus, about 850 B.C. 
A peculiar form of monarchy.

The general constitution.

A race of soldiers.

Fling, Studie's, No. 3 .

The story of the boy who had stolen the fox, in Plutareh's Life of Lycursus. Spartan fortitude. was a peculiar kingdom, however, from the fact that there were always two kings. The Spartans accounted for this peculiarity by a tradition that in early times a king had left twin sons who were given equal authority and founded two lines of kings. It is more probably explained by some forgotten fact of their primitive history, like the union of two tribes to form the state.

The kings performed the same duties as the Homeric king, but their power was much less. The real government of the state was in the hands of the council of " elders," twenty-eight in number, elected by the public assembly. This was composed of all Spartans who had reached full age, thirty years, but it had no power except to sanction the acts of the council. In later times there were elected each year a body of five men, called ephors, or "overseers," whose business it was to look after the interests of the state, and especially to check any attempt on the part of the kings to become real rulers.

15. A Military Communism. - The avowed object of the government was to make of the Spartans a race of soldiers. The work of selection was begun at birth, for only strong and well-formed children were allowed to live. At seven years of age the state assumed the training of the future soldier.

He was made to be strong in body, skilful in the use of arms, and to endure pain without complaint. At twenty years the young man was admitted to the army, and from this time he lived almost as a soldier in camp, having his meals with his military mess.

The training of the women was almost as severe as that of the men, and led naturally to that Spartan fortitude which made them rejoice over their relatives who had died with honor on the field, and sorrow orer those who had survived disgracefully. Luxuries were forbidden and commerce discouraged in order to prevent the possible enervation of the race. The state was almost a communism. The interests of the individual were sacrificed to those of the state, or they were by the Spartan so identified with those of the state that he could not distinguish between. 


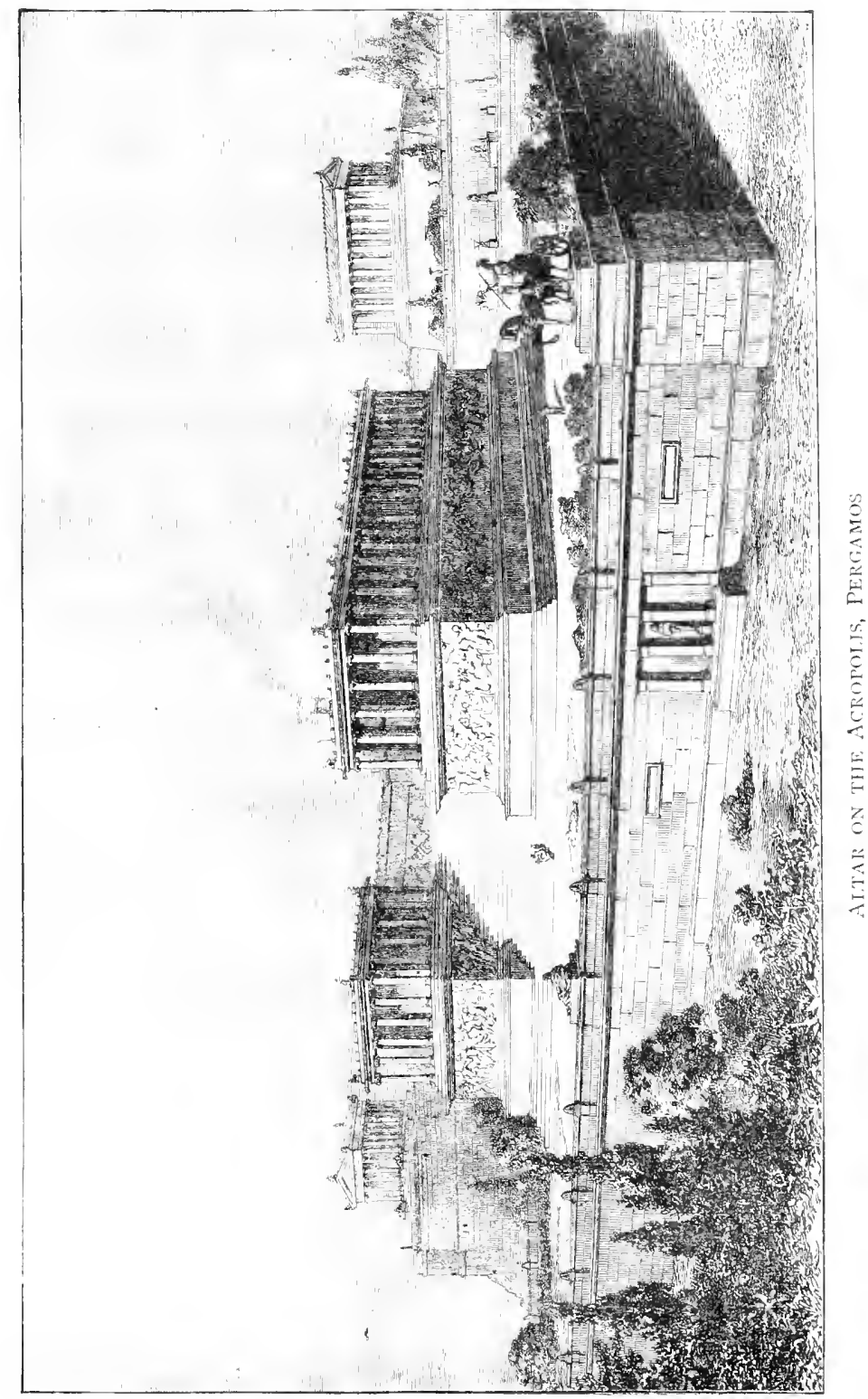


The true Spartans few in number.

The Perioeci.

The Helots.

Spartan conquests,

and military prestige.

Earliest history.

The Athenian constitution increasingly democratic.

16. The Spartans, a Ruling Minority.- Institutions of this sort were practically forced upon the Spartans, for they were a small body ruling a much larger population. Sparta seems never to have had more than ten thousand citizens, and in later times the number was much smaller than this. Their subjects were divided into two classes, each many times their own number. The Periœci were free men, though they had no political rights. Their position, however, was a good one. They served with the Spartans in war and might even become officers. On the other hand, the Helots were serfs. attached to the soil. They were employed as light-armed troops, but the Spartans were constantly in fear of their insurrection and watched with the greatest vigilance for any sign of insubordination, which was cruelly punished.

If, as tradition said, these institutions were established when Sparta was still a small state, closely surrounded by neighbors as strong as herself, they soon had their effect in military successes, which in the course of two centuries resulted in the conquest of Messenia, and in another hundred years Sparta became the most powerful state in the Peloponnesus throngh the overthrow of the Arcadians and the Argives. By this time also the Spartan heavy-armed infantry had acquired the reputation throughout Greece of an invincible military force, and this reputation Sparta long maintained.

I7. Athens. - The legendary history of Athens ascribed the foundation of its greatness and of its supremacy in Attica to Theseus. Certainly at the beginning of historic times the country territory was ruled by the city, though apparently in primitive times it had formed many states. The early monarchy of the Homeric type had been abolished before this date, legend said, in recognition of the devotion of the last king, Codrus, who gave his life to win a battle.

18. Constitutional Changes in Athens. - Through all the first centuries of its history, the constitution of Athens was constantly changing, and always towards a more democratic type. At first the changes were in favor of the aristocracy at the expense of the king, who was forced to give 


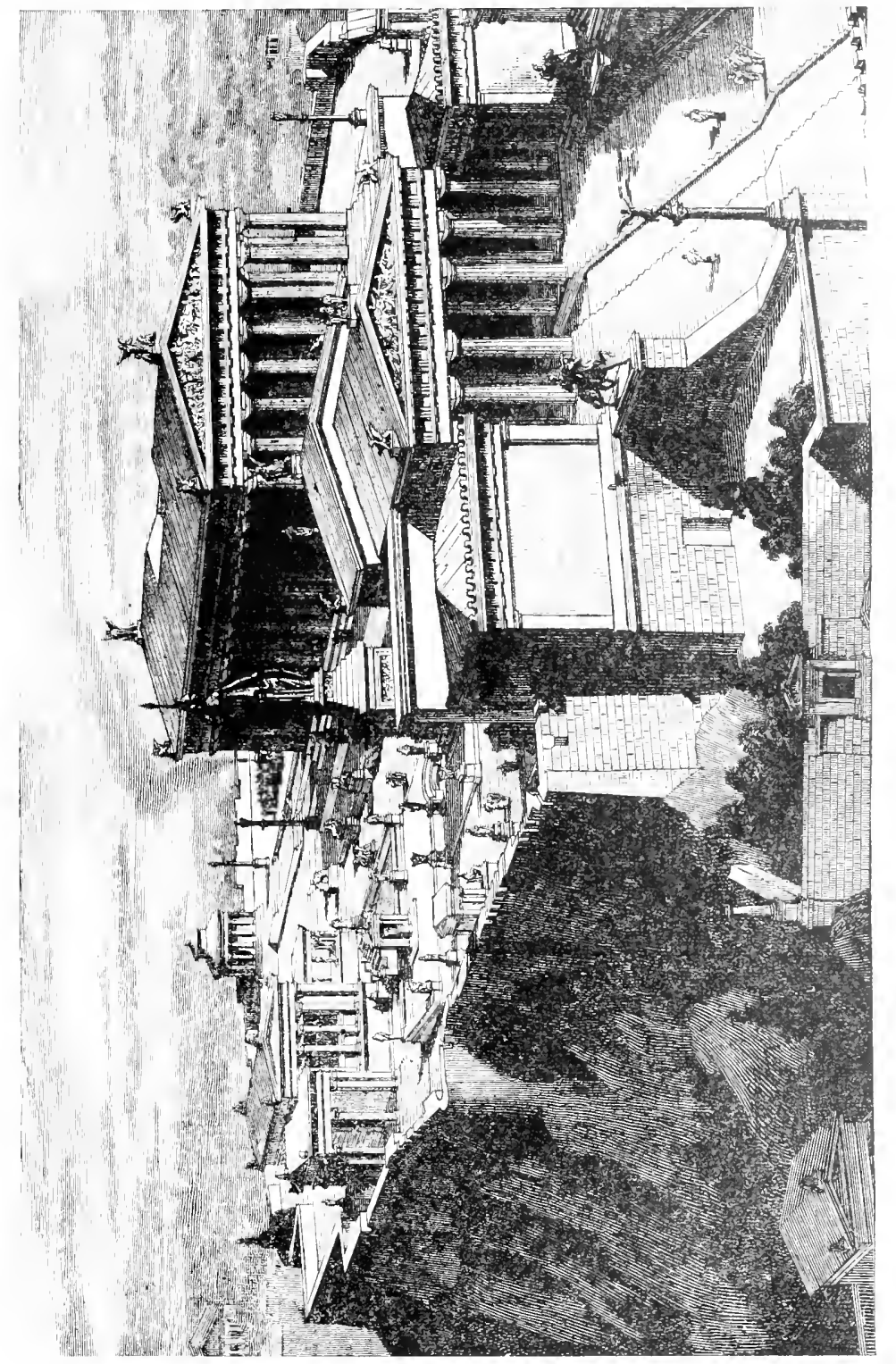


Fling, Studies,

No. 2. Brownson's Smith's History of (iriece, Chap. V. Holm, I., Chap. XXVI. Aristotle's Athenian

Constitution, translation of Poste (Macmillan).

Changes in the councils.

Early strife and the tyrannies.

Draco, $62+$ B.C. up first one and thein another of his functions to elected officers. In 752 B.c., the term of the officers was made ten years. Later it was reduced to one year, and the number was made nine to whom the name of arcons was given. These offices were confined at first to the nobles, and only at a later time thrown open to all citizens. But these changes were accompanied with a gradual reduction of the powers of the arcons, and the powers taken from them were transferred to the council and the assembly.

At the beginning the Athenian public assembly, the Ecclesia, had little real power, but the changes in the constitution tended to enlarge its membership greatly and to give it a larger share in the direction of affairs. The original comcil, or senate, was the Areopagus, which when the aristocracy was supreme, had been the real governing body, but which was finally limited to a general censorship of religion and public policy. Its place as an active council, supervising the business of the assembly, was taken by a second senate called the Boulé, established by Solon, or perhaps earlier by Draco, and composed at first of four hundred, and later of five hundred, members.

The period of these constitutional changes, which extended through several centuries, was characterized by much party strife, by the measures of celebrated reformers, and by the establishment or attempted establishment of tyrannies in the Greek sense ; that is, the arbitrary power of one man, founded and maintained in an illegal way, but not necessarily tyrannical in the modern sense.

I9. The Great Reformers. - Near the end of the seventh century Draco reduced to writing the unwritten laws of the state, which up to this time had been known to the nobles only. This made evident to all the cruel character of the old laws, and assisted in the process of change. Soon after the opening of the sixth century reforms were made under the leadership of Solon. These were partly economic in character. They favored the poorer classes in the state by making the laws in regard to debt less severe and by limit- 
ing the amount of land which one person could hold. For solon, purposes of government, improving perhaps upon an earlier classification which had been made by Draco, he divided the citizens into four classes according to their weatth, giving to the wealthiest class the most power and an exclusive right to the highest offices, but giving to the poorest class some slight voice in public affairs through membership in the Ecclesia. 'This was an arrangement not entirely satisfactory in itself, but it seems to have been a necessary step in the transformation of an aristocracy into a democracy.

The reforms of Solon did not bring party strife to an end, however, and within a short time power was seized by Pisistratus, who made himself tyrant. His rule was a very enlightened one. The city was beautified, art and literature encouraged, and the foundations of the sea-power of the Athenians were laid. His sons, Hippias and Hipparchus, ruled with less prudence, and the tyranny was overthrown at the end of the sisth century.

Soon after this event the reforms of Cleisthencs were carried through, and these completed the organization of the Athenian democracy. The practice of ostracism was also adopted at this time, by which any citizen whose growing power seemed dangerous could be banished by a simple vote of the assembly without assigning reasons.

20. The Two Typical Greek Constitutions. - These two constitutions, the democratic of Athens, and the aristocratic of Sparta, may be regarled as types of the constitutions of all the Greek states. Each had its aristocratic and its democratic party, and these were constantly striving with one another for supremacy, often with appeals to arms, or with secret plots leading to assassination and to massacre. In many of the states tyrants were able at some time or other to take advantage of the bitter party strife to establish their illegal power, which in some cases lasted for several generations. When the time came of the rivalry of Athens and Sparta for the headship of Greece, the democratic party in each state looked naturally to Athens for support, and sparta

$59+$ I.C. Plutarch's Life of Selon.

Pisistratus, tyrant, 560 B.C. Herodotus, I. $59-6.4$. 510 H.C. The final reforms.

Ostracism.

Parties in the Greek cities.

Their relation to Athens and Sparra. 
sought to establish her control by putting the aristocracy in power wherever she could.

\section{Topics}

The migration and settlement of the Greeks. Their earliest cirilization. Threefold division. The legendary age. Government in Homer. The two great Greek states. The peculiarities of Spartan government. Its military and communistic features. Why were these features necessary? Spartan conquests and military reputation. Early history of Athens. Its democratic tendency. Points of contrast leetween Athens and Sparta. The code of Draco. The reforms of Solon and of Cleisthenes. What was a tyrant in the Greek sense?

\section{Topics for Assigned Studies}

Lycurgus and the Spartan government. (irote, Part II., Chap. VI. Ilolm, Vol. I., Chap. XV. ('urtius, Book II., Chap. I. Plutarch's Lifi of Lycurgus. Fling, Studies, No. 3 .

The Greek tyrant. Grote, Iart II., (hap. IX. Curtius, Book II., Chap. I. Mahaffy, Problems in Greck Ilistory, Chap. IV.

The Greek colonies. Curtius, Vol. I., Book Il., Pp. $43^{2-500 . ~ H I o l m, ~}$ Yol. I., Chap. XXI. Cirute, Vol. IlI., Chap. XXII. Greek colonies and English colonies are compared in Freeman's lecture, Greater Greece and Greatir Britain (IIacmillan).

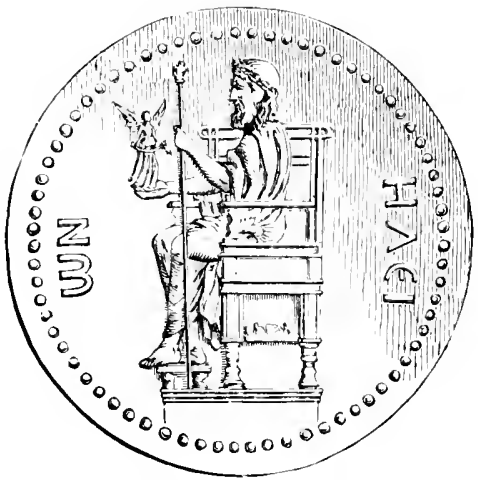

Coin of Elis with Figure of ZeUS 


\section{CHAPTER II}

THE STRUGGLE OF GREECE WITH PERSIA AND ITS RESULTS

2r. The Beginning of the Persian Wars. - Hardly had the constitution of Athens assumed its democratic form when the state was called upon to take a foremost part in the desperate struggle of the European Greeks, to keep themselves from absorption in the great Oriental empire of the Persians which had been created by Cyrus and his successors. The independence of the Greek cities of Asia Minor had somewhat earlier been destroyed by the Lydian king, Crœsus, but his kingdom was now annexed by the Persians, the Greek cities included.

About the year 500 a revolt of the Ionian cities of Asia Minor occurred, and the Athenians sent a force to aid them, either because of their relationship to them, or because they already feared an extension of the Persian control to Europe. The revolt was for a time successful. The Greeks burned Sardis, the Persian capital of the province, to the great anger of King Darius, but the Ionian cities were soon reduced, and the chief result was that Darius formed a fixed determination to chastise the Athenians for their presumption.

22. The First and Second Invasions. - A first attempt at invasion through Thrace was a failure. A second was planned by sea to land in Attica. In the meantime many of the islands of the Egean had been reduced by the Phœnician fleets in the service of Darius. In 490 a great Persian army was landed at Marathon on the east side of Attica. The Athenians had only about one man for ten of

Danger from Persia.

A. J. Church, The Story of the Persinn

llar, from Herodotus. Herodotus, Books VI.-IX. Cox, The Greets and the Persians (Epochs). The Greeks of Asia Minor rebel.

Herodotus, V. 105.

First invasion, 492 B.C. 
the Persians, for the little state of Plataa only had sent its

Battle of Marathon, 490 L.C.

Holm, II., Chap. II.

Darius' dealh.

The thind invasion, 480 B.C.

Holm. II., Chap. IV. Thermopy. lie, Heruiotus, III. 201-233; Grote, lui.l. Chap. XI, Curtius, liol. II., Pl. $300-$ 3 II.

The battle of Saliomis, Herodutis. VIII. 70

Final victory of the (ireeks, 479 B.C. army to aid them. But the skilful tactics of Miltiades completely defeated the enemy, and by a quick march across the land he reached Athens in time to protect it from the Persian fleet, which had sailed around the peninsula.

Darius' anger was only increased by these failures, and he began great preparations for another invasion, but died before the time of rengeance came. His plans, however, were taken up by his son Xerxes. The Athenians on their side made equal preparations. Under the lead of Themistocles they turned the Peiræus into a fortified harbor, and built great fleets. Aristides opposed the plans of Themistocles from equally patriotic motives, but the Athenians decilled in faror of the sea-power, and Aristides was ostracizecl.

23. Xerxes' Invasion. - In the spring of 4 So Xerxes began his invasion, passing through Thrace with an enormons army, while a great fleet accompanied him, sailing along the coast. At the pass of Thermopyla the first resistance was met. Here perished Leonidas, one of the Spartan

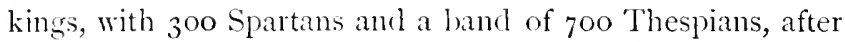
a traitor had shown to the Persians a way to the rear of the pass.

Central Greece was now open to Xerxes. Athens could not hope to defend herself. The citizens abandoned the city, which was destroyed by the Persians, while the Greek fleet took position in the bay of Salamis to defend the Peloponnesus. The naval battle which followed was a complete victory for the Greeks. Xerxes became alarmed for his own safety, and returned to Asia, comforting his conscience by leaving behind a picked army under his brotherin-law Mardonius to complete the conquest of Greece.

The next spring this army was destroyed by the Greeks at the battle of Platæa. At the same time the Greek fleet gained a great victory on the coast of Asia Minor at the battle of Mycalé. These victories secured the freedom of Greece. Xerres never renewerl the attempt at conquest. 
Even the Greek cities of Asia were allowed to become free, and the Greek fleet gradually drove the Persians and the Phœenicians from the islands of the Egean.

24. Leadership in Greece passes to Athens. - For a time after the first victories, the traditional headship of the Spartans, which had been recognized during the war, was continued and the command of the fleet given to their king Pausanias. But his pride and ambition led him into treasonable correspondence with the Persians, and he was recalled to perish of hunger in the temple where he had taken sanctuary.

This left the control of the fleet in the hands of Athens, whose more energetic leadership was already recognized by the Greeks. Under the command of Aristides the Just, whose character gave the Greek cities all conficlence in the plans proposed by the Athenians, and of Cimon, the son of Miltiades, the work of liberation was completed. While it was going on, Athens formed a league for mutual defence with the cities of the islands and coasts of the Egean, called the Confederacy of Delos. Of the forces of this league Athens had commani, and the money collected for defence was administered by her. In the meantime, under the direction of Themistocles, the walls of Athens were rebuilt in a better manner and the Peiraus more strongly fortified than ever before, in spite of the opposition of Sparta. For some cause not made known to us Themistocles spent the last years of his life in exile.

25. Rise of the Athenian Empire. - As the war with Persia died out, the character of the Confederacy of Delos changed. The allies ceased to make contributions of men and ships, but paid money instead. These moneys Athens appropriated to her own use without rendering accounts to the allies, while maintaining fleets strong enough to prevent successful opposition from any member of the Confederacy. This was the beginning of an Athenian empire, which might have grown into a united Greek nation had the course of Athens been liberal and wise.

The Confecteracy of Delos, 477 I.C.

The beginning of Athenian empire.

Cox, The Athenian Empirc (Epochs). 
A most inpoitunt age in Greek history.

The character of Athenian rule.

The most brilliant age of Athenian history, 45943 I B.C.

Abbott, Pericles (Heroes) ; Plutarch's Life' of Pericles: 'Thucydides, II. 65 .
The period following the Persian wars must be regarded as the tuming-point in Greek history, and to a considerable extent in that of Rome also, for had Rome been obliged to overcome a united Greek nation, the construction of her empire in the East would very likely have been impossible. It would certainly have been very difficult. But the Greeks seem to have been fatally incapable of holding others under a rule at once generous and firm. The policy of Athens was selfish and arrogant. Discontent was harshly suppressed. She even interfered in the local govermment of the cities in her own supposed interests, and took no pains to attach the allies to herself, while the rivalry of Sparta was becoming more open and signs of a coming struggle multiplied.

26. The Age of Pericles. - At home this was the most brilliant age of Athenian history. The government grew more democratic. Pericles shortly rose to long and com.. manding influence over the policy of Athens as the leader of the people. The wealth which poured into the city was spent with liberal hand in its fortification and beautifying. The long walls were built to connect the city with the Peireus. Athens was filled with beautiful buildings. Artists, like Phidias, produced their immortal works. The great literary age of Athens, so short in time but so entirely unsurpassed in product, began and was continued with the works of the great tragic poets, Aschylus, Sophocles, and Euripicles. It was one of the most brilliant ages in the history of the world, 
but the struggle with Sparta was drawing nearer with every year, and Athens' unskilful management of her empire was preparing a disastrous result.

\section{Topics}

How did the war between the Greels and the Persians begin? The battle of MIarathon. The invasion of Xerxes. Battle of Thermopyle. The plans of Themistucles and their success in the battle of Salamis. Irinal defeat of the P'ersians. The confederacy of Delos. Ilow did this lead to an Athenian empire? Why did Athens fail to form a Greek nation? Character of the age of Pericles.

\section{Topics for Assigned Studies}

The preparations of Xerxes. Grote, Vol. V., Chap. Xxxill. Curtius, Vol. 1I., Book III., Chap. I., pp. 275-2So. Ilerodutus, Vill. $20-25$.

The policy of Themistocles. Grote, Vol. V., Chap. XXXIX. Curtius, Vol. II., Bouk III., Chap. I. Ilerodotus, VII. 143-144. Plutarch, Lizes of Themistocles and Aristides.

The founding of the Athenian empire. Grote, Vul. V., Chap. XLV. Curtius, Vol. II., Book III., Chap. II.

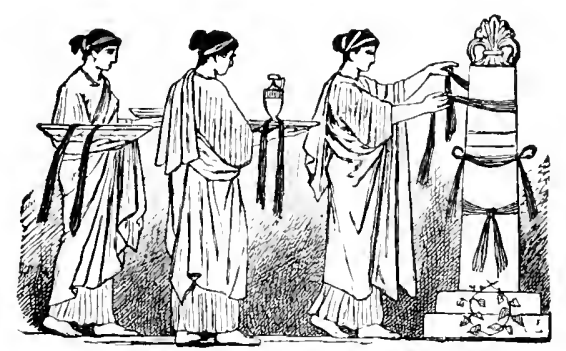

Greek Women decorating an Altar 


\section{CHAPTER III}

\section{THE PELOPONNESIAN WAR AND ITS RESULTS}

The occasion of the war.

43 I li. .

Character of the first period of the war.

Pericles' ontion over the deadi; 'Thucyclicles, $1 \mathrm{I}$. $35-46 ; \operatorname{In}$ diana, No. I ; 'Thucvdides' description ot the plague, 11. $47-53$. 1 he death of l'ericles, +29 lic: The rise of demagogues.

Spartans forced to surrender, t25 1..C:
27. The Beginning of the War. - The great war between Athens and Sparta, for the headship of Greece, the Peloponnesian War, began before the death of Pericles. Its immediate occasion was the defeat inflicted on Corinth by the Athenians in support of Corcyra, a colony of Corinth at war with the mother city. Other incidents, like a commercial decree of Athens against Megara, hastened the decision which was taken by a congress of the Spartan allies about the beginning of $43 \mathrm{I}$ li.c.

When the war began, Athens had an orerwhelming force on the sea, and Sparta on the land. It was thus difficult for either to strike a decisive blow. This fact gives its character to the first period of the war, which lasted ten years. Athens chring the most of this time suffered more than Sparta. An army laid waste Attica every spring, and though it could not successfully attack Athens, the city, crowded with refugees, suffered severely from pestilence. In turn Athenian fleets ravaged the coasts of the Peloponnesus and inflicted what damage they could on Sparta and her allies.

The death of Pericles was a great loss to Athens. No real statesman rose to take his place, and the democracy, growing constantly more selfish and passionate, began to listen with more favor to the demagogues who flattered its prejudices but could not lead in the adoption of any far-sighted policy. 28. The Close of the First Period. - In the seventh year of the war, the Athenians gainerl a decided arlvantage. Pylus, a point on the north sicle of the bay now called Nav- 


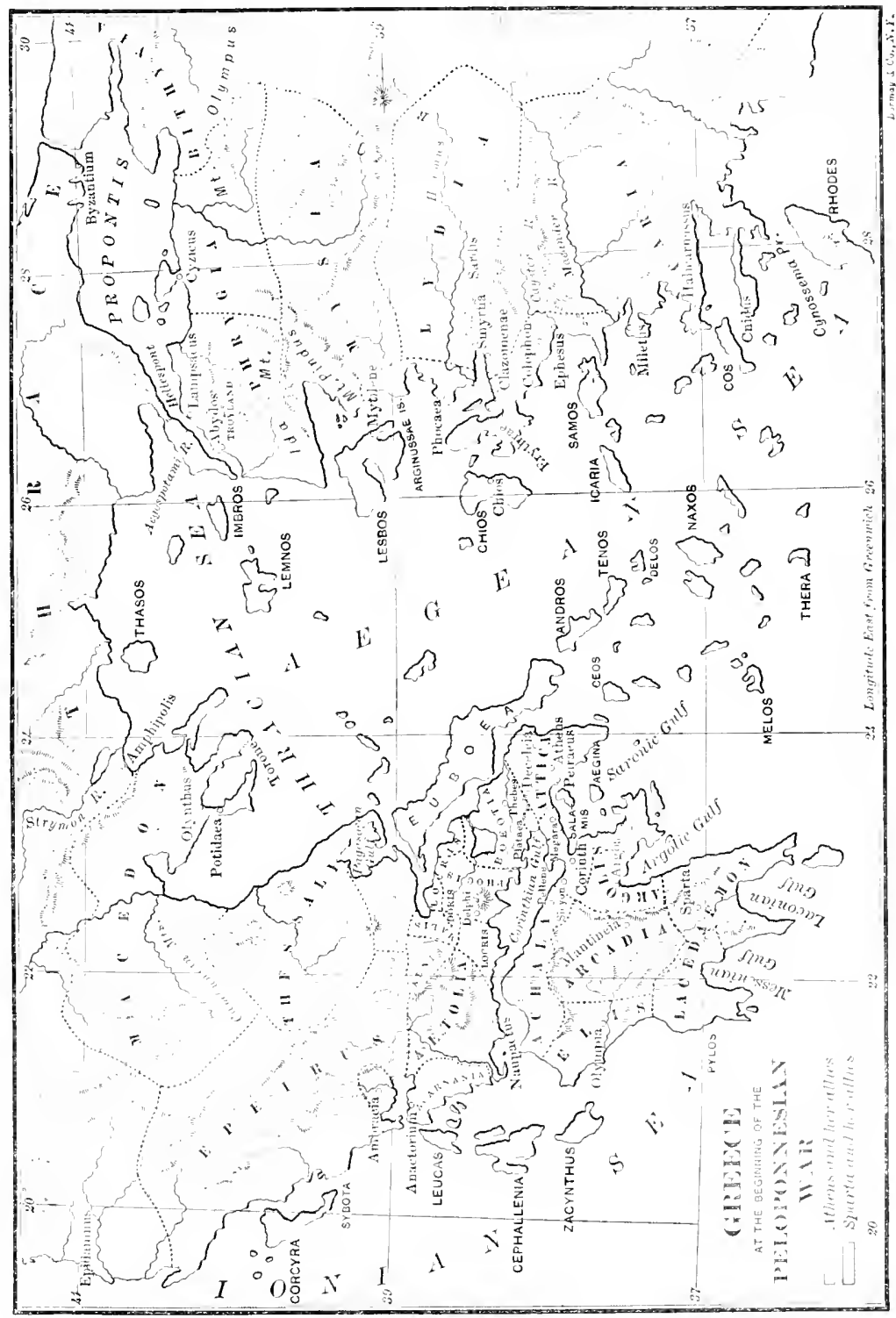



arino, was seized and fortified. A force of Spartans, who had landed on the island which closes the mouth of the bay, were then first blockaded, and finally defeated and forced to surrender. 'This act, so contrary to the Spartan reputation, made a profound impression throughout Greece.

Athens could now have made peace on very favorable Athens' conditions had she been willing. It was a serious mistake that she did not do so. She was defeated the next year in the great battle of Delium in Buotia, and rebellion, supported by the Spartans, destroyed her empire in Thrace. Then she was ready to end the war. In the spring of $42 \mathrm{I}$, the Peace of Nicias was concluted for fifty years. By its terms conquests were to be restored by both sides, as if things could be put where they were before the war.

29. The Sicilian Expedition. - As this peace settled nothing, it was not likely to last out its fifty years. The second period of the war was not, however, in form a war between Athens and Sparta. Alcibiades, a young man of all brilliant and popular gifts but without character and of boundless ambition, persuaded the Athenians to send an expedition to Sicily at the invitation of the Egestreans. It was an attractive plan. A successful struggle with Syracuse, a Dorian colony and the ruling city of Sicily, would give the Athenians as rich an empire in the west as they had in the east, and make them masters of the whole Mediterranean Sea.

It was determined to send a great fleet and army, with Alcibiades as one of the commanders. He was not destined, however, to reach Sicily. While yet on the way, he was summoned home to stand trial for acts of impiety and sacrilege with which he was charged. He managed to escape, and for many years rendered valuable services to the enemies of Athens.

Whether or not the expedition would have been successful if he had continued in command, cannot be $s^{\circ} \mathrm{d}$, but certainly it owed much of its failure to bad generalship. At first the Syracusans despaired of successful resistance. But the

Alcibiades.

Peace of

Nicias, $42 I$ B.C.

The expedition to Syracuse, 4 I5 li.c. Holm, II. Chap. XXVIJ., Freeman, Sicily, Chap. VIII. (Nations).

The loss of the Athenian fleels and armies. Thucydides, VII. $4^{-87}$. 
Athens near to ruin, but full of courage.

Church, Callias: A Tale of the Fill of Athens (Novel). The plots of Alcibiades.

He joins the Athenian fleet, 4 II B.C.

The Athe. nians vole to break their own laws.
Curtius, Vol. I II., Pp. 537$5+5$. siege was pushed with little energy. Through an incomplete and unguarded part of the siege lines, a Spartan force made its way into the city. From this time the tide ran steadily against the Athenians, and, though they sent another great expedition, staking almost their whole resources on the issue, in the end their splendid fleets and armies were totally destroyed, only a few stragglers from them all ever returning to Athens.

30. The Last Period of the War, 4I3-404 B.C. - In the third period of the war, the ruin of Athens seemed always near at hand. The Spartans pushed the war with great vigor. Under the advice of Alcibiades, they took up a permanent station in Attica. The allies of Athens began to revolt. The Persians sent their assistance to the Spartans. But still against such odds Athens showed a most determined spirit and surprising resources. She soon had a large fleet on the sea, and made it evident that she could yet hold her own with Sparta.

After a time Alcibiades, who had been obliged to flee from Sparta, persualed the Persians to adopt a neutral policy, and began to make plans to get recalled to Athens. One result of his plots was an aristocratic revolution in the city by which the oligarchy of the Four Hundred was established in power, but the fleet refused to recognize them, and they ruled for only four months. The fleet, however, took the responsibility of recalling Alcibiades, and for three years the Athenians were almost constantly successful.

31. Declining Respect for Law in Athens. - An inciclent of the year 406 shows how thoroughly the Athenians had learned from the demagognes ideas which are the destruction of all self-govermment. At the battle of Arginusæ little effort seems to have been made by the commanders to rescue from the disabled vessels the survivors or to secure the bodies of the dead for burial. This excited the anger of the people at home, and in a moment of passion they condemned all these officers, six in number, to death at a single vote. It was contrary to a fundamental law of the 


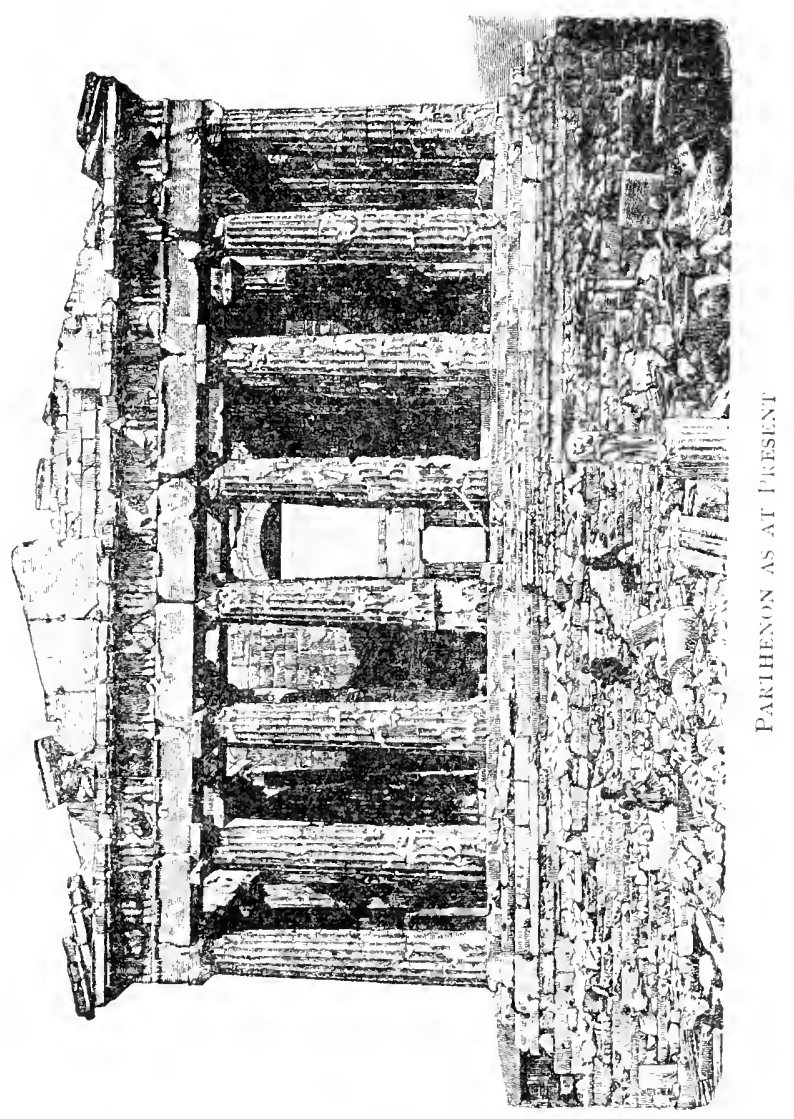


The last Athenian fleet destroyed, to5 B.C.

The walls of Athens destroyed, 404 b.c.

Spartan rule was severe.

Sankey, 7he stortall and The bat

Supremacie's (Epochs). Character of the next age.

The Spartans establish oligarchies. state to condemn more than one man in a single vote, but they brushed aside the protest of Socrates and others on the principle that the people made the law and they have the right to violate it if they choose.

32. Fall of Athens. - The next year the whole Athenian fleet, collected in the Hellespont, was surprised by the Spartans while in a defenceless condition, and of $\mathbf{r}$ So ships only about a dozen escaped. This meant the fall of Athens. She could build no more fleets, and she could soon be starved into surrender when the importation of grain was cut off. Slowly the Spartan fleet drew near, taking possession on the way of the islands allied with Athens. There was no need of haste. The resources of Athens were exhausted. She stood as long a siege as possible, but famine compelled her to yield.

The long walls and the fortifications of the Peiræus were destroyed to the flute playing and dancing of the Greeks, foolishly rejoicing at the overthrow of the only state which, had she remained powerful, conld have saved Greece from her later misfortunes. The fall of Athens was really due, however, to her own lack of political skill and self-control; for she shared, though to a somewhat less degree than others, these fatal defects of the Greek race.

33. The Supremacy of Sparta. - The Peloponnesian War left Sparta supreme. Her hand was found, however, far heavier than that of Athens, and she proved even less capable of moulding the Greeks into a common nationality. The sisty years which passed before Macedonia became supreme were years of civil strifes, revolutions, and petty intrigues, and of a declining civilization. 'The brilliant days of Greek independent life were over; the days were coming on when Greek civilization was to be carried over the whole Eastern world, but only by a half-barbarian despot who forced the Greeks to that unity and foreign dominion which they could not acquire themselves.

True to their own ideas, the Spartans established oligarchies wherever they came. In Athens the "Thirty" over- 
threw the constitution and held power through a few months' reign of terror and blood, when the democracy was reëstablished by a successful revolution. But one of the first acts of the restored sovereign people was to put to death the philosopher Socrates in a moment of mob passion, bitterly regretted afterwards.

34. The Invasion of Persia by Cyrus the Younger. - Meantime the Greeks had learned, through the expedition of Cyrus the Younger, the great superiority of their troops to the enormous armies of Persia. Cyrus had attempted by the aid of a few thousand Greeks to overthrow his brother, Artaxerxes, and make himself king of Persia. His little force defeated the great Persian army, but Cyrus was killed. The story of the march of the Greeks and of

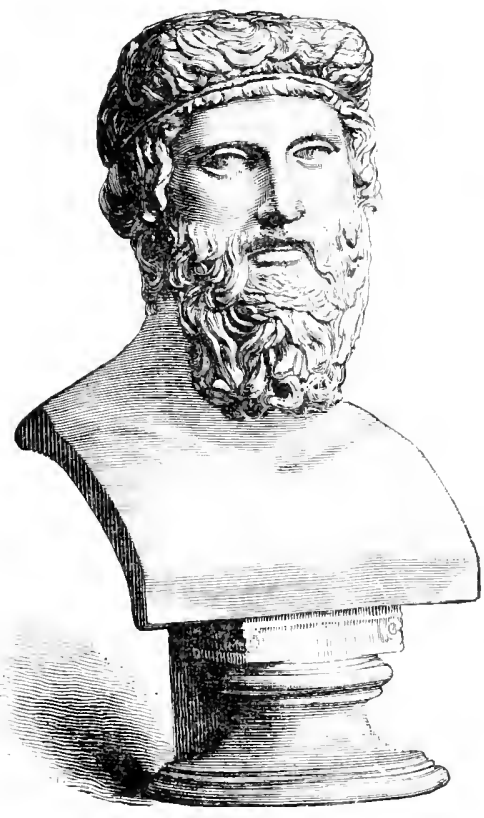

PLATO
$\mathrm{H} \cap \mathrm{lm}, \mathrm{II}$. Chap. XXX.

The death of Socrates, 399 B.C.

The expedition of Cyrus the Younger, for B.e. Holm, II I. Chap. I. the retreat through Armenia to the Black Sea is told by Xenophon, an Athenian in the army, in one of the most interesting of Greek books, the Anahasis.

35. A New Persian War. - Sparta was the first to attempt to profit by this lesson. She determined to make war on the hereditary enemies of the Greeks, hoping perhaps to regain something of the popularity she was conscious of losing through the harshness of her government. Some successes were gained at first, but Persia intrigued in Greece

Sparta atlacks I'ersia, 399 B.C.
The battle and the death of Cyrus, Xenophon's Anabasis, I. 8. 
Rebellions in to arouse the enemies of Sparta against her. Thebes first Greece. took arms, and was soon joined by Athens, and even by Corinth and Argos, so long allies of Sparta.

The wargoes In the war which followed, neither side gained any against Sparta. decided advantage, but the balance fell on the whole against Sparta, in spite of the determined efforts of her lame king Agesilaus. The Thebans learned the advantage in war of careful drilling and skilful tactics, and their ambition was awakened to succeed Sparta as the ruling state of Greece. Athens regained much that she had lost. Her long walls were rebuilt, a new fleet was formed, and the beginning made of a new Athenian empire in the north of the Ægean.

Peace at the dictation of Persia, $3^{87}$ B.C.

The fall of Spartan power, Holm, III. 93-127.

The death of Epaminondas, $3^{62}$ B.C.
36. The Decline of Sparta. - At last Sparta and Persia became tired of the war and joined to force peace on the other states, so that the Greeks endured the disgrace of a peace dictated by Persia, - the Peace of Antalcidas, - which left Asia Minor to the Persians, and the states of Greece independent.

Sustained by the old enemies of the Greeks, the Persians, the rule of the Spartans was worse than before. Especially was the indignation of Greece excited by her seizure of the citadel of Thebes by taking advantage of a religious festival. Soon the war broke ont again, and it was now characterized by the rapid rise of Thebes. Epaminondas, the greatest of the Thebans, gained the great victory of Lenctra, invaded the Peloponnesus, set free Arcarlia and Messenia from Spartan rule, and defeated the Spartans in another great battle, Mantinea, in which he was himself killed. His death prevented the further success of the Thebans, but Sparta had been ruined, and she never recovered her power even in the Peloponnesus.

\section{Topics}

The real origin of the Peloponnesian War. What incidents led to its beginning? The claracter of the first periol. Athens' first artvantage. The peace of Nicias. What led the Athenians to attack Syracuse? The result. Alcibiales in the last period of the war. The illegal punishment of their officers by the Athenians. The fall of 
Athens. The character of Spartan rule. The death of Socrates. The expedition of Cyrus. Greece makes war on Persia. Civil war in (ireces. Peace at Persian dictation. The fall of Spartan power.

\section{Topics for Assigned Studies}

The character of Alciliades. Thucydicles, VI, -15-1S. Xenophon's Memorabilia, I. 2, 12-28. Plutarch's Life of Alibliades. Grote, Vol. VIl., (hap. LV. Curtius, III. 297-334.

The condemnation of Socrates. Ilatu's Afology. Xenophon's Memorabilia, I., 1 ant 2; IV., S. Curtius, IV., 148-164. Extract from the Apology in Indiana, No. IV.

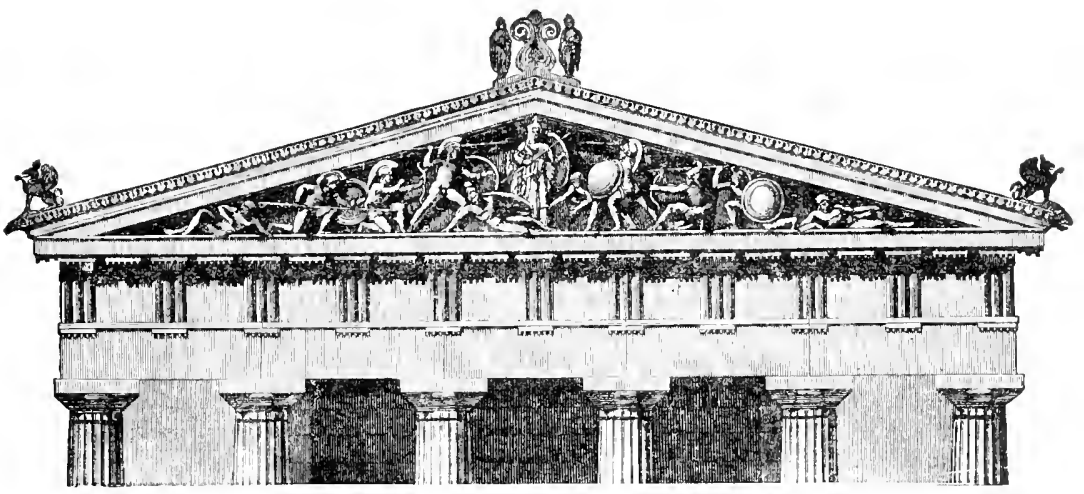

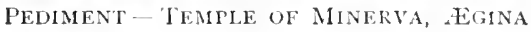




\section{CHAPTER IV}

THE RISE OF MACEDONIA AND THE CONQUESTS OF ALESANUER

Macedonia succeeds to the task in which the other states had failed.

Curteis, The Macedentan Fimpire (Epochs).

The training of Philip for his work.

$3591 . \mathrm{C}$

He first advances into 'Thrace.
37. The Rise of Macedonia. - The rapid decline of Thebes, after the death of Epaminondas, left the way open for a new power to assume the headship of the Greeks. Athens, Sparta, and Thebes, each in turn, had failed to make a Greek nation, or even to unite the race in a common policy. The task in which they had failed was performed by a state which they would hardly recognize as Greek. Its government was that of a strong monarchy, and its success was partly due to its centralization, but chiefly to the extraordinary ability of two kings, whose united reigns covered only a single greneration, - Philip and Alexander of Macedon.

Macedonia lay in the very north of Greece, occupying the territory inland around the northwestern corner of the Egean Sea. The work of Philip was to extend its power to the south, over the whole of Greece. His early experiences harl trained him for success. A hostage in Thebes during the life of Epaminondas, he had observed the divided and incapable policy of the Greek states, and learned the immense value of disciplined troops in war. Returning to Macedonia while still young, he gained the throne in spite of numerous rivals, formed a powerful army, subdued the barbarian tribes of the frontier, and consolidated his kingdom. In a single year after his accession he was ready to begin the extension of his power over the Greeks.

38. Philip's First Steps.- - His first step was to get control of the cities of the northwestern coast of the Egean, and 
of the valuable mines of Thrace. Here he came into collision with Athens, and with the Olynthian Confederacy, a union of the local cities. By diplomacy, as unscrupulous as it was successful, he outwitted both his rivals, and secured the control he desirel. Athens was at the same time weakened by the Social War, a revolt of her allies, whom she had not yet learned to treat with generosity.

The footing thus obtained upon the coast Philip afterwards extended to the complete conquest of the region by the capture of Olynthus, despite the earnest efforts of Demosthenes, who exerted all his eloquence to persuade the Athenians to oppose the plans of Philip with all their might. In the meantime, civil strife in Thessaly gave him an opportunity to interfere there, and finally to extend his influence into Greece.

39. The Sacred Wars. - The central Greek states were at the time engaged in the first of the three Sacred wars. The Phocians, in whose territory was situated the celebrated shrine of Apollo at Delphi, had put into cultivation some land belonging to the temple, contrary, the other Greeks said, to the law. The Amphictyonic Council, a kind of federal council having a guardianship of the Delphic temple, tried to make them pay a fine. This the Phocians refused to do. They seized Delphi instead, boldly converted the treasures of the temple to their own use, and with the forces they were thus able to hire, sivept all before them in central Greece. Philip interfered as champion of the violated temple, at first because the Phocians opposed his policy in Thessaly, and afterwards at the invitation of the Thebans and of the Amphictyonic Council.

40. Philip conquers Greece. - In the third war, fifteen years after his first interference in central Greece, he suddenly revealed his true purpose by advancing to the borders of Bœotia and seizing a post which commanded at once the road to Athens and to Thebes. The Athenians were now convinced, and were forced to lay aside their hostility to Thebes, and to unite with her in resisting Philip. In the

Athens and

Thebes defeated. quest of Olynthus, $34^{8}$ r.c.

Demosthenes.

Brodribb,

De'mesthenes

(Ancient

Classics

Series) ;

Butcher,

Demosthenes

(Ancient

Classical

Writers

Series) ;

Sources in

Indiana,

Nos. 2 and 3 .

The Sacred

War gives

Philip his

opportunity. 
338 B.C.

Greece submits to Philip.

A war of Greece against Persia. The accession of Alexander, 336 B.C. Pluiarch, Life' of Alexinter: T. A. Dodge, Alexanter (Military History, Houghton). The desiruction of Thebes, 335 B.C.

great battle of Chæronea the Macedonian army was completely victorious. The Theban sacred band was slain to a man, and the Athenian army dispersed.

This was the end of Greek independence. A Macedonian garrison occupied Thebes. Athens was treated more generously, but she was forced to acknowledge Philip as the

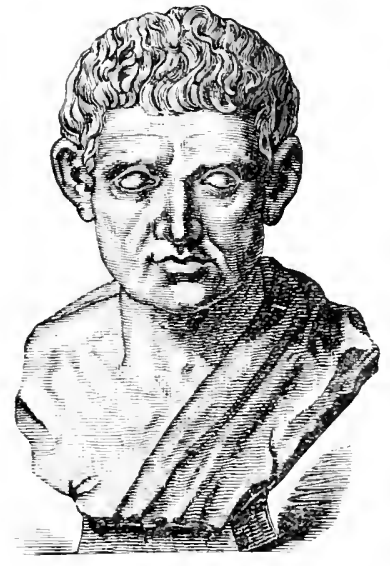

ARISTOTLE head of Greece. The same year a congress of the Greek states was held at Corinth, which formed them all into an organized union with local independence, but with their general policy and their military force under the control of Philip. A common war against Persia was resolved ujon. which Philip was to condluct. But before he could begin the war, lhilip was murdered ly a private enemy.

4I. Alexander takes up the Plans of Philip. - The war of vengeance against Persia, or of ambition and expansion for Greece, which Cyrus had foreshadowed and Philip had planned, was undertaken and completed hy Alexander. He was only twenty years of age at his father's death, but he was equal to the place.

The first morement for independence at Athens and Thebes on the news of Philip's death, he quickly repressed, and when the Thebans took advantage of his absence in the Danule region to revolt, he surprised them by his sudden return, stormed the city, and razed it to the ground. Another congress completed the arrangements for the Persian war, and in $33+$ Alexander was ready to set out.

42. The First Successes of Alexander. - Xerxes invaded Greece with an army which was said to contain millions of men. Alexander began the conquest of Asia with 
$3^{0,000}$ infantry and 5000 cavalry. These were, however, The invasion thoroughly disciplined Greek soldiers. He found the Hellespont unguarded, but was opposed by an army a little further on, at the passage of the Granicus River. This he dispersed in a battle in which he fought in person with most reckless bravery. The victory opened to him the possession of Asia Minor. He passed successfully through the mountains, and found Darius and a great army ready to dispute his further advance at Issus, near the northeastern corner of the Mediterranean. Alexander's victory was complete. The Persian army was scattered. Darius himself barely escaped, while a part of his family was captured together with a large treasure.

Alexander then turned towards Egypt. All the country through which he passed submitted at once, but the great city of Tyre, deeming itself impregnable, refused him admittance within its gates. Alexander determined to punish the presumption of the Tyrians, and though he was occupied nearly seven months with the building of a mole to enable the army to reach their walls, the city was finally stormed. Egypt had no love for her Persian master, and welcomed Alexander as a deliverer. Here he remained during the winter, founding the first and greatest of many Alexandrias, and visiting the shrine of Jupiter Ammon in the desert to get authoritative evidence of his descent from the gods.

43. The Conquest of Asia. - In the spring of $33 \mathrm{I}$, he returned to the direct attack upon Darius. He reached him in September, totally destroyed his army in the battle of Arbela near the Tigris River, captured in rapid succession the Persian capitals, Babylon, Susa, Persepolis, and Eclaatana, making himself master of immense treasures stored in them, and continued on rapidly in pursuit of Darius to the southern end of the Caspian Sea. His hope to take the king alive, however, was frustrated by the murder of Darius by one of the king's own officers.

From this point Alexander continued his march to the

Persia conquered, 33I B.C. of Asia, Holm, $11 \mathrm{I}$. $32 \mathrm{I}-36 \mathrm{I}$;

Translation of Arrian in Bohn. On Alexander's methods of warfare, Fling, Studie's, No. 4 . Alexander's first great victory, 333 B.C. He turns south.

Egypt sulmils. 
Alexander's east, and spent three years in subduing central Asia, going empire in central Asia.

Death of Alexander, 323 B.C.

His empire short lived.

A common Greek civilization throughout the Eastern world.

Rome brought under its influence. as far as the river Jaxartes, conquering also Afghanistan and the right bank of the Indus to its mouth. He might, perhaps, have overcome even central India, but he was compelled to turn back by the refusal of his soldiers to follow him further. The army returned to Babylon along the southern coast of Asia, while a fleet accompanied them by sea. At Babylon, Alexander began extensive preparations for new conquests, but in June, 323 , he died, not yet thirty-three years old.

44. The Fate of Alexander's Empire. - The conquests of Alexander fell apart soon after his death. Very likely he would himself have failed to hold them together, though it was not an unwise policy, if it may be called a policy, which led him to transform himself into a monarch of the Oriental type, and which sought to unite in interest the conquering (ireek with the conquered Persian.

45. Influence on Civilization. - But whether or not Alexander's empire could have been permanent as a political unity, it did establish a cosmopolitan civilization which was as long lived as anything has yet been in history. Throughout all the western Orient there came to be a common language and literature, and a common body of philosophy, art, and science, and to a somewhat less extent the same thing was true of central Asia. The conquests of Greek civilization were even wider than those of Alexander's armies. Greek thought and art long influenced India, were cherished for centuries in Afghanistan, and can even be traced in the farthest East, in China and Japan.

When Roman armies conquered the larger part of the empire of Alexander, they were not able to conquer the civilization or to Romanize the people. They were themselves rather brought under Greek influence. Because of the position which Alexander had given to the intellectual work of Greece throughout the East, she was able to rule a still greater empire through the Romans, and finally, to extend her sway over the Teutonic conquerors of Rome and on to us. 


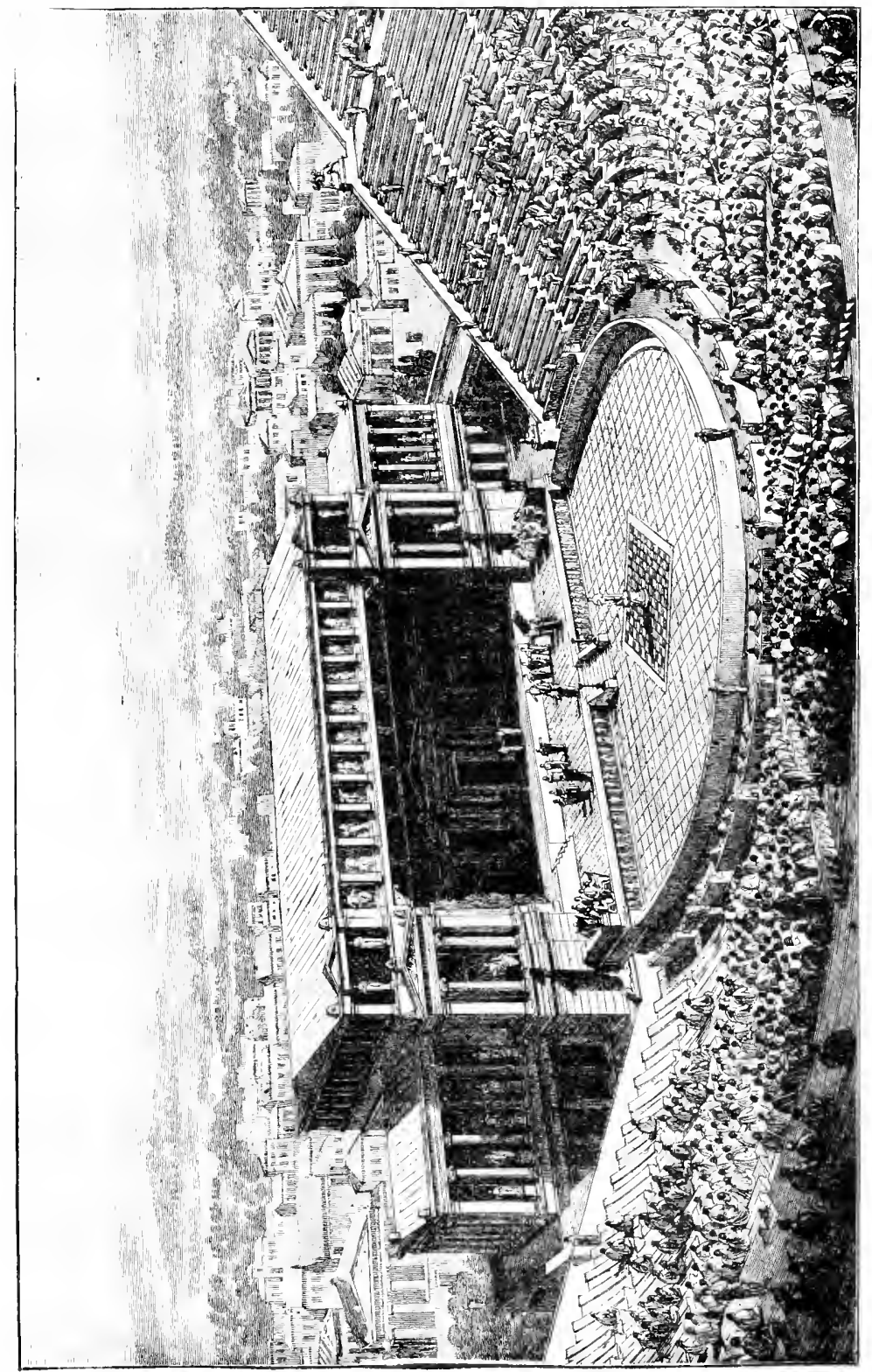


Alexander gave permanence to the work of Greece.

'The Greek stales which succeeded Alexander. Mahaffy, The' Empire of the Ptolimites (Macmillan).

In Greece itself.

The Achaean League. Fling, Studie's, No. 5 .

Commercial inleresls. Mahaffy, Greek Life and Thousht, pp. $33^{\circ}-35^{6}$.
The compulsory union of the petty Greek states, at a slight cost to their independence, gave to Greek thought and ideals a permanent hold upon the world, and made them the common possession of all men. There soon began also a new age of intellectual activity, which may be typified by the science and philosophy, the schools and libraries of Alexandria. Alexander may have been himself a mere conqueror of the crudest type, but the Greeks and all later generations owe him a large debt of gratitude.

\section{The Greek World between Alexander and the Roman} Conquest. - The succession to his empire was left unsettled at the death of Alexander. There was no member of his own family influential enough to secure its interests. His son, born soon after his death, was speedily sacrificed to the rivalries of his generals, and, after twenty years of civil strife, three states emerge which survive until the Roman concurest, and are of special interest to us. These are Macedonia, whose government was subject to many revolutions; Syria and the Euphrates valley under the Seleucidre; and Egypt under the P'tolemies. The farther East broke up into several states, some of which lasted a long time. Rather the most important of these was the kingdom of the Parthians in Persia.

In Greece proper, many of the states maintained a kind of precarious independence, protected from one another ly the interference of Macedonia. Pesides the single states there was a most interesting federal union of the Acham cities, for mutual protection and the conduct of common affairs, which lasted until the coming of the Romans. The naval and commercial power which had once belonged to Athens passed to Rhodes, which long maintained a leadership in an age of much wider commercial relations than earlier Greece had known. The rich goods of Intlia reached the Mediterranean through the Red Sea and Alexandria, or by caravan rontes to Antioch. Even China at one time had a direct connection with the Greek world of this age through the Black Sea. As compared with the 


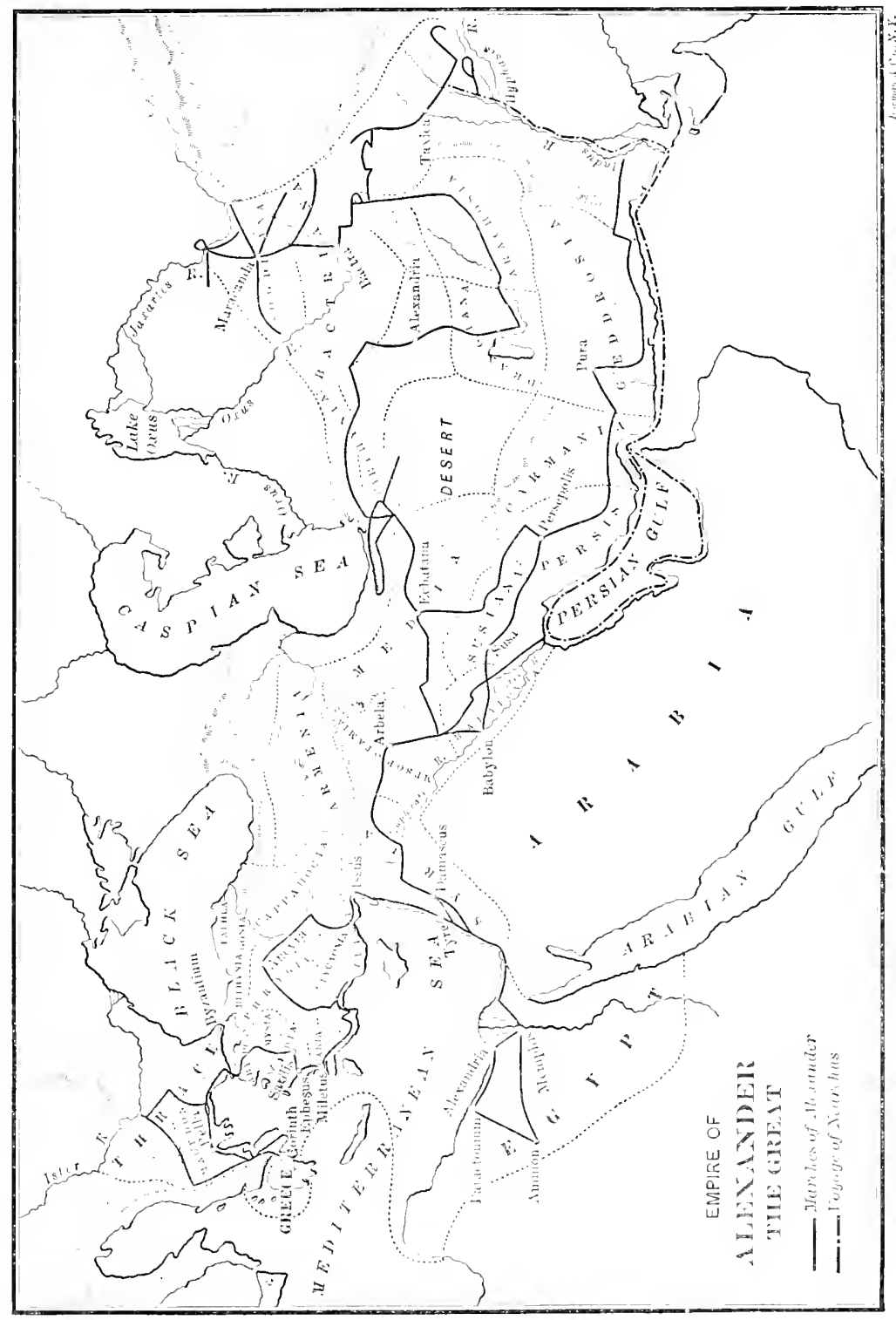



pre-Macedonian period this was a time of great luxury and wealth.

47. The Age Intellectually. - The conquests of Alexander were followed by a brilliant literary age, most of whose productions have been lost, and by an age of art, whose products, as they have come down to us, - the Venus of Milo, the Apollo Belvidere, the I)ying Gladiator, and others, Chap. Xiv.

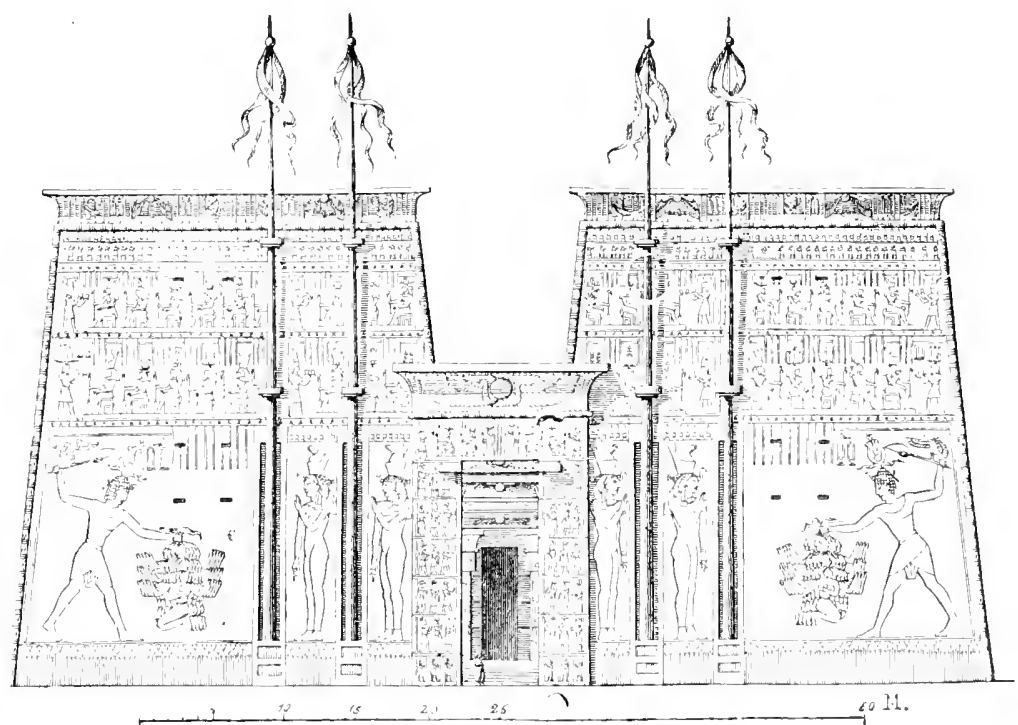

TEMPLE AT EnFU, THM OF THE I' COLEMIES

- the world still admires as among the most beautiful specimens of Greek art. In philosophy, the Epicurean and the Stoic systems were developed, both as speculative philosophy and as practical ethics, the one, in its ideal form, finding the highest good in a noble and high-minded enjoyment of life, the other, in the strong control of all desires and the manly endurance of all evils.

Alexandria

This later Greek world hat at lifferent times three intel- as an intel- This later Greek world had at different times three intel- lectual lectual capitals, Athens, Alexandria, and Antioch. Alexan- capital. 
Mahaffy, Greek Life' and Thought, pp. I60-I99. Interesting scenes from life in Alexandria in Matthew Arnold's translation from Theocritus in Essay's in Criticism, I. 200-208.

A virtual federation of states.

Iria remains to modern times the most typical of the age. The Ptolemies collected there a great library, and endowed a university, the Iuseum, to which they attracted as many as possible of the learned men of the day. In the creation of new literature, the results were not so great as in com-

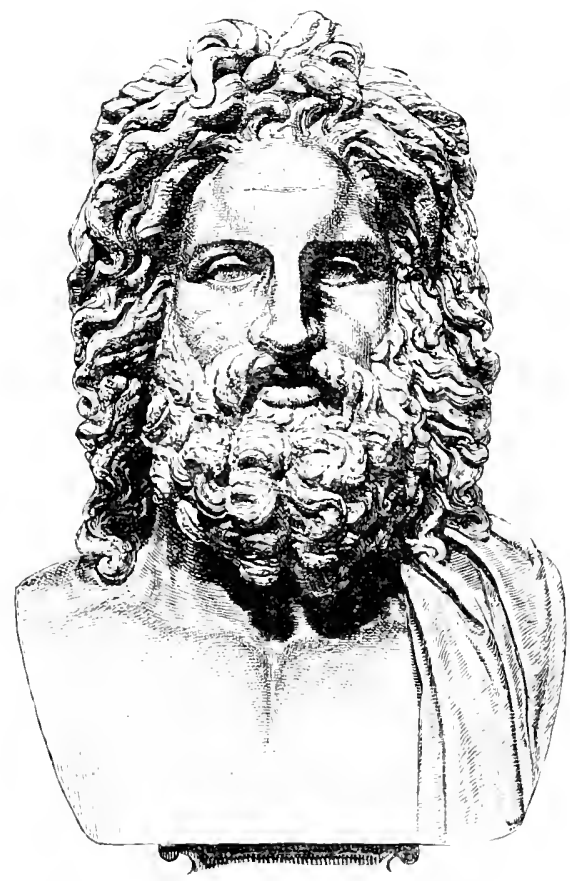

MASK OF TIIE OTRICOLI ZETS, NAPLES ment on the old and in the study of philosophy and the physical sciences. 'The city became the meeting point of all forms of thought from every source, and exerted an especial influence upon the future in the union effected there between Greek and Semitic ideas. One product of this was the translation of the Old Testament into Greek which we call the Septuagint.

48. Condition at the Roman Conquest. - This wis the Creek world as it was when it was conquered by the Romans. The empire of Alexander had fallen apart into a number of independent states, but they were closely held together by common interests, and formed a virtual federation or world system as intimate as modern Enrope. They created a considerable body of international law, and paid much attention to the balance of power. This close connection on the political side was made a real soli- 
darity by a uniform civilization. Language, literature, art, and philosophy were one throughout all the East.

\section{Topics}

The situation and government of Macedonia. Philip's education. His first successes. Opposition of 1)emosthenes. The Sacred wars. The battle of Chæronea. Philip's plan of a war against Persia. The first two years of Alexander's reign. Ilis first battles with the Persians. Trace Alexander's march from Asia Minor to the Tigris. Why did he not advance directly against Darius? Trace the mareh of Alexander east of the Tigris. What parts of his empire now belong to Russia? What to England? The influence of Alexander's conquests upon the later history of the worll. The states which succeeded Alexander. Art and philusophy in this age. Alexandria as the intellectual capital of the world.

\section{Topics for Assigned Studies}

The policy of Demosthenes. The Orations on the Croith. Phatarch's Life of Demosthenes. Grote, XI., Chap. LXXXil. Curtius, V. $467-4$ S2. Mahaffy, Problems in Greek Ilistory, Chap. VIl. Holm, III. 235-2So.

The effects of Alexander's conquests. Mahaffy, Grek Life and Thought from Alexander to the Roman Conquest. $11 \mathrm{olm}$, Vol. III., Chap. XXViI. An article, Greck Cirilisation in the East, in London Quarterly Review', Vol. I49, or Littell's Lizing . $t_{5}$, Vol. I44.

\section{Important Dates for Review}

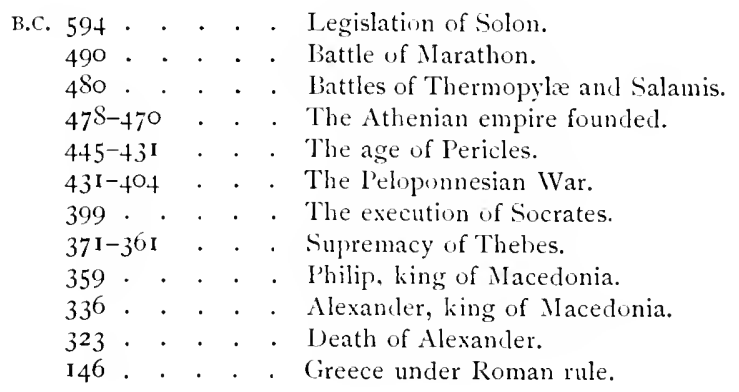





\section{PART III}

\section{THE RISE OF THE ROIHANS}

\section{Books for Reference and Further Reading}

Monmsen, History of Rome. 5 vols. (Scribner; \$10.0o.) Very interesting. Full on the constitutional and social history.

Mommsen. Abridged in one volume by Bryans and Hendy. (Scrib. ner; $\$ \mathbf{I} .75$.)

Thne, History of Rome. 5 vols. (Longmans; 15 sh. per vol.) Carefully critical, especially on the early history.

Merivale, General Kistory of Rome. I vol. (Longmans; \$2.oo. I Iarper; \$I.25.)

How and Leigh, Ifistory of Rome. 1 vol. (Longmans; \$2.0o.)

The best one-volume histories. Merivale goes to $47^{6}$ A.D.; How and Leigh to the death of Casar.

Pelham, Outlines of Roman History, to $47^{6}$ A.1. (Rivington; 6 sh.)

Preston and Dodge, Priz'ate Life of the Romans. (Leach, Buston, $\$ 1.25$.

Cruttwell, Iistory of Roman Literature. (Scribner; \$2.50.)

Mackail, Latin Literature'. (Scribner; \$I.25.)

Roman authors, including the historians of this period and of the Empire, are to be found in translations in the Buhn Library and in Harper's Classical Library.

\section{SumMary}

European history begun by Greece was carried on by Rome. The permanent influence of the Romans on the world was far different, however. from that of the Greeks, for it was not literary or scientific, but political. It was their work to bring together the whole civilized world into one great state. and to furnish this 
state with laws and institutions which have had a most profound influence on all later times. The unity, the world-wide civilization which they established, is also the great underlying fact of all later history. Never since it was first made has it ceased to be. The beginning of this empire of the world was very gradual. At the start Rome was a little city-state like those of Greece, surrounded by others like herself. The first step must be the conquest of these cities, and this goes on for a long time, partly because some of them were almost a match for Rome, and partly because of the constant civil strife going on in the city orer changes in the constitution which were by degrees allowing to the people more and more rights. Hardly had Rome come to be the head of a little state around the city when another long struggle began with the Samnites, who ruled another state of the same kind to the south of the Roman. Before this obstinate struggle was over it involved almost all Italy, and at its close brought the Romans into contact with the Greek colonies of the south. They appealed to Greece for aid. and Pyrrhus, king of Epirus. came to their protection. His armies defeated the Roman, but with such loss that he had to abandon Italy. Supreme in Italy, Rome now stood face to face with the only great empire of the West. that of Carthage. For both, the measuring of strength was a necessity. and the result a matter of life or death. The issue of the first Punic War was not decisive, though the balance of gain lay with Rome. She had become a naval power. had driven the Carthaginians from Sicily, which became the first province, and had forced Carthage to pay an indemnity. In the interval before the second war Rome seized Sardinia and Corsica, and made further conquests to the north, while Carthage. or rather the family of Hannibal, built up a new empire in Spain as a support in the coming final struggle with Rome. From Spain in the second war Hannibal led an army into Italy, where at first he gained great victories, but was later only able to maintain himself, waiting for reinforcements from Spain or for foreign interference. The reinforcements under his brother Hasdrubal were cut off, and the attempted interference of Macedonia and of Syracuse availed nothing. Scipio conquered Spain and then carried the war into Africa. Hannibal was recalled to defend Carthage, but was defeated, and the Carthaginians had to accept the terms proposed by Rome. To complete the conquest of the world there now remained only the states of the eastern end of the Mediterranean, formed in the breaking up of Alexander's empire. These were capable of no real resistance. Macedonia 
was soon punished for her attempt to aid Carthage, and Greece became a virtual Roman province. Antiochus, king of Syria, tried the issue of war but was overthrown. Egypt adopted the wiser policy of friendship with Rome, and became a willing vassal. The empire of the world was united under the Romans, but in the meantime a great change had taken place among the conquerors themselves. Mankind had not yet found out that a clean civil service and official honesty are necessary to the government of an empire. Rome looked upon her provinces as spoils won in war, and her officers thought they had a right to enrich themselves in their offices. Manners and morals among the Romans became rapidly corrupted. and vast wealth easily won pouring into the city completed the loss of character. With the age of the Gracchi there opened the period of the demagogues. The people were taught to sell their rotes, not for individual bribes but for valuable gifts to the masses as a whole. They were taught to yield to the passion of the moment, to disregard the laws and the constitution if they stood in the way of the gratification of their passion, and to worship the hero of the hour and to follow his lead without question. All this was preparation for the absolute rule of one man, and it quickly came. Nearly a century was spent in civil strife or actual civil war before the Republic finally fell. The first war was between Marius and Sulla, during which Marius ruled the city like a tyrant for a little time while Sulla was absent in the east, as did Sulla for a longer period after his return. He soon voluntarily surrendered his power, however, and left the way open for a new civil war between Caesar and Pompey. Casar's victory virtually brought the republic to an end, though after his murder there was another civil war among the rivals for his succession. In this Caesar's nephew Octavius won, and became the first Roman emperor of the unbroken series. 


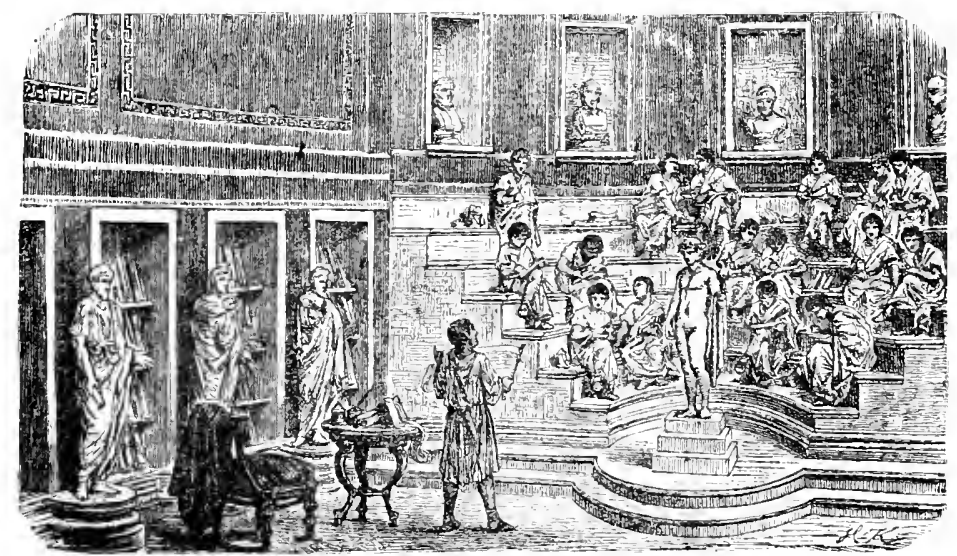

AN OLI, ROMAN SCHOOL

\section{CHAPTER I}

\section{BEGINNINGS ANI CONHITLTIONAL CHANGES}

Rome the successor of Greece.

Differences between the Romans and the Greeks.
49. The Relation of the Romans to the Greeks in History. - During the later ages of Cireek history a power had been growing up in the West which began to come in contact with the Greeks in many ways soon after the death of Alexander, and which was destined to absorb into its empire the world civilization which he had founded, and to be the successor of (ireece in history. This was Rome.

In many ways the Romans were like the Greeks, as we should naturally expect since they were a closely related Indo-European race; in many more, they were unlike them. One most striking difference had a profound effect on the course of history. The Romans had the empire-making capacity in a remarkable degree. Their military talents were great, but these are not so unusual as the power, which the Romans also had, of attaching their subjects to themselves, of centralizing and consolidating their conquests 


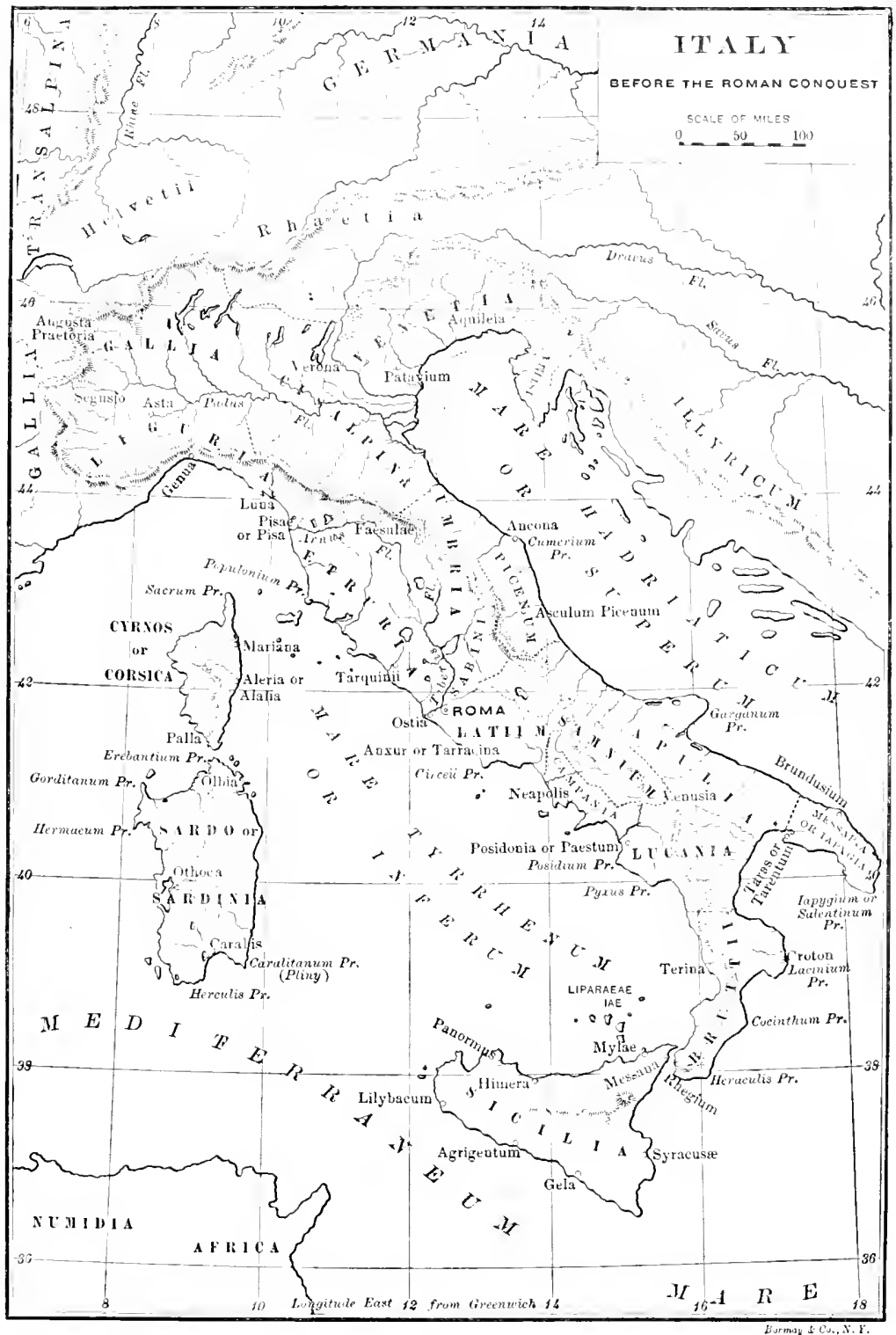




$$
\text { • }
$$


into a single state, and of making the world Roman. 'This power enabled them to continue the work of Greece and of Alexander on a larger scale. The common civilization of the Orient which had resulted from his conquests they carried over the West as well, and the system of balanced states into which his empire had divided, they changed into a political unity which bound the whole world of that time still more closely together.

50. Steps in the Making of the Roman Empire. - Originally Italy was divided into a great number of little states like those of Greece. One of these was Rome. Her first step in the conquest of the world was to overcome her immediate neighbors, small city-states like herself, and to First, the conquest of Italy ; form a larger power by their absorption. 'This growth brought the Romans into collision with confederations of city-states or of tribes, fairly a match in power for the enlarged state. Victory over these gave possession of central and a part of southern Italy. The conquest of the (ireek cities of the south was only delayed for a moment by the interference of an army from Greece. Then followed the first attempt of the Romans to extend their dominion outside of Italy, in Sicily, and this brought them into conflict with the other growing empire in the West, the great commercial and naval power of Carthage. The struggle between these rivals was long and desperate. In the course of it Rome obtained possession of northern Italy and of Spain, and the fall of Carthage made her mistress of the West. There was in the East no power which could long resist the Romans after this, and the conquest of the civilized world was soon completed.

5I. The Geography and Peoples of Italy. - The physical geography of Italy rendered its political consolidation easier than that of Greece. Its mountain system runs in a long chain like a backbone through the whole of the peninsula, and serves to bind together rather than to separate into small divisions. The position of Rome near the centre was also favorable to the control of the whole of Italy.

then of Cirthage and the West;

then of the East.

Italy unlike Greece in physical features. 
The peoples of Italy.

Mommsen, Vol. I., Chap. IX. Ihne, 1. $8 \mathrm{I}-84$.
The founding of Rome. Church, Storie's from Liz'y. Plutarch, Life of Komulus.

Rome under Kings.

Ihne, Eirrly Rome (Epochs).
At the beginning of historical times, the southern part of Italy was occupied by Greek colonies and the northern by Gallic tribes. Central Italy was much divided. The Etruscans dwelt toward the north, a strange race, of great energy, who seem in very early times to have ruled a large portion of central Italy and to have had a very considerable naval power in the western Mediterranean. They were great builders, and apparently much interested in a kind of primitive study of nature. In the very centre were the Latin cities, of which Rome was the most northern, perhaps originally an outpost against the Etruscans. South of them were the Samnites, a shepherd people, loosely united, but of much military power.

52. The Founding of Rome. - The legends which the later Romans told of the beginning of their city - the founding by the twin sons of Mars, Romulus and Remus, exposed to perish but suckled by a wolf; the population of the city by outcasts and robbers; the seizure of the Sabine women to provide wives, leading to a great war and the final union of the Sabines and Romans in one state, - these point undoubtedly to a military origin and to that kind of growth, even in very early times, by union and absorption, which remained characteristic of Rome to the end.

53. The Period of the Kings. - The first period in the history of Rome is, according to tradition, a period of the rule of kings. After the reign of Romulus came that of Numa Pompilius, who gave the Romans laws and organized their religion. Tullius Hostilius, the next king, was a warrior and spread the dominion of Rome over other Latin cities. The territory of the state was further enlarged by the fourth king, Ancus Martius, who also founded Ostia, the port of Rome, and extended the city by a fortified outpost on the north side of the Tiber. Rome then passed under the rule of an Etruscan dynasty. In the reign of Tarquinius Priscus, the first of the new kings, Roman conquests were continued and great building enterprises were undertaken, like the Capitol and the Cloaca Maxima. Under 
Servius Tullius, Rome became the head of the Latin cities; the army and the constitution were remodelled together, the soldier being made identical with the citizen, and the enlarged city was surrounded with a new wall. The third Etruscan king, Tarquinius Superbus, ruled as a tyrant, and the Romans finally drove him ont with all his family, and took a solemn oath never to allow kings in Rome again.

54. Early Changes in the Constitution. - Even if the stories of this early period are too legendary to be considered history, they imply a line of changes in the Roman constitution undoubtedly historical, and in general similar to that in the Athenian, though with many differences of detail. The king of the early state was elected, and his power was limited by a senate or council and by the assembly of the people, called the comitia curiata. The unit of the state was the family, of which the father was the head, with absolute power over slaves and children alike, and also over his clients or dependents, though these were legally free. The heads of families were the paties, and the power which they possessed was the patria potestas of the Roman law. The assembly of the "fathers" formed the senate. The descendants of the "fathers" formed the patricians, who controlled the comitia. Besides the patricians there was also the class of the plebeians, composed of later settlers in the city or of the emancipated clients of the patricians. The plebeians were free men and were enrolled in the comitia curiata, but had no influence upon its decisions. The early state was thus a limited monarchy, with the real power in the hands of the aristocracy. It seems to have been an attempt on the part of the Etruscan kings to make their power more real by the aid of the plebeians which led to their expulsion, and the revolution of 5 ro would therefore be in the interests of the aristocracy.

The first step towards the admission of the plebeians to political power was taken, according to tradition, by Servius Tullius before the expulsion of the kings. He organized a new assembly, the comitia centuriata, in which political The reforms of Servius Tullius.

5 IO B.C. Church, Stories from Liry.

Macaulay,

Lays of Anciont Rome.

The king's power not unlimited.

\section{The}

Patricians.

The

Plebeians.

(1) 
As in Solon's power was given not to birth, as in the old comitia curiata, reforms in Athens.

See p. 26.

Two consuls at the head. Like the two kings at Sparta. but to wealth. This admitted the rich plebeians to a share in the government, but left the poor, the great majority of the order, grouped in a single century with only one vote, while the two richest classes had a majority of all the centuries.

55. The Early Constitution of the Republic. - After the expulsion of the kings the executive power was given to

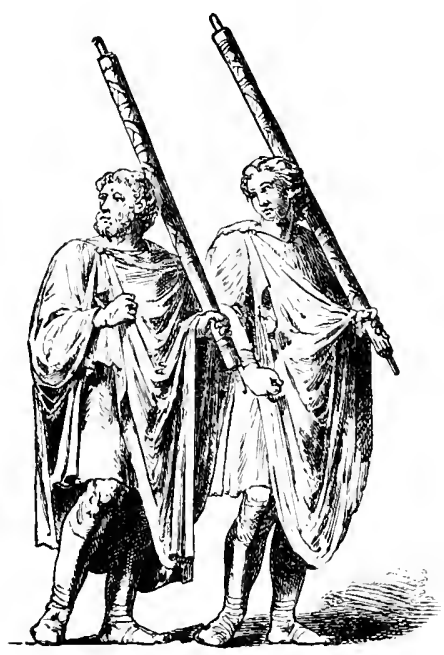

ROMAN LICTORS two consuls, holding office for a year, whose powers were equal and each of whom acted as a check on the other. The difficulty which might arise from a divided command in times of great public danger was avoided, whenever it arose, by the appointment of a dictator, who suspended the constitution and exercised an absolute power, but only for a period of six months. The comitia centuriata elected the consuls and now became the chief political assembly in place of the comitia curiata. The revolution in this way protected the aristocracy from any increase of the executive power at their expense, but did not give to the plebeians any larger share in the government.

Conquest and constitution-making go on together.
56. Rome begins her Conquests. - For something more than a century and a half after the establishment of the Kepublic, the two processes which have already been described went on steadily and together in the history of Rome: the conquest of central Italy, and the gradual making over of the constitution in the interests of the 
plebeians. In the first direction the overthrow of the kings seems to have been followed by a great decline of Rome's power in central Italy. For many years she had all that she could do to resist the attacks of her enemies, the Etruscans on the north, the Aquians on the east, and the Volscians on the south. Abont 490 a new league was formed with the Latin cities which was of great assistance to Rome. It was not until the last part of this century, however, that Rome began to gain decided advantages over her neighbors, and to capture large towns both north and south of the Tiber. The most important of these was the Etruscan city of Veii, which was taken in $39^{6}$ after a long siege.

Soon after this Rome was herself taken and burnt by an army of the barbarian Gauls who had taken possession of north Italy. This was only a momentary check to the progress of the Roman arms. The city was immediately rebuilt and her power restored. About fifty years later her position was so well recognized that the city of Capua, attacked by the Samnites, appealed to her for protection. In granting this request Rome was brought into hostility with a confederation of strong tribes, which had been forming a dominion in the south in much the same way that Rome had been in the centre of Italy, and the struggle began which was to decide the sovereignty of the whole peninsula.

57. The Struggle of the Plebeians for Rights. - In the other direction, the gradual changing of the constitution, the process began almost immediately after the establishment of the Republic, and continued for more than two hundred years, though it was at intervals interrupted for considerable periods. The changes made were due to continued efforts of the plebeians to obtain equality with the patricians. In this process of change there are three wellmarked stages in which different interests take the lead, though others occasionally appear. The first stage was the struggle of the poor for better terms as debtors and for a share in the public lands; the second was the struggle for the publication of the laws, and the third that for the right

Capture of Rome by the Gauls, 390 B.C. Mommisen,

I. 429 ;

Ihne, I. $266-276$;

Livy, V. + I-49.

A long period of constitutional changes. Three stages. 


\section{2

to be elected to public office. Tradition ascribes the first constitutional change to the same year with the formation Rome's of the Republic. This was the passage of the Valerian law, Habeas allowing any citizen conclemnerl by a magistrate the right of

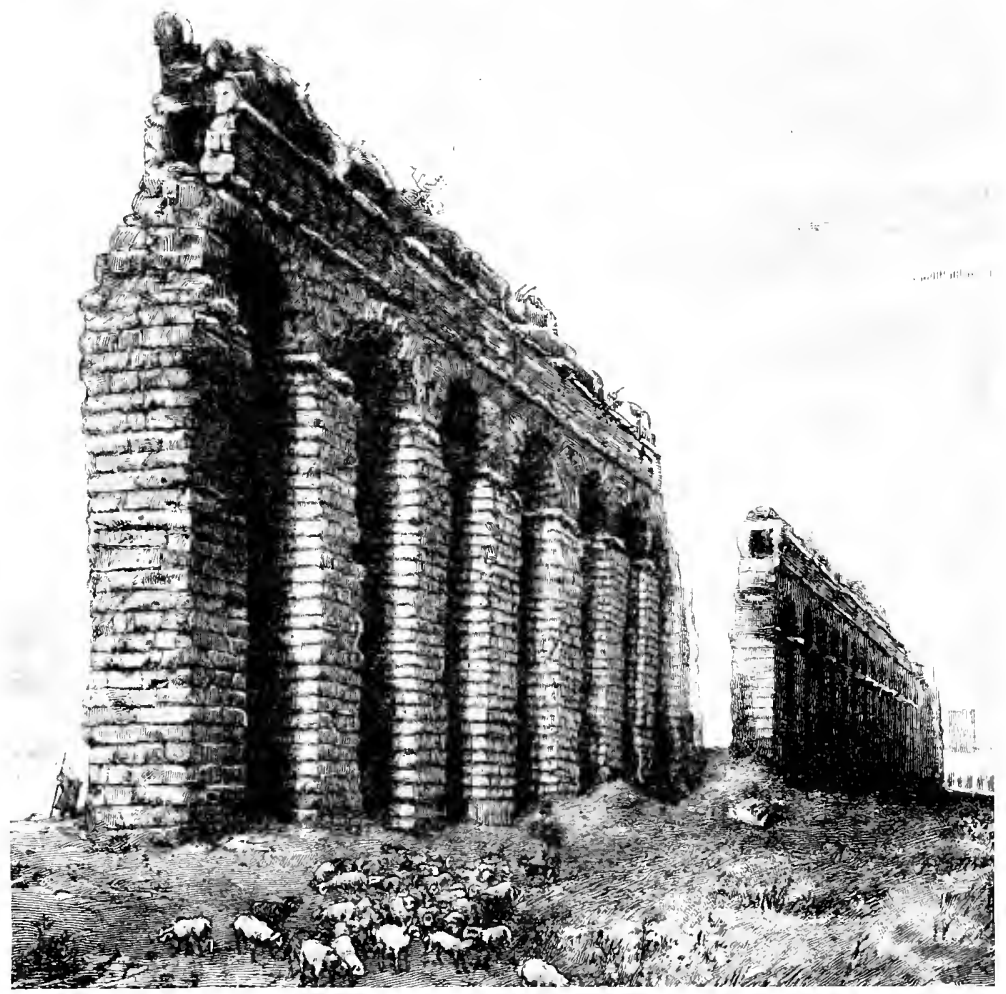

RUINS OF TIE AOUEDUCTS, ROME

Corpus Act. appeal to the people. This law, which had to be reënacted Mommsen, more than once before it was made entirely effective, has I. 320 ;

Ihne, I. I28. been rightly called the Roman Habeas Corpus.

58. The Debtors demand less Severe Laws. - The laws 
of early Rome, framed by the wealthy, were very severe The early toward the debtor, like those of early Athens. They gave the creditor right over the person and family of the insolvent debtor, as well as over his property, and their object was, no doubt, not merely to protect the property of the rich, but also to hold the plebeians in subjection. The increasing number of the plebeians, however, gave them a power which they were not slow to realize when complaints and persuasion failed. In $49+$ the army of the plebeians, returning from a victorions campaign, abandoned Rome, and began to establish a new city on the Sacred Nount, not far away. This brought the upper classes to terms. Some immediate relief was grantesl to the debtor class, and more important still, the plebeians were granted two officers, the tribunes, who were to protect their interests against oppressive acts public or private. The "veto" of the tribune could stop for the time the action even of the consul. About twenty years later the election of the tribunes was vested in the comitia tributa, a plebeian assembly organized upon the democratic principle of equal suffiage. It was long leefore the debtor was fully protecterl by the law against the injustice of the creditor, but the beginning had been made by the first secession. In 486 the equally long process of almitting plebeians to a share in the public lands was begun by the agrarian law of Spurius Cassius.

59. The Struggle against Secret Laws. - The struggle to compel the patricians to put the laws of Rome into writing that they might be known by all, and so in a sense to bestow equality before the law upon all, was a comparatively short one. Ten years of agitation, during which tradition says a commission visited (ireece especially to study the laws of Solon, secured the appointment of "I)cemvirs," who suspended the ordinary magistrates, and were instructed Reform of the laws. See Draco's reforms in Athens, to put the laws into writing. A second year completed their work, which formed a code called the laws of the twelve tables. The extraorlinary power which had been granted to the decemvirs to enable them to carry through

laws favored the creditor, as in Athens.

'The first secession, $49+4$ k.C. Livy, II. 32-33.

The

'Trilsunes.

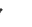


their work, they contrived to extend into a tyranny of something like the Greek type. Tradition fixes the responsibility for this upon Appius Claudius, and relates how his attempt Virginia. to seize the free maiden Virginia as a slave, led to a new Church, Stories from Licy;; secession of the plebeians to the Sacred Mount to force the overthrow of the decemvirs. In securing this they secured Macaulay, Lay's of $\cdot$ incient Rome; Livy, III. $44^{-5}$.

The third secession, $4+5$ B.C.

The censorship.

The victory of the plebeians, Livy, VI. $35-4^{2}$. at the same time other concessions. The Valerian law of appeal was confirmed; all plebeian officers were to be held sacred during their term of office; and the enactments of the comitia tributa were to be treated as binding laws.

6o. The Conflict for Equality in the Offices. - The third struggle, for equality in holding office, began inmediately. In 445 a third secession again forced the patricians to yield, but to avoid yielding in form, the consulship was, so to speak, put into commission, and it was agreed that military tribunes with consular powers, part of whom might be plebeians, should take the place of consuls. At the same time the patricians made a further concession which was a virtual surrender of their claim to an exclusive position in the state - intermarriages between the two orders were legalized. To avoid the consequences of conceding the consular power to the plebeians, the patricians created a new office, the censorship, to which only patricians could be elected, and which was to have the exclusive control of several important matters in which the aristocracy was immediately interested.

But the tide was now running steadily in favor of democracy. One after another the varions offices were thrown open. In 376 the Licinian Rogations were proposed, and carried after nine years of agitation. These decreed the restoration of consuls and declared that one of them must always be a plebeian. Other provisions relieved the debtors and limited the amount of public land which one person could hold. In $35^{6}$ the first plebeian dictator was appointed; in 35 I the first plebeian censor. In 339 it was declared that one censor must be a plebeian, that the legislation of the comitia tributa should be law for all the Romans, and the comitia curiata, which had enjoyed a kind of veto on the acts 
of the other assemblies, was reduced to a mere form by The Roman being required to give its assent in advance. The long conflict was closed by the passage of the Lex Hortensia in 2\$6, which finally made the comitia trituta the supreme assembly.

The conclusion of this long struggle with the victory of the plebeians did not destroy the nobility of Rome. New plebeian noble families rose to take their place beside the patrician families. But it did give the political power in the state to the people expressed through a

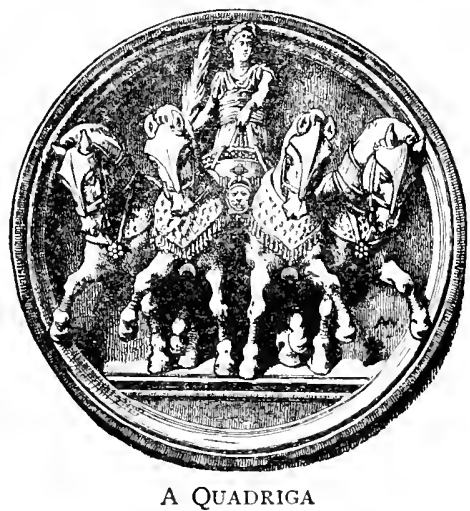

A QUADRIGA constitntion as described by Polybius, VI. II-26, in Fling, No. 6.

The rise of a new nobility, though the laws were democratic. Nommsen, II. 393; Ihne, I. $428-43$ r.

democratic assembly, and the power of the aristocracy in the later Rome was based upon the influence of wealth and position and not upon legal privileges.

\section{Topics}

In what way's were the komans the successors of the Greeks in history? Rome's steps in the conquest of the world. The various peoples of Italy. The situation of kome. Its earliest government. The first constitutional changes. The earliest republican government. The first conquests of Rome. The struggle of the debtor class for more farorable laws. The demand for written laws. What were the differences between the three koman comitia. The opening of all the offices to the plebeians. Result.

\section{Topics for Assigned Studies}

The first secession and the tribunes. Mommsen, Vol. I., 347-357. Ihne, Book II., Chap. II.

The decemvirs. Livy, III. 33-55. Ihne, Dook II., Chaps. IX. and X. Mommsen, I. 36I-369.

The comitia. Iommsen, I. 93-96, 326-329, 360. Ihne, I. 63 , I3 8 , 202-207, 449; IV. 9-42. 


\section{CHAPTER II}

THE STRUGGLE FOR EXPIRE

6r. The First Samnite and the Latin Wars. - In tracing the growth of the Roman constitution to the point where the victory of the plebeians had been secured, we have brought it down to the close of the struggle with the Samnites, and to the eve of the conflict with the Greeks which settled the destinies of Italy. Of the details of these

The history largely legenclary.

Church, Stories frim Lizy.

The First Samnite War, $3+3-3+$ I B.C. wars we know comparatively little. The history of them as written by the later Romans, like that of the constitution, was full of legends in which it is difficult to discern the exact facts. But the legends of military and constitutional history alike reveal the race qualities of the Roman - personal bravery, devotion to the state, contempt of suffering and deith, iron will and relentless discipline - the qualities which made Rome mistress first of Italy and then of the world.

The union of Latium under the headship of the Romans brought them into contact with the Samnites, who had formed a state southeast of Rome in the Apennines and who were now trying to extend their power to the south and west. A struggle for supremacy was inevitable between these two strong military states. The appeal of the city of Capua to Rome for help led to the First Samnite War. This was of short duration and indecisive. Signs of mutiny among the plebeians and of discontent among the Latins warned the Romans that they were as yet in no condition The Latin for a desperate foreign strife. In fact, in the interval beWar, 3.40$33^{8}$ B.C. tween the first and second of these wars, the Latin cities revolted and tried to force the Romans to admit them to 
an equal partnership in the state. But the Romans were victorious, and though the suffrage was granted to some of the Latins, the most were reduced to the condition of subjects.

62. The Conquest of the Samnites. - The Latin IVar was followed by nearly a half century of conflict with the Samnites and their allies, usually divided into the second and third wars, though there was no real interruption. It was in fact a war for the control of Italy from the Gauls on the north to the Greek on the south, and it involved before its close both these peoples in enmity with Rome. The Samnites were not unequal enemies of the Romans. They were kindred peoples in race characteristics and military methods.

About ten years after the opening of the war, the Romans were outgeneralled at the Caudine Forks and their army was forced to surrender. The terms of peace which the commanders accepted were, however, promptly rejected by the Senate, and the officers who had made the treaty were handed over to the Samnites, but they, with more of the spirit of honorable dealing than the Romans, refised to hold their prisoners responsible. Slowly but steadily the Romans drove the Sammites back into the mountains and began even to get possession of these. In the last period of the war the Samnites were able to form a union of all the central Italian states whose existence was threatened by the success of Rome. Samnites, Etruscans, and Umbrians united, and the Gauls lent some aid. But Rome gained the decisive victory of Sentinum, and the league was broken up. This was the last hope of the Samnites, and by 290 the supremacy of Rome was established.

63. War with the Greeks. - A war with the Greeks of southern Italy followed almost immediately. Their cities were mostly without military strength and incapable of resisting Rome. The city of Tarentum, however, had considerable naval strength and was well fortificd. She resolved, therefore, to check the progress of the Romans, attacked

The Second and 'Third samnite Wars, 326-29o B.C.

A Roman army surrenders.

Livy, IX. $2-6,8-11$ Ihne, I. $396-400$. A similar incident in the conquest of Spain. Mommsen, III. 228. Other states join the Samnites.

A quarrel with Tarentum, 282 B.C. 
and drove off a Roman fleet from the neighboring waters, and contemptuously rejected the overtures of peace which the Romans made, perhaps because they were conscious of the danger of an invasion from Greece to aid the Italian Greeks. Tarentum did appeal to Pyrrhus, king of Epirus. He seems to have been ambitions of emulating in the West The plans of the exploits of Alexander in the East and of founding a great Pyrrhus, king of Epirus. Greek empire on the foundation of the Greek cities of Italy recovered from Rome and of Sicily recovered from Carthage. This plan brought him into collision with very different enemies from any that Alexander conquered. What would have been the result of a conflict between the Romans and the army of Alexander it is impossible to say, but the army of Pyrrhus was decidedly inferior to that of Alexander.

The invasion of ltaly by a Greek army. Holm, $H_{l i s-}$ tory 'f (iracie, 11. Chap. Vill.

Pyrrhus landed in Italy in 2 So, and in that year gained a victory over the Romans at Heraclea, and in the next year another at Ausculum, both largely by the use of elephants which threw the Roman horse into confusion. But these victories were dearly bought, and Pyrrhus himself acknowledged that they were almost equivalent to defeats. After an interval spent in sicily, where he gained some success, he returned to Italy and in 274 suffered so severe a defeat that he was forced to retire to Greece. Tarentum could not maint:iin herself alone, and all Italy to the borders of the Gallic territory on the north now passed under the dominion of Rome.

64. The Roman Colonial System. - In the course of their conquest of Italy the Romans hiul brought into use certain political methods for the treatment of their subjects and the securing of their empire which they continued to employ as

Roman colonies were garrisons. their conquests extended over the world. Very early, even before the capture of the city by the Gauls, Rome had begun to plant colonies of her citizens in the subject lands to act as garrisons, and also as a local ruling class. The colonists retained their Roman citizenship, though they were obliged to return to the city to rote. Later, Rome began to plant colonies of another kind, those of the Latin right, 
which did not carry citizenship with it, but did secure large local independence and valuable rights. Of the towns in the subject lands, some were admitted to full citizenship, some received a limited citizenship which gave them equality with the Romans in private law but not the suffrage, and others were reckoned as allies with independent local governments. Rome retained a strict control over all questions of general policy, but allowed very considerable independence in merely local questions.

All the subjects of Rome looked forward to an extension of their rights, and finally to the gift of full citizenship as a reward of faithful services. In the meantime they enjoyed valuable pecuniary privileges from the conquests which they assisted to make, since the duty of military service rested on all. Rome's policy was a liberal one, and from it she reaped many advantages, though it was not always consistently followed. Before the conquest of Italy was complete, Rome had also begun her system of splendid roads by which the empire was finally linked together, and communication with the most distant provinces made easy and rapid.

65. Rome and Carthage, Rivals for Empire. - The conquest of Italy brought Rome face to face with a new and most powerful enemy and rendered inevitable a long and desperate struggle. The Phœnician Carthage was the great naval and commercial power of the western Mediterranean. The western half of the North African coast was under her rule. Her trading stations were scattered everywhere and her commerce extended out into the Atlantic and as far north as Britain. Her wealth seemed exhaustiess and her army, though composed mainly of mercenaries, seemed fairly a match for the Roman army. The odds were against Rome at the beginning of the war. She was comparatively poor, with no extended commerce, depending for the insignificant navy which she had upon her subject cities, and hardly able, it would seem, to use her powerful land forces against an enemy in full possession of the sea. The event proved that in another way the balance was somewhat redressed. The

Rome's

liberal policy, Compare with Athens' policy toward her allies.

The Roman roads.

The power of Carthage.

Church, Carthage (Nations); R. Bosworth smith, $C a r$ thage and the Carthaginians (Longmans).

Rome had less resources, 
but more devoted subjects. Smith, Rome and Carthage (Epochs).

An ineritable contlict.

A crisis in Roman history, and in that of the world. Freeman, Feriods of Eurofidin Histery, pp. $+7-5+$.

subjects of Carthage found her rule oppressive and her mercenary armies were not always to be trusted. Rome's liberal policy on the other hand had attached her subjects to her cause and her armies had a profound personal interest in the result.

66. The Importance of the Struggle. - The conflict was an inevitable one. Two expanding empires had come into contact with one another. Any further advance of the one must be at the expense of the other. Peace between them could only be an armed peace, and for the terrible strain of long-continued and jealous watchfulness with arms in hand the world was not yet ready. That has only been possible in the most recent times.

The position was an especially dangerous one for Rome, with almost no naval power and with a very long and exposed coast line. But this conflict was, in the history of the world, more than a conflict between Rome and Carthage. It was a struggle between the East and the West, between Asia and Europe, between one type of civilization and another. Far more truly than in the Persian wars of Greek history, but not for the last time, the Aryan was called upon to lefend his possession of Europe and the growing civilization of the world against the attack of alien races. Rome savel compact organization and disciplined order, the future foundation of Christendom, when she saved her empire from absorption in that of Carthage.

A strugglefor 67. The First Punic War. - Sicily was the prize conSicily, $26+4_{-}^{-}$ 24 I B.C. Freeman, Sicily, Chap. Xiv. (Nations). Sources in tended for in the First Punic War. Carthage already possessed more than half the island. Hiero, tyrant of Syracuse, ruled in the east, and a band of revolted soldiers, the Mamertines, had seized Messana at the northeast corner and were at war with Syracuse. Hiero appealed to Carthage Fling, No.7. for aid, and the Mamertines to Rome. With great exertions Rome got together a fleet equal in size to the Carthaginian. An ingenious invention enabled the Romans to make up for their lack of naval training. 'They arranged on their ships a great boarding platform so that it could be 
thrown across to the deck of the enemy's ressel and be Rome infastened there with great spikes projecting from the under sicle. By this contrivance, a naval battle was changed in great measure into a land battle.

At first the war went decidedly in faror of the Romans. An army relieved Messana, defeated the Carthaginians, and forced Hiero to make peace. Convinced of the greater strength of the Romans, he remained during the war their successes. faithful ally. In consequence of these successes a consider-

vents new naval tactics, IIommenth, Vol. II., I72 175 ; Ihne, Virl. Il., 50-55.

Roman

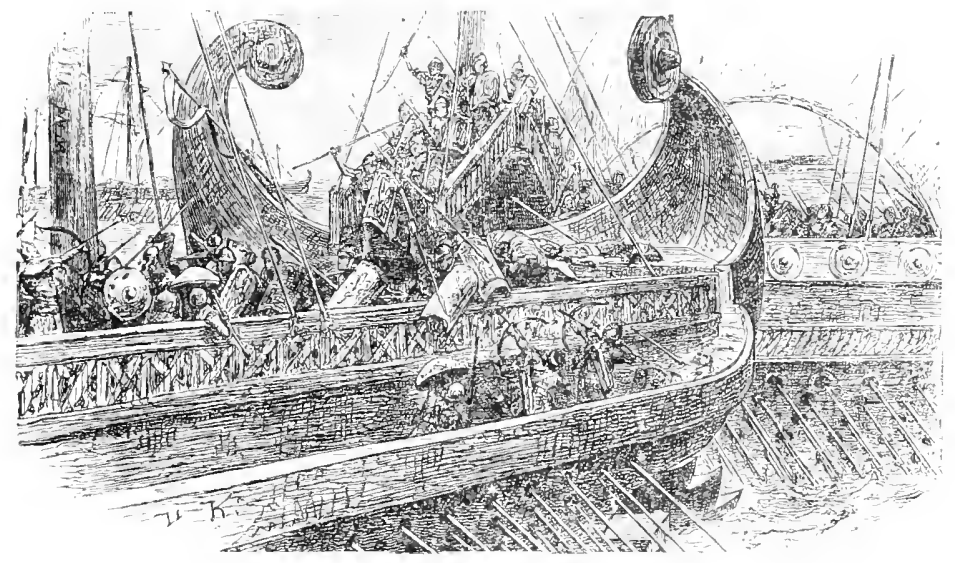

ROMAN TRIREME, WHH BOMRIING BRITGE

able part of Sicily fell into the hands of the Romans. In 260 the new Roman fleet gained a victory over a Carthaginian fleet. In $25^{6}$ another naval victory off Ecnomus opened the way for the army of Regulus to land in Africa. At first this invasion was successful, but the generalship of Regulus was poor, and in the next year the Carthaginians, aided by a Spartan general, Xanthippus, defeated him and forced his army to surrender. From this time the war was without decided advantage to either side. A request of the Carthaginians for peace was rejected, tradition says ly The Romans invade Africa. the advice of Regulus, who returned a prisoner to die 
Roman losses.

Terms of peace.

Preparing for a new war.

Hannibal's plans.

Morris, Hannibal (Heroes). T. A. Dodge, Hannibal (Houghton, Military History).

Livy,

XXI. I-4.

His first victories.

Battle of Canne, 2 I6 B.C. Mommsen, II., 280-29I. Ihne, II. $219-240$. Livy, XXII. t+ 49 . in Carthage. Three Roman fleets were destroyed by storms and only with great difficulty replaced. Finally both states became anxious for a time of peace in which to recruit their strength, and peace was made in $24 \mathrm{r}$. Carthage had on the whole suffered the most and she had to purchase the peace by abandoning Sicily, which now became a Roman province, the first of the provinces, and by paying an indemnity.

Both sides knew that the war was unfinished and employed the interval in gaining strength for a new struggle. Rome seized Sardinia and Corsica, conquered the Gallic tribes of northern Italy, extending her boundaries to the Alps, and took the first step towards the East by subduing the pirates of the Illyrian coast. Carthage, after a desperate struggle with her revolted mercenaries, allowed Hamilcar and his family to build up a new empire in Spain to replace Sicily. 68. Hannibal's Invasion of Italy. - The second war began in $2 \mathbf{2} 8$. The Carthaginian army in Spain was better than any that she had had during the first war, and it was in the hands of the greatest soldier of her history, Hannibal, son of Hamilcar. He formed a bold plan of striking at the heart of the enemy by an invasion of Italy, and succeeded in forcing his way through the Alps against the difficulties of the passage and the hostility of the natives, and arrived in northern Italy with a reduced but still formidable army. Some of the lately conquered Gauls joined him. Three Roman armies in succession were defeated, on the Ticinus, the Trebia, and at Lake Trasimenus. Hannibal then marched by Rome and into southern Italy. His hope was that the subjects of Rome would revolt on the approach of his army, and that he could thus destroy her empire. In this he was deceived. Few joined him even after his overwhelming victory at Cannæ, where the Roman commanders were practically forced to fight by the democracy tired of the "Fabian" policy of the dictator, Q. Fabius Maximus.

69. Rome's Fortunes at their Lowest, and their Turn. Capua, the second city of Italy, now went over to Hannibal, 
with some of the other south Italian subjects of Rome, but the most remained faithful, and Rome herself had no thought of yielding. She organized for a last resistance what force she had. Slaves and boys were enlisted. A

Roman courage. new army was soon in the field and Hannibal was forced to recognize the fact that he could not yet strike the city itself. His victories had been bought with heavy losses. The army which he had created in Spain was growing constantly smaller. No reinforcements arrived from Carthage and his Italian allies were not the most trustworthy or efficient. For twelve years he maintained himself in southern Italy, unable to gain any decisive advantage against the cautious tactics of the Romans, but strong enough to keep the field and await the two events on which he now depended for final success. These were, first, a general war on Rome by other Mediterranean states, especially by Macedonia and Syracuse, and second, the invasion of Italy by a new Spanish army led by his brother Hasdrubal.

70. The Failure of Hannibal's Hopes from without. - The battle of Cannæ had been soon followed by the death of the old ally of Rome, Hiero of Syracuse. His grandson, Hieronymus, went over to the side of Carthage, and though he was assassinated in a few months, the city had still to be reduced and a considerable portion of the island. It was not until $2 \mathbf{2} 2$ that this work was completed, for Syracuse had been strongly fortified and was ably defended by the genius of the famous mathematician Archimedes, but this war afforded no relief to Hannibal.

The Macedonian IVar which began in $2 \mathbf{I}_{4}$ was equally without avail. Philip, king of Macedonia, feared the advance of the Romans in Illyria and he was ambitious of military glory, but he conducted the war with great irresolution. The Romans found allies in Greece itself in the Atolian League, and though the war lingered till 205, it compelled no change of the Roman plans against the Carthaginians.

The failure of Hannibal's hopes from Spain was more
Hannibal isolated and powerless to end the war.

The siege of Syracuse.

Livy, XXIV. 34.

The First Macedonian War, $24^{-205}$ B.C. 
The Scipios tragic. At the beginning of the war the Romans had hoped in Spain.

Hasdruba! invades Ita!y, 207 B.C. Mommsen, II. $3+5-349$; Ihne,

I1. 385-393;

livy,

XXVII.

$4^{6-5}$ I.

His death.

Scipio ends the war.

Battle of Zama, 202 b.C.

to be the attacking party in Spain and to keep the Carthaginian forces occupied there, and the army which had been sent for this purpose kept on its way even after it was learned that Hannibal had crossed the

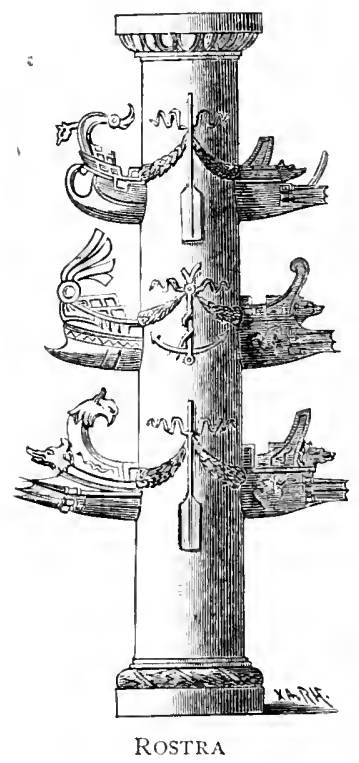
Alps. The Roman campaign was ably managed by the two Scipios, Cneius and Publius, and after their death by the young Publius Cornelius Scipio, son of Publius. For years Spain could spare no reinforcements for Hamnibal and even demanded itself reinforcement from Africa. At last, Hasdrubal seems to have outmancuvred Scipio, crossed the Pyrenees to the west of the Roman forces, and after a long passage appeared in northern Italy. His despatches to his brother from this point fell into the hands of the Romans. The consul Nero, who commanded in the south, with a part of his army succeeded in joining his colleague in the north without the knowledge of Hannibal, and together they fell upon Hasdrubal, and destroyed his army. The head of his brother pitched into his camp was the first news to Hannibal both of his brother's arrival and of his destruction.

7I. The War carried into Africa. - In the same year Scipio practically completed the subjection of Spain. Immediately he began to carry out his plan for transferring the war into Africa, and so forcing Hannibal to return. With difficulty the reluctant sanction of the Senate was secured. In 204 he landed in Africa and within a few months by two decisive victories he had forced the recall of Hannibal. In 202 the final battle of Zama closed the war. 


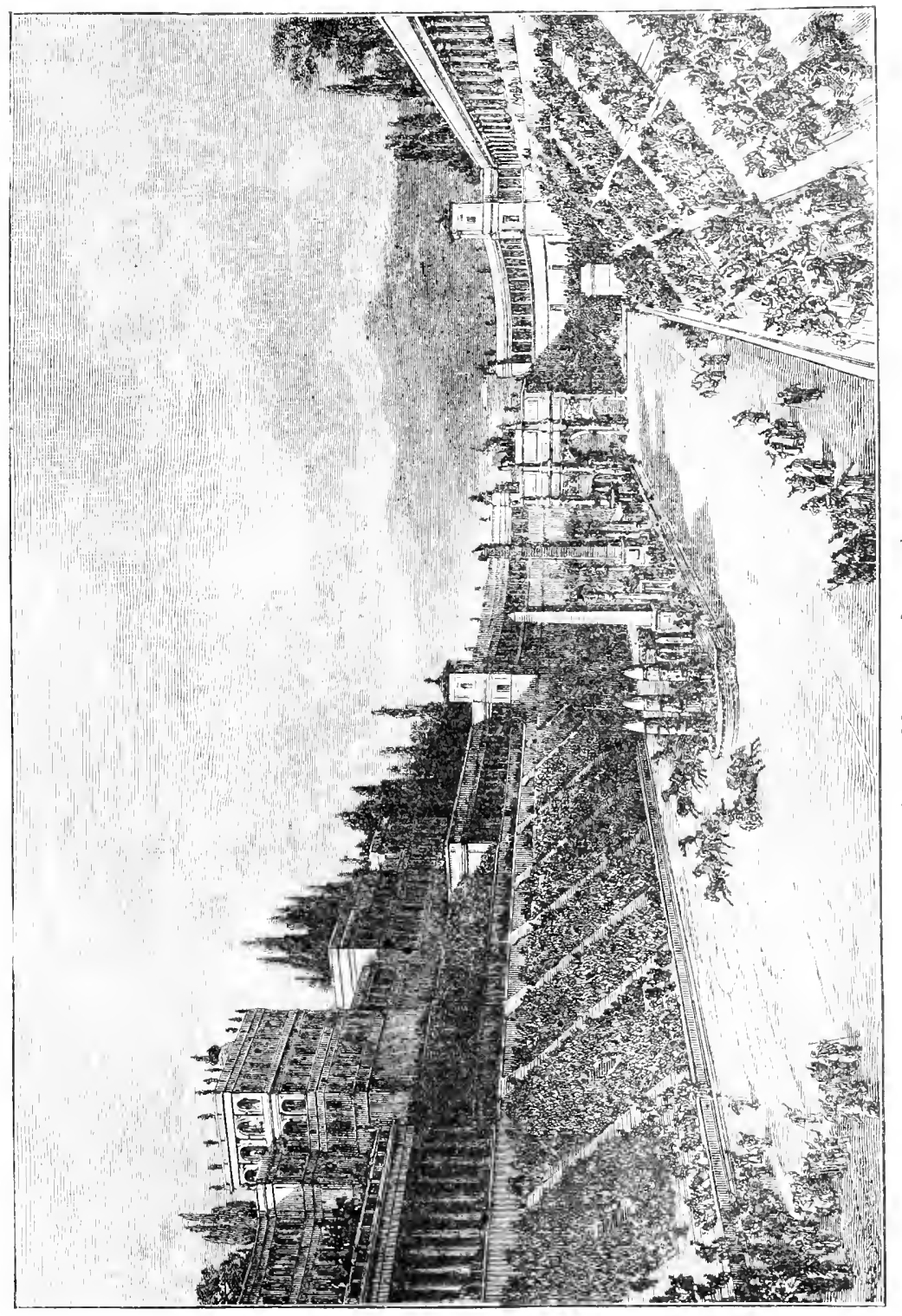


Mommsen, In military skill the two commanders were not unequal but II. 357-361; the superior quality of the Roman army decicled the battle. Ihne,

II. $+49-+53$;

Lisy,

XXX. $32-35$.

carthage

vitually

subject to

Rome.

Rome enters upon a new: age.

Changes in the Koman spirit and character.

Ihne,

IUl. II.,

Cliat?. IX.; Iommsen, II. $366-368$.

Class distinctions become more extreme. Hannibal himself with difficulty escaped to Carthage.

Carthage retained her local independence, but without her foreign possessions and without the power of making a war unless she obtained the sanction of Rome. She surrendered her nary and her elephants, gave up her prisoners and the Roman deserters, and promised to pay a war indemnity of about \$200,000 a year for fifty years.

72. The Effect of the War upon Rome. - Rome had orercome her greatest enemy and was mistress of the West. Spain was in her hands. The province of Sicily included the whole island. Her unfaithful subjects in Italy were heavily punished. The war had moreover forced her into relations with the further East, and this entailed a new policy. Rome had now entered upon the career of empire in which there was no stopping until the whole civilized world was united under her rule.

But equally important changes had occurred during the war and began to show themselves soon after in the spirit and character of the Roman people. Enormous losses had been suffered and at the same time vast plunder had been secured. The losses tended to fall hearily upon the poorer classes. The plunder and the other opportmnities of the war presented the almost irresistible temptation of sudden wealth to the officers and the classes in control of the state. The gulf between the rich and the poor grew wider and wider. Especially did the small farmer, once the strength of Rome, tend to disappear, and the great farms of the rich to spread themselves over the country, tilled by slaves or by the once independent farmer now almost a serf. The city began to fill up with an unemployed mob - the proletariat, - having the right to vote, but having no real interest in the state beyond the satisfaction of the moment's need or passion. Profuse luxury side by side with squalid poverty became a common sight. Foreign manners and modes of thought became fashionable. A smattering of Greek cult- 
ure, which no one tried to make genuine or universal, served only to mark more plainly the distinction of classes. Oriental religions and superstitions made their way among the people, and by their rariety and by the extravagance of their counter claims taught a distrust of all religion. Scipio, by his love of luxury, his support of foreign religions, and his contempt for the forms of law, was a power on the side of decay, especially harmful because of his really great services to the state. His famous answer to a constitutional objection: "If all the Quirites wish to make me arlite, I am old enough," reveals a new spirit among the Romans, a willingness to override the law for the purpose of the moment, which should help us to understand how they came in the end to lose their liberty. Not all these results became evident at once, but the currents had begun to set steadily in their direction, and no statesman arose to tum them aside. Indeed, no statesman could have persuaderl the Roman people, in the full tide of success, of the possibility of any danger ahead.

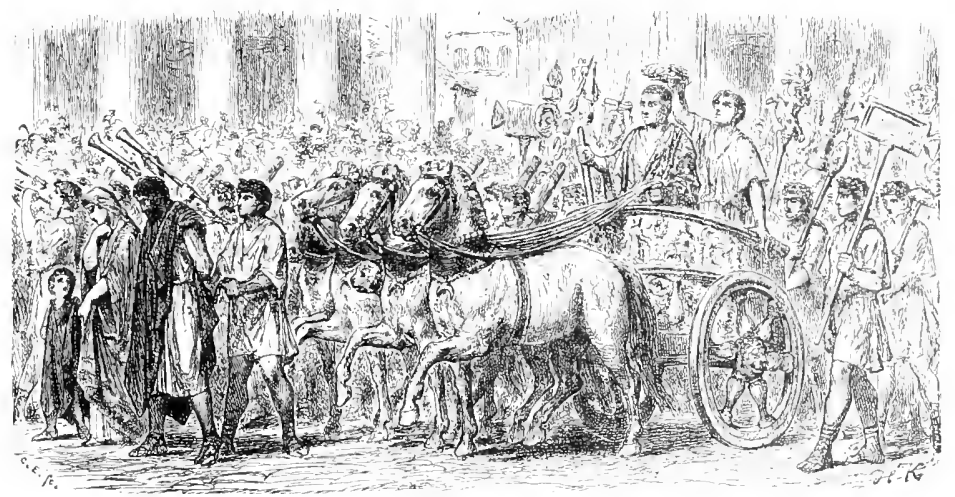

ROMAN CHARIOT - A TriUMif 


\section{Topics}

The beginning of the conquest of Italy. The union of Italy against Rome. The first conflict between Romans and Greeks. The Roman colonies. Rome's policy in the government of her conquests. Compare the resources of Rome and Carthage when the Punic wars began. Why was the struggle ineritable? What was its importance in history? IIow did the Komans gain their first province? Ilannibal's plans and his first successes. What were the causes of his final failure? The fall of Carthage. The effect of the war on Rome's foreign policy. The change in the Roman spirit, socially and politically.

\section{Topics for Assigned Studies}

The position and power of Carthage. Ihne, Vol. II., Chap. I. Nommsen, Vol. JI., Book III., Chap. I.

Ilannibal's passage of the Alps. Mommsen, Vol. II., Pp. 259-265. Ihne, Il. I71-177. Dodge, Hannital, Chaps. XV. and XVI. Livy, AXI. $3^{\mathrm{I}-37}$. Extracts in Indiana, No. 5.

Rome's colonies and sulject communities. Mommsen, I. 438-443;

II. 46-5S. Ihne, I., pl. 54I-549. 


\section{CHAPTER III}

THE EMPIRE COMPLETED. ITS EFFECT ON ROME

73. Ten Years of Rapid Expansion. - The period of Conquests seventy-five years which followed the close of the Second Punic War was the period of the organization of Rome's empire. In the year 200 she was really mistress of the Mediterranean lands, but her rule was not yet undisputed. In ten years more every state bordering on the sea was reduced to the condition of a vassal state.

First the Gallic tribes of north Italy were taken in hand and the Roman frontier carried to the Alps. A rebellion in Spain was put down and the country organized in two provinces. Within four years Philip of Macedon was beaten in the battle of Cynoscephale and forced to make a treaty by which he surrendered all his possessions outside of Macedon, and agreed that Rome should control his foreign policy. The Romans then issued a proclamation restoring their independence to all the Greek states - an independence more nominal than real. The wise steps which the Carthaginians had begun to take towards financial and commercial prosperity excited the fear of the Romans, and they insisted upon the expulsion of Hannibal, who took refuge at the court of Antiochus III. of Syria. Antiochus had now to choose between war and submission. He was not yet ready for submission and invaded Greece apparently with the intention of striking the first blow, but his inferior army was defeated at Thermopylæ, and, pursned into Asia Minor, was beaten again near Ephesus. Antiochus was finally obliged to accept humiliating terms. Hannibal fled to the east and west, 200-I9O 1,C.

Macedon sulbject to Rome.

Greece independent. Mommsen, Vol. II., p. +36 .

War carried into Asia. 
The fate of king of Bithynia, but found he could end the pursuit of the

Hannibal.

Nommsen,

Vol. II.,

pp. $482-+83$;

Ihne,

III. I86-I88;

Livy,

XXXIX. 5 I.

Greece a

Roman

province,

Mommsen,

Vol. III.,

pp. $270-272$;

Ihne, III.

$315-317$;

Holm, His-

tory of Gireace.

IV., Chup.

XIX.

Carthage

destroyed,

Mommsen,

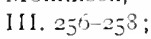

thine, III.

$3^{61-365 ;}$

Plutarch,

Lite of trifio

Emilanus.

The first province in

Asia.

Form of the provincial governmenl.
Romans only by taking his own life. Egypt had already allied herself with Rome in a way that meant practical submission. The whole coast of the Mediterranean was now under the rule of Rome, though she had as yet made no annexations outside of Sicily, Sardinia, and Spain.

74. The Close of Greek History. - Twenty years later Perseus, king of Macedonia, abler than his father, began to take steps towards the recovery of his independence, and brought on the Third Macedonian War, but he was speedily subdued, and the kingdom of Macedonia came to an end. Twenty years later still, Greece again revolted under the lead of the Achran League, but the attempt was hopeless. Corinth was sacked by a Roman army and Greece made practically a province. Just before this date Rome had satisfied her long hatred of Carthage by an unworthy vengeance. The city made a heroic defence, but in vain, and was totally destroyed. About the middle of the century a series of revolts breaking out in Spain, supported by the still unsubined tribes, occupied the Romans for nearly twenty years and were closed by the famous siege of Numantia, which demanded Rome's best general, Scipio Amilianus, the Jestroyer of Carthage. Roman annexations in the further East, as clistinguished from the ruling of vassal states, were begun when Pergamus was left as a legacy to the republic by the last king of that country. 'This territory was made the province of Asia.

75. Abuses in Rome's Provincial Government. - The Roman Republic was more successful in making conquests than in governing them afterwards. Her system of provincial govermment provided for a governor and a staff of officials sent out from the city with practically unlimited powers and held to no real responsibility. Rome continued to allow, as she had in her Italian conquests, a considerable amount of local independence, and her rule brought with it a degree of security never before enjoyed, together with the extinction of war. But these advantages were purchased 
by heavy taxation and financial oppression. Rome sup- Taxation. ported her government and almost her citizens at the cost of the provincials. The method of collecting the taxes increased the burden umnaturally. 'The right of collecting the taxes of a province was sold at an auction in Rome, and the tax collector, or publican, paying to the government a sum in alvance, had the authority of the state behind him in extorting from the provincials enough to cover his investment and such profits as he might consider satisfactory. The temptation to governor and publican to make common cause and divide the spoils was almost irresistible, and, though a special court was early established at Rome for the trial of officers on charges of extortion, the juries were drawn from the class which furnished the governors, sympathized with the accused, and soon showed themselves open to gross bribery.

76. The Abuses affect Rome herself. - The spoil of the provinces poured into Rome through many channels. All citizens shared in it through the relief from taxation. All to whom a special opportunity came made the most of it for their personal gain. The officer who returned from his province as poor as he went out was rare. The corruption of the community which had begun in the Second Punic War went on rapidly in the following century. The rich The corruption of Roman life. were growing always richer and manifesting their wealth in a constantly increasing luxury. The public lands continued to be absorbed into great estates. The poor were falling into a more and more hopeless proletariat. The trenchant criticism of the elder Cato, unaccompanied by any practicable measure of reform, availed nothing. In a very large measure the fall of Rome - the beginning in the state of diseases which progressed rapidly without check - was due to the fact that she could not establish what we should call a reformed civil service - an honest and unselfish government of the provinces, seeking chiefly their advancement and prosperity.

In the home government, before the close of the second G 
Corruption century, the drift had begun, steadily though unconsciously, of the gorermment. towards monarchy. The democratic public assembly of a city coukl hardly in any case manage the govermment of an empire. The Senate, forming a new nobility, half of the old patrician families, half of the new plebeian families who had risen to high office, drew into its hands almost the entire control of the imperial policy and government, while

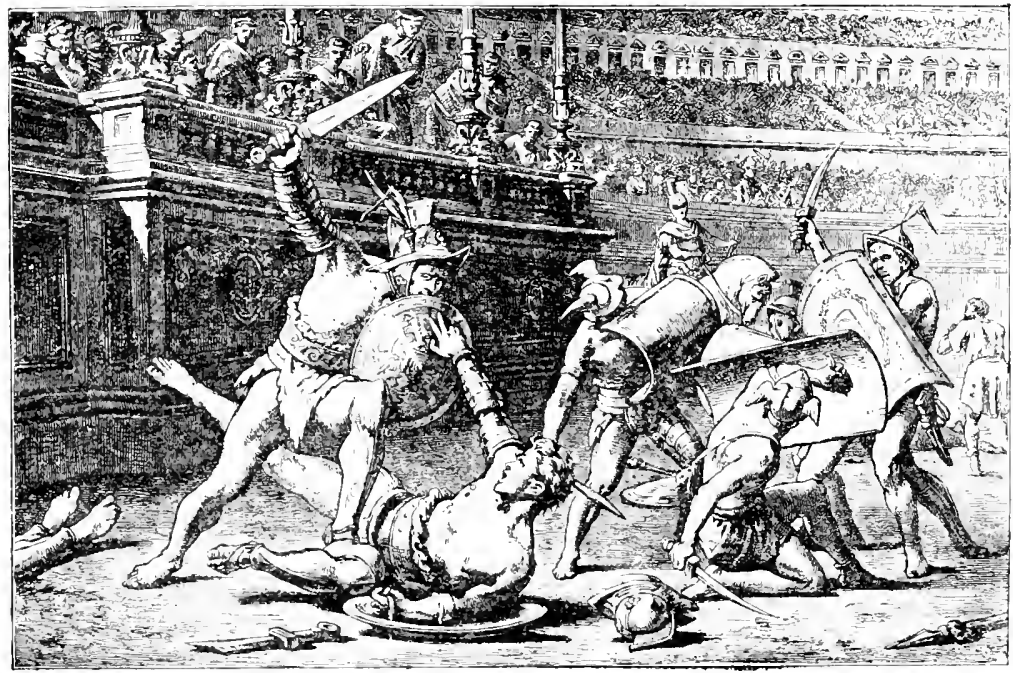

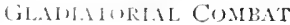

the mass of the citizens occupied themselves more and more exclusively with attempts to improve their economic condition, and to limit the abuses on the part of the wealthy from which they suffered. It was an ideal condition for the rise to absolute power of a demagogue who should feed the citizens with bribes, overawe the Senate, and stand ready to violate the constitution. The especially important thing to notice in the next stage of Roman history is the gradual preparation for the Caesars. 
77. Tiberius Gracchus. - The methods by which the two brothers Tiberius and Caius Gracchus tried to carry through their reforms mark a long step in the fall of the Republic, though this was far from their intention. With the purest motives and the highest patriotism, they accomplished no permanent good, but aided in the further corruption of the citizens and showed the way to future demagogues. The chief object of the reforms of $\mathrm{T}$. Gracchus was to recover the public lands from those who unjustly held them, and to employ them for the relief of the poorer classes of the capital by colonization. This plan of course excited the most bitter opposition, and it was carried at last only in a way which shows how easy it was then, as it is always, in the violence of party conflict, with the best intentions, to inflict an injury on the state more deadly than the evil which the reform would cure. Octavius, the colleague of Gracchus in the tribuneship, interposed his veto to prevent the passage of the law. The act was plainly in the interests of the rich, but it was a strictly constitutional act, and the people had a constitutional remedy by waiting till another election. But this Gracchus was not willing to do, since loy the same constitution he would then be out of office. When his colleague refused to yield to persuasion, Gracchus hat the assembly declare that when a tribune refused to obey the will of the people he vacated his office, and he justified this action on the ground that the people had a right to control their officers. No longer single step was ever taken than this towards the destruction of liberty and the establishment of absolute government at Rome. What could be done for a good cause could be done for a bad one, and angry passion under demagogic lead never makes distinctions. This act meant that the Romans were growing unwilling to govern themselves, and were losing their respect for the institutions which secured their liberty.

78. Caius Gracchus. - Tiberius Gracchus lost his life in a riot excited by the Senate, the first in the series of appeals to force which led in the end to the direct use of the army

The retorns of the

Gracchi. Beesly, The' Gracithi, Marius, and Siullia

(Epochs) ; Mommsen, IBk. IV., Chaps. II. and III. ; Ihne, Bk. VII., Chaps. II. and VI. ; Plutarch, Life of Tiborius and of Cizius Gracchus.

The purpose of Tiberius, I33 B.C.

The tribune Octavius deposed. Mommsen, Vol. IlI., pp. $3^{22}, 35^{6}$. 
Plans of Caius Gracclus, I23 1.C.

to decide political rivalries in Rome. The cause of reform, however, was taken up ten years later by his brother, Caius Gracchus, whose plans were much more extensive and farreaching. This involved not merely the agrarian legislation of Tiberius, but also a reduction of the power of the Senate and an enlargement of that of the people. Our knowledge of the fate of his proposals is not complete, but a consilerable number of them seem to have been adopted at least temporarily. Of one thing we are sure, that in his effort to secure popular support for his measures he resorted to direct bribery of the people in his corn law. 'The state had

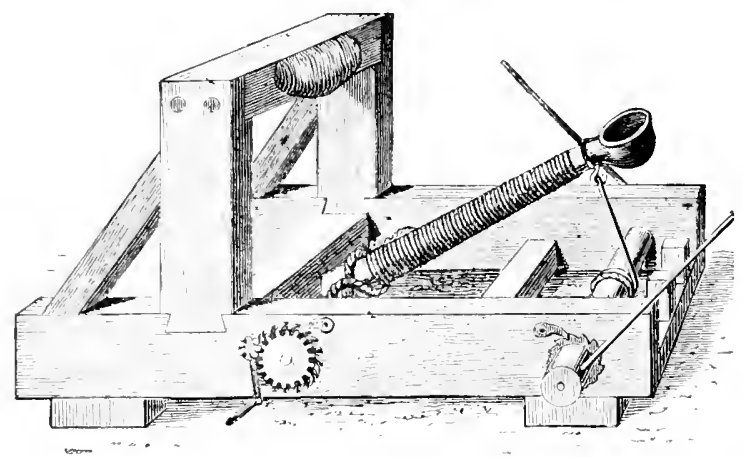

A Baimista, Time of C.ESAR

been for some time selling corn at wholesale prices to citi-

The begin. ning of the distribution of food. zens. Caius proposed to reduce the price to about onehalf the average. Taxation of the provinces would make good the loss. The people of Rome would gain the benefit. If this plan was to aid in the ruin of the small farmer and to drive him into the city to swell the proletariat, Caius probably dicl not foresee it, nor the other natural result that one demagogue would inevitably bid against another till at last the city would be supporting an unemployed mob, a great voting machine run for the benefit of the highest bidder or the moment's favorite, and serving as the foundation of his rule of the state. Cains perished as his brother had of mob 
violence, and his measures led to no permanent reforms, but the age of revolution had opened with bribery, plain violation of the constitution, and direct appeal to force.

\section{Topics}

Rome's conquests between 200 and 190 в.C. The end of independent Greek history. The first province in the East. The character of Rome's provincial government. Effect upon Rome herself, in life and in government. The objects sought by Tiberius Gracchus. By Caius Gracchus. State fully the three steps towards revolution taken in connection with their measures.

\section{Topics for Assigned Studies}

Rome's methods of provincial government. Mommsen, II. 208-2I4; III. 29-35; IV. 157-I66. Ilhne, IV. 197-208. IIow and Leigh, pp. 310-313. Arnold, Roman Provincial Administration, Chap. II. The elder Cato. Plutarch, Life of Cato. Ihne, IV. 324-337. Mommsen, III. 45-55.

Changes and problems in Rome. Mommsen, Vol. III., Book III., Chaps. XI.-XIII., especially pp. IO4-I2S. Ihne, IV., Chap. XII. How and Leigh, Chaps. XXX. and XXXI. 


\section{CHAPTER IV}

THE FALL OF THE REPUBLIC

Both parties too selfish to guide.
The Jugurthine War, I 12-I06 1.C. Sallust, Fusurthu, extracts in Fling, No. 8; Ihne, V., Chap. VIII. ; Mommsen, III. 388-409.
79. No Patriotic Leadership in Rome. - The overthrow of the Gracchi was the triumph of the aristocracy. The Senate was really best fitted to govern Rome in this age of its history, but it was without definite policy except to retain power and to enrich its members, and it proved itself unable to meet the crises which arose, or to prevent the drift towards one-man power. On the other hand the democracy was equally without a policy and without leadership, and became the ready tool of the demagogue, whether he was of the democratic or of the aristocratic party.

80. Jugurtha measures Rome's Corruption. - The events which follow in rapid succession serve only to reveal the universal corruption and the lack of capable leadership. Jugurtha, grandion of Massinissa, the Numidian king and ally of the Romans against Carthage, ambitious and unscrupulons, killed one brother, seized his share of Numidia, and attacked his other brother. One commission after another, sent to arrange matters, returned to Rome heavily bribed. Finally Jugurtha was summoned to Rome and escaped by further bribery there, but venturing to go so far as to murder a rival in the city, he was expelled. The words which he is said to have uttered as he departed: "City where everything is to be bought, awaiting only a purchaser to sell herself," whether spoken by Jugurtha or not, show at least that some one not long after read the case aright. The war itself in which Jugurtha was destroyed is of interest only from the rapid rise of the plebeian soldier 
Marius to the consulship and to a fatal popularity with the Roman people.

8I. The First German Invasion. - Before the fall of Jugurtha, a great danger had begun to threaten Rome from the north, which it required all the real generalship of Marius to repel. The Cimbri, a German tribe, had appeared on the borders of Italy with their families and household possessions, seeking a new home in which to dwell, the advance guard of the great flood of Germans which was in after centuries to sweep away the Roman power. Defeating first one Roman army and then another, they turned off into Gaul for a time, where they were joined by other tribes. Fearful of their return, and believing no one but Marius able to deal with them, the Roman people kept him in the consulship for four successive years. That this was contrary to the constitution did not now seem a serious objection. Finally, having carefully prepared his troops and skilfully chosen his ground, he defeated the invaders in two great battles, the Teutones at Aquæ Sextiæ and the Cimbri near Vercellæ. Marius then returned to Rome ambitious of civil distinctions and by an alliance with a demagogue of the worst type, Saturninus, he secured a sixth consulship. But he was hardly ready to go the length demanded by his associates, and by his hesitation and his vacillation in dealing with the mob he lost the respect and support of both parties, and fell from power.

82. The Causes and Results of the Social War. - In the meantime a danger was coming upon Rome greater than any that had yet threatened her. The allies of Rome in Italy, really her subjects, had long furnished her armies and borne the burden of her campaigns. But they were excluded from the citizenship and so from a full share in the spoils of war. For a generation or more various efforts harl been made to open to them the franchise, but these had all failed. The Roman people seemed determined to keep to themselves the monopoly of their privileges. The last failure, that of the tribune Livius Drusus in the year $9 \mathbf{r}$,

Narius' sixth consulship.

Marius. Nommsen, Vol. III.,

Bik. IV.,

Chap. VI. ;

Plutarch,

Life of

dharius.

The Cimbri and Teutones, I I $3^{-}$ IOI B.C.

The allies demand citizenship. 
left behind it among the allies the feeling that peaceable means were useless, that the reform must be gained by arms if gained at all.

The Social The allies rose in the year following the murder of War, 9०-88 B.c. Mommsen, Vol. III., Bk. IV., Chap. VII. Drusus. Rome was almost surrounded by a chain of rebels. Their army was as large as hers. It was as well drilled and at first better led. So great was the danger of their complete success that Rome at last resolved to make concessions to avoid being forced to yield everything. Near the end of the year the franchise was granted to the Latins and to all the allies who had not rebelled or who had submitted, and the next year it was granted to all who would submit and apply for it within two months. These concessions brought the war to an end except with the Samnites, the old enemies of Rome, who perhaps were fighting for independence, but, though they could prolong the struggle, it was a hopeless one and they were at last forced to submit.

The Romanization of

83. The First Step towards a New Nation. - Roman Italy. citizenship was now open practically to all Italians who wished it, though it must be exercised in Rome. Under this arrangement the various peoples of Italy began to grow into a common nationality, one in feelings and interests. Some independence of local government still remained to them, but they had henceforth larger interests. The triumphs of Rome and her empire were theirs. It was a foreshadowing of the condition of things which Rome was one day to establish throughout the whole civilized world in the common citizenship of the empire and the Romanization of her subjects. It was also in a slighter degree a foreshadowing of the modern nation which the ancient world had never known, with all the population of the state equally members of it, and with no distinction of city and country. This situation was never quite reached in Roman Italy, but the results of the Social War were a long step towards it.

84. Fierce Party Strife. - Marius, discredited by his failures as a political leader, had not recovered himself in 
the Social War, but a new soldier had arisen to popularity The rivalry by success, Sulla, who had acquired his first fame as a anisulli. lieutenant of Marius in the war with Jugurtha. 'The next Buesly, The' stage in the fall of Rome is the struggle between these two for the command in the war with Mithridates.

(i) incilite

H(i) $\cdot i l l, a n d$ sill $/ / \mathrm{ll}$

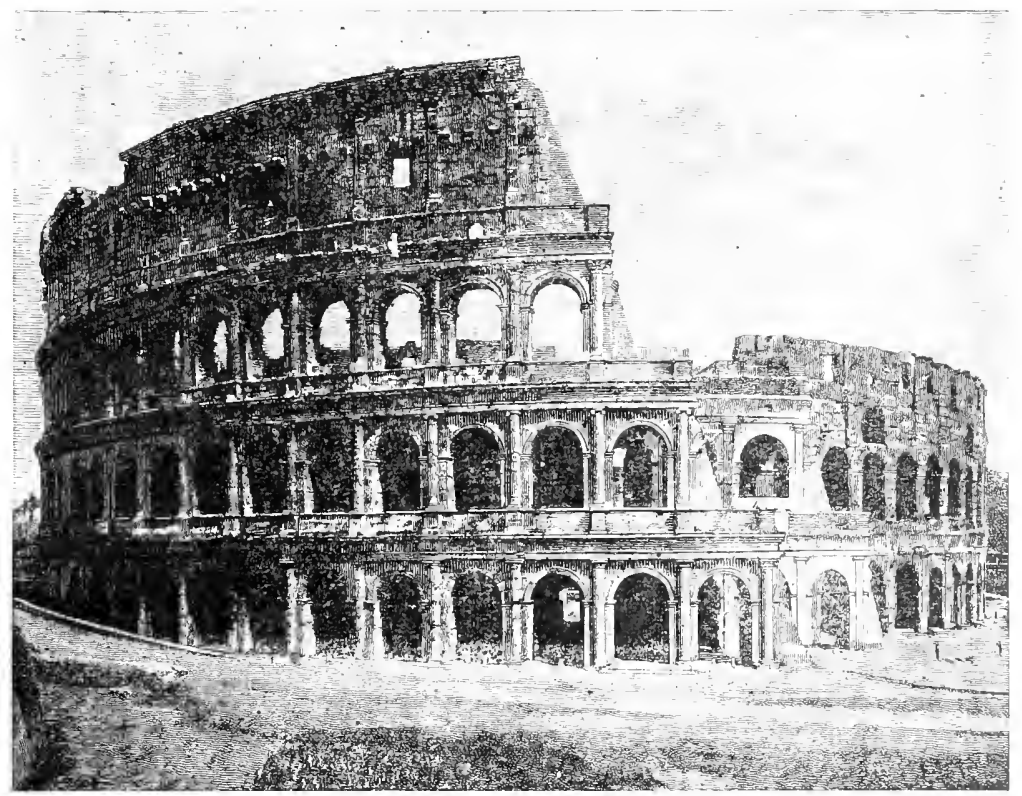

THE CirISELII

The protection of Rome's long frontier entailed upon her a constant succession of small wars with barbarian tribes, and occasionally even small conquests were necessary, as in southeastern (aaul, but for nearly a generation there haul been no foreign war with any strong state. Meanwhile, such a state had grown up in the kingtom of Pontus around the Black Sea. Nithridates VI. had so extended his original kingdom that his interests came into collision with those of Rome and war became inevitable. The Social War was

(Epochs) ; Plutarch,

Life af

Sillit;

Freeman,

Sillht, in

Historical

IEssays,

rol. II.

The kinglum of Mithri-

dates. 
Mommsen, Vol. IV., Chap. VIII.

Sulla's army enters Rome. How and Leigh, Chap. XL.

The military foundation of the emperors' power. not yet ended and Rome was hardly prepared for war when it began. Mithridates rapidly overran Asia Minor, ordered a general massacre of the Italians found there, forced the passage of the Hellespont with his Black Sea fleets, took possession of the Egean Sea, and entered Greece with his armies, where some of the states went over to his side. The heary exactions and oppression of the Romans in the provinces had made the way easy for Mithridates' first successes.

In 88 , Sulla, who was of the aristocratic party of the Senate, was made consul and given the command against Mithridates. After his departure for his army, Marius appealed to the mob and obtained a decree transferring the command to himself. Sulla's army, however, refused to submit. They murdered the officers who brought down the new orders and marched upon Rome. There was no power in the city to resist them. Marius and his party were driven into exile. Some laws were passed to strengthen the position of the Senate, and Sulla departed for Greece to carry on the war.

85. The Army becomes a Political Power. - This was the beginning of a new influence in Roman history. The army had entered politics, and henceforth questions might be decided and power gained in the city by military force. The way for this, which was practically the last step to the monarchy, had been for a long time preparing in the appeals to physical force, to the mad violence of the mob, which go back for their begimning at least to the times of the Gracchi and which had become more frequent of late. Of course, the possibility of such appeals to force rested still further back upon the decline of the early Roman respect for the laws and the impatience with the delay of the constitutional way of doing things which were the ultimate causes of the overthrow of the Republic. If the citizens of Rome had never allowed themselves to do by violence what they could not do by law, the appeal to the supreme force, to the army, would never have been made. 


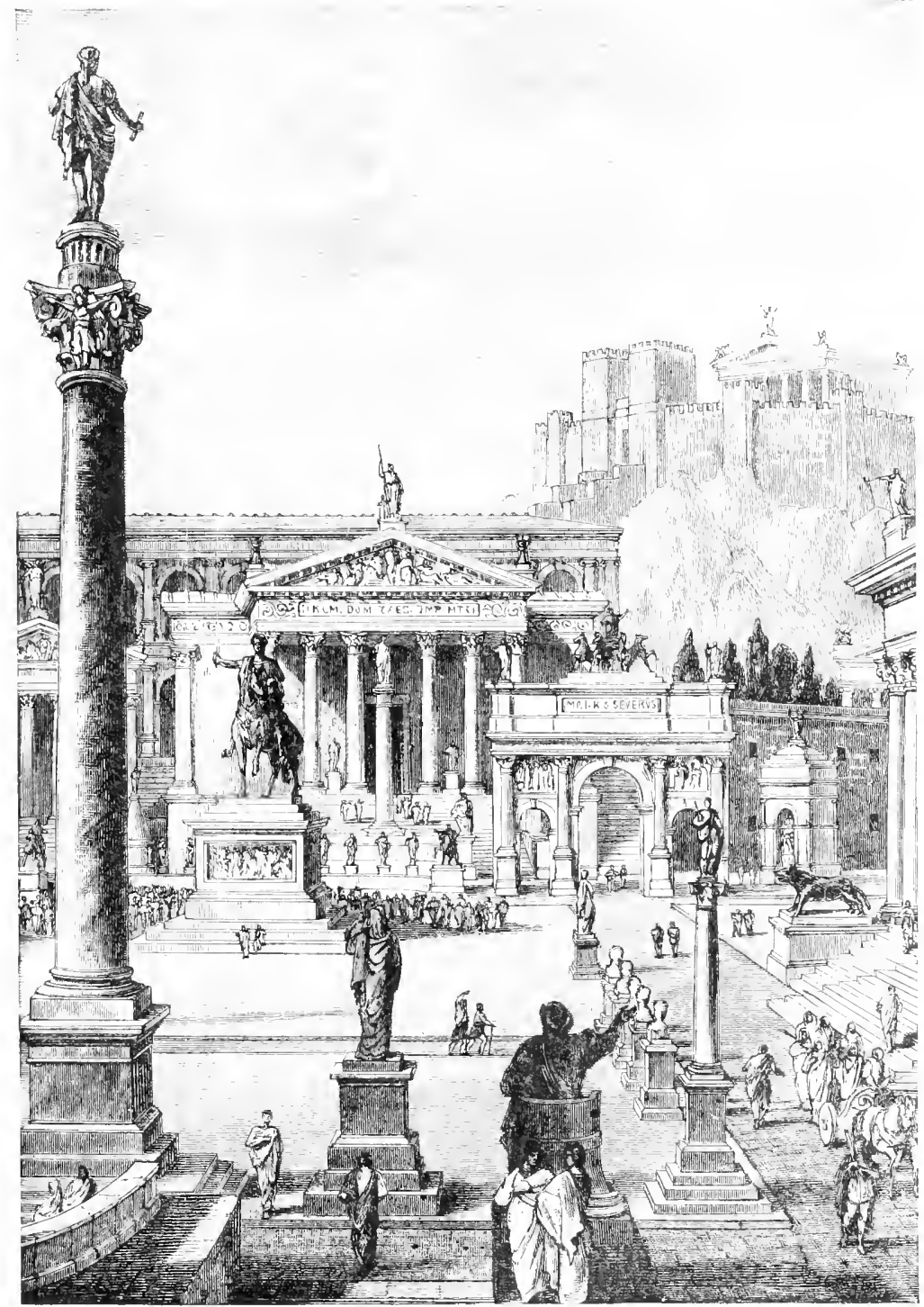

The RUMan Forum ResluRED 
Clange in the eharater of the army.

Seeley, The Great Roman Revolutum, in Romun linferialism (Roberts).

Marius agitin in power.

It should be remembered that by this time the character of the army had entirely changed. The constant warfare and long campaigns, together with the decline of the Roman middle class, had rendered professional soldiers necessary, and had compelled dependence upon allies and subjects for the bulk of the army. Citizen armies no longer existed. The soldier, looking upon the military service as his profession and career, was deroted entirely to his commander, indifferent to the politics of the city, and formed a possible support to despotism entirely lacking in the early history of Rome.

The occupation of Rome by Sulla's army was really the fall of the Republic, but some further time was necessary before the fact was fully realized. The next fifty years, to the final triumph of Augustus, is a succession of contests between individual learlers, settled by civil war, in which success depends upon military genius and the strength of armies.

86. Civil War and the "Proscriptions." - In the course of three years, Sulla defeated the armies of Mithridates in two great battles, and forcel him back into his Asian kingdom. But his departure from Rome had been followel by the almost immediate renewal of civil strife. The consul Cinna, attempting to recall the Marian exiles, was expelled after desperate fighting and illegally deposed. He returned at once with an army, accompanied by Marius, and seized the city. Then followed a systematic butchery of the leaders of the opposite party and a reign of terror in the city. Marius dierl in a few weeks, and Cinna shortly before the landing of Sulla in Italy in $\delta_{3}$, but the position of their party was so strong that the struggle which ended with The retum of the occupation of Rome by Sulla was a real war lasting Sulla, 83 B.C. about two years. Sulla followed the example set him by Narius but in a somewhat more regular way, posting up lists of those who were to be killed, the "proscriptions."

Sulla's

87. Sulla really the First Emperor. - Once in possession retorms. of the city Sulla had himself made dictator without limit of time, to reform the constitution. Under his direction a 
number of laws was passed designed to establish the Senate firmly in the government, to deprive the people of any real control, to render the tribunes powerless, and to take away the privileges of the knights. But Sulla's changes in the constitution were not permanent. After he had carriel them through he laid down his dictatorship to the surprise of the Romans, and retired to private life - a step) which shows how unconscious even the leaders in the movement were of the change which was taking place in the Roman government.

\section{Topics}

Why was there no clear party policy in Rome at this time? What reasons had Jugurtha for his opinion of Rome? The first German invasion. Its effect upon Marius. What did the allies of Rome demand? The result of their receiving the citizenship. The civil wars of MIarius and Sulla. The first use of the army in party strife. II sw hall the way for this been prepared? Where was the kinglom of Mithridates? What were the proscriptions? Were Sulla's measures really reforms?

\section{Topics for Assigned Studies}

The first German invasion. Ihne, V., Chap. IX. Mommsen, III. 430-45 I. How and Leigh, Chap. XXXY'.

Sulla's constitutional changes. Ihne, V., Chap. XXI. Nommsen, Vol. IV., Book IV., Chap. X.

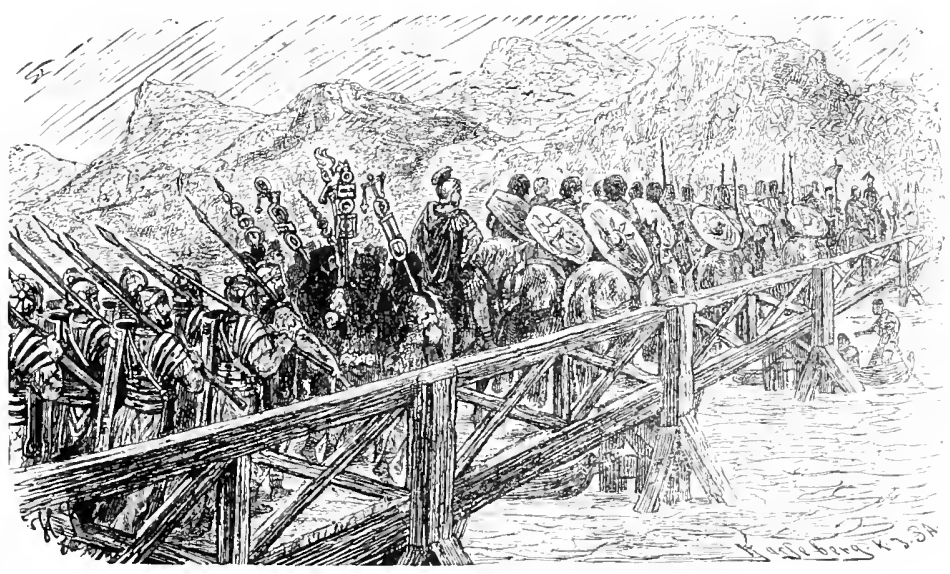

CAESAR'S BRIDGE 


\section{CHAPTER V \\ TIE BEGINNING OF THE CASARS}

88. The Rise of Pompey. - Following Sulla a succession of remarkable men contended with one another for the possession of power, with the strength of their armies and the rotes of the proletariat as their weapons, while the Senate strove in vain to retain the direction of affairs. Pompey. Pompey was the first of these men to achieve distinction. Mommsen, He had laid the foundation of a great military reputation $384,+44^{-}+4^{8}$; V. I 66,365 ; with the people by the aid which he had rendered Sulla in Plutarch, Life of Pomper.

The pirates. Mommsen, IV. $307-313$. the war against Marius. This he had built up by overthrowing Sertorius, a partisan of Marius who had raised a revolt in Spain, and by destroying the last forces of the revolted gladiators who had risen in a dangerous rebellion under Spartacus. Still later he had swept the Mediterranean clear of the pirates, who were almost an organized government and terrorized all the coasts of the sea with their great fleets. Then he completed the overthrow of Mithridates and reduced his kinglom to a province, and captured Jerusalem and made a province of Syria. Pompey was by birth an aristocrat and was inclined to the Senate, but he was often obliged in orcler to gain his ends to ally himself with the party of the people, so that between his inclination and his interests his policy was vacillating and uncertain and doomed to failure.

Julius

Cæsar.

Fowler,

Casar

89. Cæsar and Cicero. - Julius Cæsar was also of noble (Heroes); birth, but connected by marriage with the party of Marius. He was highly gifted by nature as a soldier, orator, statesman, and writer, and must be regarded as one of the ablest 
men of history. He seems to have seen clearly from the beginning of his career the goal to which events were tending, and to have shaped his course skilfully and with steady purpose to make himself master of Rome.

Cicero was not of a family of high rank, but he hail made a position for himself by his power as an orator. especially by his prosecution of Verres for his extortions in Sicily. But Cicero was a man of too high moral and intellectual cultivation for the violent measures by which the highest power must be gained in Rome, and he can hardly be called a rival of Cæesar and Pompey.

90. The First Triumvirate. - When Pompey returned from the East in $6 \mathrm{I}$, he formed a combination with Casar and Crassus, - a man

who had made himself very rich by the purchase of confiscated estates and was now ambitious of political honors, - to control the State and secure for each of them what he wanted. Casar was given the province of Gaul for five years and an army, which was what he especially wished. This command was later extended, and Pompey received Spain and Crassus Syria, where he was killed in war with the Parthians. In these years Casar made his famous conquest of Gaul, and invaded Germany and even Britain. More to his own purpose was it that he learned the art of war and trained an army devotedly attached to himself.

9r. A New Civil War. - As the second five years of the Triumvirate drew to a close, it became evident that one of 
the two, Cæsar or Pompey, must go down before the other. Pompey had the city and was supported by the Senate. Cresar had his army, but by law he could not use it outside

The crossing of the Rubicon. Mommsen, V. I90I92.

The batt'e of Pharsaila, 48 B.C.

Monarchy the only alternative to civil war and anarchy. his province. Cæesar endearored to secure a continuance of his office until he could be elected consul, and so be able to meet Pompey on more even terms in Rome. This Pompey succeeded in preventing, and the tribunes who had taken Casar's part were driven from the city. Cæsar now judged that the time for which he had been preparing had come, and he crossed the Rubicon, the boundary line of his province, and marched his army against Rome. Pompey was taken unprepared, and was prevented from gathering a sufficient force by the rapidity of Cresar's movements. Within a few weeks Cæesar had possession of Rome and Italy, and Pompey and his friends had been driven over into Greece. After conquering Pompey's province of Spain, Casar crossed into Greece, and in the great battle of Pharsalia destroyed Pompey's army. Pompey himself fled to Egypt where he was murdered, and Cisar soon gained all the provinces and was master of the Roman world.

92. Monarchy a Necessity.- Crsar's possession of the supreme power was short, for his death occurred only four years after the battle of Pharsalia, but within this short period he showed a marvellous ability to deal with the political and social difficulties of the state. He seems to have seen clearly that any government which would give order and prosperity to the Koman world must now be a monarchy. In this he was quite right. The people and the Senate had both shown themselves entirely incapable of bringing the erils of the time to an end. Their changeable and selfish management of affairs was, indeed, a part of the evil to be cured. Masterful and permanent government was demanded, and no form of government had as yet been devised which could combine centralization and a definite and continuous policy for a great state with a democratic constitution, capable of holding the administration to a real responsibility to the people. A monarchy was the only pos- 
sibility, and this Casar proposed to establish in some form. He had himself made dictator for life; he was allowed to retain in Rome the title and powers of the imperator, that is, of the general in the field; and he was also given the powers of the tribune for life.

\section{Cæs ar's} Measures.-Cresar used his powerwith great moderation, and showed his intention to be the head of the state, and not merely of a party; but his will was law in every part of the government. In the reforms which he inaugurated he showed as great a genius for statesmanship as he had for war in his conquest of Gaul. The regulation of the currency, the improvement of the condition of

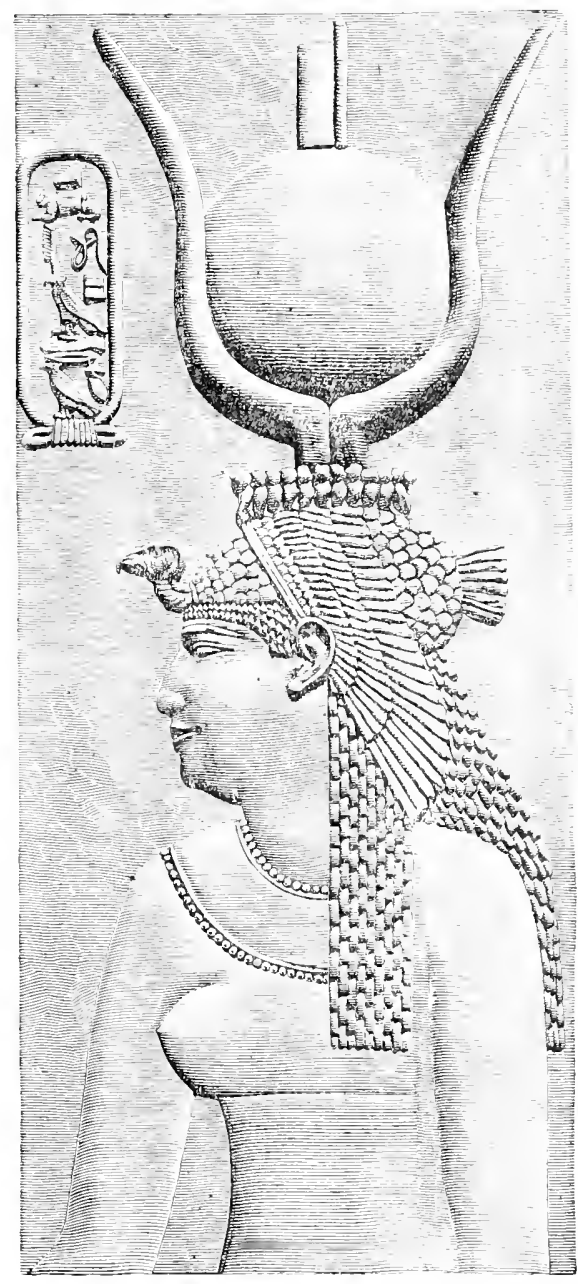

CLEOTATRA, WTH HER CARTOLCJE
Cæsar's reforms.

the small farmer and of the free laborer, the limitation of the 
food distributions to the poor of Rome, the relief of debtors, the establishment of a direct responsibility of the provincial governors and tax-collectors, the founding of citizen colonies outside of Italy, and the extension of the Latin right and even of the suffrage to provincial towns, - these are measures which give evidence of wise political judgment and of a desire to cure the evils of the state.

The assassination of Cirsar, Shakspere, Fulius (risur (Drama).

The Second Triumbirate.

Octavius sole ruler, 3 t B.C.

But Caesar was not allowed to carry his plans to completion. Not all in Rome were yet convinced that the monarchy was a necessity. A conspiracy was formed of a variety of elements, in which Brutus represented an honest desire to reëstablish the Republic and Cassius personal spite, and Casar was murdered in the Senate chamber at the foot of Pompey's statue.

94. The Second Triumvirate. - But the Republic was not restored. Marcus Antonius, one of Cresar's officers, roused the fury of the mob by his oratory and expelled the conspirators, but he failed to secure Casar's power for himself. The young Octavius, Casar's heir, returned from his school in Greece and rapidly made himself powerful. A new triumvirite was formed by Antonius, Octavius, and Lepichs, a man who happened at the time to be at the head of an army. In the proscriptions, which were renewed, Cicero was killed. After destroying at I'hilippi, in (ireece, the army of Brutus and Cassius, the trimmvirate divided the Roman world between them. Such an arrangement could only be temporary, however, and in a final struggle the power of Antonius, who had fallen under the spell of Cleopatra, was destroyerl at Actium, and Octavius, who had previously overcome Lepidus, becane sole master of the empire of Rome.

\section{Topics}

The services of Pompey to Rome. Points of difference, in character and policy, between Pompey, Cxsar, and Cicero. What were the purposes of the first triumvirate? Why did Cesar cross the Rubicon? Why was monarchy now necessary for the government of Rome? 
Casar's reforms. Compare these with Sulla's. Why was Caesar murdiced? How did Octavius become sole ruler?

\section{Topics for Assigned Studies}

The character of Cicero. Plutarch, Lifi of Cicero. Nommsen, IV. 470,516 ; V. 132-134, 503-507. Davidson, 164-171, 426-429. Trollope, Life of Cicuro, 2 vols. (Harper; $\$ 3.00$ ), is a defence of Cicero against Iommsen.

Ciesar's measures in government. Mommsen, V., Chap. XI. Merivale, Romans, II., Chap. XX.

\section{Topics for Studies in Review}

Compare the early constitutional development of Rome with that of Athens and of Sparta.

Contpare, geographically, the eonquests of Rome with those of Alexander.

Sketch the intellectual and economic changes which followed the expansion of Rome's empire by eonquest. Were there any similar effects in Greek history?

Compare the position and power of Julius Ciesar, after the fall of Pompey, with those of a Greek tyrant.

Compare the Greek and Roman colonial systems.

In Plutarch's Liz'es there are many interesting comparisons between Greek and Roman statesmen and soldiers. Study and criticise some of these, as, for example, Aristides and Cato, Alcibiades and Coriolanus.

\section{Important Dates for Review ${ }^{1}$}

13.C.

5 IO

The kings expelled.

B.c.
510

The tyrants expelled from Athens.

494 The first secession.

451 Decemvirs appointed.

390

367 Rome captured by the
Gauls.
The Licinian laws. Battle of Marathon.

Peloponnesian War begins.

1 Pupils often become greatly interested in the making of comparative chronological tables for themselves, and where this is the case nothing assists so greatly to fix the skeleton of history in mind. In such tables, care should be taken to use only suggestive facts, which recall others to memory, and not to insert too many dates, for a crowded table loses its usefulness. 
B.C.

343 First Samnite War beB.C.

359 Philip, king of Macegins. donia.

290 End of the Samnite wars.

Death of Alexander.

2So The invasion of Pyrrhus.

264 First Punic Var begins.

as II Samibal crosses the Alps.

202 Battle of Zama.

$18_{4}$ Censorship of Cato.

I 4 Destruction of Carthage and of Corinth.

133-121 The Gracchi.

II Jugurtha in Rome.

Ioo The sixth consulship of Marius.

SI The dictatorship of Sulla.

49 Casar crosses the Rubicon.

31 The battle of Actium. 


\section{PART IV}

\section{THE ROMAN WORLD-STATE IVITH ITS FALL AND ITS REVIVHL}

\section{Books for Reference and Further Reading}

Merivale, The kionans under the Empire. 7 vols. (Longmans; $\$ 15.00$.) (6 vols. Appleton; \$1 2.00.) From the death of Sulla to ISo A.I. Fills the interval between Mommsen and Gibbon.

Gibbon, Dedine and Fall of the Roman Empire. Edited by Bury. 7 vols. (Macmillan; \$I.00.) Edited by Milman. 6 vols. (Harper; \$3.00.) Still of value, especially in Bury's edition. Goes to 1453 .

Bury, 7he Later Roman Empire. 2 vols. (Macmillan; \$6.00.) From 395-Soo. The history of the empire in the West briefly, in the East more in detail. Of great value.

Hodgkin, Italy and Her Invuders. 6 vols. (Clarendon Press; $\$ 32.00$.) The most detailed and best account in English of the concuest hy the Germans.

Kingsley, The Roman and the Teuton. (Macmillan; 1.25 .) Very interesting, but somewhat idealized history.

Mlommsen, The Proainces of the Roman Empire from Casar to Diocletian. 2 vols. (Scribner; $\$ 6.00$.) Organization, government, anel condition.

Kaufmann, Deutsche Gischichte. 2 vols. (Leipzig; I5 M.) Probably the best narrative history in German. From the earliest times to $\mathrm{SI}_{\mathrm{I}}$ A.D.

Schaff, Mistory of the Christian Church. 6 vols. (Scribner; \$24.00.) The most recent detailed history in English. Full bibliographies. Alzog, Church Itistory. 3 vols. (Rubert Clark \& Co.; \$ro.50.) The best in English from the standpoint of the Catholic church.

Fisher, Mistory of the Christian Church. (Scribner; \$3.50.) A valuable one-volume history.

As the history advances into the medieval period, translations from the sources become less accessible. 


\section{SUMmary}

The history of the world had now been brought into one current by Rome. The period of the Roman Empire beheld the introduction into that current of two great streams of new influence-Christianity and the Germans. With the end of the Republic the age of Roman conquest was finished. The work of the new age was not expansion, but it was to assimilate the provincials, to make of all the West one great Latin nation - the East was already Greek - and to perfect the laws and institutions by which all the empire was ruled. This work went on under good and bad emperors alike, and at the end of three centuries was complete. During the first century of our era. Rome suffered much from the capricious tyranny of the emperors, but the government of the provinces was greatly improved. The second century, the age of the "good emperors," was a time of apparent prosperity till near its close, but the empire was growing weaker, and the third century was filled with civil strife and attacks on the frontiers which were resisted with difficulty and not always with success. The constitution of the empire, which had been growing more and more monarchical, was completed by Diocletian and Constantine at the close of this period, and became that of a highly centralized despotism. In the meantime Christianity, which had been slowly spreading over the empire from its little beginning in Palestine in the reign of Tiberius, had become so strong that Constantine sought it as an ally in his struggle for the throne. Recognized by the state the progress of Christianity was now very rapid, and the church began to assume clearly the monarchical constitution towards which it was already tending. In the fourth century also the Germans finally entered the empire. The Visigoths, fleeing before the Huns, were allowed to cross the Danube, but they quickly arose and defeated and slew the emperor Valens. Theodosius was able to bring them to submission again, but it was only for his lifetime. On his death, under their young king Alaric they invaded both Greece and Italy. Soon after, the Rhine was crossed by a number of tribes who held Gaul and 
Spain at their mercy, and Rome was sacked by Alaric. This was the first invasion, after which the authority of the Western Empire was never restored. It left southern Gaul and Spain in the possession of the Visigoths; eastern Gaul under the Burgundians and northeastern under the Franks; and Africa in the hands of the Vandals; while a union of tribes ruled Italy under Odovakar. But a second invasion soon followed. The Franks under Clovis spread out from the Rhine valley in both directions, gradually occupying all Gaul and central Germany. The Anglo-Saxons occupied Britain. The Ostrogoths under Theodoric invaded Italy and made it the seat of a most promising kingdom. His successors were not able to maintain its strength, however, and when a revival of the Eastern Empire came under Justinian it fell, as did the kingdom of the Vandals in Africa. Justinian's best title to fame. however, is not derived from his conquests but from his codification of the Roman law. The law had been given a perfected form by the scientific lawyers of the second century, and it was now brought together into a systematized shape which made its preservation for the future easy. This new Roman occupation of Italy lasted but a few years. The Lombards, another German tribe, conquered the most of it, but left fragments here and there under the Roman governor. Upon this fact hinged the history of the future. One of these fragments was Rome and a little territory about it. Difficulty of communication with the governor, whose seat was at Ravenna, threw the political rule of this territory more and more into the hands of the pope. His power in the church had already become almost definitely monarchical, and now he became the sovereign of a little temporal state. The Lombards, however, could not give up the hope of possessing Rome, and were pressing towards its capture at every favorable moment. The popes could not hope for aid from the Eastern emperors, they were more often than not quarrelling with them on some point of doctrine, - and they naturally turned to the most powerful German state of the West, the Franks. The period which followed Clovis had been one of decline. His descendants had soon lost physical strength and moral character, and in their weak hands the empire he had founded threatened to fall to 
pieces. It was reëstablished by the rise of a new family, the Carolingian. of great energy and political ability. The way for an alliance with the papacy had been opened at the conversion of Clovis when he adopted Catholic, or organized Christianity, in place of the Arian, or separatist form. Pippin the Short, now ready to assume the crown of the Franks, needed the aid of the pope, and the alliance was soon concluded. Pippin became king, and the advance of the Lombards was checked. This connection with Italy and the papacy was drawn still more close by Pippin's son, Charlemagne. Italy was an important link in his great empire, which included all western Europe except Spain, which the Arabs still ruled as a result of the wonclerful impulse which had been given to their tribes by the new religion of Mohammed. The union of all the West under Charlemagne and the strong centralization with which he ruled it, made the revival of the title emperor of Rome seem a natural step to all the world. On Christmas day Soo Charlemagne was crowned in Rome by the pope. 


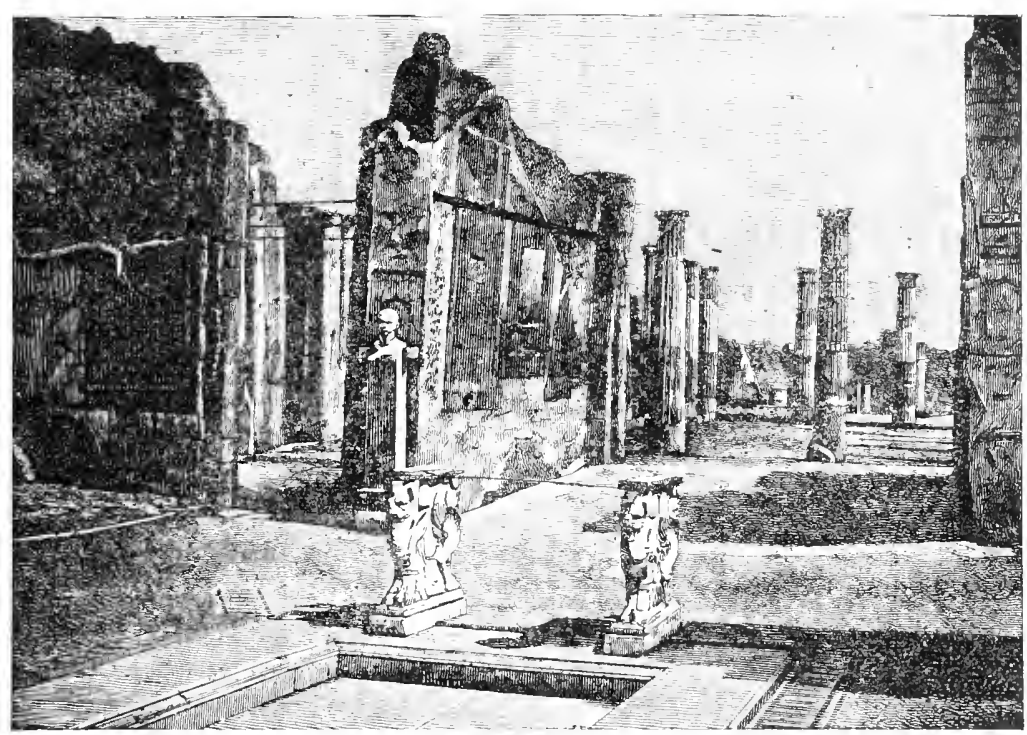

A STREel in POMPEH

\section{CHAPTER I}

THE EMPIRE ANI ITS DECLINE

95. The Character of the Early Empire. - His victory at Octavius Actium marle Octavins undisputed master of the Roman emperor. world. The form of government which he established, following the model made by Julius Cresar, was a new and peculiar type of monarchy in history. But it was a very natural form for a monarchy created by the slow and unconscious transformation of a republic. For a generation or two longer, it might perhaps have been easy for a Roman to persuade himself that no great change had been made. The

character of the Empire. The 1 lomumentum

Incr)anlum, translated, I'enn. V., No. I. The old magistrates continued to be electerl as usual. The assemblies still met and made laws. The Senate still exer- 
cised its functions of general direction and administration.

Capes, The Early Empire (Epochs) ; Bury, The Reman Empire, I.C. 27 to A.I .180 (Student's Series, Harpers).

The constitutional position of the emperor. Merivale, Komans, Chap. XXXI.

"Emperor" means "general."

The only difference, and this would not seem a striking

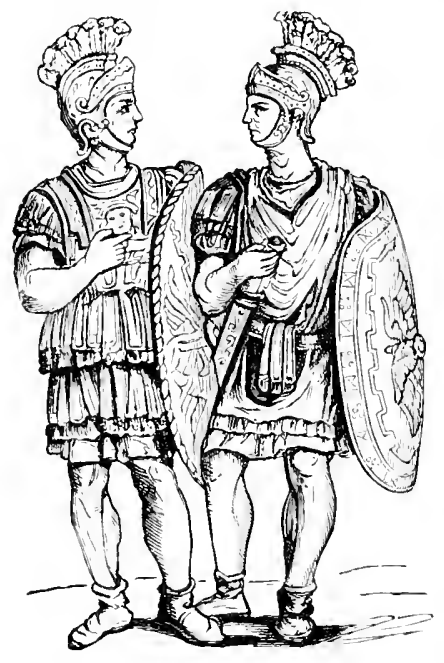

PRETORIAN GUARISS difference to the Roman who remembered the recent past, was that a citizen who held no formal office controlled everything as he chose. But this was a wise and beneficent control, as it seemed to the Romans. Civil war and the strife of parties came to an end. Life and property were secure, and such peace reigned within the Empire and on the frontiers as the oldest could not remember. It was a change which no one could regret, and yet it carried with it the destruction of the Republic, and the establishment of an absolute monarchy.

96. Constitutional Forms. - The constitutional form of the early Empire has already been described. Without holding formally any of the offices, Octavius had the powers of each conferred upon himself, so that he was a kind of informal and supplementary consul, tribune, and censor. MIore important still was the fact that he was allowed to retain and exercise in the city the powers of the general in the field at the head of the army, the imperator. This was the office which in the end gave its name to the new monarchy, and has come down to us as the monarchical title of highest dignity, emperor. The family name of Cæsar also became a title for the monarch, and still exists in two of the greatest of modern states as Kaiser and Czar. To Octavius was given the title Augustus, by which he is generally known, and this passed also to the succeeding emperors. 
97. Economic and Literary Character of the Age. - For the city of Rome a great age opened with the accession of Augustus. Peace and security were followed by a rapid revival of prosperity in which Rome had a full share. Commerce flourished and dealt in the goods of the most remote countries. Augustus gave much attention, not merely to the great roads leading from every part of the Empire to the capital, but also to the adornment of the city. His boast was not a vain one that he found a city of brick, and left one of marble. One of the new buildings was the Pantheon, in which were gathered all the gods of the Empire, something new in the world, but symbol of a still more important thing that was new - the community of nations in a common system. This community of nations once established by Rome has never ceased, though it has changed its form, and out of it grew the idea of the unity of all men - the brotherhood of men, as they began to call it in the early days of the Empire. This idea, of such immense value in the civilization of the world, and soon to be so strongly reinforced by the teachings of Christianity, first rose to consciousness in the minds of men as a result of the conquests and organized Empire of Rome.

The Stoic philosophy, which had been developed among the Greeks, gave the Romans a scientific foundation for such an idea as the brotherhood of man, to which their own history had led them, and furnished them also many other lofty moral ideas. The Stoic philosophy, with its emphasis of the strong virtues, and of manly endurance and calmness under trials, was particularly attractive to the Roman character, whose natural ideal was one of unyielding courage. The early Empire produced some of the most famous of the Stoics, like Seneca and the emperor Marcus Aurelius.

In literature the reign of Augustus is as remarkable as in other directions. The names of Livy in history, and of Vergil, Horace, and Ovid in poetry give evidence of a wealth of production which has made the name Augustus

The Stoic philosophy. Capes,

Stoicism (S. P. C. K.) ; an article:

Reman

Stoicism,

llistminster

Ke'ilew'

Jan. I882;

Selections

from

Epictetus

(Putnam).

Literature. 
stand for an age of literary brilliancy in the history of later nations. Yet there are few great names in the history of Roman literature to add to these, and in total product it is far below the Greeks.

Changes in the government of the provinces. Arnold, Roman Provincial Administration:

Merivale, komans, Chap. XXXII.

End of the age of Roman conquests.
98. Provincial Administration. - The statesmanship of Augustus appears most clearly of all in his reorganization of the provincial government of the Empire. The provinces were divided into two classes, the senatorial and the imperial. The interior provinces, long conquered and well organized. were left under the administration of the Senate as originally, though their governors were held to a more real and strict responsibility. The more recent provinces and those on the frontiers, which were unsettled and exposed to attack, the emperor held in his own hands, that is, he governed them by officers appointed by himself and immediately responsible to him for their conduct. The change was one of great advantage to the provincials. The larger part of the old oppression and extortion came to an end, and though it might occasionally reappear in later times, the subjects of Rome from now on began to look upon the imperial government less as that of their conquerors, and more as a government in which they had a share, as in a sense their own. It was the beginning of a change which made the last step in the process of making all men Romans, members on an equal footing of a worldwicle state, from which the people and city of Rome had disappeared as rnlers. thongh they survived in the language, laws, and institutions, which had become universal.

99. Augustus and the Germans. - On the frontiers it was the object of Augustus to maintain peace, a policy which, followed by nearly all later emperors, brought the age of Roman conquests to an end. On one frontier Augustus could not carry out his policy of peace, that of Germany. This was due to the warlike and restless character of the German tribes, and the constant warfare of his reign along the Rhine and the Danube was only the opening of a ceaseless conflict which runs through all the later history of the 
Empire, until from increasing weakness Rome could no longer maintain her ground, and the Germans broke through and conquered the West.

One attempt to teach the Germans the danger of attacking the Romans led to a great disaster. Varus with three legions invaderl Germany, as Julius Cæsar had done, but

The defeat of larus.

Merivale, Romans, IV. $268-276$.

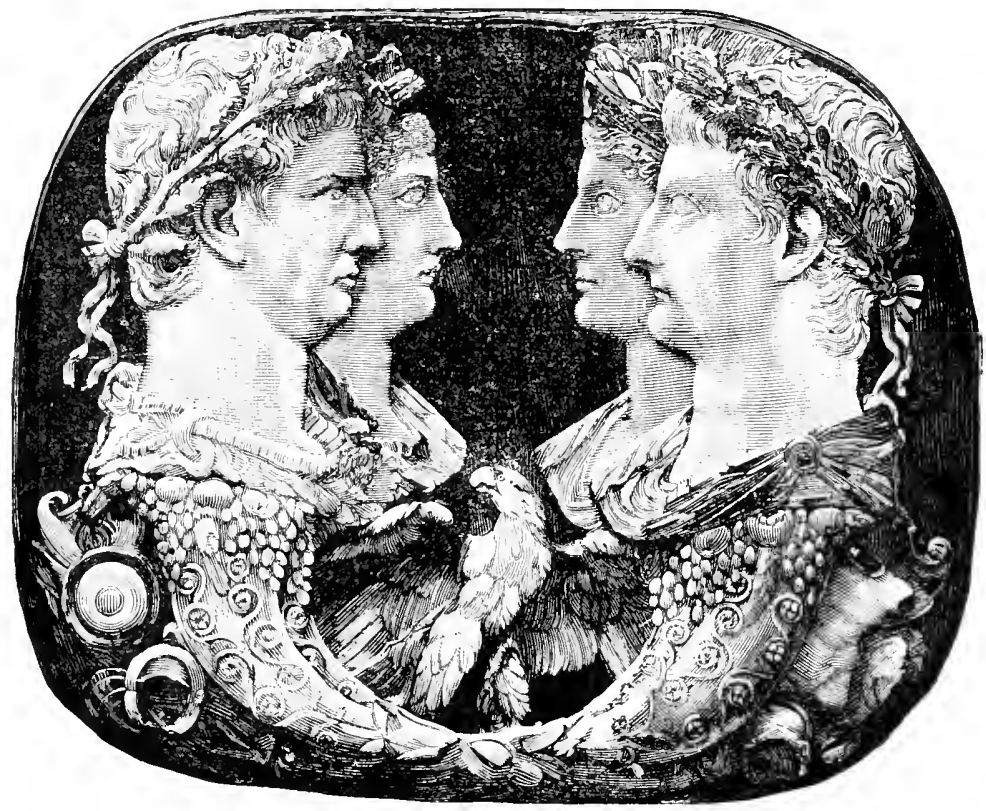

A CAMEO

Claudius, Agrippina the Younger, Livia, and Tiberius

was killed and his army annihilated by the Germans under Arminius, or Hermann, in the battle of the Teutoberger Forest. This battle is regarded by the Germans as in a way the beginning of their national history, and Hermann as the first of their national heroes.

I00. The Period of the Julian House. The reign of Dates of Augustus, which is usually reckoned as beginning with reign. 
29 B.C., runs on to 14 A.D. and so includes the beginning of the Christian era and the birth of Christ, an event which was to have such momentous consequences both for the Roman Empire and for all mankind.

The

successors of Augustus.

S. Baring Gould, The Tragedy of the Casars, 2 vols. (Scribner) ; Tacitus, Annals, translation of Church and Brodribb; Suetonius, liz'e's of the Therlate (atsirs (Bohn) ; The reign of 'Tiberius, If -37 A.1). (Galigula, 37-44.

Claudius, $4 \mathrm{I}-54$.

Tacitus, Annals, XII. +6-47.

Nero, 5t-68.

Sienkiewicz, Quo liadis (novel): lacitus, Annals, XV. $3^{8-4 I}$, 44 .

The adoptive and the lineal descendants of Augustus reigned for a little more than fifty years after his death. The story of the half century is one of almost unbroken tyranny and brutal debauchery, and the patience with which the Roman people endured it shows how soon they had completely reconciled themselves to the monarchy as the only possible government.

ror. From Tiberius to Nero. - The immediate successor of Augustus was Tiberius, son of his wife Livia and adopted by the emperor after the death of his grandsons Caius and Lucius Casar. He was past fifty years of age at his accession, had distinguished himself in war and gave promise of a wise and happy reign. But he soon abandoned the power to his farorite Sejanus, who hoped to make his own way to the throne. The last years of Tiberius were filled with violent deaths in the emperor's family and with suspicion and terror for all who came near him.

Caligula his successor made his favorite horse consul and wished the Roman people had a single neck to save the trouble of so many executions. Claudius, made emperor by the Pretorian guard after the murder of Caligula, gave the Empire at large a few years of better rule, but could not bring to an end the reign of intrigue and assassination in his own court. He was himself finally poisoned by his wife, Agrippina, to secure the throne to her son by another marriage.

Nero, the last of the family of Augustus, is the typical tyrant of the period. He murdered his mother, whose crimes had made him emperor, and a long series of others, among them his wife, his early tutor, the philosopher Seneca, and the poet Lucan; he was suspected of having kindled the great fire which destroyed half the city during his reign as a fitting scene for the recitation of his great poem on the 



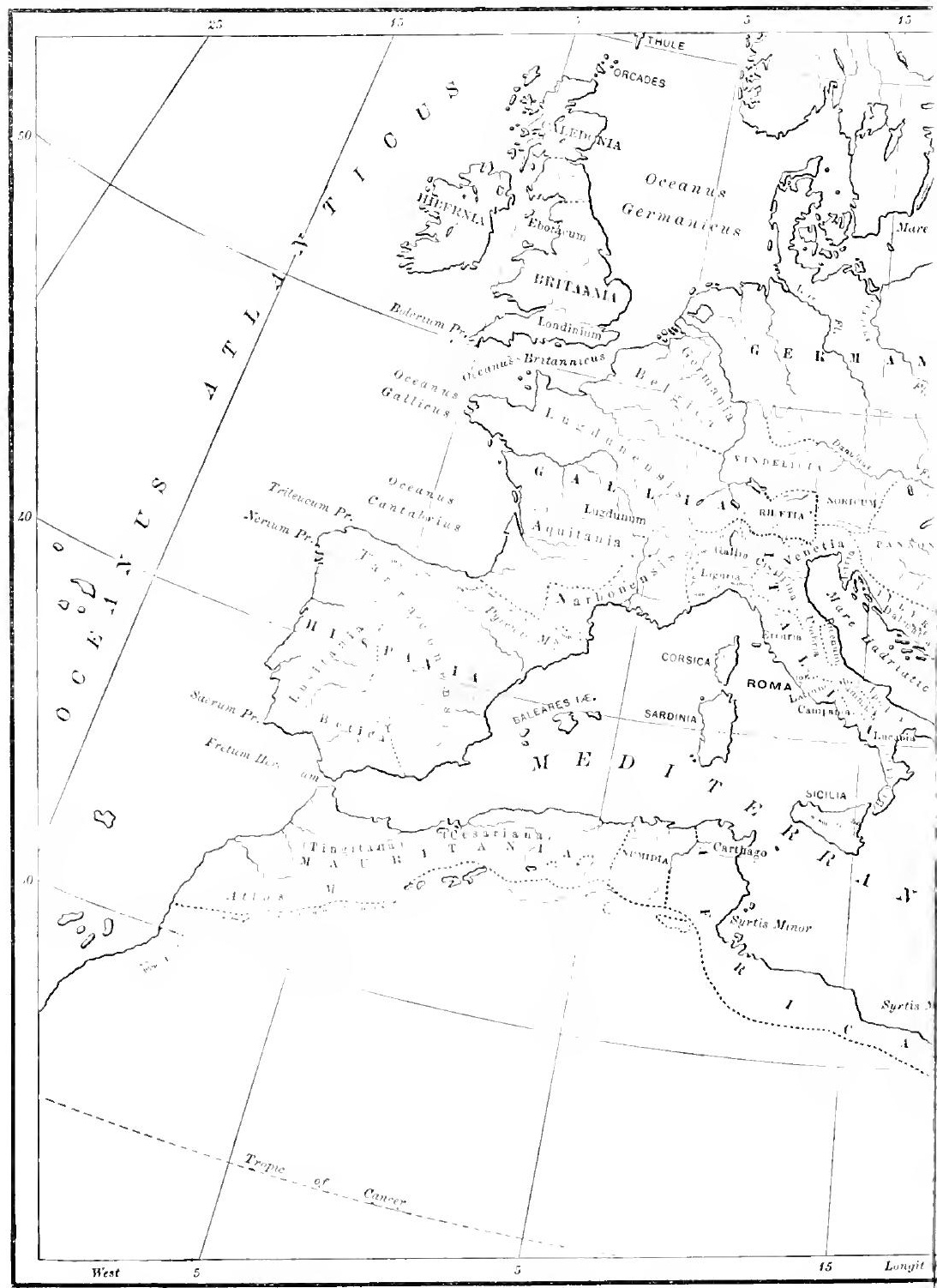




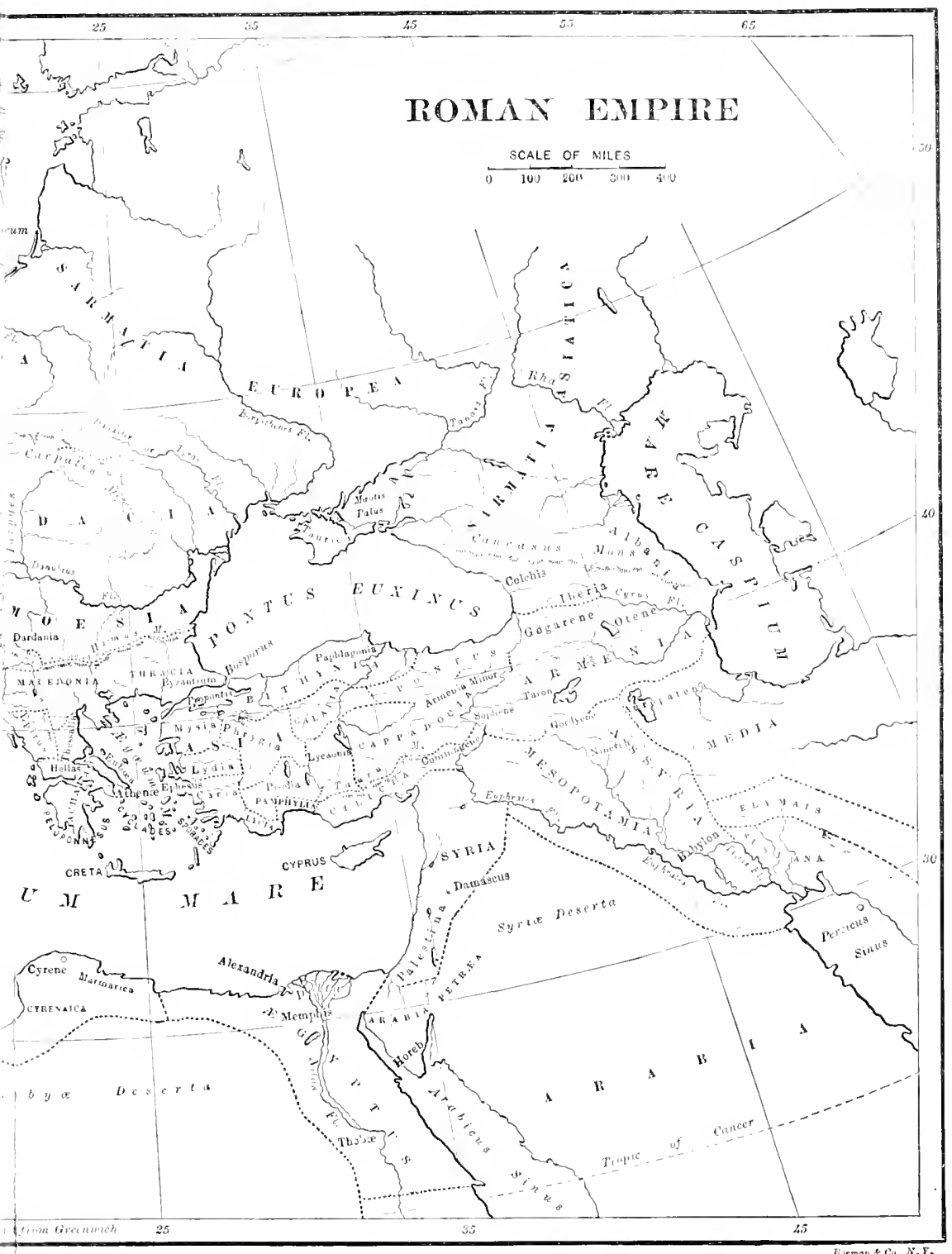




$$
\text { - }
$$


siege of Troy; and to divert suspicion from himself he is said to have accused the Christians of the crime, and to have burnt many of them. In this persecution the apostles St. Peter and St. Paul are believed to have perished. At last the patience of the world was exhausted and the armies in several of the provinces rose almost at the same time. Nero killed himself to avoid a more cruel death, exclaiming : "How great an artist is about to die."

ro2. The Flavian Dynasty. - Three emperors, Galba, Otho, and Vitellius, follow one another in rapid succession, set up and deposed by their armies or by the Pretorian guards. Finally the army in the eastern provinces made their commander Vespasian emperor and the founder of a new dynasty, the Flavian. He was succeeded by his son Titus, the conqueror of Jerusalem, in whose reign occurred the great eruption of Vesuvius which destroyed the cities of Pompeii and Herculaneum. Vespasian and Titus had been emperors of the best type. Titus was called the "delight of mankind." But Domitian his brother was another Nero, and after too long a reign filled with cruelties was murdered by one of his own slaves.

I03. Growth of the Imperial Constitution. - The end of the Flavian dynasty, so near the end of the first century, A.D., marks the close also of the first age in the history of the Empire. The constitution had now become much more monarchical in form. Tiberius took wtray from the assemblies the election of the magistrates and gave it to the Senate, and the last lex was passed by the people in the reign immediately following Domitian's. The Senate ceased to be an independent part of the government and became a great council of state for the emperors. The reign of terror under which the capital lived during almost the whole period did not extend to the provinces, and they enjoyed almost unbroken prosperity under governors whom the provincials could impeach at Rome for misconduct with some chance of success and with provincial assemblies which had some influence on the conduct of local affairs.

Vespasian and his sons, 69-96.

Freeman, The Flavian Ciesce: in Histerical Essays, Vol. Jl.; Bulwer, The Last Days of Pompiii (novel).

The constitu. tion more monarchical.

The provinces prosperous. 
I 2

The frontiers of the Rhine and Danube were made secure against the Germans, and the eastern frontier against the

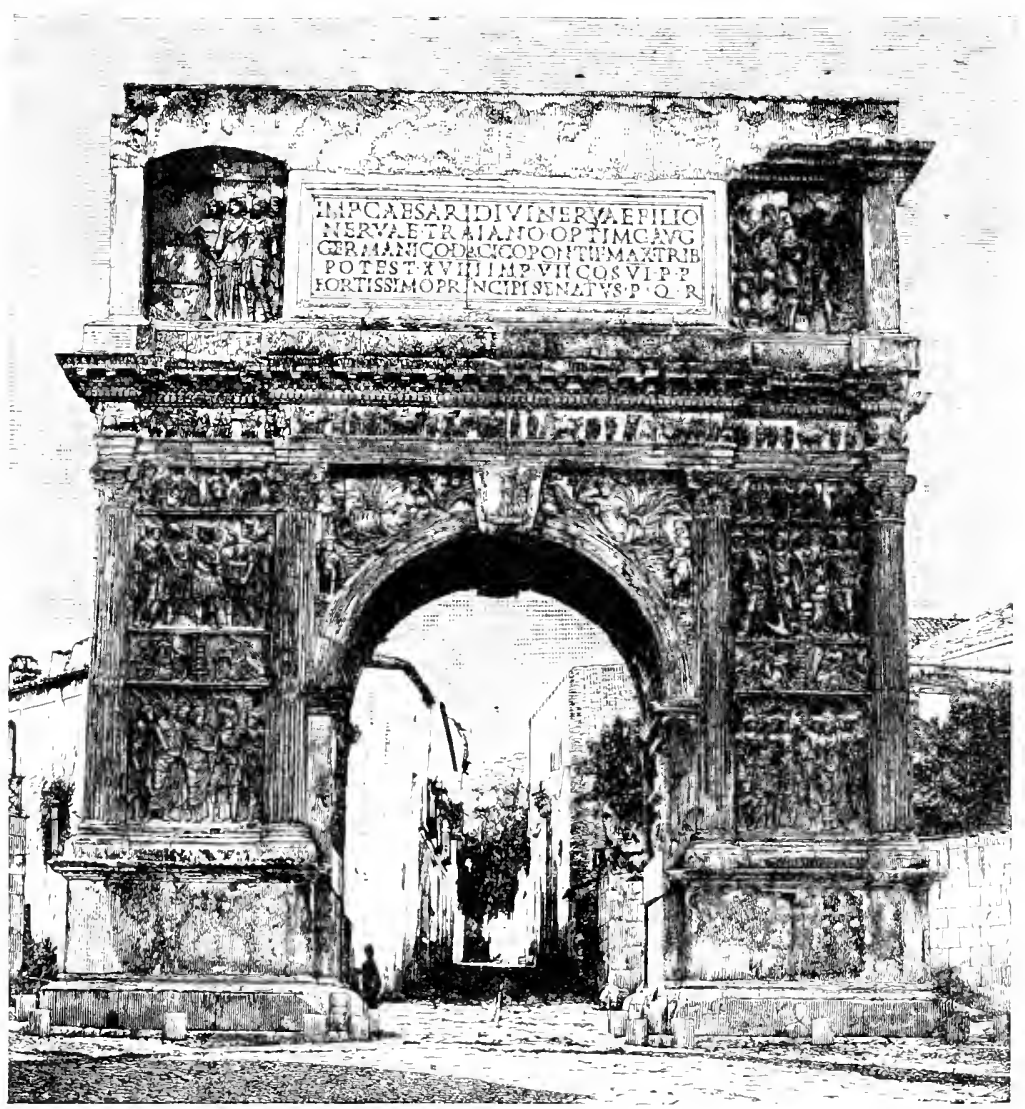

ARCH OF TRAJAN

Parthians, the successors of the Persians. A great insurrection of the Jews was put down after a desperate strugule by Vespasian and his son Titus, and one in Ciaul muler 
Civilis about the same time. The conquest of Britain, begun under Claudius, was completed by Agricola, the father-in-law of the historian Tacitus, under the Flavian emperors.

Still more important were the processes of Romanization and centralization which go on rapidly during this century. Claudius adopted the plan of admitting distinguished provincials to the Senate, and this policy, followed by his successors, did much to form one nation of the Empire. The worship of the emperor's genius, as the guardian genius of the state, became during the century a universal religion, the one universal religion of the Empire, serving not merely to bind the Empire together, but to awaken a feeling of personal devotion, akin to patriotism.

104. The Five Good Emperors. - The second century, A.D., is the age of the Antonines, the reigns of the five good emperors, Nerva, Trajan, Hadrian, Antoninus Pius, and Marcus Aurelius, closed by the reign of Commodus who, though the son of one of the best sovereigns who ever ruled, Marcus Aurelius, was himself one of the worst. The period from 96 to 180 , the date of Marcus Aurelius' death, is the golden age of the Roman Empire, - one of the happiest ages of history. The Empire was at peace and seemingly prosperous within and strongly defended without. Although almost the whole of the reign of Marcus Aurelius was a desperate struggle with the Germans in which we can begin to detect the failing powers of the Empire, he succeeded in maintaining the frontiers.

Nerva's short reign brought the abuses of Domitian's to an end. Trajan, a Spaniard, that is, a provincial, and so a sign of the growing Romanization, was a soldier and added a province to the Empire - Dacia, north of the Danube. This was abandoned almost immediately after his death, but its present name of Roumania preserves the memory of the Roman occupation, and the colonies settled there by Trajan Romanized the language so thoroughly that the modern speech of the country is as truly a descendant of the Latin

Civilis.

Tacitus, History, Bk. IV.

Tacitus, Agricola, translation of Church and Brodribb.

Romanization of the world. Gibbon, Chap. II.; Fisher, $B e$ ginnings of Christianity, 47-73. See Claudius' speech in Tacitus, Annals, XI. $24-25$. The five good emperors. Capes, Tht

Age of the Antonines (Epochs) : Gibbon, Chaps.1.-III.

Nerva and Trajan, 96-117.

The origin of Roumania. Capes, Antonines, 36-38; Merivale, Romans, VII. 189-I97. 
as Italian. Hadrian and Antoninus Pius spent laborious lives in the faithful service of the state, and the Stoic philosopher Marcus Aurelius, even more famous for his little book entitled "Thoughts" — thoughts on living, on conduct and character - than as an emperor, spent an even harder life in desperate warfare on the Danube.

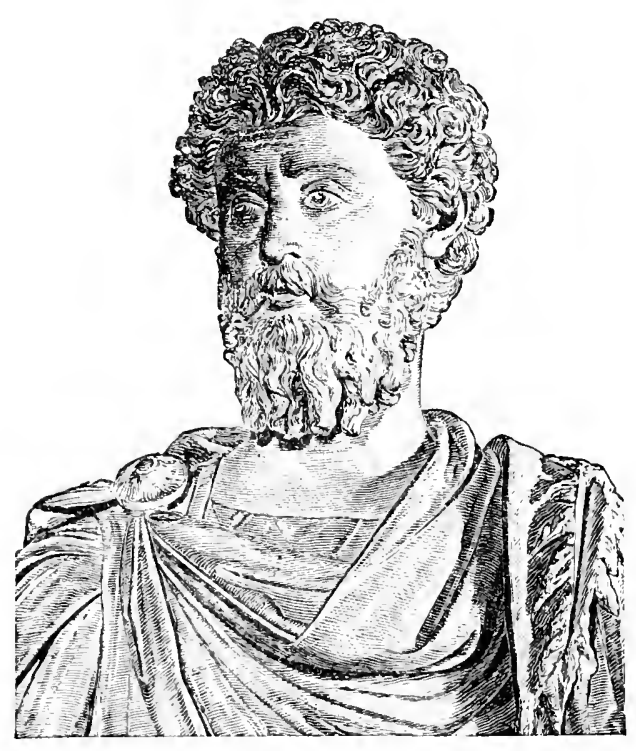

MARCUS AURELIUS

Roman law given scientific form.

Fxtracts from Justinian's Institute's, Fling, studies, No. Io; the Institutes, translated hy Novle (Clarendon).
105. The Roman Law. - The two processes which had characterized the first century went on steadily through the second, the Romanization of the Empire and the gradual transformation of the constitution into an undisguised monarchy. This age, however, saw a new process beginning which was of the ntmost importance for the future history of the workl. It was the reduction of the Roman law to definite and scientific form. We shall see later the deep and permanent influence which the Roman law has 
exercised on all the civilized nations of later times. It was in the second century that it began to be put into the shape that enabled it to exert this influence.

In its growth the Roman law was in many ways like our own Anglo-Saxon law. It had two chief sources, the written or statute laws, made by the people in the days of the Republic and by the emperors later, and the unwritten law, founded on the customs and precedents established in the administration of the law in the courts. The body of this law had naturally come to be after so many generations enormous in size and very confused and intricate.

Now begins the process of putting it into simple and scientific form. It began in two ways. One was the act of the emperor, following a practice begun much earlier. The pretor, or judge, in taking possession of his province issued an edict which stated the principles by which he would be guided in his administration of the law. These edicts had now become very numerous and often contradictory, and the emperor Hadrian issued what was called "the perpetual edict" to take their place. This stated the principles which should be followed by the judges in the provincial courts uniformly throughout the Empire. Ii was a limited and partial codification, but it introduced a process which went on by degrees through four hundred years and finally resulted in the great codification of the emperor Justinian. The other process was the writing of scientific treatises on the law, or on special points of it, by the great lawyers of the time. These writings came to have very great authority in later times, and tended to reduce the law to systematic form and to bring out clearly the scientific principles on which it rested. One influence was exerted on the teachings of the Roman law at this time, and mainly through the writings of these lawyers, which is very interesting. The Stoic philosophy was, as we have seen, very much cultivated at Rome under the early Empire, and from it the writers on law took many maxims of ethics to prove the justice or to give brief and

How the law had been formed. Hadley, Introd. to hiem. Law, Lect. III.

The beginning of codification.

The writings of the jurisconsults.

The influence of Stoicism. 
Rapid decline of the Empire.

Gibbon, Chap. X.

The Illyrian emperors. Freeman, Historical Essay's, Vol. III.

Diocletian, 234-305.

Gibbon, Chap. XIII.; Bury, Later Empire, Bk. I., Chap. IV. pointed statement to the principles of the law. Several of these, on this account, because taken up into a system of law which was to be so permanent, have come down to our own time as maxims of legal or political ethics. The most interesting of these to us is the one used in several different ways in the documents of the American and French revolutions: All men are by nature free and equal.

106. The Disorders of the Third Century. - After the close of the second century the Roman Empire went on rapidly to its fall. The third century was filled with disorder and anarchy. Emperors of the worst type, like Caracalla or Elagabalus; disputed successions in which several emperors at once, set up by their armies in the provinces, fight with one another for the throne, - at the middle of the century was a period called that of the thirty tyrants from the number of pretending emperors; and incursions of barbarian tribes who could no longer be kept out by the weakening frontier guards; all these at once indicate the decline of Rome and show us what helped to produce it. 'The Alemanni broke through the Rhine frontier and even invaded northern Italy; the Goths crossed the Danube, defeated and killed the emperor Decius, ravaged the shores of the Bosphorus, and escaped without adequate punishment. The Persians invaded Syria and captured the emperor Valerian. It might almost seem as if the Empire would be broken up at once. But in the last quarter of the century came a succession of emperors, who checked for a time the rapidity of the decline. Aurelian (270-275) beat back the barbarians, restored the frontiers, and subdued Gaul and Palmyra.

107. The Reforms of Diocletian. - IVith Diocletian a great statesman became emperor, and great changes were made, intended to restore the strength of the Empire. He thought, very wisely, that there were two necessities to be supplied, one that there should be an able man in supreme command on every frontier to maintain it unbroken, and the other that the order of succession should be so clearly 
marked out that the danger of civil war would be avoided. To accomplish these results he decided that there should be two emperors, one looking after the East and one the West, and that each of these should appoint an assistant who should take the title of Casar, be responsible for the government of a part of the provinces, and succeed to the throne in regular order. Besides these changes Diocletian made many others. The provinces were reorganized, their number almost doubled, and all were made imperial provinces. The military were entirely separated from the civil offices, and the latter were given a very strict organization from the highest to the lowest. In the court, Oriental etiquette was introduced, and the government became in external appearance as in reality, a true despotism.

ro8. Constantine the Great. - The system of Diocletian was very well planned, but it did not take into account the strength of ambition. When he abdicated in 305 , civil war almost immediately broke out among the rivals for supreme power, and lasted for nearly twenty years. In the end Constantine, whose father had been Casar in Britain and Gaul, by his genius, and by his readiness without scruple to make use of any means, gained the victory over all the others, and became sole emperor (323). Constantine, the equal of Diocletian in statesmanship, maintained the strength of the Empire to the close of his reign, and, though he dropped Diocletian's plan of emperors and Cæesars, he kept up and perfected his system of internal organization. Two things especially mark his reign as a great turning-point in history. The first is his recognition of Christianity as a legal religion to be protected by the state. This was done by Constantine, as nearly as we can judge, not from any conviction of the truth of the religion, but from motives of policy. The other was his change of the capital of the Empire from Rome to Constantinople on the Bosphorus. The situation of Rome was very favorable in the early ages of its history when its task was the conquest of the Mediterranean lands, but now when its northern and eastern frontiers de-

Division of the Empire. Arnold, Roman Pro. vincial Administration, I66-178.

Renewed civil war. Gibbon, Chap. XIV.

Constantine, 323-337.

Gibbon, Chaps. XVII. and XVIII.

Constantinople the capital of the Empire. Bury, Later 
Empire, Bk. manded the constant watchfulness of the government, it was I., Chap. V.; far to one side. Even before the time of Constantine, Rome Oman, $B y-$ zantine Empire (Nahad practically ceased to be the residence of the emperors, and afterwards, when the West had an emperor of its own, tions). Chap. he preferred to reside at Milan, nearer to the threatened II.

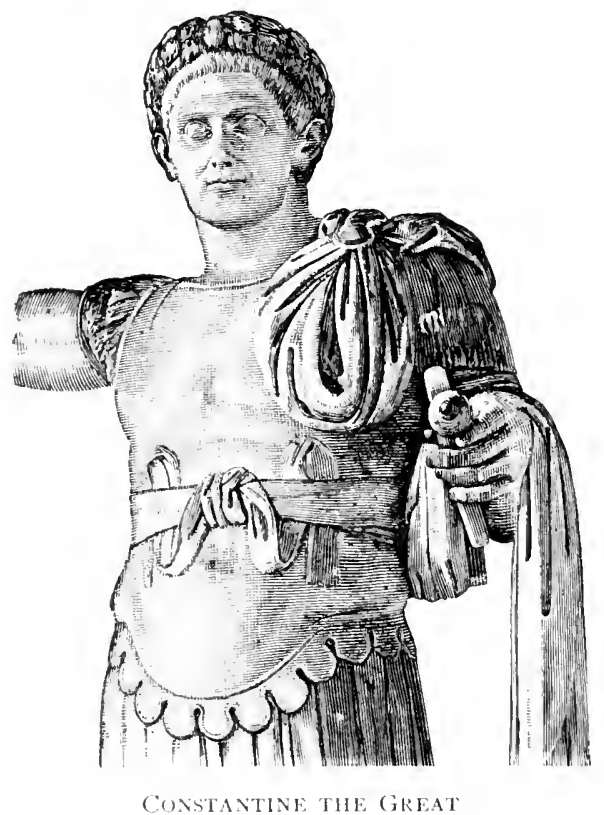

(From a Colossal Statue in the Vatican)

frontiers, or in Ravenna made still more secure by the swamps which surrounded it. On the other hand, the situation of Constantinople was most admirable both for rule and for defence. It commanded both Europe and Asia in days before men had begun to make highways of the oceans, and so profound an impression did its strategic advantages make upon history that even now, in totally changed conditions, men cannot get rid of it. 


\section{Toples}

Describe the position which Augustus held as ruler, as the Romans would look at it. Can you mention anything of a similar kind in morlern politics? What changes for the better were made by the establishment of the Empire? How were the provinces governerl? Put together the facts showing the relation between Rome and the Germans during this period. Character of the emperors of Augustus' family, especially of Nero. The Flavian dynasty. What is meant by the Romanization of the Empire, and what were its permanent consequences? The age of the good emperors. Growth and systemizing of the Roman law. The character of the third century. The changes made by Diocletian. Those made by Constantine.

\section{Topics for Assigned Studies}

Nero. Tacitus, Annals, XV. 13-16. Merixale, Romans, Chap. LV. Capes, Early Emfire (Epochs), Chap. V.

Marcus Aurelius. Ilis Thoughts, translation of Long or of Jeremy Collier. Natthew Arnold, Essays in Criticism, I. 344-379. Capes, Antonines (Epochs), Chap. V. 


\section{CHAPTER II}

\section{THE ESTABLISHMENT OF CHRISTIANITY}

\section{Books for Reference and Further Reading}

Fisher, The Beginnings of Christianity. (Scribner; \$2.50.)

Ramsay, The Church in the Roman Empire. (London, Hodder; Putnam; \$3.00.)

Uhlhorn, The Conflict of Christianity with Heathenism. (Scribner; $\$ 2.50$.)

Hatch, Organization of the Early Christian Churches. (Longmans; $\$ 1.75$.

Allen, (hristiun Institutions. (Scribner; \$2.50.)

Renan, Influtuc of liome on (hristiunity. (Scribner; \$1.50.)

Burckhardt, Die Zeit Constantins de's Cirosses. (Leipzig; 6 marks.)

Nearly all the original Christian literature of this period is to be found in translation in the Ante-Vicine Library, or in Bohn.

A few workmen and women.
I09. Christianity at the Death of Christ. - The recognition which Christianity received from Constantine was due to its strength in numbers and organization. When we remember the situation of this new religion at the death of its founder, it seems a most remarkable fact that it had reached this position of influence in the Empire in less than three hundred years. It that date it had not been preached outside of Jutlea, one of the most insignificant divisions of the Empire. Its adherents were a mere han:lful of workmen and women, who up to that time do not seem to have understood the mission of their teacher. His death, however, wrought a great change. The disciples became leaders and apostles, and the number of converts among the Jews rapidly increased. 
I Io. Christianity becomes a World Religion. - The first great step in advance was taken when the wall of Jewish exclusiveness was broken down and the gospel was proclaimed on equal terms to all men. From the New Testament we learn that this was begun by St. Peter, to be carried out most logically and completely by St. Paul. Our records of the early progress of Christianity are incomplete, but we know that churches were established in many of the chief cities of the Empire within thirty years of the crucifixion.

Especially interesting is the church at Rome, because this first came into serious collision with the government of the state. With this church we know from the New Testament that St. Paul labored for a time, and tradition asserts that St. Peter did also, a tradition to which history lends some slight support. Here as elsewhere the adherents of Christianity were drawn mainly from the poor, slaves, and the lower classes, who were especially attracted by its message of hope and comfort. The higher classes of Rome would know but little of Christianity in its early days, and if it was persecuted by Nero it was not with the deliberate and thoroughgoing intention of the later emperors.

III. Why the Romans persecuted Christianity. - This condition of things began to change in the second century. In some parts of the Empire the number of the Christians increased so largely as to draw the attention of the state. There were among them now also many more persons of rank and education than formerly. When the Roman govermment began to be conscious of this and to understand the character of the Christian church, it began to be hostile to it.

Rome had been very tolerant of the religions of all the peoples it had conquered, but it could not be tolerant of Christianity. This was because Christianity differed from all the other religions in its exclusive character. It denied the gods of Rome, and refused to allow them to be worshipped. To the earnest Roman citizen or officer this seemed

Preached to the Gentiles. Fisher, B' ${ }^{\prime}$ simnings, Chap. XV.; Acts, Chaps. $\mathrm{X}$. and $\mathrm{XV}$. and Galattians, Chap. II.

The church at Rome. Farrar, Darkness and Dazin (novel) ; Fisher, $B e^{e}$ gimnings, 520-533: Pemn. IV., No. I.

The state begins to notiee the Christians. Pliny's letters on the Christians, Fling, Studies, No. 9; Indiana, No. 8; Penn. IV., No. I ; in general, Fling, Studies, II., No. I.

Rome intolerant of Christianity alone. Fisher, 
Beginnings, to be treason. The Romans believed that the safety and 539-5+2; Capes, Antonines, Chap. VI.; Chureh, To the Lions (novel).

The best emperors perseeute. Natthew Arnold, Essays in Criticism,

I. 359-363;

Penn. IV., No. I; Uhlhorn, (imflict, 282-297; Gregg. The Decian Persecution (Blackwood) ; Newman, Callista (novel). Carr, The Church and the Roman Empire (Epochs, Ch. Hist.), Chap. II.

The eariest organization simple. Causes of ehange. prosperity of the state depended on the favor of the national gods, which was to be won only by paying them their due worship. To refuse to worship them was to invite public calamities. When the state was merged in the emperor, his guardian genius became the especial guardian genius of the Empire. To refuse a simple act of worship before the emperor's statue, which was the test often demanded of the Christians, seemed to the Roman a more open act of treason than it would to us if a man should refuse to promise allegiance and fidelity to the state.

This explains why we find an extended persecution of the Christians under Marcus Aurelius, who was one of the best sorereigns of history, and why as a rule it is the best emperors, those who are endeavoring to restore the strength and simplicity of early times and remove the causes of corruption and weakness which have come in, who persecute the church the most severely. The last of these great persecutions was under Diocletian, whose efforts to reform the state we have seen. It was a most determined and systematic persecution, carefully planned to destroy the leaders and the Christian writings and to bring the common people back to the national religion. It ended, however, in failure, and the state had abandoned the attempt before the victories of Constantine changed the attitude of the government.

I 2. The Beginnings of Church Government. - During all the third century Christianity was spreading rapidly. The persecutions rather aided than hindered its growth. As the membership of the church increased, it gave itself a stronger and more complex organization. The New Testament does not allow us to say beyond the possibility of dispute what was the exact organization of the earliest churches, but the best scholars of all present churches unite in holding that it was much simpler than it came to be when numbers and wealth had so increased that a more definite constitution was possible. The hostile attitude of the Roman state was 
favorable also to a close organization. Then again the dissensions which early began to arise in the church concerning various points of doctrinal belief, and which gave rise to the great heretical parties, had the effect to draw together those who held the orthodox belief into a united body against their opponents.

The government of the Roman Empire was followed somewhat closely by that of the church as it developerl, for it was the only form of political organization with which the

The Empire a model.

Schaff,

Church His-

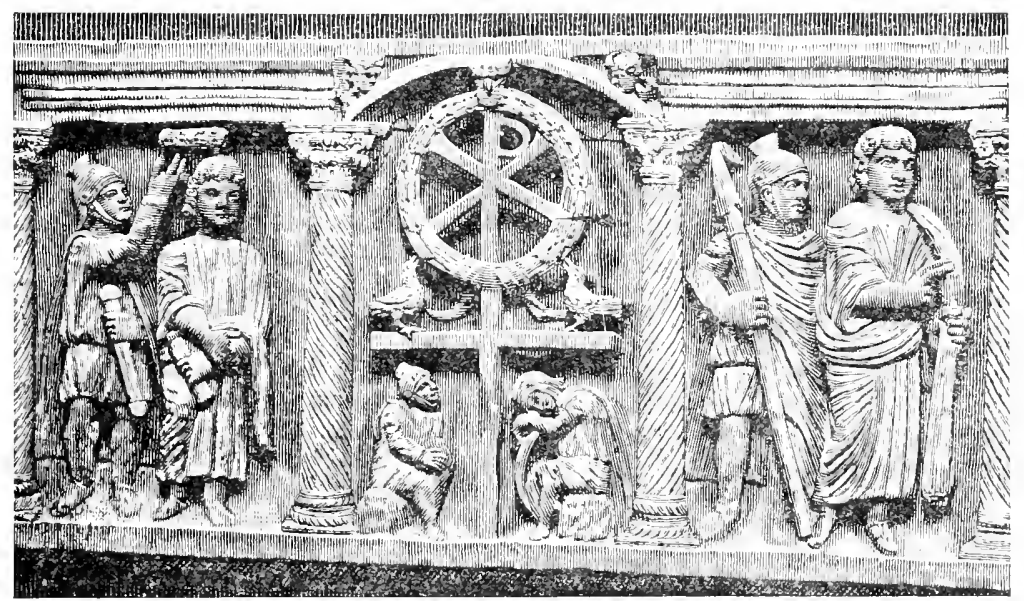

CHRISTIAN SARCOPIAGUS, WITI LAMARTM, EI:

men of the time were famitiar. The bishop naturally took up his residence in the local capital of the provincial subdivision, the archbishop, or metropolitan, in that of the larger province; and some of the greater cities, like Antioch and Alexandria, became the seats of still higher officers, tuly, II., Chap. 1V.; Alzog, Church Histery, 1. 389415. the patriarchs. It was the beginning of a monarchical constitution, but at the end of the third century it was still only a beginning. Progress enough har heen mate, however, to give the church a compact organization and to make it a power within the state. This Diocletian had discovered in 
his persecution, and Constantine was shrewd enough to see it at the outset of his career, and to take advantage of it by allying himself with the Christians.

The beginning of monasticism.
Constantine, the first Christian emperor. Cutts, Constuntine (S. P. C. K.).
By this time, also, another of the most characteristic features of medieval Christian life, the monastic system, had begun to assume its later form. Monasticism had its origin in the Eastern Empire, in the effort of individuals to escape from $\sin$ by withdrawing into the wilderness, where they hoped to avoid temptation by escaping all contact with men and society. These were the original hermits, and the practice was at first without system or any rule of life. But as the number of such recluses increased rapidly they began to form communities and to take on something of an organization. It was in the Western Empire, however, rather than in the Eastern, and at a later time, that the great monastic orders arose.

II3. Christianity recognized by the State. - Whether Constantine was moved to his acts in favor of Christianity by a conviction of its truth or not has long been a subject of dispute. He was probably more strongly influenced by motives of policy, as has already been said, and it was certainly a wise step from policy alone, for, aside from its strong organization, the Christian society now contained the most vigorous and energetic elements of the population. It must not be supposed, however, that Constantine made Christianity the religion of the state. The most that he did was to make it a legal religion, under the protection of the state and on the same footing as paganism, and to allow the influence of the court to be exerted in its favor. In 324 he advised, by edict, his subjects to become Christians. In 325 he presided over the great council of Nicæa, in which representatives of the whole Christian world met to discuss the question of the divinity of Christ, denied by the followers of Arius. He thus made Christianity the religion of the court, and in some sense put himself at the head of the church, but Paganism was still legal and still the formal religion of the law. 
The effect of Constantine's step was, however, enormously to the advantage of the church. Christianity became popuEffect upon lar, and even fashionable. The numbers and influence of the Christians increased rapidly. The government of the church took on more and more the monarchical form to which it had been tending, and became constantly more powerful as the Roman state was growing weaker. Before the end of the fourth century paganism was made illegal, and the triumph of Christianity was complete.

\section{Topics}

Christianity at the death of Christ. Its first advance. The church at Rome. Why did the good emperors persecute the Christians? What causes led to the growth of a governmental organization in the church? Why would the Empire naturally be taken as a model? Ilow did monasticism originate? What motives of policy would lead Constantine to recognize Christianity? What was the effect upon the church?

\section{Topics for Assigned Studies}

Constantine's recognition of Christianity and its results. Carr, Church and Roman Empire (Epochs, Ch. Hist.), Chap. IV. Uhlhorn, Conflict, 420-444. Schaff, Church History, III. II-37. Alzog, Church History, I. 463-473.

The primitive church organization. Schaff, Church History, I., Chap. X. Alzog, Church History, I. 195-206. Hatch, Organization, Lect. II. Allen, Institutions, Chaps. 1I. and III. A very valuable statement of the position of the best scholars of the Catholic church is to be found in an article in the Revue des Questions Historiques, Vol. XLIV. 329-384, by the Jesuit Father De Smedt, president of the Bullandists.

Monasticism. Kingsley, The Hermits. (Macmillan.) On early monasticism, containing translations from the original lives of its founclers. See also story of St. Columban, Nilman, Latin Christianity, II. 237-247, and translation of his life by Jonas in I'enn. II., No. VII. The rule of St. Benedict, in IIenderson, 274-314, and of St. Francis, 344-349. See Daily Life in a Midiceral Monastery, in Jessupp, Coming of the Friars (Putnam), and in Nineteenth Century, Jan., I884; and Allen, Christian Institutions, 137-178. Also Fling, Studies, II., No. 6. 


\section{CHAPTER III}

THE LAST AGE OF ROME

A tair degree of prosperity and security.
Julian "the apostate." (iardner,

Fulian (Heroes): King, fultum the Eimpiror's llirks (Bohn); Fulian and the Germans, Zeller, I.

Disease within and attack from without.
I I4. Character of the Fourth Century. - The reforms of Diocletian and of Constantine began the last age of prosperity of the Roman Empire. The frontiers during threequarters of the fourth century were preserved from any permanent break, and within the Empire there was a fair degree of security. Civil Wars for the possession of the throne did not cease. Constantine showed during his reign a very cruel disposition, ancl this nature descended to his sons. To secure their possession of power they murdered all their relatives, their cousin Julian escaping only because of his youth. But the brothers quarrelled among themselves and had usurpers to resist, and after some years but one survived, Constantius, sole emperor for a time.

In 360 Julian was proclaimed emperor by his soldiers in (iaul, against his will, and by the speedy death of his cousin obtained the whole Empire. His reign of three years is famous for his attempt to restore paganism to the supremacy which it had lost. Direct persecution was not possible, but he tried to exclude the Christians from the means of education and to throw contempt upon the religion in every way possible. The attempt proved a failure and was never renewed. Julian was the last of the family of Constantine to reign, and after him emperors chosen by the armies were engaged in a constant struggle, rapidly becoming hopeless, to protect the frontiers.

115. Causes of the Fall of Rome. - During these centuries since Augustus, despite all reforms and every tempo- 
rary restoration of strength, the double progress of disease within and attack from without was steadily going on, and became increasingly difficult to resist. Of these two dangers the one which was fatal in the end was that from internal disease, for Rome fell not so much because the attack from without was stronger, as because she could no longer resist it with her earlier strength.

It is not possible to explain briefly this decay of Roman strength. Its causes were mainly economic. The universal use of slaves, which is a very wasteful means of production, wasting both men and capital, and one that makes free labor degrading; heavy taxes which were so collected that the burden of them rested with killing weight on the middle class; a debased currency, giving a very unsteady standard of value; a practice, begun in the last days of the Republic, of feeding a part of the city population at the expense of the state, making an idle and dangerous mob and constantly tempting the middle class to give up the hopeless struggle with taxes, slave competition, uncertain prices, and declining production, and take life easy at the public cost ; official corruption, which, in spite of all the efforts of the emperors and of temporary reforms, continued to look upon public trusts as sources of private wealth; a general decay of the earlier Roman manhood and moral strength, which greatly weakened the army and the resisting power of the whole Empire ; and a decline of the population, which no effort of the state seemed able to check.

Causes like these exhausted the resources of Rome in men and capital. Thousands of Germans had been colonized in the Empire before the conquest. The army was largely barbarian. The soldiers spoke German and fought in the German style. Comparatively little was left on the eve of the conquest that really belonged to Rome, except - her best gifts to the world - her language, law, and institutions, and the idea of her universal and eternal empire, which Christian and German believed as implicitly as did the pagan Roman of Vergil's day. 
The origin of serfiom.

Arnold, Roman Prorincial .18ministration, I6I-I6t; Bury, Later Empire,

I. $28-29$; II. 4 I $8-42$ I.

I 6 . From Slavery to Serfdom. - The economic condition of the Empire during the age of its decline led to some changes which had most permanent and beneficial consequences. They made the beginning of the transformation of the class of manual laborers from slaves into serfs. These changes were made under quite a variety of different forms and for several different reasons, but we may say that the most prevailing reason was the growing scarcity of laborers and the difficulty of keeping the lands of the Empire in cultivation. To secure this result the right of the master to

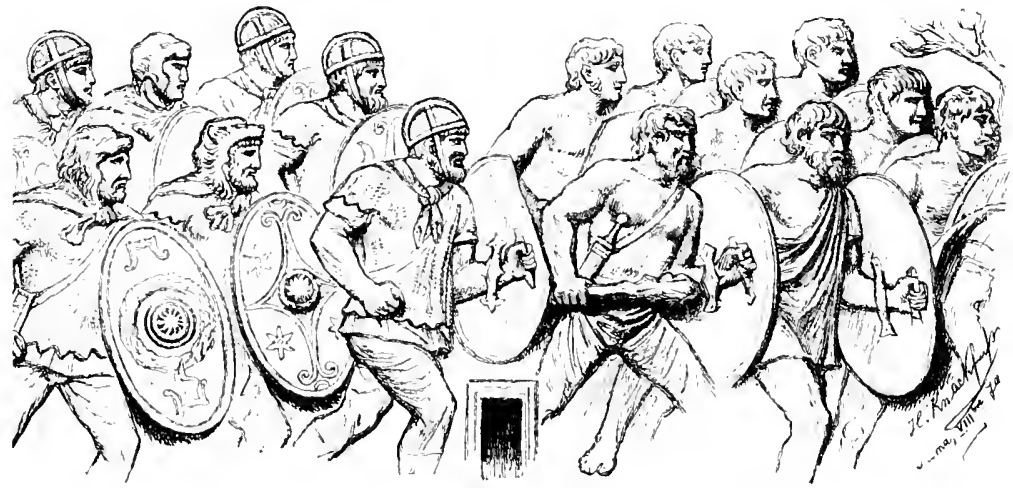

German Bongguard, Colimn of M. Aurflues

sell his slaves was in certain cases taken away, and the slaves were fixed by law to little pieces of land which they were required to cultivate. The state did not do this in order to improve the condition of the slave. Its only object was to keep up the supply of food. But in doing so it gave to the slave, who had before had no rights at all, a certain very limited number of rights which the master could not take away. Looked at from the side of slavery this was a great step in advance, and in the history of the laboring class serfdom is the stage through which it passes in advancing from slavery to freedom. 
I I7. The Attacks upon the Frontiers. - While political and economic disease within was thus steadily sapping the strength of the Empire, attacks almost without a pause on every frontier revealed the presence of dangers which it would have required the resources of the best days of Rome to overcome. The resistance had been long and obstinate, fairly successful for four hundred years, but we have now reached the point when it breaks down, because the resources of the Empire would no longer sustain it, and new races take possession of the provinces.

On the eastern frontier the struggle was with a renewed and powerful Persian empire under the Sassanid dynasty. This family had arisen early in the third century, and from that time had waged many and fierce wars to push their dominions towards the West over Roman territories. Jovian, the successor of Julian, was obliged at last to yield them five provinces, and their gains might have continued if they had not been involved, as the Empire was, in the great danger that swept down from the north of Asia on all the south, the invasion of the Huns.

On the western frontier Rome's enemies were the Germans, and it was their attack which was finally fatal to the Empire. Ever since the day when Julius Casar had turned back the invasion of Ariovistus, the German king, this conflict had been going on. For the first century and a half the trials of strength came only at considerable intervals, and the Romans were sometimes at least the attacking party, trying to teach the Teutonic tribes respect for their arms by a raid into Germany. With the reign of Marcus Aurelius the attack of the Crermans became more determined and more like an organized invasion, and the defence of the Romans more desperate.

As the decline of population in the Empire became serions, and the difficulty of keeping up the army greater, large numbers of Germans and of other barbarians were enlisted

Germans also defend the Empire. as soldiers in the service of the emperors, and even whole tribes, or portions of tribes, were in some instances settled

A new Persian empire. Gibbon, Chap. VIII.

The German altack is the fatal one. Gibbon, Chap. IX. 
in lands which had become racant within the borders. It was a dangerous expedient, but they proved, on the whole, faithful to their engagements so long as there was anything left to which they could be faithful.

In an early stage of civilization. Tacitus, Germuthiu, translation

I 8 The Characteristics of the Germans. - These Germans were still a primitive people, in a stage of development corresponding to that of the earliest days of Cireek and Roman history Their gorernments were tribal. Some of the tribes had kings of the Homeric type, exercising a

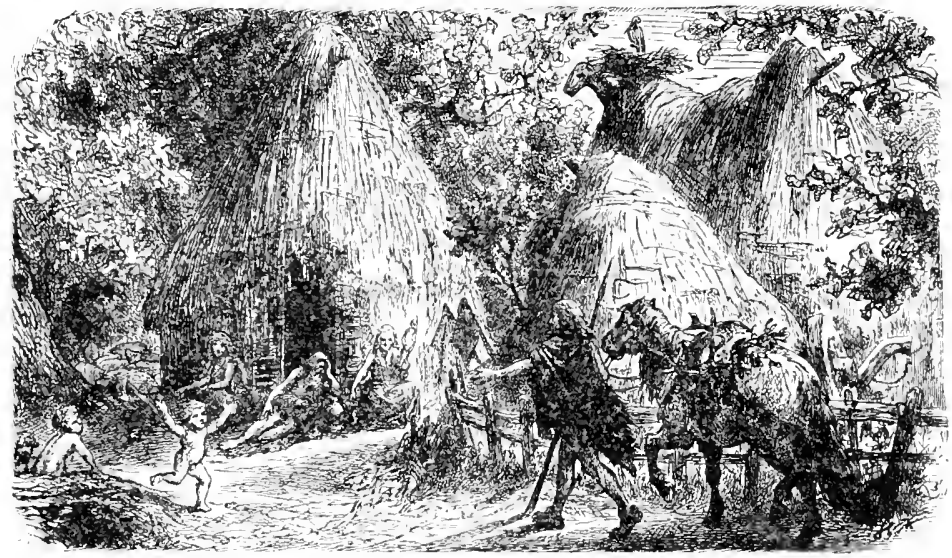

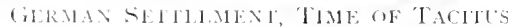

of Church limited authority, with councils of elders and nobles and a and

Brodribls:

alsig in $1 \mathrm{n}$ -

diana, No. g. ling, studies, II., No. 2 . pullic assembly of the people. Other tribes, like our own Saxon forefathers, harl not advanced even as far as this, and scarcely had a common political organization. In habits of life and manners and customs, both in war and peace, they were in many ways like the more advanced North American Indians. Their agriculture was simple. War was a farorite occupation of the men, and in peace they spent much of their time in the chase and in drinking and gambling. On the other hand, in many of their political and ethical ideas, they were much above the ordinary barbarian. They had a 
simple religion of nature gods, with some darker superstitions. Their regard for woman and their standard of morals were high. Their criminal law was crude, but based upon sound and just principles, and their method of trying the accused, though attaching great importance to the following of certain fixed forms, really provicled for a decision of the important points of the case by the public opinion of the community. In political questions, also, like war and peace, or the choice of magistrates, the public opinion of the tribe had the final decision.

I I9. The Third and Fourth Centuries. - The middle and last part of the third century was the most terrible age of this conflict, at least until the final ruin came. The Alemanni burst through the barriers in the West, and appearing in northern Italy threatened Milan. 'The Goths crossed the Danube and invaded the Eastern Empire, killed the emperor Decius, even crossed the Bosphorus, and, finally, carried off great plunder. The Illyrian emperors restored the frontiers, but only with great difficulty. In the first part of the fourth century the German attack lessened in severity, but only to be renewed again after a couple of generations of comparative security. Julian had another fierce conflict with the Alemanni, and overcame them only with an army so largely made up of Germans that, when they proclaimed him emperor they put him up on their shields after the German fashion.

I20. The Goths cross the Danube. - The final breaking down of the frontier defences was the result of the attempt of the Germans to escape from a still fiercer race of warriors which had attacked them from the East. 'These were the Huns, a Tartar tribe from northern Asia, who fell first upon the kingdom of the Goths which occupied at that time a considerable portion of European Russia. When they could not resist further, the two divisions of the Goths followed different counsels. The Ostrogoths, or East Goths, submitted to the Huns and became their subjects: the Visigoths, or West Goths, fell back before their advance,

Extracls from the law of the Salic Franks, Henderson, $170-189$. Forms of |rial, Penn. II., No. IV., and Henderson. $3^{I} 4$.

The frontiers often broken and reslored with difficulty. Freytag, Ingo: Dahn, Filicitias (novels).

The attack of the Huns. Hodgkin, Italy, Vol. II., Chap. I.; Gibbon, Chap. XXVI. 
Hodgkin,

Italy,

I. $250-256$.

The battle of

Hadrianople, $37^{8}$.

Oman,

Iysantine

Empire

(Nitions), Chap. III. : Hodgkin,

Italy,

I. $27 \mathrm{I}-275$.

'The last great enperor of the united Empire, $379-3 \times 5$. Hodskin, I youty of The disilus (Ciarendon), Lect. IV.

and coming to the Danube besought the Romans to take them within the frontier. This the Romans agreed to, the Goths surrendering their arms and giving hostages for their good conduct.

It is likely that the Goths would have kept the peace but for the injustice of the Roman officers who had charge of the arrangements. They were trying to make all the money they could out of the business, and they finally allowed the Goths to buy back the arms they had surrendered. Then they rose and marched towards Constantinople. The emperor Valens foolishly risked battle without waiting for reinforcements, and was totally defeated and slain.

I2I. Theodosius the Great. - The new emperor, who shortly was given the throne in the East, Theodosius, a man of great ability, succeeled in settling the Goths in territories south of the Danube, which they agreed to defend. During his reign of about twenty years they remained faithfial to the Empire.

Theodosius united for some years the whole Empire under his rule, but this was for the last time in history. On his death, in 395 , it was divided between his two sons, Honorius becoming emperor in the West, and Arcadius in the East, and the Empire was never again united except in mere form.

Alaric, king 122. The Invasions of Alaric. - Theodosius' death was of the Visigoths. Bury, Fmfire, lik. II., Chap. IV.; lodgkin, Dymassty of Theodosius, I.ect. V.; Gibbon, Chaps. XXX. and XXXI. the signal also for the Visigoths to attempt new conquests, or this may have been because the young and ambitious Alaric came to their throne at about the same time. They marcherl into Cireece plundering and destroying, passed Athens, and went on into the Peloponnesus. Here their course was checked by an army from the West under Stilicho, a Vandal, who was the commander of the forces of Honorius. Alaric escaped from Stilicho with his army, and crossed into Epirus, but was persuaded to settle down in Illyricum as Roman commander in that province. Here he could make preparations for an attack on either half of the Empire as circumstances might invite. 
In 402 he set his army in motion again and this time attacked the West. Descending into the valley of the Po, he threatened Milan, and began the siege of Asti where the emperor had taken refuge. Again Stilicho saved the Empire, and drove him back, but he only retired to the head of the Adriatic and waited for another opportunity.

r23. The Breaking of the Rhine Frontier. - Meantime events had taken place in Germany which led to the speedy collapse of the Roman power. The Huns had pushed their conquests towards the West, and many of the Germans, representing several tribes, falling back before their advance, had collected on the east side of the upper Rhine, waiting an opportunity to pass over into Gaul. From these a large force of various tribes under Radagaisus turned south and invaded Italy. Stilicho met them in the neighborhood of Florence, surrounded them with his army, and starved them into submission. Rome was relieved of this danger, but it was her last success in Italy.

On the last day of the year 406 the Germans who had not joined the expedition of Radagaisus forced the passage of the Rhine and entered Gaul. The most important of these tribes were three, the Suevi, the Vandals, and the Burgundians. The Burgundians settled in the country about the upper Rhine which still bears their name, and soon were able to make a treaty with the Romans by which their occupation received the sanction of the emperors and they were recognized as a Roman army of occupation. The Suevi and Vandals, after spending some time in plundering Gaul, passed through the Pyrenees and took possession of Spain, which they made into kingdoms for themselves. Rome never recovered any real control of Gaul.

r24. Rome's German Defender sacrificed. - Shortly after this breaking of the Rhine frontier, Stilicho was put to death as the result of a conspiracy of his enemies. With his great enemy out of the way Alaric knew that his opportunity had come, and he came down into Italy once more. This time there was no one to turn him back. In 4 ro Rome was

The occl1pation of Gaul.

Zeller, I.
The Germans pushed on by the Huns.
The death of Stilicho the Vandal, 408. Hodgkin, Italy, I., Chap. XVI.; Zeller, I. 
taken and sacked. But Italy was not to belong to the Visigoth. Alaric died in the south soon after the capture of Rome, and the new king led the nation into southern Gaul. There they settled down to live under an arrangement with the emperor, whose sister was married to their king, and from there they extended their rule over Spain, gradually conquering the Suevi and Vandals who had occupied that country earlier.

The Vandals occupy Africa, 429. Curleis, Roman Empire, Chap. VII.; Hodgkin, Iy'nasty of Theodosius. Lect. VII.

\section{Attila in-} vades G.uul, $45 \mathrm{I}$.

Hodgkin, Dymasty of Theodosius, Lect. VI. ; Curleis, Roman Empire, Chap. VIII. ; Zeller, I.

He invades Italy, $45^{2}$. Carr, Church and Roman Empire, Chap. XXIII.

A few years later an opportunity came to the Vandals to cross over into Africa, a province which up to that time had not been plundered by the Germans. The story goes that they were invited to make the invasion by the Roman officer in command. At any rate there was civil war among the Romans in the province, and the Vandals easily conquered it, and made Carthage the capital of a new kingdom which soon became, like the old Carthage, a great naval power in the Mediterranean. In 455 in one of their raids they stormed the city of Rome and carried off a great booty.

I 25. The Invasions of the Huns. - Just before this happened, however, the smitten Empire had made its last desperate attempt at self-defence. Attila, the young king of the Huns, at the head of a great army composed of his own people and of the German tribes who had submitted to their rule, invaded Gaul, and threatened to sweep all before him. By a heroic effort the Roman commander, Aëtius, "the last of the Romans," succeeded in getting together an army strong enough to oppose him. It was made up, however, largely of Germans. The army of the Visigoths was there, led by their king, and Franks also aided in the defence of the Empire. The great battle at Chalons-surMarne, called sometimes the battle of the nations, was desperately fought and not decisive, but Attila's loss was so heavy that he decided to give up the attempt. 'The next year he entered Italy with another army. Aëtius was this time unable to meet him, but we are told that the pope, Leo I., came to the help of the Empire and persuaded the 
Hun to turn back. The story is very possibly true. At any rate, for some reason Attila did abandon the attack, and Italy was saved. In the following year he died, and his empire fell apart, the Huns remaining in the Danube valley and the German tribes becoming independent.

126. The End of the Western Empire. - Already the Saxon settlements had begun in Britain, and now not a province of the Western Empire was really Roman. Italy kept up the pretence of being so for some years yet, and the throne was occupied by some one who called himself by the title of emperor, but the army was German and its German commander was the real ruler of the country. Finally this army revolted, made a German, Odovakar, king in the German fashion, deposed the emperor Romulus Augustulus, and sent to Constantinople the imperial insignia, saying that one emperor for the whole Empire was sufficient. This meant, of course, though they might express it differently, that Italy had now become a German kingdom like the other provinces of the West.

The date of this event, 476 , is usually taken as the date to separate "ancient" from "medieval" history, and it serves as well for the purpose as any date, if such a division The close of "ancient history," 476 . is to be made, for it does mark in a somewhat striking way the great fact which makes a real separation - the fall of the Roman power and the coming in of the Germans. But it must not be thought that this event seemed especially significant to the people who were living at the time or that they were at all conscious of any passage from one age of history to another. It was to them an incident like a great many others which were happening on all hands, and they were able easily to persuade themselves that Rome continued, for was there not an emperor of Rome reigning all the time at Constantinople. To after ages, which realized more clearly that the IVest had ceased to be Roman, this dramatic surrender of the title seemed to mark the close of a great period in history. 


\section{Topics}

The last age of prosperity. The attempt of Julian against Christianity. The economic diseases of the Roman Empire. What was the real reason why Rome could no longer resist the Germans? How does a serf differ from a slave? What frontiers were especially subject to attack? The Germans on the side of Rome. The civilization of the Germans. The events which led to the battle of Hadrianople. The final division of the Empire. Alaric and Stilicho. The name and place of settlement of each of the German tribes occupying the Western Empire. The history of Attila. What happened in the year 476 , and the meaning of the event?

\section{Topics for Assigned Studies}

The causes of the fall of Rome. Hodgkin, Italy, Vol. II., Chap. IX., and an article in the Contemporary Reziezi, Jan., ISgS. Seeley, Roman Imperialism, Lecture II. Bury, Later Roman Empire, Book 1., Chap. III. Adams, Ciritiation during the Widdle Ases, $76-\$ 7$.

A glimpse of IIun life. Bury, Later Emfire, Book II., Chap. XI., a translation.

The end of the Western Empire in 476 . Bryce, Moly Roman Empire, Chap. III. IIodgkin, Italy', II., Chap. VIII. Bury, Later Empire, Book HII., Chap. V.

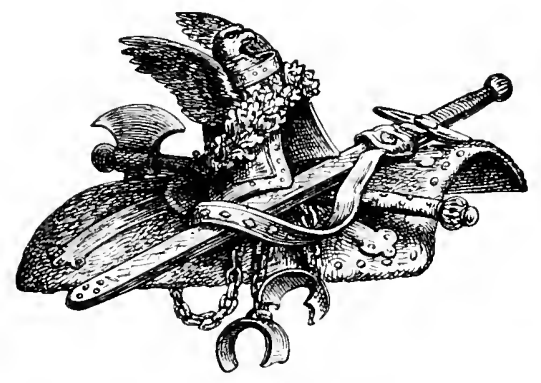

GERMAN IVEAPONS 


\section{CHAPTER IV}

\section{THE FOUNDING OF THE GERMAN STATES}

I27. A Second Period of German Conquests. -- With all their appearance of success these first German states were not destined to be permanent. Another series of conquests followed these earlier ones, made by tribes which were not directly impelled by the attack of the Huns, and theirs were the states which grew into the modern nations.

The Franks were the first to begin the new movement. A part of their race had been allowed by the Romans to occupy lands along the western bank of the Rhine long before that frontier was finally broken. They were not always peaceable allies of the Empire, but they continued to hold these lands; their numbers were increased after the invasion of 406 ; and when they began their career of conquest they were occupying the territory on both sides of the middle and lower Rhine. Their conquests differed from those of all the other German tribes in the important fact that they were an expansion, the Franks spreading out in all directions while they still retained possession of their original home as the centre of their dominion.

128. The Founder of the Frankish Empire. - Clovis was the founder of the greatness of his race. He was the king, at the beginning of his career, of a small subdivision or clan of the Franks on the Roman side of the river, with Tournai as his capital, for at this time the Franks were in a somewhat backward stage of political development and had no common or national govermment, but several kings of tribal subdivisions. This gives us the double task in which Clovis

The first conquests not permanent.

The Franks. Sergeant, The Franks (Nations); Freeman, The Frunks and the Guuls, in Histerical Essizy, I. (Macmillan); Zeller, II.

Clovis, 48I5II. Sergeant, Chaps. VIII.andX.; Gibbon, Chap. XXXVIII. 
was to be successful, the conquest of new territory and the consolidation of his own race.

His first conquest, 486.

The

Alemanni overcome.

The question of the divinity of Christ. Gwatkin, The Arian Contriersy (Epochs, Ch. Hist.) ; l'enn. IV., No. II.

To the west of Clovis, in north central Gaul, lay a territory which had not as yet been occupied by any German tribe. A Roman officer, Syagrius, commanded here, but he was of course really independent, and he is called by the historian of the Franks, Gregory of Tours, the king of the Romans. This was an opportunity for Clovis, and with a small army he marched against Syagrius and completely defeated him in 486 . In territory and resources this was a great increase of Clovis' power, and is the first event in the history of the empire which was to succeed the Roman.

Ten years later the second step was taken. Clovis led the Franks against their enemies the Alemanni, who held the lands to the southeast. The decisive battle was hotly contested, and we are told that in the midst of it Clovis cried out that if the God of his Christian wife, Clotilda, would give him the victory he would become his follower. The victory was gained. The Alemanni were conquered and their land made subject to the Franks, and Clovis kept his promise.

I 29. Arian versus Catholic. - The conversion of Clovis brings us to a fact of great importance in the history of the Christian church as well as in the political history of Europe. Early in the fourth century a theological controversy had arisen in Alexancria on the question of the divinity of Christ. Arius and his followers, called Arians, maintained that Christ was not coll. To get an authoritative decision of the matter Constantine called the first great council of the church, the council of Nicra, in 325. Its decision was in favor of the doctrine of Christ's divinity, but this did not finally settle the controversy, and for a considerable portion of the fourth century the government of the Eastern Empire favored the Arian belief.

The West, on the other hand, when left to itself, steadily farored the orthodox view. The German conquest of the fifth century, however, threatened the church of the IVest 
with a serious danger arising from this question. For these Germans had been converted before the crossing of the Danube by missionaries from Constantinople who were Arians. The most famous of these missionaries, Ulitas, The Roman W'est Catholic, the German translated nearly all the Bible into Gothic, and the fragments which have come down to us of this translation are our earliest written specimens of the Teutonic languages.

When the Arian German became the ruler of the provinces of the West, the difference of religious belief gave rise to constant suspicion between himself and his Romanized subjects. The Arian was nearly always liberal and lid not try to force his views upon others, but he could not avoid knowing that the Catholic looked upon him as a heretic, and the suspicion was natural that the rule of the orthodox emperor was preferred to his own, and that conspiracies to establish it might be constantly expected. Still more important was the fact that the Arian did not acknowledge the supremacy of the bishop of Rome, even in the undevelopect form of the fifth century. The permanence of this faith, therefore, in the West would mean a very loose organization for the church there, and very possibly no organization at all but independence and separation, which in turn would mean a far more slowly developing civilization.

I30. Clovis adopted the Catholic Faith. - The Burgundians like the rest were Arians at the time of their settlement, but a portion of the race had been converted to Catholicism, and Clovis' wife was of this party. Whether he was led by this reason or by the obvious advantage which he might expect to gain if he were a Catholic in extending his conquests over his Arian neighbors, Clovis at his conversion adopted the Catholic belief. As in the case of Constantine, Clovis' conversion made no apparent change in his character or conduct, and the real importance of the act is to be found in its political consequences, especially in the fact that he thus prepared the way for a close union in interest and policy between the papacy and the Frankish nation, which was of the greatest value to them both.

Clovis' conversion not unlike Constantine's. Sergeant, Franks, Chap. IX. 
The Burgundians conquered. Sergeant, Chap. X.

'The Visigoths also, 507 .

The Franks made a nation.

Results of the reign.

I3I. The Last Years of Clovis' Reign. - Not long after his conquest of the Alemanni, Clovis attacked the Burgundians, skilfully fomenting a division in the state. At first he was entirely successful and reduced the country to the condition of a tributary state, but later the Burgundians recovered something of their independence, and were not incorporated in the Frankish dominions until after the death of Clovis. Next came the turn of the Visigoths, whose territories south of the Loire Clovis naturally coveted, and who could be attacked as Arians. Again Clovis gained a decisive victory and would have annexed all the territory to the Pyrenees but for the intervention of the Ostrogothic king Theodoric from Italy. He saved Septimania to the Goths, the land along the coast of the Mediterranean, and so kept open a line of communication between the two Gothic states.

In the last years of Clovis' life the process of consolidating the Franks into a nation was carried to completion. The way was prepared for it by a series of treasons and murders which are evidence enough that his conversion had had no influence on the character or conduct of the Frankish king.

Clovis died in $5 \mathrm{I} \mathbf{I}$, after the accomplishment of a great work. If we consider with how small a power he began, and what a really great dominion he had brought together, the solid foundation of the empire which was to be the source of institutions and law for the Middle Ages, we cannot refuse to Clovis, savage though he was, the title of one of the great men of history.

I32. The Ostrogoths conquer Italy. - During the years of Clovis' life another German kingdom had been founded which deserved a better fate than awaited it, by a man as great or even greater than Clovis. After the death of Attila, the Ostrogoths, now independent, had crossed the Danube and settled on its southern side, where they made an arrangement with the emperor in the East. About the same time that Clovis became the king of the Franks, the 
young Theodoric became their king. Like Alaric and Theodoric Attila under similar circumstances, he was probably moved the Great. by ambition to attempt new conquests.

Italy was the province which he finally selected as the seat of his kingdom. Here Odovakar was still in power, and Theodoric did not find it an easy task to conquer him. He only succeeded in the end by murdering Odovakar with his own hand after a nominal peace had been made between them.

133. The Character of Theodoric's Rule. - This act, however, was not followed by others like it. Theodoric's reign was wise and liberal. He seems to have desired to lead the two races, German and Roman, to live in harmony and to rule as the king of all his people. Though he was an Arian, he respected the religion of his Catholic subjects and did not persecute them. In the later years of his life, when perhaps his mind had been darkened by family and public misfortunes, he showed more of the disposition of a tyrant, and put to death several of the leading Romans on suspicion of conspiracies to restore the rule of the emperor. Among these was the philosopher Boëthius, whose books were in such common use during the Middle Ages. Outside his own kingdom, Theodoric's influence was very great over all the Germans of the IVest. He was connected with almost all the states by marriage alliances or other ties, and came as near to exercising a universal rule as was possible at the time. For twelve years during the minority of their king he acted as king of the Visigoths, and the two parts of the race were united again as they had been before the attack of the Huns. In government, Theodoric, though he was himself a German king, retained much of the machinery of the Roman state, and there promised to be made among the Ostrogoths a thorough and early union of the two sides of future civilization, German and Roman.

But it was the Franks who were in the end destined to make this union of German and Roman, and not the Goths. No king like Theodoric came after him, and in not many

The conquest of Italy, $489-493$.

The wisest and best of the early German kings. Bryce, Holy Romall Empire, 27-29.

His influence international.
The Ostrogothic kingdom short-lived, 493-555. 
Dirisions, artificial and real.

New conquesis.

The " donothing" kings.

Zeller, II. years the kingdom of the Ostrogoths was overthrown and the race annihilated.

134. The Growth of the Frankish Power. - The dominion of the Franks, on the other hand, continued to grow. Clovis' kingdom was divided on his death between his four sons, and divisions of the kingdom continue to be frequent in Frankish history, but these do not split the race or the empire into permanent fragments. Towards the west, in the lands which had a large Roman population, the Franks themselves were slowly becoming Romanized, and as those to the east remained German there was beginning in this way a division in the race which was to be permanent and to have most imprortant consequences in history. It was, however, many generations before these consequences began to appear.

In the meantime new conquests were made. The Burgundians were annexed and received a Frankish king. The Visigothic territories in southern Gaul were more completely incorporated. In central Germany the Thuringians were conquered. Finally, southeastern Germany was included, and about the beginning of the seventh century the Frankish dominions reached their widest extent for this period, covering all Gaul, the valley of the Rhone, and central and southern (iermany.

I35. The Decay of the Merovingian House. - At this same date the Merovingian house, the family of Clovis, entered upon a period of rapid decay and exhaustion, the period of the faincant or do-nothing kings. The savage passions of Clovis descended in his family. Its history is full of treachery, murder, and crimes of all kinds. In the last half of the sixth century two famons queens, Fredegonda and Brunhilda, strove for supremacy and triumph over one another, in a most barbarous and brutal conflict from which begins the corruption of the strength of the line. Dagobert, who was king from 628 to $6_{3} 8$, was the last of the Merovingians who really ruled. After him the control of the state passed into the hands of the great officers 
who were called the mayors of the palace, and the kings were reduced to mere shadows, with no voice in the conduct of affairs.

One characteristic of the Frankish constitution made the The Finkish dissolution of government comparatively easy. The ma- count.

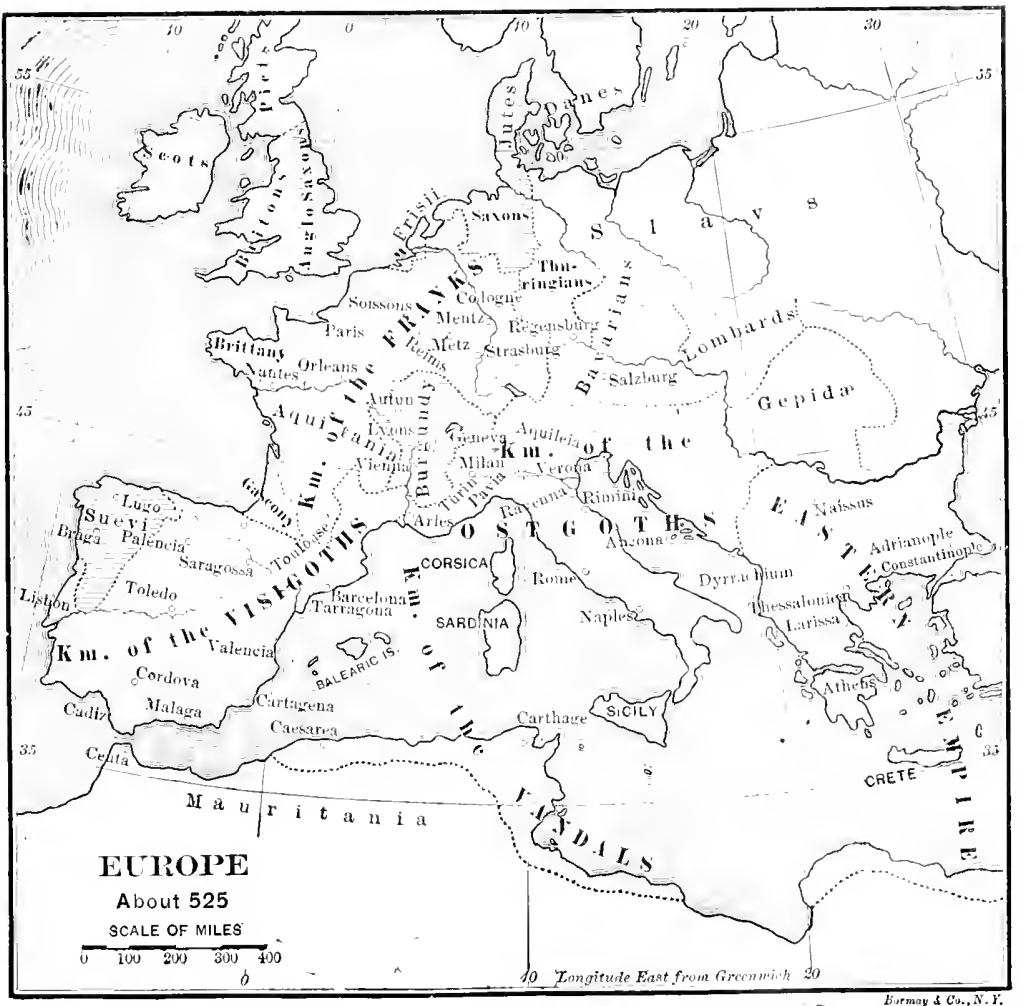

chinery of the state was very simple. The chief adninistrative officer was the count, or graf, an officer of the primitive Germans whose duties had been enlarged under Roman influence. The territory of the state was divided into districts called counties, each of which was adminis- 
tered by a count. In his hands were concentrated all the various functions of the state. He collected the taxes, administered and enforced the laws, presided in the courts of justice, was the military head of his county, and represented the interests of the state in all directions. So much power in the hands of an individual, who was often, to begin with, one of the great landholders of his county, made it very easy for the count, especially when the central government was weak, as in the age of the "do-nothing" Merovingians, to throw off his dependence upon the government, and become practically the independent ruler of a little principality.

C.inges in it.i.

Cha scter of the impire : the East.

l:ts s tian, $527-55$. litil lim e. Bk. il.. 'rap. 11. : r) nan, Bive it ne Empir

(Na,is 1s), Chats. VI. and $Y \%$.
136. The Roman Empire in the East. - In the meantime, the Ostrogothic kingdom established and made so powerful had come to an end, and Italy had been taken possession of by another German race. This change was due to a sudden revival of strength in the eastern half of the Empire and to a desire of the emperor to rule the West once more.

Since the death of Theodosius and the final division of the Empire the East had taken but little interest in the affairs of the West. Its own difficulties were enough for all its strength. To be sure it was not exposed to the full fury of the German attack, but the Huns were long a threatening danger, and the new Persian Empire was constantly trying to push towards the West, while civil and religious strife was frequent within the borders. On the whole, however, the Empire in the East was well maintained through the stormy times of the fifth century.

r37. The Reign of Justinian. - Early in the sixth century, an Illyrian peasant, Justin, a brave soldier, obtained the throne, and prepared the way for his nephew, Justinian, whose reign is the last great period in what may be called Roman history in any true sense. The cherished purpose of Justinian was to resture the old Roman Empire by the recovery of the provinces of the West from their German conquerors. Fortune farored him in this purpose, for it 
gave him in Belisarius a general of great ability, and in the weakness and dissensions of the German states a comparatively easy task.

The kingdom of the Vandals in Africa was first attacked. They had never got on well with their subjects, largely be. The Vandals conquered. cause as Arians they were inclined to persecute the Catholics, and the provincials stood ready to welcome the conquest of Justinian. The king and his army made a brave defence, but it was unskilful, and the task of Belisarius was not difficult. The province of Africa remained under the Empire of the East until its conquest by the Arabs a century later.

Belisarius was next sent against Italy. There he found a task which required all his powers. The Ostrogothic race was not as strong as it had once been, but its resistance was long and heroic. Once when everything seemed at an end they recovered possession of nearly all they had lost. If they had had the leadership which they deserved they might have been successful, but they were not fortunate in their kings and the protracted conflict undermined their strength. Finally they were entirely overcome and the race was practically annihilated, for the few survivors passed into Spain where they were absorbed in the Visigoths.

In Spain a civil war among the Visigoths enabled Justinian to obtain possession of some territory in the southeastern quarter, but there his successes were limited. He had not A part of Spain recovered. reëstablished the old Empire of Rome, but he had taken vengeance on the first conquerors of the IVest, and he had added new strength to the name and jdea of the Empire.

138. Justinian's Work for Civilization. - The greatness Building. of Justinian's reign is not measured by his wars alone. He was a great builder both of fortresses for defence and of beautiful buildings like the church of St. Sophia in Constantinople, and the revived interest in architecture in his reign long influenced the art of building even in the West.

But his greatest title to fame of all is his codification of the Roman law. In this work the great body of the Roman 
In codifica-

I1. of the

Ku, san law.

1.) rets

the

tute's,

S.

St: le's,

․ IO.

[1: nian's in the

t.

I ine Lombasts enter It: 568 .

Char icter of the Lombard cony lest. law, which had been growing for so many centuries, was put into systematic and easily accessible form. The work comprised three parts: the Code proper, containing the laws made by the emperors; the Digest, based upon the writings of the great Roman lawyers the jurisconsults; and the Institutes, treating of the funclamental principles of the law, as an introductory text-book for the law student.

This system of law Justinian's conquest introduced into Italy, where it remained in use, and whence it spread, some centuries later in the Middle Ages, to the other countries of the West, becoming at length powerfully infuential in the formation of the national law of all the continental states, as well as in the development of the royal power at the expense of the feudal system. Probably there is no textbook of law in such extensive use to-day as the Institutes of Justinian.

139. The Invasion of the Lombards. - The possession of Italy by the Eastern Empire was not of long duration. The conquest by Justinian had merely opened the way for another German tribe. The Lombards had followed the Ostrogoths across the Danube, and now they followed them into Italy. Justinian had been dead but three years when they descended into the valley of the Po and took possession of that part of Italy almost as easily as if it were a vacant land, only a very few of the cities making any resistance. Of the rest of the country, however, their conquest was very slow and never complete.

The Lombards were very rucle and uncivilized, in a backward stage of political development, and not yet thoroughly accustomed to a national government. For some years after the conquest they lived without a king, ruled in little states by dukes, while others were trying to make new states for themselves in the unconquered parts of the country. These later conquests were made without much order or system, wherever it pleased the leader of the band to settle. Thus it happened that the eastern Romans retained many fragments of territory scattered about in the 


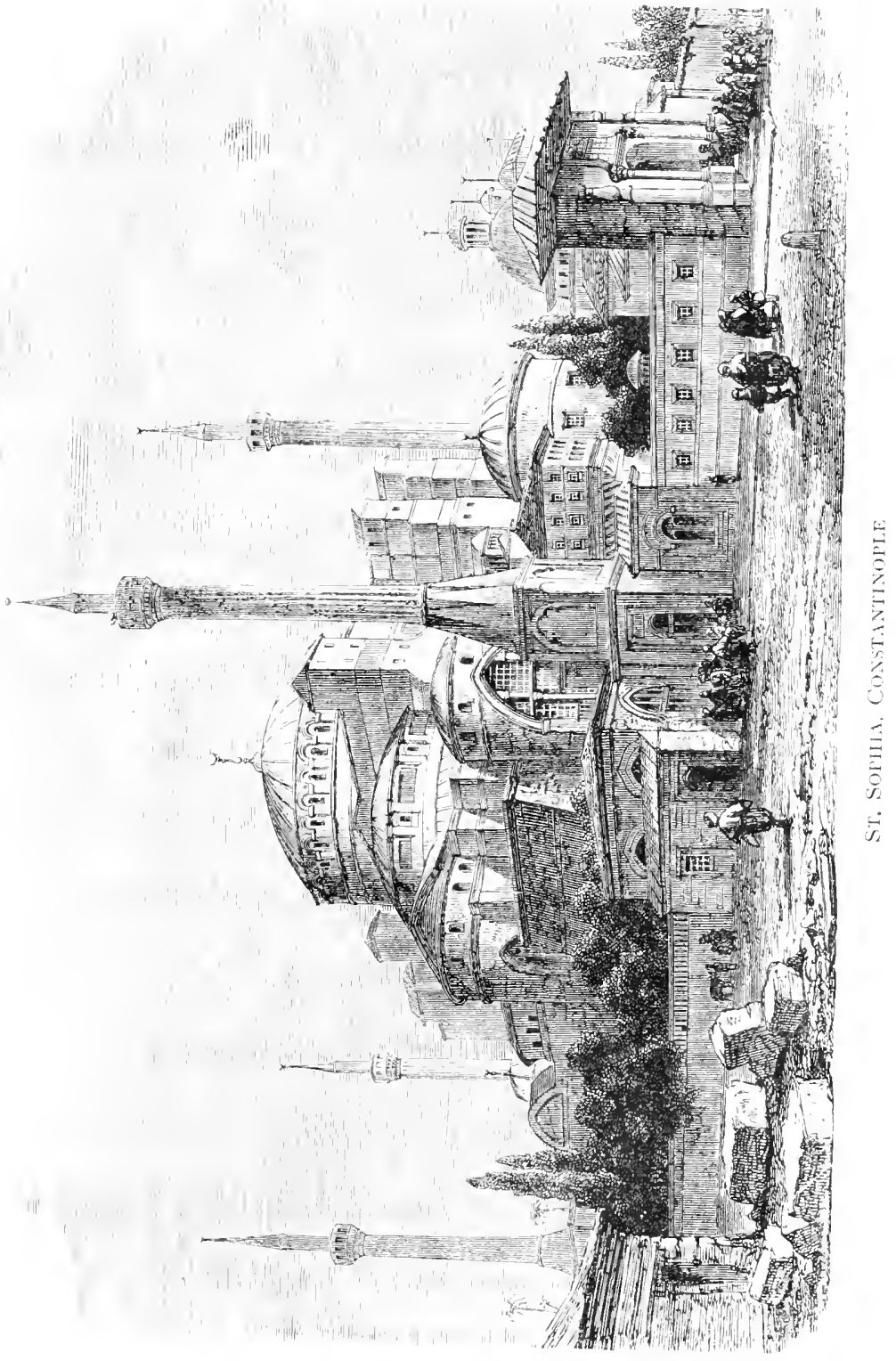




\section{48 The Founding of the German States [\$\$140, I+1}

peninsula, and separated from one another by the Lombard lands.

The Eastern Empire retained parts of Italy.

The attack began before the Romans withdrew.

Church, The Count of the Six ron Simere (novel).

The first settlement, $4+9$.

The development of government.
This fact had very important consequences in later history. Sonthern Italy remained a part of the Eastern Empire for almost five hundred years. Rome and Naples, Genoa, Venice, and Ravenna escaped the Lombard occupation, and though the exarch of Ravenna was in form the representative of the emperor, he could exercise no very effective control over the cities which were separated from his by Lombard territory. This meant local independence, and in the case of Rome it meant the beginning from which grew the pope's temporal sovereignty.

140. The Saxons in Britain. - One German settlement remains to be described, and one in which we are especially interested, the Saxon. They had begun to make plundering raids along the coasts of Britain, exactly after the fashion of their later relatives the Northmen, long before the Roman troops withdrew from the island. After this had occurred, about the year 407 , the abandoned provincials suffered severely and were not able to protect themselves, either from the saxons or from the uncivilized Celts of the north and west.

By the middle of the century the German invaders had begun to make little settlements along the coasts. 'The first of these was probably made in the isle of Thanet, at the southeastem corner of England, by the Jutes - invited to assist in keeping off the wilder Celts. They did not long remain satisfied, however, with 'Thanet, but spread over the neighboring territory by conquest, and established the first of the German kingdoms, that of Kent.

I4I. The Saxon States.-Other settlements followed during the next hundred years, the Saxons occupying the southern coasts and the Angles the eastern. The Saxons had at this time no idea of a national government, and those who remained in the original home on the continent did not have even at the time of their conquest by the Franks more than two centuries later. The new conditions, however, 
which arose from their making a conquest and occupying a conquered land, led the Saxons in England to transform their leaders into kings and to a steady increase of the royal power.

Of the earliest states we know almost nothing. They seem, however, to have been very small, and to have tended early to coalesce, by conquest or voluntary union, into larger states. From this stage of their history there emerge seven larger kingdoms of which we have some definite knowledge. They are the kingdom of the Jutes in Kent; three Saxon kingdoms, Sussex and Wessex on the south coast and Essex on the north side of the lower Thames; and three states of the Angles: East Anglia, now the counties of Suffolk and Norfolk, Northumberland, stretching finally as far north as Edinburgh, and Mercia, the last to be settled, a kingdom of the interior lying to the west of East Anglia. These are the kingdoms known sometimes as the Heptarchy, a term which must be understood to mean merely that there were seven states, not that they were united in any kind of union which could be called by this name as a government.

142. No Roman Elements in the Saxon States. - In one very important respect this Saxon conquest differs from those made by the other Germans. Whatever may have been their treatment of the Romanized provincials, whether they drove them entirely out of the land which they occupied or made subjects of them, and we are not quite sure which they did, they underwent themselves no Romanization. Their strictly legal and political institutions show no traces of Roman influence. No union of German and Roman was made in these states, but the development was purely Teutonic. In institutions of a more economic character, especially in those relating to the holding of estates of land and the management of their cultivation, there may have been a more direct Roman influence.

One line of connection with ancient civilization was, however, established not long after the conquest in the conversion of the Saxons to Christianity. The new faith had been

The so-called Heptarchy. Green, English People. I., Chap. II.

Pure German government and law.

Green, Making of England, I3I-I52; Church. Early Brituin (Nations).

The conversion of the Saxons. 
Translation introduced into the island under the Romans, and still of Bede in endured among the unconquered Celts of the west and Bohn, $34-40 ;$
Letters of Pope Gregory to Augustine;

Gee and Hardy, 2-1o. 664 . than that which now prevailed upon the continent. After the introduction of Roman Christianity by the mission of St. Augustine to the Saxons in 597, these two types of faith and practice became rivals for the adherence of the new German rulers. In the Synod of Whitby the decision was made in favor of the Roman forms, a decision which brought the Saxons into contact at once with the best remaining channel of influence from ancient civilization, with the growing unity of all the Christian West under the papacy, and with the contemporary life of the continent.

\section{Topics}

How did the Frankish conquest differ from that of the other Germans? What conquests were made by Clovis? What was Arianism? What difference did it make whether Clovis became an Arian or a Catholic? State all the changes which took place among the Franks under Clovis. The character of Theodoric's government in Italy. Divisions in the Frankish state. Territories of the Franks at their widest extent. What is meant by the "do-nothing" kings? The duties of the count. The conquests of Justinian. The fall of the Ostrogoths. The codification of the Roman law. The geographical character of the Lombard conquest. How did the Saxons get their first footing in Britain? What effect had the conquest on their goverument? Was there anything like this in Frankish history? What is meant by the Heptarchy? What states composed it? Roman influence on the Saxons.

\section{Topics for Assigned Studies}

The character of Theodoric's rule. Gibbon, Chap. XXXIX. Bradley, Goths, Chap. XVII. Hodgkin, Theodoric the Goth (Heroes), Oman, Periods, 20-32. Hodgkin, The Letters of Cassiodorus (Frowde), gives in translation a large number of the letters of Theodoric's minister, which illustrate the character of his government and the Roman elements in his state.

Compare or contrast Theodoric and Clovis. 
The corlification of the Roman law. Iury, Empire, Book IV., Chap. III. Gibbon, Chap. XIIV. Iladley, Introduction to Rioman I.ai" (Appleton), lectures I. and II. Sheldon Amos, Roman ('iall Law (Lundun, Kegran I'aul), I'art I., Chap. IV.; Part III., Chaps. ]. and II.

The first Saxon settlement. (ireen, Making of England (Harper), 13-5+. Green, Ilistory of the Einglish People (Macmillan), I. 22-27. Social England ('utram), 1. 116-121. Church, Early Britain (Nations). Translation of Bede in Bohn's Library, 23-26. There is also a translation of the Anglo-Saxon Chronicle in Bohn.

\section{INEPIT Lib UाI}

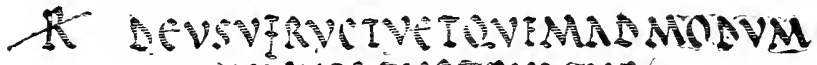
DVISUIATVRFRVATVR

PaLlusluboteprLadurtellumLsusfou ctusE: TULALLNLSFE bUSUTENDIFRUENd SALLLARERLIMSLLLSTINTLA.

Celsus Libponetaludeciondigestopume,

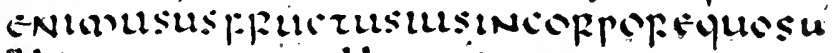

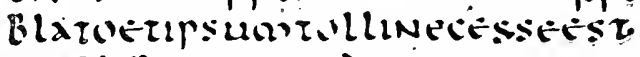
GMUS Lliposecunoopepumicrzidanapun

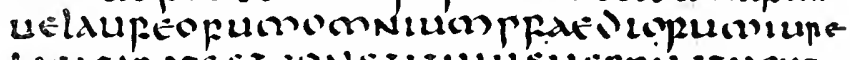

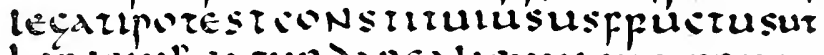
befestubeatupsapealicum sumppuet?

Fragment from the Digest of JUSTINiAN 


\section{CHAPTER V}

\section{THE FRANKS, THE ARABS, AND THE PAPACY}

The Carolingian family. Sergeant, The Franks (Nations), Chap. XIV.; Hodgkin, Charles the Great (Macmillan), Chap. II.; Zeller, II.

Sources of their power.

The mayor of the palace. Sergeant, The Franks, I9t-200.

Pippin, Grimoald, and Arnulf.
143. The Second Frankish Dynasty. - The conditions which have been described as existing in the Frankish state under the later successors of Clovis - turbulence, civil war, and weak kings - were very favorable to the rise of some strong man into power alongside the king to exercise the authority which the kings failed to exercise. 'This is the way in which the second dynasty of Frankish history, the great family of the Carolingians, obtained its power.

Aside from the opportunity which the general condition of things gave them, the new family was assisted in its rise by two important facts. One was their own great wealth and resources, especially when in the third generation the possessions of two of the richest families of the Rhine valley were united in their hands. The second was that they early obtained a practically hereditary hold upon the office of mayor of the palace in Austrasia, the eastern kingdom. This office seems to have been that of a kind of steward of the royal estates, from which the Frankish king's revenue was chiefly derived. It therefore gave its holder some control over the disposition to be made of the lands and of the revenues, and so put into his hands a means of influence, of favoring his friends, and of punishing his enemies, of great value to a growing power.

r44. The First Carolingians. - The first of this line was Pippin of Landen, who was mayor of the palace under Dagobert I. His son Grimoald, under weaker kings, exercised almost royal authority for nearly twenty years. At last he made a premature attempt to transfer the crown to 
his son, and was killed by the other nobles, who were not willing to allow a strong king to take the place of a weak one, and who were not yet used to seeing the royal authority in the hands of any family but the Merovingian. Grimoald's sister carried on the line through her marriage with the son of Arnulf of Metz, who had been a most influential man in the days of the first Pippin. Their son was the second Pippin, of Heristal, and he recovered the power of his grandfather and uncle.

r45. Their Power established. - In the meantime, in the west Frankish kingdom, Neustria, a similar course had been run, except that no really hereditary power had been created by the mayors of the palace who ruled for the kings. The difference between the Romanized Frank of the W'est and the pure German of Austrasia had, however, been increasing, and many wars had been fought between the two states. Perhaps one result of the difference was that Neustria, after the Roman model, was a more centralized state than Austrasia, and the nobles were less independent there. In 687 the two states and the two differing systems came to a decisive conflict in the battle of Testry. Here Pippin and the east Franks gained a complete victory. This battle gave to Pippin the control of both kingdoms and of all the Franks, which he retained to the end of his life and passed on to his descendants. But its results were more than this. It gave ascendency again to the German element in the nation, and it checked for a time the development of an absolute monarchy.

146. The Government strengthened. - Pippin had won his victory as the representative of a loose organization and of an independent aristocracy. But when he was once in possession of the supreme power he naturally strove to make it as great as possible. The next stage of Frankish history then is filled with a new conflict between the central power in the hands of Pippin, and after him of his son Charles Martel, and the aristocracy. It is a conflict in which the central authority was finally successful, and Charles Martel

Differences between Neustria and Austrasia.

The battle of Testry.

Hodgkin, Charle's the Great. pp. 33-39.

Centralization of the state. 
154 The Franks, the Arabs, and the Papacy [\$ 140

passed on to his son, the third Pippin, a strong government in which, however, he still ruled in the name of the king, not having rentured to try again the experiment of transferring to himself the crown in whic.s the line had once so disastrously failed.

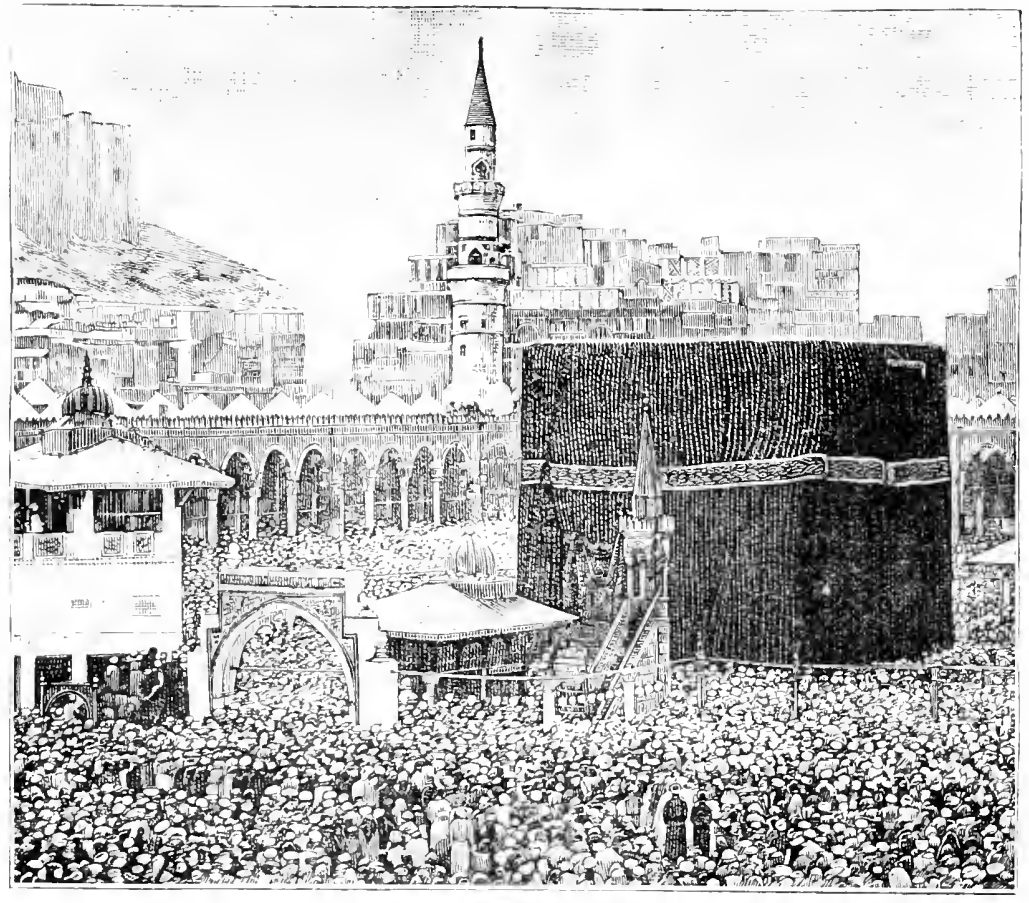

THE KAABA AT MECCA

Under Charles Martel a new line of influence of the greatest importance enters the history of Europe, having had its rise in the Orient some time before. This was Mohammedanism. 
I47. Arabia before Mohammed. - $\mathrm{U}_{\mathrm{p}}$ to the time of Mohammed Arabia had had no part in the history of the world. The most of its territory was occupied by wandering tribes, and only along the shorés of the Red Sea was there a commercial and agricultural population with some development of city life. The Arabs had no national government, nor anything which could be called a national culture or religion. Necca was the centre of what national feeling existed, and there was the Kaaba, a temple full of idols from many sources, under the charge of the priestly family of the Koreishites. Idolatry prevailed in general throughout the country, and in some parts the worship of the stars.

148. Mohammed and uis Religion. - Mohammed was born in 57 1 . Left an orphan while a mere child, he spent a youth of poverty, and finally obtained employment as a driver in a caravan. His employer, a widow named Khadijah, was attracted by his high character, fidelity, and gentle disposition, and married him. This was the turningpoint in his career, for her wealth gave him the influence in the community which he had lacked before, and the leisure necessary for his work. He could now give play to the strongly religious and mystical tendency of his nature. $\mathrm{He}$ began to have visions and to receive revelations. His wife encouraged him to believe in them, and to obey the injunctions which he received to teach to Arabia the true character of God and a new religion.

So far as the religion itself is concerned, which Mohammed taught, it was a distinct advance upon anything in Arabia before his time. In its conception of God and of responsibility in the future life for conduct in this life, in its influence upon the position of woman, and upon many lines of conduct, it reveals the fact that Nohammed had studied some at least of the results of the best religious and ethical thinking of mankind up to his times. His religion reveals also its human origin in the appeals which it allows to the lower side of human nature, and in the fact that progress under its influence seems possible only up to a certain point; but

No unity of national life or of religion. Bury's Gibbon, V. 31 I-333.

Mohammed's early life.

The character of Mohammed's religion. Muir, The corcan, its composition and Teaching (S. I.C.K.); all imporran passages translated. See also the common translation by Sale; and Fling, studies, II., No. 3 . 
certainly to more than one race in the lower stages of advancement conversion to Mohammedanism has been followed by rapid progress in civilization. This was its original effect upon the Arabians.

At first his converts were confined to his own relatives. Mecca, and especially the priestly family of the Koreishites, who feared the loss of their influence, could not be perThe Hegira, suaded. In 622 Mohammed fled from persecution in 622. Mecca and found refuge in the rival city of Medina. This event in Mohammedan history is called the Hegira, and is the date from which the Mohammedan chronology begins to reckon. It seems to have produced a change also in the character of Mohammed, and in that of the revelations

Conversion l,y the sword.

Reasons for the rapid expansion of Mohammedanism. Freeman, Histery and Conizuests of the Saracens (Macmillan). which he received. The idea began now to be cherished that men may, for their own good, be forced to accept the truth even against their will, and this idea was carried out in Mohammed's lifetime in the conquest of Arabia. After the death of Mohammed the central and eastern portions of Arabia revolted and the unity of the nation was reëstablished only after a violent civil war.

I49. A Religion of Conquest. - In the meantime conquest outside Arabia, which Mohammed had foreshadowed, had already begun. In an incredibly short time the Arabians created the largest empire of civilized history, the largest at least before the nineteenth century. Provinces indifferent to a change of masters or states weak and decayed offered no adequate resistance to the tremendous enthusiasm of the new nation. 'The religion also was distinctly that of a conquering race. With its doctrine of fate - that the moment of every man's death is absolutely fixed and with its promise that the soul of the martyr dying in battle should be admitted at once into the joys of paradise, it tore down the ordinary barriers of prudence and gave enthusiasm unchecked sway. From the heretical Christian sects along the borders of Arabia, who had descended from Arianism, Mohammed had learned also to put the enormous emphasis which he did upon the doctrine that "God is one God." 
This teaching, together with the tolerant character of the early Mohammedanism, made its victory not unwelcome to the oppressed sectaries of the Eastern Empire.

I50. The Conquests of the First Century. - Syria and Persia were conquered within ten years of the death of Mohammed, Egypt in about five more. By the close of the century their empire had practically reached the Atlantic, the limits of the Roman Empire, on the west, and on the east and northeast in Asia those of Alexander the Great. Ten years later the turn of Europe came. 'The Arabs crossed the straits of Gibraltar and easily overthrew the great Visigothic kingdom of Spain, which was now weak and full of civil strife. Only a little land remained Christian behind the mountains in the northwestern corner.

During this time repeated and fierce attempts were made to get possession of Constantinople, which the Saracens seem to have thought indispensable to their empire, like the Russians of modern history. We are told that the city was saved by the mysterious Greek fire, but the Empire evidently had some reserve of strength and was able even to dispute the possession of Asia Minor with the Arabs.

With Spain in their hands, it was natural that the Saracens should try to make further conquests in Europe. But north of the Pyrenees they came in conflict with a new kind of enemy, a race as young and powerful as themselves, the Franks. The struggle between them for the rule of southern Gaul lasted for twenty years, and for twenty years longer the Saracens held a little portion of the southeastern corner. The great battle of the time, sometimes called one of the greatest battles of history, is that which we name the battle of Tours, though it was fought nearer the city of Poictiers, not far south of the Loire. Here Charles Martel, the son and successor of Pippin of Heristal as mayor of the palace and ruler of the Franks, totally defeated and drove back the greatest invasion of the period. He had much fighting afterward to recover the lands along the Rhone which the Mohammedans had occupied, as did his son the third Pippin, but this great

In Asia, Africa, and Europe. Bury's Gibbon, $\mathrm{V}$. 397-486.

Spain, Bradley, Goths (Nations); Chap. IXXV.

Attacks on Constantinople. Oman, liyantine Empire (Nations), Chaps. XII. and XIV.; Oman, irt of Il arr, $5+5-5+8$. Greek fire, Bury, Emfire, II. 319;

Mohammedan expansion checked by the Franks.

The battle of Tours, 732. Zeller, II. 
End of the age of conquest.

rictory and his vigorous defence of Gaul strengthened the hold of his house on the government of the Frankish nation.

I5r. The Revolution of $75^{\circ}$. - The age of conquest in Mohammedan history goes to about the year $75^{\circ}$. Then occurs a dynastic revolution which is followed by a division in the empire, and a change in the character of the Saracen civilization.

Mohammed made no arrangement for the government after his death. The first caliphs, or "successors," whose The Caliphs. reigns were mostly short, were chosen from the companions Muir, The Cialiphute (Lond. Rel. 'Tract Soc.).

The rise of the Atshassides. Nuir, ciliphate, $422-429$.

The empire divided. Lane, . irizbuth seclety in the widille Ase's.

The most important service of Nohammehunism to civilization. of Mohammed. During this period the constitution of the empire was gradually taking shape. In 66I the caliph Ali, the nephew of Mohammed, was murdered and the hereditary dynasty of the Ommiads seized the throne and made Damascus the capital of the empire. They ruled the united empire during the whole age of conquest.

A little before 750 leaders who claimed a descent from Abbas, another uncle of Mohammel's, raised an insurrection to avenge the wrongs of Ali. Their insurrection was successful. The Ommials were overthrown and cruelly punished, and the dynasty of the Abbassides took their place. One prince of the Ommiads escaped and later appeared in Spain, which recognized him as caliph and made itself independent. From this time on the Saracen empire was divided into two, an eastern and a western, as the Roman had been. Not long afterwards another dynasty, claiming descent from Ali himself and Fatima the daughter of Mohammed, established the independence of Egypt. The Abbassides changed the capital from Damascus to Bagdad on the Tigris, and this city became speedily the centre of a rich and brilliant civilization which has left us an extremely interesting picture of itself in the Arabian Nights.

152. Arabian Science. - In its influence upon the larger history of the world, the most important feature of this civilization was its scientific character. For work of this kind the early Mohammedan people seem to have had as 
great a liking as the Greeks. From every ancient civilization with which they came in contact, they absorbed what could be learned, - Greek science, Persian philosophy, Hindoo mathematics, - and these they wrought into a single body of scientific teaching. To what they had borrowed they marle some additions of their own, especially in astronomy, chem-

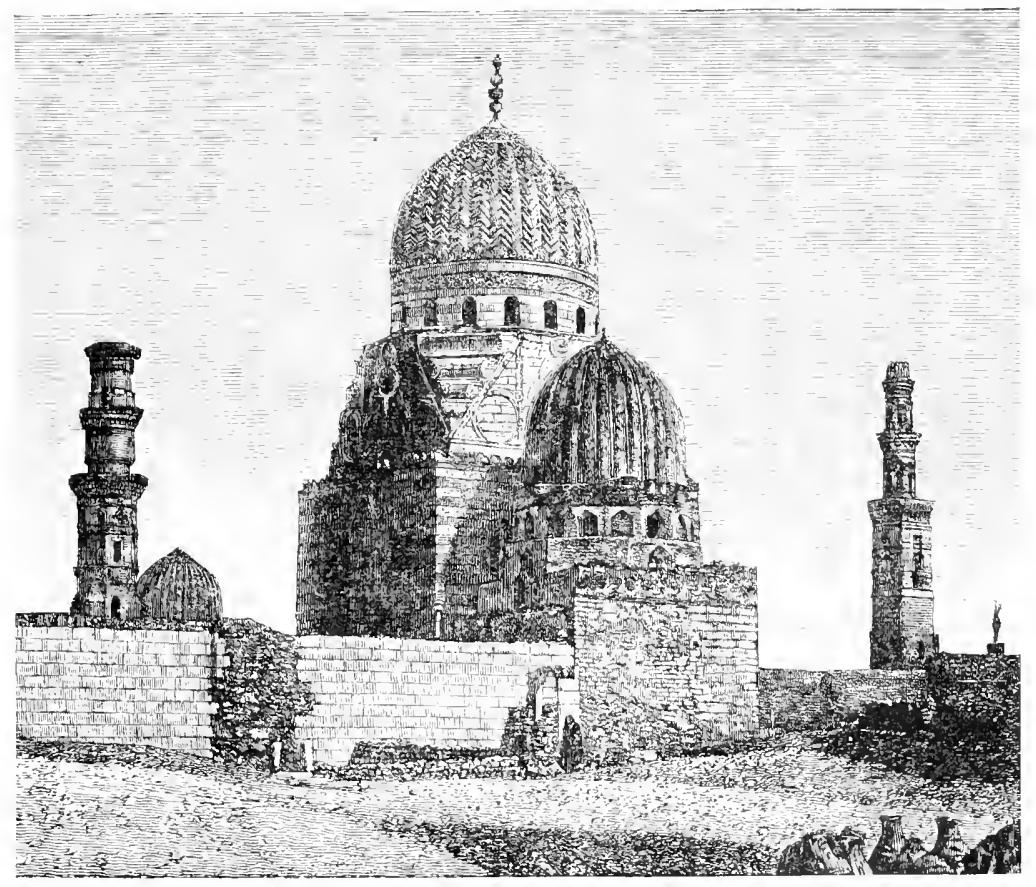

TOME OF THE CALAPHS AT CALO

istry, and mathematics, though their work in arlvancing The foundascience was less important than in transmitting it. For this the world owes them a great debt of gratitule. The service tion of modern which the church and the Franks performed in handing on Roman institutions and law, the Mohammedans rendered to science. 
Decay of the Abbassicles.

The Seljuk Turks.

The early Merovingian conquests recovered.
Greek and Oriental science, preserving it through the dark ages as the foundation of modern science when the revival of learning finally came.

I53. The Coming in of the Turks. - The decline of this brilliant Mohammedan civilization was as rapid as its rise. In the East the Abbassid family fell into speedy decay like the Frankish Merovingians, whom they rivalled in cruelty and corruption. In the days of their greatness they had begun the introduction of Turkish slaves to form a royal bodyguard, and when the age of decline came on these soldiers and their officers were able to usurp the real rule as the Carolingians did among the Franks, restricting the caliphs to a religious headship. In the eleventh century the Seljuk Turkish dynasty established itself in the political power, and it was with them that the first crusaders fought for the possession of the Holy Land. When the Turks came into power civilization speedily died in the eastern caliphate, as it has everywhere under the Turk. In the West the Spanish caliphate had a long and varying history, at times weak throngh dissension and civil war, at other times reinforced by a revival of enthusiasm in the Mohammedan world of Spain or Africa. Its history is closely connected with the growth of the Christian states of Spain, which will be followed later.

154. The Frankish Empire restored. - In the Christian world of the West, the eighth century is one of steady recovery in the Frankish state under the princes of the Carolingian house. The reconstruction of the authority of the central government has been already noticed. At the same time is carried on the reestablisbment of the rule of the Franks over the early Merovingian conquests, which as in the case of the Bavarians, for example, had tended to become independent during the age of weakness in the state. The work of recovery in this direction was not completed by the first two Carolingian princes, but goes on through the time of the third, Pippin the Short. Charlemagne, the son of Pippin, began his reign over no more 
territory than the Franks had ruled in the days of Dagobert I.

But some new things had been done by Pippin the Short. About the middle of the century he came to believe that the experiment of Grimoald could be safely tried again, and that he might be king in name as well as in fact. But he felt obliged to proceed with great caution. Something of divinity might still attach in the popular feeling to the old house. The change must carry with it a religious sanction which all would recognize. So application was made to the pope to lend the weight of his approval to the assumption of the crown. 'This was quickly granted, and in addition the new king was consecrated with holy oil by a religious ceremony which was an imitation of that by which in Old Testament times David had been anointed king in the place of Saul.

This reference of the question to the pope shows us clearly the position which the pope had come to hold in the West at this time. Pippin could as easily have obtained the sanction he desired from the assembled bishops of his own realm. It is manifestly Pippin's judgment, however, that the opinion of the pope will have more authority and carry more weight than that of the church of Ganl.

155. The Lombards threaten the Pope's Independence. But the pope at this time had as great need of Pippin as Pippin had of him. We have seen how at first the Lombard conquest of Italy had not been complete. Rome and some little territory about it had remained as before. Nominally it was under the rule of the exarch of Ravenna as the representative of the emperor at Constantinople. But he could not easily exercise any practical control in Rome, cut off as he was from any quick or safe communication with it. As a result the conduct of political affairs drifted steadily into the hands of the pope, as the only one to whom it seemed naturally to belong. Gregory I., the great pope of the end of the sixth century, assumed the direction of political affairs, and exercised almost all the functions of a tem-

The influence of the papacy. Carr, (hurch and the lioman Empire, Chap. xxiv. The origin of the papal states. Oman, Periods, I 98-203.

Gregory the Great, 590-604. Barnaby, Gregory the Great (S. P. C. K.). 
The Lombard advance. Oman, Periods, Chap. XVI.

The appeal to the Franks.

The donation of Pippin. poral sovereign in his little state. This sovereignty, assumed by the popes because it was necessary for them to do so without any thought of what it might grow into, became in the course of time the sovereignty of a little state in central Italy, of which they were the kings, though they did not bear the title, a position which lasted until the FrancoPrussian War in 1870 , and which is known in history as the "temporal power" of the pope.

After almost a century of this partial occupation of Italy, the Lombards now began to press forward to obtain the rest. Dissensions which had sprung up between the popes and the emperors orer the use of images in the churches, which the emperors called idolatry and wished to prohibit, had also divided Roman Italy into parties, and gave some prospect of success to the Lombard attempt. For the pope, to be brought under the rule of a king of Italy, near at hand and constantly under temptation to interfere, would threaten very serionsly the position which he had now come to occupy in the West. The danger must be avoided if it could be in any possible way.

I56. The Franks protect the Pope. - The emperor would not or conld not protect the pope. The Franks were the only other power capable of checking the Lombard advance. The first invitation to interfere in Italy was sent to Charles Martel, but he was still too busily occupied in the work of reconstruction at home to suspend it in any foreign interest. In 753, Pope Stephen II. went in person to Gaul to induce Pippin to come to his aid. His mission was successful. Pippin returned with him at the head of his army, and forced the king of the Lombards to restore all that he had taken of the lands which the pope clamed. After the return of the Franks, however, the Lombard king forgot his promises and even laid siege to Rome. Pippin at once came to the rescue of the pope, and with complete success. This time he made sure of the surrender of his conquests by the Lombard king. These included the exarchate of Rarenna on the eastern side of Italy, in which the pope had 
never exercised any authority, but instead of restoring these lands to the emperor, Pippin made a formal gift of them to the pope. By this gift the state over which the pope exercised temporal sovereignty was carried over to the Adriatic and assumed the geographical outlines which it retained through almost the whole of history.

So far as concerned the Franks this was no immediate extension of their empire, but it prepared the way for Charlemagne's invasion of Italy and annexation of the Lombard kingdom to his own.

\section{Topics}

What things aided the rise of the second Frankish dynasty? The office of mayor of the palace. What mistake was made in the second generation of the new family? Why was it a mistake? Points of difference between Neustria and Austrasia. Results of the battle of Testry. The events of Mohammed's life. What changes did he make in Arabia? Mohammedanism as a religion. The Hegira. The extent of the Mohammedan conquests at the year $75^{\circ}$. What changes occurred with the accession of the Abbassides? The services of the Arabs to science. The beginning of Turkish rule. $110 w$ was the crown changed from the Merovingians to the Carolingians? What does this show of the position of the pope? How had the popes obtained a political authority in Italy? In what way was this threatened by the Lombards? What bearing had these facts on Frankish history?

\section{Topics for Assigned Studies}

Study carefully the opening paragraph of the story of the Forty Thieves in the Arabian Nights, and notice what it implies as to facts regarding Arabian life, the position of woman, and certain points of law.

Mohammed. Muir, Mahomet. (London, Rel. Tract Soc.) Gibbon, Chap. L. Bury, Empire, Book V., Chap. VI.

The appeal of the Popes to the Franks. Bryce, Holy Roman Empire, 34-41. Sergeant, Franks, 207-212. Lury, Empire, II. 499. Oman, Periods, 286, 327-332. 


\section{CHAPTER VI}

THE EIIPIRE REVITED. CHARLEMAGNE

\section{Books for Reference and Further Reading}

Einhard, Life of Charlemagne. Contemporary. Translation by Turner in Harper's Half Hour Series ( 15 cents), and by Glaister (Bell).

Hodgkin, (harles the Great. (Macmillan; 75 eents.)

Mombert, Charles the Great. (Appleton; \$5.00.)

Cutts, (harlimagne. (S. I. C. K.; E. \& J. B. Young; \$r.25.)

Mullinger, Shools of Charle's the Griat. (Longmans.)

West, Alawin. (Scribner; \$r.oo.)

Abel and simson, Jahrbïcher des frankischen Reichs unter Karl des Grossen. 2 Bde. (Leipzig.)

The beginning of Charlemagne's reign, 768 . Zeller, III.

Bavaria in- $\quad$ One bit of work in the way of reconstruction remained to corporated in the Frankish state.

157. The Way prepared for a Great Empire. - Charlemagne succeeded his father as king of the Franks at the age of twenty-five. The last two generations of his house had prepared the way for a great reign. The government of the king was once more strong and well obeyed, though constant watchfulness was necessary against the perpetual tendency to independence on the part of the local aristocracy and of the counts who acted for the government. 'The old conquests, also, of the early Merovingians had been practically recovered, so that the kingdom existed once more as in the days of its greatest extent under Dagobert I. Everything was ready for a new age in the history of the Franks, an age of expansion, and this is the character of the reign of Charlemagne. be done, the complete incorporation of the Bavarians of southeastern Germany in the Frankish kingdom. This Charlemagne accomplished without much effort, and more 
thoronghly than it had ever been done before. Their native dynasty was deposed, and disappeared from history, and they submitted entirely to the rule of the Franks, though they retained their identity of race.

158. The Conquest of Italy. - In four directions Charlemagne added to the territory of the Franks. In Italy his father had prepared the way. The Lombards were no match for the Franks, but they had not yet learned how thoroughly in earnest their new enemies were in protecting the pope, or perhaps in controlling Italy. Soon after the accessions of Charlemagne, the Lombard King Desiderius marched against Rome. The pope was probably not sorry to have an opportunity to call upon the Franks once more, so much was to be gained from them, and he sent at once to Charlemagne to ask his aid.

As soon as other interests would permit, the king came down into Italy with a great army, and though Desiderius made a brave resistance he was forced to yield. Charlemagne sent him into a cloister, and had himself crowned king of the Lombards. He made but few changes in government or in the Lombard laws, and the people were so well satisfied with his rule that they made no effort to recover their independence. To the pope Charlemagne confirmed the donation of his father.

The papacy was now relieved from this danger. It was some centuries before another power arose in Italy strong enough to threaten the independence of the little state which the pope ruled as a temporal sovereign. For Charlemagne the greatest gain from this conquest was in the fact that it brought into his kingdom the city of Rome with all that Rome still stood for in the minds of men.

I59. The Conquest of the Saxons. - Before his expedition into Italy, Charlemagne had begun another conquest which was to occupy three-quarters of his reign, that of the A long struggle, $772-802$. Saxons of North Germany. This proved about as difficult a conquest as ever was made. The obstinacy of the Saxons in refusing to see that they were conquered, apparently a

Charlemagne invades ltaly. Hodgkin. Chap. V.; Mombert, 86-100. $77+$.

Results of this conquest. 
The character of the war.

The Saxons at last submit.

In Spain. Hodgkin, Chap. VIII.

In the East. Avars. Zeller, III. hereditary trait of the race, was only equalled by Charlemagne's patience in doing the work over again year after year until it was finally completed.

Charlemagne would enter the country early in the summer with a great army, easily overcome the resistance of the Saxons in the field, establish Frankish garrisons and colonies of monks and priests, force the people, in so fir as he could get hold of them, to accept Christianity in form, and return home at the end of the summer, leaving the land apparently subdued. But after he was gone, the Saxons rose, massacred his priests and garrisons, and threw off every mark of subjection, including Christianity, and all the work had to be repeated.

Gradually the intervals between the insurrections became longer, and at last the Saxons submitted, overcome, it would seem, not so much by the military force of the Franks as by conviction, by the influence which the real teachings of the Christian religion were beginning to have over them, and by the realization of the fact that the government of the Franks was in every way better for them than their own. The Saxons of a later time looked upon Charlemagne with gratitude, as the great apostle to their race and the founder of its civilization.

I60. Charlemagne's other Conquests. - The other conquests of Charlemagne were less important and occupied but little of his own attention. By invitation of one of the factions of Mohammedan spain, he crossed the Pyrenees and marched through the northern part of the country. Little was gained in this experlition, but afterwards the Frankish dominion was slowly pushed over a small triangle of territory in northeastern Spain, including the city of Barcelona.

Against the Tartar Avars in the Damube valley, who could not abandon their old habit of making plundering inroads on German territory, Charlemagne conducted one great and successful campaign and then left the conquest to be completed by others. In wars with the emperor at Constanti- 


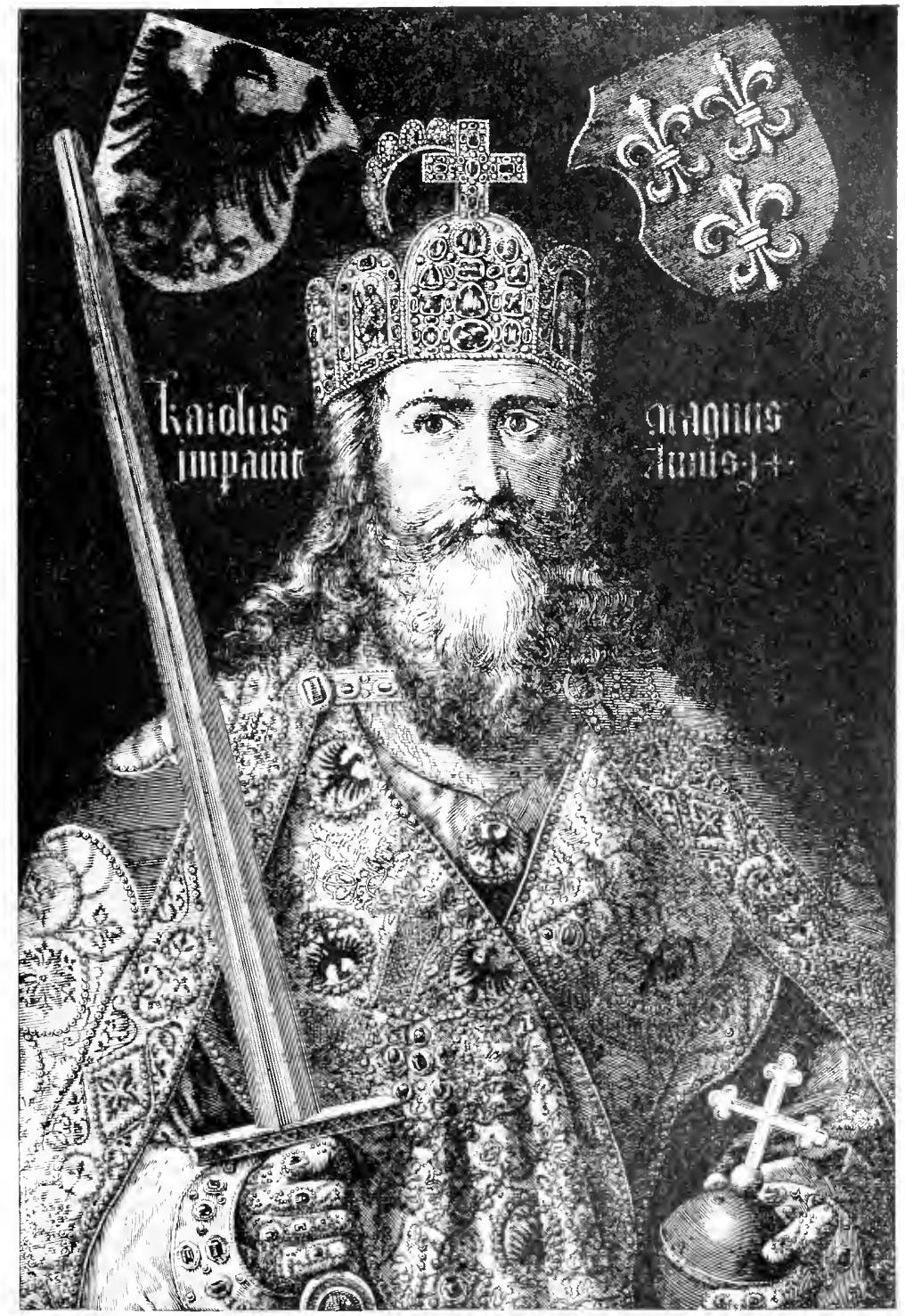

CHAKLEMAINE 
nople he aiso gained lands east of the Adriatic, and thus joined his territories in Italy with those of Germany, and carried his boundaries nearly to those which had marked the Western Roman Empire on the east. Many of the Slavic tribes that joined the Germans on the east acknowledged his supremacy, and the Danes were taught to respect his power.

The belief that the Empire still existed.
The pope crowns Charlemagne emperor, 800 .
I6I. The Revival of the Roman Empire. - The territories of Charlemagne were, by the year Soo, practically those of the old Roman Empire in the West. All the lands of the continent, which were still Christian and which had ever been Roman, were now in his hands, and Germany besides. To all men who thought about it, it would seem that the Western Empire had been reconstructed. The theory of the eternal dominion of Rome had not been forgotten, especially not in Italy. In a vague way, sometimes in a real way in the case of the pope, the supremacy of the emperor at Constantinople had been recognized, and even after the quarrel about the worship of images, the rights of the emperor were not denied, only those of the wicked emperor who refused to follow the true Christian faith. No one who knew anything of the past realized that the Empire of Rome had come to an end.

Now the time had come when the West could have its own emperor again. On Christmas day, Soo, as Charlemagne was worshipping in St. Peter's church, the pope crowned him emperor of Rome. In this way was begun a new succession of emperors of Rome in the IVest, which continned through medieval and modern history to the beginning of the nineteenth century. This title must be carefully distinguished from that of king in all history which follows the crowning of Charlemagne. There could be, as men thought, only one emperor, the emperor of Rome. There was no emperor of Germany nor of Austria until Napoleon changed the fashion of things by making himself emperor of the French. Since then emperor has meant but little more than king, but before, it had been the highest 
. 


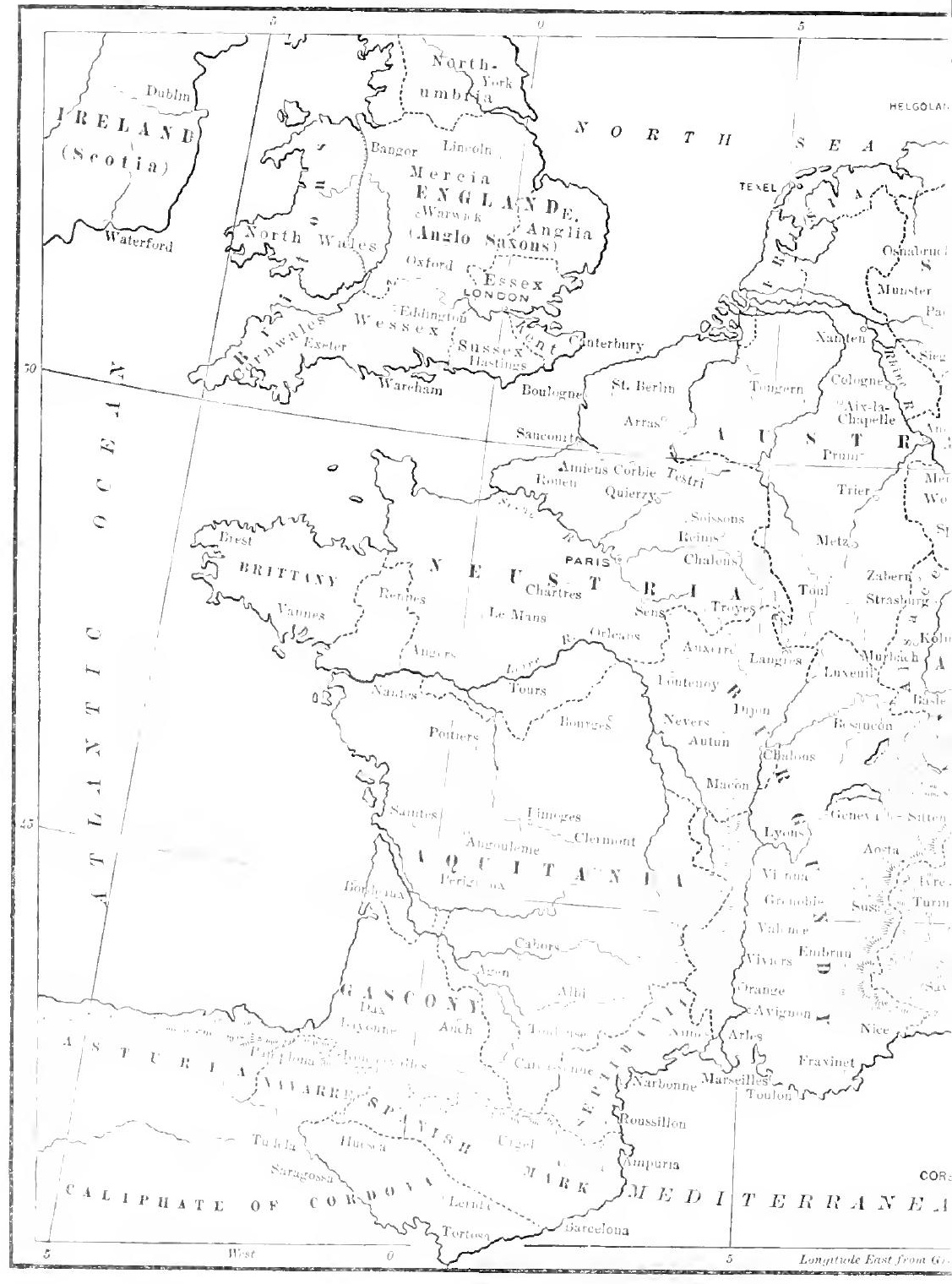



of all temporal titles, and in medieval times, when men believed in what they called the Holy Roman Empire, the emperor was thought to have the same sort of headship of the temporal world that the pope had of the religious.

I62. The Missi Dominici. - This title added but little to Charlemagne's real power, though much to his position in the minds of men. But the power which he actually exercised was growing as his territory grew. As great a statesman as he was a warrior, Charlemagne devised a new political institution to overcome the constant tendency to local independence, and to hold the counts under a close responsibility to the government. This institution was the office of the missi dominici, or king's messengers.

The counties of the Empire were grouped together into circuits. To each of these circuits were sent every year two officers from the court. In each of the counties assigned them they were to hold an assembly of the freemen, or they held a great assembly for the whole circuit, and in these assemblies the counts must make a report of the way in which they had administered their office, complaints were heard against them, and all abuses were inquired into. On their return the missi made Charlemagne familiar with the condition of things throughout the whole Empire.

It was an institution admirably adapted to keep a great empire closely centralized and under control, to overcome, that is, the tendency to local independence which we have noticed in the case of the counts, and it was destined to a long life. In the age that followed Charlemagne it lost something of its efficiency, but it passed from the Franks to the Normans, and, revived in England still later to serve something like its original purpose, it finally grew into the Anglo-Saxon circuit court system.

r63. Charlemagne's Schools. - Charlemagne was also A kind of greatly interested in education. He called from England Alcuin, who passed for the most learned man of the time, and other teachers from Italy, and tried to organize a gen-

A new

institution of government. Hodgkin, $242-245$; Adams, Civilization

during

Middle Ases, 159-162.

To hold the counts to a strict responsibility. Edict concerning the Nissi, Henderson, 189-201. See also Zeller, III.

This institution has come down to us. public school system. Zeller, III. 
eral system of schools throughout the Empire. In the school of the palace his own children were taught, with others from various parts of the Empire, who were especially promising; the monasteries and cathedral churches were expected to maintain good schools, and even the parish priests to give elementary instruction. As an organized system Charlemagne's reforms were not permanent, but the impulse which he gave to learning lasted. Some of the individual schools

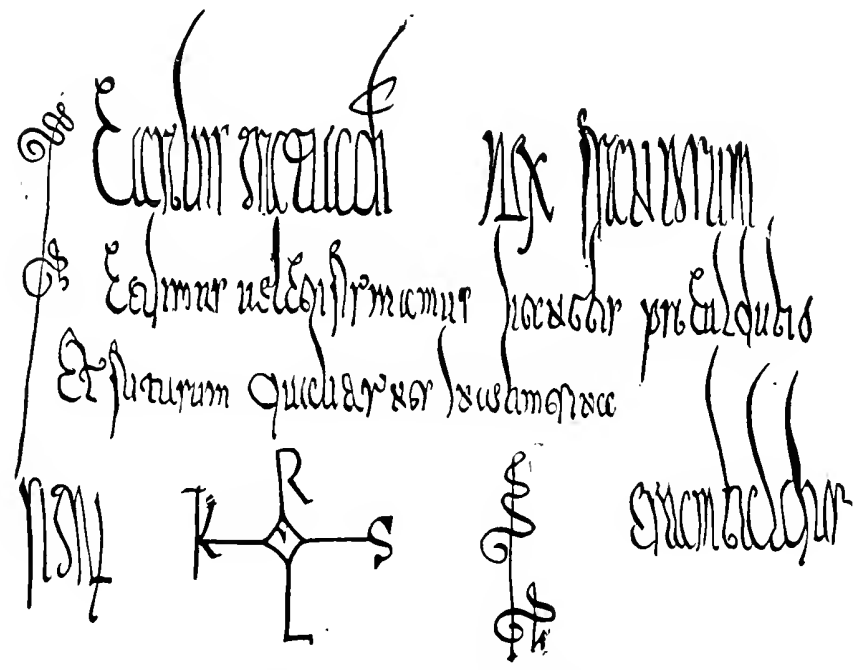

Siminatere of CharlemagNe

survived, men knew more of books, and wrote better Latin than they had done before, and those who wished to learn

A turning point in history. Bryce, Holy Roman Eimpire, $63-75$. Hodgkin, Chap. XIII. found it easier to do so.

I64. Charlemagne's Place in History. - Charlemagne's reign fills but a short time in the long period of the Middle Ages, but it binds the whole together. In him is completed the process which runs through the first half, the Germanization of the Roman Empire. There was a Roman Empire again uniting Christian Europe together, but it was, as it 
called itself later, "The Roman Empire of the German Nation." The ruling race was German and the emperor was a Frank. From the end of his reign, also, begins the process which runs through the second half, the formation of the modern nations, independent members of an international system, which we call now, not the Roman Empire, but Christendom. All the forces of union and of civilization were strengthened by his reign, and though his empire was not permanent, its influence never ceased.

\section{Topics}

How had the way been prepared for what Charlemagne was to do? How did the position which he took in Italy differ from lis father's? The character and results of the Saxon W'ar. Why were not the Spanish conquests carried further? State the territuries finally embraced in Charlemagne's empire. In what points was this like the Western Roman Empire? Why, in your opinion, was the title Emperor of Rome revived in 80o? How did "emperor" differ from "king" in meaning before Napoleon? The duties of the missi dominici. (harlemagne's school system. His place in history.

\section{Topics for Assigned Studies}

The Saxon wars. Einhard, Chaps. VII. and VIII. IJodgkin, Chap. VI. Nombert, $101-153$.

The revival of the Empire. Bryce, Holy Roman Emfire, 4+-6r. (Three original accounts translated.) Horgkin, Chap. XI. Mombert, 357-368. Sergeant, The Franks, 243-247.

The school system. Mullinger, Schools, 68-ro8. Einhard, Chaps.

XXIV, and XXV. Mombert, 24I-270. Ifodgkin, 235-238.

Charlemagne as a landlord. The capitulary de villis. Penn., III., No. II. Zeller, III.

\section{Topics for Review}

Compare Nero's reasons for persecuting the Christians with those of Marcus Aurelius.

Compare the conversion of Clovis with that of Constantine.

Trace the passage of the Visigoths from their entrance into the empire until their final settlement. 
Trace the history of the Roman law through the whole of this period. What historical events in succession were witnessed by "Father Rhine" during this period?

Of each province of the Western Empire, state what German or other conquerors occupied it in succession, and by whom it was permanently held.

\section{Important Dates}
A.D. 14 . . . Death of Augustus.
ISo . . . Death of Marcus Aurelius.
250 . . . An invasion of the Goths.
284 . . . Diocletian emperor.
323 . . . Constantine emperor.
325 . . . The council of Nicrea.
378 . . . The battle of Hadrianople.
379 . . . Theodosius emperor.
410 . . . Capture of Rome by Alaric.
449 . . . First German settlement in Britain.
476 . . . Romulus Augustulus deposed.

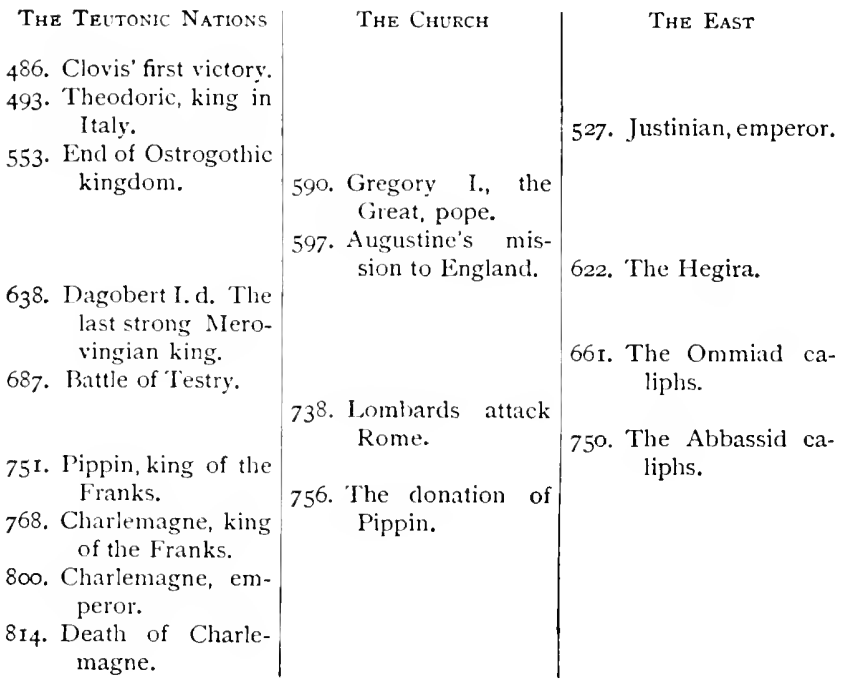




\section{PART V}

\section{THE FORIIATION OF THE NATIONS}

\section{Books for Reference and Further Reading}

Gregorovius, Mistory of the City of Rome in the Midille Ages. (Bell, Macmillan; \$1 2.00.) 5 vols. now translated, to beginning of the XIV. century. A history of the papacy and of the Middle Ages as related to Rome.

Bryce, The Holy Roman Empire. Sth edition. (Macmillan; \$I.0o.) Jenks, Lais and Politics in the Middle ffos. (Holt ; 2.75.) Institutional history.

Lavisse, General Tiew of the Political History of Europe. (Longmans; \$I.25.) Suggestive outline sketch.

Luchaire, Manuel de's Institutions Frangaises sous le's Cafíticns directs. (Paris; 15 francs.)

Schröder, Lehrbuch der deutschen Rechtsgeschichte. (Berlin.)

Both very valuable on all points of institutional history.

Green, History of the Enstish People. 4 rols. (Harper; \$Io.oo.)

Traill, editor, Social England. 6 vols. (Putnam; $\$ 3.50$ per vol.)

Kitchin, History of France. 3 vols. (Clarendon Press; \$2.60 per vol.)

Henderson, History of Germany in the Midalle Ages. (Bell, Mac. millan; \$2.60.)

Reber, Medizz'al Art. (I Tarper; \$5.00.)

Tout, Empirc and I'apacy. "Teriods" series, 9IS-I273. (Macmillan; \$I.75.)

Emerton, Medical Europe. SI4-I 300. (Ginn ; \$I.65.) Gives references to the chief collections of sources.

Adams, Cirilization during the Hidalle Ages. (Scribner: \$2.50.) The connection and significance of historical events.

Bohn's Libraries (Macmilan) contain many translations of medieval sources, especially of English chronicles. These are specifically referred to in the course of this part. 


\section{SUMIIARY}

The strong union of Christian Europe which Charlemagne had formed did not long survive him. The forces of disunion were many and powerful, and his descendants were not able to deal with them. The Empire was broken up after a time into many states, but its first real successor was the feudal system which had begun to assume its final form even under Charlemagne - a system which allowed great independence, both economic and political, to the fragments of the state while maintaining in form the general government. The anarchy of the time and the need of local protection were greatly increased by the inroads of the Northmen and of the Hungarians. The Northmen established permanent colonies in northern France and in England, and in the latter country postponed for some time the union of all the Anglo-Saxon states into one which had been rapidly advancing under the West Saxons. On the extinction of the family of Charlemagne in Germany a native dynasty was elected, and under the first kings of the Saxon family there was great promise of the formation of a strong nation. In France somewhat later a native clynasty also obtained the throne in the family of the Capetians, but here the kings remained very weak for several generations. In England still later real national existence began, first under the Danish king Cnut, and then under William the Conqueror. The German kingdom was so strong under Otto 1 . that a revival of the Roman Empire of Charlemagne seemed a natural thing, but this step fatally weakened the government at home, and it brought the new Empire, the Holy Roman Empire. into a long rivalry and conflict with the other great medieval world power, the papacy. The government of the Church was now beginning to assume its modern form under the influence of the ideas of Cluny, carried out by the great statesman Hildebrand. Pope Gregory VIl. The first period of the conflict between these ideas and the Empire under the Franconian emperors ended in a compromise in the Concordat of Worms, but it was really a victory for the papacy, which was never again subject to the control of the Empire. The second period of the strife under the Hohenstaufen emperors saw not merely the destruction of the imperial power, which could never afterward be reconstructed, but also the dissolution of the German nation into a host of independent and even hostile fragments; and Italy experienced a similar fate. At the close of this conflict the age of the crusades was also closing. Europe had 
thrown itself upon the Saracen world to recover the IHoly Land with immense enthusiasm, but without definite system or good leadership, and after establishing the kingdom of Jerusalem had ended by losing all. But the economic and indirect political results of the crusades constituted a revolution in history. Commerce increased rapidly, great cities multiplied and accumulated wealth and through wealth power, money circulated in larger quantities, the condition of the serf was improved, the third estate rose to political influence, the state by taxation and a paid army was made independent of the feudal system, and in alliance with the new conditions overthrew that system. It was the time when medieval economic and political conditions passed away and modern began. France and England were the two states in condition to profit the most from these changes, and their later medieval history is that of one long struggle. on the part of France to secure possession of all her territory and to organize a strong state, and on the part of England to retain her French possessions. For a century France gained nothing. Then Philip Augustus conquered northwestern France from John, and his son and grandson secured southeastem through the troubles of the Albigenses. After an interval came the long struggle of the Hundred Years' War, in which twice the English nearly conquered France and an English king was crowned in Paris but in the end the French nation, under the lead of Joan of Arc expelled their enemies and reëstablished their independence. In the meantime in government the French kings had been able to create an absolutism, and the English barons and commons a limited and constitutional monarchy. Germany had never recovered either the imperial power or national unity, nor were national governments possible in Italy or Spain.

\section{CHAPTER I}

\section{THE BREAKING UP OF CIIARLEMAGNE'S EMPIRE}

165. Causes of Division. - The unity of Christian Europe which Charlemagne had established did not last. The time had been too short to weld the different peoples together into a single nation, and the causes of separation were too many and too powerful to be overcome. Local patriotism

Numerous influences working againsi unity. 


\section{I76 Breaking up of Charlomagne's Empire [\$ I66}

or tribal feeling, - we may very soon begin to speak of this as national feeling, - the constant tendency of the counts and barons to make themselves independent, the working of the Frankish idea that the king's territories must be divided among his heirs, combined with the fact that the genius of the Carolingian house comes to an end with Charlemagne, were too strong for the still feeble idea of the Empire and even for the more real world monarchy of the Church.

Communication from place to place very slow and difficult.

166. Economic Condition.- One great difficulty in the way of ruling so large a state as Charlemagne's underlay all the others, and made it almost impossible for a united government to be maintained. This was the difficulty of communication from one place to another in those days. Roads and bridges had fallen rapidly out of repair when the Roman supervision had come to an end, and the means of conveyance were now very primitive and slow. It was a time when there was very little commerce carried on between one part of the country and another, and even very little money in circulation. Each little portion of the country depended very largely on itself to supply its own needs. Now we may be very sure that if the difficulties in the way of commerce were so great that men gave up such a universal practice as trying to make money by conveying goods from one place to another, the government would find it very difficult to keep up communication, to know what was going on in distant parts of the state, and to maintain its authority in widely separate places. Charlemagne's institution of the missi dominici had been very wisely planned to meet this difficulty by carrying the anthority of the king down into each locality, but this office rapidly lost its efficiency under his successors, and even went out of general use.

The locality becomes the economic and political unit.
The result was that each little locality was thrown upon its own resources to supply not merely what it needed in the way of goods, but also what it needed in the way of government and protection. This meant at last the local independence of the count or baron against which the Carolingians had so long struggled. In other words, this meant the final 
establishment of the feudal system, and this is the age when feudalism becomes the prevailing form of political organization for Europe, and its growth is one of the forms of the dissolution of the Empire.

I67. Lewis I. the Pious. - The Empire of Charlemagne passed to the next generation undivided, for only one of his sons survived him. He was called Lewis the Pious, because of his devotion to the Church, and in his case this meant a degree of submission which seems to us superstitious in a sovereign. He has also been called Lewis the Debonnaire, which means the Good-natured, and in such times to be a king who seemed to everybody good-natured was to be a weak king. This was the character of Lewis. $\mathrm{He}$ was a weak king. He could not keep control of things as his father had done. In the last years of his reign he had many quarrels with his three sons, who were anxious to enter into the inheritance, but were never satisfied with the divisions of it which were made. At his death, Lothair, the eldest, became emperor, and kingdoms were given to the other two, - Lewis and Charles.

I68. The Treaty of Verdun. - The brothers quarrelled at once, and in just a year after the death of their father, the great battle of Fontenay was fought, the two younger being united against Lothair. The two brothers won the victory, and the next spring cemented their alliance by the "Oath of Strasburg," which has come down to us and is the earliest specimen we have of the languages which have grown into modern French and German. Lothair was forced to accept their terms, and in the following year the great treaty of Verdun was made - the most permanent in its influence on the map of Europe of any treaty ever made. The way in which these three brothers divided their father's empire shoukl be carefully fixed in mind because it helps us to understand many things that have happened in history even down to the present time, and it explains some of the peculiar features The "Oath of Strasburg." Oman, Periods, 408-409; Emerton, Europe, $25-28$.

$8+3$. Oman, Periods, +10-412; Emerton, Europe, 28: Bryce, Empire, $76-78$. of the map of Europe as it now exists.

Lothair was recognized as emperor. In all the divisions N 
The division made by the treaty of Verdun.
The place of the little states of Europe. of these times the Empire is never divided. Every one believed that to be one and indivisible. The territory of the Empire might be cut up into kingdoms, but there was only one emperor. To Lothair was given a very peculiar territory, and in this lies the significance of the division for later history. He was given Italy of course, because that contained Rome, and starting from Italy a long narrow strip of land following first the course of the Rhone and then that of the Rhine to the North Sea. As Charles' kingdom afterwards became France, and Lewis' Germany, the effect of this arrangement was to put between these two states a very important strip of territory to which at the beginning neither harl a valid claim. When some time later the title of emperor became attached to the kingdom of Germany, this fact seemed to give that country the best right in the intermediate land, and for a time at least Germany did acquire the larger share of it, but after a time the French language began to make inroads into these regions, and following it the French government obtained possession of many pieces of the territory. Some of these Germany has recently recovered, and very possibly the question to whom they shall finally belong is not yet settled.

It was in this territory of Lothair also that small states had an opportunity to form themselves. Five of these have hacl some important place in history, and three of them, Holland, Belgium. and Switzerland, still exist. Just south of Switzerland was the county of Savoy, which grew into the duchy of Saroy, and then into the kingdom of Sardinia, and finally into the present kingdom of Italy. As near Switzerland on the other side was the county of Burgundy, which became attached later to the French duchy of Burgundy and promised with it at one time to grow into a rich and powerful state and to include nearly all the northern part of Lothair's land.

I69. The End of the United Empire. - In the period which followed this treaty many subdivisions were made, and the power of the general government, that is of the 
Empire, was constantly growing less. For a little time Charles the Fat, son of Lewis of Germany, became king of emperor of all the larger kingdoms as well as emperor, but he could not magne's

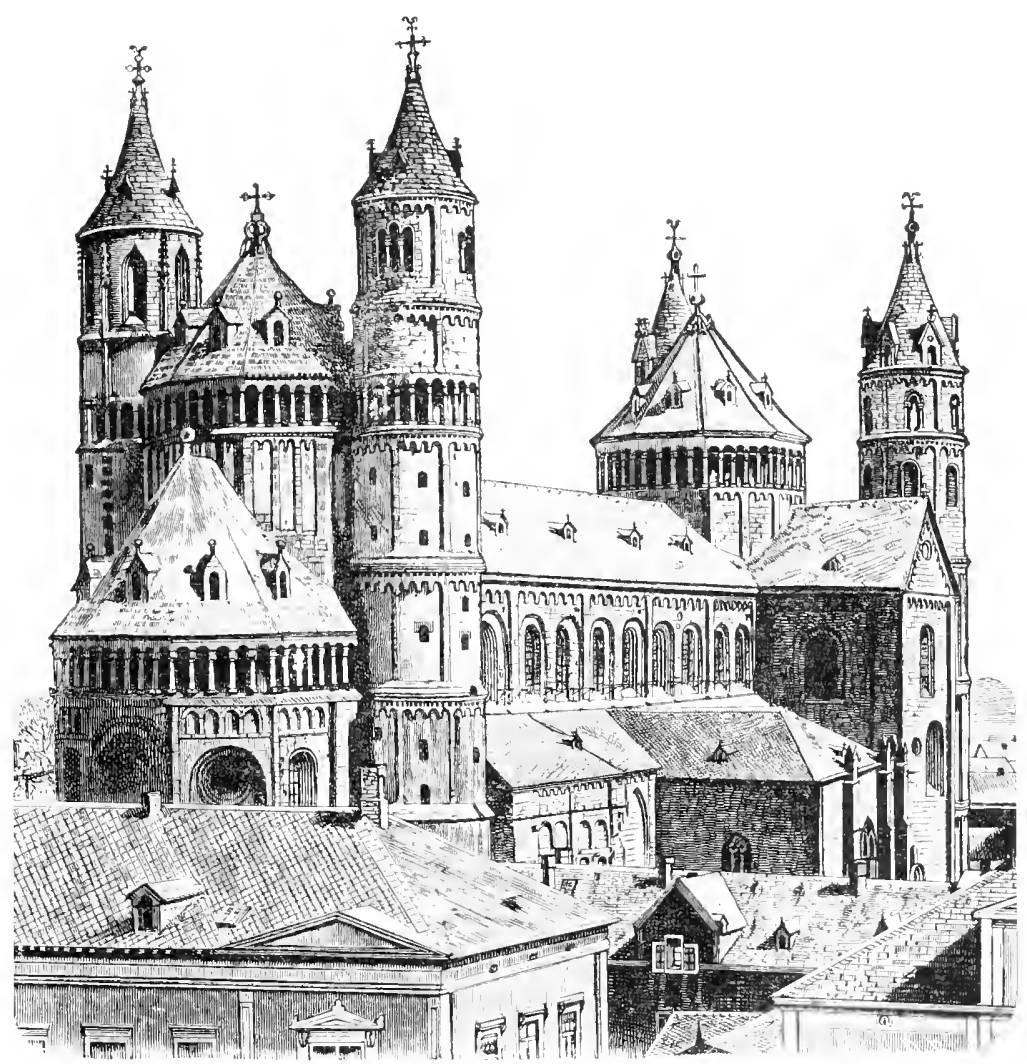

THE. CATHEIRAT, AT MORMS

master the difficulties which confronted him, and was finally whole deposed. This may serve as well as any event of the time empire. to mark the dissolution of Charlemagne's united empire, Priods, and the point at which the organization of the morkern $44^{\circ-}+43$. 
887.

Saracens, Hungarians, and North-

men.

Oman,

Periods, Chap. XXIV.

The last of the German migrations. Keary, likings in Ilistern Christendom (l'utnam); Johnson, The Vormans "n Europe (Epochs).

The extent of the incursions of the Northmen. Johnson, Normans, Chap. II.

In America, Am. Hist. Leaf. No. 3 ; Old South, 3I;

Fiske, Discozery of America. I. $15 \mathrm{I}-226$. nations begins. It is some time yet before they have a definite existence, but their formation is the most important fact of the period which follows.

I70. The New Barbarian Invasions. - The difficulties which general government had to contend with in this age were greatly complicated, and the insecurity which made easy the growth of little local powers was everywhere greatly increased by incursions of barbarians from almost all directions. The Saracens troubled the southern frontiers. The Hungarians were beginning the invasions from the east which lasted a long time and finally gave rise to modern Hungary. But most harassing of all were the attacks of the Northmen, which affected every coast and which were so unexpected and swift that general defence was almost impossible and each locality harl to do the best it could for itself.

The invasions of the Northmen were the last of the German invasions. They were the only German people left who had not already taken part in this movement. That they made their attacks by sea was due to their situation, and in this fact and in all details of method their invasion is exactly like the earlier Saxon conquest of Britain. Danes and Norwegians composed most of the bands which went to the west, and the Swedes those going east, where in the neighborhood of the Baltic a kingdom was established under the dynasty of Ruric, which in after times expanded into the empire of Russia.

I7I. The Northmen. - All the coasts of the world which were within reach were visited by these adventurous rovers: all the British islands, the Atlantic coasts of Europe and Africa down to the desert, the whole Mediterranean, and to the west Iceland, Greenland, and some part of eastern North America. Wherever they found anything which they wanted they took it, and all Europe was in fear of them for a hundred years. They made people everywhere extremely concerned about the means of defending themselves, and this led to a great age of building walls around towns, and of strong castles which might protect the country districts. 
Such a time sifted out also the skilful leaders of defence from the poor ones, and some of the later great families of Europe got their start in this way.

The Northmen founded a number of colonies; for example, in Iceland, northern Scotland, and northeastern Ireland. But we are especially interested in two of their colonies, because they had so much to do with our own history, - that of Normandy in northern France, and that of England itself.

172. Rollo in Normandy and the Danes in England. Early in the tenth century a great force of the Northmen was in northern France, where they had seized Rouen and were threatening the rest of the kingdom, when the Carolingian king, Charles the Simple, proposed to their leader, Rollo, that he should settle down with his men in permanent possession of the country and become his rassal for it. This Rollo consented to do, and so was created in the course of time the great duchy of Normandy, which came up the Seine almost to Paris, and embraced the whole north central coast of France. Here more and more Northmen settled. They became Christians and were quickly civilized, dropping their own language and customs and adopting those of their new home. The dukes of Normandy were in general faithful vassals of the French kings, but they were very independent and were for a long time as powerful as their sovereigns.

In England the colonization affected a larger portion of the country, and the whole of it was at one time a Danish kingdom. The conquest of the island by the Saxons had founded, as we have seen, seven independent kingdoms. The next stage in the history of England was the formation of a single kingdom by the union of all the seven. But it took a long time to decide which one of the kingdoms was to unite the others under its rule. For a while Northumberland and Mercia strove with one another for the supremacy. Then just after the close of Charlemagne's reign, Wessex rose to be the ruling state under King Ecg-

The Northmen were called Danes in England. Green, Conquest, Chap. II.; Keary, likings, Chap. XII. 
berht. But in the next generation, and before the union was completed, the attacks of the Danes became very frequent. Soon after the middle of the century they began to make permanent homes in England and speedily overran the country north of the Thames. Here they made one of their leaders king, and at once advanced to the conquest of Wessex.

Elfred the Great, $871-$ gor.

Stubbs, 62; Powell, Alfred and the Dane's (Contemporaries).
A united England forming.
A Scandinavian empire. Green, Conquest, Chap. VIII.;

Freeman, Norman Conquest, I., Chap. V.

I73. Elfred the Great. - This was the condition of things when Elfred became king. $\mathrm{He}$ was a brave and skilful warrior, but at first the enemy was too strong for him, and he was forced to abandon the field and even to conceal himself in the swamps and among the peasantry. Finally he collected new forces and gained a great and decisive victory at the battle of Ethandun. After this the Danes were willing to make peace, to recognize Alfred as the lord of their king, whose kingdom was bounded by the Thames, to become Christians, and to settle down peacefully in the land. Flfred reigned for nearly twenty-five years after this treaty, and ruled in his little kingdom as wisely as Charlemagne in his great empire. He did a great deal for learning, translated many books himself, reorganized the army and the navy, improved the laws, and left to his people the memory of a noble character.

I74. The Second Danish Invasion. - The successors of Alfred undertook the work of recovering northern England from the Danes, and pushed it steadily though slowly' forward until by a little past the middle of the tenth century they had carried their rule as far as Edinburgh. A united English nation was rapidly forming throughout the territory occupied by the Teutonic settlers, Saxons, Angles, and Danes, when at the end of the tenth century there came a new Danish attack. This differed from the earlier one in the fact that its object was less to find a new land for the Danes to dwell in than to conquer England and annex it to a great Scandinavian monarchy ruling the whole north of Europe.

'Two Saxon kings strove.to defend England against these 
invasions, Ethelred the Unready, or the king without counsel, - so called because he never seemed to know what to do, - with very little success, and his son, Eadmund Ironside, with greater skill and vigor. Eadmund died, however, within a few months of his father, and then the Danish king, Cnut, of whom so many stories are told us, became undisputed king of all England. Cnut was really a great man, and he ruled a great kingdom, uniting England, Denmark, and Norway, and other lands about the Baltic. England he strove to rule not as a conqueror, but as a native king, as indeed he was to a large portion of the people, and in his reign the union of all the various elements into a nation went rapidly forward. Cnut's kingdoms separated on his death; and though two of his sons succeeded in turn in England, their reigns were short, and on the death of the last the English were glad to restore the old West Saxon line in the person of Eadward, the brother of Eadmund Ironside.

\section{Topics}

Why was not the united government created by Charlemagne maintained? What was the condition of commerce? Why? The effect on government? What would be the effect on our civilization of a return to the last century's methods of travel and transportation? The character of Lewis I. Give the boundaries of the divisions made by the treaty of Verdun, and state the influence of this division on the later map of Europe. How long after Charlemagne's death did his empire remain united in name? What parts of the Empire were attacked by the barbarians? The character of the attack of the Northmen. What parts of the world did they visit? Their permanent settlements in France and England. Reign and character of Elfred. Character of the second Danish invasion of England. The empire of Cnut. By which one of the original Saxon states was the united kingdom of England formed?

\section{Topics for Assigned Studies}

Lewis the Pious. Oman, Periods, Chap. XXIII. Henderson, Germany, Chap. VI. Emerton, Europe, 13-25. Alams, Civilization, 170173. Zeller, III. The Division of 817. Henderson, 20I. 
I 44 Braking up of Charlimagne's Empire

Elfred the Great. Hughes, Alfred the Grat. (Macmillan.) Pauli, Alfied the Great (Bohn), contains translation from .Elfred. Green, Conquest of Englind (Harper), Chap. IV. English People, I. 75-82. Freeman, Norman Conquest, I. 33-35. Keary, Vikings, $38.4-404$.

Cnut. Green, Conquest, Chap. IX. Engrlish People, I. 99-102. Freeman, Norman Conquest, I., Chap. VI. 


\section{CHAPTER II}

\section{THE FEUDAL SYSTEM}

175. The Conditions which gave Rise to Feudalism. While the older Empire was falling to pieces and the new independent monarchies were taking on their first forms, a great system, half political and half economic in character, was coming into existence, - a system which has had a most profound influence on all later history. This was feudalism. The double character of this institution, partly political and partly economic, shows that two distinct sets of causes were at work to produce it. Underlying both was probably one prevailing condition of things which favored the action of these causes. This was the difficulty of intercommunication which followed the destruction of the Roman system of roads and bridges, and the substitution of more primitive methods in both government and commerce for the highly organized Roman civilization.

As government proved by degrees in the age of decline unable to do its work throughout the wide extent of the Empire, the localities were more and more thrown on themselves to provide for their own necessities in the way of protection and order and the enforcement of law. So also economically, with the decline of commerce and the increasing scarcity of money, each locality was in the same way thrown on its own resources to supply its own needs. Again, it was inevitable that in a time of little commerce the chief form of wealth should be land; and on one side that, in a time of a very scanty currency, the rich man, who would get an income from his wealth, should be obliged to

Partly political, partly economic.
The independence of the neighborhood in government and commerce. 
The importance of land.

Taine, $4 n-$ cient Régime (Holt), 5-9.

Their origin Roman.

The feudal theory of the state. Emerton, Europe, 494-507; Adams, Civilization, 217-222. rent his land for services, and on the other, the man who had only his personal services with which to earn his support should be obliged to sell them for the use of land. Both these causes tended to the same result. The state was broken into fragments becoming more and more independent. The rich and strong man who could furnish protection to a smaller or larger territory became its ruler. The duties and rights usually belonging to the government passed into his hands. The military force and the local fortification, which kept off the enemy, - that is, the castle, - belonged to him. The court which enforced the law was his court. He was able to obtain and pay his little army by renting his lands to the fighting class, who paid him in military service. He and they furnished support to the laboring class by renting these same lands to the men who cultivated them and so paid for them by their work in ploughing and harvesting, thus forming the serf class at the bottom of this system.

I76. The Forms of the Feudal System. - The institutions which regulated these relations and formed the foundation of the feudal law go far back for their origin into Roman times, when the imperial government began to decline and to be unable to protect the provinces, but by the ninth century they had been so transformed by the operation of these new causes as to be quite different from their originals. Some idea must be obtained of the forms into which they grew, because of their permanent influence on social organization and on some departments of law.

The theory of the feudal system which has come down to us represents it as a much more orderly and regular organization than it was in reality at the time of its height in the tenth and eleventh centuries. This is because the theory was put into shape by lawyers, who drew up law books based upon the feudal law at a time when the system itself was falling into decay, and who naturally systematized the law as far as possible. This is, however, of less importance for our present purpose, because it was very largely 
through their work that permanent influence was given to feudal institutions. In this theory the king was the lord, or suzerain, of the whole kingdom. Next to him were the great barons, or peers of the realm, who held large portions of the kingdom as his vassals. Their territories in turn were

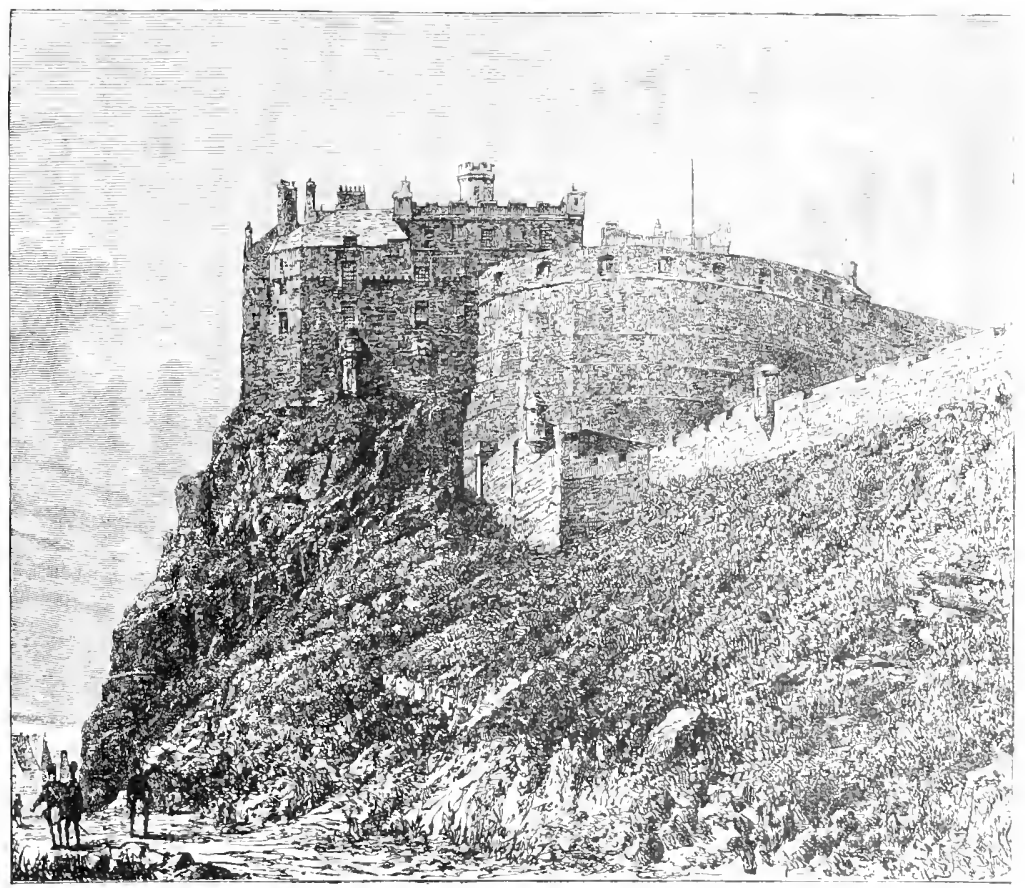

EDINHURGII CASTLE

divided among their vassals, who were thus the rear vassals of the king, and so on down to the smallest piece of land which would give a man income enough from its cultivation by serfs to enable him to make fighting his whole business. The name "vassal" must not be supposed to have carried with it any reproach or dishonor in feurlal days. Quite the 
contrary. The vassal was a noble, and throughout the feudal ranks all were at the same time vassals, except the highest, and suzerains, except the lowest; indeed, so strong was the idea that all land must be held of some one, that it was sometimes said that the king was God's vassal for his kingdom.

France the most feudal of countries. Tout, Periods, 8293, with map.

177. The Feudal System in France. - It was in France that the facts most nearly corresponded to this theory, but the correspondence was by no means complete even there. The kingdom was divided up into a number of great feudal baronies. In the north was the duchy of France, which belonged to the Capetian family, the duchy of Normandy, which was held by the descendants of Rollo the Northman; the county of Brittany at the western corner, and that of Flanders at the eastern; while nearer to the duchy of France lay on the west the county of Anjou, and on the east the county of Champagne. In the centre on the eastern side was the duchy of Burgundy, sometimes held by the Capetians; and in the south was the great duchy of Aquitaine and the county of Toulouse. But these great baronies were not all held of the king, nor were they equal in rank, while by no means all the lords of the smaller baronies held their lands of the great barons. Some of them were the king's immediate vassals. It was only when the feudal system was overthrown as a political institution and the feudal baron was transformed into the modern noble, that the grades of rank and title became regular and fixed. In the tenth and eleventh centuries, customs and practices - and these were what made law then - differed very widely in the different localities, and the real feudal system is characterized by a great deal of what seems to us confusion.

Relief, homage, and investiture. Hallam, Widdle fors, I. $170-18 \mathrm{I}$; Emerton, Europe, 483-
I78. The Feudal Rights and Obligations. - When a vassal died his heir had no legal right to succeed to the fief because it was land which his father had held merely as a tenant. He must obtain the lord's permission, and pay a large sum for it, called the "relief," though the lord was required by custom to grant this permission unless he had 
some very good reason for not doing so. Before succeeding, the vassal must perform the ceremony of "homage," and take an oath to be faithful to his lord, and sometimes, also, an oath of fealty or political allegiance. He then received "investiture" of the fief, and this completed his legal right to the holding. When certain circumstances arose affecting the lord or his family, the vassal was required to pay an "aid." There were usually only three of these: when the lord was taken prisoner and had to be ransomed; when his eldest son was knighted; and when his eldest daughter was married. In certain other circumstances, affecting the vassal, the lord had a right to a payment or to the fief itself. One of these was the relief just spoken of. Another was the right of wardship when the vassal was a minor. This gave the lord all the income of the fief as long as the minority lasted. A third was the right of marriage, or the right of the lord to select a husband for the heiress of a fief, on the ground that he must be sure that the new holder of the land wonld be acceptable to himself and fully able to perform the duties by which the fief was held. Very often the lord simply sold to the heiress the right to make her own selection. Escheat occurred when the vassal left no heirs, and then the fief fell back entirely into the possession of the lord.

I79. The Serf Class. - These regulations, and indeed the whole body of the feudal law, affected the vassals only, or the fighting class. But these lands had also to be cultivated to keep people alive. This was done by the serf, or laboring class, and the same lands which were held by the vassals under the feudal regulations, or as the expression was, by " noble" tenures, were also held by serfs under different regulations, or by servile tenures. Wach lord, instead of granting out to vassals who paid military service the whole of the fief which he held, kept in his own hands a part of it, which was called the "domain" lands of the fief. This he granted to serfs, who paid him in labor or by giving him a part of the crops which they raised, and these payments of

The culti vators of the soil. Emerton, Europe, $510-520$ Duruy, Mliddle Ages, 208-2I3. 
the serfs formed the main support of the lord and his family.

The origin of tive serf class (stee ए. I28).

Ihe sert is the slave on the way to freedom. Alams, Growith of French Nitwon, 6568.
We have seen how the serf class began to be formed in the last days of the Roman Empire, on account of the growing scarcity of laborers. To keep the soil in cultivation, the state gave to the slave a little piece of land, and took away the master's right to remove him from it. It was not a very large amount of legal right which the slave secured in this way, but it was a beginning, and it led in time to the change of the whole slave class into serfs. By the end of the tenth century the slavery of Christian men by Christian men had almost entirely disappeared from Europe, and it never returned. In the history of labor, serfdom represents an intermediate stage between slavery and free labor. It is the condition through which the slave passes in being transformed into the freeman.

I80. The Condition of the Serf slowly Improving.Looked at in this way the serf is one who has a part but not all of the rights of a freeman. As time goes on he is securing more and more of these, until at last he cannot be distinguished from a freeman. This is exactly the history of medieval serfdom. The general condition which had led to the change at first, the scarcity of cultivators, continued throughout the whole period, and kept securing to the serf better and better terms for his labor. The progress was very slow during the first half of the Middle Ages, because until the cities began to fill up and manufactures to increase there was almost no place to which the serf could go to better his condition. If he left the piece of land which he held, he ran great risk of starving to death. But there was much new land brought into use during these centuries by clearing and draining, and this made now and then a strong demand for labor from which the serf always gained something. In the last half of the Middle Ages we shall see new causes coming into operation which carried on this advancement much faster.

As serfdom represents a transition stage in the history of 
labor, we should expect to find the individual serfs on a Numerous domain standing in different grades of that transition. Ant this is the usual condition of things. Some serfs of the manor at the bottom are hardly to be distinguished from slaves. Their rights are very few, and the lord's arbitrary power over them is very great. Others have made more advancement and are protected in a larger number of rights, while at the top may be a class hardly to be distinguished from freemen.

In picturing to ourselves the organization of society in feudal times, we should be careful to distinguish between the vassal and the serf. They were two entirely distinct classes, subject to different kinds of law, and very sharply separated from one another in the days when the feudal system was at its height.

\section{Topics}

What economic conditions assisted in the rise of feudalism? What political? Why was the land so important in the feudal system? Why was protection, which we obtain so easily, so clifficult to get in those days? How far back in time do the forms of the feudal system go? What was the feudal theory of the state? Where most nearly realized? How nearly there? Explain the most important feudal rights and obligations. Explain the terms "suzerain " and "vassal." State fully the difference between vassal and serf. What was the place of the serf in the feudal system? How did the serf class originate? Ilow did the general feudal conditions improve the position of the serf?

\section{Topics for Assigned Studies}

The origin of the feudal system. Adams, articles in Andozer Revieze, Vol. VII., and Cizilization, I94-2I7. Emerton, Introduction to the Iiddle Ases, Chap. XV. Penn. IV., No. 3.

The manor and its working population. Penn. III., No. 5. Andrews, The Old English Marnor. (Johns IIopkins Press.) 


\section{CHAPTER III}

\section{THE RISE OF THE NEIV NATIONS}

Three states assume their modern form.

No real national unity yet possible.

Tribal disunion.
I8r. General Conditions. - While the Danes were attacking and conquering England, great changes were also taking place on the continent of Europe. The dynasty of the Carolingians disappeared from history in all its branches, and the great states which were emerging from the empire of Charlemagne began to assume the appearance and to organize the governments which they were to retain until almost the present time. These were the states of Germany, France, and Italy.

One fact, it must be remembered, characterizes all these countries alike during this period; that is, separation into fragments, the lack of any real national unity. We saw in the age that followed Charlemagne the causes which were at work to make it impossible to maintain unity. In the tenth century these causes were still at work, and it was still impossible to overcome them entirely. With this century we come to a time when something like modern national feeling begins, and aids very possibly in the establishment of new dynasties, but it is not strong enough to unify the nation, or even to assist in the establishment of a strong government. We have to notice how in these varions countries the new dymasties take the place of the old, how they attack the difficulties of government, with what degree of success or failure, and to what extent these states are coming to be like the modern ones of the same name.

I82. The Beginning in Germany. - In Germany the ordinary causes of separation were reinforced by the old 
tribal differences which had not yet died out and which in one way strengthened themselves in this period. Saxons, Franks, Bavarians, and Alemanni or Suabians, each retained a local patriotism, and in the weakness of the state tended to rally around some one of the local families which by getting possession of the office of duke strove to found a local dynasty. The state was weakened also by the plundering raids or more serious attempts at conquest of the Hungarians, a Tartar race that had followed the Huns and the Avars into the Danube valley, and who were now trying to force their way up the river into central Germany, as the 'Turks did later.

On the deposition of Charles the Fat the Germans chose as king Arnulf, a German Carolingian who strove with much energy and success to maintain a strong government; but his line died out in a few years, and they were obliged to make a new choice. Disregarding the French Carolingians the other side of the Rhine, they selected Conrad of Franconia. Like Arnulf he struggled manfully to maintain the authority of the crown, but with less success. The power of the dukes was greater than it had been, and Conrad came at last to recognize the fact that the king must depend for the power to rule the state on the resources of his own family. With remarkable patriotism, before his death he advised the Germans to transfer the crown to the strongest of the dukes, Henry of Saxony.

I83. The Saxon Kings. - Both Henry and his son Otto I. were very able men. They beat off the Hungarians, and forced the great nobles who were striving for independence into submission. They attempted also to bring about a permanent reduction of the power of the dukes by withdrawing from their control all the lands helonging to the king within their territories, and by granting to the bishops the same political powers over their lands that were possessed by the counts and the dukes. These measures were for a time successful, and by the year $95^{\circ}$ the king of Germany was really master of the state, and the German

Arnulf, 888-899. Oman, Periods, Chap. XXVII.; Emerton, Europe, 90-100.

Conrad I., 9I I-9I 8 .

Oman, Periods, 475; Emerton, Europe', 100; Henderson, Germany, I 17.

Henry I., 918-936. Otto I., the Great, 936-973. Fout, Periods, I 2-29; Emerton, Europe, IO3-II4; Henderson, Germany, 119-128; 
Scheffel,

EkAhard.

(novel).

Nap,

Putzger,

No. 15.

No nation.a: government

had taken form in Italy. Henderson,

Germant,

I28-I fI ;

Emerton,

Eurote?

I I5-I 29.

$9^{62}$.

Bryce,

Empire,

80-88.

The title of

emperor

altached to

that of kiner

of Germany.

Bryce,

Einfore,

I22-I.5.

Otto $11 \mathrm{I}$.,

933-1002.

The emperor

of Rome

loses power

as king of

fierminy.

Bryce,

Eimfire,

I $+5-$ I 49 ;

rout,

lereids,

+o- 47 ;

Emerton,

Furepe,

I.49-I6I.

nation was in a fair way to be formed. Then occurred an event which had the most momentous consequences both for Germany and for the world. Otto was invited to go down into Italy.

I84. The Empire revived by Otto I. - Italy, like all the states at this time, was broken into fragments. It differed from the others, however, in the fact that no one of the local dymasties was strong enough to establish even the form of a national government which could have any permanence, and begin the construction of a nation. They were in perpetual conflict with one another for suprem-iy, and out of this conflict came the invitation to Otto. In 95 I he made a first expedition, in which he contented himself with forcing several of the local princes to recognize him as their lord. Ten years later he responded to another invitation, and this time he was crowned king of Lombardy and emperor of Rome.

Since Arnulf, no king of Germany had been crowned emperoi of Rome, but the act of Otto united the two crowns in such a way that from his time the chosen king of Germany was supposed to have a right to the imperial crown if he would go to Rome to receive it. This was the founding of "the Holy Roman Empire of the German Nation," which lasted in form at least to the opening of the nineteenth century. It was destined to have most disastrou; consequences both for Germany and for Italy, and these began to show themselves at once.

I 85. The Effect of the Revival of the Empire. - The short reign of Otto II., filled with strife and a third of it spent in Italy, wa followed by a long minority, and then Otto III. became kino and emperor. He was of a highly imaginative mind, and b canse he was descended through his mother from one of the Greek dynasties which had held the Empire at Const inople, he believed that he represented in a peculiar way the ancient emperors. Germany seemed to him of little account, and all his life was centred in Italy and Rome. In the reigns of these two Ottos the power of the 
German king which the first two Saxons had built up with such difficulty went rapidly to pieces. The last sovereign of the family, Henry II., was a good man, but not a strong king, and he could only begin the recovery of what had been lost.

On the death of Henry II. the Saxon family became extinct, and the Germans went back to Franconia and elected another Conrad, probably of the same family as Conrad I. He proved to be a vigorous and determined king and rapidly reconstructed the royal power. The kingdem of Burgundy was annexed to the Empire in his reign, and though he sought the imperial crown in Italy, he did not allow his interests there to interfere with his power in Germany. Since the time of the first Conrad the feudal system had been introduced into Germany, and one of the ways by which Conrad II. strengthened his power was by encouraging the independence of the smaller nobles and protecting their interests against the dukes and great barons. At his death Conrad left the royal power far stronger than it had ever been before, and Germany more thoroughly centralized under a single government. The reign of his son Henry III. opens a new age in the history of the Empire.

I86. The Beginning in France. - By this time also a new dynasty had firmly established itself in France. In the troublous times which followed the first attack of the Northmen, a family of unknown origin had come into possession of Paris, because they furnished the most skilful and vigorous leadership to be had against the invaders. $\square$ om this point their lands grew into a little feudal state mcluding Orleans and commanding the two great rivers of northern France.

On the deposition of Charles the Fat, the hes of this family, Eudes, son of Robert the Strong, was made king of France. But this was not a permanent change of dynasty. He was succeeded by Charles the Simple, a Carolingian, who gave Normandy to Rollo, and for a hmolred years the crown was transferred back and forth from one family to the

The second

German dynasty.

Recovery

under the

first

I'ranconians.

Conrad II.,

I02.t-I039.

Tout,

Piriods,

$+7-60$

Emerton,

Europe,

162-185;

Henderson,

Germany,

I 66-I 73 .

The teudal

policy of the

Franconians.

The origin of the Cape-

tians.

Adams,

French

Nition, 54.

Two families rivals for the crown. Kitchen,

France,

I. I69-178;

Tout,

Periods.

Chap. IV.; 
Emerton, other. Hugh the Great, who was the head of the new Europe, 400-420; Zeller, IV.

The first four Capetians, 987-I 108. Kitchen, Frentic. I. $185-189$; Alams. Fiench Nietom. Chap. VI.

The last saxon king, Edward the Confessor, IO+2-1060. Green, linglish l'eople, I. $103-107$; stubbs, 76 . family during the middle years of the tenth century, might have made himself king if he had chosen, but he preferred to sustain the Carolingians. On the death of Louis V. in $9 S_{7}$, Hugh Capet was made king, and from his reign on the Capetians have held the throne of France in unbroken succession as long as kings have reigned there at all.

187. Kings of Little Power. - In truth, during all this time and for another century still the king had only nominal power. The feudal system was at its height in France, and the great barons who divided its territory among themselves were really independent sovereigns, each in his own land, and they would allow to the king no control over their subjects. The early Capetians had a strong position in northern France and ruled as their own one of the most powerful of these feuclal states, the duchy of France, and they were very faithfully supported by the Church. These two things were the source of what power they had as kings, but the next three kings after Hugh Capet, - Robert, Henry, and Philip, - whose reigns fill the whole eleventh century, could do no more than make a beginning. They kept secure possession of the crown and prepared the way for better things, and that was success enough in such an age as theirs.

188. The Norman Conquest of England. - In England as well as in these other states the old dynasty comes to an end and a new one takes its place. After the two sons of Cnut the English made Eadward the Confessor king, brother of Eachund lronsile, but a very different man. He had passed his youth during the time of the Danish kings in Normandy, which was his mother's home, and he had become more Norman than Saxon. He liked to follow Norman ways, anıl to have Normans about him at the court. Besirles, he was a man of rather weak character, likely to be under the influence of some one else. As a result much of his reign was occupied with the struggle of Saxon and Norman parties which prepared the way for the Norman conquest after his death. 
Eadward left no children, and the English elected Harold, son of the great Earl Godwin who had been the leader of the Saxon party; but William, duke of Normandy, insisted that the throne had been pronised to him by Eadward, and that Harold had taken an oath to support his claims. He immediately collected a great army and soon landed on the southern coast of England not far from the town of Hastings. Harold, who had only just beaten an invading army under the king of Norway in the north of England, made a brave fight for his crown in the battle of Hastings, but was defeated and slain. William then marched through the country, turning a great circle to the north side of London, which then surrendered and accepted him as king. There was some resistance in other parts of the kingdom and some rebellion against the Norman king, but William subdued all opposition with vigor and often with great severity, and finally the whole land was brought into obedience.

\section{Topics}

What three states of the continent began to assume a modern form after the dissolution of Charlemagne's empire? How near was this to national unity in each case? What difficulties were there to be overcome in Germany? What was done by the Germans on the extinction of their branch of the Carolingian house? The two great kings of the first German dynasty. Their measures to strengthen the royal power. Why were these interrupted? The situation in Italy. The effect on Germany of the revival of the Empire. On Italy. What was the relation of the two titles, "Emperor of Rome" and "King of Germany"? How does the reign of Otto III. show the effect of the revival of the Empire? Policy followed by the second German dynasty to strengthen the royal power. The origin of the Capetians. Compare the substitution of a local dynasty in France for the Carolingians with that in Germany. The power of the crown under the first four Capetians. The character of the last Saxon king. What did the English do on the extinction of the Saxon line? Had William any right to the English throne? How did he get the throne?

Harold king. Freeman, William the Conqueror. (Macmillan), $5 \mathrm{I}-62$; Tennyson, Harold.

(drama) ; Bulwer, Harold (novel). 'Tlue battle of Hastings, Io66.

Freeman, Hilliam the Conqueror, 82-99; Social England, I. $23 \mathrm{I}-2.44$; Sources, Stubbs, 79-9I ; Gee and Hardy, 54-59; Penn. III., No. 2 ; Henderson, 7; Kingsley, Hereciard (novel). 


\section{Topics for Assigned Studies}

The Holy Roman Empire. Dante's De Monarchia; translated in Church, Dante. (Macmillan.) Lryce, Holy Roman Emfire, Chap. VII. Freeman, essay in Historical Essays, I.

the battle of Hastings. Freeman, Vorman Conqu'st, III. 30I-339. Original accounts, all in Bohn: Orteric, I. ${ }_{4}$ So- 4 S8. William of Malmesbury, 274-2Sr. IIenry of I Iuntinglon, 209-212. Matthew of Westminster, I. 559-564. Sice the controversy on the battle in the volumes of the English Ilistorical Reaiew. 


\section{CHAPTER IV}

\section{EMPIRE AND PAPACY}

I 89. The Papacy during the Tenth Century. - During the age when the feudal system was at its height, the papacy had suffered in common with all general governments a great decline. At the middle of the tenth century, its authority in Europe was almost nothing, and in Italy and Rome it was used as the tool of local factions in their conflicts with one another. From this condition it was rescued for a time by the Ottos, who appointed a series of reforming popes and brought the papacy under the control of the Empire as it had been in the days of Charlemagne. These reforms were followed by a speedy relapse, as soon as the hand of the Emperor was less felt, in the reigns of Henry II. and Conrad II. Soon after the death of Conrad we find three popes at once, each claiming the papacy and each refusing to recognize the rights of the others. It was a situation which called for the intervention of the emperor as loudly as in the time of Otto $I$.

In the meantime there had been forming and growing stronger and stronger in the Church a theory of the absolute power of the pope, as the especial representative of God in his moral government, which was much clearer and more logical than any that had been taught before. It may be put briefly in this way: The Spirit of God dwells in His Church, guiding it in the right path on all important occasions. The pope as the centre and representative of the whole Church is especially under this divine influence, and will not be allowed to make any serious mistake in deciding

Great decline of papal influence.

Alzog, Church History, II. 392298; Schaff, Church History, IV. 279287; Adams, Civilization, $227-23^{8}$.

Three rival popes.

A clear theory of papal supremacy. "Dictate" of Gregory vil. Henderson, 360 ; also in Nathews. 
disputed questions. Therefore all parts of the Church should yield him implicit obedience.

190. The Reforms of Cluny. - These ideas had been reforms. Adams, embodied in the law books which were now current in the

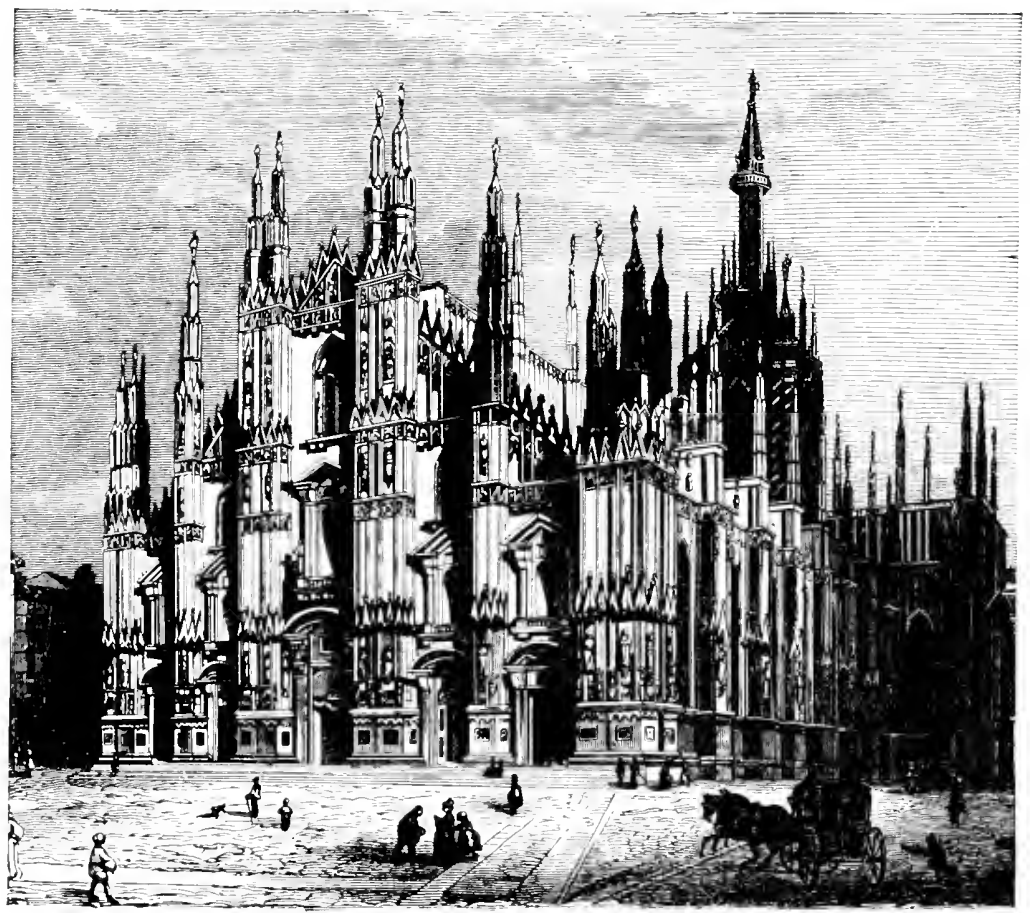

MILAN CATHEURAL

ciailiation, Church, and they had been taken up and made still more $239-244 ;$ Emerton, Europe, definite by the leaders of a strong reform movement which had started from the monastery of Cluny in eastern France. I $9.4-200$. These reformers saw more clearly than had ever been seen before that if the ideal papacy was to be realized in fact, the Church and the pope must be entirely independent of 
the State. 'The special reforms which they lemanded were all directed to this end. In the first place, the pope must be chosen by the Church. The emperors must have no longer any power of appointment. In the second place, the bishops and great officers of the Church, also, in the different countries must be freely elected by the Church without dictation from the State, nor could the State even be allowed to grant to the prelate investiture of the lands which formed the endowment of his office. These lands in the feudal age were looked upon as a fief, and the bishop was considered a baron, so that the State had really some right to claim a voice in his appointment. It was the demanding of this reform which gave rise to the great investiture conflict with the Empire. Finally the rule which had been of long standing in the Church, that priests should not be married, was to be rigorously enforced, and all the clergy separated entirely from the world and its interests.

To carry out these reforms would demand very great changes, and it hardly seemed possible that they coukl be realized in an age of so general corruption. But the time proved more favorable than could have been anticipated, and the century which followed saw an enormous increase in the independence of the Church and in the power of the pope.

I9I. The Power of the Empire under Henry III. - The result of the policy which Conrad II. hat followed in (iermany had been to make the king very strong again. His son, Henry III., is the most powerful (ierman king of history, and Germany in his reign had the strongest government and was the nearest to a united nation in the molern sense of any of the states of Europe. The strength and the union depended, however, far more on the character and vigor of the monarch than in a modern state, and the government was likely to go to pieces very quickly if anything went wrong with the king. But for the time being the State was so strong that Henry III. could safely give much attention to affairs in Italy.

Circumstinces favor the church.

Ilenry IIJ. $1039-1055$. Tout, lerveds, q,6-Io3. Matp, Intzger, No. 15. 
The emperor gives the papacy to the reformers. Stephens, Hilderand. (Epochs Ch. Hist.), 20-22; Fisher, Church History, 173 .

The minority of Henry IV. Stephens. Hiddetrand, Chap. VI.

The cardinals. Alzog, Church History, II.

$3+4-34^{8}$;

Fisher, essay in Insiussions (Scribner): the decree in Nathews.

The investiture strife.

Alzog, Church History, II. 48I-5II; Emerton, Europe, Chap. VIII. ; Tont, reriads, (his. VI.
The three popes whom he found in Rome were all deposed, and another was appointed in their place. He was a German, and in succession Henry appointed four popes, all Germans and probably all reformers. Certainly with the third of these popes, Leo IX., the party of the Cluny reformation came into possession of the papacy, and, if not under Leo, at least soon after, the man who is especially identified with this great age of papal history began to direct the policy of the Church. This was Hildebrand, who afterward himself became pope as Gregory VII.

192. The Beginning of the Conflict. - If Henry III. had lived longer, he would probably have continued to control the popes, and the Church would have been unable to secure its independence so early as it did. But his early death was the opportunity of the papacy. Henry's son was then but six years old, and a long minority followed during which Germany was divided between hostile factions, and no continuous or determined intervention in Italy was possible. By a decree of 1059 the papacy declared its independence of the emperor in the choice of the pope, which was to be henceforth made by the college of cardinals.

In Germany the strifes of the long minority had greatly weakened the government, and when Henry IV. himself began to rule, his character did not make it easy for him to recover the power of his father. A great rebellion of the Saxons was hardly subdued, when he found himself involved in open and desperate conflict with Gregory VII., who had just been made pope. This conflict fills the whole of his reign and almost the whole of his son's. It was upon the special question of the appointment of bishops, and is known as the investiture strife, because of the great interest of both Church and State in this ceremony in the feudal age. In reality it was a struggle for the independence of the papacy from the Empire, and for a position of equality with it as a great European power. 
r93. The Conflict and its Results. - At first things went decidedly in favor of the pope. All the elements of opposition to Henry in Germany joined the party of the pope, and the emperor's friends even stood aloof, for his life was such that many believed the excommunication was deserved. The isolation of Henry forced him to that famous scene of humiliation at Canossa, where he met Gregory, humbly confessed his sins as a penitent, and received the absolution of the pope. There could be no reconciliation between the Empire and the papacy at this time, but Henry succeeded in dividing for the moment his enemies and in gaining an opportunity to form the party of his friends. When he was excommunicated a second time, it was easser to see the political motive of the act than in the first case; and only at the end of his life, when his son turned against him, did his fortunes again reach the lowest point.

Henry V., though he had joined the party of the Church against his father, was obliged to take up his father's cause as soon as he became emperor himself. The strife was only settled in I 22 by the Concordat of Worms, which was a fair compromise, giving to the Church the choice of the bishop, but allowing the State to reject the candidate if it did not approve of him. In the larger question of the independence and power of the pope, the conflict closed with a great victory for the papacy, which never again came under the control of the emperors, as it had once been, and which was from this time on one of the greatest powers of the world.

I94. The Third German Dynasty, the Hohenstaufen. Henry V. was the last of the Franconian dynasty. After the interval of a single reign, a new dynasty obtained the crown of Germany and of the Empire, the Hohenstaufen, one of the most brilliant families of all history. But Germany was now greatly changed from the times of Henry III. The power which had been lost in two generations of civil war could not be recovered. The great emperors of this new age, Frederick I., Henry VI., and Frederick II., seek to

Henry $V$., I $106-$ I 125.

The Concordat of Vorms. Henderson, 408; also in Mathews; in England, Gee and Hardy, 63;

Emerton,

Europe, 269;

Adams, Civiliantion, 246.

The emperors abandon Germany for Ilaly.

Adams,

Civiliation,

$247-252$;

Balzani, The

Pope's and the

Hohenstule'te

(Epochs

Ch. Hisl.). 
form in Italy rather than in Germany the basis of the imperial power. Frederick I. does not actually abandon Germany. It still remains, nominally at least, his residence; but he makes many and long visits to Italy, and freely spends all the resources he can draw from Germany in the attempt to conquer his enemies there. Henry VI. and Frederick II. hardly visit Germany at all, and plainly regard it as second in importance and interest to Italy.

Absorption in an Italian state.

The Norman kinglom of sicily.

Iout.

Periuts, IO3-109; Emerton, Eureper, 223-229; Johnson, Vinmetrs (bipochs), 75-81;

Gibbon, Chap. LII.

195. The Danger to the Papacy. - The policy of the Hohenstaufen emperors to form a strong government in Italy brought them at once into conflict with two determined and powerful enemies. The one was the pope. If Italy were formed into a single state, the independence of the popes would be destroyed, as they believed, and the great power which they had now attained in Europe and even their healship of the Church would be threatened. It was the same danger over again which had menaced the papary in the advance of the Lombards in the eighth century. It is very probable that these fears would have been realizer in the Midkle Ages, though when the temporal sovereignty of the popes was at last destroyed by the present Italian kinglom, these consequences did not follow.

This danger became a very immediate one when the marriage of Henry VI. with the heiress of the Norman kingdom of Sicily brought that rich and military state into the hands of the emperor. Some Norman adventurers had established themselves in southern Italy early in the eleventh century, and begun a little state which grew rapidly and soon became formidable. After some wars with the popes, the Norman rulers formed an alliance with them, and were accepted as the rassals of the papacy by Nicholas II. This alliance had proved of great assistance to the popes in their conflict with the Franconian emperors, but now the Norman kingdom was on the side of their enemies, and was to be made the very foundation of their power.

I96. The Cities of Northern Italy. - The other enemy of the Hohenstaufen, and the one which finally prevented 
the accomplishment of their plans, was the great cities of Frederick I., northern Italy. These had been growing rapidly rich and strong during the Franconian period through the (levelop)ment of commerce, and had made themselves as independent as were the feudal princes of Germany. That independence was of course as much threatened by the plans of the I I 52-I I go. Bryce, $:$ :mpire, Chap. XI. Freeman, in $1 / i$ torical Essays, 1.;

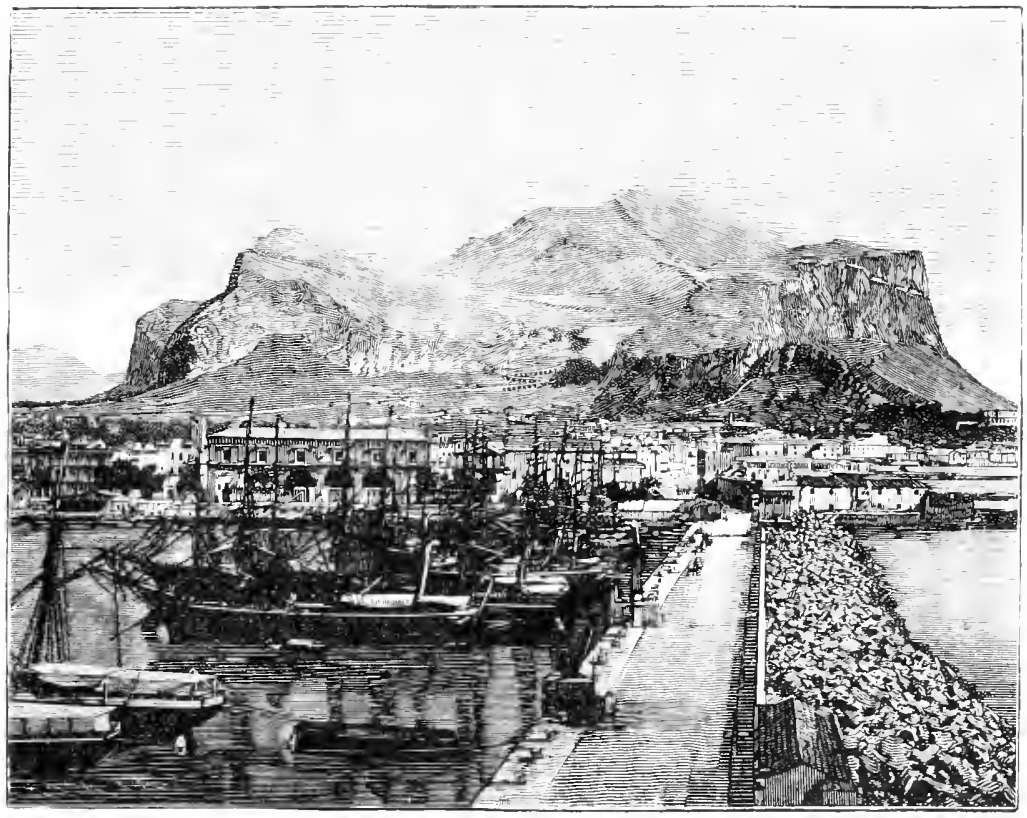

HARBOR OF PALERMO

Hohenstaufen as was that of the popes, and the cities were resolved to protect it to the utmost. They allied themselves with the popes, and formed with one another the Lombard Leagne, that they might use their united strength. Frederick I. found some allies among the cities, and was at first sucressful. At one time the city of Milan, which was the leadEmerton, Europe', 282-312; Tout, Pertods, Chap. XI.: Henderson, ing city of the League, was totally destroyed. The ancient 4 IO- 43 O. 
The Lom- Roman law, which had begun to be actively studied in these

bard

L.eague.

Duffy, Tuscan Republics (Nations), Chaps. Vil. and IX.-XI.

The battle of

Legnano,

1 7 6. Peace

of Venice.

Henderson, 425 , and

Mathews.

Peace of

Constance,

Mathews.

The Guelphs, the German rivals of the Hohenstaufen.

Their power broken by Frederick I.

Tout,

Periods, 264-269.

Innocent

III., I $198-1216$.

Alzog, inurch History, II. $57+-586$ cities with the growth of commercial interests, Frederick tried to some extent to use to assist his plans, because it was the law of a strong monarchy and because he was in name the emperor of Rome. Finally, in the great battle of Legnano, Frederick's army was destroyed, and he was forced in the treaty of Constance to recognize the virtual independence of the cities.

197. Guelf and Ghibelline. - Frederick might perhaps have succeeded in this battle if it had not been for the opposition in Germany of the great rival house, that of the Guelfs. They had been rivals of the Hohenstaufen for the crown to succeed the Franconian dynasty, and had never become reconciled to their defeat. As the most conspicuous leaders of the opposition to the emperor, their name was taken as that of the party of the pope and the cities in Italy, while those who farored the emperor were called Ghibellines. These names continued in use for the political parties in the Italian cities, and become of especial interest to us again in connection with the life of Dante. After the battle of Legnano, Frederick turned his whole strength against Henry the Lion, who was the head of the Guelfs, drove him into exile, and confiscated his lands. The Guelfs never recovered their power in Germany, though the son of Henry the Lion, Otto IV., became emperor for a few years after the death of Henry VI., - and as emperor was forced to be a Ghibelline against the pope. They recovered part of their lands, and some of these, Hanover and Brunswick, they retained into the nineteenth century.

I98. The Papacy at its Highest Point of Power. - Henry VI. was a very able diplomatist, and he came near accomplishing by negotiation what his father had failed to do by force. But as his plans seemed on the point of being realized he suddenly died, leaving his son, the future Frederick II., a mere infant. The long minority which followed is filled with the reign of the most powerful pope of history, Innocent III. Circumstances favored him throughout all Europe, 
and he exercised a power which was really above kings, and came near to being that imperial power which the theory of the Holy Roman Empire would have given to the emperors. He humbled the kings of England, France, and Germany ; directed a great crusale; and destroyed the first great heresy which had arisen in the west, that of the Albigenses.

Frederick II. Owed the possession of the throne of Germany and of the Empire to the support of Imnocent III. against the Guelf emperor, Utto IV., but he was soon involved in the old conflict with the papacy and the cities. In this strife he depended mainly on the resources which he coukl draw from Sicily, and though this kingdom was rich, it proved unable to sustain the long strain of this war. Frederick gained some great victories, but in the end he failed as his grandfather had done. The city states of Italy secured their local independence. In Germany, also, left so long to itself, the cause of local independence strengthened itself, and both these great states pass at this time into that condition of hopeless division into fragments from which they have been rescued only in recent times. The papacy gained even more from the conflict than had the little states of Italy and Germany, and is henceforward one of the great powers of Christendom, not in military strength, but in influence and moral power, while the Empire, which had behind it such a great past, sinks now to be a mere title and a theory.

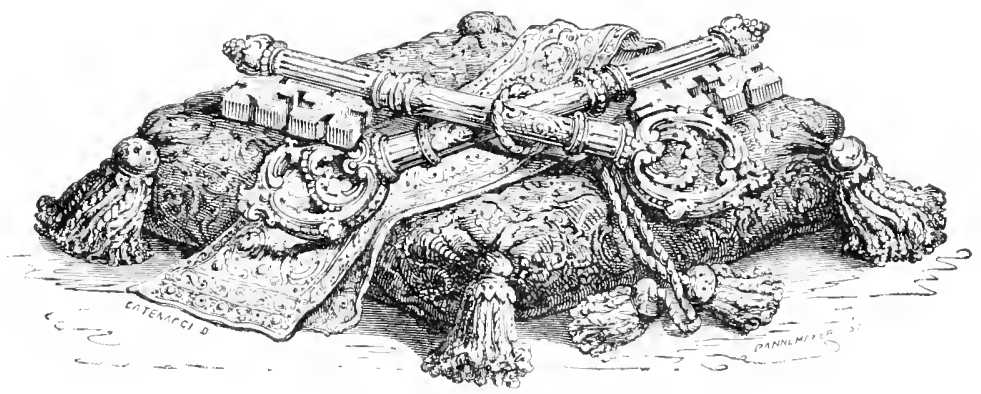

PAPAL KEYS 


\section{Topics}

Position of the papacy during the tenth century. The idea of the reformers in regard to the position of the pope. The three great reforms demanded by Cluny. What circumstances favored the reform party? The power of Henry 1fl. and his relation to the papacy. Effect of the death of Henry III. What was the "investiture" question? Begun by what pope? What led Henry IV. to go to Canossa? How was the question finally settled? What was the policy of the third German dynasty in regard to the Empire? Why was this especially dangerous to the papacy? Why opposed by the Italian cities? The origin of the Kingdom of Sicily. Its relation to the papacy. Ifuw did the Ilohenstaufen family obtain it? Its bearing on their plans? What was the Lombard League? The result of the Italian plans of Frederick I. The original and the later meaning of the names Guelf and Ghibelline? The power of Innocent III. The result of the reign of Frederick II. What change had taken place in this periorl in the positions of the Empire and the papacy?

\section{Topics for Assigned Studies}

Henry IV. at Canossa. Stephens, Milkebrand (Epochs, Ch. Hlist.), 125-134. Tout, Periods, I 29-1 32. Emerton, Europe, 25 I-255. Henderson, $3 S_{5}$.

Guelf and (Ghibelline. Irowning, Guelfhs and Ghibellines (London; Nethuen). Nachiavelli, History of Forince (Bohn), Book 1., (hap. V. Duffy, Tuscan Republics (Nations), Chap. X. Tout, Periods, Chaps. A., XI. 


\title{
CHAPTER V
}

\author{
TIIE CRUSADES
}

\section{Books for Reference and Further Reading}

Kugler, Geschichte der K'rewsïg'. (lierlin; I 1 marks.) The best manual of the extermal facts of the age.

Prutz, hultureschichte der Krewäse. (Berlin; I4 marks.) Very full on all sides of the life of the agre.

Vun Sybel, Geschichte des ersten krumsurs. 2d edition. (Leipzig; 10 marks.) Detailed and critical. A translation of the first edition is antiquated.

Archer and Kingsford, Kingram of ferusalem. (Nations.)

Cox, The crusudes. (lipochs.)

Chronicles of the (ruscades. (Bubn; \$I.5O.) Translations of chronicles of crusales of Richard I. and Louis IX.

Pears, The Fall of Constantinople. I'vurth crusale. (IIarper; \$2.50.) Gray, The (hildren's Crusade. (IToughton; \$1.50.)

Oman, Art of $\|^{\prime}$ ir in the Niddle Ages. (I'utnam.) Military criticism of the crusales, pp. 229-350.

199. Place of the Crusades in History. - Almost at the same time with the beginning of the conflict between the Empire and the papacy, there begins another great Emopean movement, which is as thoroughly characteristic of the Middle Ages, but which also forms the tuming-point towards morlern history, - the crusades. In the causes and motives which brought them about, the crusarles are typically medieval; in the results which followerl from them they began the transformation of the medieval into the modern.

200. Motives of the Crusaders. - The crusaders themselves were personally influenced by two very strong motives. One was the religious - the belief that pilgrimages, especially to such holy places as those in I'alestine,

The turningpoint loward modern history.

Religious and worldly molives togetler. 
Adams, would be the best penance for their sins. 'The other was Cirilization, the love of adventure and the enjoyment of personal combat, 259-268;

Archer,

Ferusilem,

I-I7;

Cox,

(imalesis

Chap. I.

The advance of the Turks. Archer,

Ferusalem, $17-25$. which is a little later so prominent a feature of the age of chivalry. Mingled with these motives were, eren from the beginning, more selfish ones - the desire of the leaders to secure principalities for themselves from the conquests made, and motives of commercial gain, which become especially active in the later crusades.

20r. The Beginning of the First Crusade. - The special occasion of the first crusade was the adrance of the Seljuk Turks. We have already seen their rise into power in the caliphate of Bagdad, and they continued to push steadily to the west. About twenty years before the first crusade they captured the city of Jerusalem from the Fatimite caliphs of Egypt, and the pilgrims from the west began at once to suffer grievously from their more barbarous disposition. At the same time their progress in Asia Minor alarmed the Greek emperors at Constantinople, who began to fear the total destruction of their empire. Their call upon the West for help came just at the time when the West was leginning to be aroused by the stories of the returning pilgrims, and when the rapidly increasing power of the popes gave them an interest in heading a great European religious movement of the sort.

Council of

Clermont.

Cox,

irusades,

(Whap. II. ;

Archer,

Yorusidin, 28-3t; Penn.

I., No. 2.

The march of the first crusade, 1095.

Archer,

Ferusalem. Chap. III.; Scott, Count Robert of

Pope Urban II. proclaimed the crusade and preached it at the council of Clermont in southern France, where his sermon aroused great enthusiasm. "God wills it," cried the great andience, and this became the watchword of the crusaders. The first crusade was composed almost wholly of Frenchmen or Normans. It marched in four divisions to Constantinople, one from the region of Lorraine, west of the Rhine, one from the north, and one from the south of France, and one led by the Normans of southern Italy. The year before their march a great crowl of unarmed peasants and rabble of the lower orders had been led in alvance by Peter the Hermit and Walter the Penniless, expecting to take possession of the Holy Land by 


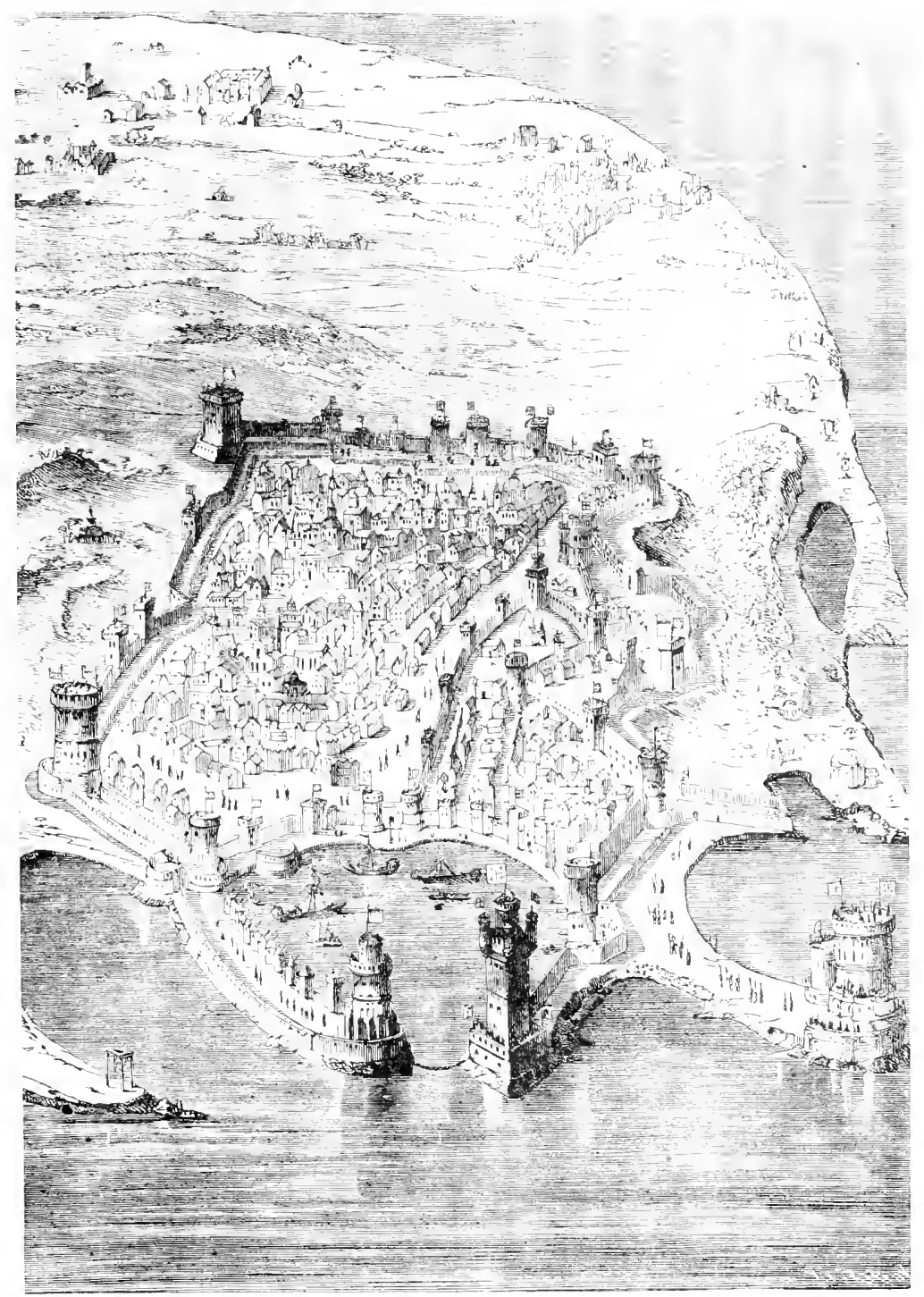

BIRIS EYE VIEW OF RHOHW TIMF OF THF CRUSAHF 
Faris miracle, but perishing miserably of hunger and by the (novel). sworl of the Turks in Asia Minor.

The conquest 202. The Results of the First Crusade. - The real cruof the Huly sale had much trouble at constantinople in arranging

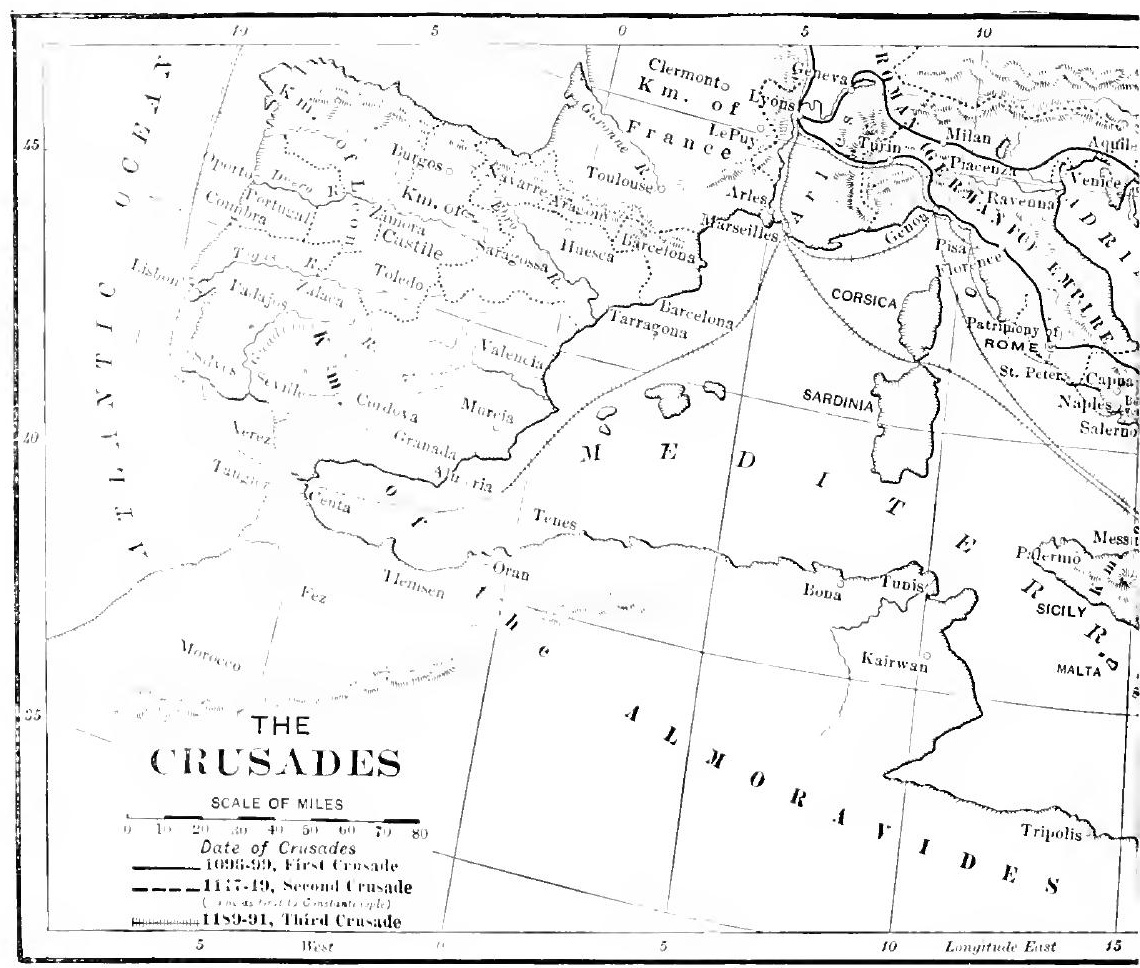

Land. matters with the emperor, who had not expected quite so Cox,

Crusales, 60-та; Archer, Finualtm, Chap. I.; much help, and feared the crusaders almost as much as the Turks, and after getting free from Constantinople, the crusaders met with great suffering and loss in their march throngh Asia Minor. At the northern end of Palestine the great fortress of Antioch had to be taken. This was 
accomplished only after a long siege and very heavy losses, Penn. I., and the crusaders had no sooner obtained it than they were No. 4 . besieged in turn by a great army of Turks which was advancing to occupy the Holy Land. The Turks finally

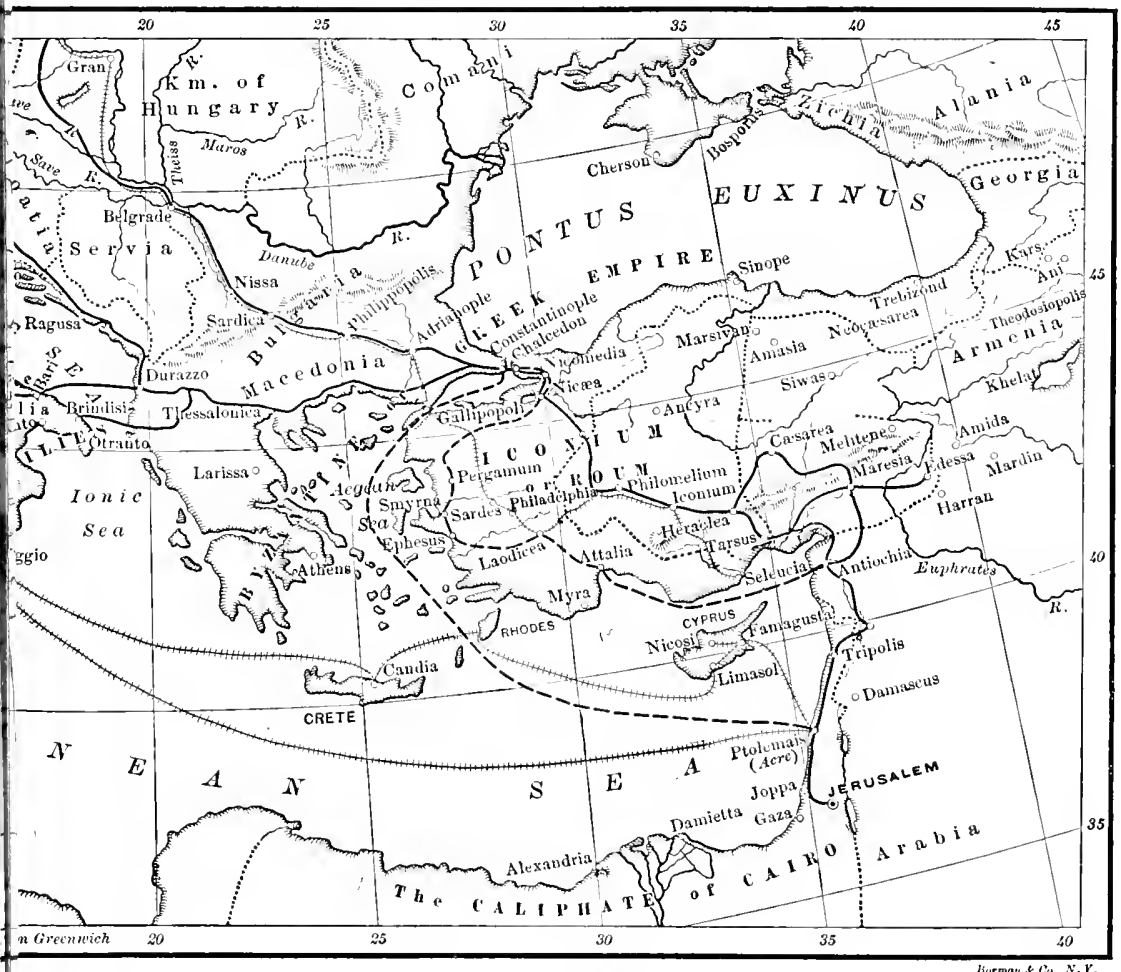

retired, however, after inflicting still further losses on the Christians, and the way was at last open to Jerusalem. That city had been recovered by the Saracens of Egypt, and from them the crusaders took it by storm in the middle of the summer of 1099, three years after their departure from Europe. 
The kingdom of Jerusalem. Archer, ferusalem, inap. VII.

The second crusade, II 47 . Archer, ferwsalem, Chap. XIV.; Cox, Crusades. Chap. V.

The third crusade, Saladin and Richard I., Cour-deI ion, I $189-$ I 192. Scott, The Talisman (novel).
The army of the crusaders was now reduced to less than one-tenth the number with which they were said to have left Europe, and nearly all of these returned home on the capture of Jerusalem. The garrison left in the Holy Land would hardly have been able to hold it but for the divisions and civil war which existed among their enemies, and the reinforcement constantly received from small bodies of knights who came every year to make individual crusades of their own. The conquests of the first crusade were organized at its close as the kingdom of Jerusalem, but as the only political system with which the crusaders were familiar was the feudal, the king, Godfrey of Bouillon, the ablest and least selfish of the leaders, had no real power. The great barons of the kinglom were as independent as those in France at the same time.

203. The Second and Third Crusades. - Europe was aroused to the second crusade, about fifty years after the first, by the capture of Edessa by the Turks. 'This was a fortress to the east of the Euphrates, and its loss seemed to expose the Holy Land to a dangerous attack from that side. The crusade was led by Conrad III., king of Germany, and Louis VII., king of France. 'They tried to reach Palestine by the overland route, but failed to force their way through Asia Minor, and made the last part of the journey by water. An attempt to take Damascus failed, and the crusade really accomplished nothing.

A little later the power of the great Sultan Saladin arose in Egypt, and in I 87 he captured the city of Jerusalem. This called forth the third crusade, the most brilliant and the best known of the series. The old Hohenstaufen Emperor Frederick I., Philip Augustus, of France, and Richaril the Lion-Hearted of England were its leaders. Frederick died on the way, Richard and Philip quarrelled, and the king of France returned home, and though the strong fortress of Acre was captured from the Saracens, little else was accomplished, and Jerusalem remained in the hands of Saladin. 
204. The Later Crusades. - The fourth crusade started almost immediately on the failure of the third. It was proclaimed by Innocent III., the most powerful of the popes, and was organized with the highest hopes. Its decision to go by water, however, and the bargain which it made with Venice for transportation, placed it at the mercy of that unscrupulous commercial republic. With much hesitation the crusaders consented to attack Constantinople, with some idea of obtaining a base of operations against Palestine, but really in the interest of Venice in her conflict for control of the commerce centring

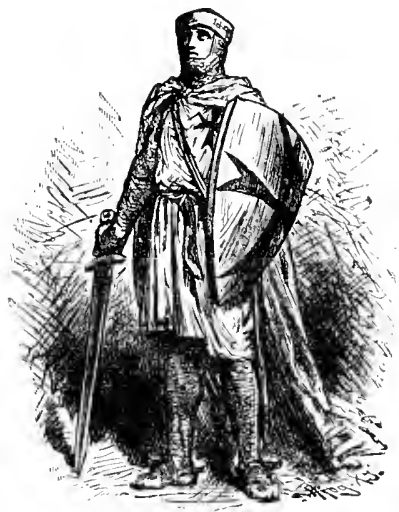

KNIGHT TEMPLAR

there. The attack was successful. The Greek emperor was driven out. The so-called Latin Empire was established with Balkwin of Flanders as emperor. The territory of the. Empire was divided into feudal states, and the Venetians obtained the supremacy which they desired. This Empire maintained a declining existence for about sixty years, when I26r. the Greek emperors in alliance with the Genoese, the commercial rivals of the Venetians, recovered their old position.

The later crusades are of little interest. The emperor Frederick II. recovered Jerusalem by a treaty, but it was retained only a short time. Louis IX. of France, just before the middle of the thirteenth century, made an attack on Egypt to conquer the Holy Land there, but was unsuccessful. His attack on the Turks in Tunis twenty years later is usually reckoned the last of the regular crusades. Individual efforts continued to be made for some time later, but European states and sovereigns could no longer be aroused to such great expeditions as once. Other interests had arisen

The decline and end of the crusades. Chronicles (Bohn), Penn. I., No. 4. 
to occupy their attention which seemed to them of more immediate importance, and indeed the spirit of the whole world had changed, largely through the influence of the crusades themselves.

\section{Topics}

Why is the age of the crusades a most important one in history? What motives especially influenced the crusaders? What had the advance of the Turks to do with the first crusade? What divisions composed the first crusade? What did it accomplish? The character of the kingdom of Jerusalem. What was the occasion of the second crusade? Ifow dicl its route differ from that of the first? What diu it accomplish? What event led to the third crusade? Who were its leaders? What did it gain? The peculiar character of the fourth crusade? How was Venice interested? Why was the government establisher by this crusade called the "Latin Empire"? How long did the age of the regular crusades continue?

\section{Topics for Assigned Studies}

The crusade of Richard I. Archer, Crusade of Richard I. (Contemporaries.) Chronicles (Buhn). Archer, Jerusalem (Nations), 305-34S. Cox, Crasates (Epochs), Chap. Vil. Tout, leriods. 295-304.

Arms and armor of crusalling age. Oman, Art of thar, Book Vi., Chap. VI. Archer, Jerusalem (Nations), Chap. XXIII. Fling, Studies, II., No. 5 .

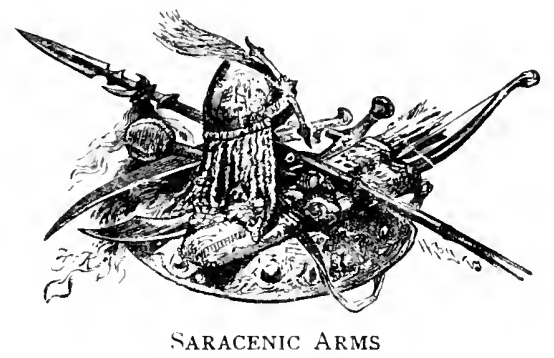




\section{CHAPTER VI}

\section{THE CHANGES IVHICH FOLLONED TIIE CRUSADES}

205. The Direct Results of the Crusades. - The crusades had a most profound effect on the people of Europe. The age was one of great stir and stimulus. Mind was aroused. The crusaders were brought into contact with better civilizations than their own, and were taught that they had many things yet to learn. Before the age of the crusades harl closed, and produced at least in part by them, there occurs the great intellectual epoch of the thirteenth century which created the scholastic system in philosophy and founcler the universities of Europe. This intellectual and scientific awakening of Europe we shall take up in detail at a later point.

An even more immediate effect of the crusades was the stimulus which they gave to commerce, and the changes which followed in this direction were as far reaching and profound as the intellectual. There had always been some commerce since the days of the Romans, specially in some parts of Europe as in the towns along the seacoasts, but in most regions of the West it had been very scanty and irregular. There are indications of increasing trade all through the eleventh century, but the crusades when they began acted immediately to increase commercial intercourse in various ways. They created a strong demand for transportation both of men and of supplies. They brought a number of new articles into use in the West for which there arose at once a good demand. An interesting example of these new articles is sugar. They also introduced the merchants of Europe to new peoples with whom to trade, and

Intellectual stimulus. Adams. Civllaation, $270-276$; Emerton, Europe, $3^{88}-397$.

The growth of commerce. Adams, Cirilization, 279-290; Emerton, E'urate', 52I-54O. Zimmern, Hansil (Nations), I I -20 . 
improved their knowledge of commercial routes and of the science of navigation.

Increase in number and power of the cittes.

Adams,

irillization,

290-300;

Fling,

studie's, II.,

Nos. 8 and 9.

The "third estate."

Adams,

Civilization,

30+ 310 .

The demand for security.

The demand for better law.
206. The Rise of the Third Estate. - Certain results of this increased commercial activity began to appear at once. One of these was the rapid growth of cities in all the countries of Europe, with large population and with great accumulations of wealth. This meant the rise of a new class beside the others who had up to this time controlled public affairs. This fact is called the rise of the third estate. In medieval language the first estate was the clergy, and the second was the baronage. Now for the first time there appears a third, that of the mercantile and manufacturing class, and from its numbers and its wealth it has power to make its demands listened to and to enforce them. The two older estates can no longer control the state alone. They must now share their power with the third estate.

207. The Third Estate on the Side of Strong Government. - One of the things which this new class began to demand at once was security - both for the protection of property and for safer and better means of communication. The growing government of the state found great assistance from this source in its efforts to suppress lawlessness, and to bring the private wars of the barons to an end. The indivilual noble also soon found it profitable to put the roads and fords of his fief in order and to build bridges, charging the merchants tolls for his services, or to furnish an armed escort to their caravans of wagons from one place to another. He did not realize that in doing these things he was ailing to destroy the economic conditions which sustained the feudal system and his own power.

Another demand of the third estate was for better systems of law and of law courts. It was of great importance to the merchant that law should be uniform and should be systematically enforced. To supplement the defective local laws for this purpose they brought into use in many parts of Europe the old Roman law, which had been highly developed on the side of commercial law. The study of the 
Roman law in the code of Justinian had begun in Italy just The Roman before the crusades, and from there it had spread to other law. parts of Europe, especially after the founding of the universities. As for law courts the purposes of the commercial classes were better served by national courts than by the local courts of the feudal baronies.

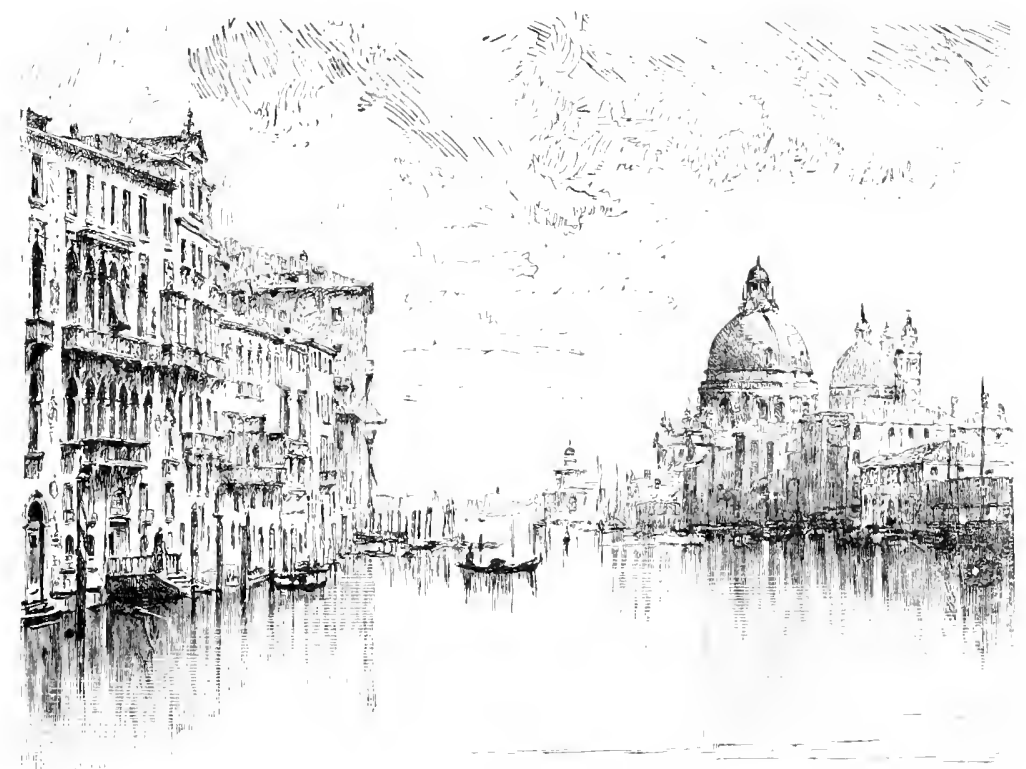

Grand CANAL, VenjCE

In these ways the growth of the towns and of their wealth assisted, directly or indirectly, in the great political transformation which took place in Europe from the beginning of the thirteenth century on - the substitution of more general and more uniform government for the narrow and local political arrangements of the feudal system. The Roman law, if taken by itself alone, was a strong influence in this direction, for it was the law of a centralized and powerful
The growth of stronger government. 
government, and it breathed throughout the spirit of such a system.

Destroys the economic foundation of the feudal system.

See very interesting statement, Dialog. de scac. I., VII., in Henderson, 55 , and Stubbs. 193; Ashley, English Economit Histery, I. +3-49.

Taxation begins to support the state.

Feudalism attacked on all sides.
208. The Effect of the Increased Use of Money.-Another most important result of the increase of commerce was the large amount of money which it necessarily brought into use. This fact was even more destructive of the feudal system than the rise of the third estate with its new demands, for it cut from under that system its whole economic foundation. The regime of barter was no longer necessary. The owner of land could now obtain an income from it in the form of money, and he could purchase with this the services which he needed to much greater advantage than when he rented his land directly for services. So the man who hal services to sell could now exchange them for money. The feudal relationship had become so strongly intrenched in society that naturally it passed out of use very slowly, but the specially important change now made is that it became no longer necessary. The purpose which it had once served better than anything else was now still better served in another way.

The increased use of money also affected the fendal system as lecisively on its political side. The State was no longer dependent on it for the formation of its army or for any other public service. The government could now derive an income in money from a regular system of taxation, and with the money thus obtained it could provide an army, more effective because more directly and completely under its control, and it could provide in the same way for all other public necessities. In England the king had begun to take money from his vassals in place of their military services before the third crusade, and from the beginning of the thirteenth century the governments of the different states gradually introduced regular taxation and made themselves independent of the feudal services.

209. The Fall of the Feudal System. - Of course the natural inclination of all sovereigns was to develop their governments along just these lines, for their own power was 
in this way very greatly enlarged and strengthened. Thus in all ways, by the natural ambition of the kings, by the demands of the commercial classes for security and uniform government, by the destruction of its economic foundation, and by the growing financial independence of the State, the feudal system was attacked and gradually destroyed both as a political and as an economic system. In two ways it remained and exerted an influence on later times. One was as a system of land law by which the ownership, inheritance, and sale of land were regulated. The other was in the systems of nobilities which took the place of the feudal baronage in all the European countries. The titles, legal distinctions, social privileges, and various caste regulations of these nobilities were based on feudal usages, though very much modified from the earlier days when they were something more real than the marks of mere nobilities.

2 ro. Changes affecting the Serf Class.-Upon the serf class these economic changes had as great an effect as upon any other. The growth of the towns offered the serf a place to which he could escape from the hard conditions of agricultural life. The rise of manufactures gave him the possibility of a livelihood by which he could support himself. Soon the landlord found himself forced by this competition to grant them better and better terms if he wished to retain his laborers. The introduction of money transformed, for the serf as well as for the vassal, payments of services into payments of money, and left him free to sell his services for the best terms he could make. This was the emancipation of the serf and his transformation into a free laborer. Like the other, it was a slow change, and was only completed in the Middle Ages in a few of the more advanced regions of the West. In some of the more backward, indeed, it was not made until in the nineteenth century.

2I I. Institutions of the Cities. - In the cities the mercantile and manufacturing classes were universally organized in corporations or guilds, somewhat like our trades unions. They differed radically from these, however, in one or two

The permanent influence of the feudal system.

Increased competition for labor.

In what emancipation eonsisted. Asbley, English Economic History, I. 19-33. The guilds. 
points. Employers and workmen were members together of the same guild, and the masters or employers passed regularly through the lower grades of apprentice and journeyman before reaching the higher grade. The purpose of the guild was not so much to look after the interests of

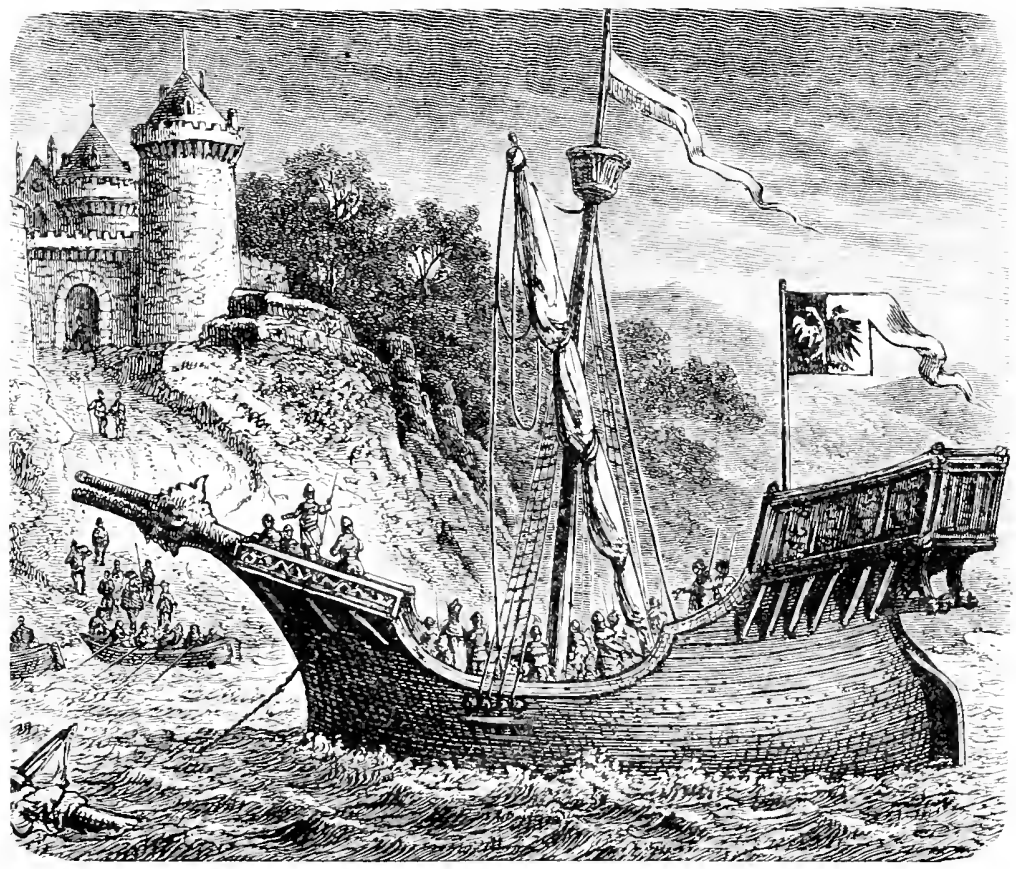

A HANSEATIC SHIP

laborers or of capitalists in their conflict with one another, - labor and capital were closely ilentified, almost in the same set of persons, - as to regulate methorls of manuficture, the quality of goods, and frices, and other conditions. of competition. In a very large number of the nedieval

The guilds governed the lowns. towns, these guilds were the governing bodies, electing the aldermen and uther officers of the city, and having the sole 
direction of its affairs, so that persons desiring the right of voting or taking part in the government sought the privilege of being enrolled in some one of these guilds, though they might have nothing to do with the trade which it represented.

In some countries, where the government did not prove The city strong enough to remite the State after the period of division into the feudal fragments, especially in Germany, the cities sought to protect their interests and accomplish the results which should have been brought about by the genleagues. Zimmern, The Hansa Towens eral govermment, by means of unions among themselves. The greatest of these was the Hanseatic League, which almost made a state and which was very powerful in the north of Europe for several generations.

\section{Topics}

What was the intellectual effect of the crusades? The commercial? What was the effect upon the cities? What is meant by the third estate? What is the class corresponcling to the third estate at the present time? Why was the thircl estate interested in the formation of strong governments? What change in the matter of law clid it assist in bringing about? Why toes more money come into circulation at this time? What effect has this on the feurlal holding of land? How loes it affect the relation of the State to feurlalism? The beginning of motern taxation. IHow was the position of the serf affected by these changes? In what did the emancipation of the serf consist? The purposes served by the guilds. The city leagues. The Hanseatic I.eague. Nake a list of all the way's in which the fendal system was affected in this age.

\section{Topics for Assigned Studies}

The medieval towns, chiefly English. Green, Town Life in Fifteenth Century. 2 vols. (Nacmillan.) Luchaire, Le's Communes Françaises. (Paris; 7.50 francs.) Cunningham, Growth of Engr lish Industry and Commerce (Cambrilge Press, Nacmillan), I. 197-214. Green, English People. I. 206-225. Zimmern. IIansa (Nations), S2-125; Penn. II., No. I; Stubls, S2, S7, 164, 307. The English guilds. Gross, Guild Merchant (Clarendon), I. jo6126, 167-191. Cunningham, Industry and Commerce, I. 309-318. Ashley, English Economic History (I'utnam), I. 68-96., II., Chap. II. 


\section{CHAPTER VII}

\section{THE FORIIATION OF TIE FRENCH NATION}

The State attacks the feudal system. Adams, Cirilialion, 3I I-3I3.
The first Capetians. Tout, Periods, $70-82$; Adams, French Nation (.Iacmillan), Chap. VI.; Zeller, 1V. Four great kings.

See table of French kings on p. 235.
212. General Conditions in France. - In the various ways which have just been described, the economic changes which followed the expansion of commerce undermined and weakened the feudal system. At the same time in the most fortunately situated countries feudalism was exposed to a vigorous attack from withont. The time had now come when national governments could be formed, and their existence necessarily meant the destruction of the local independence of the feulal baron. These new governments arose first of all in France and England, and these two countries are so closely connected during all this period of the Middle Ages that their history is almost that of a single state.

We have seen how weak the first Capetian kings were, and how little their authority was recognized in fact by the great feudal barons who divided the land of France among themselves. The first four generations of the Capetian dynasty seem to have been able to do no more than to secure possession of the crown for their family. The real work of making the French government and forming the French nation began with Louis VI.

In the first two hundred years, - the period which laid the foundations and made success certain, - there were four kings who did the most of the work, whose reigns accomplished far more than all the others in bringing about the final result. These were Louis VI., Philip II., Louis IX., and Philip IV. During the reigns of the other kings of the 
period, but little which had been won by the great kings was lost even if but little was done to advance the work.

2 I3. Two Great Difficulties. - To create modern France these early Capetian kings harl two very difficult things to accomplish. They had in the first place to bring the territory of France under their direct rule; that is, to recover it from the possession of the great barons. This was in many cases a work of real conquest and annexation, so independent were many of the feudal lords, and it was made still more difficult by the fact that one of these barons, the duke of Normandy, was also king of England. In the second place, they had by degrees to create new institutions of government, to form the constitution of the State, as their rule was gradually extended over more and more of France. One of the chief reasons why the government of France down to the French Revolution was an absolute monarchy is to be found in the fact that the work of making the constitution fell to the kings alone. The barons, who in England had so much to do in forming the constitution, were occupied in France in defending their own independence against the king, and were at last conquered and forced to complete submission.

2I 4. The Work of Louis VI. - Louis VI. was harlly able to do more than to mark out the road which later kings were to follow, but his vigorous opening of the way was at the time a great advance. His greatest actual success was in reducing the minor barons of his own feudal state, the duchy of France, to obedience, so that its resources were entirely at the command of later kings. He asserterl, however, the superior rights of the sovereign over the great fiefs as opportunity served, and began the policy so long followed of taking advantage of the frequent quarrels in the English royal family and of trying to get their French lands into the hands of some one who was not at the same time king of England.

Just at the end of his reign Louis secured a great opportunity for his son by marrying him to Eleanor, the heiress of

To recover and unite the terrilory of France.

To create a government for the nation.

Louis VI., I $108-$ I I 37 .

Kitchin, France, I. 249-260; Tout, Periods. 274-282: Adams, French Nation, 73-78; Zeller, IV.

Eleanor, heiress of Aquilaine. 
the duchy of Aquitaine, the largest of the feudal baronies of France. But Louis VII. and his wife did not get on well together. He lacked the energy of his father, and Eleanor, who was masculine in character and lively in disposition, had but little respect for him and took no pains to conceal the fact. Finally Louis divorced her, and she immediately married Henry of Anjou, who shortly became King Henry II. of England.

The 2I5. France threatened by the Angevin Empire.-This dominions of marriage made the dominions of Henry almost an empire; England. Green, Henry $I I$. (Macmillan), Chap. II.

Philip II., I $180-1223$.

Tout,

Periods, 29I294, 393-405; Adams, French Niation, $8 \mathrm{I}-88$; Zeller, IV. for besides the whole southwestern quarter of France which his wife brought him, he held also the northwestern quarter, partly from his father, the count of Anjou, and partly from his mother, who was the granddaughter of William the Conqueror. This was about two-thirds of France as it then existed, and it was more than six times the territory which Louis VII. had under his direct rule. It seemed almost as if all France would be united in the end under the king of England and the two nations become one. This would not at that time have been so difficult as later, because the French language was quite generally spoken in England by the higher classes, many of whom looked upon themselves as more French than English.

2r6. The First Great Advance. - Against this danger the next king of France, Philip II., contended most vigorously. He took the part of Henry's sons in their wars upon their father, and when Richard became king, of John against him, and then of Arthur of Brittany against John, always against the reigning king of England whoever he might be. He gained but little success, except to prevent the growth of the English power, until John became king. Then his opportunity came. John was not lacking in ability or courage, but he was careless, and selfishly bent on his own pleasures, and his energy only flashes up at intervals into a strong defence against the French king's attack. His cause was a bad one, for he had committed some serious offences against the feudal law. He had married the betrothed bride 



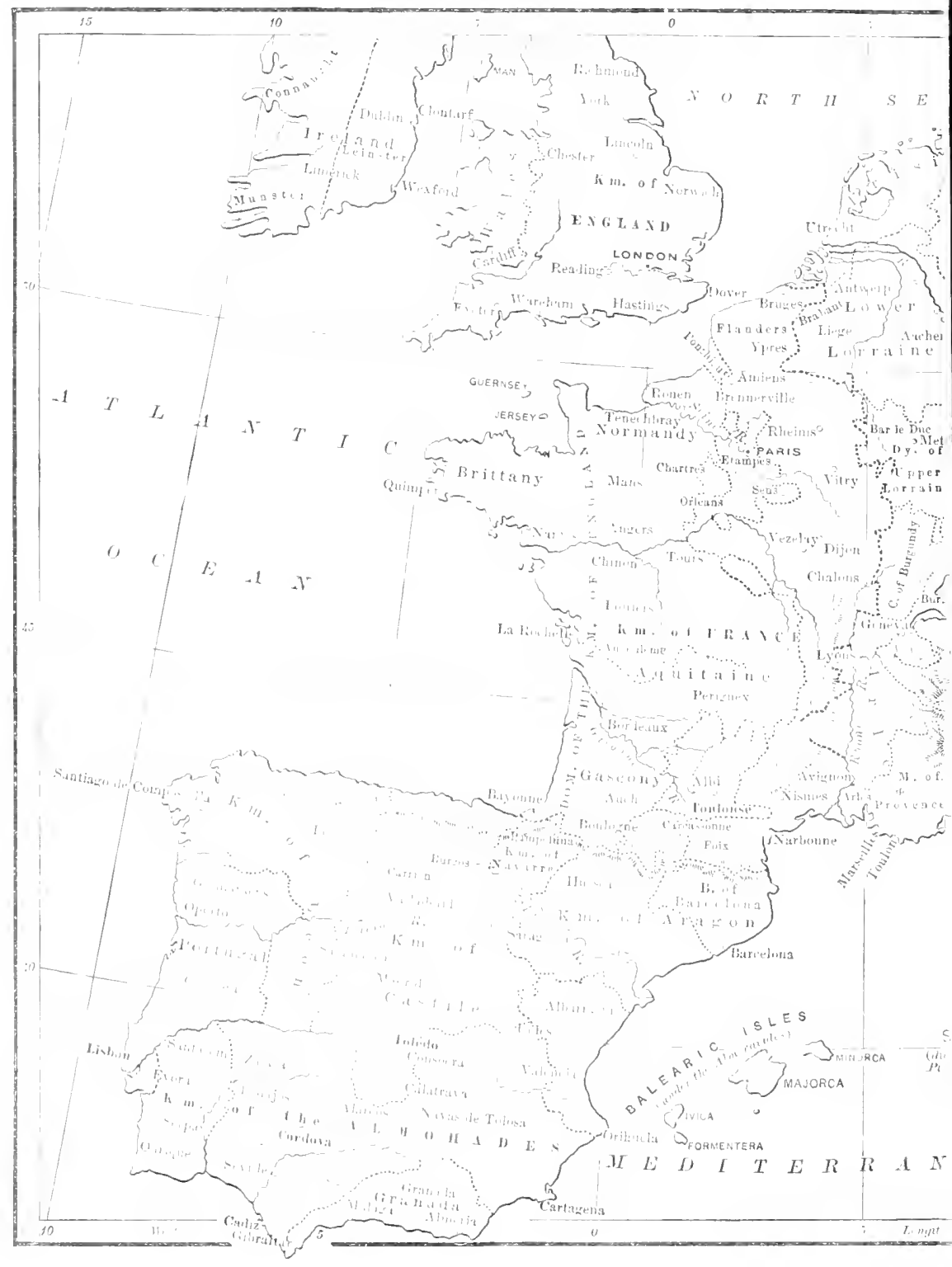




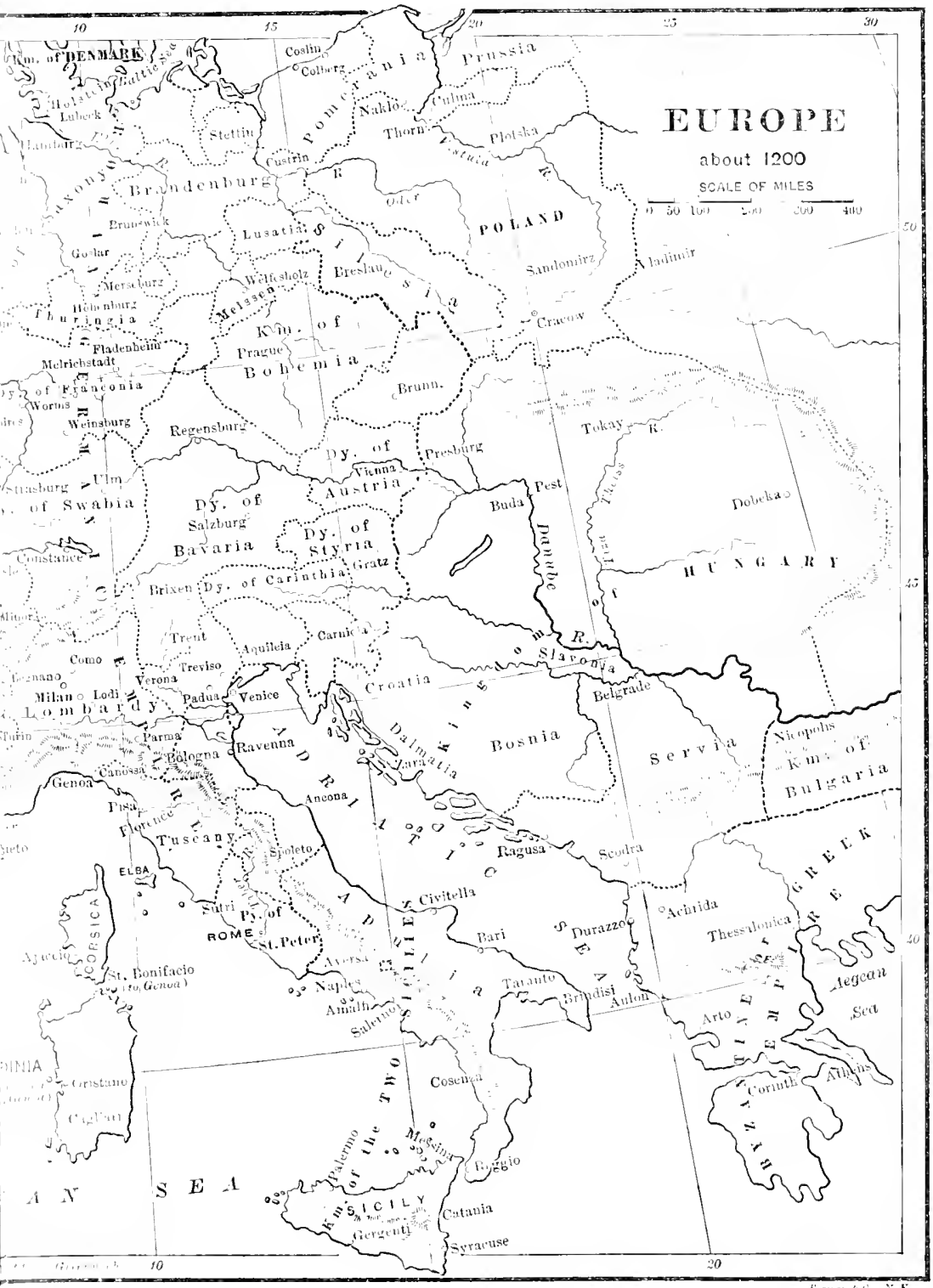



of one of his own vassals, and had refused to appear at the Hutton, court of his suzerain, Philip, to answer to the charges made against him on this account. So the court had decreed the confiscation of his French fiefs, and Philip was executing this sentence. 'There was a suspicion also that John had murdered Arthur, whom he had taken prisoner, and this chid

I'hilip

Aturustus

(Macmillan), $63-87$.

France rains Normandy and Anjou.

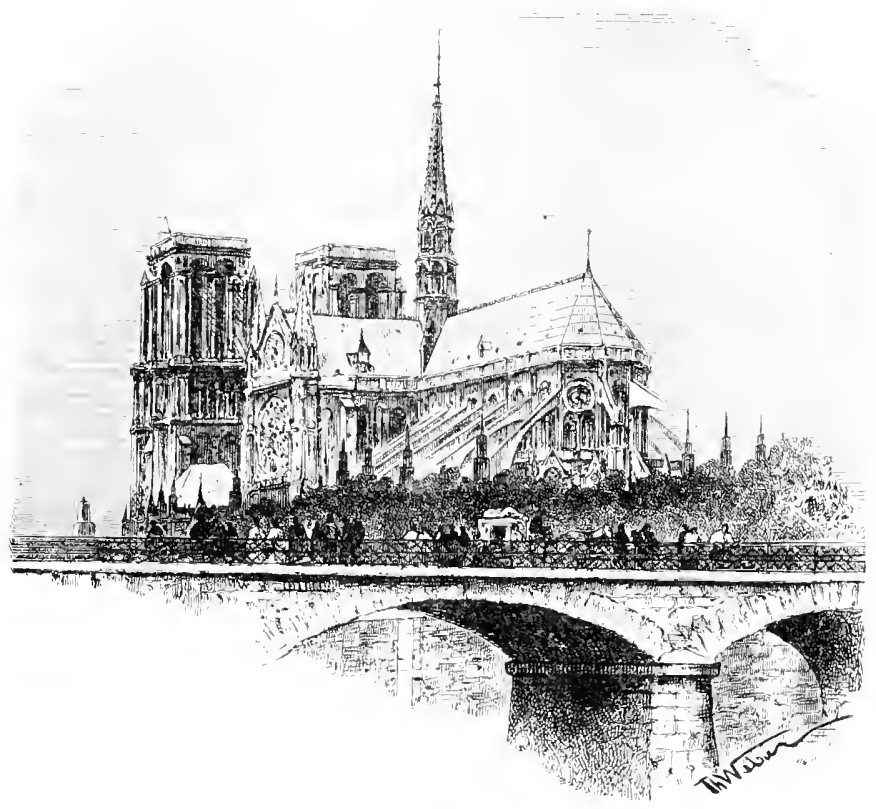

Notre Dame, Paris

not help his cause, though it never has been proved that Arthur was murderer. Philip was entirely successful, and the English king lost all his lands north of the Loire. This was the first great success of the Capetian kings and one of the greatest in their history. It multiplied the territory in their hands by three or four and almost made the kingdom of France a reality. 
The

Albigensian crusade, a step in the expansion of France. Hutton, Philip Augustus, 180-196; Emerton, Europe, 333-3+2; Waldenses, Hale, In His Vame (novel).

The beginning of government institutions. Hutton, Phalip Ausustus, I23-138; Emerton, Europe, $423 \mathrm{ff}$; Adams, Civalization, $32 \mathrm{Iff}$.

Louls IX., 1226-1270. Tout, Periods, 405-427; Adams, French Vation, 89-95; Zeller, V.
The way was prepared in the reign of Philip II. for another great annexation in southeastern France by the Albigensian crusade, though these lands were not actually added to the king's domain till some time later. The Albigenses were a sect accused of heresy, and they certainly held some peculiar religious notions. Theirs was the first great rebellion against the medieval Church, and it was very severely repressed. The pope proclaimed a crusade against them; that is, he offered the same spiritual rewards to all who would go to make war upon them that would be gained by going to the Holy Land. The crusade was led by a French baron, Simon de Montfort, the father of Earl Simon, so famous in English history, and many took part in it, while the king watched it from a distance, conscious no doubt that France would reap the greatest advantage in the end from the ruin of the local barons, as was indeed the case.

The territory of France had expanded so greatly under Philip that the simple machinery of earlier times no longer sufficed to do the business of the State, and a beginning of institutional growth was made. The lands under the rule of the king were divided into districts, and to each of these an officer was appointed whose duty it was to represent the king, to look after his interests, and to see that his law was obeyed by all. This was the beginning of an administrative system which has continued with some slight changes of form and name under all the governments which France has had down to the present time.

217. The King begins to make himself Obeyed. - The reign of Philip's son, Lonis VIII., was a short one, and Louis IX. began his reign with a long minority. An attempt of the French barons with the help of the English king, Henry III., to undo the work of the last hundred years was a failure, and Louis found, when he reached his majority, the royal power undiminished. He is known in history as St. Louis, and as he supremely loved justice and peace, his canonization was deserved. The universal confidence of the people in his character was of great assistance in the 
chief work of his reign - the suppression of private war and the establishment of national law courts. These two rights were chief among those which marked the independence of the feudai baron - the right of making war at his will and that of holding a court from which there was no appeal to any higher court. Both these rights Lotis attacked and greatly limited without completely destroying them. Louis also continued the work of his grandfather by developing the administrative machinery, and he prepared the way for that of his grandson by beginning the organization of the national finances.

218. The King becomes the Strongest Power in France. - The grandion of Louis who continued his work, was Philip IV., the Fair. In the making of French institutions his reign was the greatest of all. By its close the monarchy was the strongest power in France, and the political independence of the feudal baron was practically broken. All parts of the government machine shared in this advance, while the chief work of the reign was to complete the organization of the courts, to introduce a modern system of taxation and national financial machinery, making the State independent of the feudal system for its income, and to begin a national legislature by the addition of representatives of the third estate, the cities and towns, to the other two estates, creating thus the Estates General. This institution contained of course a danger for the monareby in the possibility that it might, as in England, bring the kings under a responsibility to itself for their acts. But there never came a time when the Estates Cieneral were able to do this. The kings called it together only when they had need of it for their own purposes, and managed to keep it almost always under strict control.

Philip IV. had thonght at one time soon after the beginning of his reign that the time hal come to complete the conquest of the English lands in France, and he had brought on a war with King Eclward I., but he soon found his hands so occupied with a strife with Pope Boniface VIII.

Philip IV., I 285-I3I.4. Rapid progress in inslitutionmaking. Kitchin, Fintie?. I. $35+\mathrm{tf}$; Adams, Finch Aition, 05-103: Zeller, V.

An attempt to conquer soulhwestern France. 
Ionitace

vils.

loole.

Ilicliffe

(Epochs,

(h. Hist.),

Chap. 1.;

his bulls,

Henderson,

432 tt.; Gee

and Hardy,

87.

'The succession strictly limited to the male line.

Alams,

Finth

Nation,

103-I07 :

Kitchin,

Firthic,

1. $3^{8}+$.

Philip I'I., I $328-1350$.

The Hundred Years' War begun. Warburton, Edard III. (Epochs),

$37-+1$;

Kitchin,

Fince,

I. 39I-399;

Frolssart, cinronicles (.Macmillan); Zeller, VI.

lhe first period of the war. The English victorious. Froissart, Chronicles, Bk. I. over the question whether the lands of the Church should be subject to his new system of national taxation, and also with the people of Flanders, who were the allies of the English from commercial reasons, that he was obliged to give up these plans. They could not be taken up again until the reign of Philip VI., the first king of the Valois family.

2I9. The Salic Law. - Three sons of Philip IV. had succeeded him in rapid succession, and each of these had left at his death no son. Under these circumstances that law of succession to the French throne was adopted which was afterward called the Salic law, according to which the crown couk not descend to a woman nor be inherited through a woman. On the death of Charles IV., the last son of Philip, Edward HI. of England, who was Philip's grandson, laid claim to the throne, but the French nation applied the Salic law strictly, as it was natural that they should against the king of England, and gave the crown to Philip of Valois, the cousin of Charles IV.

\section{The First Period of the Great Struggle with Eng-} land. - There were grounds in plenty on which to renew the conflict with England, and soon after his accession Philip opened the long war which is known as the Hundred Years' War. 'I'hough France suffered terribly during this period, Philip can hardly be blamed for bringing on the war, for it was a necessary one both for the monarchy and for the nation. So long as the English held great portions of the national territory there could be no permanent peace, and France could not be complete. Soon after the war opened Edward assumed the title of king of France, though he evidently did so as a war measure and with no expectation of making himself actual king.

'The Hundred Years' War, during its first period, is one of the most brilliant and interesting wars of history, the last war of the age of feudalism and chivalry, now rapidly coming to an end. It was, however, entirely indecisive of the real question at issue. 'The English gained the overwhelm- 
ing victories of Crécy and Poitiers against great odds by the use of the terrible long-bow, and they captured the seaport of Calais, and made it a strong fortress to protect their commerce passing through the Channel from the French privateers. France, exhausted by the English invasions, by the Black Death, and by her own revolted peasants, with her king, John, a prisoner in London, captured in the battle of Poitiers, did, indeed, agree in the treaty of Brétigny to grant Guienne in full sovereignty to Edward in return for his surrender of the title of king of France; but the treaty was never carried out, and Charles V., the successor of John, after careful preparation, renewed the war.

Success now turned to the French side. Their cause was very skilfully managed, allowing no advantage to the English, but taking carefully every advantage which they offered. Edward III. seems to have lost his mind in his old age, and the Black Prince was suffering from the disease of which he soon died, so that there was no good leadership on the English side to match that on the French. Slowly they were driven back to a small territory near the sea, but the great city of Bordeaux with the lands around it the French could not yet recover. In government Charles $\mathrm{V}$. was as skilful as in war. He held the Estates General in check, and laid the foundations of royal independence in taxation and in a standing army, thus advancing greatly the French absolute monarchy.

221. The King of England becomes King of France. The reign of Charles $V$. is a little period of prosperity in France between two long periods of disaster and suffering. His son, Charles VI., was insane during the most of his reign, and the nation was divided into factions contending for power and finally fighting with one another in open civil war. England, during the same time, was hardly in better condition, and the war between the two countries was practically suspended. At last Henry V. came to the throne in England, young and full of ambition, and he was tempted by the helpless state of France to renew the war and to

John, I350-1364. Zeller, VI.

Charles V., the "Nise," $1364-1380$. The Irench victorious.

Kitchin, Irance. 1. $454-473$; Adiams, Frelle Sation, II9-125; Zeller, VII.

An insane king.

Charles VI., $13^{80}-1+22$. Kitchin, Fiance, I. $485-499$; Zeller, VIlI.; Monstrelet, crronicles. Bk. I. see especially Chaps. $36,146,210$. 
hope that he might really make himself king of that country.

Henry V. of Everything went at first in his favor. He won the great England almost completes the conquest of France. Church, Henry $I$ : (Macmillan); Kitchin, France, I. 500-512.

The tide lumed against the Englinh. Lowell,

Foran of the (Houghton); Green, $E n_{i} r_{-}$ lishlielele

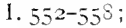

Kitchin, Frinter, I. 522-539. Nonstrelet, Chronicles, Bk. II., first successes, Chaps. 57-64; capture, 86; trial, 105 . victory of Agincourt, which was almost a repetition of those of Crécy and Poitiers; he occupied the whole northern and southwestern parts of France, including Paris. The duke of Burgundy. one of the most powerful princes of the time, went orer to his side, partly because his father had been murdered by the leaders of the opposite faction, the Orleanist, and partly because the commercial connection between England and Flanders, which was now under his rule, was still so strong; and finally the court party, the queen acting in the name of the insane king, recognized his right to the throne in succession to Charles VI. Henry dieal before Charles, but his son, Henry VI., was crowned king of France in Paris. The English soon after laid siege to Orleans, and, if it should fall. apparently all France would be theirs, and Charles VII., the rightful king, would be forcerl to seek refuge abroarl.

222. Joan of Arc. - At this moment appeared Joan of Arc, a simple country girl, who was fully persuaded that she was called by divine voices, which had spoken to her in visions, to thive out the enemies of France. Her mwavering belief in herself and her inspired mission restored to the French soldiers and nation the confidence they had lost. The tite began to turn against the English. The siege of Orleans was raiserl. The way was opened for the crowning of Charles VII. in the city of Rheims, where the French kings had always been crowned. With this event the real work of Joan - the arousing of a national enthusiasm and the restoration of confilence to the French - was finished; but very soon after, when she fell into the hands of the English, they foolishly did all that they conkl to make her leadership permanent by making her a martyr. for they burned her at the stake.

223. The Final Triumph of France. - Nothing which the English could do after this checked the advance of the 
French. Charles VII. followerl the methods of his grandfather, Charles V., in conducting the war, and refused to allow the English any advantage in the field. The sympathies of the French people behind the English lines were always with the cause of their own nation, and they gave it every assistance possible. Finally the duke of Burgundy abandoned the English side and took up the cause of France. The leaders of the English did as well as they could with a hopeless cause, but step by step they were driven back, till soon after the middle of the century all that they had ever held in France was lost, except the very strong fortress of Calais, which for another century continued to defend the commerce of England passing through the Channel.

Thus ended the long struggle which for $35^{\circ}$ years the French kings had renewed in almost every generation to expel the kings of England from the territories of France, and thus was almost completed also the geographical formation of France, as it existed at the beginning of modern history. Three considerable provinces yet remained to be annexed, Burgundy, Provence, and Brittany, but these were all joined to France before the fifteenth century closed.

In the conduct of the government as in that of the war, Charles VII. followed the policy of Charles $V$. His reign completed the absolute monarchy, freed the king from all outside control, and reduced almost to a form the national legislature, the Estates General, which scarcely ever meet again in French history except in times of civil strife and disorder.

224. Louis XI. and Charles the Bold. - Louis XI. continued the policy of his father with even greater skill and by the methods of a cunning and unprincipled diplomacy. A combination of the princes and great nobles, formed to overthrow if possible the absolute power of the king, he broke up and defeated. The plans also of the dukes of Burgundy to create a strong middle kingdom between France and Germany ended in failure in his reign. The duke Charles

Charles VII., I.422-I 461 . Masson, Medicial France (Nations), Chap. XIII.: Zeller, IX.

The geographical completion of France. Kitchin, France, II. 8-I5.

The absolute monarchy also completed. Adams, Fench Vation, I33-I35.

Louis XI., I. 46 I-I 483 . Masson, Medicéal France, Chap. XIV.

Kitchin, France, II. 53-86, with map; 
Commines, the Bold was defeated by the brave mountaineers of SwitzerMimoirs

(Bohn) ; Zeller, IX.; scott, Anne of Geierstein and Quentin Iluritderd (novels): see p. 30 r.

Austria obtains the Netherlands. land and then slain in battle in an attempt to conquer Lorraine. At once Louis seized upon the duchy of Burgundy as a vacant fief of the crown, and he was strong enough to retain it, though Mary of Burgundy kept possession of Flanders and the other territories of her father and carried them to the house of Austria by her marriage with Maximilian I. With the next reign, that of Charles VIII., France passes into the current of a new age, the age of transition to modern history.

\section{Topics}

What was the situation of the first Capetian kings in France? What was the task before them and what were its especial difficulties? Ilow much was accomplished by Louis VI. ? Of what territories was Eleanor heiress? What led to her marriage with Ilenry II.? The effect of this marriage on the position of the Capetians in France. The policy of Philip II. against the English. What gave him his opportunity and what did he gain from it? What dill France gain from the Albigensian crusade? Why was this a crusade? The institutional beginning under Ihilip 11. Why was Louis IX. rightly canonized? IIow did he strengthen the royal power? What new institutions under Philip IV. ? Why could he not push the conquest of the English lands? The "Salic law." What reasons hal Philip VI. for beginning the IIundred Years' War? The character of the first period of the war. The treaty of Bretigny. The policy and successes of Charles $V$. The condition of France under Charles VI. Why was IIenry V. able so nearly to conquer France? The situation when Joan of Arc appeared. What did she do for the French? The result of the war. Ilow nearly was France now completed geographically? How nearly was France an absulute monarchy? The plans of Charles the Bold. What became of his lands?

\section{Topics for Assigned Studies}

The long-bow. Oman, Art of War, Books VIl., VIII. Archery (Badminton Library; Longmans), 105-120. Social England, II. 172-174. Doyle, The White Comfany' (novel).

The battles of Crécy and Poitiers. Oman, Alt of II'ar, 600-615, 62563t. Warburton, Edzidall III., 101-112, 15t-162. (ireen, Eng. lish Peotle, I. +16 ff. In Froissart's Chronicles, Book I. 


\section{The Capetian Kings of France}

II ugh Capet, 987 .

Robert, 996.

I Ienry I., 103I.

I'hilip I., I060.

1

Louis VI., I IOS.

Louis VII., II 37 .

Philip II., I ISo.

!

Louis VIII., I 223.

I

Louis IX., I 226.

Philip III., I 270.

Philip IV., 1285.

Charles of Vahois.

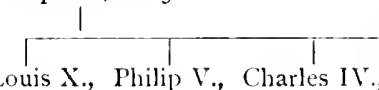

Isabella.

1314 .

I 316 .

I 322 .

Edward III. of England.

Philip VI., I328.

John, I 35 .

Charles V., $\mathrm{I}_{3} 64$.

I

Charles VI., I380.

harles VII., 1422.

Louis XI., I 461 .

Charles VIII., $\mathrm{I}_{4} 8_{3}$. 


\section{CHAPTER VIII}

\section{ENGLAND}

\section{Books for Reference and Further Reading}

Stubbs, Constitutional IIistory of England. 3 vols. (Clarendon; $\$ 2.60$ eaeh.) Also full on the political history.

Round, Fcudal Enslind. (Lond., Sonnensehein ; r2s. 6d.) - Geoffrey de Mrandeaille. (Longmans; \$5.00.) Critical studies on the Norman period.

Norgate, England under the Ansetin Kings. 2 vols. (Macmillan; $\$ 5.00$.)

Wylie, History of England under Henry IIT 4 vols. (Longmans; $\$ 20.50$.) Very detailed study of the first Lancastrian.

Ramsay, Lancaster and lork. 2 vols. (Clarenton; \$9.0o.) The fifteenth century. Very fully and carefully studied, especially military affairs.

The Paston Letters. Edition of Gardiner. 3 vols. (Macmillan; \$6.0o.) Edition of Fenn. (Bohn.) Very interesting pictures of life at about the midllle of the fifteenth century.

Gardiner, Atlas of English Ifistory. (Longmans; \$1.50.) A very helpful little atlas.

On all points of English history constant reference should be marle to the articles in the Dictionary of National Biegraphy (Nacmillan, $\$ 3.75$ per volume), many of which contain the best accounts we now have of their portions of the history.

A contrast to Frencli Histrory. diams, Tiriliation, I $33,339 \mathrm{ff}$.
225. General Character of English History. - English history follows a very different course from that of France. The government which had been established by the Norman conquest was a strong and powerful monarchy. All the land of England was subject to it, and the feudal barons had no independent political rights. Geographically while the $\mathrm{Ca}-$ petian kings were creating France, the kings of England were losing their French territories, and were extending their 236 
rule over Wales and into Ireland, and were trying to do the same in Scotland. In the growth of the English constitution, also, the process was in contrast to that in France, for instead of growing more absolute the English kings were growing less so, and the new government machinery which was coming into use was placing all the time more and more limitations on the exercise of their will. This constitutional side of English history is, however, so important for us because it is the constitution we have inherited, that we shall study it by itself.

226. Period of the Norman Kings. - Milliam the Conqueror had been followed as king of England by two of his sons in succession, William II. and Henry I., and both had ruled as very strong kings. Henry $I$. left no son, and he had pledged the English barons to accept his daughter Matilda as their sorereign, but on his death her consin Stephen, who was a brilliant and popular young man, persuaded them to place him on the throne insteat. He proved to be a very weak king, and during his reign there were great disorders in England, partly because the king could not control the turbulent barons, and partly because Matilda and her party were continually trying to get the throne away from him. Matilda had married (seoffrey, count of Anjon, and finally their son Henry, who had invaded England, entered into a treaty by which Stephen was to remain king as long as he should live and on his death Henry was to succeed him.

227. Henry II. Abroad and at Home. - Within a few months Stephen died, and Henry of Anjou became Henry II. of England. He ruled wide lands on the continent, as has been described in connection with French history, but his real power was much less than it seemed, for the French barons were turbulent and hard to control, and in the last part of his reign his wife and his sons were continually at war with him, so that none of his plans for the extension of his power in France was successful. In Fngland his chief work was to institute a system of king's or national courts with judges going about from county to county both to try cases

The forming of a free government.

The disorders of Stephen's reign, I $35^{-I}$ I 54 . See the chronicles in Bohn : William of Malmesbury, 509-5II; Henry of Huntingdon, 26I-297. Roger de Hoveden, I. 226-254; Situbus, Plantigenets (Epochs), Chap. II.

Henry II., I $5 t^{-I}$ I 89. Documents on the judieial reforms, in Subbs, I $35 \mathrm{ff}$., $25^{8}$; Penn. I., No. 6; Henderson, I I- 20 . 


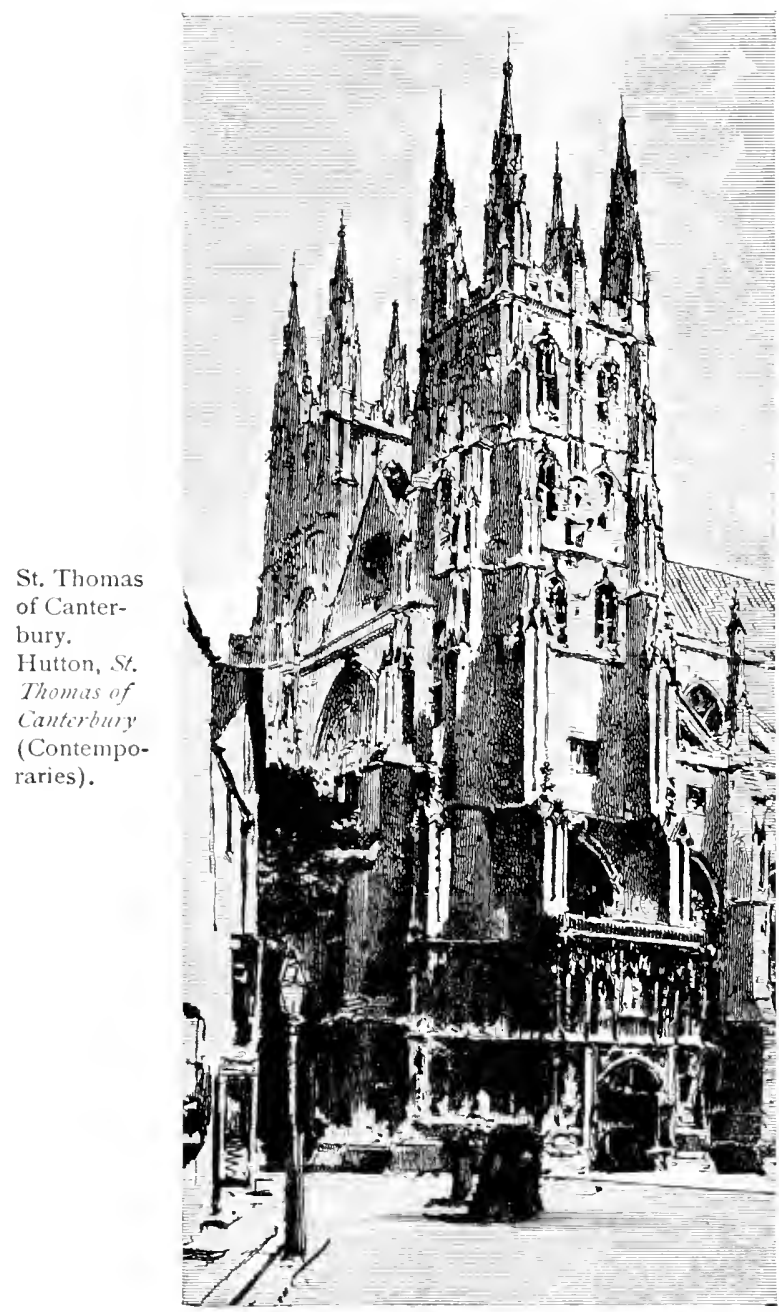

Canterbury Catheiral

and to hold the sheriffs to their duties as the administrative and financial officers of the State. This led him to try to limit the independence of the Church courts and brought on a quarrel with his former friend Thomas Becket, archbishop of Canterbury. Angry words which he spoke in a moment of passion led to the murder of the archbishop, and Henry was forced by popular feeling to yield something of his demands, but the organization which he gave to the law courts of the State is still to be seen in our judicial system, and several of the judicial institutions whose growth he encouraged, like the jury, we have still in use. 
228. England and Ireland. - The English claim to rule Ireland dates from the reign of Henry II. The island was at this time in a very backward condition both in civilization and in religion, and the popes were anxious to bring the Irish Church into better order if possible. Almost at the beginning of Henry's reign Pope Adrian IV. is said to have issued a bull giving Henry the right to enter Ireland and take possession of it, based on the claim of the popes to all islands. It was many years before Henry found opportunity to go himself to the island, but Norman barons had begun to go over earlier and to enter into alliances with the native chiefs, and in this way to form little principalities for themselves. It was probably this fact more than any other which finally determined Henry to cross into Ireland. He received the submission of the Normans and of some of the native chiefs, and began the reform of the Church, but his stay was very short, and all that he did amounted to no more than to establish a claim which future conquest might make a reality.

229. Henry's Two Sons. - Two of Henry's sons, Richard and John, reigned after him and were both very bad kings. Richard had little interest in England as compared with the crusade or with the more exciting feudal life of his French possessions. England was of use to him mainly as a place from which to draw money, and he did not hesitate to sell for cash almost any valuable right, among others the claim of the English kings to the overlordship of Scotland which had come down from Anglo-Saxon times.

John's government led to more open opposition because he was himself more openly tyrannical. The increasing expenses of the State forced him to try to provide a secure national income, that is, to begin a system of regular taxation, and this could not be done without a violation of some of the fundamental principles of the feudal law. The angry barons found an ally in the most powerful of the popes, Innocent III., who made an issue with the king over the right of appointment to the archbishopric of Canterbury. Finally, to avoid the consequences of yielding in England,

The beginning of the occupation of Ireland. Green, Henry II., Chap. VIII.; Green, English Feople, I. I75-I78.

Adrian's bull, Henderson, p. 10 ; Barnard, Strongbear's Conquest of Ireland (Contemporaries).

Richard I., I1 89-I 199. Stubbs, Plantagenets, Chap. VI.; chronicles in Bohn; Scott, Iranhoe (novel).

John, I I99-I 216. Stubbs. Plantagenets, Chap. VII.; chronicles in Bohn; Shakspere, hing Fohn (drama).

Joln's grant to the pope. 
Gee and Hardy, 75; Henderson, 430; Stubbs, 284.

Forced to sign the Magna Charta. Roger of Wendover (Bohn), II. 303-324.

Edward 1., I 272-I 307 . Legislation, Tout, Edaidall. (Macmillan), Chap. VII.; Secial England, 11 . 32-38; Stubls, 457 , 469, 478 ; Henderson, I $48 \mathrm{ff}$.

The conquest of Wrales.

'Tout, Edriard I., Chap. VI.

The conquest of sicotland. Tout, Edtirdar. Chaps. X. and XII.; Stubbs, Plintagenets, Chap. XI. : Green, Enslish People, I.
John gave up to the pope and became his vassal for the lingdom of England, one of the most signal trimphs of the papacy in the field of its political chams. But the advantage which John gained from this step was only temporary. The great plan which he formed to recover the lands which he had lost in France and to overcome all his enemies in alliance with Flanders and with his nephew, the Guelf emperor Otto IV., was defeated lyy the great victory of P'hilip II. in the battle of Bourines, and John was soon forced by the barons of England to sign the Magna Charta, the beginning of the conscious growth of the English limited monarchy.

\section{The Greatest of the Angevin Kings. - Henry III.} was a weak king, greatly moler the influence of favorites, and his long reign was full of civil strife. of importance chiefly in the constitutional history of England. His son, Edward I., in marked contrast to Henry, was one of the greatest of English kings. He was as much a lawser's king as his contemporary Philip IV. of France, and has been called the English Justinian, but in the political history of England he ranks as conquering king. In the first part of his reign the conquest of Wales, which had long been lingering, was at last completer and the country lorought fimally under English rule and law. Is an honor to his new subjects, Edward's son Edward was male the first Prince of Wales.

The conquest of Scotland, which Elward later undertook, was not so easy a matter. A disputen succession there gave him an opportunity to interfere and to reassert the overlordship of the English kings, and when he attempted to make his supremacy a real one, even Balliol, whom he had made king, turned against him. Edward's armies were victorious in the fiell, but the conquest of the people was another matter. Wallace, whom Scothand afterward idealized and turned into a national hero, made a brave defence, but one marked by all the horrors of savage warfare, and Bruce, the national candidate for the throne, though for a 


\section{\$230] The Greatest of the Angeain Kings 24I}

long time on the side of Edward, at last took the lead $3+\mathrm{Iff}$., against the invader. At one time it seemed as if Edward $305 \mathrm{ff}$; Max had incorporated scotland, as well as Wales, into England, the but just before his death a new insurrection of Bruce's (Heroes). called him into the field.

Matthew of

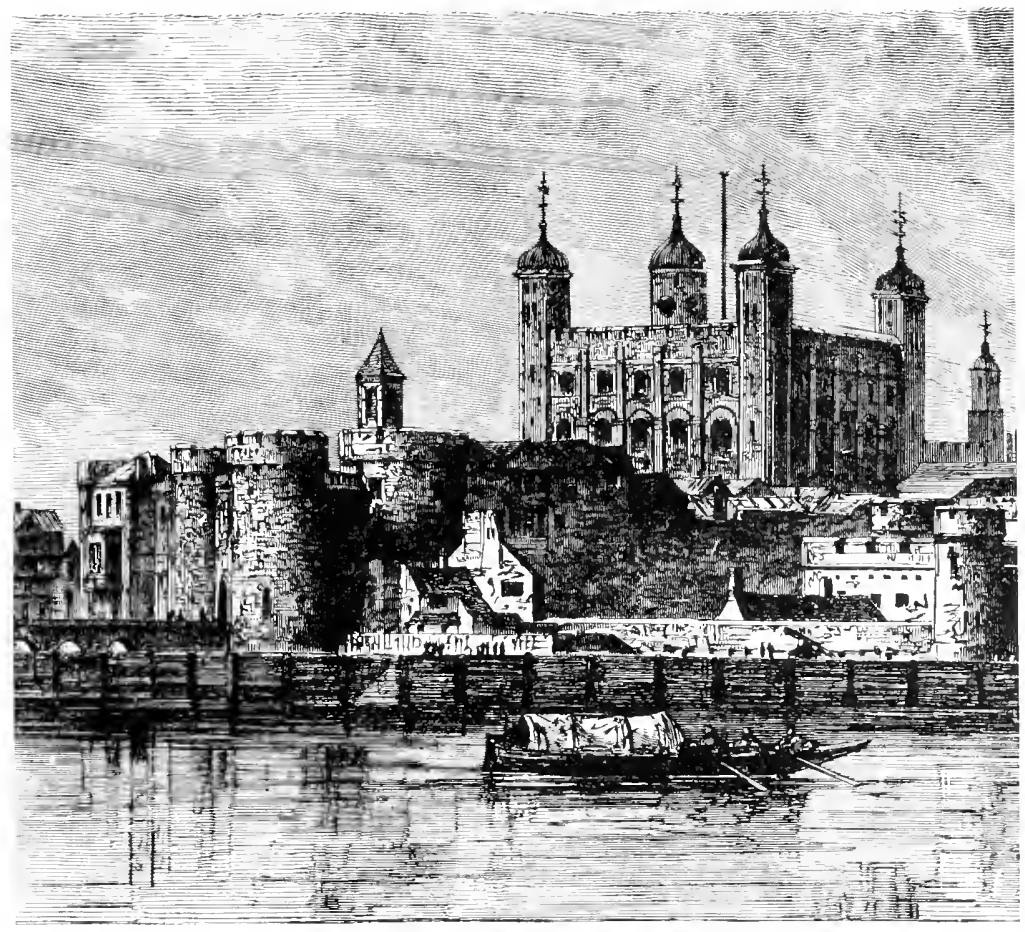

THE TOWER OF LONDON

The king of the next generation, Edward II., displayed Westminster all the weak and bad traits of the Angevin family. He lost (Boln), II. all that his father had gained, wasted the revenues of the State, and allowed his favorites to govern as they would in $583-596$. Elward II., his place and to enrich themselves. In the end his wife sarlowe, 
Ediard II. joined the opposition to him and he was forced to yield the (drama).

Edward IIl., 1327-1377.

A brilliant age.

Varburton, Edzidard III. (Epochs): Ward, Life of Chancer (Harper) ; Social England, II. 202-231; Chaucer's Prologue (Clarendon); Ashley,

Edward III. and his

Ifars (Contemporaries).

A rapid decline.

Skeat, Piirs the Ploneman rClaren(don); Smith, Troublous Dayss of Richard II. (Contemporaries).

Henry V., $\mathrm{I}_{4} \mathrm{I}_{3}-\mathrm{I}_{4} 22$. Church, Henry $\mathrm{I}$. (Macmillan); Gairdner, Lancaster and York throne to his son, Edward III.

23I. The Hundred Years' War. - Nearly all the reign of Edward III. was filled with the great Hundred Years' War with France, of which we have had the story elsewhere. It was for a time the most brilliant age that England had seen. The surprising victories which were won in France and Scotland and other successes wakened a new national pride and enthusiasm; many were enriched by the plunder brought home from abroad; there was also much commercial activity; and life was easy and bright. This reflects itself in the first great age of English literature, especially in the poems of Chaucer, which give us such interesting pictures of English life in this age, filled with the spirit of the genial poet who had such an intense enjoyment of life in the world and of the world itself.

But the last part of Edward's reign was clouded with many misfortunes. England suffered from the Black Death as severely as France, and the peasants here also, believing that they were wrongfully oppressed by the land-owners, took arms and tried to better their condition in a hopeless civil war which is known as Wat 'Tyler's insurrection. Langland's poems, contemporary with Chaucer's but seeing rather the hard side of life, give us many pictures of the wretched condition of the lower classes. At the same time the English arms abroad were meeting with constant ill-fortune from the new military methods of Charles V. of France. The next generation under Edward's grandson, Richard II., is one of party strife and revolution, mainly of interest in the history of the English constitution, and it resulted in the accession of the house of Lancaster to the throne.

232. The House of Lancaster. - With the second Lancastrian king, Henry V., a young and ambitious sovereign began to reign, who could not resist the temptation which divided and distracted France offered, and he invaded that unhappy country apparently with the full intention of making himself its king. This war fills his reign and almost the 
whole of that of his son, Henry VI., and ended at last, as it deserved to, in failure and the loss of the lands in France which the English kings had held so long.

Henry VI. was weak in mind - he was the grandson of Charles VI. of France - and not able to rule the State with a strong hand. The long course of disasters in France,

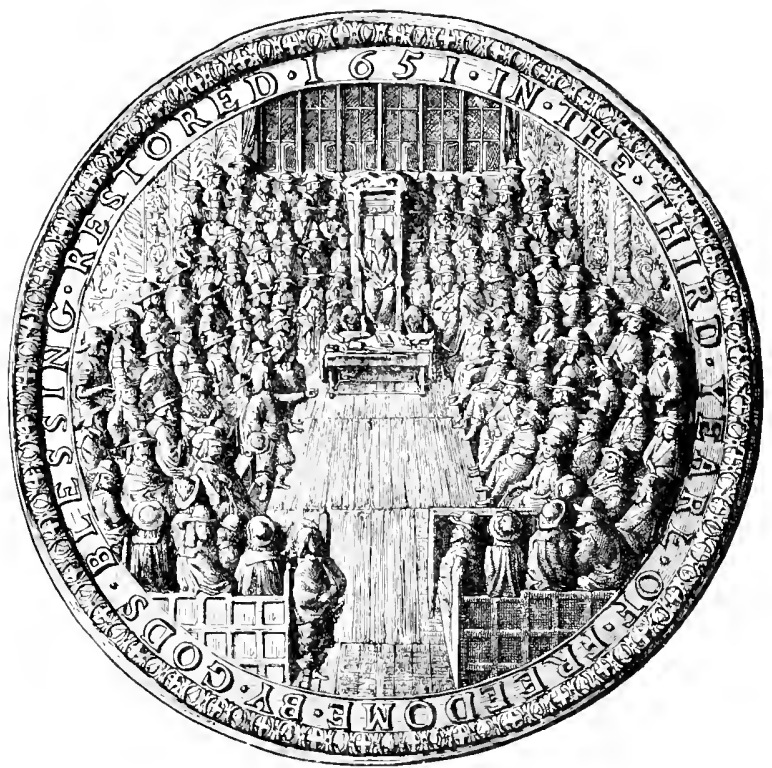

THE GREAI SEAL, UF ENGLAND

which no one seemed able to check, gave rise to much Henry VI., popular dissatisfaction with the government and made it I422-I $4^{6 \mathbf{r}}$. easy to form a strong opposition party. 'The king's uncle, the duke of Gloucester, was a man of selfish ambition, disappointed because he did not possess the power in the State which he thought he ought to have, and he did not hesitate to make himself the leader of the discontented party. 'The strife between this opposition party and the government grew

(Epochs), Chap. V.; Shakspere's plays on the whole period. 
and lork, more and more bitter as time went on. On the death of 134-159; the duke of Gloucester, his place as leader was taken by Green, English People, I. the duke of York, whose title by descent to the throne was $547 \mathrm{ff}$., $559 \mathrm{ff}$. for the control of the government, for the king's mind was gone, and it rapidly passed into actual civil war.

The charac- 233. The Wars of the Roses. - This was the beginning ter of the war.

Gairdner, Lancaster and lork, I6r ff. :

Ramsay, Lanciaster and lork; Thompson, Itiz's of lork and Lancaster. (Contemporaries).

The Yorkist kings. Stevenson, The Black

Arrow; Church, Chantry, Priest of Barnet, Bulwer, Last of the Burons (novels). of the IVars of the Roses, between the houses of York and Lancaster, though the duke of York did not advance his claim to the throne until after the opening battles of the war had been fought. At first Parliament refused to entertain his claim, but after his death his son boldly proclaimed himself king as Edward IV. The civil war which followed was a war of the nobles and their retainers. The nation it large had comparatively little interest in it, and though there was unusual slaughter of the leaders, quarter not often being given, the general suffering and destruction of property was not great.

Edward IV. was a vigorous and able king who ruled with a strong hand, as was his brother, Richard III., who obtained the crown by putting his nephews out of the way. All the princes of the house of Lancaster had now been killed except the young Henry Tudor, earl of Richmond, who had been sent to France for safety when a boy. There he waited for his opportunity, which came with the growing umpopularity of Richard. When he knew that the time was ripe in England he landed with a small force, was soon joined by many opposed to the king, and advancing to meet Richard won the decisive battle of Bosworth Field, in which Richard was killed, and was at once recognized as King Henry VII. 


\section{Topics}

Compare the general course of English history with that of France. The character of Stephen's reign. What things hampered the plans if llenry II. abroad? IIis chief work at home. The quarrel with Archlishop Thomas. The leginning of English rule in Ireland. The character of IIenry's sons. Why did John become the rassal of the pope? What events in England followed the battle of Bouvines? What conquests were marle by Elward I.? How was Scotlanl lust? The character of the first part of Edward III.'s reign. Of the second part. How did the house of Lancaster gain the throne? IJow did party strife begin in the reign of llenry VI.? How did this learl to the Wars of the Roses? The character of this war. The government of the Yorkist kings. The accession of Henry VII.

\section{Topics for Assigned Studies}

Thomas à Becket. (ireen, II'n'y /I., Chap. VIl. Stubbs, Plantrgenets, Chap. IV. Green, English Pcople, I. 164-170. Froule, Thomas à Bickit. (Longmans; 6 sh.) Freeman, Itisturial Essay's, II. Roger de Hoveden (Bohn), I. 335-34I. Roger of Wendover (Bohn), II. 15-19. Documents in Stubbs, $135 \mathrm{ft}$. Gee and Hardy, $68 \mathrm{ff}$. Ilenderson, i ft. Penn. I., No. 6.

The Black Death and its effects. Jessupp, in the Coming of the Friurs. (Putnam.) Social England, II. I33-146. Rogers' Six Centuries of Work and Ilages (Putnam), Chaps. VIII. and IX. Sergeant, IVyclif (Heroes), Chap. AV. The Statute of Laborers. IIenclerson, 165 . Penn. II., No. 6.

Shakspere's character of Richard III. Gairdner, Richurd III. (Longmans.) Gairdner, Lancaster and York, 210-227. Social England, II. 31S-319. IIenry Cabot Lodge in Scribne's Mayasine, February, I $\$ 97$, presents very vigorously, but with some exaggeration, the argument against Shakspere's portrait. 


\section{The Kings of England}

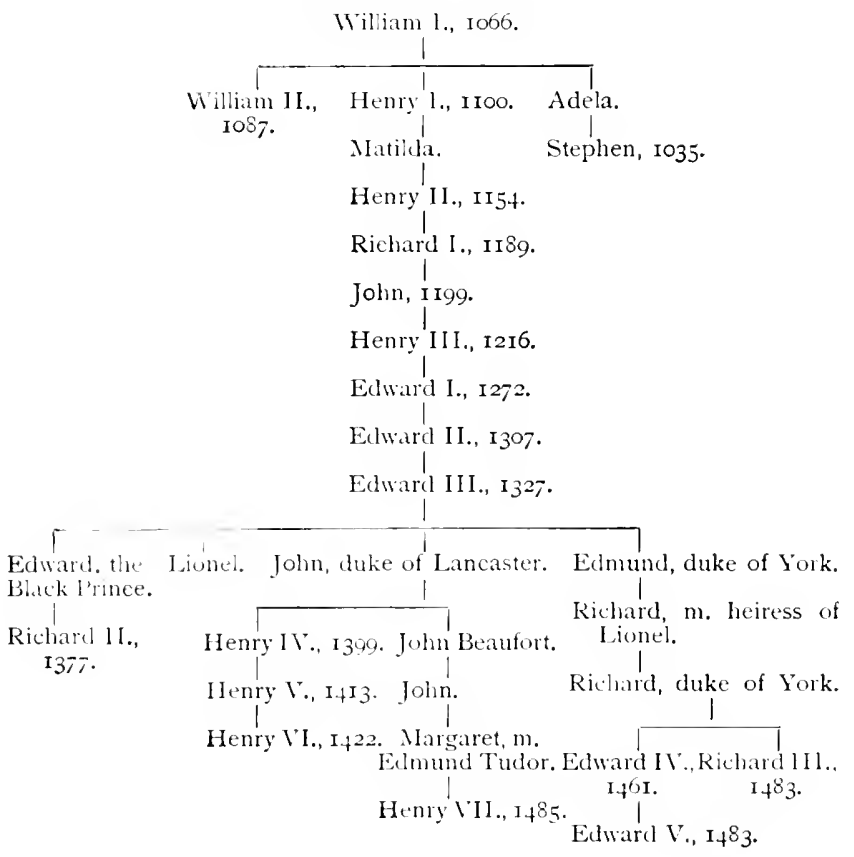




\section{CHAPTER IX \\ THE OTHER STATES OF EUROPE}

234. The Situation in Germany and Italy. - The long conflict between the Empire and the Papacy, which had grown out of their rival claims to the headship of the Christian world, left behind it only the ruins of a national government in Germany, and hardly so much as this in Italy. Both countries were hopelessly divided into many small states, whose governments were really independent, but no one of these, with the possible exception of some of the great city states of Italy, had size or strength enough to take rank among the states of Europe until towards the close of the Middle Ages.

Immediately after the fall of the great Hohenstaufen dynasty, a little after the middle of the thirteenth century, came a period which is known as the Great Interregnum. It was not strictly an interregnum, for there were emperors in name, but they were foreign princes, like the king of Castile and Richard, the brother of Henry III. of England, and they made no attempt to rule Germany. The period fills a whole generation, and in it Germany grew accustomed to the absence of any national government, and to the exercise of all sovereign rights by the rulers of the small states.

So firmly intrenched was this local independence at the close of this generation that no later emperor ever made any attempt to break it down, but all recognized the impossibility of reconstructing a strong national government, and they all made use of the opportunity which the office of

No national governments. Adams, Civiliaation, $356 \mathrm{ff}$.

The "Great Interregnum," 1256-1273. Henderson, Germany, 4or ff.

National government impossible in Germany. Bryce, Holy Roman Empire, Chap. XV. 
Rudoli of Hapsburg, I 273-I 29 I. Lewis, (re)many (Harper) $239-243$.

Ottokar of Bohemia. A war of slavs and Germans. Naurice, bohtmia (Nations), 8o-106.
The house of Luxemburg. I.ewis, (iermuny, $2+9 \mathrm{ffi}$; Leger, AustroHalls'aly (lutnam), Chap. XI.; map. Putzger, No. 18. emperor afforded them to create a family state of their own, or to enlarge and strengthen the one already possessed by their house. The greatest of the states created in this way was Austria, which came in the end to be one of the great powers of Europe.

235. The Foundation of Austria. - The founder of Austria was Rudolf of Hapsburg, who was elected emperor at the end of the Great Interregnum. He was before his election a mere count with small possessions and little power, and this was very likely the reason why the electors chose him for emperor, but he was a man of much rigor and strength of character, and would perhaps have made a great emperor in better times. In his reign the long conflict of the Slav and the German for the possession of the border lands between them broke out into open war. Ottokar II., king of Bohemia, had brought under his rule a powerful dominion on the borders of Germany and had even added to it some German territories in the sontheast, including the duchy of Austria. It seemed as if the tide, which had long been rumning steadily in faror of the Germans, might be turning, and a Slavic dynasty be about to rule over German lands. But this dicl not prove to be the case. When Ottokar refused to do homage to Rudolf for the lands he held of the Empire, all Germany supported the emperor in his war upon him. Ottokar was defeated and deprived of his German territories, and the larger share of these Rudolf bestowed upon his own sons. In this way Austria came into the possession of the house of Hapsburg, which still retains it.

236. A Period of Many Dynasties. - The electors feared probably that the Hapsburg family load gained a dangerous power under Rudolf, for they were unwilling to continue it in the possession of the Empire, and for a century and a half there was no settled dynasty of emperors. But the other houses all followed the example of the Hapsburgs. The most important of them was the Luxemburg family, whose first emperor was Henry VII., from whom Dante 
hoped to see the restoration of the Holy Roman Empire in Italy. To him the opportunity came to marry his son to the granddaughter and heiress of Ottokar II., and so to obtain all that remained of his dominions. This appeared to be a greater gain than even that which Rudolf had made, but the house of Luxemburg was not destined to a long life, and all that it brought together went at last by marriage and inheritance to swell the possessions of the Hapsburgs.

237. The Hussite War. - The last of the Luxemburg emperors, Sigismund, was involved in another long Slavic war, which has a double meaning, as in part a war between the races and in part a great religious war. John Huss, a professor in the university of Prague, who had read the books of Wycliffe of England, and learned to believe in his teachings in opposition to the doctrines of the Catholic Church, began to teach them in Bohemia and obtained many followers among the people. Finally this movement became so nearly a rebellion against the Church that the great council which had been called together at Constance to settle the troubles in regard to the papacy summoned Huss to come before them and explain his teachings. He went under the promise of a safe return from the emperor, but was condemned by the council and burned at the stake.

His followers in Bohemia took arms to defend their faith, and a war of twenty years began. It came in the end to be really a war for the national independence of Bohemia, which had now been for a century under German kings, but the religious cause furnished additional inspiration and enthusiasm. In spite of their bravery and of their desperate resistance the Hussites were at last subdued, partly because they were not united among themselves; but though they continued to be ruled by German kings, the Church granted them some concessions in matters of religious practice which they were willing to accept. Once again in later times the Bohemians attempted to secure national independence by war and failed, and it is only

A national and religious war. Maurice, Bohemia, Chaps. IXXI.; Leger, AustroHungary, Chap. XII.

The conflict of Slav and German not yet ended. 
within the past few years that by peaceable means, through the introduction of democratic institutions and a constitution, they have begun to drive the Germans out of power. This conflict, which has lasted so many centuries, is still being waged with great bitterness on both sides, but the ultimate victory seems now likely to fall to the Slav.

The Germans win Slavic lands by colonization.

Tuttle, History of

Prussia

(Houghton),

I. I I $2-118$;

Lewis, Girmany, $229 \mathrm{ff}$.

The Hohenzollern creale modern

Prussia out of Brandenburg.

Tutle.

Prussia, I. $6+70$.

Siwitzerland. Putzger, No. 18 , side map.
In another portion of the Slavic world, on the southern shores of the Baltic Sea, the Germans were winning large territories during these centuries. This was in the main by peaceful colonization under the direction of the Order of the Teutonic Knights. From this colonization came the Baltic provinces of Prussia, and also those of Russia which are German, all territory that was once Slavic.

238. The Rise of Other German States. - The foundations of the great state which we now call Prussia, as well as those of Austria, were laid in this period. The central territory around which other lands were gradually gathered by the house of Hohenzollern to form the modern kingdom was the electorate of Brandenburg. This state was granted early in the fifteenth century to Frederick of Hohenzollern by the emperor Sigismund, first as security for a loan and later in full possession. The Hohenzollern princes managed their new dominion with great care and skill and began at once the process of enlargement by the annexation of neighboring lands, which they have continued down to the present time.

Another state whose history is interesting, the republic of switzerland, has its origin in this period. The Austrian princes had some lands and feudal rights in the neighborhood of the three original cantons, Uri, Schwyz, and Unterwalken, and they naturally tried to extend these and to form out of them a little state of which they should have the political sovereignty, as many princes were doing in other parts of Germany. Here, however, they had to deal with a people who had long been free and accustomed to rule themselves. The Swiss did not propose to submit to any foreign rule, and they defended their mountain 
valleys with success against all the strength of Austria. After generations wove many stirring legends about this early struggle for independence, some of which Schiller used as the foundation of his great drama "Wilhelm Tell."

239. Italy. - In Italy there was even less pretence of respect for the emperors' authority than in Germany. Those who went to Rome to be crowned were not allowed to interfere in the actual government of the states. 'They might sell or give away titles and even valuable rights, but they could exercise no real power themselves, and sometimes the cities treated them with open contempt and insult. Almost the whole of north Italy was divided among the city states which were constantly contending with one another for the enlargement of their territories or for commercial supremacy. The most powerful of these states were Venice, Milan, Florence, and Genoa, though the power of the last was rapidly declining at the close of this period.

In government many changes occurred in these city states after the middle of the thirteenth century. Venice became a close oligarchy, Milan a monarchy under the Visconti, and later under the Sforza family, and in Florence, where there was more of a tendency towards democracy than in the cities generally, the Medici family were able to establish a virtual monarchy through the forms of the Republic. In the south the Norman kingdom of Sicily, which the Hohenstaufen had possessed, was divided into two during the most of this age. In the island of Sicily, the house of Aragon, which claimed to represent the Hohenstaufen, succeeded in establishing itself; but on the mainland, the house of Anjou, which had been called in by the popes, was in power. In this way there came to be two kingdoms of Sicily. Central Italy was still a loose and unorganized monarchy with the pope as its sovereign.

240. Spain. - Spain did not come into existence as a The growth united state until the accession of Ferdinand and Isabella in the last part of the fifteenth century. Its history for the preceding seven hundred years had been filled with war-

The leading states of Italy. and union of the states of Spain. 
Watts, fare with the Moors or with dynastic conflicts. At the

Christian

Recoi'ery of

Spain

(Nations) ;

Lane-Poole,

lloors

(Nations);

Tout,

Periods,

Chap. XX.

Spanish character made ho

Spanish history.

A second race of

Turks.

Creasy,

Ottomin

Turks

(Holt) ;

Freeman.

Ottoman

Powere

(Macmil-

lan); Lane-

Poole,

Turk'

(Nations).

Fall of Constantinople. Gibbon,

Chap.

L.XVIII. ;

Freeman,

Ottoman time of the Mohammedan conquest at the beginning of the eighth century, some bits of northern Spain had remained unconquered. Later, Charlemagne had recovered a part of northeastern Spain from the Saracens. In the'se territories several little. Christian states arose and began the long task of driving out the Moors. Five of these, beginning earlier or later, have a long history. They are, in order from the east, Aragon, Navarre, Castile, Leon, and Portugal. Navarre was early shut out from any chance of further expansion when the territories of Aragon and Castile came together on its southern frontier, and Leon was finally absorbed by Castile, but three large states remained until the marriage of Ferdinand of Aragon and Isabella of Castile created the kingdom of Spain. The predominantly military and religious character of Spanish history, during so many centuries of conflict with the Moors, had made the nation a brave and high-spirited race of soldiers, devotedly attached to the Church, and this is the character with which Spain enters upon the next age of history.

24I. The Rise of the Ottoman Empire. - In the southeast of Europe, events occurred during this period which have been followed by the most important consequences down to the present time. We have already had the history of the rise into power of the Seljuk Turks in the eastern caliphate and of their conflicts with the crusaders. About the beginning of the fourteenth century, another tribe of 'Turks - the Osmanlis or Ottomans - began to found an empire in western Asia Minor. They were a race of fine soldiers, and one of their early rulers organized the dreaded corps of the Janissaries, composed of Christian boys brought up by their captors as Mohammedans and trained to a military life under the strictest discipline. Soon after the middle of the century, the Turks had obtained a footing on the European side of the straits, and from that point their do minion spread rapidly over the Greek lands and up into the Danube valley. Before very long the Eastern Empire was 
reduced to a little territory about Constantinople, and in Paice, I 453 that city also was captured, and the Roman Empire in the East bronght to an end, after surviving for a thousand years the fall of the Empire in the West. The Turks were not as yet satisfied with the conquests which they harl made, and their attempts to force their way into central Europe are important elements in the history of the next age,

I I $t^{-}$I 20 ;

Iane-Poole,

Iurkin, IO2-I 33 ; Oman, Livomitine Empirc, Clap. XXVI.

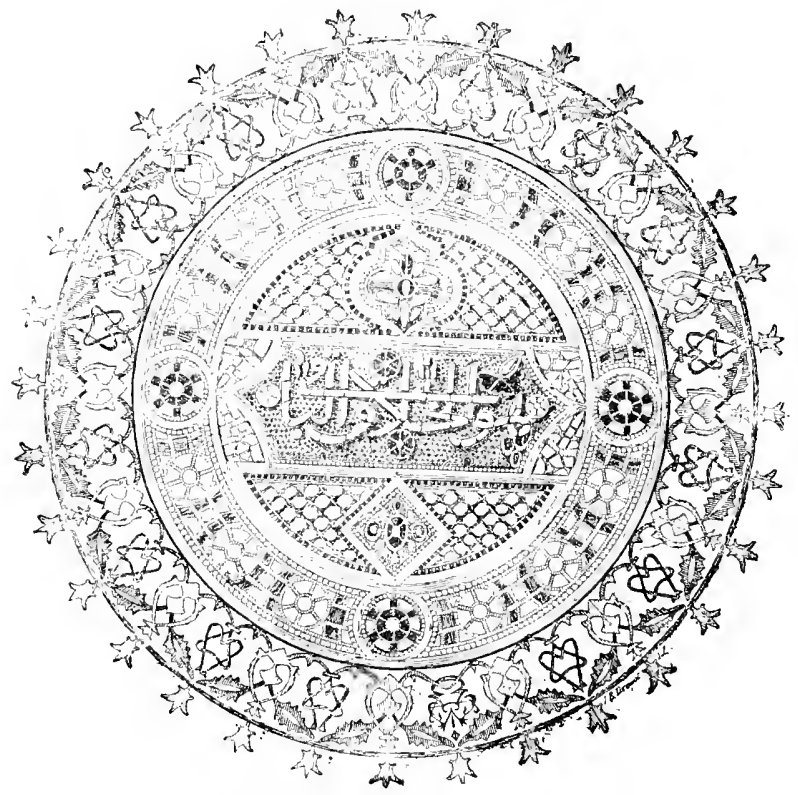

CARVING FROM A MOSLEM SCREEN 


\section{Topics}

Why had Germany and Italy failed to obtain national governments? The "Great Interregnum." The policy followed by the later emperors? How did the Hapsburgs obtain Austria? What possessions were obtained by the Luxemburg family? Where did these finally go? What wars between Slav and Germans in this period? What other question in the IIussite war? How, besides by war, did the Germans gain Slavic land, and where? How did the Hohenzollern family gain Brandenburg? The origin of Switzerland. The leading states of Italy and their governments. What difference between the north and the south of Italy? The origin of the Spanish states. What two processes run through Spanish history? When and how was modern Spain formed? The effect of Spanish history on Spanish character. The rise of the Ottoman Empire.

\section{Topics for Assigned Studies}

The freeing of switzerlant. Buchheim, Wilhclm 7ill. (Clarendon.) Introrluction, pp. xxxviii-lxii. II ug and Stead, Saiticiland (Nations), Chaps. X. and XI.

The character of the Cicl. Clarke, The Cid. (Heroes.) Watts, Christian Recorery of Spain (Nations), Chap. III. LamePoole, Hoors of Sfain (Nations), 191-213.

The regulation of the German electorate. Hryce, Holy Roman Empire, 225-23S. Text in IIenderson, 220-261.

\section{Topics for Review}

The states which were formed from Charlemagne's empire.

The history of the title "Emperor of Rome" luring this period.

What actual power attached to it in different ages?

The experiences of the city of Constantinople during this period. Of the city of Jerusalem.

Compare the pulitical development of the states of England, France, and Germany.

The history of commerce.

The position of the working classes, and the influences which affected them.

The rise of the papacy to European power.

The results which followed the crusades. 


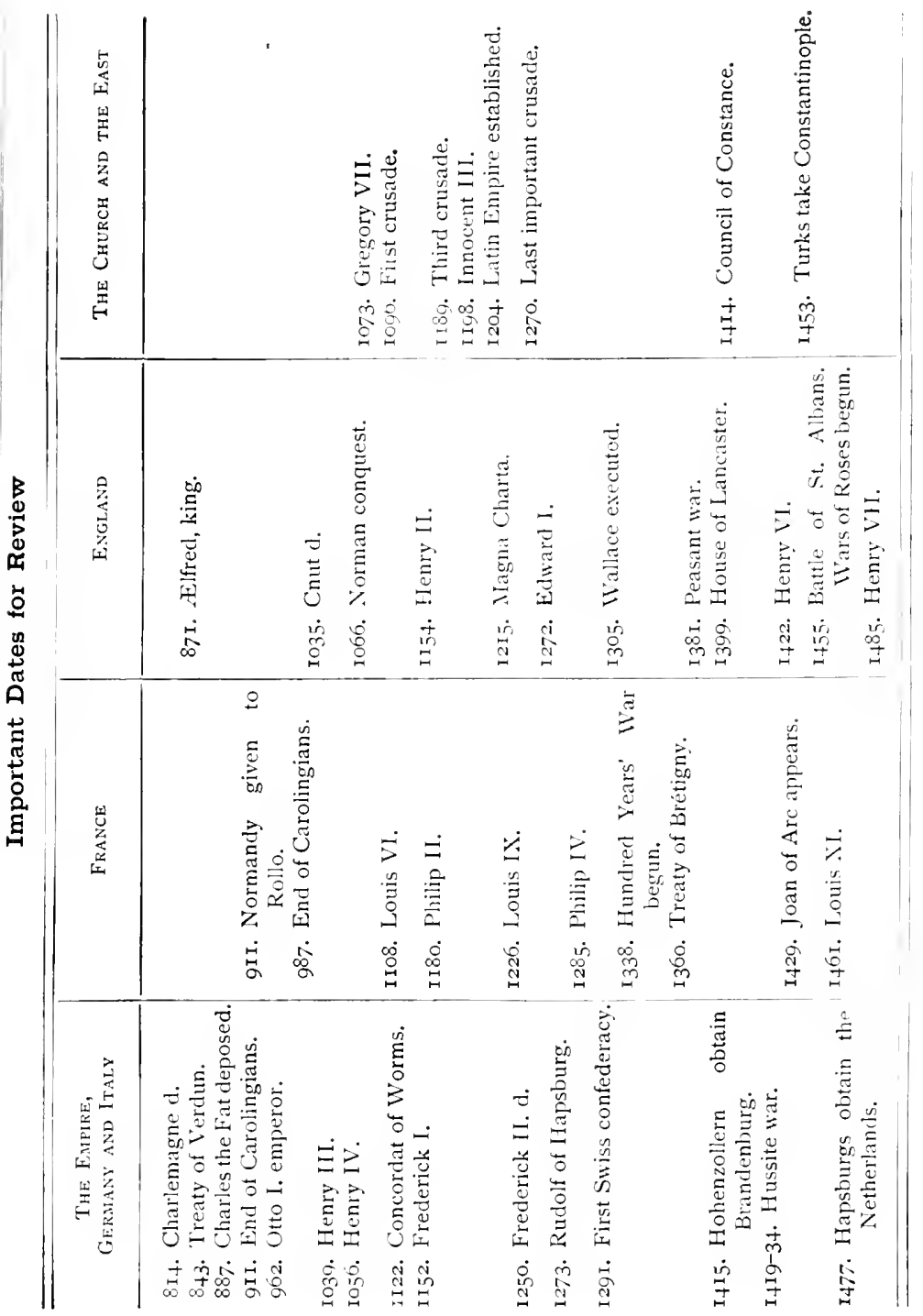




$$
\checkmark
$$




\section{PART VI}

RENAISSANCE AND REFORMATION

\section{Books for Reference and Further Reading}

Pastor, Itistory of the Popes from the Close of the Middle Ases. Translated from the German hy F. J. Antrobus. (London; Kegan Paul ; 3 vols., $36 s$.

Janssen, History of the German People at the Close of the Middle Ages. (St. Louis; Herler; $S$ vols.; $\$$ I $S .50$.)

Both translations from the German as yet unfinished. Pastor is a tine specimen of Catholic scholarship. Janssen, also Catholic, has been very severely criticised, but is very interesting.

Creighton, IIistory of the Papacy from the Great Schism to the Sack of kome. 6 vols. (Longmians; \$12.00.)

Symonds, The Renaissanie in Italy. 7 vols. (Holt; \$14.0o.) Condensed in I vol. by l'earsun. (Ifolt ; \$1.75.)

Burckharlt, The Cizilization of the Renaissance in Italy. 2 vols. (Nacmillan ; \$4.00.)

Küstlin, Life of Luther. (Scribner; \$2.50.)

lisher, The Keformation. (Scribner ; \$2.50.)

IItusser, The Period of the Reformation. 1517-1648. (Am. Tract Soc.; \$2.00.)

University lectures given in $\mathbf{I} \mathrm{S}_{59}$, but still a very useful book.

Froule, History of England. I 2 vols. (Scribner; \$IS.OO.)

Busch, Fingland ander the Tudors. Vol. I. IIenry VII. (I485-1509). Translated from the German by Miss Alice M. Tudd and the Rev. A. H. Johnson, M.A., with an Introduction by Mr. James Gairdner, Editor of "The Paston Letters." Demy Svo, cloth. (London; Innes; net $\mathbf{I} 6 s$.)

Robinson and Rolfe. Petrarch, the First Modern Scholar and Man of Letters. (Putnam; $\$ 2.00$.) Translations of P'etrarch's letters with notes.

Whitcomb, Source-Book of the Italian Renaissance. (Penn.) Annuunced. 


\section{SUMMARY}

With the beginning of the fifteenth century conditions began to favor a real revival of learning as they had never done before. In the previous century even, the revival had been begun by Petrarch in collecting the Latin classics and awakening a taste for their study. The fifteenth century opened with the revival of Greek and the recovery of the Greek writings. By the middle of the century a true scientific method had been restored, especially in the study of language and of history. Then came at once the invention of printing, which cheapened books immensely and spread the results of the new learning broadcast over Europe. The century closed with the great oceanic discoveries, the sea route to India and the New World. The first generation of the sixteenth century brought the Renaissance to an end, involved in the revolutionary conflicts which followed the Reformation, but not until it had produced its finest product in two directions in the great age of Italian art and in the scientific criticism and earnest practical spirit of Erasmus, and taken the first long step of modern physical science in the work of Copernicus. Meanwhile another line of great interest runs through the fifteenth century - the attempt to change the constitution of the Church and to modify some of its teachings. Under the influence of the kings of France the popes had lived for more than half a century at Arignon. The increasing complaints of Europe had led to an attempt to restore the papacy to Rome, but the only result had been to split the Church in two with two opposing popes. Then arose the theory of the supremacy of the general council in the government of the Church, and the attempt to carry this out in the councils of Pisa and of Constance early in the fifteenth century. The council of Constance succeeded in restoring the unity of the Church and almost in providing for regularly recurring representative assemblies, which would have changed the constitution of the Church into that of a limited monarchy. Contemporary with this movement, Wycliffe in England led a revolt against some of the most characteristic teachings of the medieval Church, and when this failed. John Huss took up the same ideas in Bohemia, where they led to a long religious and race war with the Germans, though Huss himself was burnt as a heretic by the council of Constance. The demand for reform, however, continued to grow stronger throughout the fifteenth century, and at last found its leader in Luther, who opened the Reformation by 
posting his theses against the current ideas of indulgences. In the midst of general excitement Luther was gradually led on to a position of open rebellion against the old Church, and when the brilliant assembly of the Diet of Worms failed to overawe him. he was placed under the ban of the Empire. The political situation of Europe was such, however, that Charles $V$. found no opportunity during the life of Luther to enforce this edict. The French. determined rivals for the possession of Italy, maintained at first almost constant war; the pope, anxious to protect the independence of his little state. was a most uncertain ally; and the Turks on the east threatened the conquest of the whole Danube valley. Charles was obliged for years to suspend the execution of the edict, and finally to make a peace with the Protestants which referred the points in dispute to a general council of the Churcin. Outside Germany the Scandinavian states adopted the teachings of Luther; England separated itself from the papacy, and by degrees became Protestant; from Genera a new type of Protestantism of a decidedly political and militant sort, taught by Calvin, spread through France and Holland and into England. Hardly was Calvinism well established before European history turned rapidly into the period of the religious wars.

\section{CHAPTER I}

\section{THE REVIVAL OF LEARNING}

242. A Transitional Epoch. - By the beginning of the fifteenth century it is evident that the medieval period is drawing to a close. It is, of course, not possible to fix upon any exact date when mankind passes out of one great age of its history, which we distinguish as an age by itself because it has certain well-marked and definite characteristics of its own, and goes on into another epoch of the same nature but with different characteristics. Every such transition is a very gradual one and is not perceived by the men who are bringing it about. When we look back upon such a period from a much later time, we can see the passing away of the old characteristic traits and the coming in of the new. 
Characier of this age.

Renaissance and Retormation.

A second birth.

Srmonds, is ire of the lespots. Chap. 1.; Adams, Ciàlizalion, $364-365$.

'The fifteenth and the first half or the sixteenth centuries form an age which has many of the marks of such a transitional epoch. The old influences and the new are mingled together and are contending with one another for the possession of the field. (iraclually the new show themselves to be the stronger. Some of the old ideas and institutions give way entirely to new ones; others are transformed; others still remain, but under such changed conditions as make them something different from what they were, and new forces come in the end so clearly into the lead as to give their coloring to the times, so that we can see clearly that the world has moved on into a new stage of its history. In every age which is not a time of dead stagnation such changes are going on. But some periods are so revolutionary in their character, so full of striking and dramatic changes, that they appear in a peculiar sense epochs of transition.

This is the character of the fifteenth and the first half of the sixteenth century. The striking changes of this time, affect, as we shall see, almost every department of human activity. In two directions, however, the intellectual and the religions, they were so peculiarly revolutionary as to have given their names to the period. This is the age of the Renaissance and the Reformation. The fifteenth century is especially characterized by the first, the sixteenth by the second.

243. The Meaning of Renaissance. - The term "Renaissance " is an especially good one with which to designate the intellectual revolution. It was a new or second birth. The methods of intellectual work, the literary and artistic feeling, the way of looking at life and its purposes, which the fifteenth century brought into vogue, were not then introduced into human history for the first time. They had all been in use or strongly felt before. But for a long time they had been lost to sight, or the same as lost, and now they were revived. So great was the change, so rich and full was the world into which it introduced mankind, that com- 
mon consent has rightly called it a second birth time of the race.

244. The Place of the Middle Ages in History. - According to the view of history which is embodied in this word, between the life of the ancient world and the life of the modern there lies a period during which the human mind was unconscious, unconscious of itself and of its powers of what men had already done and of what remained still to do; a period during which life was not felt to be so much concerned with this world as with the preparation for another.

Whether this view be a correct one or not, it is certainly true that the Micldle Ages are below the level of either ancient or modern times in intellectual civilization. This is probably because it was the period in which the Teutonic barbarians who had taken possession of the IVest were being raised to a point where they could comprehend and go on with the work of civilization which (ireece and Rome had begun. As a distinct period in the history of civilization, therefore, it begins to draw to a close when men begin to appreciate at its true worth the intellectual results of classic times. The fourteenth century is the age in which this appreciation in the true sense hegins, and in the fifteenth it becomes more general. This is the age of the revival of learning or of the Renaissance.

245. Learning in the Middle Ages. - It is not true that all knowledge disappeared during the Middle Ages. A very great deal was preserved by the Church, especially in the monasteries, but it took on a peculiar character, not like that of ancient times, and often it was entirely misunderstood. Greek certainly could be read by here and there a man only, and that very imperfectly. But many of the best Latin writers, like Vergil and Ovid, were in frequent use. Their use, however, was not as literature, but almost wholly as text-books of language and grammar, to teach vocabulary and forms of sentence construction. The literary sense hardly existed at all, or expressed itself feebly and in

The civilizing of the Teutonic race.

Formal learning, but no literature.

Symonds, Revival of Learning, 58-69. 
strange form in the lives of the saints who wrought wonderful miracles, or a little later in the romantic legends of heroes, like Alexander or Arthur, in which perhaps there moved a faint breath of history. Those who attempted to write more formal history slavishly followed one another for the times before their personal knowledge, and the Bible narrative formed the common foundation of all.

No science or art.

The ninth century.

The eleventh century.

Poole, Illustrations of iledieinal Thought, 85 -IOI.
With the knowledge of Greek that of the natural sciences also practically disappeared. Most men, even among those who had the ellucation of the times, believed that the earth is round and the centre of the motion of the sun and the planets. Astrology as a means of foretelling the future and alchemy as a search for the philosopher's stone or the elixir of life, came the nearest of anything to real scientific work. Even mathematics fell far behind the point of ancient knowledge. Art, also, hardly existed outside the Church, which kept alive the tradition of painting in rude altar pictures, and something better in the architecture of the cathedrals, but a true artistic feeling was as rare as the literary.

246. Medieval Revivals. - There was, however, no little progress dluring the course of the Middle Ages from the lowest point of ignorance, which was reached in the sixth and serenth centuries, and this progress is marked by several epochs of distinct revival which are preliminary to the final one of the fifteenth century. The first of these was Charlemagne's revival of schools, of which we have had the history. Better schools and better Latin style were permanent results of his efforts. At the end of the tenth, and in the first half of the eleventh centuries, there is a second revival in which we can trace a Greek influence coming from the Empire in the East through the marriage connection of Otto II. with the Byzantine court, and an Arab influence from the higher æsthetic and intellectual civilization in Spain. Sylvester II., who had been the tutor of Otto III., and whose strange learning made people suspect him of magic and communication with the Evil One 
even after he became pope, is one of the most famous men of this revival. We can trace back into this age also the beginnings of those methods of philosophical speculation which afterwards gave rise to the great systems of scholasticism.

247. The Age of Scholasticism. - Two centuries later, in the last part of the twelfth and the first of the thirteenth centuries, occurred a still more active and interesting revival. The intellectual keenness and rigor of the time has scarcely ever been surpassed. Nind was, indeed, far in advance of the materials with which it had as yet to work, and of the general preparation in other directions for a true revival. The characteristics also of the leaders were purely intellectual without those artistic and literary elements which seem to have been necessary to the Renaissance. Material limited to a single line, and a passion for abstract speculation determined the character of the epoch. It was the great age of Scholasticism.

The influence of one sille of the Arabian civilization, the philosophical, was strongly felt in this period. Through them came a knowledge of much more of the Greek philosophy than had been known to the earlier Middle Ages. It was still an incomplete and very one-sided knowledge. It was Aristotle without Plato, and of Aristotle it was his formal or deductive logic almost alone. This fell in very well, however, with the tendencies of the time, which, from the fact that almost all educated men were interested first of all in theology, were chiefly speculative. The rules of deductive logic were a sufficient guide in the construction of great systems of thought from the foundation of doctrine which the Church supplied in the works of the early fathers, and Aristotle, as the great teacher of logic, acquired an absolute authority which no one could dispute. In the field of theology this was one of the greatest ages of history and has had a decisive influence on all later thinking. St. 'Thomas Aquinas, who was probably the highest product of the time, put into definite form the great Catholic doc-

The scholastic philosophy.

The thirteenth century. Fisher, Christian Church, 208-218; Bacon, Adiancement of Learming (Clarendon), IV. 5 . (1) in 
trines, and exercises still an influence hardly equalled in this field.

Rise of the 248. The Founding of the Universities. - In another diuniversities. Foundation charter of Heidelberg. Henderson, $262 \mathrm{ff}$. rection the age of Scholasticism exerted a permanent influence upon the intellectual history of the work. This was in the organization of the mirersities of Europe. The intense eagerness to learn which characterized the times,

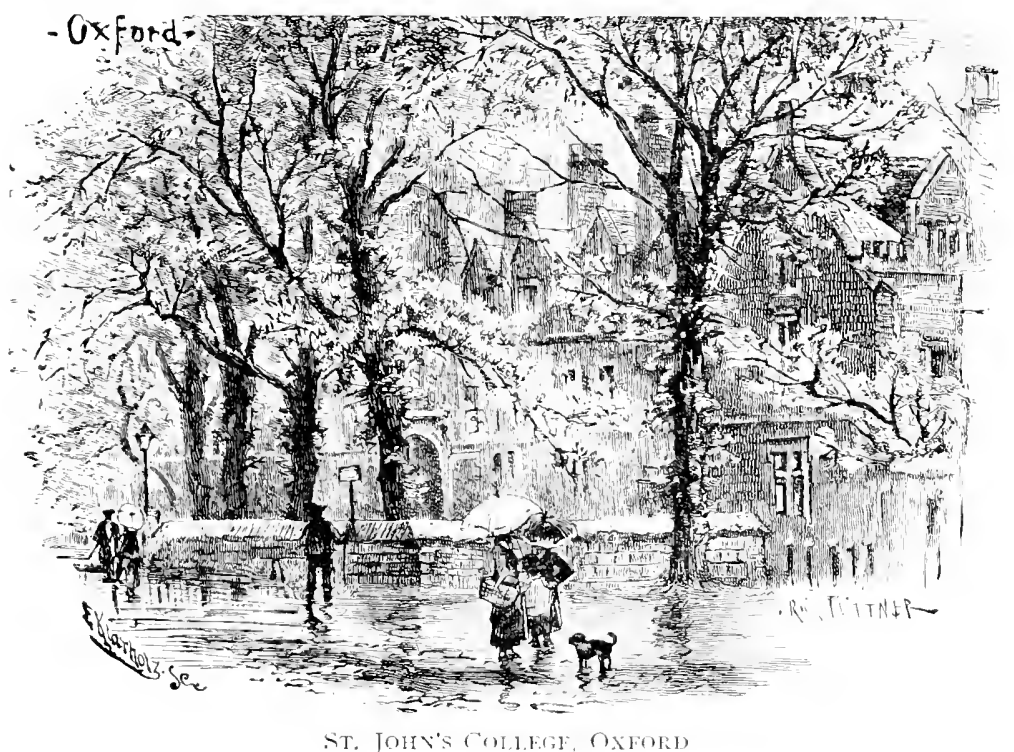

seized upon the best of the alrearly existing schools and transformed them. The number of the students grew enormously, and at the same time the number and the skill of the teachers. The branches of learning began to be differentiated from one another, and teachers and students to specialize in their studies. New methods of study were also introlucel - dialectics in theology and the use of Justinian's code in law. With the increase in numbers, these schools took on a more definite organization and became 
great self-governing communities of a democratic cast, or at least democratic after a certain stage in the course of education had been reached. Together they formed, indeed, a kind of international community, with a common language, very frequent migration from one to another, and a recognized standing in any one for those who held the degrees of another. In most of these universities, the student life and much of the instruction centred in the college system, which survives to-day in the English universities.

There was so much that was truly scientific both in ideal and in method in these schools that it seems strange that they did not lead to a complete revival of learning. The reasons for the failure are the same as those given for that of the thirteenth-century morement as a whole, - the lack of material, the need of a more general preparation, and the absence of a literary sense. Scholasticism seized upon the universities and intrenched itself so strongly in them that when the true revival came it found there its bitterest opponents.

249. The Renaissance comes first in Italy. - The Renaissance waited some generations longer before the general conditions became favorable. It was in Italy that the preparation was first made. Here the constantly extending commerce of two or three centuries had led to great accumulation of wealth, the growth of great cities, and the collecting together of the materials of culture. These were soon followed by the awakening of a literary and artistic feeling, the growth of a native literature and art, and the perception of the fact that there had been, long before, ages of high culture, and great writers and artists. Italy led all Europe in the Renaissance because these conditions were first combined in that country.

In Italy, indeed, one of the greatest works of modern literature precedes the real revival of ancient learning. If there show themselves in Dante a more human and intimate feeling for the ancient world and its great men, a

No Irue revival of learning.

Conditions most favorable in Italy.

Dante, I265-132I. 
closer and more kindly observation of nature, and a greater independence of judgment than was usual before him, he still remains in almost everything a thorough man of the

The work of Peirarch, I304-1374. Symonds, Revizal of Learnings, $70-98$ Adams, Civilization, $375-377$.
The beginning of Renaissance arl.

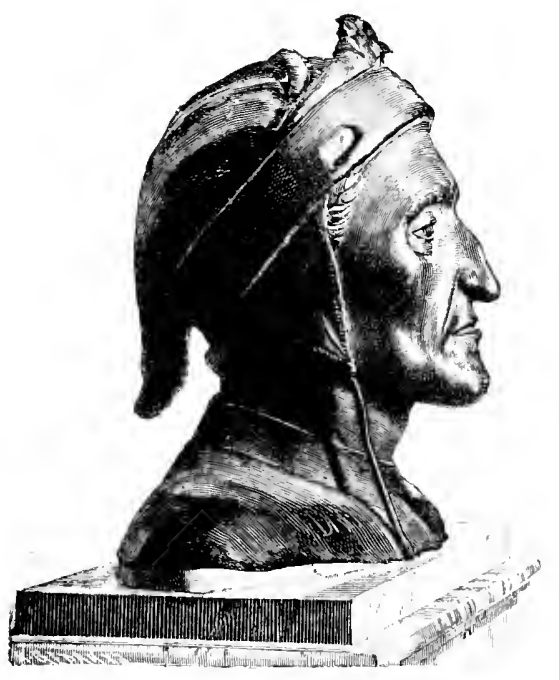

DANTE ALIGHERI

Middle Ages. The most that can be said is that he reveals the first faint light of the coming day.

250. The Beginning in the Age of Petrarch. - It is in the generation of Petrarch and Boc. caccio that the day breaks. These two men alone almost created a new literature in the lyrical poetry of the

first and the prose tales of the second. But Petrarch himself believer that his Latin poems would bring him greater fame than his Italian lyrics, and his devotion to the ancient classics was his strongest passion. He sought through all the countries of the West that were open to him, in the neglected libraries of the churches and monasteries, for the writings of the great authors of antiquity, and had them copied whenever he coull not purchase them. This represents the first stage of the Renaissance, an eager love for the treasures of the classic world and the collecting together of all that was left of them as the material of devoterl study.

In the same age, even a little earlier than Petrarch, Ciotto had opened a new epoch in painting, seeking to give a true representation to nature and human life as they really exist. 
25I. The Revival of Greek. - Petrarch could not read Greek, though he earnestly desired to do so, and the second stage of the revival of learning is the recovery of the knowledge of the Greek language. This was acquired from teachers who came to Italy from the Eastern Empire in the generation immediately following Petrarch and before the close of the fourteenth century. As the Ottoman Turks steadily progressed in their conquests of the territories of the Greek emperors, shutting them up to a constantly decreasing circle of land around Constantinople, many Greek scholars abandoned the East, and in other ways intercourse between the two parts of the Christian world became more frequent. The Eastern emperors hoped to secure the military aid of the West in a new crusade, and the popes hoped that the time had come when the whole of Christendom should be united under their authority. For a moment this last hope seemed to be realized in the decisions of the council of Florence. But in the end both pope and emperor were disappointed. The one permanent result, aside from the triumph of the 'Turks, was the revival of the study of Greek in the West.

As soon as Greek could be read, there was the same eager desire to collect Greek manuscripts, as there had been and still was to get together the Latin, and great numbers of these were brought into Italy before Constantinople passed out of Christian hands. By $145^{\circ}$ the learned world was in possession of the larger share of those remains of classical literature, both Latin and Greek, which have ever been recovered.

252. Scientific Method Recovered. - The third and final stage of the Renaissance, regarded as a revival of learning, followed immediately on the recovery of Greek. This was the awakening of the scientific spirit. Petrarch had foreshadowed this as he did many traits of the full Renaissance, and it had been slowly growing since his time, but it is the characteristic mark of the middle of the fifteenth century. Its first great field was in the criticism of the texts that had been recovered to ascertain exactly what had been originally

Greek learned from the Eastern Empire. Symonds, Reviñal of Learnins. IO8-II3.

\section{Greek} writings recovered.
The revival of science completes the Renaissance. On Pelrarch, see article with translation, Iale Rericio, Vol. I. 
written, and in the reconstruction of ancient history and mythology. But it was the genuine scientific spirit of questioning and criticism, using the method of collection and comparison, and it soon branched out into wider fields. tion of urunting.
The inven-

253. The Invention of Printing. - Just at the middle of the century came a most wonderful invention which gave an unparalleled impulse to learning and literature, and to the whole intellectual life of

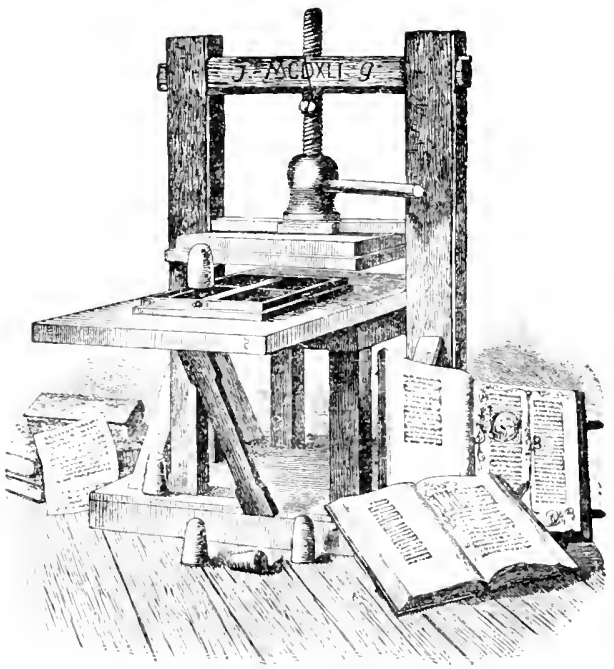

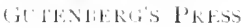
mankind. 'This was the invention of printing. From whence the suggestions were derived which led to this invention we do not know, nor even with certainty by whom it was made, though the place was somewhere in the Rhine valley. To develop the art of printing books from its nearest precursor, the printing of wood engravings, two important steps would be necessary : first, to cut the engraved words into single letters, that is, movable type, so that different sentences could be printed with the same characters; and second to adapt the press to the process of making copies. It is quite possible that these Rapidsprean two steps may have been taken at slightly different times 1 prining. l.inssen, irmiln $\therefore$ Pic, I. (1) -24.

Si:n+131<

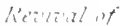
lidemins, 300391 . and by different men. Though it cannot now be said with certainty by whom these steps were taken, the evidence seems to indicate that it is from Gutenberg, that we first have the art in its perfected form. He certainly was printing at Mainz at the mirldle of the century. Irom here the new art spread rapidly in all the countries of Europe, particularly in Italy, where the way was especially prepared for 
it. Almost every Italian city had its printing business, and Venice became the first centre of the book trade.

The early printers found a great work already waiting to occupy them for many years in two classes of book for which there was a peculiar demand. These were theological and religious books for which the Church made a great market, and the works of the classic authors which the revival of learning had brought into demand. Twenty editions of St. Augustine's "City of God" were printed before the year I 500 , and nearly one hundred of the Latin Bible, while there were more than thirty of one of the minor poems of later Latin literature.

254. Results of the Invention of Printing. - In two ways the invention of printing immediately became a powerful influence in the intellectual advancement of men. It increased enormously the number of copies of a book in existence, so that it became easily accessible everywhere and to everybody; and it reduced the price of books so that whole classes to whom they had been impossible luxuries now found them within their reach. Printed books of the fifteenth century are not extremely rare. A library in Nunich possesses more than twenty thousand specimens; probably thirty thousand editions were published before I500; and the price of books fell off four-fifths. This was one of the greatest intellectual revolutions of history, not in the discovery of new truth, but in making knowledge the common possession of all men. In bringing the Middle Ages to an end and introducing the modern, it was even more effectual than the invention of gunpowder, which was coming into general use at the same time and revolutionizing the art of war and society itself by depriving the noble class of its advantages in castle walls and armor and the exclusive profession of arms.

255. The Renaissance South and North of the Alps. - In Italy, where the first enthusiasm for the revival of learning had been awakened, where such vast results in the restoration of knowledge had been achieved, and where the product in

Books first printed.

Books increased in number and decreased in price. Reade, Cloister and Hearth (novel).

Character of the Renaissance in Italy. 
George Eliot, literature and art was even richer than that in learning, the Iimola

(novel).

Renaissance remained its own chief object. Knowledge was sought for its own sake alone. The most intense pride was felt in the possession of full classical learning and an elegant Latin style, and the principal results of the age were a culture somewhat superficial in character and a science which, aside from the great work it accomplished in the classical field, was fruitless.

North of the Alps, among the nations of Tentonir race, Character the Renaissance advanced to further results. The first stage of the Renaissance in northern Europe. Seebohm, The Oxford lieformess (Longmans); sieebohm, l'rotestant Revolution, Pt. II., Chap. II.

Erasmus in England. of this is to be seen most clearly in England, in the last year of the fifteenth and the first of the sixteenth century. There a little group of scholars in the university of Oxford, of whom Colet, who founded St. Paul's School in London to further the new methods of education, and Thomas More, Henry VIII.'s minister, were the leaders, songht knowledge for the sake of reform. Their purpose was to study the New Testament and the writings of the early Church in order to find ont the real character of the original ('hristianity, and to use this knowledge to remove from the Christianity of their time the corruptions and abuses which had come in.

256. Erasmus. - About $149 S$ a young Dutch scholar, Erasmus of Rotterdam, came to Oxford to study Greek because he was at the time too poor to go to Italy, where every one went to learn Greek who conld afford to do so. He had already been for some time a student at the university of Paris, where he had made a considlerable reputation for learning, and he was destined to attain the highest fame and the widest influence of any scholar of the age. At Oxford he formed a close friendship with Colet and Nore, and seems to have been inspired by them with their earnest and practical purposes. At any rate he became from this time on a most earnest advocate of reform, and a cletermined enemy of the current abuses.

His purposes These purposes he labored for in two ways. In one he and methods.

made use of his remarkable literary talents, and ponred torrents of ridlicule over the follies and ignorance of the monks 
and scholastics, the supporters of the old abuses. His "Colloquies" and his "P'raise of Folly" were read everywhere throughout Europe and, though men laughed, their eyes were opened to the necessity of reformation. In another way Erasmus devoted the great resources of his scholarship to the same end. His life work was the preparation of carefully critical editions of the New Testament and of the writings of the early fathers of the Church. His purpose was first to ascertain just what had been originally written, as nearly as possible, and just what it had meant to those who wrote it, and then to give these results in accessible form to all scholars. It was his intention that they should be made known ultimately to the ignorant as well as to the learned, and this intention he himself directly helped to realize by his paraphrases of the New Testament narratives which were long in use in the Protestant churches. His edition of the New Testament was published in $5_{5} \mathrm{I} 6$, in time to be of great use to Luther in his translation. It was republished many times in different places in Europe and formed the foundation until very recent times both of the accepted or standard text of the Greek original and of the Protestant translations of the New Testament.

Erasmus lived for some years after Luther's first attack on the Catholic Church, but though he sympathized with him fully in his desire for reformation, he did not agree with Luther in several very important matters. He did not believe in the use of violent and revolutionary methods to bring about the reformation, while Luther preferred to break the Church in two rather than leave it unreformed, and he did not believe in the Augustinian doctrines of theology which Luther held to against those of the Church. Erasmus has been called a coward because while he went so far with Luther in demanding a reformation he was not ready to go all the way with him. But Sir Thomas More, who believed as Erasmus did, was not a coward, for he willingly died for his convictions, and we have no right to suppose that Erasmus did not go as far as he honestly could.

The New Testament.

Erasmus and I.uther. Fisher, Reformation, 127-132. 


\section{Topics}

Character of the age. Meaning of the term "Renaissance." What great work in civilization was accomplished during the Middle Ages? How much positive knowledge had the Middle Ages? Revivals of learning before the Renaissance. The source and character of scholasticism. The rise and character of the universities. Why did the revival of learning come first in ltaly? The relation of Dante to it. What was accomplished by Petrarch? Ilow was Italy taught Greek? In what ways were the methods of modern science first applied? The invention of printing and its results. Characteristics of the Renaissance in the north of Europe. The purposes and work of Erasmus. Why did he not become a Protestant?

\section{Topics for Assigned Studies}

The universities. Kashdall, The Lniversities of Europe in the Middle Ages. 2 vols. (Clarendon.) Laurie, The Rise of Cnizersities. (Appleton.) Compayre, Alelard and the Orgin of the Lniatrsities. (Scribner.) Mullinger, Cambridge, and Brodrick, Oxford (Epochs Ch. Hist.).

The medieval student. In Rashdall, L'niz'ersities, Penn. II., No. 3, and Jaskins, dm. Hist. Reticie', Vol. III.

Erasmus. Drummond, Erasmus. 2 vols. Froude, Life and letters of Erwsmus. (Gicribner.) Both contain many translations from Erasmus. Translations of the Praise of Folly and of the Colloquit's (Lombon: keeres and Turner), and in numerous other editions. Seebohm, Oxford Reformers. (Longmans.) Very full on Erasmus' purposes, with translations. For political ideas, see Mure's L'tofia. See also, P'enn. I., No. I. 


\section{CHAPTER II}

THE IMMEDIATE RESULTS OF THE REVIVAL

257. Advance in Knowledge. - Before the encl of Eras- Advance in mus' life the intellectual history of the world had been wo direccarried forward in two very different directions. In both tions. human knowledge had been arlvanced far beyond that of the classical times which it had been the especial object of the Renaissance to restore. In one direction the earth had been explored, its form and size determined, and new continents laid open to European enterbrise, and in the other the true place of the earth in the solar system and its relation to the sun and the planets had been determined.

258. The Commercial Situation of the Fifteenth Century.The increasing knowledge of the lifteenth century, combined with commercial ambition and rivalry, led to the great explorations of the age. Then, as in the time of the crusarles, the object of the merchant was to reach India and obtain a share in the exceedingly profitable trade in Uriental goods. The new ambition of the fifteenth century was to discover some route by which India itself might be reached, and thus avoid the difficulties which beset the routes through the Mohammedan countries of western Asia and Egylt. This was, besides, a real necessity for the new nations, like Spain and Portugal, which were anxious to share in the commerce of the time. The northern Merliterranean routes were practically closed by the advance of the Turkish conquests. The natural and easy route through Egypt was a virtual monopoly of the Venetians through the especially favorable arrangements which they had with the rulers of that country. 
Some new non-Mediterranean route to India must be discovered, or the hoje of sharing in the riches of the Eastern trade must be given up.

Navigation still cautious. Nap of the discoveries, Putzger, No. 32.

The west coast of Africa. Fiske, Iiscozery of America, I., Chap. IV.
Long before the beginning of the fifteenth century medieval commerce had begun to adventure ont into the Atlantic, though it was still timid, afraid of strange dangers, and rarely bold enough to go out of sight of land. The magnetic needle had become known in the West, probably as early as the twelfth century, but its most important application to the art of navigation was not yet fully understood. 'The first great discoveries of the fifteenth century were matle by explorers who still crept along the coast and were unwilling to lose sight of it for any long period.

259. The Portuguese Discoveries. These first discoveries were those of the Portuguese along the west coast of Africa.

They began perhaps in the desire of the nation to continue its conquests from the Moors in northwestern Africa, since further conquests in the Spanish peninsula were no 
longer pussible on account of the expansion of Castile, which had reached the Atlintic south of Portugal. It was soon found, however, that there were profitable articles of commerce to be had in Africa, and the Portuguese were attracted further down the coast. The classical tradition of a passage around Africa was revived, and before long the Portuguese became possessed with the ambition of reaching India by this route.

This direction was largely given to their efforts by a prince of their royal fimily, l'rince Henry the Navigator. He took up his residence on the retired promontory of Cape St. Vincent, collected all the information that he conkl, made himself familiar with the best scientific knowledge of his time, and gave his life to encouraging the explorations of his countrymen toward the south.

Prince Henry did not live to see the final success of his plans. Progress was very slowly and cautiously made. About all that each expedition did was to turn one of the difficult headlands on the African coast, and learn that so far at least the dangers of the ocean and the horrors of the torrid zone were mythical. Encouraged by this result, they next passed the next cape, and returned to report their safety. Only about $\mathrm{I}_{4}{ }_{4}$ was the equator finally crossed. The next expedition, that of Bartholomew Diaz in $\mathbf{1} 486$, was carried by a storm around the Cape of Good Hope, as it was named on his return, and found reason to hope that the extremity of the continent had been reached.

It was ten years before this discovery was followed up by a voyage to India, and in the meantime another explorer, de Covilham, going through Egypt and Ethiopia, had crossed from the east coast of Africa to India and returned. In I 497 Vasco da Gama passed around Africa, sailed up the The Portuguese reach India. Stephens, Portugal, 185-192. east coast to Mozambique, found Arabic-speaking pilots, and crossed to India. After an absence of over two years he returned to Lisbon with the goods of the Orient acquired in a direct voyage.

260. Columbus. - Before Vasco da Gima set out upon 
Columbus ideas and character. Adams, Cizilization, $388 \mathrm{ff}$.

this voyage, the greatest discovery of the age had been male. Columbus had come to believe, as did the scholars of his time in common with those of the classical world, that the earth is round. He believed it to be much smaller than

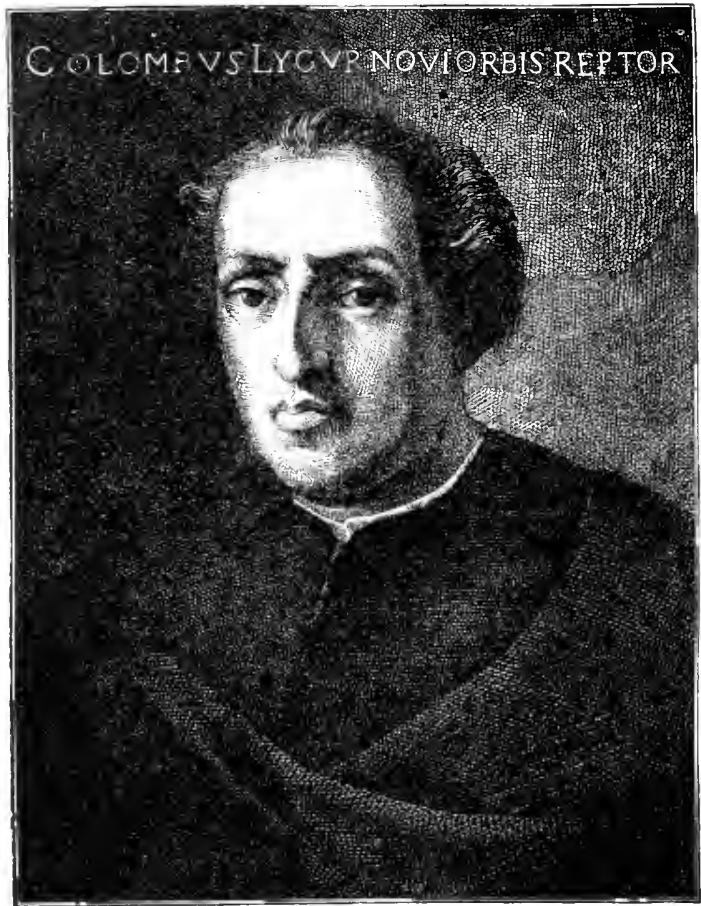

Colithous

it is and reasoned that by sailing west one could reach India with no very long voyage. He not merely believed this, but he had the courage to risk everything to prove its truth. The great difficulty which he had to overcome was that of persualing others of its probability, the scholastic clergy who were the arlviser of kings, the kings themselves who must 
furnish the means for an expedition, and the sailors who must man it, and whose superstitious terrors were especially hard to overcome. 'The most remarkable thing about Columbus was not his belief that by sailing west he would reach India, but it was the conrage which led him to dare to try the royage and to stick to it until he reached the land. This marks better than any other single event of the time the age when medieval superstitions were dying out, and modern knowledge and daring based on knowledge were born together.

26r. Columbus' Discoveries. -- Portugal and England both declined to venture anything on Columbus' ideas, and Spain was only with difficulty persuaded. The voyage occupied far less time than that to India. He sailed on the 3 d of August, I 492, and returned on the $15^{\text {th }}$ of March of the next year and announced his success. He thought the coast of Cuba which he had reached was that of the continent of Asia, and he believed he had opened a new route to India. In a later voyage he did touch the continent of South America, but not until after North America had been seen by Cabot in the employ of England. For as soon as the success and safety of these distant expeditions were proved, all nations became ambitious of a share in them. England and France joined Spain and Portugal in exploration, and new discoveries were almost daily made. Especially important were the discovery of the Pacific Ocean by Balboa in 1513 , and the voyage of Magellan, who set out in 1519 , passed through the straits at the southern extremity of South America which now bear his name, crossed the Pacific, to which he gave its name, and really reached the East Indies too late to undeceive Columbus, who died supposing that he had done this. There he was killed by the natives, but his lieutenant continued the voyage to the west, passed the Cape of Good Hope, and finally returned to Spain, proving the earth to be a sphere and obtaining the first real evidence of its size.

The share of these events in the great intellectual revolution of the age is nowhere very fully indicated by the writers

America discovered.

Other explorers. Old South, Nos.

$17,20,34-37$; Am. Hist. Leaf, Nos. 9 and 13 ; Cassell's National Library, No. 32.

A new age intellectually. 
of the time, but it must have been very large. The geographical horizon coukd not be so enormously widened without a corresponding broadening of human vision in all directions. Mankind were entering into possession of a whole world of knowledge and new ideas, as they were physically into the possession of the whole globe.

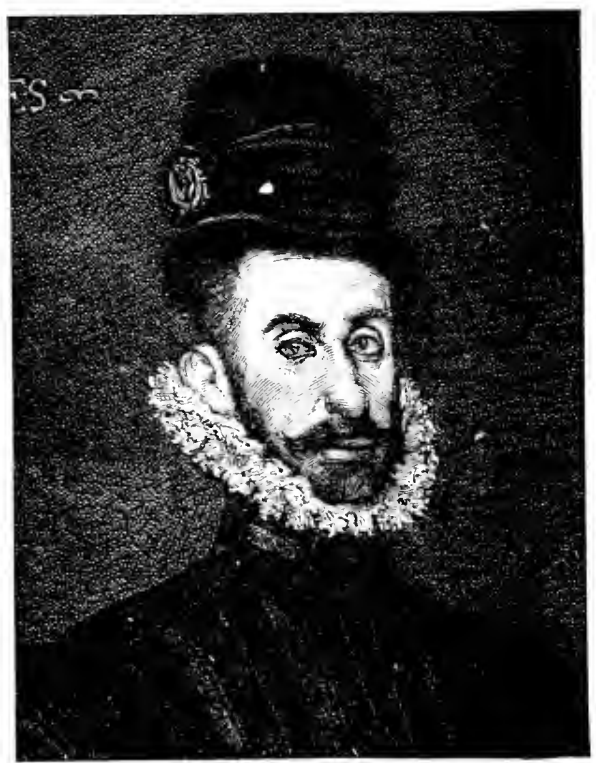

CORTES

Commerce occanic.
262. The Economic Results. - In another direction, in the economic conditions of the world, as great a revolution was wrought by these events as in the intellectual. Commerce ceased to be Mediterranean and became oceanic, as it is today. The Mediterranean Sea was no longer the centre of the world. The countries open to the Atlantic, like Spain, Portugal, Holland, and England, became the great commercial nations of Europe. Venice lost her supremacy, though she struggled hard to maintain it. Lisbon became in suc- 
cession the distributing point of Oriental goods, and the Portuguese founded the first European empire in the East Indies. The consumer shared in the benefits of these changes, for the price of spices fell to one-half at a single stroke. At the same time the stores of the precious metals of Mexico and Peru began to be poured into the markets of Europe as a result of the Spanish discoveries and conquests in America. While the goods imported into Europe fell in price in consequence of the better commercial facilities of the time, those produced by labor in Europe itself sold for higher priccs because of the declining value of gold and silver. It was a time of improvement and prosperity for the laboring classes where they were economically free enough to take advantage of the rise in prices, as they were in England and in most of France. Where they were not able to dispose freely of their labor and its products, as in Germany, it was a time of great discontent and of attempts to change their conditions by violence and insurrection, as we shall see hereafter.

263. The First Great Step in Physical Science. -- While Columbus and the Portuguese wers laying open the earth to Copernicus, $1+73^{-15+3 .}$ human knowledge, another great explorer was tracing out the geography of the solar system. This was Copernicus, who was born in Poland in 1473 . He was sent to Italy to complete his university studies, and there became especially interested in mathematics and astronomy. Very early in his studies he came to the conclusion that there must be a simpler explanation of the movements of the heavenly bodies than the one which everyboty believed at the time, the ancient Ptolemaic, which made the earth the centre of the universe.

That real science had now hegun, as compared with medieval methods of study, can he seen in the fact that no more correct methods of investigation could be employed to-day in the study of a similar problem than those which Copernicus used. He first examined the ancient scientific writings to see if any suggestion of another explanation had

Increased quantity of gold and silver.
The scientific method of Copernicus. For his ow 1 statement of his method, see Fale $R \varepsilon$ vilea, I. 160 , n. 2 . 
been made, and found in them a theory which seemed to him more reasonable. Then he began to study and compare all the observations which he could find recorded and others which he made himself, until he was convinced that this theory accorded with the facts much better than the Ptolemaic. All his life, however, he devoted to the collection of further proof, which was, at the beginning of modern

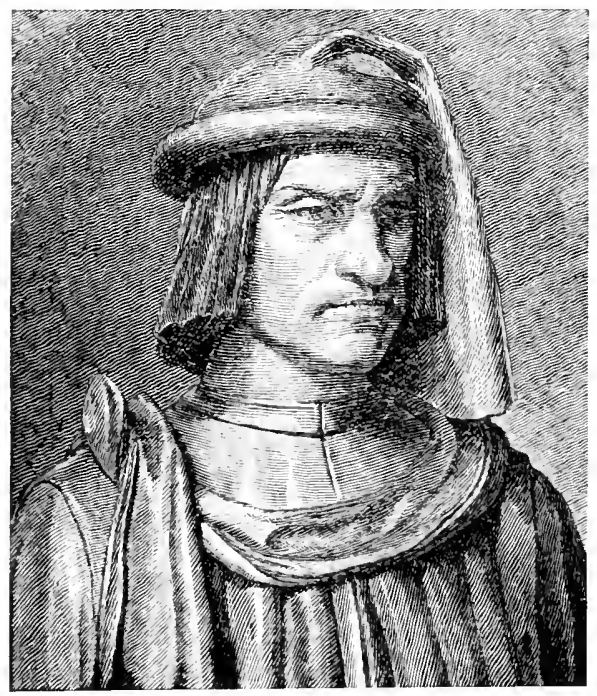

LORENZO MIGNIFICO

From a portrait in Berlin

astronomy, without observatories or instruments, a very slow and difficult process. His conclusions he did not publish until the very end of his life in 1543. A copy of the printed book was brought to him as he lay on his leath-bed.

The first work of modern science.
This was the first great step in the advance of modern science, and two things about it are especially important to notice. The first is that it begins in the use of a new method, that of observation and comparison. The second 
is that our science rests upon the work which the students of the ancient world accomplished in their time, and this is as true of the other sciences as it is of astronomy.

264. The End of the Renaissance. - When Copernicus' book was published, Erasmus had long been dead, and civil war was just about to begin between the Protestants and the Catholics in Germany, the first in a long series of civil wars over religion which laicl waste almost every country of Europe. In these political revolutions and conflicts, the age of the Renaissance came to an end. It had been an age of wonderful intellectual progress, and it had prepared the way for other great changes, and made them necessary. It is not unnatural that these now occupied the chief attention of men to the comparative exclusion of science and the pursuit of knowledge. After an interval of almost a hundred years, another age of great scientific discovery comes on, the seventeenth century.

265. Art and Literature. - Great as was the Renaissance on its purely intellectual side, it was even greater as an age of art and literature. In this direction, again, Italy led the world, and her achievement in the fifteenth and early sixteenth centuries, in the fine arts at least, remains to the present time unequalled. The great wealth with which her cities were stored was employed with lavish hand to encourage artists of all kinds and to beautify both the cities and private residences with every species of art. Of the rulers the Medici at Florence are especially famous for their liberal patronage of art and literature, and many of the popes, like Nicholas V., who founded the Vatican library, strove to make Rome the capital of the world in literature and art as in religion.

The names of the greatest of these artists are familiar to all the world, Leonardo da Vinci, Rilphael, and Michael The artists of Italy. Angelo, whose long life spans almost the whole of the period, but there is a crowd of lesser names which would have rendered any less wonderful age illustrious. Correggio, Titian, and Cellini are only less famous than those first

Favorable conditions in Italy.
The Renaissance encls in an age of revolution. In Italy, Symonds, Ciatholic Reaction, I. $20+-228$. 
named. The age is distinguished also by the fact that its artists are almost equally great in more than one branch of art at the same time. Michael Angelo, for example, is an artist of the first rank in sculpture, painting, and architecture at once.

Italian 1terature.

Art and literature in northern Europe.

In the literature of the age, Italy is not so unrivalled as in art, and no work of these generations equals the earlier work of Dante and of Petrarch. But Ariosto in poetry, and Machiavelli in history, and in the scientific observation of politics, are names which will never be forgotten.

Northern Europe in the last age of the Renaissance produced a few names which are still remembered. Holbein and Albert Dïrer in art, and Hans Sachs and Ulrich von Hutten in literature belong to Germany. Holland had led the way in the north in painting and had done much to improve the methods of the art. France, if she produced no great artists of her own, called those of Italy into her service - both Leonardo da Vinci and Cellini spent some time at Paris - and in literature she gave us Montaigne and Rabelais.

\section{Topics}

What was the motive of exploration in the fifteenth century? The character of fifteenth century navigation. The discoveries made by the Portuguese. The characteristics of Columbus. IIis and other discoveries in the IVest. The economic results of the age of discoveries. Copernicus' method of work and his discoveries. What brought the age of the Renaissance to an end? The art and literature of the age.

\section{Topics for Assigned Studies}

Prince Henry of Portugal. Beazley, Prince Henry (Heroes). Stephens, Portugal (Nations), Chap. VII.

Columbus. Fiske, Discoiery of America. 2 vols. (IIoughton.) His difficulties and the discovery, I., (hap. IV. Toscannelli's letter to Columbus, I. 356. Winsor, Columbus. (Houghton.) The tiscovery, Chap. IX. Old South, Nos. 29, 33, 71. Am. Hist. Leaf., No. 1 . 


\section{CHAPTER III}

\section{REVOLUTION ATTEMPTED IN THE GOVERNMENT OF}

THE CIURCH

266. The Papacy at Avignon. - In the early years of the fifteenth century, at a time when the revival of learning was just beginning, events of a very different sort were occurring which had an important share in preparing the way for the great religious revolution which brought the age of the Renaissance to an end. A great change in the position and character of the papacy had been brought about as a result of the quarrel between Boniface VIII. and Philip IV. of France. Boniface entertained the highest jdeas of the rights and duties of the pope in the world, the logical conclusion of the position created by the great popes, Gregory VII. and Innocent III., but he found that decided changes had taken place in the last few generations. Strong national governments had been forming, and these disputed his claims to authority, especially those of France and England. The conflict with France was a bitter one, and it resulted in the death of Boniface. Shortly afterward Philip IV. secured the election of a French pope, and persuaded him and his followers in succession to leave the city of Rome and to take up their residence in Avignon on the Rhone, where they came almost completely under the influence of the kings of France, with the result to make the other states, especially those that were on friendly terms with France, suspicious of the motives of the popes and reluctant to obey them as formerly.

There was another result also of this change of residence which was no less important. The love of luxury and of

The pontificate of Boniface VIII., I 294-1303.

See his bulls. Gee and Hardy, 87 ; Henderson, $43^{2-}+37$.

The removal from Rome 1o Avignon. Adams, Civilization, Chap. XVI. 
The growth of luxury in the Church. Poole. II ycleffe, +3-60; l'astor, lifes, I. 53-75. see the English statutes of Provisurs and Premunire, Gee and Hardy, 103, I I2-125; Penn. Il., No. 5, and declaration of German Diet; Henderson, 437.

Popes at Rome and at Avignon, I 373. Fisher, church Histery, 250-25t; Poole, llycliffe, I $26-130$.

The effect of the schism. Pastor, Popes, I. I38-I59.

Reform illeas growing more extreme. extravagant ways of living seems to have grown rapidly in the new capital. The expenses of a brilliant court were always increasing, and new methods of enlarging the revenues of the papacy must be constantly devised. This produced of course further dissatisfaction throughout the Church. Everywhere men began to feel that the luxury of the clergy was opposed to the real simplicity of Christianity, and the demand for a moral reformation in head and members soon made itself heard, and as a preliminary step to this that the popes should retum to Rome as the divinely appointed capital of the Christian world. Petrarch gives voice to this demand in several of his Italian poems. Finally in I $37 S$ (iregory XI., under the especial influence of St. Catherine of Siema, did return to Rome.

267. The Great Schism. - On his death there was much excitement in the city. The people demanded the election of a pope who would remain at Rome, and Urban VI. was chosen. But the French cardinals were unwilling to give up the more enjoyable life of Avignom, and, asserting that the first election had been forced by the mob, they elected another pope, who took up his residence at Avignon. There were thus two popes at once. Each one claimed to be the only rightful pope, and each proclaimed the excommunication and reposition of the other.

Snch a condition of things was violently opposed to the belief of the time that the Church must be one and undivided. The people of the West were obliged to divide themselves between the two popes, and the result was great confusion and uncertinty. Govermments were influenced in their obedience mainly by political reasons, and disputes as to rights and authority were of constant occurrence. Naturally also the cost of maintaining two courts was greater than that of one, and the financial burlens kept growing heavier and heavier.

268. The Demand for Reform. - The demand for reform became londer and louder. The university of Paris took the lead in efforts to heal the schism. 'The first attempt was 
to get the two popes to resign at the same time, to leave Fisher, the way open for the election of a single pope on whom all Europe could unite. This failed through the fear of each pope that the other would gain some advantage over him in the process. Then the university and others began to advocate the idea that a general council as representing the whole Church would have a right to depose a pope, if there were any sufficient reason for such a step, and to elect another in his place.

This was an idea full of danger for the strong monarchy of the popes which had been forming in the Church since very early in its history. If it should come to be believed that a council could depose a pope who refused to resign, then there would be an authority in the Church higher than the pope, and a limited monarchy would be the result. Just at present, however, there seemed to be no other way out of the difficulty.

In I fog a council met at Pisa which had been called by some of the cardinals. It declared both the popes deposed and elected one to take their place, who took the name of Alexander V. But neither of the other popes would yield, and as each had still some adherents, and was still acknowledged by a part of the Church, while the rest obeyed the new pope, there were now three popes, and matters were worse than ever.

269. Wycliffe's Attempt at Reformation. - In the meantime this unsettling of old beliefs and this demand for a reformation in the lives of the clergy had been favorable to the rise here and there of parties who insisted upon more decisive changes. In England Wycliffe, beginning perhaps in support of the political opposition of the State to the pope at Avignon, and in demanding simpler living on the part of the clergy, had gone on to attack some of the fundamental beliefs of the Catholic Church, to insist on the right of every one to read the Bible in English, and to take, indeed, almost the same positions as the Protestants afterwards. He was protected by the duke of Lancaster during

Christian

Charch,

$25 t^{-256}$

Poole,

II jitliffe,

I3I-I37;

Pastor,

Popes, I.

$76-83$.

The danger to the papacy. Alzog, Church History, II. 922-926.

The council of Pisa increases the difficulty. Pastor, Popes, I. 178-I9I.

Wycliffe's ideas. Wycliffe's New Testament, and books from his Old Testament. editions of skeat (Clarendon).

Poole, lig'tiffe, 6I-III; Social Engrland, II. I $57^{-1} 7^{2}$. 
his life, so that the Church was not able to put an end to his teachings. They were accepted by a considerable body of people in England who are known as Lollards, and some of them encouraged the peasants in their insurrection under Wat Tyler, though this was not intended by Wycliffe.

The persecution of the Lollards. Gee and Hardy, is and I26-I39.

Wycliffe's ideas carried to Bohemia. Poole, II ycliffe, 15I-I65: Alzog, Church Histery', II. 952-967.

Religious and political reform together.
When the house of Lancaster came to the throne in England it no longer agreed with their policy to protect the Lollards, and in the persecution which followed these very soon disappeared as a party, though there is some evidence that their teachings were cherished among the common people until the time of the Protestant reformation.

270. Huss and the Hussites. - Although the Lollards were destroyed in England, the teachings of Wycliffe were carried to Bohemia, and there gave rise to a new demand for great changes, and to a violent religious and racial civil war. At the time of Wycliffe there was a close connection between the universities of Prague and Oxford, and many Bohemian students learned the doctrines of $W_{y}$ cliffe and brought his books home with them. In Bohemia John Huss became the leader of this party which, like Wycliffe's, was almost the same as the Protestant, and which was rapidly extended by the ability and influence of Huss.

There was at that time, as we have already seen, a race conflict going on in Bohenia, as there is to-day, a part of that struggle on the border line between Slav and German which runs through all history. In the mind of the Bohemian the party of Huss and of reform became identical with the party of national independence, and so drew to itself a powerful national support. Wycliffe's teachings were formally condemned by the Church, and then those of Huss, but he refused to recognize the anthority of the Church in such matters and publicly burned the papal bull as did Luther afterwards.

27r. The Council of Constance. - This was the situation, then, in the Church when a second general council met. There were three popes contending with one another; the Church was divided between them; there was a loud 
demand for moral and financial reforms ; and the Buhemian nation in open opposition to the pope was insisting upon still more sweeping changes. There was surely need of a great council if ever. It was called first through the influence of the emperor Sigismund, the temporal head of Christendom, and on the eve of the meeting of the council this call was repeated by Gregory XII., the pope at Rome whom the Church regards as the one legitimate pope. It was a large and brilliant assemblage which met at Constince at the end of $\mathrm{I}_{4} \mathrm{I} 4$, and it was thoroughly representative of the Church in the West.

The council decided that its first duty was to heal the schism and give to the Church one universally acknowledged head. It secured the voluntary abdication of Gregory XII. The other two popes, who refused to abdicate, it deposed, and their adherents withdrew their obedience. Then with some representatives of the council added to their body the cardinals elected a new pope, Martin V., and the division of the Church was at an end.

272. The Council and Huss. - Before this work, which occupied many months, was completed, the case of Huss had been taken up for decision by the council. As some of his teachings were clearly in opposition to the accepted doctrines of the Church, and as he refused to give up his right of deciding for himself or to acknowledge the supreme authority in matters of belief of a general council of the Church, he was condemned and burnt as a heretic. His friend and follower, Jerome of Prague, suffered the same fate. But the Bohemians refused to submit. Some efforts of the king to repress the national movement were followed by open insurrection. The emperor Sigismund, who shortly after inherited the throne, was able to pacify the country only after long years of bloody war, in which not merely Bohemia, but neighboring states of Germany, suffered severely. He succeeded in the end only by important concessions to the demands of the Bohemian reformers, which were made with the consent of the council of Basle.

The council of Constance. I4I 4 -Iti8.

Fisher, church History, 256-259; Poole, IIjilifi: $147-150$, I66-170.

The Church united under one pope.

Huss condemned.

The Hussites resist. See p. 249. Alzog, Church History, II. 967-971. 
One of their demands which was allowed them, the right to receive the wine as well as the bread in the celebration of the mass, had given a name to their party, that of the Utraquists or Calixtines.

The

attempted change of

Church constitution.

Adams, Ciriliation, $410-415$.

The papacy escapes this danger.

273. The Council fails to reform Government or Conduct. - In the matter of the moral and financial reform of the Church the council of Constance did not succeed so well. The rules which it adopted, it had no means of enforcing, and the temptation to abuses continued too strong to resist. The most important regulation which it passed called for the meeting of other general councils at stated intervals, to exercise a general supervision of the govermment of the Church as a supreme legislative body representing the whole of Christendom. Had this regulation been carried out it would have changed the constitution of the Church. The pope could not be the supreme head of the Church under such an arrangement, and a great degree of national independence and perhaps of local diversity of beliefs and forms would have been easily possible.

The papacy recognized the danger at this crisis of its history and skilfully prevented the growth of a system of regular councils. The comncil of Basle, which attempted to carry on the ideas of the council of Constance, ended in ignominious failure, and though the Church of France succeeded at the time, in the Pragmatic Sanction of Bourges, in securing considerable national independence, the process went no further. The reformation, which had been sought ly constitutional means within the Church, was to come a hundred years later, but it was to succeed only by means of revolution and civil conflict. 


\section{Topics}

What were the events which led to the removal of the papacy from Rome to Avignon? What was the effect on the character and position of the papacy? How did the "great schism" arise? Iluw did the efforts to heal the schism enlanger the prosition of the pupe? The result of the council of Pisa. What were the reform ileas of Wycliffe? The fate of the Lollards. Where were Wyeliffe's irleas carried on? What other influence strengthened the party of II uss? What dis the council of Constance do in regarl to the schism? In regard to IIuss? Why dirt it not succeed in reforming the Church?

\section{Topics for Assigned Studies}

Wycliffe. See references in the text. Sergeant, Wrifif. (Ileroes.) Alzog, (hurch History, II. 947-952. (ice and Ilardy, 105-112. Wycliffe's Siptom Mereses, in Famphlet library, Religious l'umphicts. (11ult.) Penn. II., No. 5.

The council of Constance. See references in the text. Pastor, I'ofes,

I. 195-207. Alzog, II. $\$ 5 \$_{-} \$_{74}$. Penm. III., No. 6. 


\section{CHAPTER IV}

THE POLITICAL CHANGES OF THE AGE

Changes of the fifteenth century.
France under Louis XI., $1+61-1483$
274. Politics become International. - The Protestant revolution of the sixteenth century was dependent for its success upon the great intellectual changes of the fifteenth century, and also upon the long-continued repression and failure of earlier attempts at reformation. But it was also dependent in no small degree for the character of its success and for its geographical distribution upon the political situation of Europe at the time. The last half of the fifteenth century was an age of transformation in the political sphere as far reaching as any of the other changes of the time. It is the age from which we must date the rise of modern international politics, the rivalries of governments, now well organized and stable, with one another for the possessions of their weaker neighbors, for conquests at the expense of one another, and even for a position of supremacy in Europe. Such rivalries had been of course foreshadowed in medieval times, when circumstances allowed, but they had been the occasional and not the ordinary concern of the governments. In the last years of the fifteenth century was laid the foundation for the rivalry between France and the house of Hapsburg which lasted for centuries and involved Europe in many disastrous wars. The beginning was in the conflicting claims and interests of France and Spain.

275. The Condition of France. -- We have seen how France emerged from the Hundred Years' War with England under Charles VII. with the monarchy almost absolute, and how the next king, louis XI., defeated the efforts of the 
great nobles and princes to destroy the royal authority, as well as those of the duke of Burguncly, Charles the Bold, to form an independent kingdom between France and Germany. Louis XI. had seen clearly enough that the interests of France and Spain abroad were likely to lead to a collision between them. In his efforts to watch the plans of Spain and to prepare to meet them, he had done much to introduce the machinery of modern diplomacy, especially that of resident foreign ministers. But the domestic problems of France were still so pressing during his reign, there was still so much to be done to consolidate both the kingdom and the royal power, that he was not free to throw his whole strength into a foreign war.

276. The Creation of Spain. - The same thing was only a little less true of Ferdinand of Spain. His reign was much longer than that of Louis and continued on into the sixteenth century and the time of open war, but during the first years of his rule he was occupied with the same problems as the king of France. The double process of conquering all the territory of Spain from the Moors and of uniting all the Christian kingdoms into a single one, which had been going on for so many centuries, was to be completed. In 1492, the year of the discovery of America, the last Moorish kingdom, Granada, was annexed. Already by the marriage of Ferdinand and Isabella, the two largest Christians states, Castile and Aragon, had been brought together. Only in 15 I 2 was Ferdinand able to seize the Spanish half of Navarre. Portugal he never obtained, though he laid skilful plans through the intermarriage of the royal families to bring about the union in time.

In the other direction, in his efforts to form a centralized and absolute monarchy, he did not come so near complete Absolutism

created. success, but he did much more than to make the beginning. During the lasi century there had been much anarchy in Spain. Under the strong government of Ferdinand and Isabella this was brought to a speedy end. The influence of the great nobles in public affairs was reduced. The

The reign of Ferdinand, I $479-1516$. Conquest and union. 
Economic mistakes of intolerance. Prescolt, Ferdinand and Isabellal, Pt. I., Chap. XVII., and Pt. II., Chap. VIl.

Spain, the first great power of Europe.

lawyers were called in to take their place. Their castles were destroyed unless they served the national defence. Many robber barons were severely dealt with. The sovereigns also formed a virtual alliance with the league of the cities, and thus secured a strong support against the nobles and a military force independent of the feudal levies which proved of considerable value for a time, as in the conquest of Granada. Over the national Church of Spain, Ferdinand and Isabella also secured control and the right of making nominations to its higher offices.

\section{Result of Ferdinand's Policy, Remote and Immedi-} ate. - One serious mistake of policy was due to the narrowness and intolerance of the age. In 1492 all the Jews who remained faithful to their religion were ordered to leave the country. They were very numerous in spain and added much to its wealth. A little later the unconverted Moors of Granada were expelled in the same way, though they had made a garden of the land. These were hard blows struck at the economic prosperity of spain, but the effects were only slowly felt, or were for a long time concealed by the artificial sources of wealth which were at the same time opened in America.

In that generation Spain sudienly rose from a group of weak and unorganized states to be a powerful monarchy, and the first aspirant for a European supremacy. Ferdinand saw clearly that France would be the most dangerous rival of Spain for this position, and the chief object of his foreign policy was to mite the interests of the other great states of Europe with those of Spain and so to combine them all against France. The marriage ralliances which he formed to further this policy with England and the house of Hapsburg exercised an influence over later history such as few royal marriages have done.

The policy of 278. England. - In England the third quarter of the Henry VII. fifteenth century is filled with the Wars of the Roses, which
Green, English closed in 1485 with the coming to the throne of Henry VIII. of the house of Tudor, who united the warring factions by 
his marriage with Elizabeth of York, daughter of Edward IV. The chief object of his reign was to secure the permanent possession of the crown in his family, and it was more this than any plans of active interference on the continent that led to the Spanish marriage which was to prove so eventful in the history of England. His oldest son, Prince Arthur, was married to Catherine of Aragon, the daughter of Ferdinand and Isabella, and on his death soon after she was married again to Prince Henry, who became the heir to the throne.

279. Germany. - Germany remained in this age as powerless as before, but the house of Hapsburg was rising rapidly to a European position. Already in possession of extensive territories in southern Germany and just securing hereditary possession of the imperial crown, it secured in two generations a most remarkable extension of its power by its fortunate marriages. Maximilian I. married, in 1478 , Mary of Burgundy, daughter and heiress of Charles the Bold, and thus obtained the rich provinces of the Netherlands, and their son, Philip, married Joanna, daughter of Ferdinand and Isabella. By these two marriages all the great dominions of Charles V. were brought together, and the idea of a world empire almost realized.

280. Italy. - Italy was the first battlefield of the rival powers, the scene of the first in that long series of struggles for supremacy on one sille and for balance of power on the other which the nineteenth century has scarcely seen ended notwithstanding the rise of new and larger interests. Italy taken by itself was at this time the scene of a conflict for a local balance of power which was in miniature like that of Europe. It was still divided into numerous small states, under governments of widely different sorts, and intensely jealous of one another. These states maintained little armies of professional soldiers commanded by adventurers, the condotticri, and occasionally engaged in wars, which their soldiers had a way of making not very bloody. But if possible they preferred to gain their ends by the methods

The scene of division and local conflict. Johnson, Periods, 7-I4.
$67-77$;

Moberly,

Eilly

rudurs

(Epochs);

Gairdner,

Hemy lTl.

(Macmillan).

Foreign

policy,

Chap. IX.

The house of Hapsburg becomes a European power. Leger, AustroHungary, $251-255$. 
of diplomacy and intrigue, and in these methods Italy was the schoomaster of Europe. Nachiavelli, who was for a long time the representative of Florence, was one of the first great diplomatists of modern history.

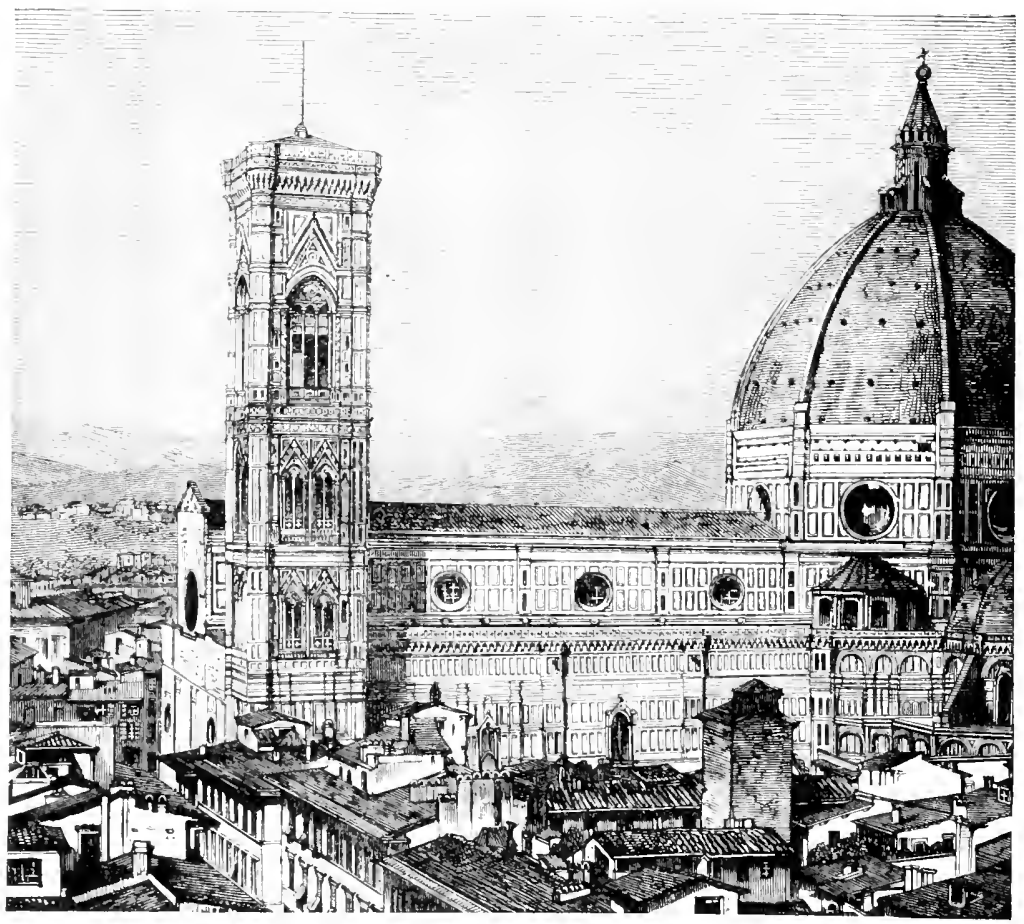

THE DTOMO, FLORFNCE

28r. The Five Leading States of Italy. - Five states of Italy are of especial interest in this opening period of interVenice. national politics. Venice, rich and powerful, but before the close of the age to undergo the ruin of her commercial monopoly, was trying to form a continental dominion in northeastern Italy, and so was intimately concerned in the 
course of local politics. In Milan, Ludovico the Moor was Milan.

plotting to secure the succession in place of his nephew, the rightful duke, and so was anxious for any ontside assistance possible. Florence was under the Medici, but was the scene at the close of the century of great popular excitement aroused by the passionate and eloquent preaching of Savonarola, who proclaimed a great religious revival, the necessity of righteous living, and the coming of the foreign invader as the scourge of God upon the wicked, and demanded the restoration of political liberty to Florence. In the States of the Church the situation was especially interesting. The popes of the last part of the fifteenth century looked upon the papacy rather as an opportunity for themselves and their families than as an office of high responsibility to Christendom. Alexander VI., who was pope at the beginning of the struggle between France and Spain, is an extreme example of this view of the papal office. His ambition was to build up in central Italy out of the lands of the Church and such others as could be joined to them a kingdom in the permanent possession of his family, strong enough, it might be, to absorb all Italy and to protect it against the pretensions of the foreigner. This he almost succeeded in doing. Cresar Borgia, with great political skill but by utterly unscrupulous and criminal means, ably seconded the plans of his father, the pope, and did found a very promising begimning of such a state, only to see it break to pieces in his hands on the death of his father. In the south the kingdom of Naples, or the continental half of the kingdom of Sicily, was held by a branch of the house of Aragon, but was claimed by both France and Spain and was the immediate object of their rivalry.

282. France begins the Struggle. - Before Ferdinand of Spain was ready to open the conflict France had made the first move under the young and visionary Charles VIII., who dreamed of restoring the Eastern Empire and the kingdom of Jerusalem by driving out the Turks, and who hoped to find in southern Italy a base of operations for this exten-

Florenee. Maehiavelli. Hist. of

Hiterince (Bohn), Bk. VIII., Chap. Vil. Armstrong. Lorenzo de Medici (Heroes). The States of the Church.

Naples.

The reign of Charles VIII., I $483^{-1} 498$. Masson, Medictal France. 304-3It: Zeller, X. 
sive enterprise. Charles VIII. had succeeded his father Louis XI. at the age of thirteen. His elder sister, Anne of Beaujen, had acted as regent with great ability for some years. She overcame easily an insurrection of the great nobles led by the duke of Orleans, the last danger of the sort which threatened the crown for almost a hundred years. She defeated an attempt of the Estates General to recover something of their lost power, and finally she married the young king to the heiress of the duchy of Brittany, the last of the great feudal states of France proper which had not been absorbed in the crown.

The temptation in Italy. Symonds, ige of De'spots, Chap. X.
Rapid success of the French. Johnson, Piriods, I7-25; Duffy, Tuscall Republics, Chap. XXVI. ; Commines, Memoirs, Bk. VII.
As the result of the vigorous policy of the last two reigns, continued by his sister, Charles VIII. found himself at liberty in $\mathrm{I}+9+$ to employ all the resources of France in asserting the right to the kingdom of Naples which he had inherited from the house of Anjou. The situation in Italy seemed especially farorable. From many sides came invitations to him to interfere. Ludorico the Moor hoped to profit from any change. Saronarola was anxious for the appearance of the "scourge of God." Enemies of the Borgia family wished to use the French to ruin the plans of Alexander VI.

283. The First Invasion of Italy. - Charles crossed the Alps late in the summer at the head of a brilliant army, with the largest train of artillery which had up to that time ever been brought together. His success was rapid and complete. At Milan he was well received, and soon after his departure the young duke died of an opportume fever. Florence dicl not find much favor at his hands, for he gave to Pisa its liberty and restored to power the Medici, who had been expelled by the people under Saronarola's lead. At Rome he trained his cannon on the castle of St. Angelo, forced the pope to grant him the investiture of Naples, and held Cæesar Borgia for a time as a hostage for his father. Naples fell into his hands without a battle, and he assumed there the imperial insignia and called himself king of Jerusalem. 
The fate of his expedition is typical of that of all the French expeditions of the period. Speedy successes were followed by just as speedy a reaction and the loss of all. Italy rose behind his army. The pope, Venice, and Milan formed a league against him, with the support of Maximilian of Austria and Ferdinand of Spain. The king's army cut its way through to France, but the force which had been left to hold Naples was driven out at once, and nothing remained of the conquest so easily made.

284. A New French Claim on Italy. - Charles VIII. was killed by an accident before he was able to repeat the attempt, and was succeeded by his cousin, Louis XII. Louis had a new interest in Italy, for through his grandmother he claimed the rights of the Visconti family to the duchy of Milan. It was the attempt of Louis XII. to assert his rights in northern and southern Italy that brought the great powers of the world together for the first time in combinations and wars to maintain the balance of power.

The new king began the undertaking at once. Milan was quickly overmn, and Ludorico the Moor died soon after in prison. Then an arrangement was made with Ferdinand the Catholic for a division of Naples. The French army did the work of conquering the country, and in as short a time as on the invasion of Charles VIII. But Louis was no match for Ferdinand in promising one thing and intending another. The Spanish suddenly claimed the whole, and though the French fought for their share, they could not keep it.

285. Rapid Changes in the Italian Situation. - Milan was not held much longer, but its loss illustrates the rapid turns of Italian politics. In $\mathrm{I}_{5} \mathrm{O} 3$ Alexander VI. died and was succeeded by Julius II., who was hostile to the Borgia family, and whose great ambition was to form the papal states into a strong monarchy, which he finally accomplished. These plans brought him into conflict with the Venetians, who had occupied some of the papal lands, and who also held some territories belonging to the duchy of Milan. Julius easily

Louis XII. the victim of the papal policy. Johnson, Periods, 54-78. 
formed the league of Cambray with France and Austria to humble Venice. Louis XII. again did the fighting, only to find, after the Venetians had submitted, that the tables were turned against him once more, for the pope formed the Holy League as soon as the French seemed too powerful in Italy. Venice, Spain, England, and Austria united with him. The French were beaten in Italy, and the Sforza family returned to Milan, while Ferdinand seized Navarre, and Henry VIII. invaded France, where he won the somewhat absurd Battle of the Spurs. Louis was compelled to yield, and to give up his claims upon Italy.

A new world empire.

Elements of weakness in the empire of Charles $V$.
286. The Dominions of Charles V. - Louis XII. died within a few weeks of this treaty, and the next years saw a great change in Europe. The thrones of Spain and the Empire became vacant and were united in the possession of Charles V., the grandson of both Ferdinand and Maximilian, who held at the same time the Netherlands, the Two Sicilies, and America. The irlea of a world monarchy, which Christentlom had so long cherished, and the plans of Ferdinand the Catholic for European supremacy seemed about to be realized together. In reality the conditions were prepared for a long and evenly balanced conflict. The three strongest states of Europe were ruled by young, able, and intensely ambitious sovereigns, - Henry VIII. of England, Francis I. of France, and Charles V., - and the Protestant reformation was just beginning.

On the map of Europe the dominions of Charles V. seemed like a reconstruction of the Roman Empire, but their real was far less than their apparent strength. They were widely separated from one another, and it was not easy to maintain secure communication between them in time of war. Germany was sharply divided into two hostile parties and constantly on the verge of civil war. The title of Emperor was a great dignity, but Charles V. would have been stronger against his enemies if he had possessed the territories of Austria and left the Empire to some one else. That he had Austria, indeed, brought against him one most 
dangerous enemy; for the Turks, now for more than half a century in possession of Constantinople, had already begun to push up the Danube valley, and the defence of central Europe against their victorious advance must make its last and most desperate stant around Vienna. On the other

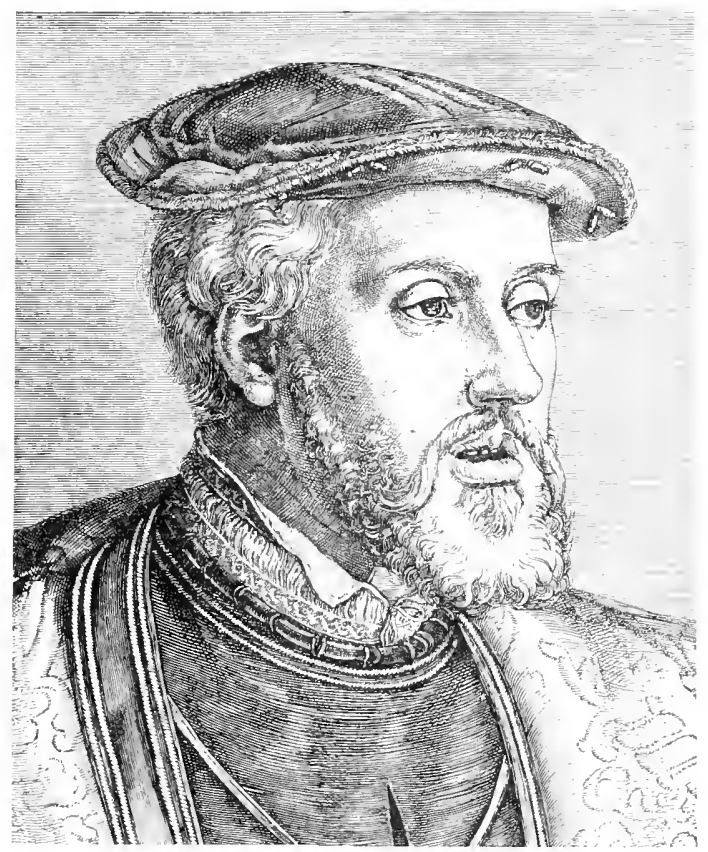

THE JMPEROR CHARLES V.

hand, France held all its strength and resources closely concentrated in the hands of its king, and, in the actnal condition of things, she was an even match for the power of Charles V., which seemed so much greater.

287. The Imperial Election and its Results. - On the death of Maximilian I., in $15 \mathrm{I} 9$, the three yomg kings of England, France, and Spain were rivals for the election to

Three rivals for the Roman crown. 
Johnson, the imperial crown. The German princes did not fully Periods, I29-137; Seebolim, Revolution, 103-106; Häusser, Reformation, 32-4I; Janssen, German People, II. 263-284.

The danger to France. trust any one of them, and would have preferred to elect one of their own number, Frederick the IIise of Saxony, the sovereign of Luther, but he thought himself too old or was too wise to accept so heary an honor in such perilous times. The election was then made in favor of Charles of Spain, who became, as Emperor. Charles V.

This election meant of course war between Charles and Francis. It would have meant war if Francis had been elected. But as things were, the situation might well seem to threaten the existence or at least the unity of France. The dominions of Charles extended along its whole frontier, both east and south. The duchies of Brittany and Burgundy had been only lately annexed, and Ferdinand had at one time forced Louis Nill to agree to give them up. Henry VIII. had still some hopes of recovering the old English possessions in France. In Italy the conflicting claims of the two sovereigns would have led to war even if the greater rivalry of European position had not existed. This war was the first stage in the conflict between France and the

More than two centuries of rivalry between France and Austria.

Francis I. in Italy, and the results for France. Kitchin. France, II. I75-183; Zeller, Xili. house of Hapsburg which dominates all the international politics of Europe from the beginning of the sixteenth to the end of the eighteenth century, and which has affected so disastrously the position of both powers in the world of to-day. For Charles and Francis the immediate object of contention was Italy.

288. France still seeks Dominion in Italy. - Already, immediately on his accession in I $_{5}$ I 5 , Francis I. had taken up the plans which Louis XII. had given up in discouragement. He had invaded Italy with a splendid army, beaten the fine infantry of the swiss, who were in the service of the duke of Milan, in the great battle of Marignano, and at once occupied Milan. Francis was now completely master of northern Italy, but his victory had given him other advantages of great importance in the history of France. IVith the Swiss he made the so-called "Perpetual Peace," by which their soldiers entered the service of France. It 
was perpetnal until the French Revolution destroyed it with almost all other existing arrangements. With the pope he made a concordat by which the Pragmatic Sanction of Bourges was so modified that the control of the French Church passed into the hands of the king. This was the foundation of the later "liberties of the Gallican Church."

This was the situation in Italy at the imperial election in I5 I9 But in the meantime a series of events of another sort had begun and was proceeding rapidly in Germany, which introduced a new complication. The demand for a reformation in the Church, which had now been making itself heard for two hundred years, had found a new leader, and in his hands; as in the case of Wycliffe and of Huss, the movement was not confining itself to a demand for the reform of abuses, but was going on to attack some of the doctrines held most fundamental by the Church. The attack in this case, however, was far more dangerous than those of a hundred years before.

\section{Topics}

The rise of international politics. What kept Louis XI. occupied in France? How was Spain created geographically? What changes in government were made by Ferdinand? I His foreign policy. Results of his reign for Spain. The pulicy of Ilenry VII. The two great marriages in the house of Hapsburg, and their results. Why was Italy the object of contention among the great powers? Its leading states. How was the struggle for Italy opened? The invasion of Charles VIII. Louis XII.'s new claim and his invasion. The policy of Julius II. What dominions were united under Charles V., and how did each come to him? Why was his empire less strong than it seemed? The election to the Roman Empire in 1519. How was the position of Charles V. a danger to France? What did Francis I. accomplish by his first invasion of Italy?

\section{Topics for Assigned Studies}

Louis XI. of France. See references on p. 233. Commines, Nemoirs. (Bohn.) Character of Louis, Chaps. X-XIII. Zeller, IX. Willert, Reign of Louis.$\%$ (Rivington.) Kirk, Charles the 
Bold. 3 vols. (Lippincott.) Louis at Peronne, Willert, I3 I- $^{-}$ I39. Commines, Book II., Chaps. VII.-IX.

Ferdinand in Spain. Burke, History of Spain. Vol. II. (Longmans.) Mariejol, L'Esfagne sous Ferdinand et Isabelle. (Paris.) Prescott, Ferdinand and Isatella, I., Chap. VI. Johnson, Periods, 9I-IO6.

\section{The Genealogy of Charles $\mathbf{V}$}

Austria. The Netherlands Aragon and the Castile and Maximilian I., = Nary, d. I 482 .

'Two Sicilies. America.

d. 1519 .

1. 1519.

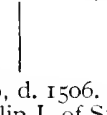

Philip, d. I 506. Called Philip I. of Spain, after the death of Isabella.

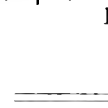

Ferdinand VII., = Isabella, d. I504.

d. 15 I6.

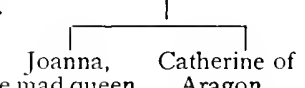

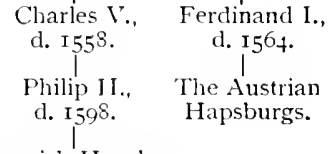

The Spanish Hajsburgs. 


\section{CHAPTER V}

\section{THE REFORMATION OF IUTHER}

289. Luther's Theological Beliefs. - Luther had been led by a most earnest religious spirit to give up the study of the law and to become a monk. In the cloister he had been led by a strong philosophical tendency of mind to examine most carefully the foundations of theological belief. As a result he had adopted the system of St. Augustine, the patron saint of the order of friars which he had entered. To Luther the doctrine of "justification by faith" seemed to be the corner stone of this system, and this doctrine, most earnestly and intensely held, seemed to call upon him to cry out against one of the greatest abuses of the time. This was the preaching which frequently accompanied the sale of indulgences, and which was often an abuse also in the sight of the current theology of the Church.

290. Indulgences. - A letter of indulgence was a written document, granted by some one in authority in the Church, by which, in view of some pious act, the temporal penalties of $\sin$ were said to be remitted or changed in character in favor of the holder. The letter itself, which was written in Latin as an official document of the Church, stated that the remission was of no avail without due repentance and forsaking of sin. For three centuries or more, it had been customary in the Church to grant these letters in return for donations of money to be applied to charitable uses or to advance the interests of the Church, on the theory that the gift of alms was a pious act which might take the place of penance in other forms. Of course such a source of

Justification by faith. Köstlin, Luther, 28-56; Adams, Ciriliation, $+20-433$.

What an indulgence was. See translation of an indulgence of I 454 in Scribner's Monthly, XII. 80 (May, I876). 
revenue was a great temptation, and subject to glaring abuse in times of general moral decline, and in later times the granting of indulgences in return for donations of money has been discountenanced or forbidden by the Church.

Popular misconception of indulgences.

Chaucer's Prologue', lines $669-714$. The ninetyfive theses concerning indulgences.

Intellectual preparation for revolt.
It is certain that the practice was popularly very much misunderstood. Few could read the language in which the letter was written. The ignorant thought that the payment of money was all that was required, and also that they could in this way escape the eternal as well as the temporal penalties of sin. Whether the preaching of Tetzel, who was selling indulgences in the neighborhood of Wittenberg, encouraged these misconceptions or not is a matter of doubt; but if he was not one, there certainly were many unscrupulous agents who took every advantage they could of the popular belief, as Chaucer seems to have thought when he wrote the "Canterbury Tales" in "Yycliffe's time.

29r. Luther posts his Theses. - In October, I5 I7, following a university custom, Luther published a general challenge to debate on the subject of indulgences by posting on the door of the castle church in Wittenberg, ninetyfive theses, or propositions, which he offered to defend against all comers. In these theses he attacked the abuses and proclaimed what he believed to be the true doctrine. 'They were written in Latin and were addressed to the university world, but within two weeks they hal been made known to all Germany. The current of discontent with the moral and financial wrongs which the masses believed they were suffering from those who had control of the government of the Church harl been so long held back that when the way was opened its depth and strength surprised the world.

The intellectual changes which had taken place by this time were also a preparation for a widespread revolt against the Catholic Church. Not only had men acquired the habit of questioning authority and of looking upon old beliefs with doubt, but also they had grown accustomed to intellectual independence and to new and strange ideas. The progress of classical learning, also, especially in the work which Eras- 


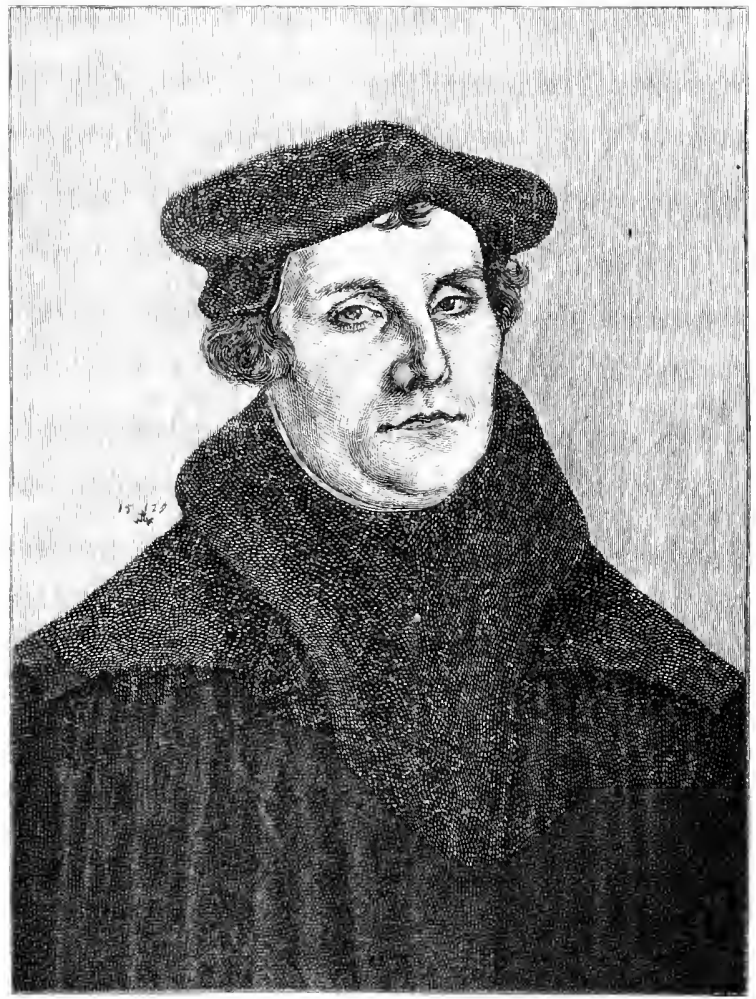

MARTIN LIIIFR 
mus had done, bat fumisherl the refomers in easily accessible shape the matcrial for attacking the historical reams of the papary.

Luther at lissl intends Hi) : : volutish. Kivilin, J.ellere, $1,5-1,1)$ : fohosem, lirind, 153157.

l'hereal yuestion wats atuthorily or pivate: judgment.

The steps of luther's progress.

292. Luther gradually led to Open Rebellion. - Still luther was himself surprised by the effect which the publication of his theses harl produced. The had up to this time intemled no revolt against the Church, and he was for a long tine uneonscions of the result towards which things were tenclings. Ciralually be was led on by the skilful attacks which were marle on the weak peints of the theses to take one position after another until he found himself in olen redellion.

The real test question, and that which leel to the final breach, was that of the infallille autherity of the Church and of the pepe. The dextrine of the infallibility of the pose was not at that time formally hekl by the Church, though it was practically the belief of a great many churchmen, but it was universally hede that the ('hurch was infallible when speaking through a gencral comeil, like that which had conclement fohn Huss. lonther would no doubt have anreed to this at the tine be prosted the theses.

(In this puestion latluer was by alegrees forced along to a position of complete opposition to the Church. finst, in the year after the pesting of the theses, in a conference

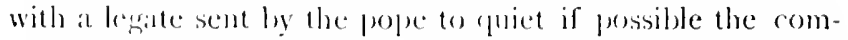
motion whinh hat arisen in fiemany, he asserted that the pepe might be in crom and that he woukd be if he was not in arcorcl with the bible. Sccombl, as the result of a great debate at leipsic: with I)r. lick, he was forced to arlmit that a gencral anoneil of the Church coukl make a wrong decision and that ene hat ardually done so when lluss was conclemnerl. This was in the year in which Charles $V$. was cetected cmperor.

The declata- In the smmmer of the next year, the pope, I eo X., issued lis, of war. a bull in which he annombeel that lather would be excommumicated if by the midlle of the next winter he had not confesiser his crors amb hecome reconciled to the Church. 
This was the bull which lather puldicly buned in Wittenberg in lecember of 1520 . This act was a kind of open ilerdatation of wat, but it dis mot make luther any more of a relel against the authority of the church than his earlier declarations harl alone.

\section{The Protestant Position in Regard to Authority.}

In taking this stand against the infallibility of the Chureh, Inther diel not intend to deny the existence of an infallible anthority in matters of religion. Ile, ancl most of the carly I'rotestants, believerl that the absolute truth eould be known and dertared loy the bocly of the belicvers, though the actual position in which they stomel with reference to the Catholic (Bumreh was inconsistent with this leclicf. What they really asserted in that position was the right of any one man to determine for himself what is the truth, uncler his responsibility to (iod alone. Prawtically the l'rotestant worled arted on this principle, for it divicled inte many parties on prestions of theology and interpretation, and it has continted rlividerl ever sine At first most of these parties were bitterly hestile to one another because they thought their differences so very impertant. Recently they have come very generally to recognise the fare that the proints of likeness are more munerons and important than those of difference, and to art areorlingly.

294. The Diet of Worms. - The first l liet of the limpire under the new emperor, Charles V., was summened for the spring of 1521 . (iermany hoperd that here would be settled many guestions of political as well ats of religious reform, but the result was disappointing. In truth, Chatrles was not alse to look at (iermam guestions purely from the cicrman point of view. The general interests of his wide dominions were always in his mind, and this must be remembered in order to mulerstand his relation to the Reformation. $\Lambda$ the time of the mecting of the liet of Worms, the difficulty which secmerl the most pressing wats the position of the French in northern Italy, which firancis I. was still holding. to the pope this was an cepual diunger. For the moment

The: actual and the. logrical position in (c)nflicel fur a time. Sice Arlantus, cientisalian, $43 \%$. I. I.

Cliarles V. really controllied loy llue intertnational sithationt. ( )n mifuenee of prolitices $1 \mathrm{~m}$ lhe Retortuat. lion, sie kanke. lepeses, (lolin). lik. I., Clap. III. 
pope and emperor each had need of the other, and their desires and interests were in harmony with reference both to Germany and to Italy.

Luther before the Diet, 1521 .

Charles V. personally opposed to Protestantism.

War makes five years' delay.
Luther was summoned to the Diet under a safe-conduct, and had no hesitation in going, though his friends feared for his safety. At the Iliet, when called on to acknowledge the opinions which he had tanght, he asked for a day's delay, and then boldly reaffirmed his position, saying that he could not do otherwise. The sentence of the Diet placed Luther under the ban of the Empire and ordered his books to be destroyed. On his return from Worms, Iuther disappeared, haring been secretly carried by his friends to the castle of the Wartburg, near Eisenach. Here he remained nearly a year, writing and translating the New Testament.

295. No Opportunity to enforce the Edict of the Diet. This decision of the I liet against Luther, though the result of an understanding between Charles and the pope, was not opposed to the real opinion of Charles. He never had any sympathy with Luther's icleas, and if his hands had been free to do as he would have liked in Germany, he woukl have put an end to the Reformation by force. The new teachings owed their long freedom from attack and the opportunity which they had to spread and strengthen themselves in Germany to the political clifficulties in which Charles was involved elsewhere.

It was five years after the l liet of Worms before the emperor came to a time when he eren thought that he could take decisive measures against heresy in Germany. War had begun between him and Francis 1 . in the spring of 1521. Towards the end of the summer the troops of the emperor and the pope drove the French out of Milan. In the spring of the next year Henry VIII. of England declared war against France, and in the same year Charles of Bourbon, constable of France, a relative of the king's, and the most powerful noble of France, made angry by a dispute over an inheritance, joined Charles and Henry in war upon 


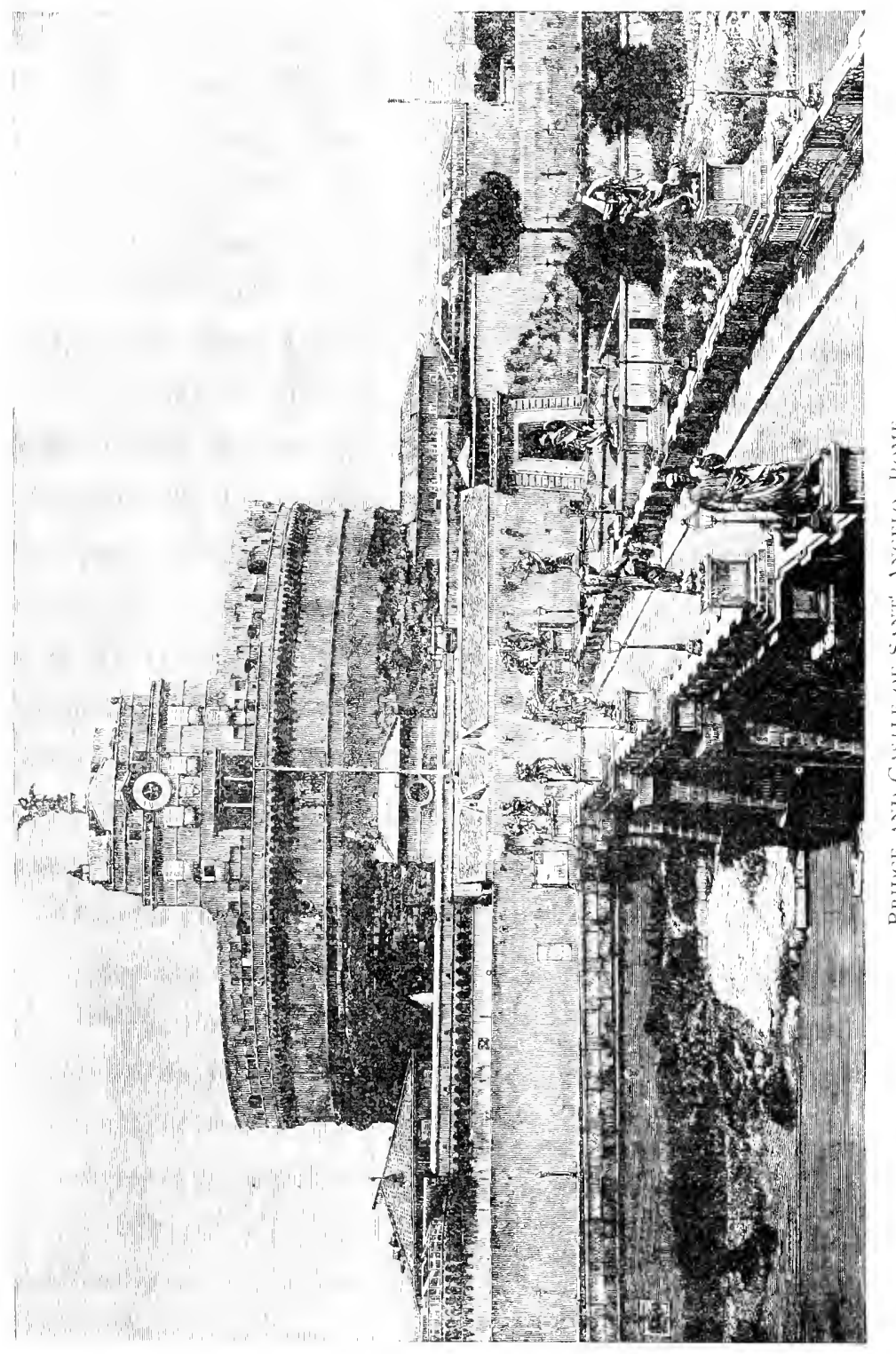


Francis and in a project to partition his kingdom among them.

The French lose and recover

Milan. Johnson, Periods, I72-I 76 ; Kitchin, France, II. I9I ff.

Francis I. captured by the Spanish.

Kitchin, France, II. I99 ff.

Charles 1 . demands too much. Johnson, Periods, 181-18.4 ; Häusser, Reformation, 106-112.

The emperor's plans against heresy interrupted.
296. Events in Italy. - It would seem as if the odds were entirely against France, lout the allies accomplished nothing in proportion to their strength. The French were indeed driven entirely from Italy, with the death of the Chevalier Bayard, one of the last and finest products of the age of chivalry, but an attempt to carry the war into southern France by Charles of Bourbon was not successful. He was forced to retreat before a great army with which Francis now adranced. By a skilful march the French passed by their enemies, appeared suddenly before Milan, and forced the Spanish garrison to abandon the city without a blow.

This was a good begimning for the recovery of Italy, but the French success went no farther. Francis began the siege of Pavia. Bourbon advanced against him with a large army, and in the battle which followed the French were totally defeated and the king was taken prisoner.

297. The Treaty of Madrid. - The battle of Pavia was in February, 1525. For nearly a year Francis remained a prisoner in the hands of Charles. The terms which the emperor demanded for his release were so high that Francis could not bring himself to consent to them. At last, worn out with his confinement and seeing no prospect of any more favorable terms, Francis yielded and agreed to the demands of Charles. The treaty of Madrid was signed in January, 1526. Francis engaged to abandon all his claims in Italy: and to surrender Burgundy, Flanders, and Artois to the emperor. Had Charles been satisfied with reasonable conditions, he might have secured their fulfilment, but as it was Francis had no intention of keeping the treaty.

298. Enforcement of the Edict again Prevented. - For the moment, however, Charles thought that all opposition to him in Europe was at an end, and he immediately sent word to Cimany that he should take measures at once for the suppression of heresy. Before he could do this he became 
aware that the situation of things in Europe had decidedly changed. The pope, - now Clement VII., one of the Medici, and greatly interested in Italian politics, - the Venetians, and Francis I. had formed a league against him, and war was about to begin.

To meet this new combination Charles would need all his resources, and could not afford to run the risk of a civil war in Germany. In consequence the Diet of Speyer, which met in June of 1526 , instead of renewing the edict of the Diet of Worms, declared that each state might conduct itself in regard to the religions question as it "thought it conld answer to God and to the Emperor." This meant that for the present the edict of Worms was suspended, but that the time might come sometime when the emperor would call the States to an account for not obeying it. This was, however, the best that could be expected, and under this arrangement a German army largely made up of followers of Luther, and commanded by one of them, entered Italy, in 1527 , stormed the city of Rome, and made the pope a prisoner. Before Charles could draw any advantage from these events, a new French army inraded Italy, took possession of many cities in the north, passed Rome, and began the siege of Naples. Then fortune turned again. The Genoese abandoned the French side, and a plague reduced the French so greatly that the siege had to be given up, and finally only a small fragment of the army returned to France.

299. Peace between France and Charles V. - Now all parties were tired of the war. In June, I 529 , the treaty of Barcelona was made between the pope and the emperor, and in July that of Cambray, or the Ladies' Peace, between Charles and Francis. Before these treaties were actually signed. Charles had concluded that the time was at last come when he conld deal with the religious difficulty in Germany according to his will. The second Diet of Speyer was summoned to meet in February of that year. For the moment nothing interrupted the emperor's plans. The Diet decided, by a majority vote, that the decision of the first

The first Liet of Speyer. The edicl of Worms suspended. Ranke, History of Germany, Bk. IV., Gap. II.

The sack of Rome, Vialde $z$ account. Seebohm's Hotestint kezolution, 157-I60; Johnson, Periods, 186.

The treaty of Cambray.

The second Diet of Spever. Ranke, 
Germany, Diet of Speyer should be no longer valid, but that the edict of Bk. V., Chap. V.; Häusser, the Diet of Worms should be enforced at once.

héformation, $113 \mathrm{ff}$.

"The " Protest."

Fisher, Reformation, I 7 : extract, Schilling. Quellenluch, 76 .

Luther opposed to fanalicism.

300. The "Protestants" and their Strength. - Against this action of the Diet, the supporters of Luther entered a formal protest, declaring that in matters of religion the majority had no right to bind the minority, "for every one must give an account of himself to God." It was from this act of protest that the name "Protestants" was given to those who followed the teachings of Luther. It was signed by five princes, the chief being Saxony, Brandenburg, and Hesse. and by fourteen cities, and this represents the strength of Protestantism in Germany ten years after Luther's open breach with the Church.

During these years the new doctrine, besides making progress among the people, hal passed through its age of trial, from the elements of fanaticism and revolution which accompany every great change. While Luther was at the Wartburg, fanatics had proclaimed extreme opinions and occasioned great excitement at Wittenberg and elsewhere in Saxony. Luther had felt it his duty to leave his retreat to put a stop to this movement.

Reasons for

301. The Greai reasant War. - Towards the end of the the peasant revolt mainly economic. Seebohm, Protestant Revolution. $59-53$, $1.40-153$. year 1524 , a far more serious danger threatened Germany. For a bundred years the peasants had been growing more and more discontented with their lot. This was partly due to the fact that in places and for individuals the burdens laid upon them by their lords had been really growing heavier. It was probably still more due to the fact that during these hundred years great changes had been taking place as a result of which they saw the condition of the classes above them greatly improved, comforts multiplied, intelligence increased, and wealth much more easily and rapidly accumulated, while they, bound down by old customs now very strictly interpreted, were not able to take advantage of these changes and had no share in the improvements taking place.

Now, as in England in the time of Wycliffe, the constant 
appeal to the Bible and the new religious teachings with their spirit of freedom, encouraged the peasants and furnished them with arguments and proofs. Open insurrection had been tried many times in the century, but now, beginning in southwestern Germany, it spread rapidly and with fury over all that part of the Empire. In many places the peasants paid their debts of suffering, now that their turn had cone, with horrible cruelties inflicted on their lords. In some of the smaller cities the artisan class sympathized with the peasants, and carried the town with them. It seemed for a time as if the revolution would be successful.

302. The Insurrection put Down. - Luther sympathized with the demands for reform which the peasants made, but with their methods he had no sympathy, and he saw that their triumph, in their present spirit, would mean the ruin of society and of his own cause. Consequently he urged the princes to put the insurrection down by force, and he did this with the impetuosity and violence of language which was natural to him when he was excited.

By degrees the princes with their organized forces took the field. Against them, so much better armed and disciplined, the peasants had no chance of success, and were everywhere defeated and slaughtered. In very few places in Germany did the insurrection result in any improvement of their condition. The slower economic forces were on their side, however, and in time gave them more rights and freedom, though in all probability their appeal to force in an attempt to hurry on the process really hindered it, and perhaps in some regions held it back entirely until the age of the French Revolution.

303. The First Attack of the Turks. - The expectation which Charles V. entertained at the second Diet of Speyer, that now the time had come for putting down heresy, was doomed to disappointment as it had been before. In this case, however, the interruption came not from France, but from the Turks.

Character of the revolt. Häusser, Reformation, 92-105: Johnson, Periods, I76-180;

Goethe, ioets von Berlichingen

(drama); the peasants' "twelve articles," Seebohm, Prot. Rev., 142 ; Penn. II., No. 6.

Position of Luther. Köstlin, Luther, 315-324.

The peasants gained nothing by trying force.

The edict of Speyer cannot be enforced. 
The advance of the Turks unites Germany.

Charles believes the time has now come.

Köstlin, luther, 402-426:

ㄱizog,

1hurch History, III. 75-87 ; lohnson, lerriods, $198 \mathrm{ff}$.

The Protestants refuse to submit.

The League of Schmalkidden and the peace of Nurembers.

The conquering age of the Turks was not yet over, though it was about to close. The last of their great sultans, Sulieman II. the Magnificent, was now reigning. He had lately overcome the Hungarians and was determined to push on into central Europe. In September the Turks appeared before Vienna, and began its siege. It was a moment of great danger for Germany. If Vienna fell, central Europe would lie open to invasion. Before this danger religious differences were suspended, and Protestant and Catholic alike prepared for the defence of the fatherland. In a few weeks, however, Sulieman found that he could not take Vienna, and retired with his army.

304. The Diet and "Confession" of Augsburg. - This was really a new trimph for Charles $V$. He had succeeded with no effort of his own over this new enemy, and he had given no promises of lenity to the Protestants. In the spring of $153^{\circ}$, he came himself to Germany, resolved now to enforce his will.

The Diet met at Augsburg. Here the emperor informed the Protestant princes that toleration would now cease, and demanded that they should obey the earlier edicts against the followers of Luther. They answered firmly that they could not do so. Charles then asked for a statement of the points in which they differed from the Catholic faith. In answer to this the first formal declaration of the Protestant belief was drawn up, the "Confession of Augsburg," and read to the Diet. In conclusion the Diet decreed that the Protestants should be allowed until the next spring to submit, and it was understood that then measures would be taken against them.

305. The Emperor's Plans again Postponed. - When spring came the emperor hesitated. Peace with France was insecure. The Turks were threatening. All through I53 I he allowed things to drift, but the Protestants had taken steps to provide for their defence. Iuther was opposed to civil war, but the princes were resolved not to yield without a struggle. In Narch they formed the League 
of Schmalkalden, promising to defend one another with all their forces. In $\mathrm{I}_{532}$, before the emperor was ready for extreme measures, came another 'lurkish invasion. 'This time the Protestant princes were in a position by their union to demand concessions of Charles, and he was constrained to yield. By the peace of Nuremberg it was agreed to suspend all hostilities until the religious differences could be settled by a general council. The Protestants then joined the emperor, and the Turks were obliged to retreat again.

Fifteen years passed before the situation changed in Germany in any material degree in the emperor's favor. The council which he had hoped to have called for a free discussion of the differences in religion he could not bring about as he desired. 'Two wars with France, in one of which the Turks took part, had kept him occupied. And in these years Protestantism had spread rapidly in north and central Germany and strengthened greatly its power of resistance.

\section{Topics}

Luther's leading theological belief. What was an indulgence? How popularly misunderstood? What dic Luther assert in his "theses"? What were "theses"? IIow were the theses received? Why? What were the steps 1,y which Luther advanced to open opposition to the Church? The Protestant position in regard to authority in the Church. What motives influenced Charles V. at the Diet of Worms? Why was the edict not enforced at once? The situation in Italy. What led to the treaty of Madrid? Why was not the edict of Worms now enforced? The first Diet of Speyer. The sack of Rome. The second Diet of Speyer. Why was its decision not enforced? The origin of the name "Protestant." What plan did the Protestant states form for protection? What did they secure in the peace of Nuremberg? How long diw this arrangement last, and its results? What led to the great peasant war? Did the peasants wish cconomic or political freelom? Character of the revolt. Its result. Why was it opposed by Luther?

The Protestants gain fifteen years. Hïusser, Reformation. I79-195: Johnson, Periods, 205-2I9. 
316

\section{The Reformation of Luther}

\section{Topics for Assigned Studies}

Luther's theses. Küstlin, Luther, \$2-94. Alzog, Church History, III. II-I5. Translation in Pemn. II., No. 6.

The Diet of Wurms. Köstlin, Luther, 222-245. Seebohm, Protestant Reziolution. (Epochs.) II5-I35. Alzog, Church History, III. $3^{6-42 .}$ Häusser, Reformation, $+2-47$. 


\section{CHAPTER VI}

THE LATEK AGE OF THE REFORMATION

306. The Reformation in the North of Europe. - Outside of Germany the whole Teutonic north of Europe had fallen away from the Catholic Church. Both in England and in the Scandinavian countries the governments had much to do with the introduction of the new forms of faith, but Protestantism had soon taken a strong hold of the mass of the people.

In England at first the change was a peculiar one. It The peculiar was the throwing off of the supremacy of the pope, but not the adoption of the Protestant faith. The personal interest of the king determined the step. Henry VIII. desired to be freed from his marriage with Catherine of Aragon, the daughter of Ferdinand and Isabella, by whom he had no male heir, and who had once been contracted to his elder brother, Arthur. Aside from motives of passion, which may have influenced him, Henry may well have desired to have the succession to the crown placed beyond the possibility of dispute, as any statesman might, remembering the Wars of the Roses, still so recent in English history.

307. Henry VIII. takes the Place of the Pope. - The pope refused to annul the marriage. But Henry was a king who was both accustomed and determined to have his own way, and the divorce which the pope could not grant him he procured from an English Church court under the archbishop of Canterbury. This act necessarily brought matters to a square issue between Henry and the pope, and by character of the first change in England. Secbohm, Revolution, Pt. III., Chap. 11.; Fisher, Reformation, 316-325: Alzog. Church History, III. 19I-202; Perry, Reformation in England (Epochs Ch. Hist.) ; Blunt, Reformation of the Church of England. degrees the papacy was deprived of all its powers in Eng- 
The "act of land. and finally the Act of supremacy was passed, by supremacy." which the king was declared to be "the only Supreme Head I 534. Gee and Hardy. 243: fenn. I. xo. s. Engiand $\therefore$ i 1 : Hoterans. on earth of the Church of England."

This step made England independent of the Roman Church. but it made at first no other change. The teachings and form of Protestantism were not adopted, and the subjects of Henry were placed in a difficult position, for he put to death on one side those who still held to the supremacy of the pope, like sir Thom More, the author of " "topia," and on the other those who farored Protestant doctrines. Gradually, howerer. these teachings, which had much in harmony with the spirit of the English nation. spread among the people. Lnter Henry himselt the Bible was transhated into English and placed in the churches to be read by any one.

Fumat VI, $1=4,-153:$ Mary i. $1 \leq 53-1538$.

3oS. England becomes Protestant. - Henry's son, Edward VI. Was still a child at the death of his iather, mit those who governel England in his name were farorable to Protestantism. so that, though the reign was short, it was one of rapid change. From it dates the English Prayer Book and the use of English in all the services of the Church. Olleen Fisher, Mary, who followed Edward, was the daughter of Henry and Fen.... Catherine of Aragon, and it was har lly possible for her to $325-331$

A.rog. (2) H.A., III. $202-20 \%$ Ienmyen. (3.2.) II:y (diama!

The rise of Cannism. Hawser. if $241-253:$ Tohnson. Find be otherwise than Catholic. Her efforts to reëstablish the power of the pope, her marriage with her comin, Philip II. of spain, and her perecution of the Protestants, which gained for her the name of " Bloody Mary", were all of no arail. and after her short reigh her sister Elizabeth had no difficulty in restoring Protestant institutions and her own supremacy in the Church. In her reign Protestantism became the religion of the great body of the English nation.

309. Calvinism. - In the meantime in the Latin kingdom of France a new phase of Protestantism had arisen which was destined to have a great intluence upon England and the Lnited siates. This was Calrinism. John Calvin, horn not far from Paris. had been educated for the profession of the law, but while still a student he had accepted the 
teachings of Lnther, and at the age of twenty-six he published a most remarkable book, "The Institutes of the Christian Religion," the first scientific treatise on Protestant theology. In $153^{6}$ he took up his residence at (ienera, where he spent the remainder of his life. T'here he was able to carry out his ideas of republican grovernment in the Church and of a state founded on the Bible and controlled by religion. Geneva became a kind of city of refuge for persecuted Protestants from all the IVest of Europe, and a training school of the new icleas in Church and State.

Calvin's was a legal mind and inexorably logical, and starting with the idea of the supremacy of Gorl's will in the universe as the most fundamental of all truths, he dereloped a system which has seemed to the modern workl, in its extreme form, - where predestination determines everything, and the individual has no true choice and no control over his own destiny, - too harsh and merciless. But it was a system which, from its very hardness, made strong men. It taught, in contrast with Luther's feeling, the silpreme duty of defending the truth and of resisting evil even in the state. This spirit of Calvinism, which will fight for the right to the death and never yield, we can trace throughout all the countries of the IVest of Europe, where the conflict was waged in the next age, in Scotland, England, Holland, and France, and in America, and we should recognize in it one of the most powerful forces determining the final results of the period of the religious wars. Calvinism. made no permanent contribution to the institutions of civil liberty. The theocratic state, taking the Bible as its law and rigidly enforcing a formal and sombre moral code, which Calvin maintained in Geneva during his lifetime, and which was attempted in some of the New England colonies, especially in the New Haven colony, passed away in the end without leaving a permanent constitutional influence. But the reinforcement which the spirit of Calvinism brought at a critical time to the hereditary spirit of the Anglo-Saxon race, in the

Calvin's teachings.

Calvin's political influence in spirit, not in institutions. 
defence of liberty and of the government of the people, must be gratefully recognized.

The Reformation in France and Holland. Fisher, Reformation, 2+2-256; Penn. III., No. 3 .

Political elements among the Huguenots.

Protestantism in Holland.

Reformation in the Catholic Church. IVard. The Counter Reformation
310. Reformation in France and Holland. - The teachings of Calvin found the way prepared for ready acceptance and great results in France. Even before Luther some of his ideas in the way of religious reform had been taught in France and had found adherents. The influence of Luther's reformation followed speedily and rapidly increased the party which had been scarcely more than begun. The government, which was really in a position to deal more consistently with such a movement than was the government of the Empire, followed no steady policy of repression, and the party of the reformers continued to grow through the early years of the period. The effect of Calvin's teaching was not merely to give to this party the reinforcement of new converts, but all the strength that comes from regular organization and clearly defined aims.

This party, which comes in time to be known as that of the Hugnenots, was naturally far stronger in France among the middle and upper classes than among the lower. In central and southern France it received a strong reinforcement from the elements representing the oller local and feudal independence of the country, and in the age of the religious civil wars has quite as much the character of a political as of a religious party.

In the northern province of the Netherlands the ground had also been prepared for the sowing of Calvin through a kind of local self-govermment in political affairs and a sturdy sense of independence among the people, who retained in many ways primitive Teutonic characteristics. The Dutch Protestants were real Puritans in belief and conduct, but like the Huguenots and the English Puritans, their importance lies in the age of struggle which follows the Reformation.

3II. The Counter Reformation. - The term "Reformation" has rather become limited in formal history to the rise of the Protestant churches, but we ought not to overlook the fact that in nearly every sense the word is to be 
as truly applied to the history of the Catholic Church in this age. The old abuses in government and conduct of which the fifteenth century so bitterly complained disappeared and have never again characterized the government of the Church as a whole. The popes of the middle of the sixteenth century were decidedly reforming popes, and the papacy has never since fallen to the hands of such a man as Alexander VI. If in some ways, in doctrine and in the monarchical tendency of the govermment, the Catholic Church emphasized the medieval tendency, it was because the body of the Church was unconvinced by the arguments of the reformers and held to the old beliefs from firm conviction.

It was the work of the council of Trent to formulate in definite statement those points of doctrine, and to establish controlling precedents for the future by its practice in regard to those points of government which the reformers had especially attacked. In belief it proclaimed the divine mission of the Church to know and teach the truth for all its members, and in government, by recognizing that the supreme legislative power rested in the pope, it completed the establishment of the papacy as an unlimited monarchy. These conclusions were not reached in the council without some opposition, and its sessions were interrupted for long intervals, partly because of the political uncertainties of the period. In general, however, the decisions of the council were in accord with the tendencies which had long prevailed in the history of the Catholic Church and which have continued to characterize it down to the present time.

3r 2. The Society of Jesus. - During the same period the revival in the Catholic Church was accompanied with the organization of many new monastic orders, of more modern spirit and methods than those of the Niddle Ages. The most important of these was the Jesuit order, or the Society of Jesus. Founded by a Spanish noble and soldier, Loyola, upon the military model, to be the army of Christ and the pope, its fundamental principle was the strict and unquestioning obedience of the soldier. In method, as compared

The council of Trent, $1545^{-1} 5^{6} 3^{2}$

Ward, Counter Reformation, Chap. III.;

Symonds, Catholic Reaction, Chap. II.; Alzog. Church History, III. $340-360$; Penn. II., No. 6.

The Jesuit order. Shorlhouse, Foin Inglesant (novel). 
with earlier monastic orders, its leading characteristic was the practice of mingling with the world in all sorts of occupations wherever infuence was to be acquired or something gained for the cause of

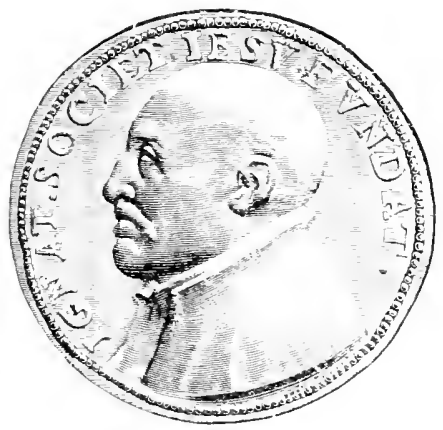

IGNALLS IOONOLA Catholicism. To education, diplomacy, and the confessional, especially to acting as the confessors of persons in positions of political activity, the early Jesuits devoted particular attention, and in all directions their efforts were of wreat value in checking the spread of P'rotestantism anl even in making some recovery of what had been lost. In somewhat later times the methods of the Jesuits excited the suspicion of all the European grovernments, and their influence has been much less than in the sixteenth century:

\section{Topics}

Just what was the change in the English Church made by lIenry Vill.? Why dir he persecute both l'rotestants and Catholics? Why was Mary naturally a (atholic? Inl Elicalseth a Protestant? The religious and pulitical iteas of Calvin. Their influence un character. Why were they suited to the Angh-Saxm race? Their influence on liberty. What combination of clements in the IIuguenot party? The character of Protestantism in the Netherlants. The reformation in the Catholic church. In the papacy. The decisions of the council of Trent. The fundamental idea and the methods of the Jesuit order.

\section{Topics for Assigned Studies}

John Calvin. Fisher, Reformation, (Thap. VII. Baird, Rise of the Huguenots, I. 198-2i6. Mlzug, Churh History, I11. 143-155 Froule, essay in shut shudies, Vul. II. I'enn. IIl., No. 3. 
The Jesuit order. Symonds, Catholic Reaction, Chap. IV. Ward, Counter Reformation, 31-46. Alzog, (kurch Ilistory, 111. 373$3 \mathrm{~S}_{5}$.

\section{Topics for Review}

An outline intellectual history of the perion.

An outline economic history of the period.

The various ways in which preparation hal been made for the Reformation.

The various earlier attempts at Reformation.

In what ways dicl the political situation in Europe protect the Reformation in Germany?

Group together all the results of the Reformation.

sketch the constitutional history of the Catholic Church in this period. 

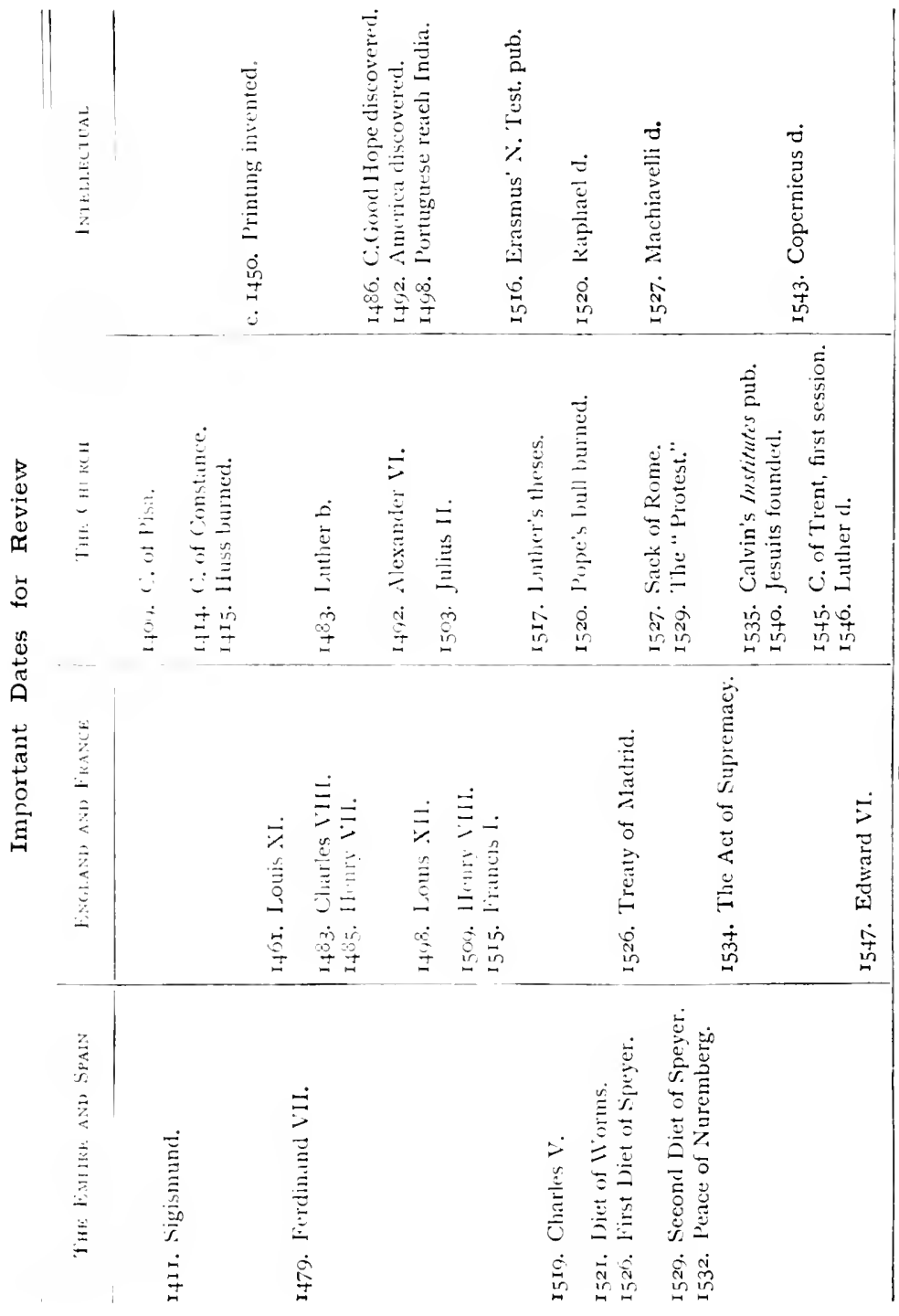


\section{PART VII}

\section{THE STRUGGLE OF THE IATIONS FOR SUPREMACY AND EXPANSION}

No reference can be made to general works covering the period of the following part which are of value for our purpose. See the general bibliography at the beginning of the volume, and the special bibliog. raphies which follow.

\section{SUMIIARY}

The age of the religious wars opened in Germany, where at the close of his reign Charles $V$, was able to begin his long-deferred attack upon the Protestants. The war was indecisive, however, and the Peace of Augsburg which closed it left so many questions unsettled that it was a truce rather than a peace. In France a whole generation was occupied by wars between Huguenot and Catholic of the most selfish character on both sides, and closed only by the accession of the Huguenot Henry IV. to the throne as Catholic king, and by the edict of Nantes, which allowed the Huguenots almost political independence in the State. In the Netherlands the efforts of Philip II. to destroy Protestantism led to a heroic resistance and finally to the independence of the northern provinces and to the foundation of a great naval and colonial power. In England the nation rallied around the Protestant queen, Elizabeth, against the attempts which were made to dethrone her, and in the struggle with Spain laid the foundations of a future world empire. The practical absolutism which they were willing to allow Elizabeth because of the national danger they would not tolerate in her successor, and when the Stuarts obstinately clung to their prerogatives, the Puritan party led a rebellion against Charles I., put him to death, and established 
a temporary republic under Cromwell. In Germany many causes of dissension between Catholics and Protestants at last led to the terrible Thirty Years' War, in which the land suffered the horrors of savage warfare from the armies of adventurers like Wallenstein, and from foreign invaders. the Danes, the Swedes under Gustarus Adolphus, and the French under Richelieu. The absolutism which had been forming so rapidly in France in the last part of the Middle Ages was completed by Richelieu, who forced the Huguenots to submission, and then the great nobles, and prepared France for a great career of foreign conquest. The treaties of Westphalia, which closed the Thirty Years' War, left Germany exhausted and the Empire a mere name, while the strength of Spain had completely decayed. When Louis XIV. assumed the government. France was the most powerful state of Europe, and there seemed to be nothing to prevent him from reaching the frontier of the Rhine and absorbing a large part of the Spanish possessions. But these plans failed through the resistance of the little republic of Holland, and though Louis was able to cripple his enemy, aided by England under Charles II., in the last part of his reign. England, rid of the Stuart policy forever by the Revolution of 1688 , united with all Europe against France in the great war of the Spanish Secession. Louis seated his grandson on the throne of Spin, but France was exhausted for a long time, and no real union of the States took place. The first part of the eighteenth century saw the rapid rise of Russia through the reforms of Peter the Great and his conquests from the Swedes and the Turks, and of Prussia through the careful husbandry of the Hohenzollern family. which prepared the way for the conquests of Frederick the Great. He seized the province of Silesia from Maria Theresa and forced her to yield it to him, and later defended its possession with brilliant energy against almost all Europe in the Seven Years' War. But, looked at in the largest way. this war was only an incident in the struggle for colonial empire between France and England which fills the century, and was settled not in Europe. but by the victories of Clive in India and the capture of Quebec in America. England's mistake in attempting to force the colonies to share the expenses of this war gave all her old rivals an opportunity to unite in revenge. and she was obliged to acknowledge the independence of the United States. A new empire was opened, however, to the Anglo-Saxon race as one consequence, by the immediate occupation of Australia. Meanwhile the corruption of the government, the enormous burden of taxation, and odious 
class distinctions, combined with the spread of a critical spirit and the knowledge of better things in England and America, prepared the way for a revolution in France. Once begun, the revolution was rapidly swept on to extremes, as it destroyed the relics of the old feudal system and the absolutism of the king. The Reign of Terror only prepared the way for a new absolutism, and in the one successful general in the war against all Europe, Bonaparte, the man was ready to exercise it. The consulship was a preparation for the Empire which was proclaimed when Napoleon seemed at the height of his power. For many years this power increased rather than diminished, but France was growing weak under constant drains, and at last the terrible losses in Russia could not be made good, and Napoleon fell. His desperate effort to recover himself which ended in the battle of Waterloo closed his history. At the congress of Vienna sovereigns and cliplomats disposed of the nations as they thought good, but the longing for free govermment and for national unity which had begum among the people in the age of revolution could not be rooted out. Revolutionary movements kept occurring at intervals all over Europe, and resulted in the grant of constitutions here and there, but final success was reached only in the great period from the close of the Crimean War to that of the Franco-Prussian. Then in little more than a decade Italy secured a national existence under the lead of the loouse of Savoy, and Germany under Prussia, and almost every State in Europe obtained a more or less complete self-government. Russia alone remained true to the old absolutism and to her traditional desire to absorb the Turkish Empire. This the Western nations combined to prevent in the Crimean War, and later in the congress of Berlin, but in the closing years of the nineteenth century the Eastern Question seemed to be losing its relative importance before the rise of world politics, clue mainly to the enormous expansion of the Anglo-Saxons, and the desire of other nations to emulate their success if possible. This world expansion of a race, and the transformation of the world itself which has accompanied it. was made possible only by the intellectual and scientific advances of the age. Rapidity of production before undreamed of demanded the widest possible extension of markets. and this was made possible in turn by revolutionary improvements in the means of communication by the use of steam and electricity. Together these things have not merely carried the most energetic and adaptable of the modern races over the whole globe, but they have led to accumula- 
tions of wealth which seem almost fabulous, and to a general dissemination of comforts and conveniences which our grandfathers would not believe possible. As history passes into the twentieth century the world seems to be on the eve of even greater transformations.

\section{CHAPTER I \\ THE AGE OF RELIGIOUS WARS}

An age of civil war.

France.

Spain.

England. 3r3. The General Character of the Age. - About the middle of the sixteenth century, a new age opens in the history of Europe. It is an age in which almost every country is involved in war - in most cases civil war, growing directly out of the Reformation, though as the period comes to an end we can see rising questions of international politics, the rivalry of nations with one another, and especially the rivalry between France and the house of Hapsburg. At the beginning of the period, France withdraws from Italy, and turns its attention to the Rhine valley, where in the end it is to pay so dearly for the conquests it makes from Germany. Italy thus left to itself falls under the practically undisputed control of the Spanish Hapsburgs. France passes almost immediately into an age of religious civil war, from which it emerges in a condition to take up again plans of national aggrandizement only after two generations. In the same years, Spain is engaged in a long and unsuccessful effort to subdue the revolted Netherlands, which would have meant the reëstablishment of the Catholic religion over a Protestant people.

During the same time also, England passed through a very critical period, in constant danger of rebellion and revolution, stimulated often by Spain, in the interest of the old form of faith, and succeeded in protecting her national independence and religion only by the exercise of the utmost vigilance and discretion on the part of the government. 
Germany opened the period of religious civil wars in the Germany. Schmalkaldic War. 'This was closed by the treaty of Augsburg, which in form established toleration for Catholics and Lutherans, but it left unsettled many causes of disagreement, and while the other nations were passing through their civil wars, the parties in Germany were watching one another with constantly increasing jealousy. At last, when the seventeenth century was well under way, the war broke out, the Thirty Years' War, the greatest and most destructive of all these civil wars, a religious war in its early stages, but changing toward the end into a war of European states. The close of the period saw also in England a great civil war between king and Parliament. a war in form upon constitutional questions, but deriving much of its character and spirit from the influence of Calvinism.

314. The First Period of the Schmalkaldic War. - In $154^{6}$, Charles $V$. was able to begin the war against the Protestants which he had been obliged to postpone so many times. 'The treaty of Crespy had given him peace with France. Francis was drawing to his end. He died in I547, and his successor, Henry II., seemed for some years to care only for the pleasures of the court. The 'Turks were also no longer to be feared. On the other hand, the Protestants were now much stronger than when last threatened by the emperor with war, and had they been united and well led, they would have been too strong for Charles. As it was, his successes were gained by the help of the ruler and army of a Protestant state, by the able but unscrupulous Maurice of Saxony. He was the head of the younger Saxon line and was ambitious of larger territories and higher titles. During the first years everything went in Charles' favor. He gained the great victory of Miihlberg, captured and held in close imprisonment the two chief Protestant princes, John Frederic, Elector of Saxony, and Philip of Hesse, and Maurice was rewarded for his treason by the Electorate and the larger part of the territories of his cousin. Soon afterward, the siege of Magdeburg, which

Religious war begins in Germany. Häusser. Keformation I96-215; Johnson, liniods, 220-239; map, l'utzger, No. 21 .

Maurice of Saxony. 
Maurice of Saxony and France against Charles. Häusser, Reformation, 226-234; Johnson, Periods, 239-246; Zeller, XIV.

seemed the last stronghold of Protestantism, was begun by Maurice.

315. The Turning-point of the War. - Then the situation suddenly changed. Gradually it had become evident to Germany that Charles had other plans than those for the supremacy of Catholicism. He seemed to be intending to establish a strong imperial power by the overthrow of the princes, and to transfer the succession from his brother, the German Ferdinand, to his son, the Spanish Philip. Naurice quickly saw that the time was ripe for a second treason which would be equally profitable with the first. He had been offended by the treatment of his father-in-law, Philip of Hesse, by the emperor, but, a still stronger motive, here was an opportunity to obtain the consent of the Protestant princes to the gifts which Charles had made him. At the same moment, Henry Il. of France, fearing the increasing strength of Charles in Germany, was thinking of interfering. An arrangement was readily made between him and the Protestant princes, by which they were supplied with money, and he was allowed to take possession for France of the "Three Bishoprics," Metz, Toul, and Verdun, "cities which have belonged to the Empire but where the French language has been spoken," as the treaty said. This was the first step of France in the policy of securing the frontier of the Rhine, and though, after peace had been made in Germany, the Emperor made a vigorous attempt to recover these lands, he failed and they remained in the possession of France.

Charles defeated.

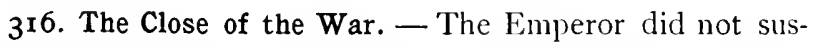
pect what was going on, and when everything was ready, so sudden was the attack of Maurice, that Charles escaped only with difficulty and by night through the passes of the Alps. The work of years was speedily undone, and Charles was forced to give up all his plans, and to leave the practical direction of affairs to his brother Ferdinand. The war was really closed by the convention of Passau in $155^{2}$, and this was followed in 1555 by the definitive peace of Augsburg. 
This established religious toleration of a very imperfect kind. It gave to the government of each State the power to llecile what should be the legal religion of its land, and then to do what it pleased with the adherents of any other, though if it decicled to expel them, they should be allowed to take their property with them. Under this treaty

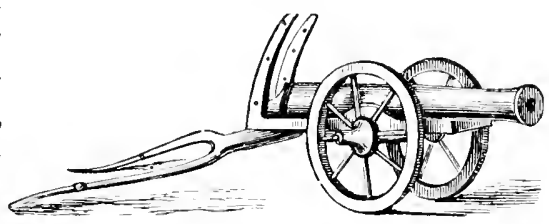

CaNNON OF TIE XVIh CENTUKY peace was maintained in Germany until the beginning of the 'Thirty Years' War in i6 8 , but very soon questions began to arise which were not thought of when the treaty was made, and whose practical settlement seemed to one party or the other a violation of its terms.

3I7. Abdication of Charles V. - Very soon after the conclusion of the peace of Augsburg, Charles V., disappointed in all his great plans and worn with disease, abdicated all his crowns, and retired to spend the rest of his days in the cloister of San Yuste in Spain. His brother Ferdinand succeeded him in the German possessions of the family, and was elected emperor, and his son Philip obtained his other possessions in Spain, Italy, the Low Countries, and America. It was much to the advantage of France and of the rest of the world as well, that Charles had not been able to unite his vast dominions into a universal monarchy, but the power of the house of Austria, even though divided, still overshadowed the world, and for generations yet was to be feared and resisted until at last its decline became evident to all.

318. The Power and Character of Philip II. - At the outset, however, the power of Philip II. was as great as that which Charles V. had had at any time. If he did not have Austria and the Empire, he escaped in that way the difficulties and embarrassments which had constantly hampered his father on their account. When he began to reign his con-

Spain and Austria separated, 1556. Penn. III., No. 3 .

As powerful as Charles $\mathrm{V}$. 
trol was undisputed over the resources of Spain, Spanish Italy, the Netherlands, and America. With power so much greater than any of his contemporaries possessed, Philip might reasonably hope to accomplish anything that he desired. That he failed in his purposes, lost some of the best portions

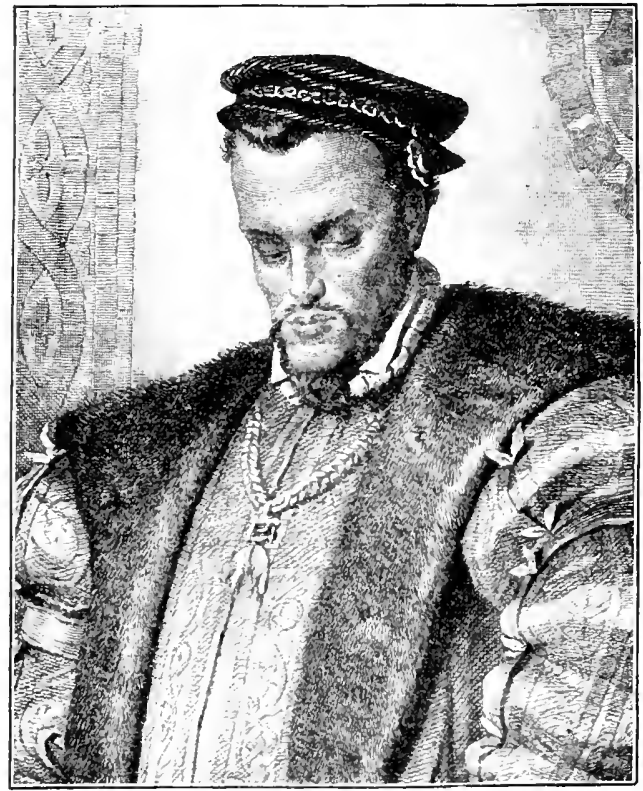

1'1111.1P II.

of his empire, and exhausted the remainder was due to his personal character and policy.

The character and ideals of Philip. Notley, Dutch
The more popular qualities of ('harles V.'s early life did not descend to his son. Philip was cold and unapproachable, secretive in disposition, hard and unpitying, and inflexibly obstinate when his purpose was once formed. His government was a typical despotism, as he sincerely believed all gorernment should be, in which, though he 
might listen to the opinions of others, every decision was his own, and, when once reached, not to be questioned by the highest. From some source Philip had derived a strong religious tendency which was the controlling influence in shaping his policy, and which determined the result of his reign. The tendency was toward a somewhat formal and theoretical religion, and it was not of a sort to control his personal morals, but it may on that very account have exercised an even more decisive influence over his public policy. To Philip the supreme thing in the world was the Church. The highest duty of every monarch was to support and defend it.

In his own case, the way of duty seemed entirely plain. With all the vast resources at his command, he must devote himself to keeping down heresy where it was not already supreme, and to recovering as many as possible of the provinces which the Church had lost. He did not recognize the depth of the current nor the impossibility of turning it back, and because he thus faced the past and not the future, he hastened the decline of Spain, which had perhaps already begun. It certainly was the blindest political policy to drive out and destroy by persecution the Moors still left in southern Spain, but he was undoubtedly sincere in saying, as he did of the Netherlands, that he had rather not reign at all than to reign over heretics.

319. Philip and Mary of England. - The power of Philip might seem at his accession to render resistance hopeless, but a type of Protestantism had already arisen in the countries where the issue nust be decided, in Holland and in England, well fitted for the conflict. This was Calvinism, whose controlling spirit of resistance to tyranny we have already noticed.

Philip had been married, some months before the abdication of his father, to Queen Mary of England. It was a union very dear to Mary, though very unpopular with her subjects, and both she and Philip hoped that it would increase the power of the great Catholic monarchy and secure the

Philip must contend with Calvinism.
The marriage of Philip and Mary.
Republic (Harper), I. I39-146; Johnson, Feriods, 309-3I3.

His mission, to suppress heresy. 
Green, complete triumph of the Church which both so much desired.

English

People, Il.

246-26I ;

Froude,

Ensland,

VI., Chap.

Xxxill.;

Creighton.

Elizabeth

(Epochs),

$29-47$.

Elizabeth, I $558-1603$. Her situation and

character. Creighton,

Elizabeth, I 28-I 48 ;

Green,

Enslish

I'ople, II.

295-302.

Documents.

Prothero,

I-20;

fise and

llardy, 1 5 j-508.
Mary, as the daughter of Catherine of Aragon, could harlly avoid being a Catholic. If she were a Protestant, she would proclaim her own illegitimacy. In her short reign she did all that she could to bring England back into the old way. She undid the legislation of her father, restored the supremacy of the pope, tried to destroy the influences which had begun to work during the reign of her brother, and put many Protestants to death. But she was disappointed in all. There was no child from her marriage with Philip to carry on her plans; England, though not yet Protestant, endured sullenly her methods of rule; Philip, disappointed also in what he had hoped to gain from England, gave her no sympathy nor personal support; and finally Providence itself seemed to desert her when Francis of Guise captured Calais, which the English had held for two hundred years against all the efforts of France. She was succeeded in the same year by Elizabeth.

320. England again Protestant. - Elizabeth, as the child of the marriage which had overthrown the supremacy of the pope, was just as necessarily constrained to be Protestant as Mary to be Catholic. Her situation was, however, critical, and demanded that she should proceed with caution. England was probably still more than half Catholic. No one who was more Catholic than Englishman could regard her as legitimately sovereign. The true heir of the crown in his eyes was Mary Stuart, queen of Scotland and wife of the king of France, and she had already assumed the arms and style of queen of England. England was a small land, and, even if it had been thoroughly united, no match for the great Catholic powers. It was with great discretion that Elizabeth met the difficulties with which her reign opened, and, though the sovereign became again the head of the Church, it was some years before the laws began to bear hard upon the Catholics.

32r. The Situation in the Netherlands. - It was in the Netherlands that Philip's plans received their first decided 


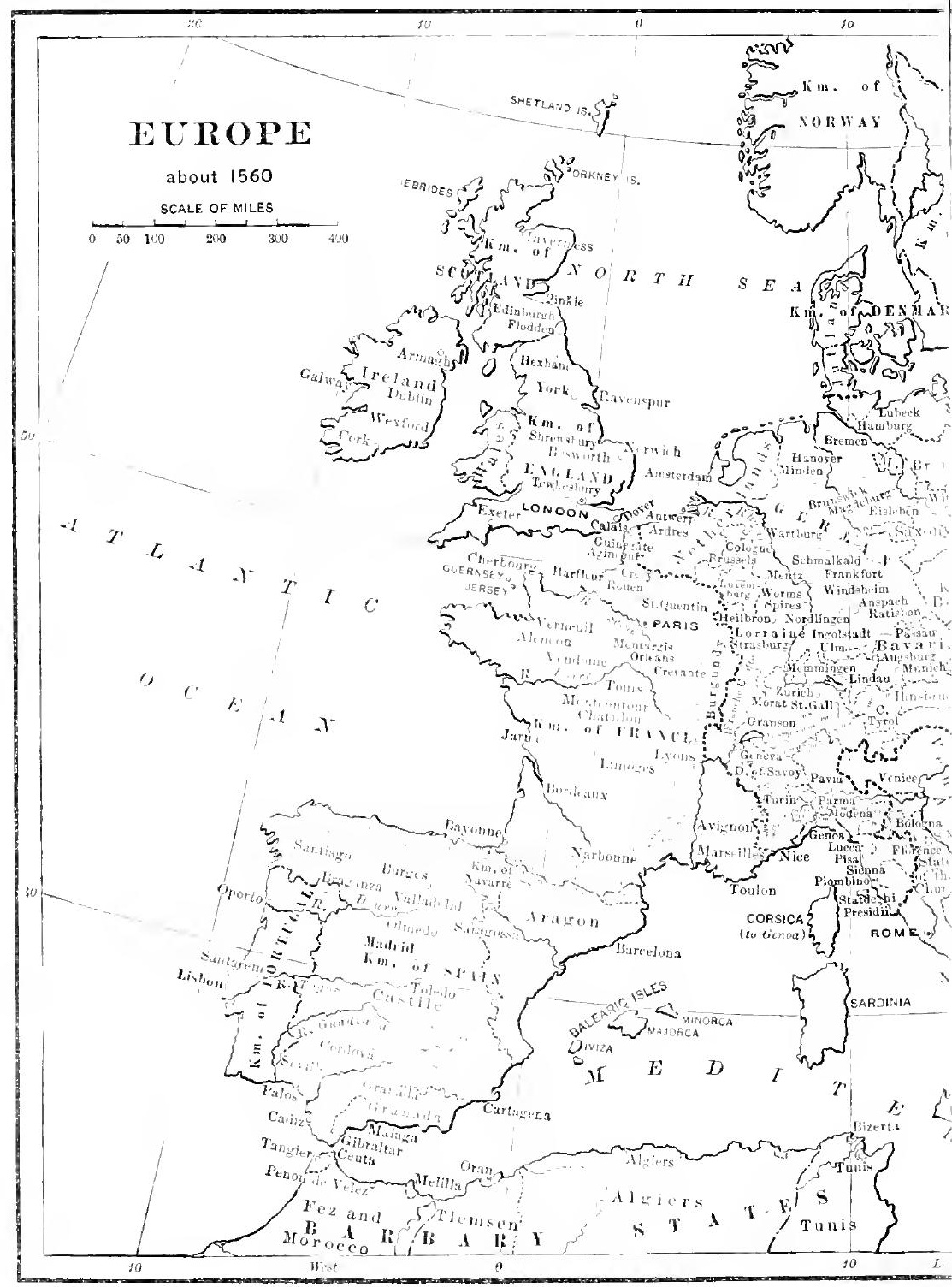



check, and the opposition which they met with there was one of the most decisive influences leading to their final failure. As we have seen, the Netherlands had descended to Charles V. from his grandmother, Mary, daughter of Charles the Bold, duke of Burgundy. Their political constitution was a peculiar one and had an important bearing on the events of this period. The provinces of the Netherlands were seventeen in number, each a separate state, dating back to the old feudal days. Each of these little states was entirely independent of all the others politically, and had its own legislature, laws, and government. The only form of union between them was that which is known in modern times as a "personal union," consisting in the fact that they all had the same sovereign. Besides this political separation, there were more natural differences of languages, economic character, and to some extent of former political relationship, which divided the provinces into two groups. The people of the northern provinces spoke a German language, were attracted by their situation to the sea, which had led them to develop extensive fisheries and commerce, and their rulers had held their lands under the German emperors. 'The people of the southern provinces spoke a dialect of French, depended chiefly in the country on agriculture and in the towns on great manufacturing industries, which had grown i1) since the crusades, while a considerable portion of them had originally belonged on the west side of the boundary line between France and Germany.

322. The Netherlands under the Hapsburgs. - These provinces had obtained from their earlier rulers very considerable political privileges in the way of making their laws and roting their taxes, and to these liberties they were devotedly attached. Charles V., when he became their sovereign, had paid little attention to their rights and had ruled much as he pleased. But the Netherlanders looked upon him as a native of their country, and he had also popular qualities which won men to grant him his will. Philip II., however, seemed to them a true Spaniard, and he did not

Separated into lwo divisions.

Charles V. and Philip II.

Political constitution. Häusser, Reformation, 285-290; Prescolt, Philip II. (Lippincoll), Bk. II., Chap. I. 
appear to care to be thought anything else. His dark and forbidding manners made him no friends, and when he began to advance further even than Charles in the way of arbitrary government, his measures excited an opposition which his father had never met.

Religious persecution leads to resistance.
Philip's measures and their effect. Prescott, Philip 1/. Bk. II., Chap. II. ; Motley, Dutch Republic, I. 26I-268; Häusser, Reformation. 290-306.

Independence declared. Old South, 72 ; Johnson, Periods, Chap. VIII.; Häusser,
323. The Beginning of Resistance to Philip. - Spanish officials in the place of native, and garrisons of Spanish troops, even heavier taxes than they had ever yet paid, arbitrarily laid, might not have led to open rebellion. When to these was added religious persecution, armed resistance followed. Protestantism had made its way into the German provinces of the north, coming in the end to be of a Calvinistic type, while the provinces of the south had remained Catholic, - another and finally one of the most important differences between the two groups. This heretical religion, of course, Philip could not tolerate. His own provinces must all be Catholic whatever the rest of the world might be. The introduction of the Spanish inquisition, the division of the country into numerous new bishoprics for its better control, and the merciless execution of heretics led to the first steps in resistance. The nobles protested against the invasion of their political privileges. The Protestants uniterl and drew up the Compromise of Breda, a declaration of their rights. They took in earnest the name of Beggars, Guenx, - which had been given them in derision, and accepted as their leader William of Nassan, Prince of Orange. one of the richest nobles of the country, a man brave and prudent, who was called William the Silent, from a wise habit of holding his tongue.

324. The Independence of the United Netherlands. - The conflict was obstinately fought on both sides, and long undeciled. The military skill, the thousands of executions and unheard-of exactions of the duke of Alva were of no avail. The country might be almost ruined, but the Catholic provinces were driven to take part with the Protestant against the Spanish troops. A somewhat milder policy which followed succeeded no better in the main purpose. Though 
the Catholic provinces in the end remained under the Spanish rule, the Protestant laid the foundations of a new government in the Union of Utrecht in 1579, and soon after declared their complete independence of Spain. It was more than twenty-five years, however, before they obtained peace and a recognition of their independence. William the Silent was murdered in $15 s_{4}$, but his son Maurice suc-

Reformation, Pt. V., Chaps. XXIII. and XXIV.

Independence recognized.

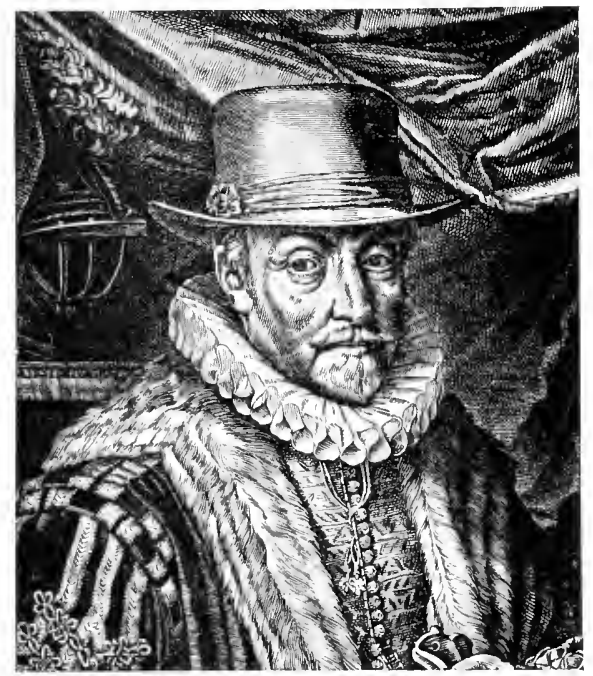

WILLIAM TIIE SILENT

ceeded him. Elizabeth of England sent the Netherlanders some little aid, but their greatest relief came from the great loss which Philip met with in the destruction of the Armada, and from his taking part in the civil war in France. At last, just before his death, Philip gave the Netherlands to his sonin-law, the archduke of Austria, and he, after failing in his turn to conquer them, recognized in 1609 the independence of the seven United Provinces, and this was formally conceded by the public law of Europe in the peace of Westphalia in 1648 . 
Civil strife continued.

Growth of l'rotestant feeling in England.

The earlier iife of Mlars. ituart. Cieighton, Elizabeth, $65-82$.

The close of the war for independence was not the end of troubles for the Dutch. Civil and religious conflict followed, between a monarchical party led by the house of Nassau, holding to the strict Calvinistic faith, and a republican party which accepted the teachings of Arminius (d. r609), who rejected predestination and the theology founded upon it, and built an opposing system upon the basis of human free will. The monarchical party finally trimmphed, and the leader of the republican, Oldenbarnevelt, was executed.

325. England. - In his plans for the recovery of England for the Catholic Church, Philip had no better fortune. The method of his warfare, attack by conspiracy and revolution upon a government which all Englishmen of whatever faith regarded as the legal and constitutional government, identified in the minds of the mass of the people the cause of Protestantism with that of national independence, and began that deep-seated fear of the political designs of the Catholic Church which has been in the past, at least, a characteristic of Anglo-Saxon Protestantism.

326. Mary Queen of Scots. - The character of Mary Stuart, the Catholic candidate for Elizabeth's throne, was not a help to her supporters. A daughter of Mary of Guise, brought up from infancy at the French court as the future wife of Francis II., light hearted and fond of amusement, and enjoying intensely the lively society of Paris, she was forced, when only nineteen, by the death of her husband to return to scotland, which had been lately converted by the uncompromising John Knox to the austere faith of Calvin. It is not strange that Mary was unable to adapt herself exactly to the situation. The crisis was reached upon her marriage to the earl of Bothwell within a few months of the murder of her second husband, Lord Darnley, - a murler which it was supposed Bothwell had committed, perhaps with the connivance of Mary. To aroid the storm which this aroused, she abdicated in faror of James VI., her infant son by Darnley, and fled to England to seek refuge with her cousin and sister (pueen, Elizabeth. 
The presence of Mary in England was a considerable embarrassment to Elizabeth, who conld hardly fail to sympathize with her troubles as a sovereign. But political The execution of Mary, necessity seemed to her and to her ministers to indicate but

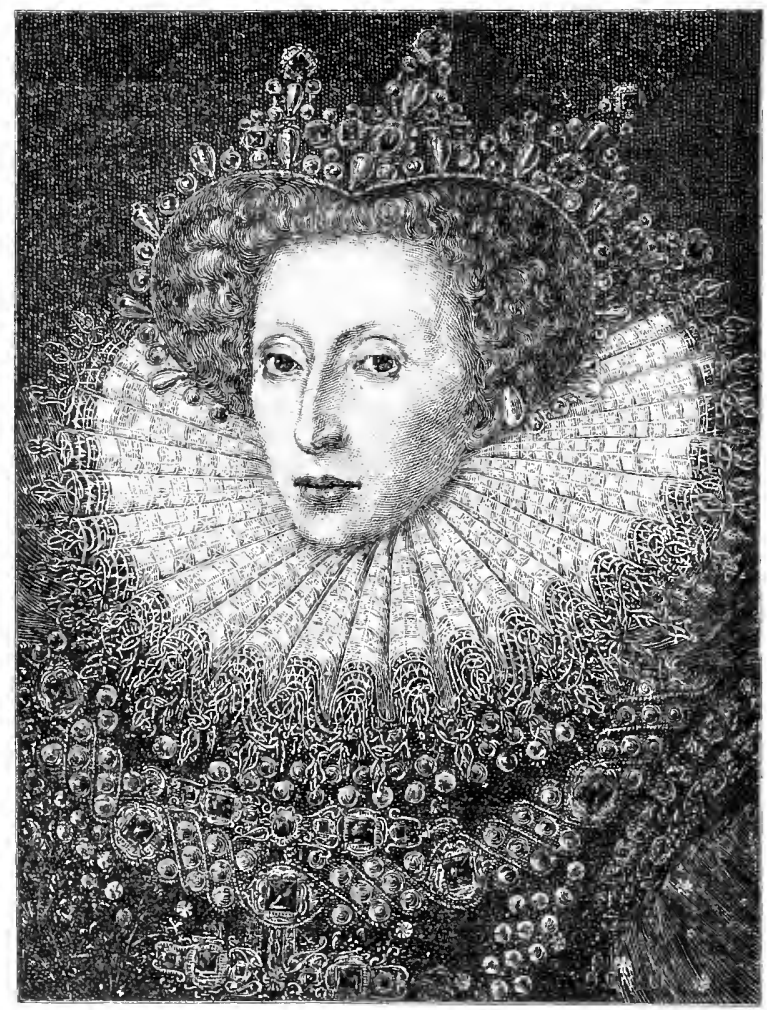

QUEFN EITHARETH

one safe course, and Mary was imprisoned. She did not Froude, cease, however, in confinement, to be mate the centre England, of plots against Elizabeth, nor to be recomized bo the Xil. Chap. pope and the king of Spain as the rightful pueen of England. 
Creighton, Finally, after she had been imprisoned nineteen years, a Lilisabith, $175^{-173 .}$ The petition of Parliament, Prothero, Iog.

Reasons for the conquest of England. conspiracy was detected which involved the murder of Elizabeth as well as the overthrow of the government, and, as the evidence seemed to indicate a guilty knowledge on the part of Mary, Elizabeth, with real or feigned reluctance, consented to her execution.

327. The Invincible Armada. - The execution of Mary, the aid which Elizabeth was giving to the revolted Netherlanders, and the injuries which Spanish commerce was receiving from the English cruisers now determined Philip to exert all his strength, overwhelming as he believed and as England feared, and with one blow be revenged upon the upstart little kingdom, and restore a lost province to the Church.

The destruc- In the summer of $\mathrm{I}_{5} 88$, the Invincible Armada set sail. tion of the Armada, I588. All England, Catholic and Protestant alike, rallied to oppose it. The smaller but swifter and better handled English ships sailed around, and clung to the skirts of the great Spanish fleet and, in a nine days' continuous battle as it passed through the Channel, practically defeated it. As the remaining ships were attempting to return to Spain by sailing around Scotland and Ireland, they were dispersed by storms, and hardly one-third reached home. This was a great blow to the naval supremacy, the resources, and the prestige of Spain from which she never recovered. It was, also, the last attempt of Philip II. to conquer England, but it was only the beginning of the English triumphs over Spain, so intimately connected with the rise of her commercial and colonial empire, which we shall study in another place.

The demand for a more complete reformation.

328. The Rise of the Puritan Party. - The troubles of Elizabeth with the Catholics, did not exhaust her religious difficulties. The English Church had retained many things in its forms which had belonged to the old Church, and this was true to some extent, also, of its teachings. But many in England had accepted the full teachings of Calvin. During the reign of Mary numbers had taken refuge from persecu- 
tion in Geneva, and they had returned, hoping to establish Calvinism in England. These men now refused to conform to the English Church, but for opposite reasons from those of the Catholics. For them the Reformation had not gone far enough. This party was itself divided into two. One, for a long time the most numerous and influential in England, was the Puritan, so called from its desire to purify the Church from all Catholic form. They believed, however, in a national, established Church. The other party, for many years small and obscure, was sometimes called the Brownist, from one of its leaders, and sometimes the Separatist from its special teaching that each separate church should be an independent, democratic community, determining all questions for itself.

The government felt obliged to punish these extreme Protestants for non-conformity, as it did the Catholics, and soon after the reign of Elizabeth closed, a community of the Separatists took refuge in Holland from this persecution, and some years later still formed the little colony of Plymouth in New England. Many Puritans coming later to New England organized there churches of the Separatist type, and these are known in the history of America as Congregational, while those retaining more nearly the original Puritan organization are known as Presbyterian.

329. The Opposing Parties in France. - For France, the last half of the sixteenth century was a most unhappy period. Ravaged by constantly recurring civil wars, religious in form but somewhat selfish in character and revolutionary in purpose, and ruled by incompetent kings and an utterly corrupt court, government was almost undone and all classes and interests suffered severely. The Protestants of France, as we have seen, differed from those of other countries in the fact that they formed a great political party in the nation, led by powerful nobles and princes of the royal family, and strove to secure their main object, a kind of independent position in the State, quite as much from political as from religious reasons.

The Pilgrims in Holland. Bacon, Genesis of New Eng. Churches, 209-227.

In New England, Old South, 55.

An unhappy period of history. 
Government follows no consistent policy.

Penn. III., No. 3:

Zeller, XIV.

Catherine de' Medici and her policy. Kitchin, France, II. 294-310; Zeller, XV.

The Reformation had an independent and early beginning in France, but it received much aid from the German movement, and still more from Calvin. At first the government paid little attention to it, but finally Francis I. and Henry II. adopted the policy of repression, irregularly carried out. During the short reign of Francis II., the same policy was continued, as the king was under the control of the Guises, the uncles of his wife Mary Stuart, and they were devoted Catholics.

On his death, in 1560 , his brother, Charles IX., became king at the age of ten. His mother, Catherine de' Medici, an ambitious woman, but up to this time without influence upon public affairs, now resolved to rule in the name of her son. This she hoped to accomplish by balancing the Catholic party of the Guises with the Protestant party led by the Bourbon princes, Antony of Navarre and his brother, the Prince of Condé. 'This was a very difficult part to play on account of the bitterness of faction, and, though Catherine was aided by the unusual abilities of her minister, the Chancellor L'Hôpital, who was tolerant from conviction, it was not an entirely successful policy.

The first war.

330. The Huguenot Civil Wars. - The first civil war Vassy, 1562.

Baird,

Rise of the

Huguenots

(Scribner),

II. $19-26$.

The

Huguenots

a slate

within the

State.

began by the massacre of Vassy, in which the attendants of Francis of Guise, who was on his way to Paris, attacked and killed many of a Protestant community who were worshipping in a barn. From this time on for thirty years there was a constant succession of wars, separated from one another by brief intervals of what was called peace, but which differed from war only in the fact that the strife was carried on by intrigues at the court rather than on the battlefield.

The peace of St. Germain, which closed the third war, is the most important peace in the series, and the interval between that and the beginning of the fourth war, the most important interval. The peace granted to the Huguenots four strong fortress towns of France, which they were to hold and control entirely independently of the government. This was done to give them a feeling of security, 
and as a kind of pledge that the terms of the peace would be honestly kept, but it had the effect of giving them a basis of political organization and of making them a little state within the State.

In the interval before the next war the effort to bring Protestant and Catholic together was more nearly successful than at any other time. The marriage of the young Henry of Navarre, now the head of the Huguenots, with the king's sister, Margaret of Valois, was to cement the union, and many of the most prominent Protestants were attracted to the festivities at Paris. The Admiral Coligny, the ablest of the Huguenot nobles and one of the ablest Frenchmen of the time, acquired a decided influence over the mind of the young king. He wished to return to the policy of extending French territory in the Rhine valley, and to turn the energies of the nation from civil strife to foreign conquest. The king was on the point of action, but his mother, Catherine de' Medici, began to be alarmed at Coligny's influence and to fear the loss of her hold on power. An attempt to assassinate the admiral failed. Then the king was with difficulty persuaded of a general Huguenot plot, and gave the orders which led to the massacre of St. Bartholomew. Thousands were murdered in Paris and throughout France, but a new spirit filled those that survived, and the Catholics gained little in the end.

331. The First of the Bourbons. - On both sides, murders were frequent during these wars, and many of the leaders perished by assassination. In 1574, Charles IX. was succeeded by his brother, Henry III., the last of the Valois. He was ambitious to rule and wished to form a party of his own, but he could not. After having the duke of Guise murdered almost in the royal presence, he was himself murdered in 1589 . By his death, Henry of Navarre was left the rightful king of France. A long struggle was necessary, however, before he obtained full possession of the throne, and among other things required was his conversion to the Catholic faith, probably not a diffi-

The last of the Valois. Zeller, XVI.

Henry IV. Zeller, XVIl. Willert, Henry of 
Navarre

(Heroes) ; his accession, Chaps. V. and VI.; Johnson, 432-437.

The close of the civil wars and the edict of Nantes. Baird, Henry of Vaz'arre (Scribner), Chap. XIV.; Johnson, Periods, $4+2-4+5$. Designs upon the Rhine valley. Wilsest, Henry of Nat̃arre, Chap. XI.

The causes of strife in the Empire. Map for the war, Putzger, No. 22.

cult thing for him, as he was not a man of deep convictions.

By 1598 the wars were over. England, which had hoped to gain something at the expense of France by alliance with the Huguenots, and Spain by alliance with the Catholics, were both repulsed; the rebellious nobles and cities were forced to submit to a reëstablishment of strong royal authority, and Henry could carry out his plans for the restoration of prosperity to France, wise according to the knowledge of the time, in which he had the aid of his great minister, Sully. The rights of the Protestants were secured and toleration made the law of the State by the edict of Nantes of April I3, 1598, which served its purpose for almost a hundred years.

332. The Foreign Plans of Henry IV. - Having secured the internal peace and begun the economic recovery of France, Henry IV. was just about to renew the policy of conquest in the Rhine valley, when he was assassinated, in i6ro. Had Henry been granted a few years longer, he would probably have made larger conquests in this region than Louis XIV. a century later, and at much less cost, for Germany was just on the eve of civil war, Spain was exhausted by the losses and mistakes of the last half century, and England and Holland would not have been ready to oppose the designs of France as they were a hundred years later. As it was, France fell back for many years into weakness and internal confusion. Louis XIII. was not yet ten. His mother, Mary de' Medici, did not know how to rule, and the nobles and leaders of all parties proved utterly selfish and corrupt.

\section{The Beginning of the Thirty Years' War. - While} France was torn with civil war, and Spain was exhausting herself in efforts to conquer the revolted Netherlands and to overthrow Protestantism in western Europe, Germany wals slowly drifting toward a civil war, the most terrible in its effects of any known to civilized history. The immediate successors of Charles V., Ferdinand I. and Maximilian II., 
were liberal-minded princes, and l'rotestantism made considerable adrances even in the Austrian territories. The later emperors, especially Rudolf II. and Ferdinand II., were entirely under the influence of the Jesuits, and determined to restore Catholicism wherever possible. Each party in the Empire had some reason to complain of the unfairness with which the other interpreted the terms of the peace of Augsburg. The Protestants had managed, contrary to its

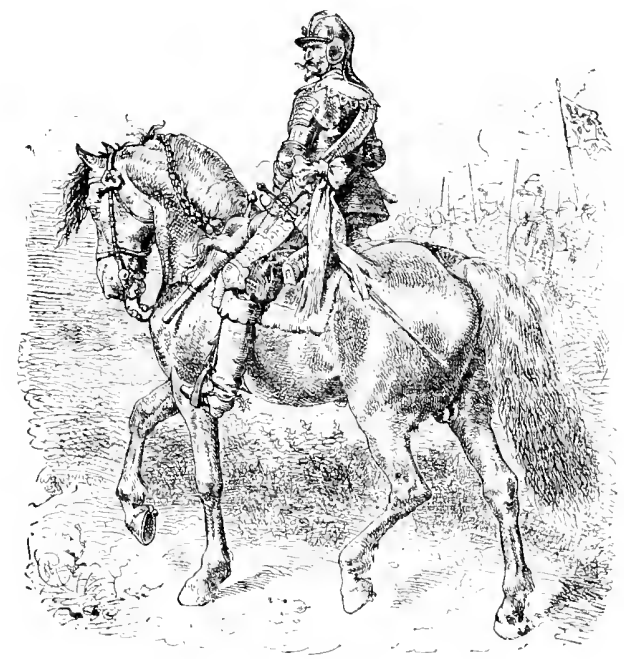

A SOldier of the THIRTy Years' War

spirit at least, to retain the endowments and government of several ecclesiastical states which had been converted. In I607, Maximilian of Bararia, taking adrantage of a quarrel which had arisen between the citizens and a monastery, had seized the Protestant free city of l)onamwörth and harl reëstablished Catholicism there. 'The I'rotestant states then formed the "Union," unler the lead of the Elector of the Palatinate. Inmediately the Catholics formed the "League," with Maximilian at its hear. 
The outbreak in Bohemia.

Gindely,

Thirty Yeurs'

llar

(Putnams),

Chap. 11.;

Gardiner,

Fiirty' Years'

II iar

(Epochs).

334. The Bohemian Period of the War. - IVar did not

Chap. II.,

Sec. 2 ;

Maurice,

Bohemia

(Nations).

Chap. XVII.

begin, however, for some years, and then in consequence of the efforts of Ferdinand to favor Catholicism in Bohemia, where nearly all the people were Protestants. The destruction of a Protestant church in Prague, in 1618 , led to open hostilities. The people rose, threw the Catholic councillors of Ferdinand out of a window of the castle, after the Bohemian fashion, deposed the king, and elected in his place, Frederick, the Elector Palatine. He was the head of the Union, and son-in-law of James I. of England, but the ail which was expected from these sources did not come. On the other hand, Ferdinand had the support of Bavaria, Spain, and even of Protestant Saxony, and in Tilly had a general far superior to any on the Bohemian side. The

The over-

throw of

Frederick.

Gardiner,

Chap. III.,

Sec. I;

Gindely, I.,

Chap. VI.

first period of the war was soon over. Frederick was defeated in the battle of the White Mountain, driven from his new kingdom. lost his dominions in the Palatinate, and even his electoral office, which was given to Maximilian of Bavaria, and never was able to recover his position. Bohemia was left at the mercy of Ferdinand, who deprived the Protestants of their rights and established Catholicism by force.

The rise of Wallenstein and his methods.

335. The Danish Period. - These successes of the house of Austria, won partly by the help of Spanish troops, and these violations of constitutional right, at last led the other Gindely, I. Protestant states of the Empire to fear for their own safety. 379-386; Gardiner, Chap. V., Sec. 3. See later edict deposing him,

Schilling, Quellenbuch. $1+5$. The king of Denmark, Christian IV., a German prince, as duke of Holstein interfered, and the Danish period of the war began in 1624 . In this period, Wallenstein appeared in the service of Ferdinand, at the head of a great army which he supported and paid without expense to the emperor ly the plunder of the country through which he passed. In carrying out this plan of making war pay its own expenses, he made but little distinction between friend and foe, and as his method was generally adopted by the other commanders, and as the armies came to be composed of adventurers and professional soldiers from all parts of Europe, attracted 
by the privilege of living as licensed freebooters, the sufferings of the German people can be easily imagined.

Success was still on the Catholic side. Tilly and Wallenstein were more than a match for the leaders on the other side, the king of Denmark was driven out, north Germany was almost wholly subdued, and Wallenstein was given the confiscated duchy of Mecklenburg, which should be held by a reigning prince. As a result of these successes, the emperor issued in 1629 the edict of Restitution, which marks the highest point of his success and shows what would have followed his complete triumph. This edict ordered the restoration to the Catholic Church of all endowments and ecclesiastical governments which has become Protestant since the peace of Augsburg. As many of these were cases of genuine conversion, and as it affected all parts of Germany, it was an edict which could have been carried out only by an arbitrary exercise of absolute power.

336. Sweden and France. - But a change was now at hand in the character of the war, which marks a great change in the deeper currents of history at large. Two nations of Europe had been for some years watching events in Germany with increasing interest. One of these was Sweden on the north. Sweden was at that time a much larger and more powerful state than it has been in recent history. The eastern shore and the southeastern corner of the Baltic were in its possession, and it was ambitious of making that sea wholly a Swedish lake. During the first years of the Thirty Years' War it had been engaged in a war with the kingdom of Poland, partly with this in view. Its king was now Gustavus Adolphus, a young man with the ambition which conscious ability always gives - a military genius who was at the same time a most devoted and sincere Protestant, ready to avenge the injuries of the German Protestants on religious grounds, even if the interests of Sweden had not been at the same time served.

The other country was France. During the minority of Louis XIII., and for a few years after, France had been

The edict of Restitution. Gardiner, Chap. VII.; Gindely, I. 445 ff.; text, Schilling, Quellenbuch, 120.

The ambition of Sweden anil of Gustavus Adolphus. 
The rise and abandoned to faction, to intrigues, and strife of the most selfgeneral policy of Richelieu. ish sort, which had reduced the royal authority to almost as low a point as during the civil wars, and prevented the country from taking any part in European affairs. But in I624 Richelieu had come into power. From this date, for almost twenty years, he followed, without wavering, a clear and definite policy in internal affairs the supremacy of the

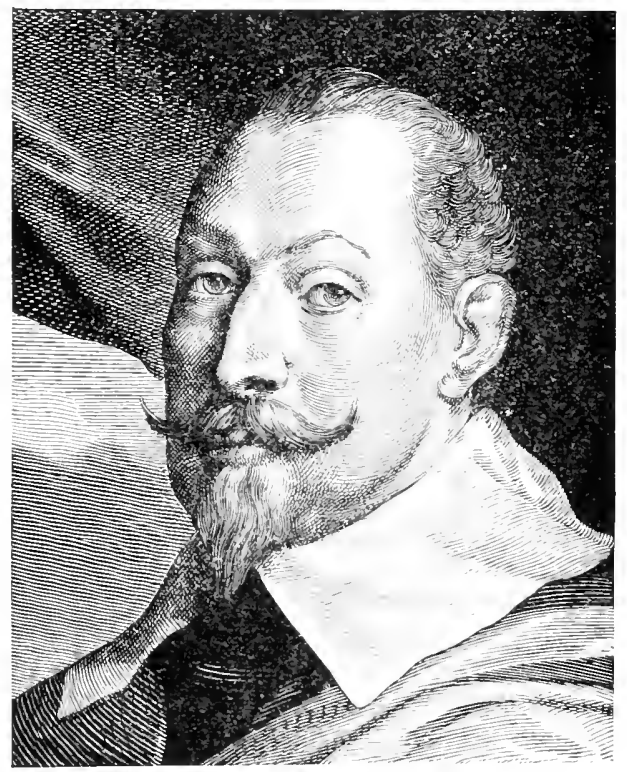

Gustarus Alolines

king, and in external affairs the dominion of France in Europe. To accomplish these things required, in France, the overthrow of the political independence of the Huguenots and of the power of the nobles, and in Europe, the overthrow of the house of Austria, and these form the special objects of Richelieu's policy.

337. Richelieu centralizes France. - Richelieu began to carry out his foreign policy almost as soon as he became 
minister, by preventing the Spanish from getting possession The indeof the Valteline pass in northern Italy, the key to the line of communication between the lands of the Spanish Hapsburgs in Italy and those of the Austrian Hapsburgs in Germany. But he found out at once that France was not prepared for a successful struggle for European supremacy until it was thoroughlycentralized at home. The conflict with the Huguenots was over comparatively soon. Their strongest fortress, La Rochelle, was taken in 1628 , after a famous siege and in spite of the efforts of England to prevent it. But little further resistance was possible for them, and in 1629 Richelieu issued the edict of Alais, which deprived them of the political independence, the position of a state within the State, which the edict of Nantes had granted them, but left all their religious privileges and liberties untouched.

The conflict with the nobles lasted much longer, all through the life of Richelieu and even on into the ministry of Mazarin, but they were in the end entirely subdued. They fought with intrigue and conspiracy, in which the king's mother, his wife, and his brother Gaston, often had a part, and which were as often directed at the life as at the power of Richelieu. The minister's weapons were the law and judicial executions which removed some of the highest nobles of the kinglom. His strongest support was the fact that Louis XIII. understood and heartily approved his policy, so that the most powerful influences of the court could not turn him against his minister. 'The success of Richelieu's policy gave the finishing touches to the absolute monarchy and made the king's will supreme without a check.

338. Richelieu and the Thirty Years' War. - At the date of Ferdinand's edict of Restitution, Richelieu was not quite ready for open interference in the war in Germany, but he was really to assist others to prevent any further extension of the Austrian power. He aided the electors in forcing the emperor to dismiss Wallenstein, whose army they feared might be used to destroy their independence. He interfered to make peace between the Swedes and Poland so that Indirect interference.

The nobles sıbdued. Bulwer, Richelicu (drama). interterence.

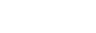
pendence of the Huguenots broken. 
Richelieu and Protestantism.

Gustavus Adolphus might be at liberty to give his whole attention to the Protestant cause in (iermany, and he afterwards supported the Swedish army with liberal supplies.

These events meant of course that a new directing influence was entering into the religious war. Richelien was a Catholic. He was a cardinal of the Church. But the great objects of his life were political withont reference to religion.

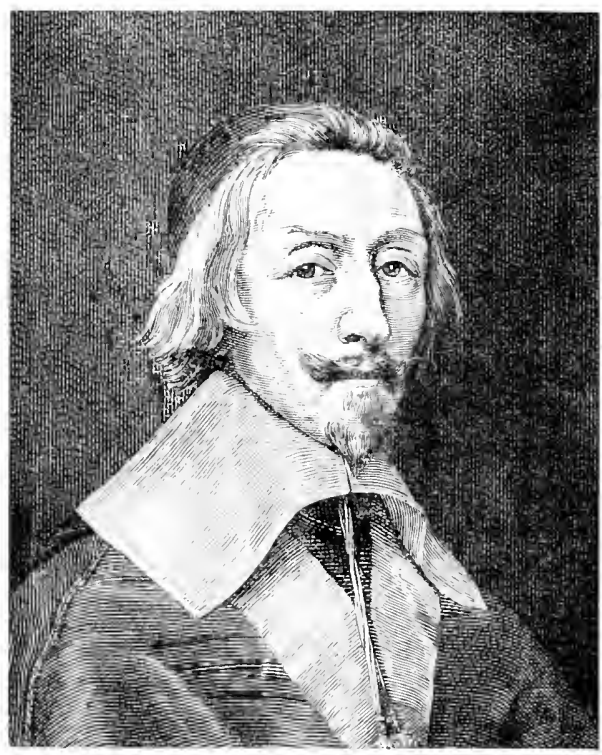

RIIIIELIEU

He made war on the Huguenots, but left them all their religious rights. He supported Protestant armies and sent his own to fight on that side, that he might weaken the Austrian power and put France at the head of Europe. This is the passing away of the Reformation as an influence which controls international politics and the action of States, and the begimning again of the conflict by diplomacy and war for national aggrandizement. 
339. Gustavus Adolphus in Germany. - The great man of the 'Thirty Years' War was Gustarus Adolphus, a most interesting study both from his positive characteristics and from his apparent contradictions. Most earnestly deroted to the Protestant faith, and at the head of an equally devoted army which he held under strict discipline, he was still ambitious for himself and desirous of conquest for his country. A military genius, the equal or even the superior of Wallenstein, and an innovator who revolutionized the art of war by the lighter arms and more mobile arrangements which he gave his troops, he won a remarkable series of successes from which he gained no corresponding adrantages, and he died in the midst of his career at the moment of victory over Wallenstein.

The interference of the Swedes in (iermany was not altogether welcome to the more powerful of the Protestant princes, who feared their ulterior designs. So long was Gustavus Adolphus in forcing his way through the territories of the Elector of Brandenburg that the great city of Magdeburg fell before the assaults of Tilly, and was almost totally destroyed, probably by its own defenders to deprive the victors of their advantage. This loss was soon made up by the great victory which Gustavus won from Tilly in the battle of Breitenfeld, near Leipsic. This defeat left the emperor without an army capable of holling the Swedes in check. but the plans of Gustavus seem at this time to have been directed to other objects than the overthrow of the emperor. Ferdinand was obliged to recall Wallenstein in order to get a new army, and gave him a position almost entirely independent of control.

340. The Death of Gustavus and of Wallenstein. - In the next year Gustavus entered Munich after again defeating Tilly, who was mortally wounded, but Wallenstein prevented The death of Gustavus, 1632. his further advance and then drew him off into Saxony, where, in the battle of Liitzen, Gustavus was killed, though the army of Wallenstein was defeated. 'The policy of Gustavus was continued by Oxenstern, the minister of the little Queen Christina, and the Swedish army remained in Ger- 
many till the close of the war, through the days of its great successes were past.

Wallenstein assassinated, 1634 . Gindely, II. I72-188; Gardiner, Chap. IX., Sec. 4 ; Schiller, Ilallenstcin's Lager,

The death of Gustavus more than balanced, for the emperor's cause, the defeat of Wallenstein, and it was followed by other successes. Not long after, the emperor became convinced that Wallenstein was engaged in treasonable correspondence with the enemy, and was planning to use his army in some design of his own, and he had him killed, but was able to retain the services of his army. The successes of Ferdinand were crowned when, in 1635 , the Elector of

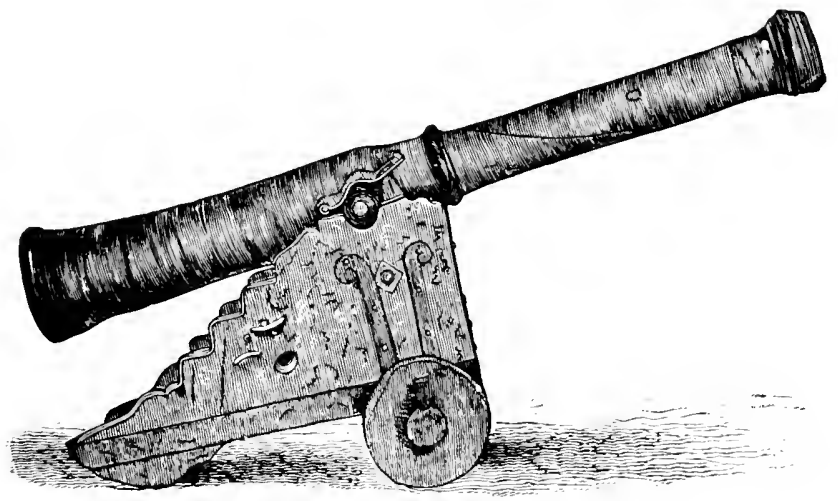

SWFIBH LAjTHER CANNON

From the time of the 'Thirty Years' War

Die Picco- Saxony, to secure certain advantages for himself, made a lomini, and II iallenstein's Tod (dramas).

Richelieu actively interferes. Gardiner, Chap. X.

The French successes compel peace. separate peace and even an alliance with the emperor.

34r. The French Period of the War. - Once more the house of Austria seemed abont to trimmph in Germany. Again Richelieu must interfere if he would prevent it, and this time with his own forces. The French period lasts from I 635 till the close of the war.

The first efforts of France were directed against the provinces which had been retained by the Spanish Hapsburgs in the Low Countries, where, after driving back a Spanish invasion which had threatened Paris for a moment, Arras 
was captured and the province of Artois conquered. In the south, Roussillon was taken possession of, and Portugal was aided to recover her independence from Spain. The Swedish army soon passed under French control, and their successes in Alsace and the Rhine valley made for the advantage of France. Richelieu did not live to see the complete fulfilment of his plans, but he saw enough to be confident of their final realization. His policy was continued by Mazarin, his successor in the French ministry. In the last years of the war, two young French generals began their career who were destined to the highest military renown, Turenne and Condé. Their repeated victories, the occupation of Bavaria, the capture of Passan and of Prague, and the threatening of Vienna, finally drove the emperor, Ferdinand III., reluctantly to consent to conditions of peace.

342. The Peace of Westphalia. - The series of treaties by which the 'Thirty Years' War was brought to an end is known as the peace of Westphalia. Considered as one, it constitutes the most important event in diplomatic history since the treaty of Verdun in the ninth century, and the widereaching dispositions which it made controlled, with some slight modifications, the political and geographical arrangements of Europe till the age of Napoleon.

From the point of view of general history, the peace of Westphalia marks, first of all, the great advance of France towards the headship of Europe, and the corresponding decline of the house of Austria. This was made evident in the treaties and secured for the future in two ways. In the first place, France was given the footing on the Rhine which for a hundred years its statesmen had been hoping to attain. The larger part of Alsace was put under the control of France, though it was not actually ceded to her, and two great fortresses on the right bank of the river, Breisach and Philippsburg, became French. She thus had an easy entry for her armies directly into Germany in the event of another war. This position on the upper Rhine enabled

The in:portance of this peace. Gindely, II., Chap. X.; Gardiner, Chap. XI., Sec. 2; selected clauses in Schilling, Quellenbuch, I59.

The great advance of France. Kitchin, France, III. 93-100. 
The decline of Austria.

Bryce,

Holv Koman Empire, 340-35I.

Map, Putzger, No. 22.

Sweden and the German states.
France also easily to extend her influence over the small states of the lower valley, and a few years later she organizerl the League of the Rhine under her leadership, which made France almost as much a German power as Austria.

343. The Empire Destroyed. - In the second place, the treaties made the Empire in law what it had been in reality for more than two hundred years - a mere form, though making at the same time the forms somewhat more empty. Full sovereignty, with the right to make treaties and alliances with foreign states, limited only by the most meaningless conditions, was given to each of the more than three hundred and fifty little states into which Germany was now divided. The position of emperor, which now belonged by a kind of customary right to the Hapsburgs, became a merely honorary one, a kind of presidency of a loose confederation with no real power whatever. As a result, the lingering ideas of a German nation, which had existed up to this time, disappeared completely. Each little court pursued its own utterly selfish and corrupt policy, bitterly jealous of all the others and of the Empire, and even such a man as Lessing conld rejoice that he was not troubled with the weakness of patriotism. Austria was reduced, by this state of things, to depend upon her own private resources in future struggles with France, and Louis XIV. was able to treat the Empire with most open contempt and insult with perfect impunity.

344. The Other States of Europe in the Peace. - The other dispositions of the treaties are of comparatively little importance. Swerlen, Brandenburg, and Saxony received large arlditions of territory. The portion of the Palatinate on the Rhine was restored to the son of Frederick with an eighth electorate created for him, but Bavaria retained the part of the Palatinate which joined her territory, together with the old seventh electorate which had been given her at the beginning of the war. The edict of Restitution was not enforcel except for the last years of the war. The religious arrangements of the peace of Augsburg were con- 
tinued in force, and the Calvinistic or Reformed Church, as it was called, was admitted to its privileges.

Spain refused to accept this peace for herself, and continued the war for ten years longer, hoping, on account of the civil conflicts in France, to be able to extort better terms. In this she was disappointed, and in the peace of the Pyrenees, in 1659, she was obliged to make considerable cessions to France, both in the Low Countries and in the south.

345. The Sufferings of Germany. - The misery which Germany suffered from the Thirty Year's War can hardly be conceived. At the end of two hundred years the losses had scarcely been made good. Armies whose business it was to make all they could from the country had been marching through the land for almost a generation. The population was reduced one-half, and the movable property two-thirds. Farmsteads and villages even disappeared, much of the country fell back into wilderness, and wild beasts that had not been seen in the memory of man became frequent once more. Manners and morals suffered with the rest, and the peasantry especially became, as they remained until the present century, scarcely more than beasts of burden with no sense of self-respect.

346. A New Era in English History. - During the last period of the Thirty Years' War, a civil war was going on in England, of a somewhat different character. In 1603 , the reign of Elizabeth, the last of the Tudors, came to an end, and that of James I., the first of the Stuarts, began. Considered in itself alone, this was an event of no small importance, since it brought together in close alliance the two kingdoms of England and Scotland which had been enemies of one another for so many centuries, and prepared the way for the still closer union of the present time. But in the history of England, the accession of the son of Mary Stuart to the throne marks a still greater change. The whole situation, domestic and foreign, was now, indeed, very different from that which had existed before the execution

Spain

continues the war for len years.

Thirty years of savage warfare destroy the gains of two hundred. Gardiner, Chap. XI., Sec. Ill.; Gindely, 11 . 393-398.

The accession of the Stuarts. James I., 1603-1625.

A great change in English affairs. 
of the king's mother, Mary Queen of Scots. Spain was no longer to be feared, and there was no heir to the designs of Philip II. Such designs themselves were no longer possible, for there was not now any claimant of the throne, like the Catholic Mary Stuart, who could serve as the centre of treasonable conspiracies.

The effect of these changes upon the share taken by England in the international politics of the continent, which

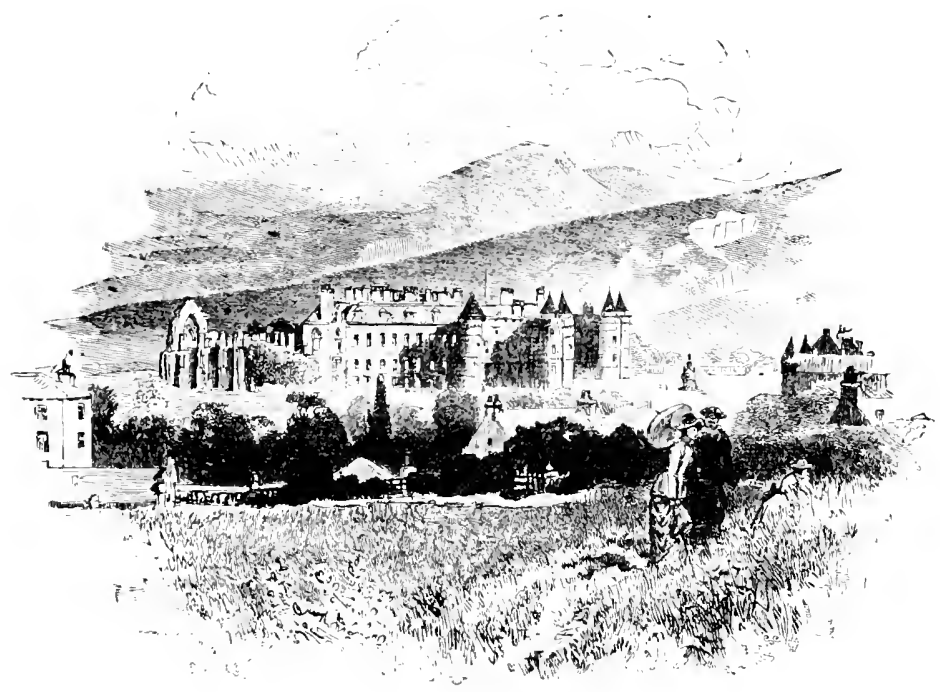

HULYRM, P'ALACE

English history returns to its old channel.

was much less during the first half of the seventeenth than during the sixteenth century, was not their most important result. In national politics, the result was the opening of a new era. The practical, though not legal, absolutism the straining of the constitution almost to the point of breaking - which the people had tolerated in the Tudors because of the dangerous crisis through which the nation was passing, was no longer necessary. The absence of all foreign danger and of any source of discontent at home which need 
be feared, enabled the nation to return to its special work of constitution making. Its first task, and that which occupied it nearly all the seventeenth century, was to bring the king completely under the constitution as it existed before the Tudors, though in the process many details of the constitution were greatly clarified and perfected.

347. The Stuarts and the Puritans. - There were two circumstances which concurred at this time to reinforce what seems to be a natural Anglo-Saxon tendency to render personal and arbitrary government impossible by means of constitutional limitations. One of these was the character of the king and of his successors. The French contemporary remark that James I. was the wisest fool in Christendom has never been improved upon. He was very proud of his learning, of which he made ostentatious display, but he was pedantic, narrow, and foolish, and gained more ridicule than respect. In action he was short-sighted and obstinate. Filled with the most extreme notions of the sanctity and divine right of kings, he was not disposed to tolerate any interference with his prerogatives nor even any independence on the part of Parliament, but his policy lacked the definite and steady guidance of a strong nature. He commanded neither the affection nor the respect of his people, and lacked entirely the popularity and brilliant qualities which had helped to carry the arbitrary government of Henry VIII. and Elizabeth. The short-sighted and narrow obstinacy of James, with his unwavering belief in the divine right of absolutism, and his vacillating will passed to his descendants and are characteristics of the Stuart kings.

The second of the circumstances favoring popular resistance to the king was the strength of the Puritan party in England. This had increased greatly in the last years of Elizabeth, and was destined to a still greater growth under James and to a leading part in the reign of Charles 1. 'Thoronghly imbued with the Calvinistic idea of the duty of resisting even the constituted authorities in defence of the right, and familiar with the constitutional position which

'The Stuart characteristics. Green, English l'eople, III. $55 \mathrm{ff}$.

The Puritan party. Green, English I'eople, III. I3-2I. 
Parliament had once occupied, this party with its allies was well prepared to meet the Jacobite doctrine of the $\sin$ of resistance to the $\mathrm{king}$, and to conduct the struggle for a recovery of parliamentary control.

His foreign policy. Gardiner, First Tion Sturts (Epochs), Chap. 1 .

King and Parliament.

The Petition of Rights. see references on this period in chapter on the English constitution.

Charles strives for independence. Gardiner,
348. The Reign of James I. - James' popularity was not increased by his foreign policy. He allowed his son-inlaw, Frederick, the Elector Palatine, to be ruined in the early years of the Thirty Years' War, against the wishes of the people. At the same time he strove without success to form an alliance with spain, cemented by the marriage of his son Charles with a Spanish princess, and though the nation no longer feared Spain as once, she was still regarded as their hereditary enemy.

Under the first of the Stuart kings, the conflict between the royal power and the Parliament went no further than the vigorous assertion of claims and counter-claims. Such positive gains as were made were on the parliamentary side, which insisted with determination on a long list of rights supported by earlier precedent - to control taxation, whether internal or on foreign commerce, to demand reforms as the necessary condition of grants of money, to impeach the king's ministers, and to criticise and discuss the government's policy regarding both domestic and foreign interests.

349. Charles I. and Parliament. - Charles I. was of more pleasing manners than his father, but he was even less disposed to yield anything of his rights to what he considered factious opposition. In $162 S$, his financial necessities compelled him to assent to the I'etition of Right, the second in the series of the great constitutional documents of our race, in which the right of Parliament to vote all taxes, and the right of the people to be secured from arbitrary imprisonment and trial, were clearly affirmed.

Charles soon showed, however, that he had not meant by this agreement to surrender any of his personal authority. He determined to rule without a Parliament, and for eleven years he dicl not call one. Two able ministers, the earl 
of Strafford and Archbishop I amul, gave him their assistance, and in the Star (hamber and the Court of lfigh Commission he hat the means of arbitrary trials without the intervention of any jury. To assist in provirling a revenue, an obsolete special tax which had been formerly paid ly the maritime counties for naval defence, the shipmoney tax, was revived and extended to all England. The refusal of Hampelen and others to pay this tax was the first step in open opposition to the king.

\section{Civil War Be-} gun. - It was in Scotland that rebellion began. Efforts of Laud to change the P'resbyterian worship led,

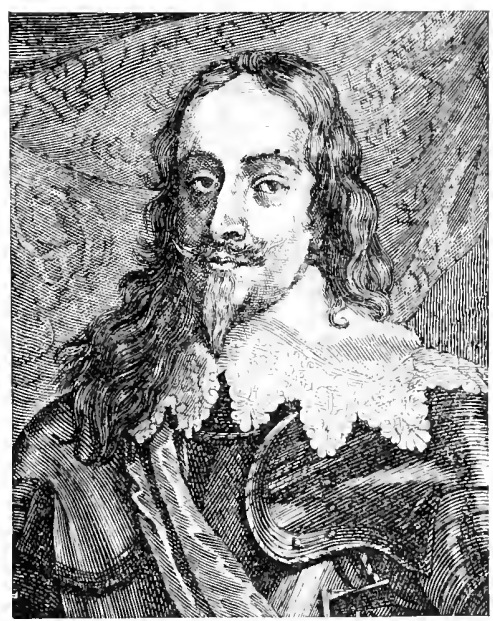

Charifs I. OF ENiLinD first to riot, and then to organized resistance. To support the army which was necessary to compel obedience, Charles was obliged to summon a Parliament, but when they showed no disposition to make a grant before a rearess of grievances, he speerlily dissolved them. Fut the Scottish army advanced into England, and the king was forced to yield.

In 1640 , the Parliament known as the Iong Parliament, and, after the execution of the king, as the Rump, came together. Charles sacrificed Strafford and Laud to the vengeance of the commons, hoping that they would demand no further concessions, but when he found that this was but a beginning, he rashly attempted to turn the tide by depriving the opposition of its leaders, and demanded in the

Charles yieldo for the moment, IO 4 I. 
presence of the House the arrest and delivery to him of five members, including Hampden. The storm aroused by this act rendered reconciliation no longer possible, and Charles abandoned London, which was devoted to the parliamentary side, and at Nottingham, on the $22 \mathrm{~d}$ of August, I642, raised the standard of civil war.

The Independents put the king to death.

Green,

English

Piople, III.

258-203;

Burle,

(liventon, 219-223.

(Clarendon); Gardiner, Deiuments, $232-291$.

35I. The Great Rebellion and the Commonwealth.-- In the war which followed, known in English history as the Great Rebellion,

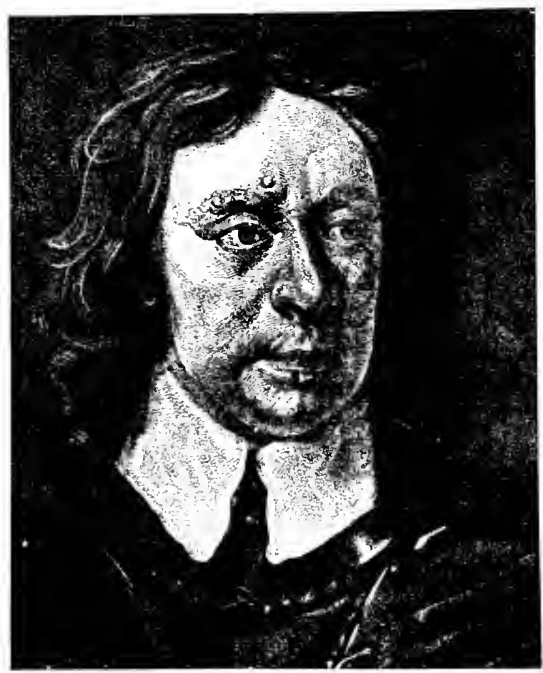

CROMWELL the war between the Cavaliers and the Roundheads, the extreme Puritan party, the Independents, under the lead of Cromwell, soon came to the front. Cromwell's troop, the Ironsides, devoutly religious, thoroughly drilled, and full of determined courage, was made the model of the army. Defeated in several battles, especially at Naseby in I645, Charles took refuge in Scotland, but was delivered to Parliament by the Scots in $\mathbf{1} 647$. After the failure of all attempts at compromise, and the expulsion by Cromwell from the Long Parliament of the members who were opposed to extreme measures, Charles was put on trial before a special High Court of justice, condemned to death as a tyrant and traitor, and executed on the $9^{\text {th }}$ of February, 1649.

The Com-

For four years longer the diminished Parliament conmonwealth. tinued to rule England in form. Cromwell was occupied 
with his army in putting down various insurrections, in conquering Ireland, where there were many friends of the Stuarts, and finally in meeting the Scots, who had proclaimed Charles II. king and invaded England with a strong army. In the two great battles of Dunbar and Worcester, Cromwell completely defeated them, and Scotland was obliged to acknowledge the government of the Commonwealth. In 1653, Cromwell and the army became so dissatisfied with the conduct of affairs by the "Rump," that he dissolved it by force, and soon became in name, what he had really been for some time, the ruler of England, under the title of Lord Protector.

\section{Topics}

The character of this age in the different countries of Europe. The first in the series of wars. The conduct of Maurice of Saxony. The new policy of France. The arrangements made by the peace of Augslurg. The close of the reign of Clarles V. Compare the power of Philip II. with that of Charles V. His illea of his highest duty. The policy of Mary of England, and the result. Why must Elizabeth be a Protestant? Ifer rival for the crown. The political constitution of the Netherlands. Ilow did they pass to the Ilapsburgs? Causes of separation into two parts. Measures of 1'hilip 1I. The rebellion and independence of the United l'rovinces. The early life of Mary Stuart. Why did she take refuge in England? Why was she executed? The history of the Armada. The origin and ideas of the Puritans. The differences between Puritans and Separatists. Which were the Pilgrims? Characteristics of the lluguenots. The policy of Catherine de' Medici. How did the IJuguenot wars begin? The political position gained by the Iluguenots. Reasons for the massacre of St. Bartholomew. The character and policy of Henry IV. His foreign plans. 'The edict of Nantes. The causes of the Thirty Years' War. The history of Frederick of the Palatinate. The peculiar methods of Wallenstein. Reasons for the interference of Sweden and France. Richelieu's policy in France. Abroad. His attitucle towards Protestantism. What change in history loes this stand for? The character of Gustavus Aclolphus. His military skill. Why was Wallenstein assassinated? The importance of the peace of Westphalia. What did France gain from the war? In what position was Austria left? How had the Empire become so weak? In what condition was Germany 
left by the war? The characteristics of the Stuarts. What change now occurs in English history, and why? The attitude of the Puritan party. Why was James I. an unpopular king? How did Charles I. differ from him, and how was he like him? By what measures dicl Charles try to restore the royal power? How did he come to allow Strafford to be executed? Cromwell's party. The end of the Long Parliament.

\section{Topics for Assigned Studies}

The Armada. Froude, History of England, XII., Chap. XXXYi. Story, British Empire (Nations), 1. 127-159. Johuson, Periods, 373-377. Kingsley, H'stiard Ho! (Novel.) Chaps. NXIX. to XXXI.

The rise of the Puritan party. Hallam, Constitutional History of Enyland, Chap. IT. Bacon, Genesis of the Nei' England Churchis. (Harper.) 73-90. Fisher, Reformation, 342-347. Ilinis, England of Elizabeth. (Macmillan.) Wakeman, The Church and the Puritans. (Epochs Ch. I Iist.) Documents in Prothero, Seled Statutes. (Clarenton.) Bk. VIII. I $S_{3} \mathrm{ff.} \mathrm{Gee} \mathrm{and} \mathrm{Ilardy}$ $416 \mathrm{ff}$. Religious Pamphlets in Pamphlet Library. (Holt.)

Policy of Richelieu in France. Perkins, Richelieu and Mazarin. (Putnam.) I., Chap. IV. Kitchin, France, III. 6-10, IS-30, 75-83. Corréard, Tertes, p. 29.

The sicge of La Rochelle. Perkins, Richelieu and Mararin, I. I IS127. Gardiner, Thirty Jears' IVar, Chap. VI., Section IV. Corréard, Textes, p. 27. 


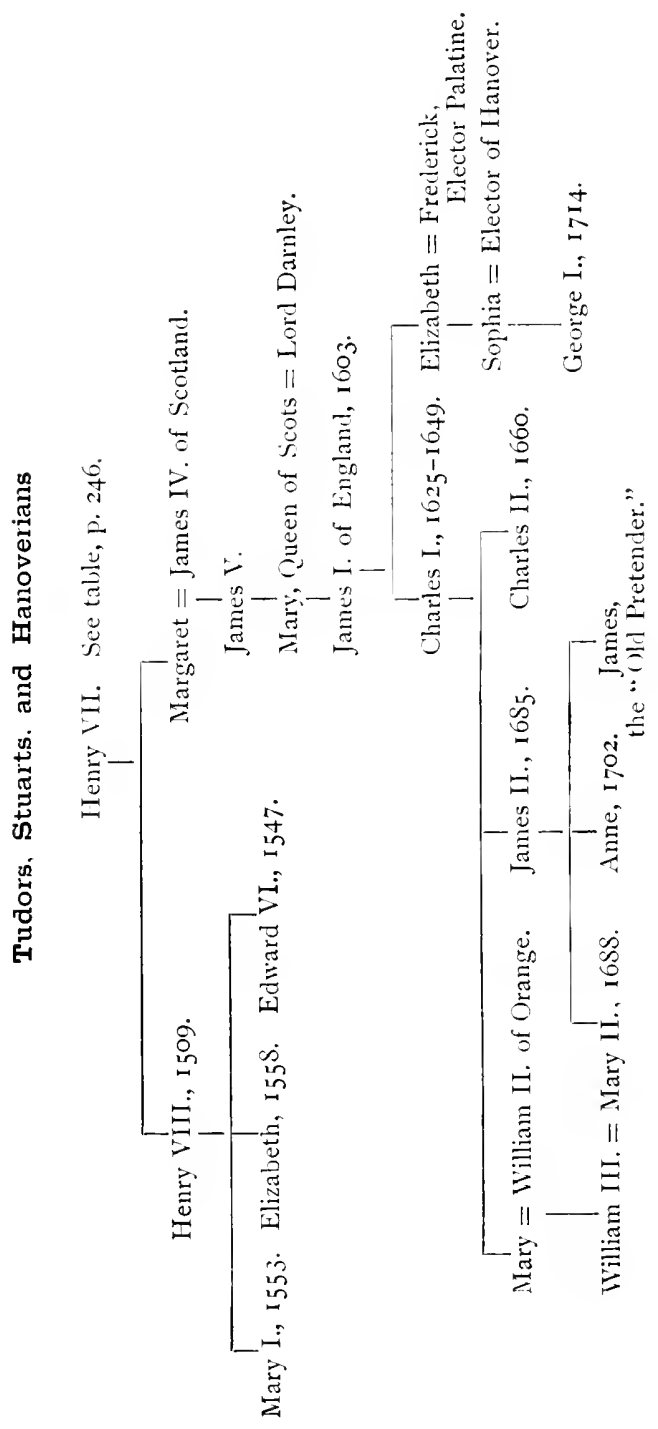




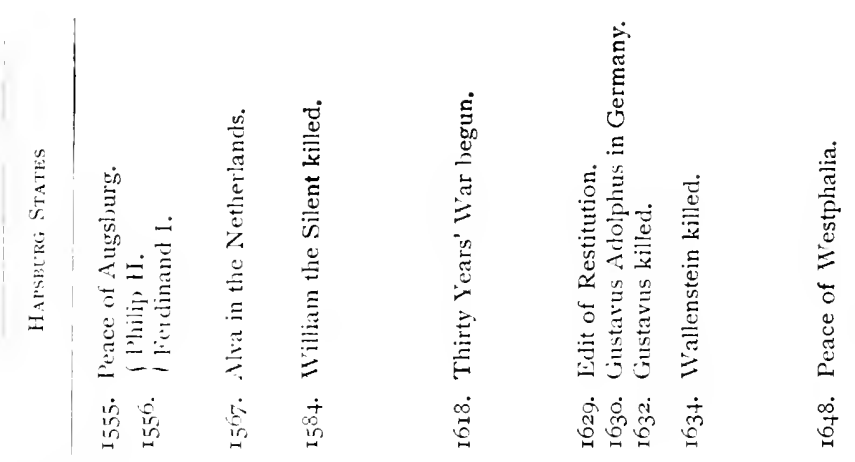

3
0
5
0
0
0
0
0
0
0
0
0
0
0
0
0
0
0
0
0
0
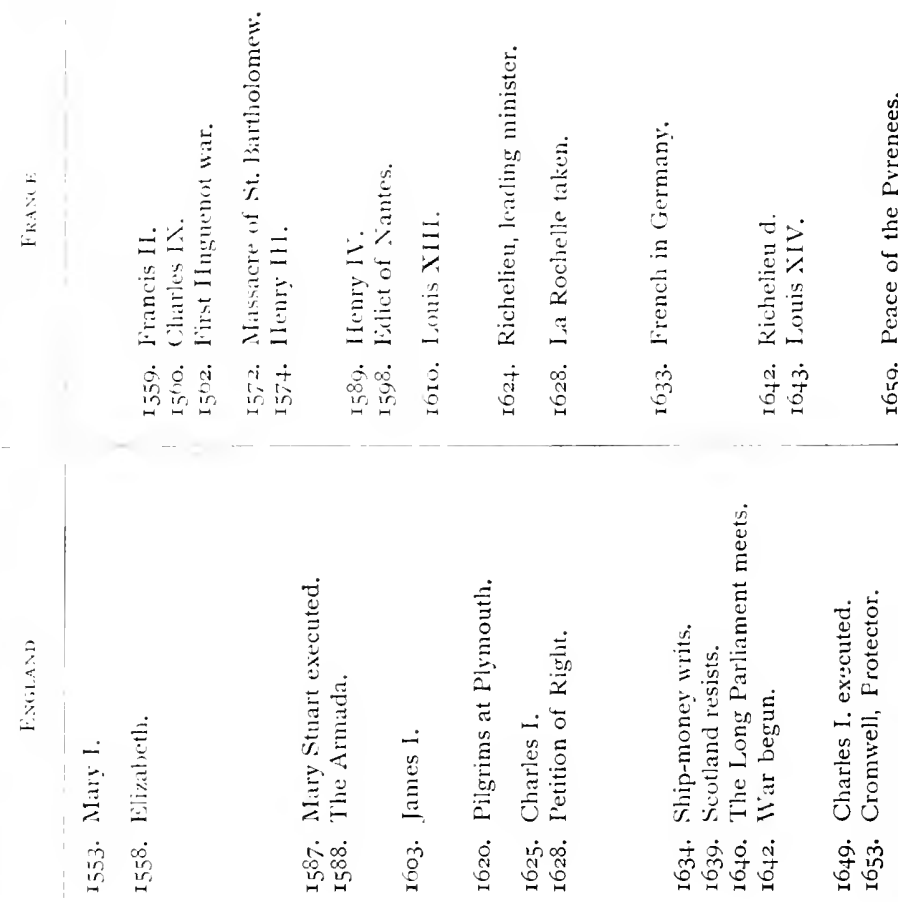


\section{CHAPTER II}

FRANCE TRIES TY DOMINATE EUROPE

352. The Hapsburgs in r660. - In 1660 , after the close of the war with Spain, France appeared to be without a rival in Europe. Spain still had widely extended possessions, - Naples, Milan, Franche-Comté, and the Low Countries, - and she still had the now diminished treasures of America at her command, but her scattered possessions were not easy to defend, and the old energy of the race, its splendid military capacity, was gone. The country had been turned from the path of the sure development of its own resources, partly by the bigotry of its rulers, and partly hy the more brilliant attractions of the New World, and it now plainly showed the result in rapiclly declining power. The royal family seemed to reflect the condition of the nation, for it had passed into a condition of physical and mental exhaustion, which brought it to an end with the close of the century. There seemed nothing to prevent the possessions of Spain in the Rhine valley from falling an easy prey to the designs of France.

The Austrian Hapsburgs showed no signs of the exhanstion of their Spanish cousins. Deprived of all chance of making a real empire of Germany, they were finding a compensation in pushing their dominion down the I lanube valley, where the loosening hold of the Turk, just beginning his long decrepitude, gave them the opportunity to recover Hungary. But under these circumstances they would plainly have less reason than a generation before for opposing the plans of France in northwestern Germany.

Austria turning to the East.
Spain weak and declining. On the whote age see Philippson, Das Zeitalter Ludrigs III: (Berlin). 
England not likely to interfere.

Holland most nearly interested.

Her resources.

353. England and Holland. - England was still in its age of revolution: I 660 was the year of the restoration of the Stuarts and the monarchy in the person of king Charles II., and, though Cromwell had shown himself at times disposed towards a vigorous foreign policy, and though commercial interests were rapidly increasing, no one could then suppose that England would take a leading part in international affairs within a generation.

Still less could any one suppose, in $\mathbf{I} 660$, that the resistance which was destined to defeat the plans of the Grand Monarque, and to check the desired advance of the most powerful state of Europe would come from the little Dutch Republic, whose independence had just been recognized by Spain and the Empire. But Holland was a country of resources out of all proportion to its size, and of the most determined resolution to protect its independence, which it believed threatened by the lesigns of Louis. Ideal reasons also were not wanting, - a hatred of despotism and of religious intolerance, which were now enbodied in Louis XIV., as they had once been in Philip II. A more republican cast had lately been given to the constitution in consequence of the failure of an attempt of William II.'s to make it more monarchical. The political and military headship of the State had been separated, and the former was now in the hands of John de Witt, Grand Pensioner of Holland. I) uring the war of independence, the eastern colonies of Portugal, then a part of Spain, had been seized by the 1)utch, and with the East Indian trade under its control, Holland had become the richest country of Europe and the mistress of the seas. England was beginning to dispute that position with her, and the struggle between them had been opened by a short war under Cromwell, but as yet Holland had not suffered greatly from the rivalry. It was quite as much the armies of France, as the fleets of England, that ruined the Dutch Republic.

354. The Situation in France. - In the government of France, the plans of Richelieu had been as successful as in 
regard to the European position of the country. After the death of Richelieu, Cardinal Mazarin had continued his policy. In the civil war of the Fronde, during the minority of Louis XIV., an attempt had been made to check the progress of the royal power, partly in the interest of the Parlement of Paris, the supreme court, which tried to secure some constitutional right to limit the king's prerogative, and partly in the interest of the great nobles and princes related to the royal house, whose more selfish object was to recover political power for themselves.

Both these attempts had been failures, and when Louis XIV. took the direction of the government into his own hands, on the death of Mazarin in I66I, there was no check on the will of the king and no constitutional means by which public opinion could express itself. The Estates General had not met since $1_{6} 1_{4}$, and they were not to meet again until the eve of the Revolution in $\mathrm{I}_{7} \mathrm{~S}$. The Parlement of Paris was obliged to yield in every case, however much it might wish to oppose the king, and all the ministers were entirely dependent upon him.

355. Character of Louis XIV. - Louis XIV. was not a genius in any respect. In the management of government affairs, he was a painstaking and hard worker, like an industrious business man. In foreign affairs, he intensely desired the aggrandizement of France and his own glory. He was ambitious to be ranked in history as one of the world's great sovereigns and conquerors, but he was narrow and short-sighted in determining the special objects of his policy, and dependent for such success as was reached on the genius of others. He was a most firm believer in the divine right of kings. He sincerely thought that he was responsible to God alone and not at all to the nation for the way in which he ruled. Intolerant of opposition or of opinions that did not agree with his, he lived upon the grossest flattery, and could be led only by adroitly persuading him that the object desired was his own. But in spite of all his faults he was, as all his age believed him, a great

An ambi-

tious plodder. A contemporary portrait, Corréard, Textes, II2; Hassall, Louis XIl: (Heroes), 82-IO2; Kitchin, France, III. I+2-I52. Theory of royal power. Bossuet on, in Corréard, Texte's, I08, and Schilling, Quellen. buch, 198 . 
king, and he honestly and sincerely sought the interests of the nation, as he understood them.

The finances in confusion.
356. Colbert and the Finances.

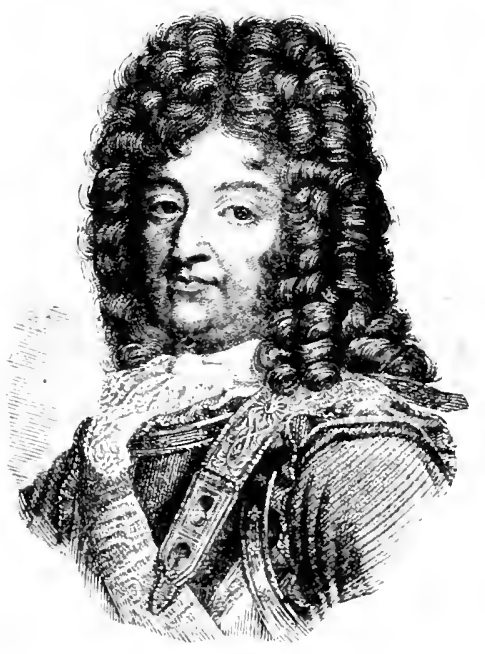

LOUIS XIV:

- In Colbert, Louis had, during the first part of his reign, a great finance minister whose skill provided the resources for his undertakings. At the death of Mazarin, the finances of France were in great confusion. Corruption in their administration was the rule, and Mazarin himself had not scrupled to comply with it. The people paid heavy taxes, but the collectors enriched themselves at the expense of the State, and only a small proportion reached the treasury. It was estimated that of eighty-four million paid in r 66 r only twenty-three were received by the government.

The fall of

Fouquet.

Cortéard, rextes, I $29-139$; l'erkins, liegency, $3 \mathrm{I}-40$; Hassall, Louis . II:, I03-123.

Mazarin's superintendent of finances, Fouquet, who had acquired an enormous fortune by these methods, fell a first victim to the new reforms. No one had supposed at first that Louis was in earnest when he had announced, on the death of Mazarin, that he would be his own prime minister, and Fouquet had hoped to succeed the cardinal in the government of the State through the king. It was the dramatic arrest and punishment of Fouquet that first convinced the court that Louis meant what he said. Colbert, who had revealed to the king the financial methods of the time, was soon put in control of the revenues, and was by degrees 
given other responsible offices, until he had nearly the whole administration of the kingdom in his hands.

The confidence of the king which he had at first, he fully deserved. Probably no minister in history ever served his country with more singleness of purpose. He attacked the old abuses vigorously. The collectors were forcel to restore to the treasury their ill-gotten gains. New methods brought in greater returns to the State, while the burdens of the people were reduced, and a surplus was accumulated which was, perhaps, a temptation to the king.

357. Colbert's Economic Measures. - The efforts of Colbert for the good of France were not confined to a reform of the taxation. He wished, like Henry IV., to increase the national wealth and bring in an age of great prosperity. In his measures for this purpose he was guided by two ideas. One was that manufactures must be the chief source of national wealth and not agriculture. 'The other was that to secure the best results industry must be under strict government supervision. 'This was a theory of paternalism quite natural to the time, and to the kind of government prevailing in France. Colbert could hardly know that the most essential condition of economic prosperity is freedom, freedom to make changes, to introduce new methods, and to conform to varying conditions. He placed a heavy protective tariff on foreign goods, introduced many new lines of manufacture, brought in colonies of skilled artisans of many kinds from abroarl, and established minute regulations intended to secure always the best quality of product. The result was at first largely what he hoped for, but the class he most desired to serve did not agree in the end that his measures had been of benefit to them.

Foreign commerce, also, and colonies he endeavored to develop in the same way. The East and the West India Companies were organized, and others of the same kind, and given monopolies of their goods. The valley and mouth of the Mississippi were occupied, and North America seemed likely to become French, but in the settlement of

Commercs and colonies. 
colonies a strict paternalism prevailed, as everywhere else, and prepared the way for the failure of the French in competition with the freer English.

Colbert's last It was not likely that a minister like Colbert, who did not days.

hesitate to preach economy and to object to lavish expenditures, would be able to control the finances of France permanently, under a king like Louis XIV. As the king became more devoted to the worship of himself, and involved in projects for his own glory, the influence of Colbert declined. His last years were filled with disappointment at the failure of his plans to make income equal expenditure, and he died unpopular with court and people alike, an example of the ingratitude of kings.

The mar- 358. Preparing to annex Spain. - The direction which riage of Louis XIV. his foreign conquests should take was marked out for Louis XIV. by the treaty of the Pyrenees, which had closed the war with Spain in 1659 , as well as by the weakness of that country. This peace had been cemented by a marriage between Louis and Maria Theresa, the eldest daughter of Philip IV. of Spain, but the treaty had provided that she should renounce all her rights of succession to the throne of Spain. The skilful diplomacy of Mazarin, however, had secured the insertion of a condition which rendered this renunciation of no effect. It was to become valid on the payment by Spain of a dower of five hundred thousand crowns of gold, a sum which Mazarin knew that it would be impossible for Spain to raise. The first successes and the final

The "right of devolu* tion."

Airy, Louis VIV. (Epochs), Chap. XII.; Hassall, Louis . III:, Chap. V.; Perkins, Regency, 52-67. failure of Louis XIV. were alike due to this provision.

359. Louis XIV.'s First War. - In 1665 Philip died and was succeeded by his son, Charles II. He was the son of Philip by a second marriage, while the wife of Lonis was a daughter of the first. Some peculiar provisions were discovered in the feudal law of inheritance prevailing in certain provinces of the Spanish Low Countries, by which the children of a first marriage should succeed to the exclusion of those of a second. That these were not provisions of the public law, but related only to private inheritances, made no par- 
ticular difference. Louis at once advanced his claim to these provinces, and a fine French army under Turenne occupied, almost without resistance, some of the strongest fortresses of the Low Countries.

These rapid successes of Louis, with the evident fact that spain could not defend herself, excited the immediate alarm of Holland. She was able to form the Triple Alliance with England and Sweden, still regarded as one of the strongest states of Europe, and offered a kind of armed mediation. Louis' first answer was the rapid occupation of the province of Franche-Comté, a part of the territory of the former dukes of Burgundy. But he did not think it wise actually to enter upon a war with the Triple Alliance, and consented to the treaty of Aix-la-Chapelle, in 1668 . FrancheComté was restored to Spain, but a line of strong fortresses was retained on the borders of the Low Countries, which promised France an easy entry into the heart of that country when the next war should begin.

$3^{60}$. Louis prepares to punish Holland.-Louis XIV. was now resolved to take vengeance upon Holland at the earliest possible moment. The little Calvinistic republic of traders and fishermen which had dared to set limits to the ambition of the greatest monarch of Christendom must be taught to know its place. His first step was, by skilful diplomacy, to deprive Holland of her allies. It was not difficult to gain Charles II. of England. To fill his empty pocket and to further his own personal designs, he was ready to sell his alliance to France, and, though so much of the bargain as became known was very umpopular, the weakening of Holland was not contrary to the commercial interests of England, which had already had two great naval wars with the Dutch within twenty years. Siveden was also gained and remained on the side of France till the close of the war, and Holland was left without an ally.

$3^{61}$. The War against Holland. - In the spring of 1672 the war began. Louis himself at the head of a great army, for those days, of more than roo,ooo men, carefully passing

The Triple

Alliance

checks

Louis.

Airy,

Louis XII., Chap. XIV.

Peace of Aixla-Chapelle.

Holland isolated. Airy, Louis $\mathrm{X} / \mathrm{l}$., Chap. XVI.

England against the Ditch.

Louis' first successes. Kitchin, France, III. 
185-189; around the Spanish Low Countries and through the territoHissall, Louis . III:, ries of his German allies on the Rhine, invaded the country Chap. VI.

The war becomes European. Kilchin, France, III. IgI-205; Perkins, Regency, b9-89. from the south. His success was rapid at first. The southern part of the land was occupied, Utrecht was captured, and Amsterdam was threatened. But Holland was no less determined in her resistance to the new representative of intolerance and despotism than she had been in the case of Philip II. The government was revolutionized. John de Witt was murdered by a moh, and the young William III. of Orange was put at the head of the State. 'Then the dykes were cut and the advance of the French was checked.

William III. immediately sought for allies, and the fear which the designs of [ oun XIV. began to excite in Europe came to his aid. Spain. the emperor, and Brandenburg

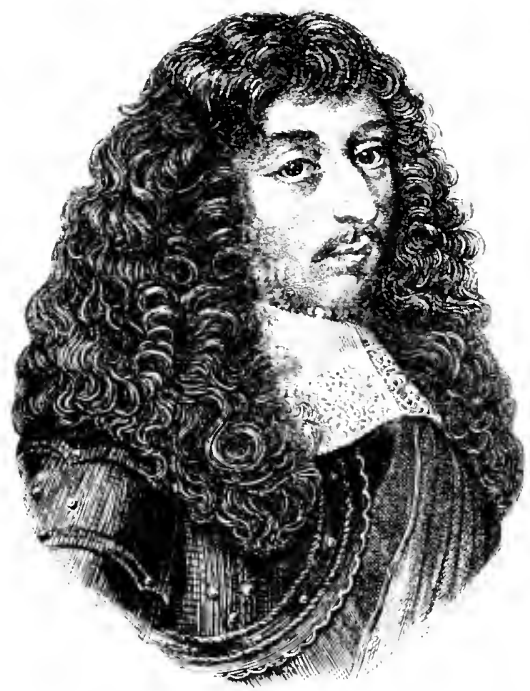

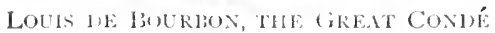
began war, and public opinion in England forced Charles II. to withdraw from the side of Louis. The war became a European war. France was forced for a time to fight on the defensive, but the genius of Turenne, until he was killed in 675 , and of Condé, until he went into retirement soon after, were more than a match for their enemies. FrancheComté was again occupied, and further fortresses in the Spanish Netherlands were captured. On the sea the Dutch suffered heavily, their great admiral De Ruyter was killed, and the French admiral Du Quesne gained several victories. 
At last all parties were ready for peace, and the treaty of Nimeguen was made in 1678 . Holland had not been inumiliated as Louis had hoperl, and received favosable terms, but she was exhausted by the strain and losses of the war. The gains of France were as usual at the expense of Spain. Franche-Comté was now retained and a new and better frontier drawn in the Spanish Netherlands.

362. The Period of the "Reunions." - The period of ten years which followed to the begimning of the next war is filled with interesting events, and forms a turning-point in the reign of Iouis XIV. and in the history of France. In the first place, Lonis had come off so well against a strong European coalition that he still believed he could do anything he pleased, and he acted accordingly. On pretext of the phrase "and their dependencies" which had accompanied the cessions from (iermany in the recent treaties, he set courts, called "Chambers of Reunion," at work in the Rhine valley to seek out every indication of former leprendence on the lands which he had received, and to rleclare that these new territories were also French. Nore than a hundred bits of territory, large and small, were thus annexed. In $168 \mathrm{I}$, the great city of Strasburg, a free city of the Empire. was seized. At the same time, Casale, a fortress in northern Italy, which would open the way to the Symish territories of Milan, was seized in the same way. Genoa, which had long been an ally of Spain, was bombarded, and forced to the most humiliating conditions of peace. Savoy was treated almost like a French province; the principality of Orange was seized, and on a quarrel with the pope, Arignon was taken possession of. Spain and the Empire were powerless to resent these insults, and Austria was threatened with and soon engaged in a desperate war with the Turks, who besieged Vienni in $168_{3}$, and were only driven back by the army of John Sobieski, king of Poland. But if resistance was for a time not possible, Enrope was growing constintly more convinced that a general combination was necessary to check the French ad-

Annexations in lime of peace. Hassall, Limis XI:, Chap. VII.; Perkins, Ke'se'thcy, 209-218; Kitchin, France, III. $213-217$. 
The League vance. In I686, Sweden, Spain, and Austria, with other of Augsburg. of the larger German states, formed the League of Augsburg to prevent the further violation of treaties.

The edict of

363. The Revocation of the Edict of Nantes. - In the

Nantes revoked. 1685 .

The loss to France.

The exhaustion of war and extravagance. year which preceded this event, Louis XIV., by an act of his own, had injured France as deeply as could a league of its enemies. From the year in which Mazarin died, he had sanctioned measures of increasing sererity against the Protestants. In 1685 , encouraged perhaps, rather than incited, by the advice of Madame de Maintenon, which fell in with his own intolerant disposition, hoping by so pious an act to appease a conscience not altogether quiet, wishing to add to the other glories of his reign that of destroying heresy and making France of one faith, he revoked the edict of Nantes, which had been granted by Henry IV., in 1598.

Since the overthrow of their political power by Richelieu, the Hugnenots harl been faithfil citizens and of the greatest service to France. They were mainly of the middle class, artisans, merchants, and lantholders. Some of Colbert's manufacturing colonies had been made up of Protestants. They formed the strength of France upon the sea. How much the prosperity of the country depended on them could not be known until it was deprived of their aid, for in spite of the eclicts against emigration hundreds of thousands escaped and carried to other lands their industrial skill and a bitter hatred of their native land. Protestantism was not destroyed, for in Louis' last war and in time of desperate need the rebel Hugnenots in the south of France kept a French army from fighting the foreign invader, but the industry of France was undermined and the navy fatally weakened.

364. The Resources of France declining. - Already the resources of the State were beginning to feel the constant strain of war and of extravagance also, for peace for the next hundred years was as costly to France as war. The vast building and other works at Versailles, where the king had now taken 11 , his permanent residence, the daily ex- 
penses of the court, and the pensions and salaries of the nobles, required enormous sums. Despite the efforts of Colbert, the taxes were growing heavier, the national debt was increasing, ant the old confusion was coming back into the management of the finances. It was a crisis in the history of France. Had the king been wise enough to see that the country was on the verge of exhaustion, and to realize the strength which the Huguenots lent to the nation, the whole history of France might have been different.

\section{Charles II. in} England. - Events were in the meantime taking place in another country which

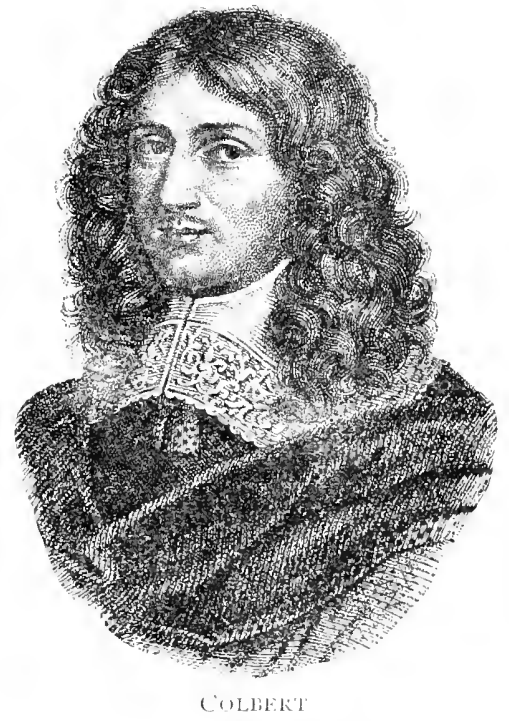

were quite as important as these in their bearing on the future of France, and more important still in their bearing on the future of the world. England passed through the last of the Stuart revolutions and entered on a new era of her history. The meaning of this in the growth of her constitution and of her colonial empire, we shall study in another place. Here we are most concerned with its bearing on the plans of Ionis XIV. and on the supremacy of France in Europe.

Charles II., though he was no more disposed to be a constitutional king than the rest of the Stuarts, had learned some wisdom from the disasters of his father. But his reign was increasingly umpopular. He seemed to have no personal interests except in the corrupt pleasures of the
The second Situart period. see references in Chap. VIII.
The reign of Charles II., I660-I685. 
court. His extravagance kept him always in need of money, and he sold Dunkirk to the French, which Cromwell had secured to take the place of Calais, and he accepted the pensions of Louis. He was willing to make war on Protestant Holland : plotted to restore Catholicism in England, with a French army to aid him if necessary; and stretched the laws granting indulgence to Catholics and dissenters as far as he dared. But he knew how to yield when the popular opposition became too strong, and he managed to keep) possession of the crown for twenty-five years and to pass it on to his brother, James II., whose known adhesion to the Catholic Church had made a large party in the State anxious to exclude him from the throne.

James II., 1685-1688.

366. The Revolution of I688. - James II. was the most narrow and obstinate of his family, and his determination to be the means of the restoration of Catholicism carried him perhaps to further extremes than he would otherwise have attempted. He assumed the right to suspend, modify, or extend laws made by the Parliament, to interfere with the operation of the courts, and to increase the standing army and commission Catholics as officers. England bore his rule with patience for three years, looking forward to the next reign, for the heir to the throne was James' daughter Nary, married to her cousin, William of Orange.

James In 1688 a son was born to the king, and the situation was deposed. changed at once. The prospect of the reign of a James III. could not be endurerl, and an invitation was soon sent to William to come to England and tike possession of the government. On the landing of William the power of James at once collipsed, and he was obliged to flee to France, where he was William III. received and provided for by Louis. William and Mary became joint sovereigns with the full consent of the nation, and the constitutional principles established by the Revolution of 1688, as this event is called in English history, were put into definite form and made law in the Bill of Rights, passed in 1689 .

367. The War of the League of Augsburg. - William III. was the soul of the opposition to Louis XIV., and he was 
now able to add England and Holland at once to the League of Augsburg. War had already been begun by Austria, and in 1689 it became a general European war. The day of rapid conquests was over, but France maintained herself against so many enemies with fair success. The events of the war are of little importance. The attempt of James II. to recover his throne through an invasion of Ireland, where he had many partisans, with the help of the French, was a failure, and by his victory in the battle of the Boyne William III. secured his position in England. The French barbarously laid waste the Palatinate, to which I ouis had laid claim at the beginning of the war, to prevent its occupation by the enemy. On sea the French fleets were almost destroyed by those of England and Holland. On land the general balance of the war was in favor of the French, but in 1697 Louis made the peace of Ryswick, granting concessions to all his enemies.

368. The Question of the Spanish Succession. - Louis was moved to make such a peace, so contrary to his usual practice, by the rapid approach of another event, in which he had a far deeper interest than he could have in any possible conquests of this war. Charles II. of Spain was plainly approaching the end of his life, and he had no heir. Louis was resolved to insist upon the claim for which Mazarin had prepared the way in the treaty of the Pyrenees, and to which Louis had looked forward as the crowning event of his reign, and to do this with any hope of success peace was necessary.

Louis had little hope at first that be could secure the whole Spanish inheritance for a French prince. There were other heirs with claims as good or better. The archduke Charles of Austria and Prince Joseph of Bavaria were lescended from Spanish princesses who had not renounced their rights of succession, as had the mother and wife of Louis, though the Austrian princess through whom Prince Joseph derived his immediate claim had made such a renunciation on her marriage. Besides this, it was hardly

Louis' plans not easy to realize.

England joins the League. Perkins, Regency, Chap.VIII.; Kitchin, France, III. 251-271.

'The peace of Ryswick.

The end of the Spanish Hapsburgs. Morris, Age of Anne (Epochs), Chap. I.: Kitchin, France, III. 272-284. 
likely that Europe would allow these two great monarchies to become so closely allied and the power of France to be so greatly increased when her comparatively small gains in the Rhine valley had been so bitterly opposed.

The Spanish

Empire to be parcelled out without leave.

Hassall, Louis XIl:, Chap. XII.; Green, Enslish People, IV. 66-7o.

Spain objecis to the partition treaties. Kitchin, III. $28+\mathrm{ff}$.

Charles II.'s will.

The will of Charles II. accepted.
369. The Partition Treaties.- Louis' first plan, therefore, was to arrange in adrance some partition of the Spanish territories among the different claimants, which Europe would accept without a war. Two such treaties of partition were drawn up and consented to by William III. of England, whose opposition Louis especially feared. William wished, however, to avoid war, and some such arrangement was absolutely necessary, since there were no other heirs to be considered. The second treaty of partition was made necessary by the death of Prince Joseph, whom the first had assigned to the throne of Spain. The kingdom of the Two Sicilies was the most important territory given France by these arrangements, and this Louis hoped to be able to exchange for Saroy on the southeast border of France.

Very naturally the parcelling out of the territories of what hacl once been the most powerful and was still the proudest of nations, without so much as asking consent, as if Spain herself were about to die, or had no will, was deeply resented by the Spanish. They proposed to dispose of their own throne and in such a way as to preserve the integrity of their empire. Their natural disposition was in favor of the house of Hapsburg, but careful consideration convinced them that France was far more likely to be able to prevent the disintegration of their dominions than Austria. Accordingly, a short time before his death, Charles II. drew up a will in which he left the whole of the Spanish lands to the duke of Anjou, the second son of the Dauphin, and grandson of Louis XIV. 370. France annexes Spain. - The news of this testament, on the death of Charles II., near the end of the year I 7oo, occasioned a moment's hesitation in France. To take what was given by the partition treaty with less risk of war, or if war must come with England and Holland as allies, or to try for the whole and face all Europe in a certain war with 
only the possible help of Spain, — this was the question. The question was soon decided. The prize was too great to be refused, and Louis introduced his grandson to the court with the words, "Gentlemen, this is the king of Spain."

It now seems likely that even this triumph of Louis' would have been accepted by Europe, so tired were some of the leading states of the constant wars of the last twentyfive years, if he had not apparently lost his head over his great success. England and Holland were disposed to give their consent in return for commercial concessions, but these were refused. Spain was to give France a monopoly of some of

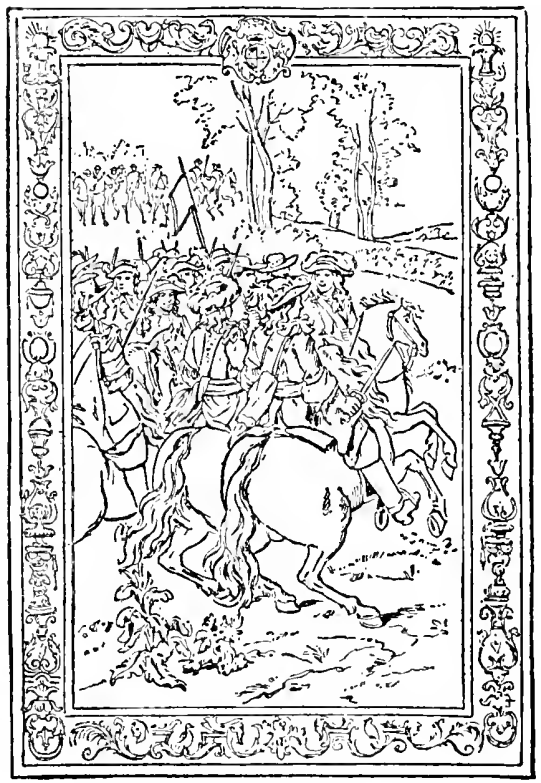

Gobelin TApestry, Time of Lovis XiV. the most profitable lines of trade with America, especially that in negroes, at the expense of England and Holland. James II. dying at this time, France immediately recognized James III. as the rightful king of England. Spain was openly treated as if it were already a subject state, as if the Pyrenees were indeed no more. Philip $V$. gave formal notice that he retained all rights of succession to the French crown, and the Low Countries were almost annexed. Such things could not be passed over, and William III. had no difficulty in forming the Grand Alliance of all the chief states of Europe, whose object was to compel a

Spain

treated as if a part of

France.

Lecky, History of England. (Appleton), I. $27 \mathrm{ff}$.
The Grand Alliance. Schilling, Quellenbuch, 209. 
Great generals and battles.

The dawn of world politics.

France makes a brave defence, but is forced to yield.

Ilassill, louis $\mathrm{X} / \mathrm{l}$ : Chap. XIII. partition of the Spanish Empire. William died just as the war was opening, but he was succeeded by Anne, the sister of his wife and daughter of James II., who continued his policy, under the influence of the Whig party.

37r. The War of the Spanish Succession. - From a military point of view, the War of the Spanish Succession is one of the greatest of European wars. The allies had two very famous generals, the English duke of Marlborough and Prince Eugene of Saroy, in the service of Austria. France had no generals equal to these, and sometimes her armies were very badly led, but they knew how to fight, and such battles as those of Blenheim, Ramillies, Oudenarde, and Malplaquet are among the greatest of history.

The War of the Spanish Succession is also more than a European war, and as the last stage of the 'Thirty Years' War marks the introduction into international politics of new motives and guiding principles, so this war indicates the coming on of a new era in history, for it was, in some degree at least, a world war, and was fought on many seas and in all colonies. In American colonial history it is known as Queen Anne's War.

372. The War goes against Louis. - The course of the war was decidedly against the French in spite of the bravery of her armies. She lost great battles. Her territory was inraded. The Huguenots in the south - the Camisardsrevolted. The Spanish people remained true to Philip V., but at one time he was driven from his capital which was entered by the archluke Charles. At one time during the war, Louis was brought to offer most extensive concessions in return for peace, but the allies demanded more than he could yield until absolutely conquered. He turned almost in despair to the French people, in an address which was sent throughout the country, and the nation, despite its intense suffering and exhaustion, responded with an enthusiasm which made its conquest impossible. Finally the archduke Charles became emperor, and as Europe had nc wish to restore the great empire of Charles V., and as Louis 
was still ready to grant concessions, the war ended with the peace of Utrecht in 17 I 3 .

England had already signed preliminaries of peace. This was due to the fact that Queen Anne had broken with her former favorite, the duchess of Marlborough, the Whigs had lost control of the State, and the Tories had come into power. They favored peace and had now the support of the queen. Marlborough was accused of peculation and passed the last years of the reign in disgrace.

373. The Peace of Utrecht. - Like the peace of Westphalia, that of Utrecht concerned almost every European state. The Spanish people retained the king they had chosen, but failed of the purpose for which they had chosen him. Spain was separated from all her European possessions. Austria received the lion's share of these : the Spanish Netherlands, Milan, Naples, and the island of Sardinia. The duke of Savoy received the island of Sicily and the title of king. A few years afterwards he was obliged to exchange this with Austria for Sardinia, and from this came the title of king of Sardinia, retained by the house of Savoy until the formation of the present kingdom of Italy. Spain, stripped of these possessions but retaining her American colonies, was given to Philip V., the grandson of Louis XIV. The Bourbons thus became possessed of the Spanish throne, the only one they retain at the present day.

374. The Rise of England. - The gains of England from this war were far greater than those of any other state, though they seem less striking than those of Austria. But Austria's gains were more apparent than real, for her new possessions, as in the days of Charles V., great as they seemed, were widely scattered, difficult to defend, and not a real source of strength. England's, however, were exactly in the line of her future greatness. From Spain she received the command of the Mediterranean, the fortress of Gibraltar, and the island of Minorca containing the strongly fortified naval station of Port Mahon, and she was given also control of the supply of negroes to the Spanish colonies, a very profi-

The Spanish possessions divided. Morris, Anne, Chap. XV.; Hassall, Louis .ill, 397-4It; Kitchin, France, III. 335-340. The Spanis: Bourbons.

England's colonial empire enlarged. 
table trade at that time. She had successfully begun in this war also the conquest of North America from the French. France ceded to her all her claims on New Foundland and the Hudson Bay territories, and Acadia or Nova Scotia.

England beginning to t.tke a first place in the world.
England's navy was now rapidly growing stronger, while those of France and Holland were growing weaker. Her commerce was widely extending. During the reign of Anne she had made a treaty with Portugal which made that country, once the greatest commercial and colonial state of Europe, almost her commercial vassal. As the treaty of

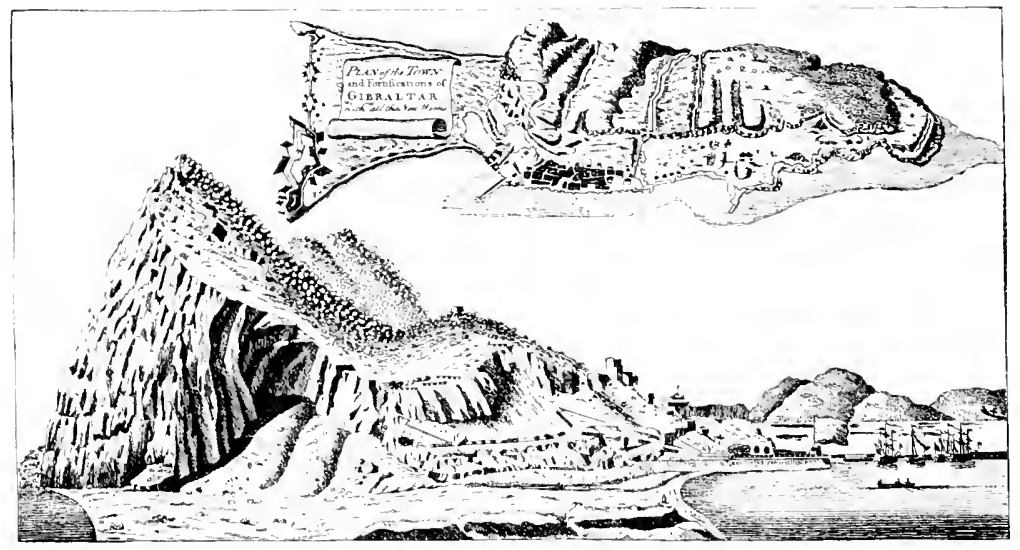

A NORH VLW OF GIBRALTAR

The exhaustion of France. Contemporary accounts.
Westphalia marks the decline of the house of Hapsburg and the rise of France to the first place in Europe, so that of Utrecht marks the decline of France and the rise of England to a first place, not now in Europe merely but in the world. 375. France Unable to prevent the Rise of England. But this change was not a sudden one. A long and desperate struggle was still necessary to complete it. Louis XIV. had gained from the War of the Spanish Succession what he had set out to gain, - the throne of Spain for his grandson ; but it was at a fearful cost, and it proved of no value in the 
end. The last half of the reign of Lonis XIV. had been filled Correard, with more disasters for France than the king knew of. The resources of the country were exhausted. Its industry undermined. Its commerce almost destroyed. Agriculture was weighed down by a heary burden of taxation, and had suffered from bad seasons as well as from the drain of men into the army. The peasantry were in a most miserable condition and sometimes even starving to death. The finances were in disorder. The court was still prodigally wasteful and corrupt, and all power of reformation seemed lost.

Bigotry and mistaken policy had turned France into the way which Spain had entered a century before. She was not destined to follow it to the same end, but it was not the government which prevented this result. It was the French nation which saved itself with that immense recuperative power which is one of its marked characteristics. French industry and frugality accunulated new resources in spite of taxes and government squandering, and in another century could endure rast expenditure of men and money in a new struggle against all Europe, far greater than Louis XIV.'s. But for the present France was exhausted, and in the struggle with England which was to settle in the next fifty years the colonial empire of the world, this is the most essential fact.

376. The Beginning of Louis XV.'s Reign. - Louis XIV. The regency. was succeeded by his great grandson, Louis $\mathrm{XV}$., then five years old. The regent was Philip of Orleans, nephew of Louis XIV., a most corrupt man. To keep himself in power he formed an alliance with England against Philip V. of Spain, who, notwithstanding his renunciation of all rights of succession in France, was plotting to make himself regent. 'This alliance, joined afterwards by Austria and Holland, and so becoming the "Quadruple Alliance," led to a war with Spain which had no important results, except to increase the financial difficulties of France and to show how little Louis XIV.'s War of the Spanish Succession had led to a union of Spain and France.

Recovery in spite of the government.

377. The End of the Stuart Dynasty. - Just before the 
Accession of end of Louis XIV.'s reign, Queen Anne of England had died. George I. See table, p. $36 r$.

Norris, tnne, Chap. Xill.;

Lecky, Engolind, I. $\mathbf{1 7} 7-\mathbf{1} 83$.

Thackeray, Henry Eismond (novel); Pamphlets by steele, swift, and IBolingbroke, in Political Pamphlets, Pamphlet Libroly.

The union with sicotiand. Norris,

Inne, Chap. Xil.; (ireen, English People, IV. $90 \mathrm{ff}$. This event had been looked forward to by the extreme supporters of the Stuart family in the hope that something might then lead to the accession of James III., the "Old Pretender." But if any plots had been made to secure him the throne they completely failed, and George I. of Hanover was quietly acknowledged king, according to the Act of Settlement which had been passed before the death of William III. By this act, failing heirs of William or of Anne, Parliament had settled the succession on the nearest Protestant heirs of the throne, the descendants of Elizabeth, daughter of James I., who had married the infortunate Frederick of the Palatinate. Thus began the house of Hanover, or of Guelf, which still reigns in England.

Another event in the reign of Anne of equal importance for the future of Great Britain, was the union of England and Scotland into one kingdom. By the accession of James of Scotland to the English throne, there had been formed what would now be called a "personal union," by which the two kingdoms had one sovereign and followed in general a common policy, but each retained its own Parliament and local government. In 1707 by the Act of Union, Scotland obtained representation in the English Parliament and ceased to have its own. The result proved a real union of the two peoples into one, of great importance in the age of expansion which was just beginning.

\section{Topics}

What reasons can you give for the decline of Spain? Why did it seem that France would have free hand in Europe about 1660 ? What interest had IIolland in the ease? What was now the character of the French constitution? The character of Louis XIV. The changes made by Colbert. The importance of the marriage of Louis Xiv. Louis' first war. His feeling towards Ifolland. I, ouis' second war. How does the period of the "reunions" show Lonis' power in Europe? The revocation of the edict of Nantes and its consequences. lit the Imerican colonies gain anything by this ? 'The effect of Louis' " ars un lirance. The relation of England uniler Charles II. to France. 
The reasons for the Revolution of $\mathbf{I} 6 S S$. Its effect on France. The thirl war of Louis. The question of the Spanish succession. What prevented its settlement as Louis would have liked? Spain's feeling on the subject. What brought on the War of the Spanish Succession? Its character. Its effect on liance. The treatment of Spain in the peace of Utrecht. The gain of England from the war. The effect of Louis' reign on France. The policy of the regent. The accession of the house of Hanover in England. The union with Sicotland.

\section{Topics for Assigned Studies}

The reforms of Colbert. Perkins, France under the liegency (IIoughton), Chap. IV. Hassall, Louis . TIV. (1Ieroes), 123-130. Corréard, Tertes, $140-207$.

The revocation of the edict of Nantes. Perkins, Regency', I69-204. Hassall, Louis .VIT., 241-252. Kitchin, Fance, III. 224-234. Text and contemporary comment. Corréaril, Téltes, 230-240. German translation, Schilling, Quellenluach, I9ı. 


\section{CHAPTER III}

THE RISE OF RUSSIA AND PRUSSIA

Changes in northeastern Europe.

Sweden a great power.

378. The Position of Sweden. -- While the War of the Spanish Succession was introducing the change which we have noticed in the relative positions of France and England, changes were taking place in the northeast of Europe which, so far as the European politics of the eighteenth and nineteenth centuries are concerned, were of even greater influence, and in the world politics of the nineteenth century of almost equal consequence. Sweden, which at the close of the Thirty Years' War hall been one of the great powers of Europe, rapidly declined into the second rank; Russia, which mil this time harl never been thought of, became a strong European state and legan its enormous expansion: and Prussia rapidly rose in power and became the rival of Austria.

'The 'Thirty Years' War left Sweden with a military reputation and a geographical position which made her one of the first states of Europe. 'This had been gained by the wise policy and the genius of her kings, by religious enthusiasm which had inspired her armies, and by unusually favorable conditions among her neighbors. The place which she had taken she could hardly hope from her own resources to maintain. The successes of the elector of Brandenburg in the second of I ouis XIV.'s wars made this evident, though he gained nothing from them at the time. Sweden, however, kept her territories and her position until the sudden rise of a new power overthrew the balance in the northeast. 
379. The Early History of Russia. - Russia was occupied From the by the Scandinarians, at the time of the great Northmen Nothmen invasions in the ninth century, as we have seen. The dy- Romanoffs, nasty of Ruric which was established at that time remained Rambaud,

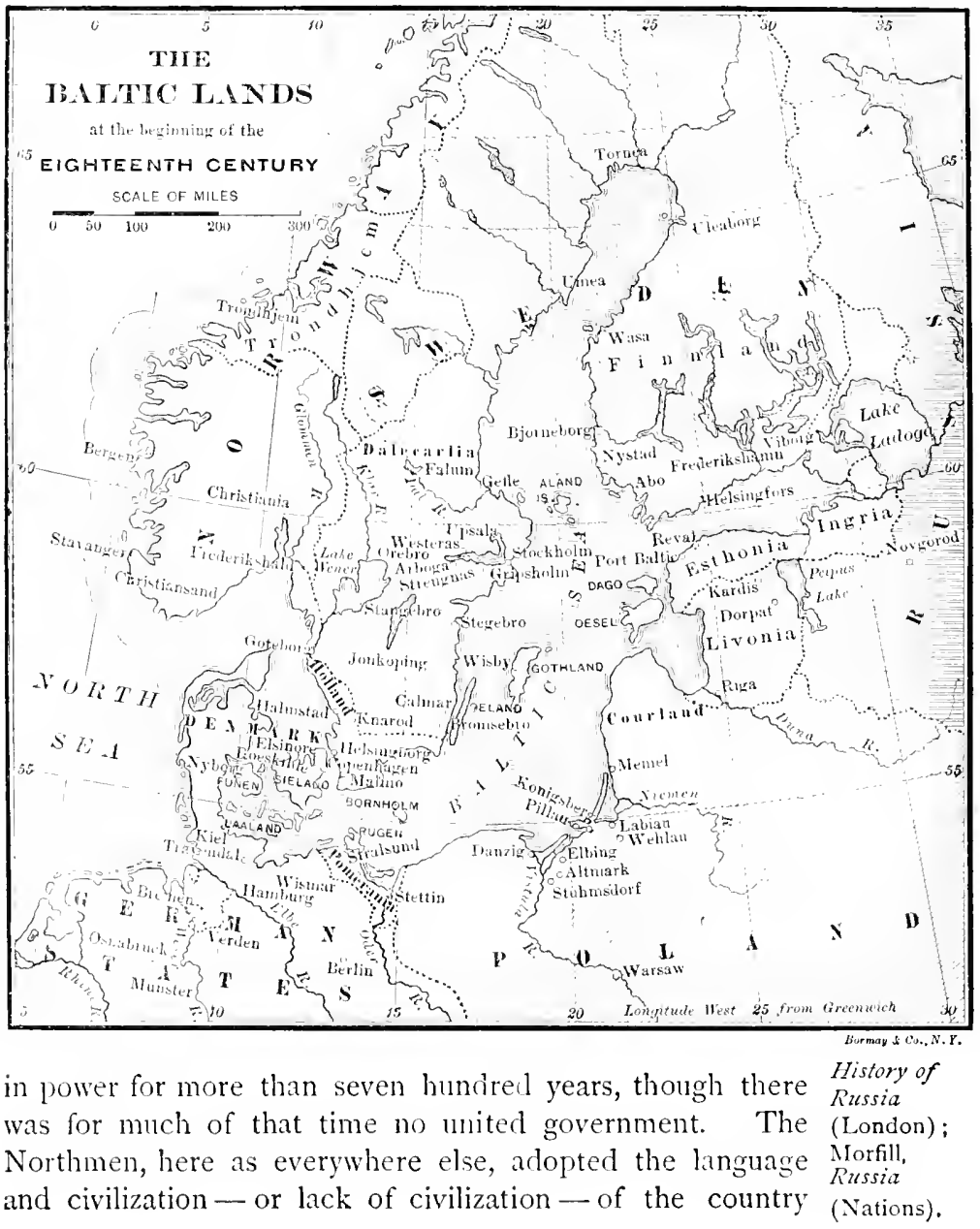


and became Slavs. They were in closer connection with the Greek Empire than with any other civilized state, and in the tenth century received christianity from there, and were organized as a part of the Greek Church under the Patriarch of Constantinople, a relation which continued until the conquest of the Empire in the east by the Turks. At the time of the great Mongol invasion in the thirteenth century, Russia came under their rule which lasted two centuries and a half. In the second half of the fifteenth century, the Prince of Moscow, Iran the Great, a descendant of Ruric, threw off the Mongol yoke, got possession of Novgorod, the great commercial city of the north, and founded modern Russia. At the end of the sixteenth century the house of Ruric became extinct, and after a few years of civil strife Michael Romanoff was made czar, the founder of the house of Romanoff.

Not really a

European state.

380. Russia in the Seventeenth Century. - Still through all the seventeenth century Russia was not a European power. She was shut out from all contact with the West. Sweden had possession of all the shores of the Baltic, and the 'Turks of all the north shore of the Black Sea. In civilization, political influence, or interest for other states, Russia might as well not have been a Christian state; she was up to this time no more a part of Christendom than was China. One of the most striking characteristics of the nineteenth century has been the extension of European international law and close political relationship, to that common system which we call Christendom, over the whole world. 'The first step in this expansion of Christendom was the sudden entering of the European system by Kussia in the reign of Peter the Great.

Obstacles to overcome. Schuyler, Peter the Great, 2 vols. (Scribner), I689-I725.
38I. The Changes made by Peter the Great. - From the beginning of his reign in $\mathbf{1 6 8 9}$, when at the age of seventeen he began to rule alone, Peter was resolved to introduce western civilization into Russia, and to make her one of the great powers of Europe. To do this he had two great obstacles to overcome. One was the opposition of the "Old Russian" party. bitterly opposed to all change, 
against which he had to contend almost to the end of his reign. The other was the isolated position of Russia, cut off from access to the sea, which could be remedied only by successful wars with Sweden and Turkey.

Peter's work in Russia was a revolution. He had from youth a band of friends from the countries of the West who encouraged his efforts, and he increased their number. He

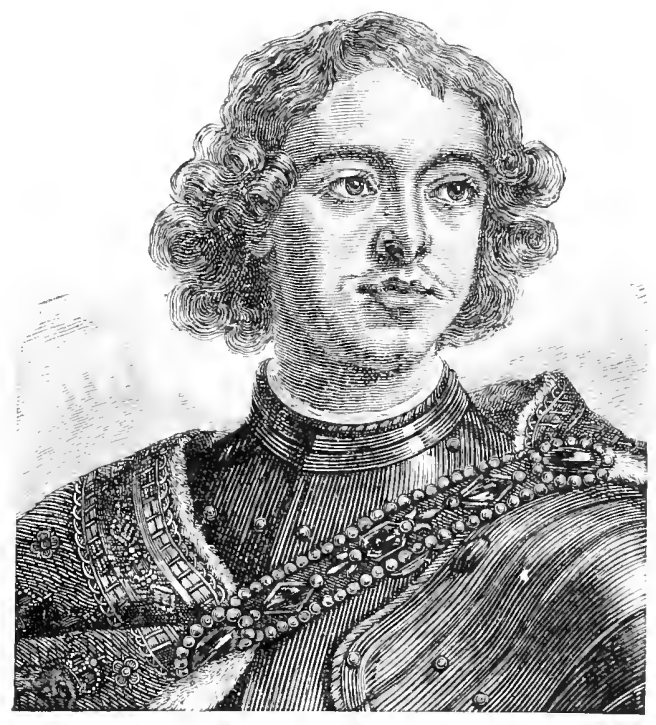

PETER THE GREAT

called into Russia artisans, merchants, officers, and artists. He organized a new army to take the place of the old royal body-guard, the Strelitz, who had assumed too much power. He compelled the nobles to submit to his absolute authority, forced them to hold their lands of him, made nobility depend upon service, and created many new nobles and deposed many old ones. He subjected to cruel punishment his sister and even his only son when they joined the opposition to his reforms. He undertook journeys to Holland and 
to England to learn ship-building and to study the methods of the western states. He began the construction of a fleet while his only harbor was Archangel on the White Sea, frozen half the year. The founding of St. Petersburg as a new capital, in conquered territory, open to the Baltic, and so in connection with the IVest, symbolizes the result of his reign. Russia had been made a new state, facing Europe instead of Asia.

The first gain from the Turks.

382. Russia against Sweden. - In opening the way to the sea, Peter's first success was gained from the Turks. Taking advantage of Austria's attack on Turkey in the Damube valley, he pushed through to the Black Sea, and in the peace of Carlowitz, in 1699 , forced the Turks to cede to him the strong town of Azof at the mouth of the Don. Immediately after this began the great war with Sweden which led to the fall of that state.

Charles XII. In 1697 Charles XII. came to the throne of Sweden at of Sweden, I $697-17$ I 8 . Norris, Age of Anne, Chap. VIII.; Bain, (harles $\mathrm{x} / \mathrm{l}$. (Heroes).

('harles's first successes. Rambaud, R'ussia, II., Chap. I. the age of serenteen. This, thought all the neighbors of Sweden who wished to partition her territories, was an opportunity not to be neglected. Denmark, Russia, and Poland, whose king was the elector of Saxony, formed an alliance against the young king. But they did not know with whom they had to deal.

Charles XII. proved to be a great military genius, but one lacking the political insight of Peter the Great. He at once attacked the Danes, and in three months, before any of their allies could come to their aid, he forced them to make peace. 'Then he turned immediately against Peter, and at Narva dispersed a Russian army much larger than his own. Here he made his first mistake. Without following up his advantage and forcing Peter to make peace as he had marle the Danes, he turned back and marched against Poland, whose king he regarded as a personal enemy. Here he was equally successful. Augustus II. was dethroned, and a Polish noble, Stanislaus Leczinski, was elected in his place. Then he advanced against Saxony and finally forced Augustus to make peace and renounce the Polish throne, (1 708). 
383. The Fall of Charles XII. - But in these operations he had used up several years more indeed than were necessary, for he had lingered long in Poland, pleased perhaps at being courted by Louis XIV. on one side, and by the allies on the other, who were now in the midst of the War of the Spanish Succession, and in these years Peter had not been idle. He had beaten the Swedes in battle, taken possession of several Baltic provinces, and in one of them had founded St. Petersburg. When at last Charles returned to the Russian war, he made his second great mistake. Instead of going back to the North he let himself be persuaded by a revolted Cossack chieftain, Mazeppa, to attack Moscow. But the Cossacks gave him no real assistance, and in the great battle of Pultava, in the summer of $\mathrm{r} 709$, he was completely defeated by Peter, and escaped with only a few followers into Turkey.

The war which he persuaded the Sultan to make against Russia brought him no permanent advantage, though Peter was obliged to give Azof back to the Turks. Charles wasted several more years in Turkey, trying to induce the Sultan to renew the war, and was at last practically imprisoned there. When he escaped in 17 I 7 the situation had so changed in the North that no recovery by Sweden was possible. The old enemies were all in the field. Augustus was again king of Poland. The Danes were threatening the capital of his kingdom. New enemies had joined the rest, Brandenburg, now the kingdom of Prussia, England, and Holland. Charles kept up the war, however, until he was killed at the siege of Frederickshall in $\mathbf{r}_{7} \mathbf{1} 8$. Sweden then marle peace at the expense of her southern and eastern Baltic provinces. Bremen and Verden went to Hanover, Pomerania to Prussia, and the rest to Russia. Sweden's short history as a power of the first rank was over. Russia and Prussia had each taken a long step forward.

384. The First Promotion of the Hohenzollern. - At the death of Peter the Great in 1725 , Europe knew that a power had risen in the East that must be taken into account Charles in Turkey.

Mazeppa and the battle of Pultava, 1709 .

\section{Charles} killed and Sweden humbled, I7 18 .

Modern Prussia the work of Frederick 
the Great. in the future. She hardly felt the same as yet in regard to Tuttle,

History of

Prussza, 4 vols. (Houghton).

Prussia. It was the work of Frederick the Great to bring his country forward into the rank of a first-rate power. But Frederick's work was only the natural conclusion of a long line of preparation steadily followed by his ancestors through several centuries.

The Hohen-

The origin of the Hohenzollern family was similar to that zollern first obtain

Nuremberg.

Tuttle,

Prussia, I., Chap. III.

Then Brandenburg. I 415 . Map of growth of Prussia, Putzger, No. 30. The Rhine provinces and the duchy of Prussia. Tuttle, Prussia, I. Chap. IV.

The Great Elector, I640-I688. l'uttle, Prussia, I., Chap. V. of the Hapsburgs. When they first appear in history they are counts of a little territory on the borders of Switzerland. Shortly afterward Frederick of Hohenzollern was made burggraf of Nuremberg. In this office the family displayed the frugal middle class traits which have always characterized it, and at the beginning of the fifteenth century the Frederick of the day was able to lend to the Emperor Sigismund a large sum of money in final payment of which he was made elector of Brandenburg, which had fallen in to the Empire by the extinction of the fanily of Albert the Bear. Then began the process by which the present kingdom of Prussia has been created - the union under a single rule of a great number of the little independent states into which North Germany was at that time divided.

385. The Chief Steps in the Making of Prussia. - IVe can follow only the most important steps of this growth. At the beginning of the serenteenth century, the inheritance of the dukes of Juliers and Cleves was claimed, and a good part of it finally secured, the origin of Prussia's Rhenish provinces. In 1618 the duchy of Prussia, the lands of the old German order, which since the Reformation had been held as a secularized duchy by a younger branch of the family, fell in to the elector, but was held as a part of the kingdom of Poland. The reign of the Great Elector, Frederick William, was a time of rapid progress. At the close of the Thirty Years' War, Brandenburg received east Pomerania, and the secularized ecclesiastical states of Magdeburg, Halberstadt, Minden, and Cammin. During a considerable part of his reign engaged in successful war with Sweden, he was however obliged by Sweden's ally, 



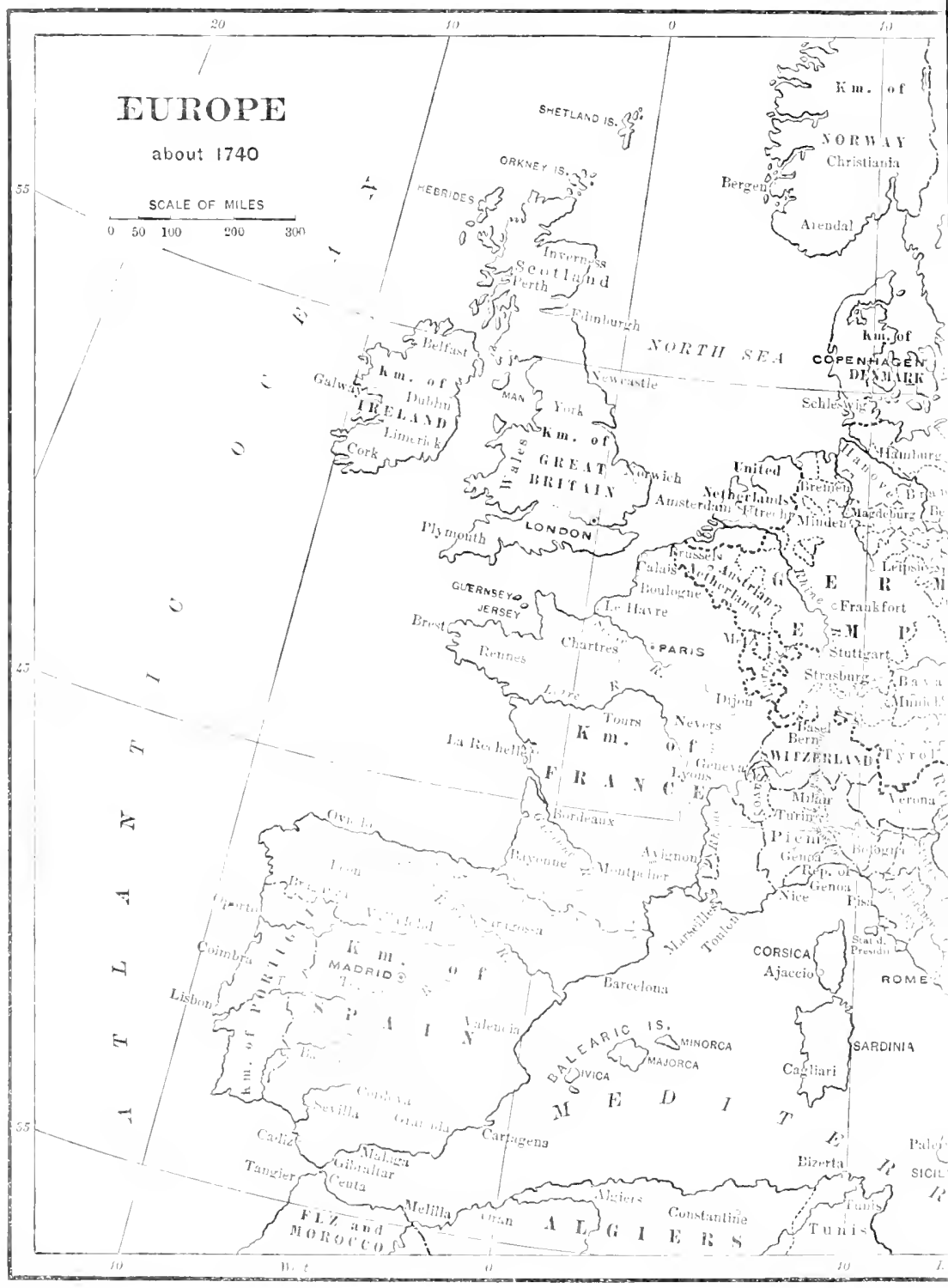



Louis XIV., to give up his conquests, and secured only the independence of the duchy of Prussia of Poland, and the reputation of having a fine army.

More important than his conquests was his work in the organization of the govermment. He centralized his scattered states into a single whole. He broke the power of the nobles and of the local legislatures where these existed, and established the absolute rule of the sovereign. His successor joined the alliance against Louis XIV. in the War of the Spanish Succession, and Europe in the peace of Utrecht, the same peace which gave the title of king to the house of Savoy, recognized his right to the title of king "in Prussia," which he had assumed in I 70 I with the consent of the Emperor.

386. The Father of Frederick the Great. - The second king in Prussia, his son and successor, the famous father of Frederick the Great, the drill sergeant, the corporal, the head of the tobacco parliament, was a coarse and brutal barbarian who cared nothing for art or knowledge, and was only interested in his soldiers. He was ambitious to have a large and finely drilled army, but he was unwilling to risk it in battle, and took no part in the wars of his time, except in the last years of the great war against Sweden. In the peace which followed the death of Charles XII., he gained west Pomerania for Prussia. His chief service was to hand on to his son Frederick the army, which the Great Elector had founded, more than doubled in size, and made one of the best in Europe, and a large surplus in the treasury.

When Frederick II. came to the throne circumstances were most favorable for a long step forward towards the destiny which the different labors of her rulers had been during so long a time preparing for Prussia, - to take the place of leadership in Germany which Austria had been obliged to give up. 'To obtain this a desperate struggle would be necessary, but Prussia was more favorably situated in north Germany than Austria in south. She was stronger than any one realized, and her young king was to prove himself a

Absolutism founded.

The title of king.

'Tuttle,

Prussia, I. 239-302.

Frederick IVilliam I., I7 $13^{-17} 4^{\circ}$.

Prussia ready for the struggle with Austria. Tutrle, Prussia, II., Chap. I.; Longman. Frederick the Great (Epochs), $3 \mathrm{I}-42$. 
genius in the art of war. The full fruits of Frederick's policy in the actual healship of Germany, Prussia did not gather for a hundred years, but before the close of his reign

The house of Hapsburg extinct, I 740 .

Frederick the first to strike.

'Tuttle,

Prussia, II. 42-56;

Longman, Friderice, $42-46$.

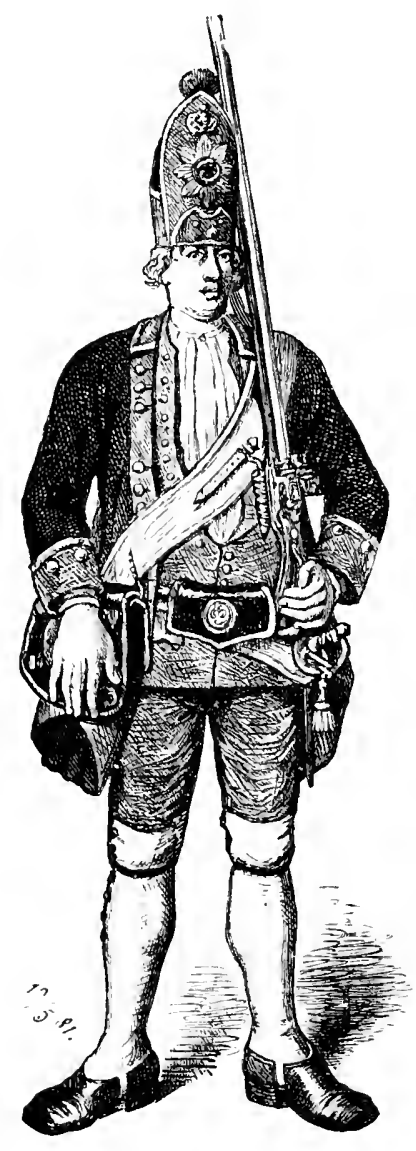

Gigantic Grenadier of FREDERICK WIILIAMI. it was plain to all Europe that there were two great powers in Germany of fairly equal strength.

387. The Pragmatic Sanction of Charles VI. - The opportunity for which everything was prepared came in the very year of Frederick's accession. The emperor, (harles VI., was the last male descendant of the house of Hapsburg. In the laut years of his reign it had been the rhief object of his policy to provide against the partition of the Austrian territories and to secure the undivided inheritance to his daughter Maria Theresa. This he had sought to accomplish by the I'ragmatic Sunction, a new law of succession in her faror, to which he had secured the consent of most of the states of Europe by treaties.

His death in October, $177^{\circ}$, revealed at once the worthlessness of these treaties. All Europe seemed to consider the time arrived to bring Austria to an end. The electors of Bavaria and Saxony advanced claims to the inheritance. Spain and France showed themselves ready to assist. But 
Frederick was first in the field. Before the end of I 740 , without waiting for an answer from Maria Theresa to his claims, and without a declaration of war he marched his army into the Austrian province of Silesia.

388. The War of the Austrian Succession. I740-I748.His success was rapid. The Austrians were defeated at Nolhwitz. An alliance was formed with France. The elector of Bavaria was recognized as Emperor. Moravia was invaded and another victory gained, and in June, I 742, Maria Theresa was ready to make peace with Frederick, that she might use all her strength against her other enemies. The peace of Breslau gave to Prussia the province of Silesia with a million and a half of inhabitants. But it was not yet in secure possession.

The tide which had been running against Maria Theresa now turned in her favor. She threw herself on the devotion of the Hungarians, and they responded with enthusiasm. The Bavarians were driven back. Prague was recovered. The English allies of Austria defeated the French at Dettingen. Saxony and Savoy abandoned the allies and joined the Austrians. Frederick began to fear that Maria Theresa would recover Silesia and he renewed the war. Rapidly he gained the victories of Hohenfriedberg, Soor, and Kesselsdorf, and captured Prague, while the French defeated the English at Fontenoy. Now Frederick thought he could agrain make peace with safety, and in the peace of Dresden, I 745, the cession of Silesia was confirmed, while he recognized Maria 'Theresa's husband, Francis of Lorraine, as Emperor.

389. Maria Theresa determined to punish Frederick. During the war Frederick II. had twice abandoned his allies without hesitation to secure advantages to himself, but when a general peace was made at Aix-la-Chapelle in 1748 the conquests which he had made were sanctioned by Europe. Frederick was, however, the only one of her enemies whom Maria Theresa could not forgive. The especial perfily of his attack on Silesia, the loss of that great province, the impudence of the little kingdom of Prussia in assuming

Frederick's second war. Tuttle, Prussia, 11., Chap. VIII.;

Longman, Frederick, Chap. $Y$.

Frederick cannot be forgiven.

Austrians recover ground. 


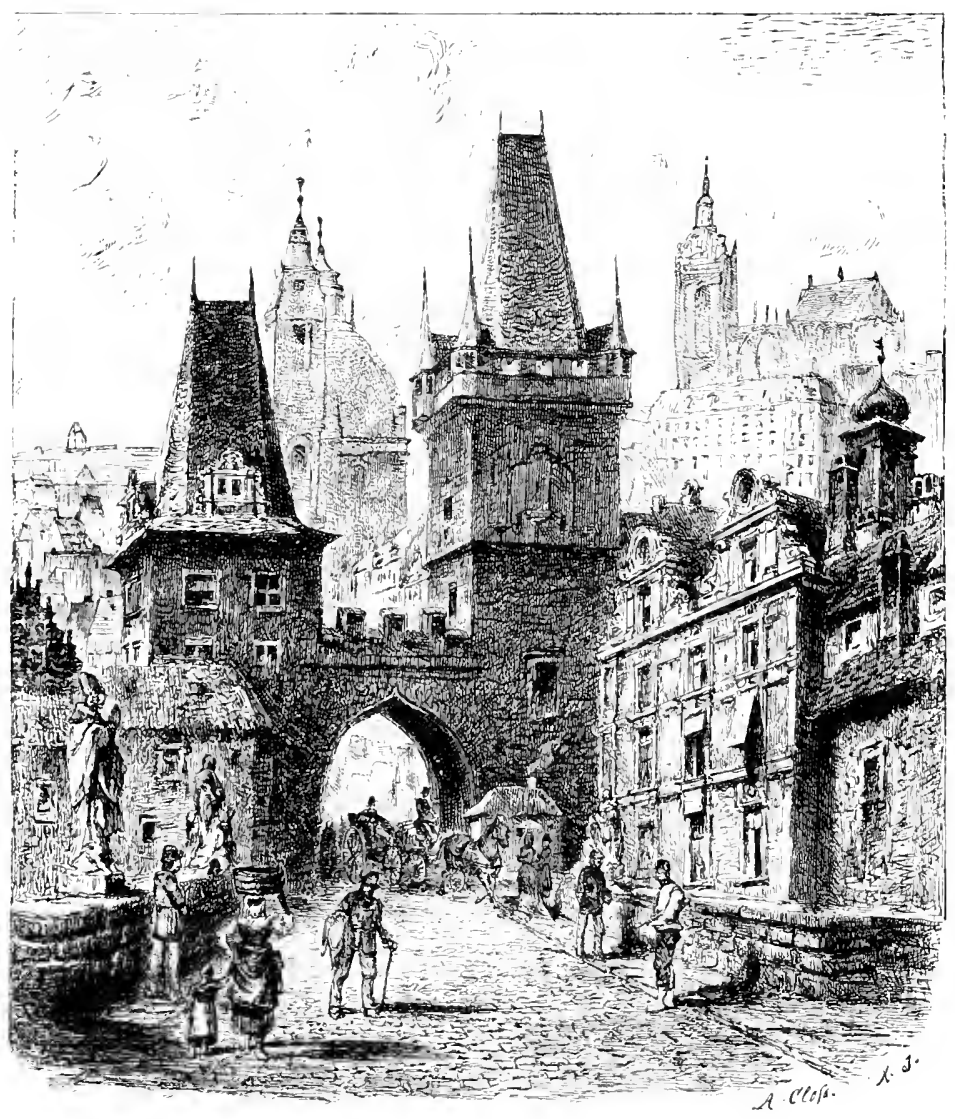

STONF BRIUGF IT PRAGUE

Europe agrainst Prussia. Hassall, so much power anct threatening the Austrian leadership in Germany, all combined to make her determined to crush Frederick in another war.

Her plan was to form a great European combination against the little state, and to raise up so many enemies that resistance woukl be hopeless; that, as the Austrian Chan- 
cellor v. Kaunitz said, they might force upon Frederick the fate which Henry the Lion had once undergone. Saxony, Sweden, and Poland were not difficult to secure. The Empress Elizabeth of Russia hated Frederick almost more than Maria Theresa, and was impatient for the war to begin. The most difficult, but a very necessary, ally to secure was France.

390. France abandons her Hereditary Enmity. -- Austria and France had been constant enemies for more than two hundred years. It seemed like reversing all history for them to join in an alliance against any other state. But there were reasons on both sides. Austria did not hesitate to make the suggestion, and she found France ready to listen. The French statesmen no longer feared Austria. That fear belonged to a stage of history now outgrown. On the other hand France did fear that the increasing power of Prussia would threaten her infuence in north Germany, and her conflict with England for colonial empire made a war with that country inevitable; in fact, it was going on almost without a pause during this interval of peace in Europe.

An arrangement which England made with Prussia early in 1756 to secure the neutrality of Hanover, of which King George was sovereign, was immediately followed by an alliance between France and Austria. The object of Maria Theresa's policy was not the mere recovery of Silesia. It was practically the partition of Prussia, and she hoped by this means to be permanently rid of her rival in Ciermany. It seemed as if the plan must succeed. Frederick's only ally was England, and England's interest in the war was not chiefly in Europe. It was in the colonial struggle with France which was now at its height, as we shall see elsewhere, and raging with equal fierceness in North America and in India. The war now beginning in Europe was the greatest of these wars, the French and Indian War of American colonial history. Indeed, we may almost say that the war which began with Spain in I 739 continued unbroken until the peace of Paris in ${ }_{7} 63$.

England Prussia's only ally.

A struggle for colonial empire. 
Frederick 391. The Seven Years' War (1756-I 763). - The allies will not wait intended to begin the war in 1757 , but Frederick, who was to be attacked. Tuttle, Prussia, IV., Chap. 1.

\section{Great} victories.

The odds against Prussia. Hassall, Periods, Chap. 1..; Longman, Frederick, Chaps. VIII.-XI., and XV.

Prussia maintains herself to the end. Brackenbury, Frederick the Great (Military history, Putnam's). kept informed of the negotiations by secret agents in Vienna and Dresden, determined to attack before their preparations were complete. At the end of August, I 756, he invaded Saxony, shut up the Saxon army in Pirna, defeated an Austrian force that came to their aid, forced them to surrender, and in less than a month was in entire possession of Saxony, which he treated as if it were annexed to Prussia.

The next year brought all his enemies into the field, but it closed on the whole in favor of Frederick. He was defeated by the Austrians at Kolin and forced ont of Bohemia, but he later gained the great victories of Rossbach over the French, and of Leuthen over the Austrians, which saved Silesia.

But the odds were really too great for Fredlerick. Russian and Swedish armies were in Prussian territory. The losses which his armies sustained, in victories as well as in defeat, could not be made good. England supplied money but not men. Berlin was captured by the Russians. Nearly all Saxony and Silesia were lost. The country held by the enemy was laid waste, and the sufferings of the people were extreme. But Frederick met these disasters with fortitude, though with occasional thoughts of suicide, and displayed the greatest military genins. He reorganized his defeated armies, faced his multitude of foes, won from them occasional victories, and made them purchase every advance.

In I 760 the death of (ieorge II. of England resulted in the withdrawal of the supplies from that country, and the following year showed the strength of Prussia almost exhausted. But at the beginning of 1762 the death of Elizabeth of Russia turned the tide. Her successor, Peter III., was an ardent admirer of Frederick's, and he made peace at once. Two considerable victories in the same year were followed by the recovery of Saxony and Silesia. All hope of destroy- 
ing Prussia seemed now at an end. France also had lost all her colonies, and was tired of the war. Early in $I_{7} 6_{3}$ peace was made between the several parties to the war. The peace of Hubertsburg between Austria and Prussia left to Frederick all his possessions at the beginning of the war.

392. Prussia a Great Power. - Maria Theresa was obliged to reconcile herself to the loss of Silesia. Prussia was henceforth recognized without dispute as one of the great powers of Europe, and as a leader in German affairs, though Austria maintained a rival leadership until i 866. A few years after the peace, when the line of the electors of Bavaria became extinct, Prussia was able to defeat the plans of Austria for getting possession of this the largest of the south German states, and organized a league of the princes - called the Furstenbund - to prevent the increase of Austrian power in Germany.

After the war Frederick devoted himself with all the power of a paternal despotism, and with success, to making good to his people the losses of the war and to restoring the prosperity of the country. Before the close of his life, Prussia was to receive another large increase of territory through the first partition of Poland. In this act the two new powers, Russia and Prussia, whose sudden rise was so largely due to unjust wars and the disregard of the rights of others, fitly joined hands against their weaker neighbor in a crowning act of robbery.

393. Catherine II. of Russia ( I762-1796). - From the death of Peter the Great to the accession of his daughter Elizabeth in $174 \mathrm{I}$, the history of Russia is one of frequent revolutions, and the policy of Peter was but little advanced. It was taken up again by Elizabeth, who forced Sweden to give up Finland, but who gained nothing from her war against Frederick the Great. Peter III., who succeeded her, was thrown into prison by his wife, a German princess, who seized the throne and became the famous Catherine II. The plans of Peter the Great for the extension of Russia to the West, she made the controlling objects of her policy.

Economic recovery of Prussia. Carlyle, Frederick the Great, Bk. XXI., Chap. II.

The plans of Peter the Great resumed. 
Sweden, Poland, and Turkey were to be forced to allow Russia a more direct outlet towards Europe.

A weak state. Rambaud, Russia, II. II $8 \mathrm{ff}$; ; Hassall, Feriods, Chap. XI.

Constitutional anarchy.

Universal corruption.

394. The Condition of Poland. - The death of Augustus III., in $I_{7} \sigma_{3}$, gave Catherine an opportunity to bring the Russian influence into the control of Poland, where it had been rapidly extending for some years. The condition of this country had for a long time invited the interference of her ambitious neighbors. It occupied a large territory in the centre of eastern Europe, extending from the Baltic almost to the Black Sea, and from the Carpathian Mountains to beyond the Dneiper. It had a population of twelve millions ruled by about one hundred thousand nobles. In form the constitution was a monarchy, but the king was elective and was only a figurehead. All real power was in the hands of the nobles, or it may be said in the hands of each noble. Since any act of the Diet could be vetoed by a single member - the liberum ieto, as it was called - a practical right of nullification existed for every noble.

The nobles were a high-spirited and brave class, but utterly corrupt and selfish. The peasantry were sunk in the lowest serfdom and degradation, hardly human beings. A middle class was wholly lacking. The business, falling to the free burgher of western Europe, was entirely in the hands of the Jews, who were without political rights and had of course no interest in the State. The destruction of Poland was a well-merited punishment of the selfish corruption of its ruling class, who would not allow reformation or abandon their privileges in the interest of the nation, but who did stand ready in large numbers to sell themselves to the Russian or the Prussian. These facts, however, do not justify the open violation of right and justice by those who destroyed the State.

Russia about to absorb Poland.

395. The First Partition of Poland. - Catherine secured the election in succession to Augustus III. of a former favorite of her own, Stanislaus Poniatowski. An attempt to reform the constitution in the interest of a stronger government was defeated by the veto and a Russian army, and the 
inflnence of Catherine increased so rapidly in the country that the fear of Frederick the Great was excited lest the whole kingdom should be absorberl by Russia, and the Baltic provinces of Prussia be threatened, and perhaps even the existence of the State as it once had been by Elizabeth.

Since the reform of Poland seemed impossible, and the country could be maintained in its present condition only

Frederick the Great interferes.

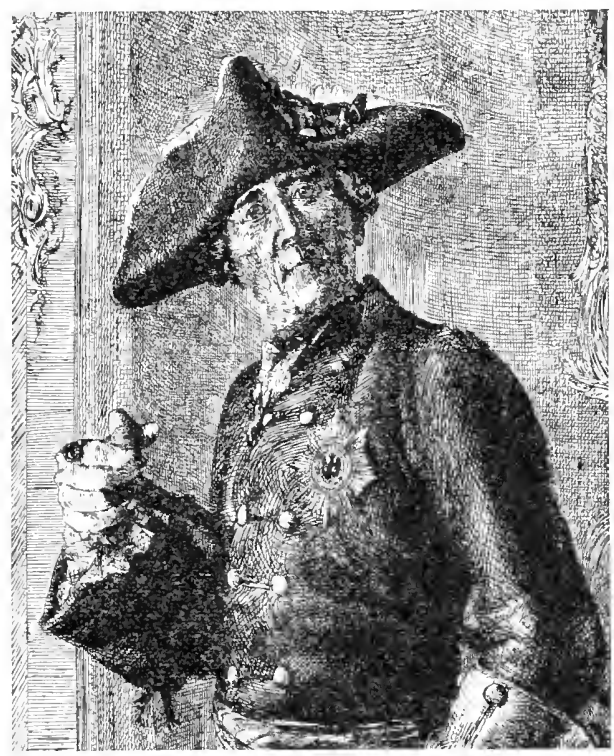

FREDERICK THF GREAT

by a great European war of doubtful issue, Frederick proposed to Austria that they should protect themselves from the designs of Catherine and obtain compensation for her increase of power by forcing her to abandon to them a part of the spoils. With great reluctance, Maria Theresa allowed herself to be persuaded to this step, and with great difficulty Catherine was made to see the wisdom of yielding part of her prey. The fall from power in France of the 
The partition duke of Choiseul, who wished to preserve the independence made, 1772 .

Map,

Putzger,

No. 25 .

War with

Turkey.

Rambaud,

Russia, II. I56-I65.

Russia reaches the Black Sea.

The other states of Europe interested in the disposition of Turkey. Hassall, Periods, Chap. XIII. of Poland. aided the conspirators, and the first partition was carried through in I772. The share of Prussia was only half as large as Austria's, and one-third Russia's, but it was of especial value to her since it united the outlying duchy of Prussia for the first time with the rest of her territories by continuous possessions, and so afforded a strong guarantee for its safety.

396. Further Russian Advance.-. Before the second partition of Poland took place, Russia had made a great advance in another direction. The Turks had declared war in 1770 , in aid of the Polish patriotic party, but fortune had been against them. A Russian army reached the Danube. Still more astonishing a Russian fleet suddenly appeared in Grecian waters, having sailed around all Europe and through the straits of Gibraltar, and surprised and almost destroyed the Turkish fleet. Constantinople itself nearly fell into the hands of the Russians. In the peace which was made in I 774, Russia recovered the conquests which had formerly been made by Peter the Great, and more, with the right to navigate the Black sea and to exercise a protectorate in favor of the Christians in the Turkish Empire, and the Crimea was declared independent of Turkey. This was the first great gain which Russia had made at the expense of Turkey, and the sudden success of the Russian arms was a further revelation to Europe of the rising power of the new Empire.

397. The Rise of the Eastern Question. - This was the beginning also of the great "Eastern Question" in the international politics of Europe, which seems to-day no nearer solution than it did more than a century ago. Catherine believed that she would be able to settle it in her own reign by taking what she pleased of the possessions of the Sultan. But Austria, for centuries interested in extending its power down the Danube, could not take this view of the case. And when Russia and Austria united in a treaty of partition in 1780 , by which Austria was to take Bosnia, Herzegovina, 
and Servia, - a part of which it actually received at the close of the last war between Russia and Turkey, - and Russia was to carry her boundaries to the mouth of the Danube, then the other states of Europe became at once interested in the great extension of power which seemed thus to open before these two countries.

France conkl not be bribed even by the promise of Egypt to consent to this arrangement, but remained as she had long been the ally of Turkey. Turkey defended herself as best she could against the Russian and Austrian armies. Sweden took advantage of the war to attack Russia and threatened St. Petersburg. Finally the accession to the throne in Austria of Leopold II., who was not in favor of continuing the war, induced Catherine to consent to peace. Russia received the Crimea and other territory on the north of the Black Sea, with the right to maintain a fleet on that sea, and Austria made a small annexation, but the Turkish Empire still survived to be a perpetual source of international plots, jealonsies, and wars.

398. Poland at last Destroyed. - This peace was fol- The second lowed in the next year, I 793. by the second partition of Poland. Another attempt had been made by King Stanislaus to reform the constitution, and this had received the sanction of the king of Prussia, now Frederick William II. Catherine, however, refused to accept it and raised an opposition party in Poland. A Rnssian army then invaded the country. A Prussian army immediately entered from the other sile. It was hoped that it came to support the constitution as the king had agreed, but it at once joined the Russian troops. A victory gained by Kosciusko did no good, and the second partition was soon completed. In this Austria had no share. Prussia's was nearly twice as large as in the first partition, but Russia's was still the lion's share.

Kosciusko and his party refused to submit and still at- The third tempted to resist by arms, but their cause was hopeless, and partition. their efforts only served to bring on the end at once. The

partition. Rambaud, R'ussia, II 165-179. 
third partition took place in 1795 . Austria hat again part in this, but her share and l'russia's were as usual much less than that which Catherine took. Almost all Poland had been absorbed in Kussia. But the extension of territory was the least important gain which Russia had made. Her whole western frontier now bordered on the great states of central Europe, on Prussia and Austria, and she had enterel as intimately into European politics as the oldest Christian state.

New states had risen and old ones fallen.

The decline of France.
399. A Revolution in the Political Situation of Europe. - These events constituted a revolution in the affairs of Europe. 'Two new states had entered the first rank of powers and three had disappeared. Sweden hat fallen from the first rank loland hal entirely ceased to exist. and 'Turkey had revealed to the world her great weakness. These three states had been the allies of France in her conflicts with the house of Hapsburg. Put into other words then, these rapid changes in kurope in the eighteenth century meant that France had been unable to maintain the great position which she had held under louis XIV. And this was true. The rupid rise of Russia and Prussia was accompanied with the decline of France. But as we shatl see in another place this age of her political decline was an age of wide intellectual influence upon all Europe, and of preparation for a new age of political leadership greater than any state had exercised since the days of Rome, - the age of Nipuoleon.

\section{Topics}

The power and possessions of sweden in i 700 . The early history of Russia. The reforms of l'eter the Great. Charles XII. of Sweden. The gains of Russia from sweden. The vrigin of the Hohenzollern. Their great promotion. In what way was P'russia formed? The Great Elector. The preparation fur Frederick the Great. What gave him his opportunity against Austria? What was gained from Austria? Maria Theresa's policy of revenge. Why did France join Austria? What was the interest of England in the matter? The course of the Seven Years' War. IIow did the war leave Prussia in Europe? In Germany? The cundition of Poland. The history of the first parti- 


\section{Topics}

tion. Russian advance towards the suuth. What is the "Eastern Question"? How did it arise? The final lestruction of Puland. The change in the European situation made in this age.

\section{Topics for Assigned Studies}

The father of Frederick the Great. Tuttle, Prussia, I., Chaps. IX-XI. Longman, Fredirick the Great, Chap. III. Carlyle, Frederick the Great, Bk. IV., Chap. IV.

The first partition of Poland. Perkins, Louis Xl., I., Chap. XXI. Rambaud, Russia, II., 122-130. Carlyle, Friderick the Great, Bk. XXI., Chap. IV. 


\title{
CHAPTER IV
}

\author{
THE STRUGGLE FOR COLONIAL EMPIRE
}

\section{Books for Reference and Further Reading}

Lucas, Historical Geografty of the British Colonies. Introduction. (Clarenton; \$1.00.)

Payne, Ifistory of Europian (olonies. (Nacmillan; Mr.ro.)

Seeley, The Expansion of England. (Little, Brown \& Co.; \$1.75.)

Story, Building of the British Emfire. 2 vols. (Nations.)

Parkman, Half intury of (onflict. 2 vols. Hontialm and ITolfe. 2 vols. (Little, lirown $\mathbb{\alpha}$ (io.; \$8.0o.)

l'erkins, firance under Lawis . IT. 2 vols. (IIoughton; \$4.00.)

Lecky, History of Englant in the Eighte'nth (entury. 7 vols. (Appleton; $\$ 7.00$.)

Mahan, Influence of Sea Poner ufon Fistory. (Little, Brown \& Co.; \$. 4.00 .)

France loses more than supremacy in Europe.
World supremacy in commerce and colonies.
400. The Dawn of the Age of World Politics. - In the international politics of Europe, France had declined, during the eighteenth century, from the position of commanding influence which she harl occupied when the century opened. In the same century, a position of far more commanding influence than any limited to the continent of Europe merely, and one which France could very likely have gained if she had followed a wiser policy, was finally lost to her. For this century covers almost the whole of and finally decides the struggle between France and England for colonial empire, for a commanding position in the world as a whole, not in a single continent, and the decision goes against France.

This is almost the same as saying that in this century new interests begin to guide the policy of European states, or at least of some of them, interests not connected with those 406 
which concerned the balance of power in Europe, but with the question of a wider balance of power, or rather with the struggle to overcome all rivals and to obtain an exclusive commercial and colonial control of all seas and continents. This new interest was slow in making itself felt as a guiding influence in the eighteenth century. England was the first to be movel by it, very greatly to her advantage. France followed some little distance after and partly, but not fully, realized the importance of the interests at stake before the struggle was concluded. It is only of the nineteenth century and perhaps only the last half of it, that we can say that these new questions have been steadily pushing those of merely European international politics down into a secondary place.

401. The First Modern Colonial Powers. - France was not the first rival of England in this struggle, nor were either France or England the first of the world's great commercial and colonial powers.

We have already studied the expansion, during the age of the Renaissance, of the medieval Mediterranean commerce into the ocean commerce of modern times in consequence of the discoveries of the Portuguese in Africa and India, and of the Spanish in America. Both these nations immediately took possession of the comntries which their explorers had reached, and so began the first age. of European colonial history.

The Portuguese established their factories along the coasts of India and in the East India Islands, and under the Viceroy Albuquerque exercised a kind of authority over the whole East. In the West. Cortez conquered Mexico for Spain, and Pizarro conquered Peru. The fabulous riches of these western lands attracted to them large numbers of Spaniards. At one time there was a fever of emigration in Castile almost like the rush for newly discovered and rich gold-fields in these days. There were very many more Spaniards who went to America than there were of Portuguese who went to the East. 
But no colonies in the English sense.

Lucas, Introduction, 6I-67;

Payne. Europian Colonies. 39-53.

The Spanish the first world empire.

In conflict with Spain. Lucas, Introduction. 74-8I ; Payne, Colonies, 53-64.

Still neither of these nations established colonies in our understanding of that word. The Portuguese establishments in India were trading-stations, to which men went for a time to make themselves fortunes and then to return home to enjoy the results. The Spanish in America were garrisons, and overseers of mines, and adventurers, whose object was the same, to send or carry back to Spain as much wealth as possible, gained from the new country. The Spanish establishments grew in the end into a much more permanent and real colonization than the Portuguese, but this was not their original intention. The idea of finding in these lands a new home for the people, where another nation of the same blood and language as the mother nation should grow up, to enlarge at once the power of the State and the prosperity of its citizens, had not yet arisen.

402. Spain's World Power Threatened. - We have seen elsewhere how successful at first this policy was of drawing as much wealth as possible for the home country from the colony, and what was its final effect. The mines of America added much to the resources of Charles $\mathrm{V}$. in his conflict for empire in Europe. When under his son Philip II. Portugal was absorbed in the Spanish monarchy and the East Indies were adderl to the West in the possession of Spain, it seemed as if a real world empire were about to be established. But the reign of Philip saw the rise of two new commercial and colonial powers, near together in time and under very similar circumstances, partly at least as the result of his own mistaken policy, as Spain and Portugal had risen together in the age of the Renaissance.

403. The Rise of the Dutch Empire. - One of these was a country which at the beginning of Philip's reign had been his own, and which his despotism and intolerance had driven into independence. Familiar with the sea from before the time when Cæasar wrote his description of them, depending for a large part of their livelihood upon the difficult and dangerous ocean fisheries, the best training-school of sailors, and having also already a good heginning of commerce, the 
rapid rise of the Dutch into a great naval and commercial power need not surprise us. Hard blows were to be struck the Spanish power on many seas, and the native vigor of the Dutch, reinforced by the trementous energy excited by their desperate struggle for inclependence, carried them far.

It was Portugal, after her absorption in Spain, that suffered the heaviest actual losses from the attacks of the Dutch, and in the East Indies the new colonial empire of Holland was created. She took the great Spice Islands and Ceylon, and established factories on both the east and west coast of India.

In 1602 the East India Company was founded, followed soon by the West India Company, which founded the colony of New Netherlands in America. Soon afterward the settlement of Batavia was made in the East, destined to great prosperity, and in no long time the Cape of Good Hope was occupied by an agricultural colony for the supplying of ships on the long India voyage. The East India commerce was still very profitable, though less so than it had once been; Amsterdam became the chief entry and distributing port for Oriental goods for Europe; and a large part of the world's carrying trade was in the hands of the Dutch.

404. The Beginning of the English Empire. - But in the meantime another commercial power was rising, not so rapidly as Holland, but very largely out of the same conditions, - a power which was destined, not to destroy the commerce of Holland, but to set a limit to its expansion. This was England.

In very early times, owing to their situation, the English had become a sea-going people. At the opening of the thirteenth century England had asserted her right to rule the narrow seas. Her commercial connection with Flanders, and still more with the territories which she held in the southwest of France, created interests which exercised a decisive influence upon her foreign policy in the fourteenth rentury. Before the close of the fifteenth, her navigators

New Netherlands and Cape colony. Story, British Eimpire, I. I90-2II.

Contemporary with the Dutch.

The English necessarily sailors. 
had had a fair share in the explorations of the time, and to one of them, Cabot, had fallen the honor of first seeing the continent of America.

The Empire begins in the struggle with spain. Story, British Empire,
Still through the whole sixteenth century, the great age of Spanish and Portuguese commerce, or at least until the very end of it, England was not a sea power. It was the conflict with Philip II., the struggle for the defence of religious and political independence, as in the case of Holland, which be-

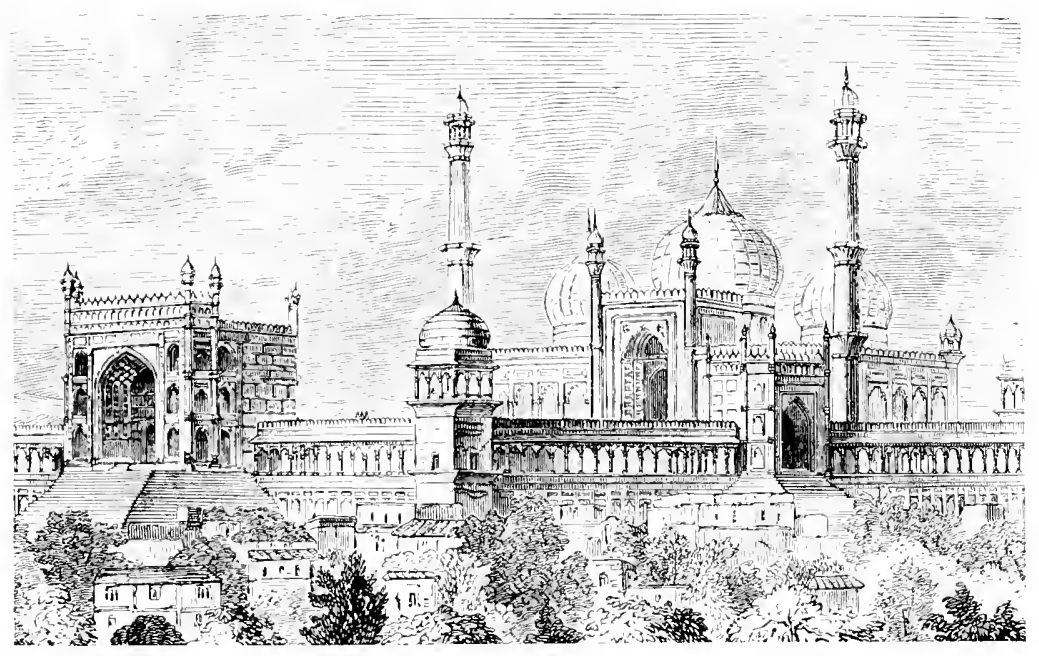

TIIE MOSuUE AT DEl.III

Bk. I.,

Chaps. 111.-

il.

The warfare in the Spanish main. The Last Fight of the Rerengen (Arber Reprints): Payne. gan the naval glories of English history and turned the attention of her people to distant commercial enterprises.

It was a most attractive warfare. Rich plunder, strange adventures, and the striking of hard hlows at the bitterest of enemies, all were to be had at one time. It is not strange that with these inducements, and with the energy and enthusiasm of a young race in an age of great events on every side, the deedls of the English seamen in the first age of the struggle for empire have never been surpassed in any later one. 
405. The First English Colonies. - In one sense the modern colonial supremacy of the Anglo-Saxon race is deserved, for the real colony, as a new home of the people, in distinction from the trading-station, was begun by Englishmen. It was the work, howerer, of the people themselves and not of the government.

Perhaps this honor is hardly to be given to the first permanent Englislı settlement in America, that of Jamestown in I606. But whatever may have been the original intention which influenced the first settlers to undertake the enterprise, it very soon found its great source of wealth in tobacco and not in gold, and grew into an agricultural colony, the planters with their families looking upon the country as their home. The same thing may be said, both as to original intention and later history, of the 1)utch colony which was established at New Amsterdam in 1614 . But in 1620 there was founder at Plymouth, in New England, a settlement whose purpose was from the start, not to open up trade or to discover mines, but to find a new and permanent home for the founders and their posterity.

These were the Pil-

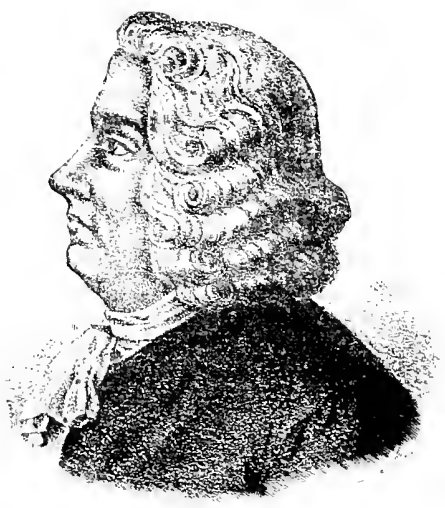

WILLIAM PENN loyage's of Eliabbethan Secamen (Clarendon); Froude, English Serzmen in XI $\%$

Century (Scribner) : Kingsley, IVestivard Ho! (novel).

The firsl real colonies English. Lucas, Intraducion, 90-99.

Virginia and Plymouth. Green, English People, III. I67-I7I ; Am. Hist. Leaf., 27 and 29; Old South, $48-5 \mathrm{I}$.

The

Pilgrims. grims, of the extreme Puritan party, called Independents, who had fled from England to Holland to escape the persecution of the State in the early part of the reign of James I., and afterwards abandoned Holland for America, to keep themselves from absorption in the Dutch, to preserve their lansuage, race, and institutions. They were followed in ten years by much larger numbers of the Puritans, who founded
The

Puritans. 
the colonies of Salem and Massachusetts Bay, and a little later of Connecticut and New Haven. In America these Puritans all became Independents, and organized the churches called Congregational.

Founded from various motives.

Sweden's colony.

406. The Thirteen Colonies. - This begimning of colonies was followed by many others of different kinds - Maryland for the Catholics, Pennsylvania for the Quakers, Rhode Island for the oppressed of all names, the Carolinas by a corporation of English gentlemen, Georgia for the debtor class during the seventeenth and the last not until near the middle of the eighteenth century. It is a very interesting indication of the feeling that was now beginning to grow up in Europe about colonies, or at least trading-stations, in the new parts of the world, and their relation to the position of a power of the first rank, that Sweden during the time of her greatness in the Thirty Year's War attempted to secure her share in the division of North America, and began the colony of Delaware. The same feeling is indicated by the attempt of the Great Elector to obtain trading-stations for the rising state of Prussia on the coast of Africa, a little later in the same century. His experiment was even less successful than that of Siveden.

Beginning about the middle of the seventeenth century.

Story, British Empire, I. $250-255$.

407. Conflict between England and Holland. - The Thirteen Colonies of North America were only begun when the conflict came on between England and Holland. This was hardly to be avoided on account of their conflicting interests in the East. England had begun to try for a share in this rich trade as early as Holland. Her East India Company was, indeed, organized first, in the year $\mathbf{r} 600$. It was a little more than fifty years after this date before their rivalries brought the countries to actual war with one another, but their traders were fighting for the possession of the markets of the East and for farorable stations before the beginning of declared war. The massacre of the English residents at Amboyna by the Dutch, in 1623 , is only the worst of many incidents in these conflicts before actual war began.

408. Government Colonial Policy, Laws, and War. - It is 
from the time of Cromwell's rule that we may date the beginning of a continuous commercial and colonial policy on the part of the English government. How far we have a right to attribute such a policy to Cromwell himself, as one consciously and understandingly chosen, is doubtful. Probably in this as in other things he did not see very far into the future, but did with great vigor and decision the thing that seemed at the moment to be the wisest. But with him began the measures which long characterized English policy, to defend and develop commerce and the colonies, not as colonies mainly but as feeders of commerce, by acts of Parliament and whenever necessary by war.

In 165 I was passed the first Navigation Act, which forbade the importation of goods into any English possession except in English vessels or in the vessels of the country producing the goods. This was aimed directly at the great carrying trade of the Dutch, and was intended to transfer this to English ships. Laws of this kind, successively passed, remained in force until into the nineteenth century. In the next year came the first war with Holland, a war of fleets, which lasted two years and closed withont decisive results, though the advantage was chiefly with England. In a war of Cromwell's with Spain was made the first important English colonial conquest, the island of Jamaica.

409. The Power of Holland broken by France. - The ruin of Holland, however, as a great commercial power, was in the end not so much the act of England as of Louis XIV., though he had the help of England in a part of the process. A short war between England and Holland a few years after the restoration of Charles II. led to no more decisive conclusion than that of Cromwell, but it is remarkable for the appearance of a hostile fleet in the Thames within sight of London, and for the conquest of New York, though this was really made before the war began.

In the great Dutch war which Lonis XIV. made upon the Dutch Republic, to punish the little state for having dared to check by the Triple Alliance his conquests in the Spanish

The beginning of government colonial policy.

The first Navigation Act, 1651 . Am. Hist. Leaf., 19.

The first colonial war, I $65^{2}$.

In the wars of Louis XIV.

Green, English Péple, III. $37 \mathrm{I}-375$.

England's last war with Holland in this age. 
Netherlands, the French monarch had the aid of Charles II. under a secret treaty and for an annual pension, until in the last part of the war public opinion forced him to withdraw. This was the last war which England made upon Holland, the last war between them until Holland joined the enemies of England in the war of the American Revolution.

England fighting for Holland.

In the later wars of Louis XIV. the two countries were allies against the French. But these long and, during some of the time, desperate wars had exhausted the wealth and greatly weakened the power of the Dutch. It was too small a state

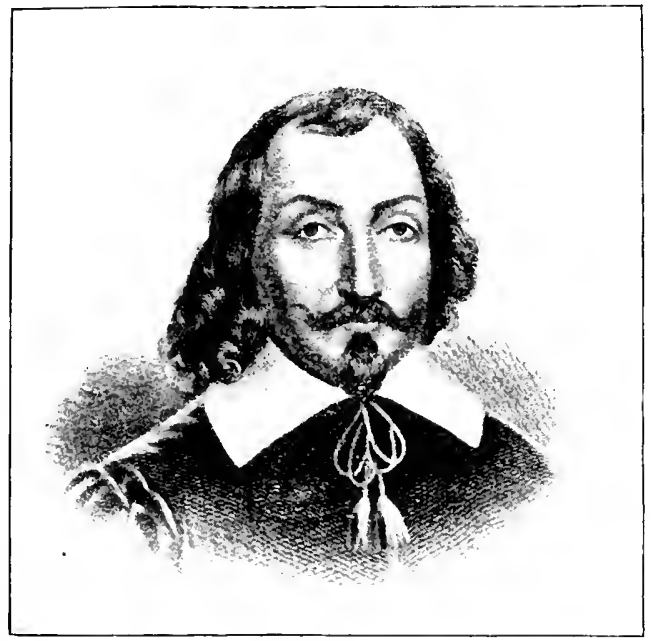

CHAMPLAX

for so long and violent a strain. On the other hand the English commerce had been rapidly extending as the Dutch declined, and England now left Holland behind in the race as both had earlier distanced l'ortugal and Spain.

In the age of Louis XIY.
4I0. The Beginning of Rivalry with France. - But these wars of Louis XIV. were not over before it became evident to the colonists in North America, and more slowly to the government at home, that there was a new and perhaps 
more dangerous rival in the field, with whom a conflict must now begin. This was France.

The French had established a settlement in North America, in 1605 , befure the English, but the English colonies, once begun, filled up more rapidly with settlers. On the other hand the French occupation was more widely extended, and they came to hold, before the close of the seventeenth century, an important strategic position which gave them a very decided advantage in a struggle for the possession of the continent. From Louisiana up the Mississippi and Ohio rivers to the Great Jakes and Canada, they laid claim to the whole interior, and would shut the English in between the mountains and the Atlantic. In America the French saw the advantage which they possessed, but it was impossible to persuade the government at home to make full use of it. France was too deeply interested in the politics of the continent of Europe to realize the rise of these new and greater interests until the opportunity was passed.

4II. The Advantages of the English. - This one advantage of position was the chief one which the French possessed. Almost everything else was in favor of the English. 'Their colonies were filled with a much larger number of permanent settlers. The bigotry of the French government came to their aid, for it refused to allow homes in the colonies to the Hugnenot exiles, and they added to more than one of the Thirteen Colonies a valuable element which would have gone to the side of the French had it been allowed. The Frencl government also extended its paternal despotism to the colonies, from the days of Colbert, vexing them with minute and unsuitable regulations, which hampered their free development, while the English colonies were especially fortunate in being left almost entirely to themselves.

4r 2. Colonial Wars. - The last two wars of Lonis XIV.'s had been colonial as well as European wars. The first is called in American colonial history King William's War, and the second, which was in Europe the War of the Spanish Succession, is known as Queen Anne's War. 'These were

In North America. Payne, Colonies, $80-89$.

The French have the advantage of position.

\section{Numbers} and independence.

French colonial policy. Parkman, Old Regime, Chaps. XII:XVI. ;

Lucas,

Introduction, 8I-89.

King William's and Queen Anne's War. 
Pashmun, Half

Century.

Chaps. III.I.: VII.-IX.
An intervial of peace, $1713-17+3$.
The founding of foreign dominions easy. mainly wars of the colonists with one another to which the home governments, absorbed in the European struggle, paid little attention. They show clearly enough, however, that in America the great conflict was opening, and that the colonists realized the importance of the issue. Neither led to decisive results, though in the second Nova Scotia-Acadia-was conquered, mainly by the efforts of the New England colonists, and was ceded to England at the peace of Utrecht, together with Newfoundland and the Hudson Bay territory.

Queen Anne's War was followed by thirty years of peace, during which the colonies of both nations in America were developing very rapidly, the English more rapidly than the French in population and resources. In Europe, France was becoming by degrees more conscious of the real character of the conflict before it, and was endeavoring to prepare for it by the strengthening of her fleets and the encouragement of commercial enterprises, but she could not, unfortunately for her future, get rid of the belief, in which she had been trained for so many generations, of the superior importance of European politics and of the great danger which threatened her from the house of Austria. Spain also was alarmed at the progress which the unauthorized English commerce with her colonies was making. This she now endeavored to stop, and she also strengthened her fleets. and made an alliance with France.

4I3. The Situation in India. - It was in India, however, that the greatest changes occurred in this quarter of a century. The situation there was one especially favorable to the building up of a foreign dominion. The Empire of the Great Mogul was falling to pieces, and numerous little states were gaining an insecure kind of independence, with the natural result that there was more anarchy than good government, and that it was easy for a strong outside power to gain a footing in alliance with one native state or another and begin the creation of a territorial dominion. It was easy, indeed, for two outside powers to carry this process on until they came into collision with one another. 
This change, by which a trading company was transformed France has into the political ruler of wide territories and millions of human beings, was a most revolutionary one, but it was well under way before the next war between France and England began. As in America, so in India, the French had at the beginning of the war much the stronger position. They had also the decided advantage in the first war in India of commanders of genius.

4I4. King George's War. - Frederick the Great's attack on Maria Theresa, in order to seize the province of Silesia and to lead in the partition of the Austrian dominions, opened the war between France and England. England was on the side of Maria Theresa, but if France had been for her, England would have been against her, as was the case in the next war. Before this European war broke out England and Spain had come to blows, in consequence of the attempts of the Spanish to break up the English commerce with their colonies. Throughont this was for England a commercial war, and this clearness of aim went far to balance the better position of France in the colonies, for France did not realize even yet as clearly as England what was at stake.

The war, which lasted from I 74 r to 1748 , did not end in the triumph of either nation, but the period is characterized by a very rapid extension of the French power in India, and hardly less so in America. In India the French interests were in the hands of Dupleix, a

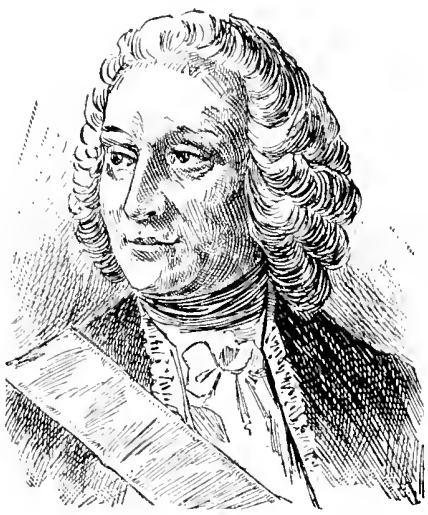

DUPLEIX the best position.

In Europe the War of the Austrian Succession. Green, English Pecple, IV. $164-173$.

England and Spain at war, 1739.

'The French gaining a stronger position in India; Perkins, Louis $\mathrm{X} V$., I., Chap. IX.; Malleson, Dupleix (Macmillan); most able and successful statesman, who marked out the way to empire which the English have since followed, - conquest 
here, alliance there, and drilled native soldiers to supplement his European troops. Had the French officers in India been more ready to coöperate heartily with one another, and had home government been willing to put its strength into their support, the issue would most likely have been different. In

and in America.

The capture and return of Louisburg. Parkman, Hiali Century, Chaps. Xix. and $\mathrm{XX}$.

The war does not stop in America. Parkman, lontialm, Chap. VII. America, also, the French became during this war conscious of the great adrantages of their geographical position in the interior of the continent, and they began to connect Canada and Louisiana with a chain of fortified posts along the great rivers, - a measure which excited the serious alarm of the English colonists.

4I5. The Close of the War. - Only one event of the war is important here. That was the capture, in 1745 , of the strong fortress of Louisburg, the "Gibraltar of America," by troops of the New England colonies. At the close of the war, Louisburg was returned to France in exchange for Madras in India, which had been taken by the French. The people of New England thought this was a sacrifice of their interests, and to a certain extent they were right, but for the interests of the Empire at large - and we have now a right to speak of the Empire - the recovery of Madras more than outweighed the surrender of Louisburg. These two erents, however, the conspicuous success of the New England troops and the apparent heartless disregard of the interest of the colonies by the home gorernment, became important influences jreparing for the American Revolution. 4I6. The Interval of Nominal Peace. - So clearly was it seen in the colonies that the conflict must go on until one purty or the other was forced to yield, that the peace of Aix-la-Chapelle, which the two nations signed in Europe in 1748 , hardly mate a pause in the war in America, and suspended it only in form in India. For the Thirteen Colonies the occupation of the interior was a matter of the most vital importance, since on it depended all opportunity of future expansion. They could not sit quietly by and let the French take possession. Washington's expedition, Brarldock's disastrous attack on Fort Duquesne, and the attack 
on the upper French posts near Lake George, were all attempts of the colonists to break through the barrier which the French were erecting against them, and they were not the less real war because no formal declaration had been made.

In India France lost her advantages through the blindness of the authorities at home. Dupleix's operations were cut short because they were too expensive, and then the English succeeded in getting him recalled because his schemes might lead to a renewal of the war. There was no other genius on the French side, but one immediately arose on the English. Clive began to profit by the lessons which Dupleix had taught, and to open a new war, under the thin veil of aiding one native state against another. His brilliant capture and defence of Arcot took place before the declaration of war.

4I7. The Great Colonial War. I756-I763. - Maria The Theresa's war of revenge, in which she united almost all Europe against Frederick the Great, the Seven Years' War of European history, was the signal for the next war in the colonial struggle. This was the great and final war of the series, for since its close France has never been able to rival England for colonial empire. Her empire was everywhere ruined. In America the English attacked the French posts along the whole line and with success. Montcalm made a brave defence, but Wolfe purchased Quebec with his life and thus forced the surrender of Montreal and all Canada. At the end of the war France withdrew entirely from North America, ceding her western possessions to Spain, and her northern to England.

In India Lally-Tollendal made a vigorous defence but with no better success. He was obliged at last to surrender. Clive won the great victory of Plassy, which carried with it the conquest of almost all Bengal. And at the peace France gave up everything but five trading-stations which she promised not to fortify.

England also made important gains in the IVest Indies

"French and Indian IVar" in America.

Story,

British

Empire, II.

85-IOI;

Payne,

Colonies,

I15-125：

Bradley,

II olfe (Mac-

millan);

Old South,

73.

Parkman, Montcalm, Chap.Xxxi. France gives up India. 
The ministry and in Africa. It was a great war, the most brilliant in the of William modem history of England. A national enthusiasm was

Lecky, aroused again as under Elizabeth. Robert Walpole wrote: England, II. "We need to enquire every morning what new victory there $555-565$; Green, English People, IV. I $76 \mathrm{ff}$.

The

American colonies less dependent on England. Lecky, Engliand, II I. 290-333; Green, English Perple, IV. $187-200$.

France rejoices in the prospect of revenge. has been, lest any escape us." These great successes had been won for England not merely by the generals in the field, but largely by the energy which a great minister, William Pitt, afterwards earl of Chatham, infused into the administration at home. He was not able, however, to make his influence felt at the conclusion of the peace, for he had lost office on the accession of George III. in 1760 , because of the king's alliance with the Tory party.

4I 8. The Ultimate Consequences of this War. - This great war involved, however, in the course of a few years, further consequences which went far to balance, looked at in one way at least, all the gains which had been won by it at first. In the first place the conquest of Canada removed from the great American colonies the constant danger which had male them closely dependent upon the aid of England. They had long been left to manage their own affairs with scarcely any interference from the mother country, and these affairs had now become equal in importance to those of the smaller states of Europe. They had lately grown accustomed to raise and direct military enterprises of considerable extent from their own resources and with their own officers. There had been good training-schools for both the statesman and the soldier. It is only what might be expected that, without an enemy to be feared upon the continent, the colonists should decide for independence upon the first serious difficulty with the home government.

At the close of the war some of the French statesmen had realized this great change which had been made in the situation of the Thirteen Colonies by the transfer of Canada to England and the probable consequences, and had rejoiced at the prospect of revenge in the not distant future at the hands of England's own colonies.

In the second place the war immediately created the 


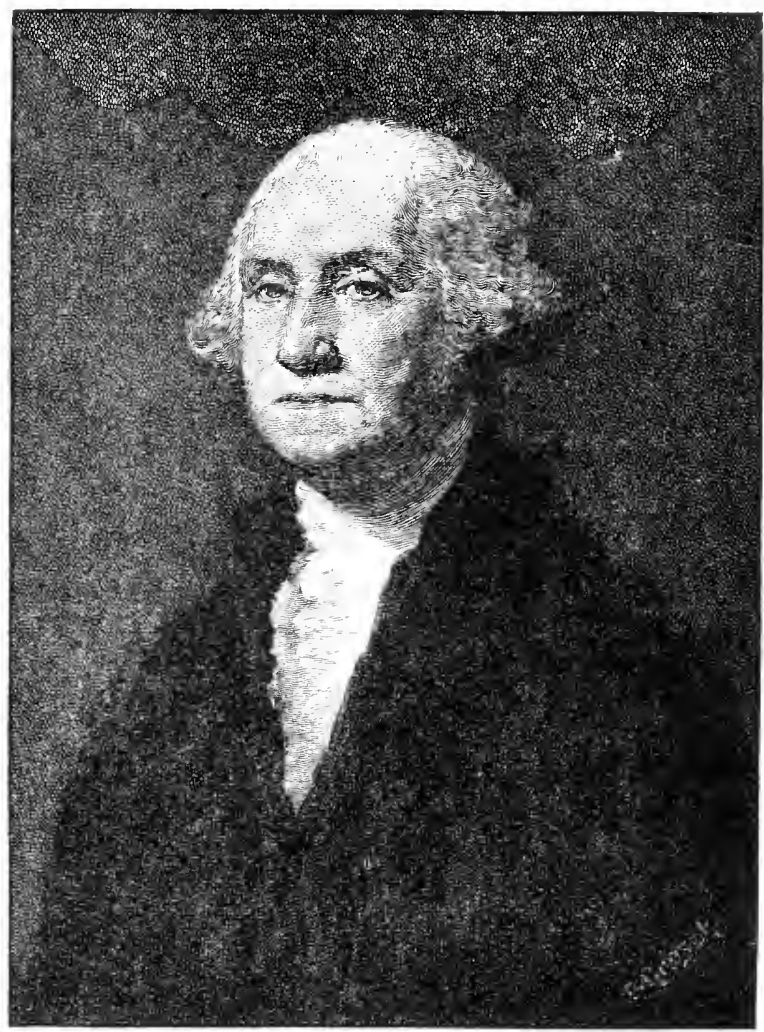

GEORGE WASHINGTON 

difficulty. The enormous cost of the war gave rise to an extremely difficult question, so difficult indeed that England after more than a hundred years has not found any answer to it. This is the question of the way in which the expense of defending the Empire ought to be divided between the mother country and the colonies. In $7^{6} 3$ it was an entirely new question. It had never risen before in the history of the world. Neither the English government nor the colonies had any experience to guide them in the difficulty. It ought not to be surprising that the wrong thing was done, perhaps on both sides.

4I9. The English Ministry determines to tax the Colonies. - The English government determined to lay taxes upon the colonies by act of Parliament. The colonies, on the principle that they could only be taxed by their own representatives, determined to resist the collection of these taxes by a war of independence if necessary. So far as the strict letter of the law is concerned there can be no doubt that the English government was within its rights. The colonies were in every particular subject to the laws made in Parliament. Repeatedly, in the past, Parliament had passed as oppressive laws as these, with special reference to the colonies, and they had been submitted to. The cabinet of George III. had reason to believe that these new measures might be successfully carried through.

On the other hand there can be just as little doubt that, not merely the attempt at taxation, but the whole practice of governing great communities of Englishmen by a distant parliament in which they had no voice, was in violation of the spirit and fundamental principles of the English constitution. England came during the nineteenth century to admit this in practice with the great colonies of that time, but this was not until long after the American Revolution, and was due to the rise of new influences. The colonies were right in the general position which they took, and England ought to have seen it and to have realized that the colonists were still Fnglishmen. It was only a hundred

The question of the expenses of defence. Am. Hist. Leaf., 2 I.

The case for England. Cook's Burkis steech on Conciliation, Introd. Pt. I. (Longmans).

The case for the colonies. Fiske, Il iar of Indefendence (Houghton), 58-7o. 


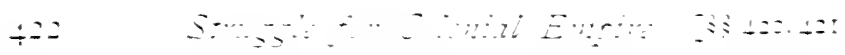

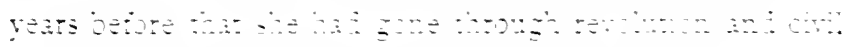

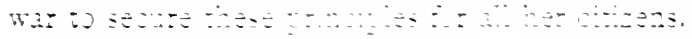

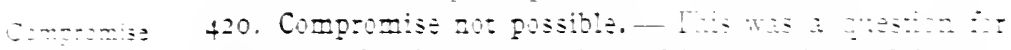

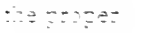

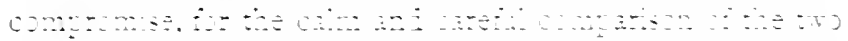

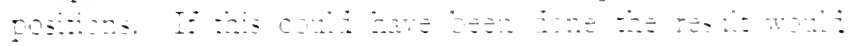

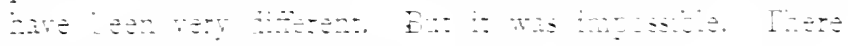

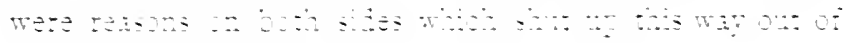

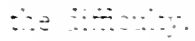

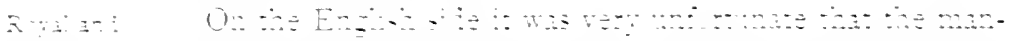

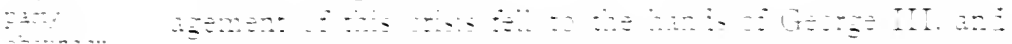

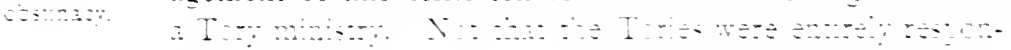

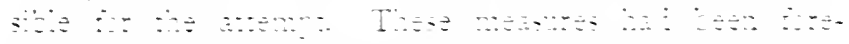

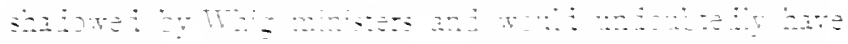

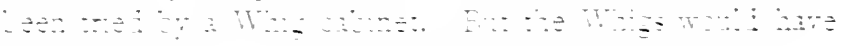

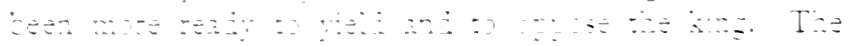

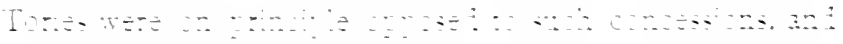

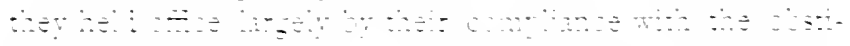

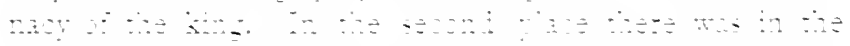

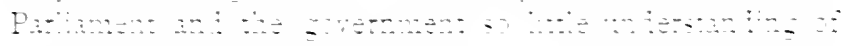

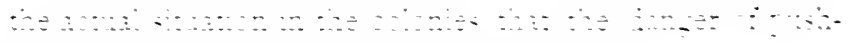

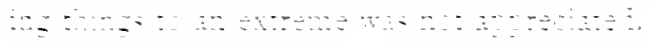

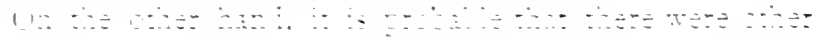

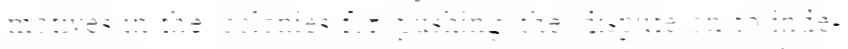

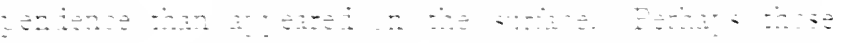
군.

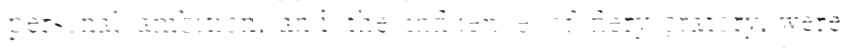

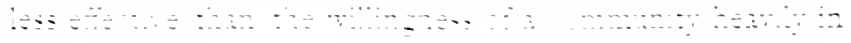

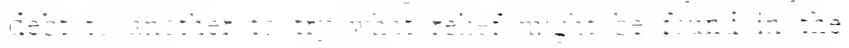

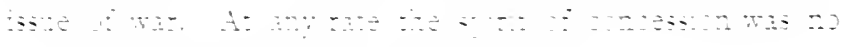

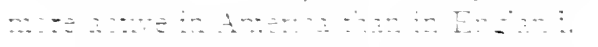

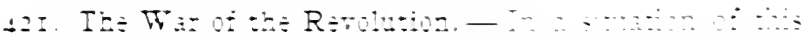

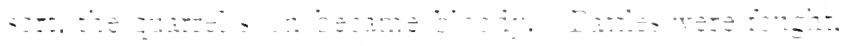

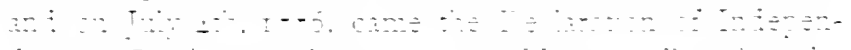

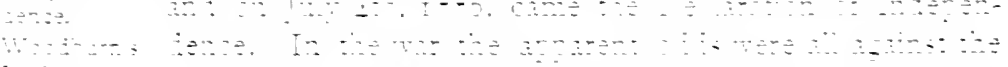

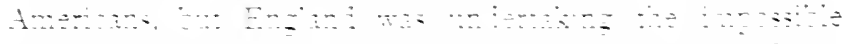

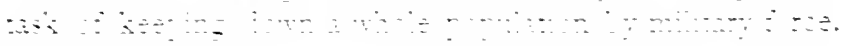

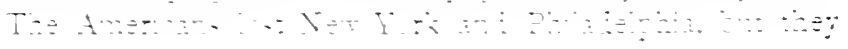


gained a great success in forcing the surrender of Burgoyne at Saratoga. This was soon followed by the alliance with France, which was anxious to take vengeance for its misfortunes in the past. Not long after, Spain and Holland joined the war against their old commercial enemy.

These events greatly changed the character of the conflict for England. It now became a war not merely to preserve the Thirteen Colonies, but to preserve the whole Empire. It was fought in every quarter of the globe, especially in

The revolt of the

Thirteen

Colonies

becomes a

We hold thare mutho to be self eerdent

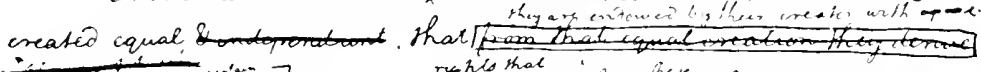

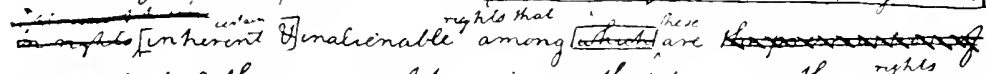
Gfe: Eberty, \& the pursuat of happiness, that to secure these resto go. vermments are insthated anong men, derwory theer just prouters from the consent of the governed. that wheneves any form of government becomes destructure of these. ends, it w the nist of the prepsle to altes or to abolish it. \& to ins litute now government. Caying ct's foundation on such pronuples torganis ury it's powers on such form, as to them shale reem mort likely to sffect theer safely \& happresess. prodence undeed wall dictute that governments long established shoukd not be changed for

The Declaration of ININETENDFNCE

Facsimile (reduced) of the first lines of Jefterson's original draft

India, the Mediterranean, and the West Indies. The bal- world war. ance of defeat and victory was about evenly divided. The French had the experience, not recent with them, of some naval victories. Suffen won a series of brilliant successes in India. Cornwallis was forced to surrender at Yorktown. On the other hand, De Grasse was beaten in the West Indies, and a combined French and Spanish fleet near Gibraltar.

Hassall, Periods, Chap. XII.

Suffren.

Mahan, Sea Pocier, Chap. XII.

422. The English Empire apparently broken up. - At the England peace in $i_{7} \delta_{3}$, England recognized the independence of the gives up 
many

United States, and thus lost her greatest colonies, and the possessions.

Lecky, England, IV. $27+-289$. only ones she had at that time in which a new English nation was growing up. In Africa, France recovered Senegal, and in the West Indies two islands. To Spain was given back Florida, and in the Mediterranean Minorca, but she failed in the great effort which she marle to regain possession of Gibraltar. In India nothing was lost. So far as the French were concerned, things remained as they were, but the English Empire was rapidly advancing under the vigorous but unscrupulous policy of Warren Hastings.

No commercial loss.

423. The Revenge of France more Apparent than Real. The revenge which France, in alliance with the other beaten colonial rivals of England, had taken, was in appearance complete. But in reality it proved to be, except in one particular, in appearance only. In commerce England lost nothing. The colonies were no longer compelled by law to trade with her, but they continued to do so from interest, and the rapid development of the United States which followed independence had its effect on commerce, so that in twenty years this had increased to undreamed of proportions.

Loss of Empire stimulates its growth.

On the growth of Empire also the revenge of France had an opposite effect to that intended. England sought compensation for her loss, as we shall see, in other regions which she would probably have long left unoccupied if she had still possessed the American colonies. The United States also grew into a nation and took possession of the great West, as it most likely could not have done if it had remained under the government of England. The Anglo-Saxon Empire in the world is to-day larger and stronger, the French Empire is smaller, than would have been the case if the American colonies had not become independent.

Ili-feeling between America and England.

See Green, English Peothle, IV. $266-27$ I.

In one particular the results were not so fortunate. The American Revolution split the Anglo-Saxon Empire into two halves, and, with other events which followed, taught the people of the two parts to dislike and distrust one another. Fortunately these feelings have been growing weaker of late, and more natural ones have begun to take their place, and 
we may perhaps reasonably hope that now all possibility of danger from them, which might sometime make the revenge of France a real one, is happily over.

\section{Topics}

The first colonial powers. Their possessions. How differ from the English? How did the Dutch Empire begin? Their colonial possessions. What circumstances like the Dutch in the beginning of the English Empire? The first real colonies. The Thirteen Colonies. The beginning of the conflict with the I)utch. What was the government policy expressed in the Navigation Acts? The effect of Louis XIV.'s wars upon Holland. The French and English in North America. In India. What advantages had the English in America? The French in India? The first colonial wars with France? The third war, King George's. What is the meaning of the fact that the colonists keep up the war during the interval of peace in Europe? What gains were made by the English from the fourth culonial war? What unfavorable results followed it? Give both sides of the question of taxation. Why not compromise? How did the Revolution become a world war? The losses of England. Why less than they seemed? What positive advantages?

\section{Topics for Assigned Studies}

Clive wins India. Perkins, Louis .Y., I., Chap X. Lecky, England, II. 541-550. Story, British Empire, II. 56 ff. Macaulay's essay. Englishmen on the right to tax the colonies. Lecky, Ensland, III. 333-36r. Green, English People, IV. 225-240. Story, Rritish Emfire, II. r2S-r4o. See also Burke's and (hatham's contemporary speeches, in many editions.

Compare in object, spirit, and language, the Declaration of Inclependence (Old South, 3); the Magna Charta (Old South, 5): the Petition of Right (Old South, 23; Gardiner, I); and the Pill of Rights (Old South, 19). 


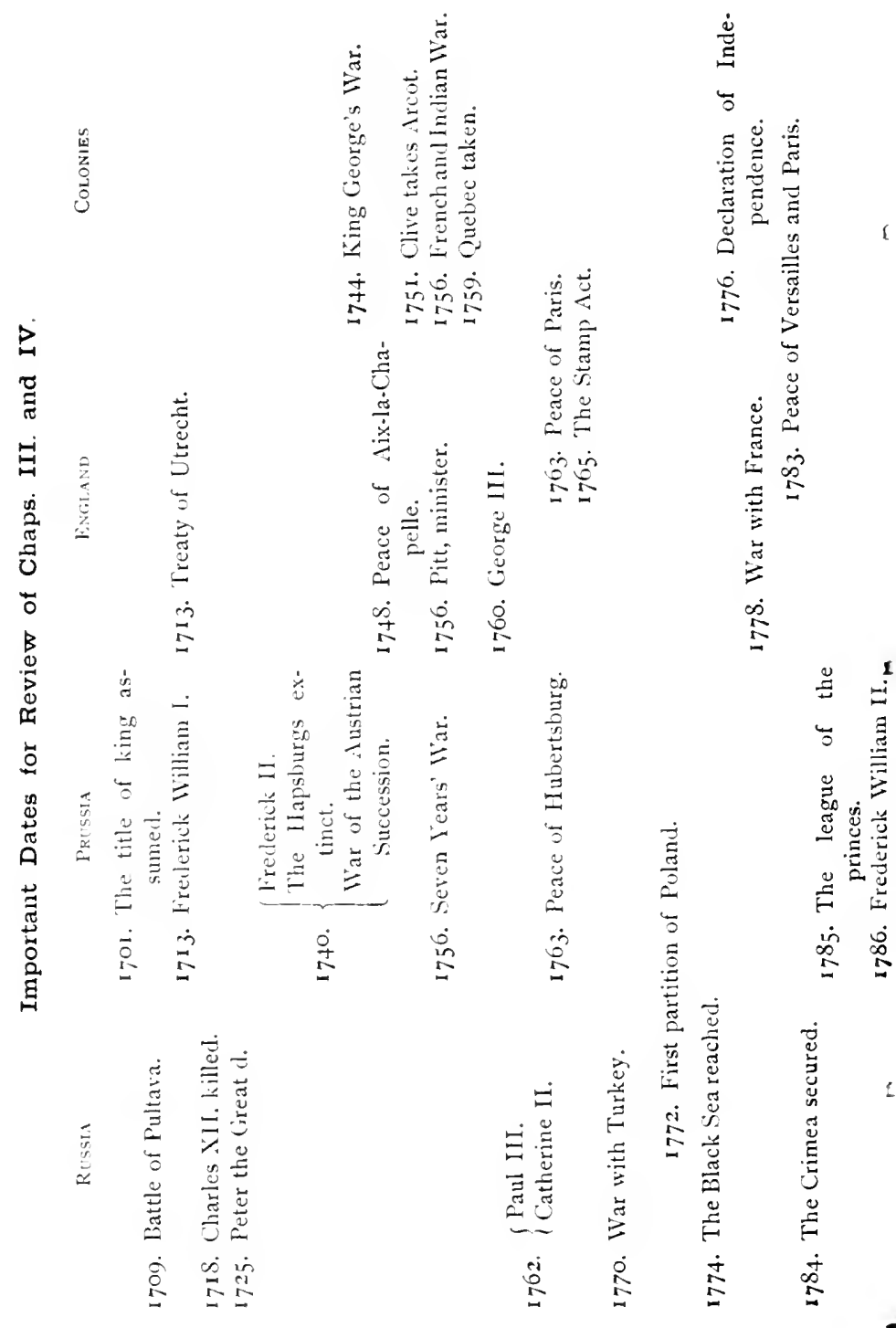




\section{CHAPTER V}

\section{THE FRENCH REVOLUTION AND NAPOLEON}

424. The Intellectual Leadership of France. - During the eighteenth century France had not been able to maintain her leadership in the international politics of Europe, and in the struggle for colonial empire she had been lefeated by England; but in another direction, in intellectual influence, and in the preparation of the nations of Europe for the next great stage of political advancement, through revolution and war to civil liberty, France exercised a leadership which is a compensation, in its real service to mankind, for all that she had lost. At the close of the century she led again in the revolution itself. And in the wars which followed, with enormous loss and suffering, though with great military glory which is dear to the French heart, she opened the doors of all the continent of Europe to the forms of free government which the Anglo-Saxons had long enjoyed.

425. The Deists. - Near the end of the seventeenth century there arose in Europe a school of thinkers who are called Deists from some of their teachings about religion. Their ideas were a result of the marvellous scientific advance of the seventeenth century, and were characterized, like the thinking of all such ages, by a tendency to criticise and call in question many old beliefs. Early in the next century several French members of this school began to criticise the government of France. It was at a time when the selfish policy of Louis XIV, had brought such misery upon the French people, when a corrupt and extravagant government

France leads Europe to free government.
A school of critical and sceplical thinkers. 
seemed to be forcing the nation under heavier and heavier burdens at home, and to be powerless to maintain its prestige abroad. In other words, it was a time when absolute government, which had so long existed in France, seemed to have failed, or at least when it should be forced to defend itself and prove its right to further existence.

The influence of England.

Montesquieu. Inwell. Eite of fivilh l'exulution (II)ughton), I 26- 153.

Voltaire. Norley. bittiri (Macmillan);

Lowell, Ei' sI-i) $^{\prime}$.

Roussean. Moriev, Rousseme (Macmillau). lhe abustos densuncer were very real.

Aclams,

Finch

Vition. Chap. Al:; Penn. IV.. No. 5 .

426. Voltaire, Montesquieu, and Rousseau. - Two of the greatest leaders of this school, Voltaire and Montesquieu, had spent some time in England, and had there studied the constitution of a limited monarchy, and observed the prosperity and freedom from oppressive exactions and galling caste privileges of the people. What they had learned in this way enabled them not merely to criticise the abuses in France more sharply, but also to describe the kind of government which should exist.

This was especially done by Montesquieu, whose praise of the English constitution had a great influence throughout Europe, and even on those who framed the government of the Initerl States. Voltaire obtainerl a reputation and an almost antocratic authority in Europe, such as have hardly been enjoyed by any other in the history of literature. Roussean, a third leader of the same school, urged a return to nature in education. society, and government. All the little courts of (iermany in the eighteenth century were making themselves as French as possible, and following the example set by Versailles as closely as they could, so that the writings of these men had as much infunence in (iermany as in France; they profoundly affected and for a long time theories of clucation and government.

427. Abuses existing in France. - It is one thing. however, to influence philosophical theories about things and quite a different one to bring about an actual revolution in the State. If the abuser in France had not been so monstrous and so plain to every one, these writings would have had no such effect. They were often exaggerated and declamatory; scarcely one of them is a permanent part of literature; and in their zeal against superstition, selfish- 
ness, and corruption, they often failed to distinguish between the false and the true. Jint the abuse's were too glaring and universal to be denied, when these writings turned the light upon them, and this macle the revolution necessiry.

The nation was practically dividert into two classes, the the priviprivileged and the non-privileged. To the first everything seemed to be given and of them nothing demanded, while the second class had to meet all the expenses. The privi-
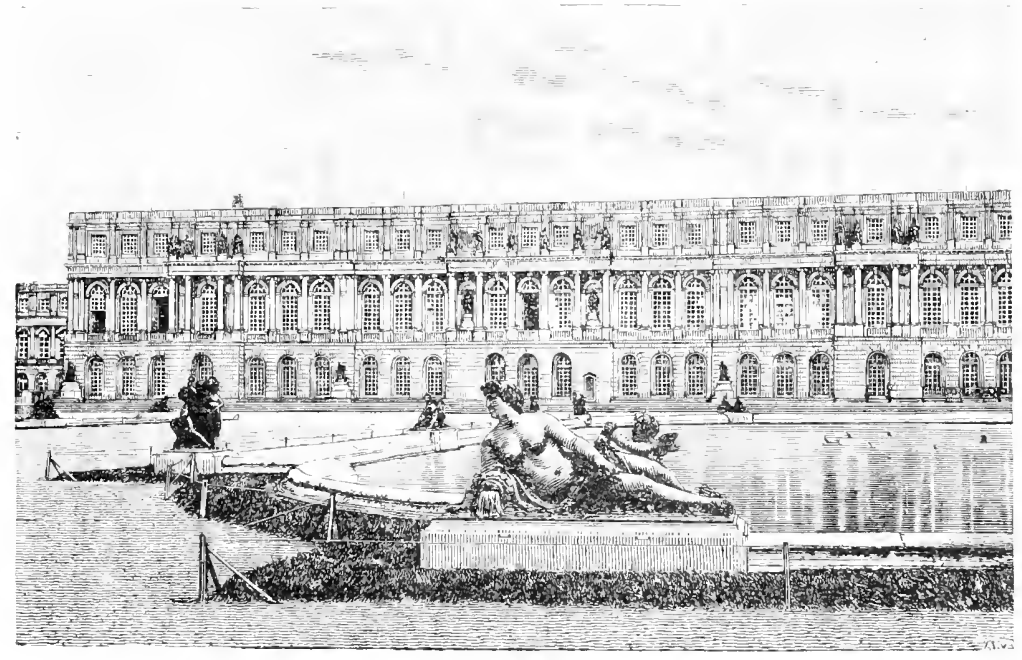

VERSAl1LES

leged orders were two, the clergr and the nobles. To them Taine, were reserved all the offires in the court, the State and the army. Many of them also received large pensions from the pulblic trenoury Two-third of all the land belonged to to them, and its cultivators pail them heary dues besides the other burdens which they bore. They were exempt, legally or illegally, from almost all the State taxes, which therefore rested with greater weight than was just on the other orclers. 
428. The Financial Condition of France. - This burden of taxes and the general financial condition of the government was one of the most decisive causes of the revolution.

France on the verge of bankruptcy. Lowell, Eik, $230-2+2$.

The experiment of John Law. Perkins, Regency, $428-519$; Adams, French Nation, $237 \mathrm{ff}$.

A burdensome method of $\operatorname{tax}$ collecting.

Taine, Ancient Rersmer, 349-373; Lowell, Ez'e, $207-229$. France had entered the century hearily in debt because of the wars of Louis XIV., and these debts had constantly grown. Salaries and pensions, reckless extravagance at the court, the cost of wars which were of frequent occurrence through the whole century, these kept pushing France nearer and nearer to bankruptcy:

A great experiment had been made at the beginning of the reign of Louis XV., under the Regency, to relieve the

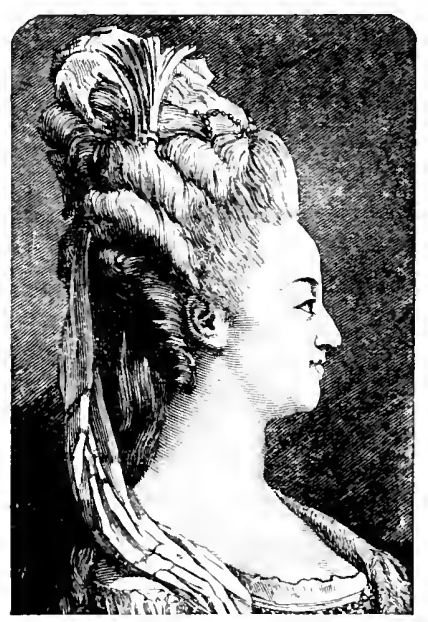

MARIE ANTOLETTE, treasury by the issue of an irredeemable paper currency, under the direction of the Scotch banker, John Law, but, after causing immense speculative excitement and making and destroying great fortunes, this proved a false hope.

The burden of the taxation was greatly increased for the people by the methor of its collection. The State dicl not collect the taxes but sold the right of collection to private individuals, the revenue farmers, who took pains to make themselves rich from their contracts by forcing the people to pay much larger sums than the treasury received. The well-to-do in each community were made responsible for the taxes of the less frugal, so that often a heavy penalty was placed on industry and saving. In some parts of France the peasantry were reduced almost to the condition of wild beasts, and in places the land fell back into wilderness. 
429. Attempts at Reform. - It was impossible that this condition of things should last, but there were only two ways out of it, - reform by the government as it existed or the overthrow of the government and the substitution for it of some other kind of a government which should be able to relieve the nation of its burdens and of their causes. The impossibility of securing reformation under the government of the king led to the opening steps of the revolution.

This was not until the alternative of bringing about a reformation under the existing govermment had been tried. Louis XV. was one of the most selfish of kings that ever reigned. He knew that the State seemed to be drifting to ruin, but he said, "Let those that come after me look out for that." No change was possible while he lived. Louis XVI. was a much better man, but he was too weak for his place. He could not resist the pressure of a corrupt court whose privileges were threatened by any reformation.

Louis promised one of his early ministers, Turgot, who was one of the first of political economists and who knew the changes which should be made, that he would support him in his reforms. But when the test came he failed to do so.and Turgot had to give 11 ) his ministry. The more moderate reforms of Necker, later in the reign, also raised too heavy a storm for the king. The war which France made to aid the American colonies and to take vengeance on England plunged the State still deeper into debt. Finally in despair, after trying every expedient except a genuine reformation, the government decided to call together the representatives of the nation, the Estates General, to see if they conld suggest any way out of the difficulty.

430. The Danger of calling together the Estates General. - It seems to us now as if the privileged oiders ought to have been able to see that this experiment was likely to be far more dangerous to them than even the reforms of Turgot. The new ideas of liberty and equality, of a state of nature in which all men stood on the same level, and of the right of the people as a whole to determine what the

The reform ministers. Turgot. Corréard, Textes, 327-344. Penn. V. No. 2. Necker.

Revolutionary ideas fashionable. 
government should be, were now the prevailing fashion and had won many adherents even among the nobles and the clergy. It was amost certain that an attempt would be made in the Estates General, as legally standing for the whole nation, to bring the government under the control of the people and of these ideas.

The Third Estate has the best of leadership, May 5,1789 . Speeches of Nirabeau. Stephens, speeches, I. t7 and 55; and Indiana, Mod. Hist., No. 1.

The Third Estate demands union. Stephens, French Revolution, I. $55^{-63}$.

It declares itself supreme, June 17.

This was revolution. see Indiana, Mod. Hist., No. 2.

This was at any rate exactly what did happen. When the Estates General came together, it was found that certain of the nobles like Mirabeau, and of the clergy like Sieyès, filled with the new ideas, had had themselves elected representatives of the Third Estate, or non-privileged order, and they at once took the leadership of its policy. 'To put the people into power two things must be done: the other two orders must be forced to accept the leadership of the Third Estate, and then the king and the government must be made subject to the legislature.

43I. The Struggle for One Chamber. - In earlier times the Estates (ieneral had met as three separate chambers each estate by itself and each having a single vote. Now the Third Estate, which had a small majority of all the deputies elected, demanded that they should meet as a single chamber in which each deputy should have a vote. This would mean that the privileged orders accepted the leadership of the Third Estate, and very naturally they refused.

The struggle lasted for more than a month, the Third Estate refusing to allow any business to be done. Finally on motion of Nirabeau they declared themselves the representatives of the people of France, and on motion of Sieyes they assumed the name of the National Assembly, and the power to regulate the taxation without the consent of the other estates.

Such action was of course revolutionary, for it was not sanctioned by the old constitution of France, but was really in violation of it. It brought matters to a crisis at once and led to the second step in the development of the revolution, the conflict between the Third Estate and the king. In reality in calling together the Estates General at all, the 
king had practically abantoned the theory of alsolute monarchy, as held by Louis XIV., that the king determined everything for the goot of his people under a responsibility to God, but not to the nation. But the king and the court did not yet recognize this, and a struggle with the Assembly was necessary to make it evident.

432. The Struggle with the King. - On this action of the Third Estate the king determined to interfere in person, and a session of the three estates was held at which he attended. He promised that in the future taxes should be voted by the representatives of the nation, but he ordered the estates to meet and vote separately, and to take up only financial questions.

On the departure of the king the Third Estate refused to adjourn as they had been directed to, and on the king's master of ceremonies repeating the order, Mirabeau cried out: "Tell your master that we are here by the will of the people, and we can be driven ont only by the bayonet." This was drawing the issue sharply between the people and the king, but Louis did not accept the challenge. He passed over the refusal of the Assembly and allowed them to score the first point. At his request, indeed, the deputies of the other estates joined the Third, and their first victory over him was thus complete, and the way well opened for the second.

433. The King completely Overcome. - Immediately the National Assembly, going on in the way of revolution, began to take measures for the transformation of the entire constitution. Then the king made up his mind to appeal to force, and troops began to be collected near Paris. Necker, who stood in the popular opinion for the reform party in the cabinet, was removed from his ministry and exiled.

These measures brought to the front at once the most terrible ally of the Third Estate, the mob of Paris, to whose influence the bloody excesses of the revolution were due. This mob now took possession of Paris amid the greatest excitement. The old government of the city was

Louis orders the houses to meet separately.

The Third Estate refuses to obey.

The king tries resistance. Stephens, Periods, 5I-57.

The first rising of the mob. 


\section{4

overthrown, its head was murdered, and a new revolutionary gorernment was put into power. A city militia was organJuly I4. ized, the first of the National Grards. The Bastille, symbolstephens, izing to the mind of the mob the tyranny and abuses of the French Rerolution, I., I35-I 45 . old regime, was stormed and its commander murdered after surrender.

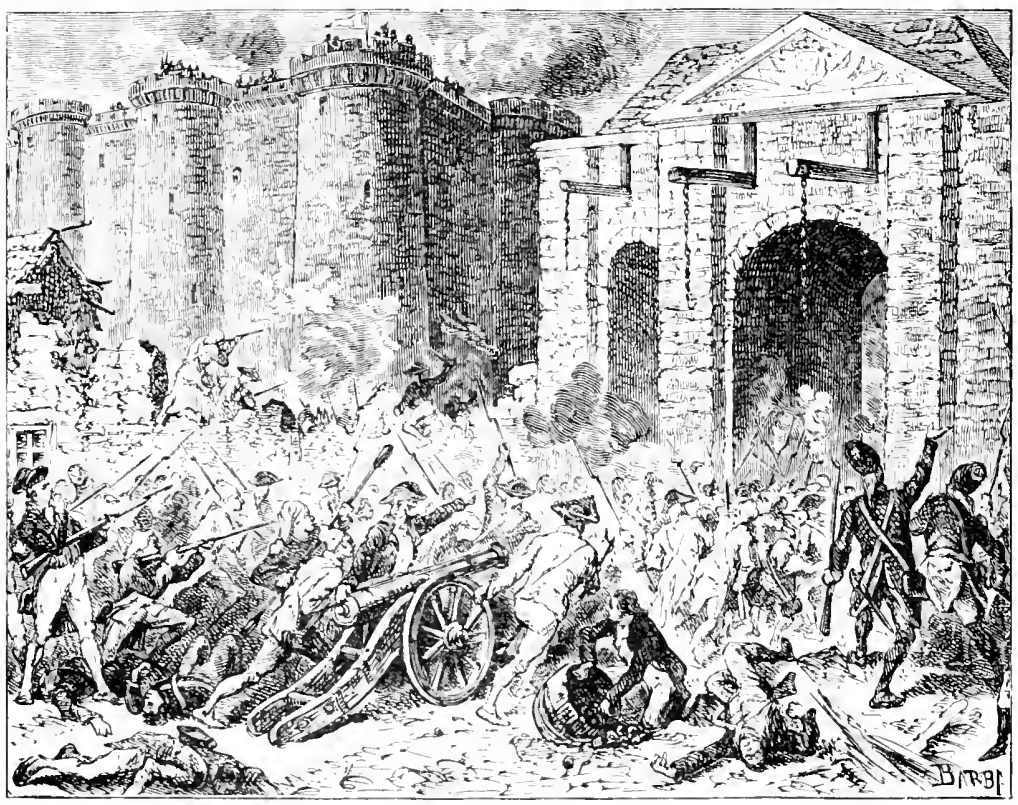

IHE TAKLNG OF THE BASTILLE

'The king surrenders.
Louis yielded at once to the storm. He promised to send away the troops and to recall Necker. He went to Paris and was received with wild enthusiasm. He recognized the new mayor, and the National Guards with Lafayette as their commander, and put on the tricolor cockade. This was the complete surrender of the king. The nobles who were most bitterly opposed to change with the king's 
brother, the Comte d'Artois, at their head, recognized the fact that the revolution could not now be held back and fled from France, the first of the émigrés.

434. Revolution Completed. - The revolution was indeed in full tide, and its progress from this time rapid. The other cities set up citizen governments like that of Paris. The peasants rose and sacked the castles of the nobles and destroyed the evidence of their feudal services. Finally on the night of the th $^{\text {th }}$ of August, the National Assembly, in a session of intense excitement, swept away all the odious privileges of the old regime, and decreed in law the reign of equality in France.

The making of a new constitution was not so easy as the destroying of the old. The French were very familiar with philosophical theories of government, but they had never had any actual experience in making constitutions or in governing themselves, and they had all this to learn. It ought not to surprise us that they did not sncceed very well at first. It was not until September, I 79I, that the new constitution was finished and accepted by the king.

435. The Rise of Opposing Parties. - Meantime many events of importance had occurred. In October, I 789 , the king and his family had been forced by the mob to leave Versailles and take up their residence in Paris, where he would be more directly under control. On the first anniversary of the taking of the Bastille, a striking ceremony took place in Paris called the "national federation," at which the king, the Assembly, the officers of the State, the National Guard, now organized throughout France, and the people present, took a solemn oath of fidelity to the nation and the law.

Notwithstanding, in June, s79 $\mathbf{1}$, the king attempted to escape from Paris with his family and to reach the frontier, but he was recognized and brought back. The endowment lands of the clergy were taken possession of by the Assembly for the benefit of the nation, and the Church was reorganized and given a civil constitution as a department

The king tries to escape.
The old regime destroyed. Penn. I., No. 5 .

A new constitution. Stephens, French Revolution, I. Chap. IX.; Taine, French Revolation (Holt), I., I87-216. The progress of events. 
Two parties torming.

Nirabeau.

The clubs.

The

Assembly dissolverl.

The finances still in disurder.

The seizure of the Chureh lands. of the State. The old provinces of France had been abolished and the country divided for administrative purposes into new divisions called departments.

Before the new constitution was finished the Assembly began to divicle into parties, especially into two, a party in favor of a limited monarchy somewhat after the English model, and a party in favor of a republic. Robespierre was a leader of the latter and Nirabeau of the former. So long as Mirabeau lived his influence was very strong in the Assembly, and the constitution adopted embodied many of his ideas. His death on April 2, I79r, was a great loss to the moderate party.

The clubs organized in Paris, at whose meetings questions of government were debated, often in a purely theoretical way and sometimes with great excitement, began to exercise an influence on the people and on the Assembly. The Jacobin club, at first moclerate, became finally more vigilant unler the leat of Robespierre. That of the Cor(leliers. led by I)anton, was early an adrocate of the extreme revolution. (On the flight of the king, the republican party attempted to establish a republic, but they were dispersed ly the National (ruards moler Lafayette. This was the first open break between the two parties.

436. Financial Difficulties still Continue. - On the adoption of the constitution and its acceptance by the king, the Assembly, which had been called in 1789 , and which now called itself the Constituent Assembly, was dissolved September 30, s $79 \mathrm{r}$.

The meeting of the listates General had been forced upon the king by the impending bankruptcy of the State. The representatives of the people, however, showed themselves no more able to find a wise and permanent solution of this difficulty than hal the absolute government. After the failure of some attempts to fill the treasury, it was proposed to take possession of the endowment lands of the Church. These were more than half the area of France, and their value, if it could be realized, wonld relieve the government of its pres- 
ent difficulties and make some provision for the future. It stephen. was argued that these lands had been given to the Church in trust by the nation, to provide for religious services, education and charity; that the clergy had not fulfilled these obligations; that instead their wealth had led to corruption and scandal; and that in consequence the nation had a right to resume the lands, both to its benefit and to that of the Church, it was asserted. The vote of resumption was passed in November, 1789 , and the lands were offered for sale. It was soon found that sales would be slow, as possible purchasers feared a speedy counter revolution and the consequent loss of their whole investment.

437. Paper Money based on Land. - In I)ecember it was voted to try a most attractive plan. Paper money was to be issued, secured by these national lands, and thus their value be realized for the State. In theory this seemed a most satisfactory arrangement. The actual value was in the land behind the notes, which would therefore circulate readily and

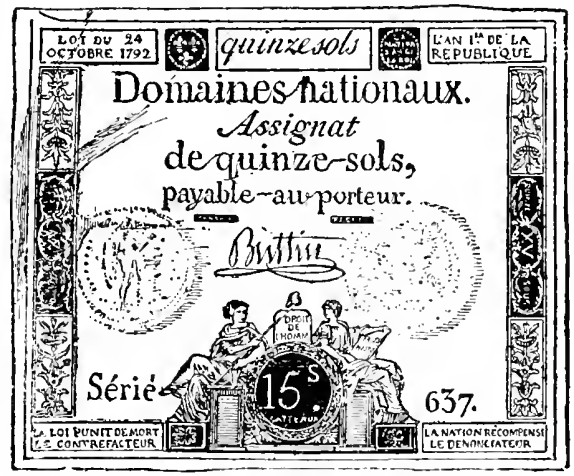

FACSIMILE OF AN ASSIgNat (REDUCED)

relieve the nation of its embarrassments. The first issue was for 400,000,000 francs. But this succeeded so well, and was so easy a way to solve problems which did not seem to admit of any other solution, that one issue quickly followed another, with the inevitable results.

In a few years the purchasing power of the paper money, The results the so-called assignats, declined to one four-hundredth of of inflation. its face value, and the printing-presses could not work fast

Frinch

kevolution,

I. $297-303$.

Civil constitution of the clergy.

Penn. I.

No. 5 .

" The land secures the notes." Stephens, Finch Kicrolution, I. $35^{\mathrm{I}-3} 52$. A speech of Mirabeau's. Stephens, speeches, I. 197. 
The Legislalive Assembiy, Oct. I, I791.

The Girondists.

War declared by France, Apr. 20, 1792.

Penn. I., No. 5 .

I'he war soes against the French. enough to supply the needs of the government. The experiment only postponed the real solution of the problem of meeting the financial needs of the State, and still further complicated it. Later governments had to devise new measures, and these included at least a partial repudiation.

438. The Beginning of a Long War. - From this date revolutionary France drifted rapidly into a war with Europe which scarcely ceased until the battle of Waterloo. A new Assembly, the Legislative Assembly, met the day after the adjournment of the Constituent. It was composed of men without experience, for the old deputies had forbidden their own reëlection. Its control was at first in the hands of the constitutional monarchists and moderate republicans, the party of the Girondists, but the extreme republicans were well represented. Outside the Assembly their influence was rapidly extending, especially through the aid of the Jacobin and its affiliated clubs.

On the Rhine frontier of France the imigre's, the nobles who had abandoned France, were collecting and organizing for an attempt to reverse the revolution. The republicans believed that the king and the court sympathized with their plans and stood ready to assist them. This belief seemed to be confirmed by the rapid veto by the king of the measures of the Assembly against the émigrés and for the national defence. Austria was plainly preparing to interfere in France against the revolution, and Prussia had formed an alliance with her for the same purpose. The emperor, Leopold II., refused any explanation of his preparations or of his relations with the 'migre's, and in April, 1792, the Assembly declared war with the consent of the king.

439. The First Step towards the Republic. - The war at first went everywhere against the French. Enthusiasm was a poor substitute for discipline and experience, and the best officers of France were on the other side. The people of Paris believerl that the successes of the enemy were due to the treason of the court, and a mol took possession of the Tuileries and forced the king to a new declaration of his ficlelity to the nation. 
On the news of this the duke of Brunsivick, at the head of the Prussian army which was advancing on Paris, issued his famous manifesto, threatening to hold the citizens of Paris responsible for any injury to the royal family. This excited the mob beyond all bounds. The palace was stormed, the Swiss guards murdered, and the king forced to take refuge in fear of his life in the chamber of the Assembly. The mob demanded the republic at once, and the Assembly voted the suspension of the king from all his functions, and called a convention to decide the question of the form of government. This was the famous roth of August, I 792. The king remained a prisoner in Paris in the Temple.

440. The Republic proclaimed and the King executed. The commune was now in possession of the capital under Robespierre, Marat, and their friends. They organized its defence with great energy, but the Prussians continued to advance, and to gain success after success. It seemed as if nothing could check them, and the mob, in an insane passion of anger at the supposed royalist traitors who were aiding their advance, burst open the prisons and massacrerl more than a thousand men and women, on the $2 \mathrm{~d}$ and $3 \mathrm{~d}$ of September. But within a few days the French army gained an advantage over the Prussians in the battle of Valmy, and the immediate danger was past.

On the next day after this battle, the Convention unanimously declared the monarchy abolished. But it was not so easy to decide what to do next. The Girondists had a majority at the opening of the Convention, but the Jacobins, or the "Mountain," had a larger number than in the last Assembly, and between the two parties was the "Plain," or the "Marsh" as it was called in derision, containing a large number of undecided members, whom the French method of allowing free entry into the galleries of the mob was likely to convert to the sirle of the extremists.

The battle of Valmy was speedily followed by other successes. The invaders were driven out. Belgium was occu-

The massacres of Septembur. Stephens,

French

Revolution, II. I 4 I-I 50 .

The monarchy abolished. Carlyle, French lievelutum, Bk. IV., Chaps. VI. and VII. A speech of Robespierre's. Indiana, Mod. Hist., No. 4. 
French pied, annexed to France, and divided into departments. successes. The conquest which the French monarchy had been striving for during more than two centuries was made by the republic in two months. This was followed by the execuThe king tion of the king. The (irondists, irresolute before the executed, Jan. 2I, I793.

Europe combines against the revolution.

A stronger executive necessary.

The Reign of Terror. siephens, French Revolution, II., Chap. X.; Carlyle,

Frinch Revolution, Bks. VI.VIII. A speech of superior energy of the Jacobins, yielded; Louis was put on trial before the Convention, and declared guilty of high treason by almost a unanimous vote, and finally condemned to leath by a small majority.

44I. War against All Europe. - The execution of the $\mathrm{king}$, together with the violation of international law which had taken place, and the evident intention of extensive conquest on the part of the republic, combined all Europe against France. War existed with Austria and Prussia, and on the ist of February, I 793, it was declared against England, Holland, Spain, Naples, and Sardinia. These were great odds, and the first results were disastrous to France. Belgium was lost, and the enemy everywhere made advances. These disasters led to a step which resulted finally in a change of government in France and prepared the way for Napoleon. The first Committee of Public Safety was elected by the Convention, and soon after, the second, which remained in power for a year. 'The object of this step was to strengthen the executive authority, in view of the public danger, and to aroid a divicled responsibility. Its power continued to increase, as was inevitable in times of so great confusion, and it passed in the end, through the stages of the Directory and the Consulite, into the Empire.

442. The Reign of Terror, followed by Reorganization and Success. - The two yeirs which followed the election of the first Committee of I'ulslic Safety, from the spring of I 793 to that of 1795 , were filled with events of the greatest importance to France and to Europe. In the Convention the extremists quickly gained the upper hand, the Girondists were expelled, the Reign of Terror began and raged in Paris and throughout France, until passion was exhatsted and the learlers of all parties had been guillotined. Then the more 
moderate recovered power, the Girondists were recalled, and Europe became aware that the days were over when the French were resolved to revolutionize all the world at the point of the bayonet.

On the frontiers the French armies had been made over. New officers had arisen, and the men had been brought under strict discipline. Continuous successes were the result. Not merely was Belgium recovered, but Holland also was conquered, and though not annexed to France, it was transformed into the Batavian republic, and made a close ally. Important successes were also gained in the south. Some of the states of Europe were now ready for peace, and in the spring of 1793 the number of the enemies of France was reduced. But England and Austria remained in the field. England's successes on the sea had been very great and almost all the French and Dutch colonies were in her hands.

443. The Work of the Convention. - In I 795 the Convention established the constitution which it had been elected to make, called the constitution of the year III. It vested the legislative power in a legislature of two houses, and the executive in the Directory of five nembers elected by the legislature, one going out of office each year. The legislative work of the Convention in other directions was of great importance. It established a uniformity of weights and measures, adopted the republican calendar, began the formation of a code of laws, and organized with great ability a new system of national education.

444. Bonaparte forces Austria to make Peace. - The new government had the war against England and Austria to carry on, but the military situation of France was now much improved. The war department was in the hands of Carnot, the "Organizer of Victory," who conducted it with great skill. Bonaparte had also risen by this time to such a military reputation that the conduct of the war in Italy was confided to him over older and more experienced generals. He quickly justified the confidence. In ten days Fyffe,

The new republican constitution.

Bonaparte's first campaign in I taly, 1796-1797. stephens. Periods. 173-193; Morris, Napoleon, Chap. 11.; 
Europe, he forced the Sardinians to withdraw from the war, and in Chap. III. six weeks he had defeated the Austrian armies, occupied

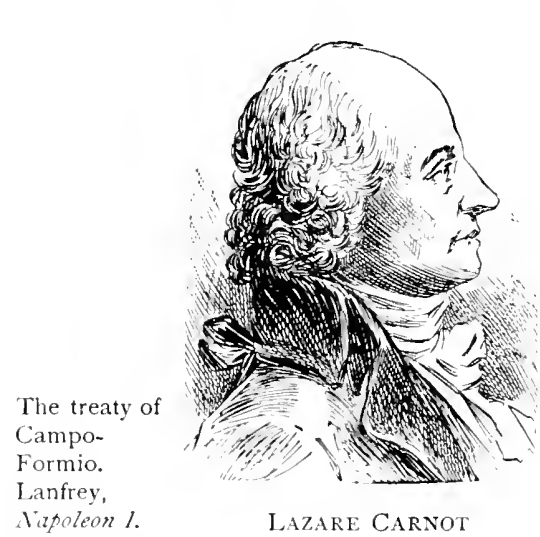

Nipteon 1. I., Chap. IX.; Penn. II., No. 2.

The way preparing for the Empire. to it.
Milan, and begun to levy heavy contributions from the Italian states. New armies from Austria were beaten one after another, and the fortress of Mantua was forced to surrender. In March, I 797 . Bonaparte invaded Austria itself, and in a month had compelled the emperor to sue for peace.

The war was closed by the treaty of Campo-Formio. Austria recognized the annexation of Belgium, the extension of France to the Rhine, and the republics in alliance with France which had been formed in Italy, the Ligurian around Genoa, and the Cisalpine around Milan. Venice, which Bonaparte had seized, was given to Austria in compensation, and was retained by her until late in the nineteenth century. This treaty completed the sanction of Europe to the great conquests which the republic had made. England alone refused to be a party

445. Revolution within the Revolution. - Before the return of Bonaparte to Paris, a series of coups d'état, of revoIutionary appeals to force in violation of the constitution, but designed to keep in power the party which had made it, had been begun; and these prepared the way by clear precedents for Bonaparte's arbitrary assumption of power two years later. The first of these was against the monarchical party which harl begun to recover strength in France. By the aid of troops, two Directors and about fifty deputies were expelled from office and new elections ordered. A second, the next May, was against the Jacobins, who were beginning to acquire a majority in the legislature. 
446. Bonaparte in Egypt. - A few clays later Bonaparte set sail for Egypt, to restore if possible the French supremacy in the Orient and to destroy that of England. By the conquest of Egypt he hoped to be able to aid the insurrection of Tippoo Sahib in India, and to injure fatally the English power there. The famous battle of the Pyramids gave him the country, and he a little later beat off the army which the sultan sent against him. But Nelson's victory in the battle of the Nile cut off his communication with France, and the British hold of India proved too strong to be shaken. In the meantime, changes in France seemed to open a brilliant prospect of advancement for himself, and he returned after an absence of a year and a half, escaping the English cruisers with marvellous good fortune.

447. A Strong Government Demanded. - On every hand in France the strong man was now demanded, and the only strong man in whom every one had confidence was Bonaparte. The Directory was unpopular and weak, and seemed able to govern only by repeated coups d'état. Their conduct of foreign affairs, as arbitrary and unprincipled as that of the early republic, had enabled England to renew the European coalition against the French, and the war was going against them, especially in Italy, where a skilful Russian general, Suvarov, carried all before him. Steady government at home, better generalship abroad, was the desire of all.

With the aid of one of the Directors, Sieyès, who had kept his head above water through every storm, a revolution was quickly carried through. Troops dispersed a part of the legislature; Consuls were put in the place of the Directors, Bonaparte among them; the constitution was revised in faror of a stronger executive, and the Consuls were made the permanent executive with Bonaparte as the first Consul and real ruler of France, a position which he henceforth held. The first and longest step had been taken toward the making of a new absolute government in France, as unlimited in power as the old monarchy, but with the old

The weakness of the Directory.

Bonaparte put into power by a revolution, Nor. I799. Stephens, Periods, 210-2I ; Fyffe, Ellrope, I35-I44; Morris, Napoleon 69-77. 
England even consents to peace with France. stephens, Perinds, $217-225$.

The Treaty of Amiens, 1802.

Bonaparte's attempt on Lonisiana, I502.

feudal distinctions and privileged orders swept away. That much at least the revolution had accomplished.

448. Bonaparte turns the Tide of War. - Bonaparte quickly restored orler to all departments of the government

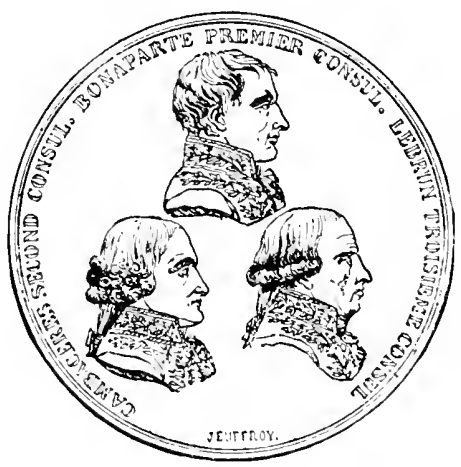

THE THREF CONSULS at home, and victory to the French arms in the war. He went himself to Italy, gained the victory of Marengo, and drove out the Austrians. Along the Danube also they were forced to fall back, and before the close of the year i Soo to make peace again, with a recognition of all the French conquests. Russia had already withdrawn from the coalition. England again remained alone to carry on the war a year or two longer. But England and France were hardly within striking distance of one another. England hat no armies on the continent. France had no heets on the sea. Nelson's attack on Copenhagen prevented Bonaparte from securing the Danish fleet. By the end of r 801 both parties were ready to end the useless war, and the treaty of Amiens was made. England surrendered nearly all her own conquests and recognized nearly all those of France.

449. The Interval of Peace. - The final treaty was not yet signed when Bonaparte began a new attempt to recover the colonial empire of France, and to weaken that of England, in the expedition which he sent to recover the island of San Domingo, which had revolted. This he proposed to use as a base of operations for the occupation of Iouisiana and the restoration of French power in North America. The first step failed through the obstinate resistance of the revolted negroes and the ravages of the yellow fever, and before a second could be taken war had been renewed in Europe. 
In the interval, the organization of France had been carried forward. The batance was established between the various parties. The arministrative machinery was centralized. The colles were completed. In agreement was male with the pope, and the ('hurch became reconsiled to the new state of things. The constitution was twice revised in

Constitutional clonges. Lanfrey, Nixpolion 1. , II., Chap. V.; Morris,

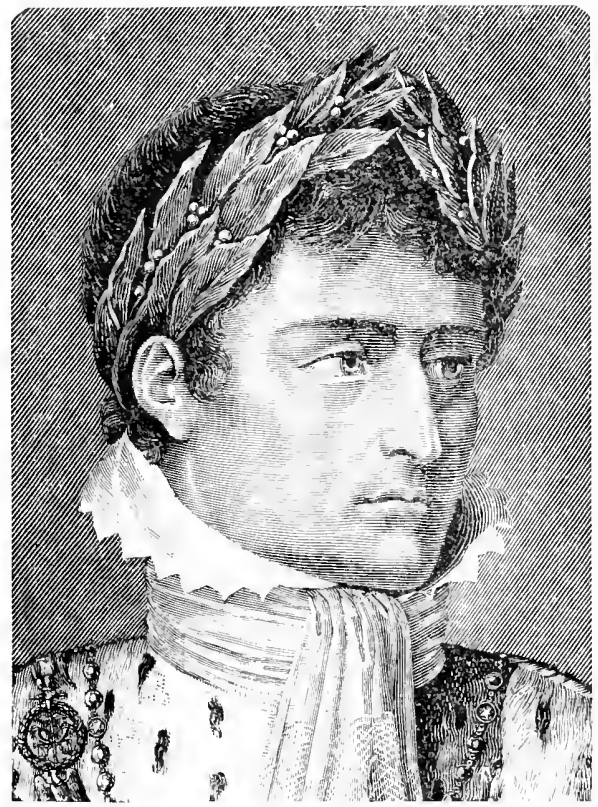

NAPOLEON

the interest of a stronger executive, and 13onaparte was mate first Consul for ten years and then for life. Everything was so arranged that a little later, in May, ISo, the Empire could be proclaimed with scarcely a change.

450. The War Renewed. - Neither Napoleon nor England could consider the peace of Imiens as much more than a truce and the war began again in the spring of $\mathrm{ISO}_{3}$,

Sirpoleon. Chap. T.; Stephens, Pertuds, 237-24I. Napoleon at the height of his power. Stepliens, 
Periods, 250-262;

Blackmose, Springhaien (novel).

The Roman emperor deposed. schilling, Gutllentuit, 331 ;

Bryce,

Holv Roman Empire, 359-358.

The map of Europe torn to pieces.

The "continental system," 1806. Penn. II., No. 2.

Joseph made king of Spain, I808.

\section{Ausiria's premature attempt. Maria Louisa. Sloane, Vipoleon, III., Chap. XX.}

The exhaustion of France. through the fault of both. Austria and Russia also took the field against France, but with the usual result. Ulm and Austerlitz forced Austria to retire. Prussia tried to take her place, but lost the battle of Jena, and could not save Berlin. Then came the turn of Russia which finally consented to the peace of 'Tilsit.

This was the moment of Napoleon's greatest success. All the continent was at his feet. Boundary lines in every direction were wiped out and redrawn where he pleased. History and the former relations of territories were not in the least regarded. His allies took what they wished at the expense of his enemies. Two of his brothers became kings. France was further enlarged, and the European Empire of Rome and of Charlemagne, of which Charles V. had dreamed, was created. But England would not submit.

45I. Napoleon stretches his Power too Far. - The tide was now about to turn. The change began through two mistakes of Napoleon's, whose results were not at first apparent. The one was his attempt to strike at England, by shutting out her goods from the markets of the continent his "continental system," which had the effect to excite against him much discontent and opposition. The other was his attempt to make his brother Joseph king of Spain. This brought into the field against him an enemy he had never met before, the determined spirit of a nation in defence of its independence, and it opened the way for the celebrated peninsula campaign of Wellington, which weakened the French so greatly.

So much in the situation seemed encouraging that in I 809 Austria tried the experiment of war again, but with no better success than earlier. Wagram was an old time Napoleonic victory, the emperor had to give up more territory, and to allow his daughter, Maria Louisa, to become Napoleon's wife, in the place of Josephine whom he discarded.

452. The Beginning of the End. - But these continuous wars, if they seemed to leave Napoleon still the Dictator of 



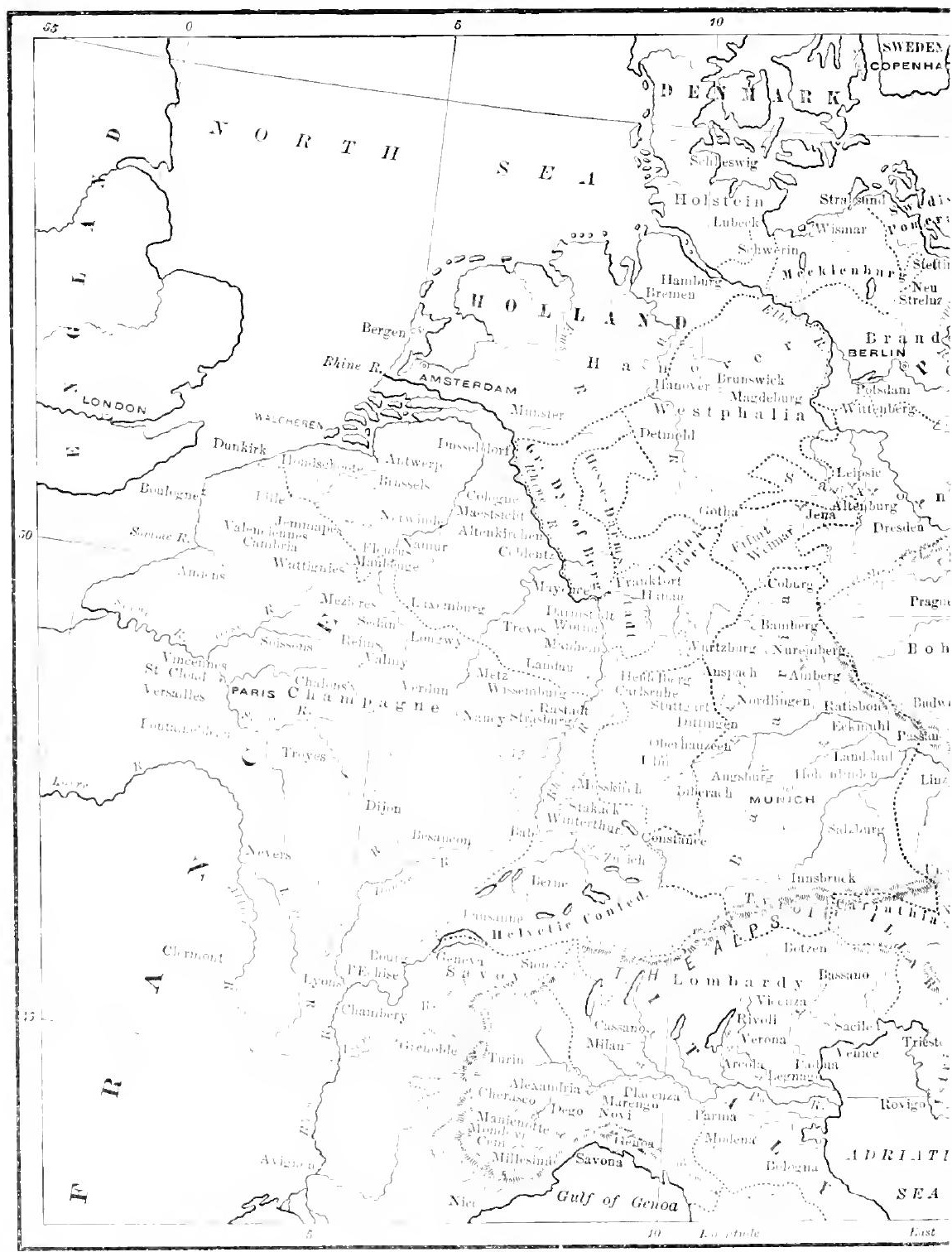




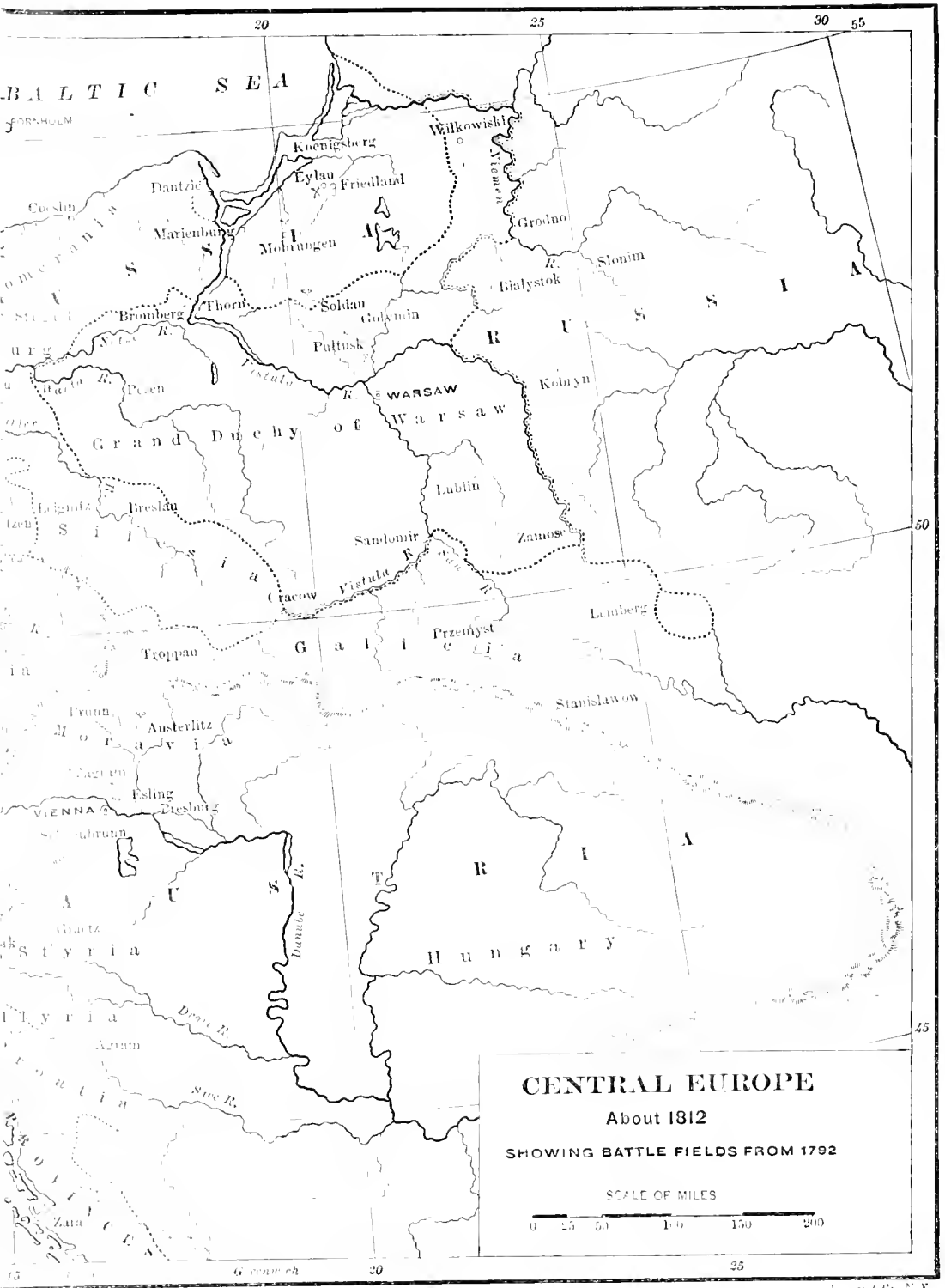


Europe, were steadily exhausting the resources of France, especially in men, and it was becoming more and more difficult to keep the quality of the armies up to the level of those that had won the earlier successes. In northern Germany also a great revolution was taking place, under the lead of Prussia, reforms in all department of the State, and the growth of that sort of national feeling which had proved so difficult to deal with in Spain.

Napoleon, however, did not seem to realize that the foundations of his power were weakening. When Russia became unwilling any longer to adhere to the continental system and began to draw towards England, he resolved to treat her as he had the rest of Europe, and set out in May, r $8 \mathbf{r}_{2}$, on the invasion which led to his fall. At first he was as successful as ever. He drove back the Russian armies and entered Moscow. But this was the limit. The Russians burned him out and forced him to retreat. Then his army began to melt away before the winter storms and the swift attacks of the Cossacks. Prussia believed the time had now come and rose against him, better prepared than ever before. Austria quickly followed. At Leipzig in one of the greatest battles of these wars, often called the battle of the nations, his army was almost totally destroyed.

453. The First Restoration. - Napoleon was now obliged to cross to the French side of the Rhine. The terrible losses which his armies had suffered he could not make good. His genius was as great as ever, but he had no longer the same material to work with. Steadily he was pushed back, and in the spring of $18 \mathrm{I} 4$ his enemies entered Paris. The Bourbons were restored in the person of Louis XVIII., brother of Louis XVI., but the old absolute monarchy was not restored. The new king promised to reign as a constitution monarch. Napoleon was sent to the island of Elba, between Corsica and Italy, where he was kept in honorable confinement, retaining his title of emperor.

454. The Charter of I8I4. - Louis XVIII. began his reign with many indications of the Bourbon spirit. He put

The awaken-

ing of

Prussia.

Penn. II.,

No. 2.

The invas-

ion of

Russia.

Morris,

Napoleon,

273-286;

Tolstoi,

It ar and

Peace,

Pt. III.

(novel).

Europe rises

against

Napoleon.

Morris,

Napoleon,

Chaps. XI.

and XII.;

map,

Putzger,

No. 29.

Napoleon

sent to the

island of

Eiba, I8I.4. 
Louis

XVIII. king by divine

right.

Fyffe,

Eurpe, 358-380.

The Charter in Penn. I., No. 3 .

What the revolution had permanently secured.

A new map of Europe to be made.

Discontent in France. aside the constitution suggested by the Senate. He claimed the constitution-making power for himself. He would grant a constitution to his people. Shortly afterwards he issued it, the so-called Charter of $18 \mathrm{I}+$. In this he called himself king "by the grace of God," and dated it from the nineteenth year of his reign, counting from the death of Louis XVII., the little Dauphin who died in the Temple prison. It was made very evident that he was determined to be regarded as the fountain and source of all authority.

But the work of the revolution could not be set aside. The old monarchy was impossible even for a Bourbon. The representative system was secured, and the responsibility of the ministers to the legislature. All Frenchmen were to be equal before the law, in taxation and in eligibility to office. Private property as transferred by the revolution, should not be disturbed. The right of suffrage was determined by a property qualification. The constitution, though bestowed as an act of the king's good grace, was not an illiberal one. In the administrative system of the kingdom, the close centralization which had been devised by Bonaparte was retained and has become apparently permanent in France.

455. The Congress of Vienna. - The removal of Napoleon and the restoration of the Bourbons were not the only things the allies had to do. Napoleon had at one time made a map of Europe to suit himself. This of course the ministers of Europe could not allow to stand, but they must agree among themselves on the new one, and such an agreement was not easy to reach. One thing was quickly settled. France was to be set lack to the boundaries of 1792 , and this was determined upon, and accepted by France, a few weeks after the entry of the allies into Paris. A diplomatic congress assembled at Vienna to settle the rest, and there the allies began to show signs of quarrelling over the spoils. News of this was carried to Napoleon at Elba.

In France, also, considerable discontent had arisen with the new government. The nation began to fear a reactionary tendency against the results of the revolution, and not 
without some reason. The censorship of the press was reestablished. The officers of Napoleon were sent into retirement and their places supplied with the nobles who had fought against him. Lands confiscated by the revolution, but not yet sold, were restored to their old émigré owners. Napoleon learned of this feeling in France also.

456. The "Hundred Days." - Suddenly at the end of February, I 8 I 5 , he left Elba, landed in the south of France, and began to advance towards Paris. Everywhere he was well received. His old soldiers joined him. Officers and troops sent to arrest him went over to his side. In twenty days the king had fled and he was in Paris. Here he tried to persuade Europe by solemn assurances that he would not renew the war, and the French people by issuing a constitution supplementary to that of the Empire that he would not renew his despotism. Neither attempt entirely succeeded. The allies certainly could not allow him to reëstablish his rule and prepare in peace for the inevitable attempt to recover the lost frontiers, and they immediately declared war.

One great battle ended the war. This fell to the English and the Prussians. Wellington held firmly his position at Waterloo until the Prussians came up and Napoleon's army was totally routed. He tried to secure the succession of his son by abdicating, but the allies restored the Bourbons once more, and Napoleon was carried by the English to the island of St. Helena, where he died May 5, I $S \mathbf{2}$.

457. The Second Restoration and the Congress of Vienna. - The second restoration of the Bourbons was more permanent than the first, but they had learned little by their experience. Louis XVIII. showed the same characteristics as before the return of Napoleon. The reaction against the revolution grew ever stronger until it led to another revolution.

The Congress of Vienna completed its work in ISI5. A little more territory was taken from France after the battle of Waterloo. Holland was made a kingdom and given the Austrian Netherlands or Belgium, Switzerland was enlarged and its neutrality guaranteed. Savoy was given back to the

Napoleon's return to France.

Waterloo, June I8, 1815.

Bourbon reaction. Adams, Democracy and Monarchy, 219-25I.

The work of the Congress. Stephens, Periods, 336-350; 
Fyffe, king of Sardinia, and the Bourbons restored in Naples and Europe, $3^{30-}-3^{8} 7$ and 4 II -418 .

Reaction and absolutism only temporary.

Sicily. Nearly all north Italy, Venice, and Lombardy was put under the rule of Austria, which retained it until the formation of the present kingdom of Italy. Prussia received a part of Saxony, which had been too faithful to Napoleon, and also considerable lands in the Rhine valley taken from the small German states of a former time and from France. England's gains were colonial, and the most important was the Cape Colony.

458. Results of the Revolution in Europe at Large. The diplomats at Vienna could treat a large part of Europe as if they were the absolute owners of it, disregarding utterly the feelings of the inhabitants, but they could no more undo the work of the revolution in Europe at large than the Bourbons could in France. The way had been made open everywhere for constitutional liberty, and if it did not at once appear, the delay was only temporary. The worst abuses of the old regime had disappeared. Feudalism, serfdom, and insignificant sovereignties were to a large extent things of the past. A new national spirit had been excited in countries like Germany, which had long been divided into fragments, and the preparation was begun for their future national governments. The next few years might be characterized by reaction, and absolutism seem to triumph, but the people of Europe were really a new people, and they had begun to cherish the spirit of liberty and democracy which reigns at the present day.

\section{Topics}

The compensation of France for her political decline in the eighteenth century. The influence of England on French thinkers. The leaclers of French thought and their ideas. The real abuses in France. Her financial condition. Why were not reforms carried through? The character of the two kings. Why was the Estates General called? Why a dangerous experiment? What was the first conflict which introduced the revolution? The result and its effect. The struggle with the king. The part played by the Paris mob. The completion 
of the revolution. The formation of two parties. The clubs. What were the assignats? Why necessary? How secured? The result. The beginning of European war. What led to the suspension, and what to the execution, of the king. Effect on Europe. Change in the executive government in France. The Reign of Terror. The military successes of the Republic. The constitution of the year III. Bonaparte in ltaly. Gains in the treaty of Campio-Formio. Why dicl Bonaparte invade Egypt? Kesult. How did he gain political office in France? What preparation had there been for this step? The treaty of Amiens. Ilow dil Ionaparte use the interval of peace? The great suceesses of Napoleon in the next war. Ilow dicl he treat Europe? What were his mistakes? What were the causes and the suceessive steps of the overthrow of Napoleon? The first restoration. Character of the Bourbon constitution. What things encouraged Napoleon to return to France? Ilow was he received by lirance? By Europe? Waterloo. The new map male by the Cungress of Vienna. Permanent results of the revolution in France. In Europe.

\section{Topics for Assigned Studies}

The execution of Louis XV1. Stephens, French Rezolution (Scribner), 11. 212-22I. Carlyle, French Realution, Bwok IV., Chap. V1II. A speech of Robespierre's. Stephens, Specines of French Rezolution (Clarendon), II. 357. In French.

The battle of Waterloo. Sloane, Napoleon (Century Co.), IV., Chap. XXIII. Ropes, Campaign of Waterloo. (Scribner.) Morris, Vapoleon (Heroes), Chap. XIH.

\section{Important Dates for Review}

\begin{tabular}{|c|c|c|c|c|}
\hline $\mathrm{I} 7 \mathrm{Sg}$. & May & & & - Estates Gener \\
\hline I $79 \mathrm{I}$. & Siept. & . & • & - The new constitution proclaimed. \\
\hline 793. & Jan. & $\cdot$ & . & . I.ouis XV1. executed. \\
\hline & June & . & . & . Keign of Terror legins. \\
\hline 1796 & . & $\cdot$ & . & . Jonaparte in ltaly. \\
\hline 1798 & & . & . & - Ijonaparte in lygpt. \\
\hline I 799. & Nuv. & . & . & - Lomaparte, Consul. \\
\hline I SO 2 & & . & . & . Treaty of Amiens. \\
\hline I So 4 & May & . & . & Bonaparte male emperor. \\
\hline I So 6 & & . & & . The continental system. \\
\hline I SoS & & . & . & . Joseph, ling of Spain. \\
\hline ISIO. & Apr. & . & 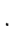 & - Napuleon marries Maria Louisa. \\
\hline $\mathbf{I} \mathbf{S}_{\mathbf{I}}$ & & . & $\cdot$ & - Imasion of Russia. \\
\hline $1 \mathrm{SI}_{3}$ & Oct. & . & & . Wattle of lecip<ig. \\
\hline IS I & & $\cdot$ & . & - Napuleon at Elta. \\
\hline 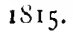 & June & . & & Battle of Watertos. \\
\hline
\end{tabular}




\section{CHAPTER VI}

EUROI'E SINCE I 8 I5

\section{Books for Reference and Further Reading}

Fyffe, Histery of Modern Europi. In one volume. (Itult; \$2.75.)

Nüller, Political IVistory of Recent Tine's. (Harper; \$2.oo.)

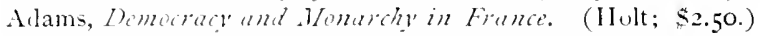

Anlrews, The Ilistoricat Detelopment of Modern Eurofe. 2 vols.

(I'utnam; \$5.00.) suggestive and instructive commentary for the use of the teacher.

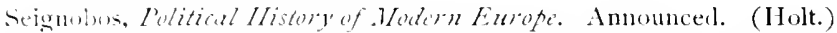
IIolland, The Europern Concert in the Eastern Question. (Claren(1) \$ \$.75) Treaties and other public acts.

Murduck, The lieconstruction of Lurope. (IIoughton; \$2.0o.) On the national morement.

Thayer, The Dater of Itatian Indefindence, ISI4-IS49. 2 vols. (Hougliton; \$f.00.)

lieber, Cinil Liberty and Silf Goremment. (Lippineott; \$3.15.) Interpretation of English liberty, especially in comparison with French ileas. Contains many documents.

The international system beginning to embrace the whole world.
459. The Nineteenth Century an Age of Transition. - By the year $S_{15}$ the workl of international politics had begun to be consilerably larger than the continent of Europe, and it has been expanding ever since. Very soon after that date the Unitel States began to make her voice heard in the councils of the nations. England had become even earlier so much more concerned with the affairs of the larger world that she had begun to consider all questions of European politics from their bearing on her wider interests, as she still does. ()ther nations have become ly degrees interested in the same way, and new nations, once unthought of and lying far remote from Europe and its local questions, like 
Japan, have entered the field of international politics and secured immediate and strong influence.

The nineteenth century is in this respect an age of transition. The twentieth century will before its close have ceased to regard the local balance of power in Europe, or the minor details of its interior boundary lines, as the leading questions of international diplomacy. There are, however, running through the whole of the nineteenth century, certain lines of European political movement which are of decided importance in the history of the world.

460. Three Lines of Great Political Changes. - Of these lines there are three of especial interest, which can be readily traced, and whose history makes up in large part the political history of Europe. They are:

First: The continued effects of the French revolution; the efforts of the people to secure a larger share in their governments, and of the sovereigns to prevent this ; the consequent revolutions and changes of government, advancing to the result, which has now been reached almost everywhere, of the triumph of liberal government and of the democratic principle.

Second: Closely connected with the first, growing largely from the same canses, and greatly aided by the increasing influence of the people upon their governments, the movement to secure for nations long broken into fragments by the arbitrary dispositions of absolute rulers, a political unity whose boundary lines should correspond to the territories occupied by the nation, and whose government should be an expression of the national will. This has resulted in a very considerable making over of the map of Europe in the interest of the idea of nationality.

Third: The Eastern question, occasioned by the slow dissolution of the Turkish Empire and the rivalry of several European nations for the inheritance. An essential part of this is the enormous expansion of Russia, both in Europe and Asia, during the century.

46r. The Absolutist Reaction. - The first results which The Eastem
The struggle for constitutional government.

The idea of nationality.

Local
European politics still of great interest.

Three lines. question. 
The sovereigns want no constitutions.

Fyffe,

Eirrope. Chap. XIII.

The Holy

Alliance,

I 815 .

Miiller,

lecent

Times, 2-5;

Penn. I.,

No. 3;

sichilling,

Guellinlinch. 407 .

Metternich. Penn. 1., No. 3 .

The universities, and the secret societics.

followed the overthrow of Napoleon by the allies were disastrous to the carse of free government. We have seen the consequences in France, where the restored Bourbons had granted a constitution, but where the whole tendency was towards illiberal government and the limitation of the rights of the people. The same was true of all Europe, both in the states whose rulers had been compelled to grant constitutions and in those where they had not been. The sovereigns of Europe had been thoroughly frightened by the revolution and they did not propose to allow it to proceed further.

Three months after the battle of Waterloo a treaty was signed at Paris between the emperors of Russia and Austria and the king of Prussia. Ostensibly the purpose of this alliance was to make the precepts of the Christian religion prevail everywhere, in the relations of states to one another and of governments and their citizens. On this account it became known as the Holy Alliance. Whether the professions originally made were sincere or not, the Holy Alliance came very soon to mean an agreement between the sovereigns to interfere in any state which was threatened with revolution, and to force the people to submit to their rulers. Count Metternich of Austria was one of the most active supporters of the policy ; he possibly gave the Holy Alliance this direction; and the arrangement has sometimes been called from him "Metternich's system." Diplomatic congresses were held at frequent intervals to carry out the policy, almost as if the alliance had created a government for all Europe with a regular cabinet.

462. Revolutionary Movements. - On the other hand, the people did not propose to give up everything without a struggle. In Germany, Italy, and Spain the movement against absolutism was especially active. The universities were seats of vigorous propaganda, as they are in Russia to-day. Secret societies were organized, the Burschenschaft in Germany, the Carbonari in Italy. In Germany some of the sovereigns thought it wise to yield a little. The king 
of Prussia made some concessions. In Bavaria, Baden, Würtemberg, and Weimar constitutions were grantel. But r'pression quickly followed. Agitators were punished and the universities put under special supervision.

In Italy and Spain insurrections took place and armed intervention was necessary. In $\mathrm{I} S 20$, in the kingdoms of the Two Sicilies and of Sardinia, the sovereigns were compelled to grant constitutions. At the Congress of Laybach the next year, Austria was authorized to deal with these cases, and her armies overthrew these constitutions and repressed agitation in Lombardy. The same result followed in Spain. There a constitution had been established in 1812, but King Ferdinand VII. had taken advantage of later events to get rid of it. In I $\$ 20$ an insurrection of a part of the army had compelled him to reëstablish this constitution. Then the Holy Alliance interfered. The Congress of Verona, in $1 \$ 22$, commissioned France to do the work, and a French army made Ferdinand VII. a despotic sovereign again.

463. The Monroe Doctrine. - The action of the Congress of Verona in regard to Spain had consequences outside of Europe of the greatest importance. The colonies of Spain in South and Central America had taken advantage of the troubles of that country during the Napoleonic wars to declare their independence and to establish republican governments of their own. It now looked as if the interference of the Holy Alliance might be extended so far as to attempt the recovery for Spain of the colonies which she herself had not been able to accomplish. England, which had farored the independence of these colonies, was opposed to such interference, and she suggested to the United States that a declaration to the same effect from that govermment would aid in preventing the attempt.

This led to the famous Monroe Doctrine, which, as then stated, was that the United States would regaril any attempt of the allied powers to extend their system - that is, the system of armed interference to establish a government opThe Monroe Doctrine, I823.

Armed

insurrections put down ly the Holy Alliance. Penn. I., No. 3 . The Spanish American colonies independent. 1823. 
Charles X., I $824-1830$. Müller, Recent Times, 96-Ior.
The revolution of 1830 . Fyffe,

Europe, 603-619; Müller, Recent Times, IO2-II 2.

posed to the will of the people, Metternich's system - to any part of these continents as an unfriendly act.

464. Further Reaction and a New Revolution in France. - The great days of the Holy Alliance ended with the death of the Czar, Alexander I., in $S_{25}$, but the opposition to free government had the upper hand for a few years longer. In France, Louis XVIII. was succeeded in 1824 by his brother Charles X., who as the Count of Artois had been the leader of the imigr's and who seemed incapable of learning anything from experience. Under him reactionary measures rapidly followed one another. More of Napoleon's officers were dismissed from the army. The National Guard was dissolved. The press was placed under stricter control. 'The Church was given more authority. A large

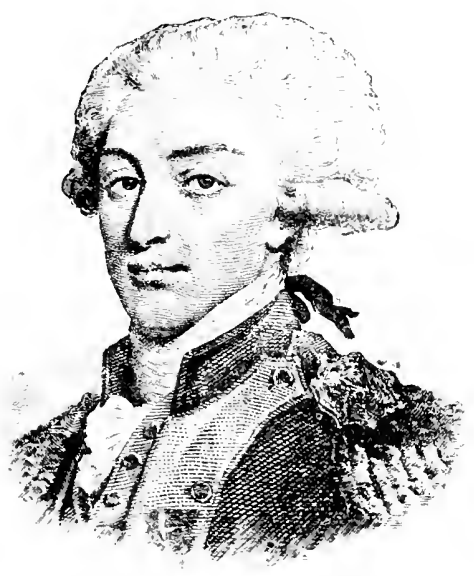

LAFAYETTE sum was appropriated to pay the emigres for the lands of which they had been deprived by the revolution. And finally, in July, I $S_{30}$, the king attempted a coup d'état. He issued a series of ordinances by which he practically made a new constitution in the interest of his own ideas.

I $m$ mediate $l y$ Paris broke ont in insurrection. The troops proved untrustworthy. Lafayette was put at the heal of a provisional government. The king fled and abdicated in favor of his grandson, the Comte de Chambord, but instead the duke of Orleans, Louis Philippe, was proclaimed king of the French. $\mathrm{He}$ was descencled 
from a brother of Louis XIV.; his family had long professed liberal ideas; he was himself popular with the people and was known as the citizen king. The constitution was immediately revised to secure greater freedom, and the king recognized the right of the people to determine for themselves the form of their government.

465. The Consequences of the Revolution in France. The July revolution, as it is called, encouraged the friends of liberal government throughout Europe, but the time was still too early to overthrow the strongly intrenched sovereigns. An insurrection in Belgium against the continued rule of Holland was successful and the two states were separated. A similar one in Poland against Russia, though bravely fought, was a failure, and resulted in the loss of the constitution which had been secured to Poland at the close of the Napoleonic period, and its reduction to a province of the Russian Empire. Insurrections in Italy were for a moment successful, but the Austrian troops proved again too strong. In Spain and Portugal, however, constitutions were secured within a few years of the July revolution, but this was due not to revolutions but to disputes as to the succession in the royal families which forced the rightful claimants to rely upon the liberal party for success.

It had proved easy to suppress insurrections for a time at least, and for eighteen years longer the absolute governments were in possession. But it was not so easy to suppress liberal ideas, and the longing and determination of the people, and these were making steady progress through these years. In the new revolution which was to advance greatly the realization of these ideas, France was still as before the leader of the nations.

466. Preparation for Another Revolution. - The reign of Louis Philippe excited no enthusiasm in France. It was marked abroad hy a policy of conciliation and concession which was not flattering to French pride, and at home by a disposition to leave the constitution as it was formed in I 830 and to allow no extension of the popular influence.

Constilution in Lieber, Cizil Liberty.

Unsuccessful attempts to follow the example of France. Fyffe, Europe, 6 I9-643; Miiller, liecent Times, II2-I43. Ideas not easy to suppress.

Louis Philippe's government unpopular. 
'The growth of socialistic ideas.

The

"February" revolution. Adams, Inemacry and

shenarchy, Chap. VII. ; Fyffe,

Europe, Chap. XIX. Miiller, Recent Times, I 86-I92.

The attempt to realize socialistic theories.
But the demand for this was not long in arising. The property qualification required for the suffrage and for membership in the legislature had been reduced at the accession of the citizen king, but they were still so high as to place the real control in the hands of a minority of the people. The demand for an extension of the suffrage was made by the liberal party and was steadily resisted by the king.

Meantime the artisan class, especially in Paris, was becoming greatly interested in economic and political questions. The rapid introduction of labor-saving machinery, together with over-production in many lines, had led to a reduction of wages and had even thrown many workmen out of employment. A group of writers of much ability began to propound socialistic and communistic theories, and in these many of the workmen became greatly interested. In this way was prepared a party which in the next revolution and in many later events in France exercised a great and sometimes a very destructive influence.

467. The Revolution of 1848 . - The revolution came in February, 1848 . The signal was given by the refusal of the government to allow a banquet to be held at which the liberal party proposed to advocate the extension of the suffrage. A public protest of the liberal leaders followed. They probably did not intend or expect a revolution, but events rapilly drifted beyond their control. The mob took charge. The king showert no firmmess of resistance and abdicated. But the people of Paris organized a provisional government and the Republic was proclaimed. 468. The Second Republic. - This was a very short-lived republic, but it is interesting for one experiment which it tried. Among the theories held by the Parisian artisans was one which asserted the right of every man to a livelihood, and the duty of the State to insure him the means of procuring it. The provisional government, which found it necessary to satisfy the demands of the workmen who had carried through the revolution, determined to fulfil this duty. 
National workshops were opened and the imemployed were guaranteed labor by the State. Though the wages were small the number of the state workmen was found to increase very rapidly, it became very difficult to keep them profitably employed, and the government was at last compelled to lay a special tax to meet the expenses, much to the discontent of the rest of the nation. The experiment lasted four months. Then the Constituent Assembly, which had been called to frame a new government, closed the national workshops. The workmen immediately rose in insurrection, and for four days fought like savages, throwing aside the restraints of civilized warfare, before they were subdued. The bourgeois, or middle class of Paris, long remembered the terrible experience of these days, and the dread of the communistic spirit was one of the things which made easy the way of Louis Napoleon and sustained the despotism of the second Empire.

469. Revolution in Austria and Italy. - With the triumph of this French revolution of ${ }_{1} \&_{4} \&$, it seemed for a moment as if constitutional govermment and political freedom were about to triumph in the whole of Europe. Everywhere the people rose against the absolnte sovereigns, and their speedy success shower the depth of the preparation which had now been made. Even in Vienna the revolution could no longer be suppressed. A popular insurrection forced Metternich into exile early in March, and made the emperor call a constitutional convention elected by universal suffrage. When a little later he attempted to withdraw these concessions he was himself forced to leave Vienna, and abdicated in favor of his nephew, Francis Joseph.

In all the Austrian dominions similar events took place, and the Empire was for a time threatened with dissolution. Prague expelled the Austrian troops, and Bohemia proposed to secure a government of its own. Hungary did the same and soon went a step further, declared its independence and organized a republic under Kossuth.

In Bohemia and Hungary. 
In Italy. Müller, Recent

Times, 2O2-2II; Fyffe,

Europe, Chap. XX.

Italy had not remained behind the other peoples. Indeed, a few days before the revolution in Paris, the king of the Two Sicilies had been compelled to grant a constitution. In Rome, Pius IX., who had been lately elected pope, granted a constitution in Narch and seemed to give promise of a liberal disposition. When, however, somewhat later in the year, he withdrew the constitution, the people rose again. drove him out of the city, and with the aid of

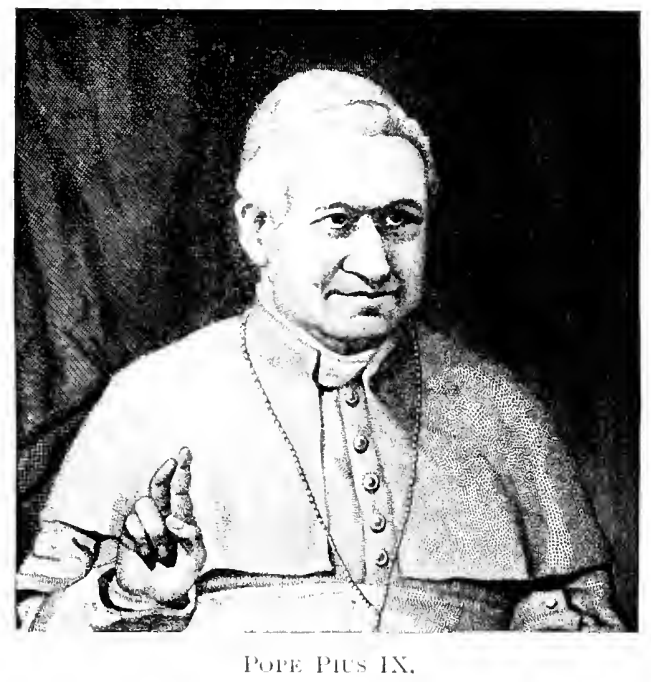

Mazzini organized a republic. Florence did the same. Milan and Venice expelled the Austrian troops.

The house of Suroy assumes the lead in Italy.

This was the opportunity of the house of Savoy, and the way in which it was used prepared for them the throne of a united Italy. The reigning king of Sardinia, Charles; Albert, put himself at the hear of the movement for national independence, and made war upon the Austrians, at first with success, and Venice and Milan accepted his rule.

470. Unsuccessful Attempts in Germany. - In Germany 
the struggle for constitutional liberty was closely bound up with that for national unity. A popular movement beginning in Baden demanded civil rights, the freedom of the press, and a constitutional government for the whole of Germany. The first step was the election of a constituent assembly, which met at Frankfort, in May, 18,8, to form a government and a constitution.

Early in 1849 the crown of a new German Empire was offered by the Assembly to Frederick William IV. of Prussia. This proved a premature realization of the ambition of the Hohenzollern family, for the king declined the offer, believing that it should be made by the state governments of Germany. Austria and some of the other larger states refused to accept the constitution, and the mission of the Assembly finally ended in failure. In Prussia itself, however, a constitution was finally secured, with a representative assembly of a limited character.

471. The Suppression of the Revolution. - Not merely in Germany but everywhere else, these promising beginnings came to nothing in the end. The czar, Nicholas I., even more bitterly opposed to liberty than Alexander had been, came to the aid of the Austrian emperor. An army of I oo, ooo Russians entered Hungary, overthrew the Republic, and restored the Austrian rule. In Vienna and Prague force also triumphed.

The Italians, not well united among themselves, suffered several defeats, and in the spring of 1849 , Charles Albert abdicated in favor of his son Victor Emanuel. Nilan and Venice submitted. In Rome the Republic was destoyed by French troops sent by Louis Napoleon, the President of France, and they remained to sustain the pope's absolute government so long as the rule of Napoleon III. lasted. In the Two Sicilies, also, the constitution was annulled. All Italy was thrown back into the old condition, except in the kingdom of Sardinia, where Victor Emanuel refused to except in Sardinia. do away with the constitution at the demand of Austria, and thus kept the hopes of Italy centred in his house.

Despotism reëstablished in Italy,

Russia interferes.

Prussia will not be emperor of Germany. Schilling, Quellenbuch, 428 and 43 I.

The czar of 
Louis

Napoleon, President.

The coup d'état of Dee. 2, I85I. Victor Hugo, Hastory of a crime; Iíller, kicent Times, I $97 \mathrm{ff}$. New constitution in I ieber, Civil Liberty.

The second Empire. Revised constitution in Lieber, Ciñll Liberty.

The cause of free government apparently hopeless.
472. The Second Empire established by Napoleon III. In the meantime the short-lived second Republic in France was drawing rapidly to its end. It had been weak from the beginning because it was not desired by a majority of the people. Louis Napoleon had been elected President by a very large popular majority, and was laying plans to make his power permanent. He set himself forward as the champion of universal suffrage against the monarchically inclined Assembly, and of order and security against the red republicans, while the army was tired of the long inglorious peace and hoped for better things from a Bonaparte.

By a sudden coup d'état on the 2 d of December, he arrested the leaders of the opposition, dissolved the Assembly, and called for a rote by universal suffrage to make him President for ten years and to authorize a revision of the constitution. An attempt to raise Paris against him failed, and the popular vote was overwhemingly in favor of the change of government.

This was but a step to the second Empire, and a year later that was proclaimed, after the sanction of another popular vote. The constitution made the emperor absolute. He was responsible to the people only, his ministers to him alone. The legislature was under his control ; freedom of speech and of the press were no more. But France had secured what it especially wished at the time, a strong government.

473. Free Government indirectly Secured. - It was now sixty years since the opening of the French revolution, and still the effort to secure real political liberty was a failure. Despotism seemed as strongly intrenched almost everywhere as before the age of revolutions began. In some few countries, like Prussia and France, constitutions existed in name, and this was a point gained, but in these constitutions the real power was most carefully preserved to the sovereign. The cause of the people might well seem hopeless, but it was in truth just on the eve of success. It had met its last great lefeat. 
The final triumph of constitutional government in Europe secured in was secured, however, not by a direct effort of the kind which was made in the revolutions of $\mathrm{I}_{3} \mathrm{O}$ and $\mathrm{I}_{4} 8$. It was brought about rather by the triumph of the right in another cause, that of national unity and independence, which had been all along closely associated with it. To this we must now turn as the leading movement in the next stage of European history.

474. The Congress of Vienna and the Idea of Nationality. - The Congress of Vienna, in rearranging the boundary lines which Napoleon had moved about to suit himself, treated Europe as if there were no such things as nations to be considered. Italy was divided up into petty states as the interests of the sovereigns dictated. Germany was treated as arbitrarily in the same interest, but many of the smaller states of earlier times which had been wiped out by the dispositions of Napoleon were not reëstablished, and the larger became larger still, but there was no Germany. The Germanic Confederation, which was established with a Diet under the presidency of Austria, was as empty a form as the old Empire.

Belgium, though differing from Holland in language, religion, and economic interests, was made a part of it. Poland remained divided, and though a part of it was given a constitution and called the kingdom of Poland, with the czar as king, this was a form and disappeared at once on the first attempt to make it more real. Meanwhile such a composite empire as that of Austria, which corresponded to no nationality but included several great races or parts of several, Germans, Bohemians, Hungarians, Italians, and others, seemed to be regarded as resting on as natural a foundation as any true nation.

475. The Independence of Greece. - But the spirit of nationality and the longing for independence, which are perhaps never entirely wanting, had been newly awakened by the uprising of the peoples against Napoleon, and they were no more destroyed by the temporary triumph of the alliance with the cause of nationat unity.

The diplomats care nothing for nationality. Maps, Putzger, No. 28.

Austria their idea of a nation.

The Greeks the first nation to rise. Fyffe, Europe, Chap. XV. 
opposite principles than was the desire for political liberty. Their first outbreak in actual strife was in the insurrection of the Greeks against the Turks, which began in $182 \mathrm{r}$. This struggle for independence involved from the beginning of course the perennial Eastern question, and was settled at last as a part of that question.

The powers interfere.

Belgium successful in I 830 .

Failure in 1848 .

Here is to be said only that at first the Greeks were left to themselves, because the powers could not agree upon their action; and after more than five years of heroic resistance, aided only by a few volunteers, like Lord Byron, the Turkish warfare characterized as always by horrible atrocities, they were practically subdued by Egyptian troops in the Turkish service. Then Russia, on the accession of the new czar, Nicholas I., interfered, seconded by England and France, and Turkey was compelled to acknowledge the independence of Greece in I829. An attempt to organize the new state as a republic proved a failure, and Otto of Bavaria became its first king.

476. The Attempts following the Two French Revolutions. - The revolution of $1 S_{3} \mathrm{O}$ in France enabled the people of Belgium to break their connection with Holland and to found a government representing the nation, with Leopold of Saxe-Coburg-Gotha as king. But every other attempt to realize national aspirations failed. Poland lost even the little that it had; Italy remained under Austria.

Again in $1 S_{4} S$ the same result followed most promising beginnings, as we have seen. The Hungarians organized a republic. The Bohemians drove out the Austrians, as did the Italians from north Italy. The king of Sardinia threw the resources of his little state into the struggle for Italian independence. In Germany a national constitution was drawn up, and the crown, which it was hoped would be that of a united nation, was offered to the king of Prussia. But Prussia hardly saw as yet that the way to the realization of her long-cherished ambition, to expel Austrian influence and to become the leading state in Germany, should be the way of national unity. 
She had already, unconsciously, taken one long step The towards this result in the Zollverein which she had organized in $18_{33}$, in spite of the opposition of Austria. This was a customs union between most of the German states, by which national unity on one most important side, the commercial, was created, and a strong influence towards political unity set in motion. But Frederick William now refused the crown; the constitution could not be put into operation; and Austria recovered control of all her revolted races.

477. The Spirit of Nationality growing stronger. - But the spirit of national unity and independence had grown much stronger in spite of these failures, and it was not much longer to be held lown. The king of Prussia soon made an attempt to form a political union between a part of the German states, but gave it up on the determined opposition of Austria. In Italy the house of Savoy stood clearly forth as the declared champion of union and independence. In both these countries the central core of a new national state was prepared.

It was in these two countries also that the current ran most strongly in this direction. Neither had ever had a government giving expression to the national feeling since they had become conscious of such a feeling. The feudal system, the Holy Roman Empire, the policy of the papacy, and the diplomacy of modern Europe, had in turn kept them broken and divided. But now that the current had begun to run, it ran all the deeper and stronger for the long holding back.

478. The Policy of Cavour. - It was ten years before another opportunity occurred. In the meantime the king of Sardinia had made, under the wise guidance of his minister, Cavour, a shrewd stroke to gain the gratitude of some of the first powers of Europe by joining the allies against Russia in the Crimean war and sending his little army to their aid. This leal directly to the desired result. The Congress of Paris, which followed the war, was not willing

The cause of unity gaining leaders.
The current strong in Germany and Italy.
Cavour wins allies for his plans. Fyffe, Europe, Chap. XXII.; Müller, Recent Times, 
$270-292 ;$ Cesaresco. Liberation of Ihaty

(Scribner). War with Austria.

to allow Cavour to accomplish his plans by diplomatic means. But the emperor, Napoleon III., was ready to enter into a close alliance with him.

Encouraged by this, Cavour began extensive military preparations. When he refused to explain these preparations at the demand of Austria, she declared war and sent a large army into Italy. Napoleon III. immediately sent against it a still larger army. The Anstrians were beaten

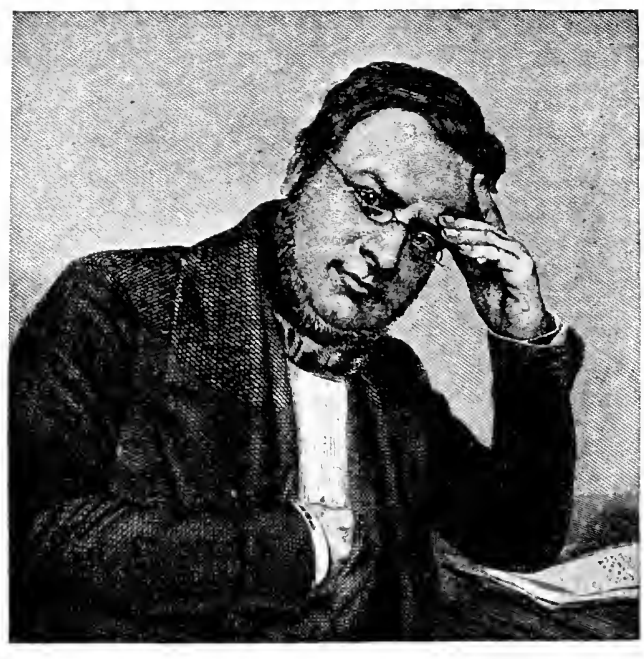

( incoretinter

in three great battles. Lombardy and Milan were occupied and Venice threatened. But Napoleon did not wish to go too far. He refused to drive the Austrians from Venetia. In November, I 859 , he concluded the treaty of Zurich with Austria, by which Lombardy was given to Victor Emanuel, and the Italian states were authorized to form a confeleracy.

The people too strong for the diplomats.
479. United Italy. - But matters had now gone too far to be controlled any longer by diplomacy. The people took matters into their own hands. Everywhere they arose, 
expelled the rulers of their little states, and voted their own annexation to Sardinia. All central Italy down to the States of the Church had done this by March, iS60. Napoleon III. signified that he would acquiesce in these arrangements if compensation were granted him by the cession to France of Savoy and Nice, and this was allowed him, - the largest permanent annexation of territory made by France since the reign of Louis XIV.

But the end was not yet. In the next month the people of Sicily rose against their Bourbon king. Garibaldi went to their aicl. In a short time the whole kinglom of the Two Sicilies and a large part of the territories of the pope had been freed, and had put themselves under Victor Emanuel. In February of the next year, the kinglom of Italy was proclaimed, - the first real one that had existed in history, - with a constitution and parliamentary institutions. Rome was not yet its capital, for the French troops still held that city and Victor Emanuel was not ready to break with France, and Austria still kept Venetia. But the occupation of Rome and Venice could only be delayed until the first favorable opportunity.

480. William I. and Bismarck. - The realization of German aspirations for national unity was deferred for ten years longer, and cost in blood and treasure far more than had Italian. Frederick William IV. of Prussia, who had refused the imperial crown in 1848 and who had been unwilling to oppose Austria with the necessary determination, was succeeded in $\mathbf{I} 86_{1}$ by his brother William I. He was a man of different stuff. Early in his reign he made Otto ron Bismarck his leading minister, and through a long reign he cordially sustained the vigorous and determined policy of his chancellor.

If Frederick William's policy had been to wait until the chance should come when everything would be farorable, Bismarck's was to force the favorable opportunity and to overturn every obstacle with violence - the policy of blood and iron, as he called it himself. So far as national mity

Garibaldi and the south of Italy.

The kingdom of I taly, I86I.

Wiliiam 1. opens a new era for Prussia, I86I. Fyffe, Enropi, Chap. XXIll.; Malieson, liefounding of the German Empire (Scribner). The policy of "blood and iron." Müiler, Récent Times, 304-309. 
The constitution overridden.

The

sichleswigHolstein question. Miiller. Rerent Times, 309-313.

Little Denmark the first steppingstone in the rise of Prussia, 1864 . was concerned that should be realized, but it should be realized by the sword of Prussia, and the new nation should remain under the dominant control of Prussia. From the beginning this was the end which Bismarck sought to reach, and this was what he accomplished.

48r. The Army made ready. - The first necessity for the success of such a policy was a strong army. This William had seen before Bismarck entered the ministry; and while he was regent, in the last years of his brother's reign, he had begrun to increase the size of the standing army, and to improve its organization and discipline. In the Prussian legislature a majority was opposed to these measures, and repeated dissolntions failed to secure the lacking votes. But the policy could not be abandoned. Soon after Bismarck took office, it was announced to the legislature that the govermment would go on with its plans without the required constitutional sanction. It was only after the first great military successes of this army that the representatives of the people acquiesced in this policy.

482. The New Prussia's First War. - The opportunity to try the army came very soon. The king of Denmark was the sovereign also of two German duchies, Schleswig and Holstein, lying directly south of Denmark proper. According to existing diplomatic arrangements, these were to remain separate states and could not be incorporated in the kingdom of Denmark. At the end of 1863 a new constitution was made for Denmark, which was arranged to apply to Schleswig also in such a way as practically to annex that duchy to Denmark. The German Confederation objected. Denmark persisted. In January, 1864, an army of Austrian and Prussian troops invaded the country. Resistance was determined but hopeless against such odds.

Denmark was forced out of the country in a few weeks, and in October ceded the duchies. After some disagreement between Austria and Prussia as to the disposition to be made of the conquest, Prussia took Schleswig and Austria Holstein. The immediate gain was very consider- 


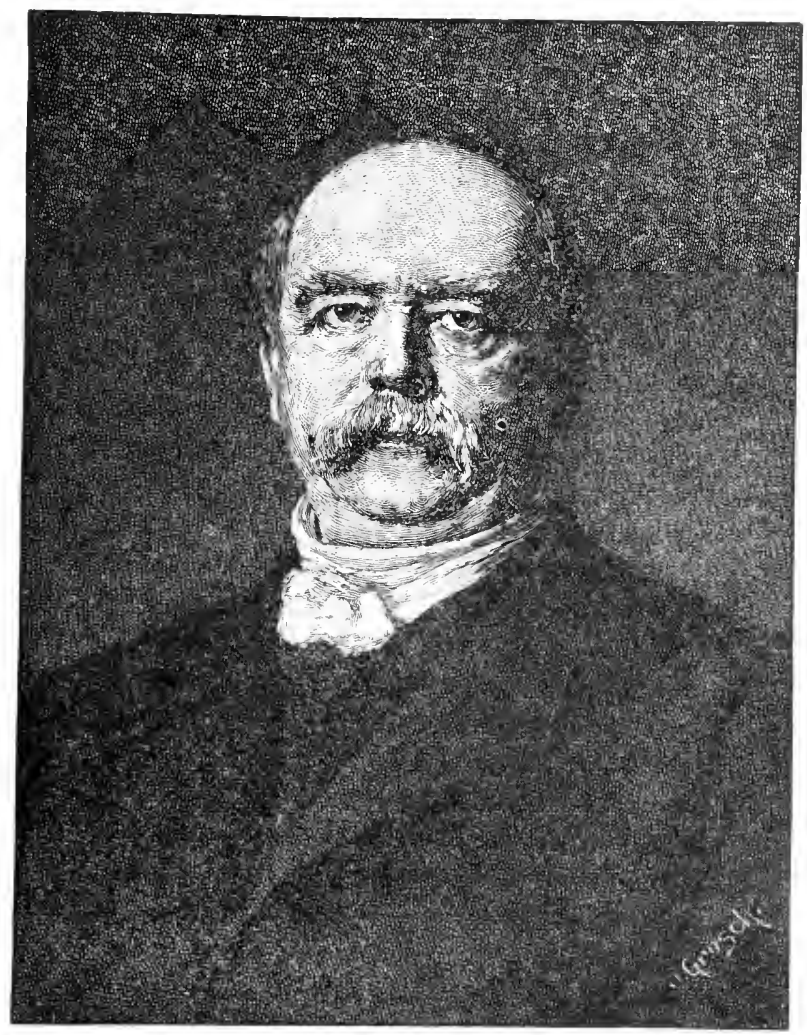

BISMARCK 
able for Prussia and almost nothing for Austria. Still more important was the fact that this arrangement would be likely to afford grounds for a quarrel with Austria as soon as Prussia was ready for it.

Irussia could not unite Germany without first overthrowing Austria.

Careful preparation made for the war.

The odds against Prussia. Fiffe,

Europe, Cirap. S.XIII, Miiller, liecent limes, $318-368$;

483. War with Austria must come. - This conflict was a necessity, both for the realization of the plans of Prussia and of the hopes of German patriots. Prussia could not be the dominant power in the nation unless Austria were humbled. No national unity was possible so long as these rival powers stood upon an equal footing. All through the middle of the century public opinion in Germany had looked more hopefully to Prussia than to Austria as the power from which unity was to be expected. Lately, feeling had begun to turn against Prussia on account of the violence which the government had shown to the constitution and on account of its treatment of the Schleswig-Holstein question.

Bismarck made careful diplomatic preparation for the coming war. Measures were taken which it was hoped would secure the neutrality of Napoleon III. With Italy, which was more than willing from its eagerness to obtain Venice, a close alliance was male for the event of a war of either state with Austria. Immediately after the making of this treaty, Bismarck proposed to the l)iet the calling of an assembly for a revision of the constitution of the Confederation. This could only mean one thing, the formation of a new confederation without Austria. The Diet decided, however, rather in faror of Austria. Thereupon Prussia formerly withlrew from the Confederition, and war began at once.

484. The "Seven Weeks'" War. - The war was a real civil war. On the side of Prussia were the small states of the north. But on the side of Austria all the south, and all the large states of the north, like Hanover, Saxony, Nassau, and the electorate of Hesse, whose governments had the most to fear from the designs of Prussia. The odds seemed to be against William and his minister, but the advantage of their thorough preparation was quickly manifest. 
The war was soon over. It has been called the Seven Leger, Weeks' War. In three weeks, indeed, Austria had been so thoroughly beaten in the great battle of Königgratz, or Sadowa, in Bohemia, that no further resistance was for the moment possible, and the Prussian army reached the neighborhood of Vienna before an armistice was arranged through the mediation of Napoleon III. The allies of Austria could not hope to overcome Prussia alone, and were obliged to accept the result. The Italians had had no corresponding good fortune in their campaign. They had been beaten on land and at sea, but the destruction of the Austrian army at Sadowa had compelled the recall of her Italian troops and the abandonment of Venice.

485. The Results of the War for Germany. - The peace of Prague, which closed the war, did not create German unity, but it made its creation very easy on the next opportunity. Austria withdrew from Germany. Prussia made large annexations. Hanover, Nassau, Electoral Hesse, Schleswig-Holstein, and Frankfort were taken, and thus for the first time her provinces on the Rhine were connected by continuous territory with those in the east.

Then a new confederation was formed with the other North German states, a union whose constitution formed the foundation of that of the present German Empire. 'The foreign policy of the Confederation was to be under the control of Prussia, and its military resources in time of war. The large South German states, though not members of this confederation, in a short time made secret treaties with Prussia, by which their troops were to be placed under the command of the king of Prussia in case of war. It needed but slight changes to transform this arrangement into a federal state, the present Empire.

486. The Results of the War for Austria. - The withdrawal of Austria from Germany did not constitute all the change which the war forced upon her. Venice was ceded to Italy, and so that country advanced a step towards national completeness. But also the spirit of race independence and

Prussian annexations.

The new German confederation.

The creation of AustriaHungary under constitutional governments. 
Leger, of constitutional government triumphed elsewhere in the AustroHungary, $572-588$.

Empire. Francis Joseph had granted a constitution to the Empire, after the war with Italy and France in 1860 , but it had been rery imperfectly carried out. Now Hungary was created a separate kingdom, with its own constitution, ministry, legislature, and local self-govermment. A similar constitution was also given Austria, and the two states were united in a kind of federal legislature for the consideration of common affairs. The day when the Bohemians and the other races under Austrian rule should obtain their local independence was postponed, but the way was made easier by what Hungary had gainel.

A necessary 487. The Franco-Prussian War desired by Both Governwar. Fyffe,

Eiserope, ments. - Another greater and more glorious war was to complete the process of nation making in Germany, the war Chap.XXIV. with France. This was a war which seemed equally necessary to the governments of both countries. If Prussia needed it to complete the organization of the new Empire, Napoleon III. thought that by a victorious war with Prussia, whose growing power seemed a menace to France, he could strengthen his government.

Discontent

Things had not been going well with the emperor of in France. recent years. The failure of his attempt in Mexico to overthrow the republic and set up an empire under his protection had reacted against him in France. The republican opposition was growing constantly stronger, not merely among the people, but in the legislature. The concessions which Napoleon made from time to time, going at last so far as to grant the responsibility of the ministry to the legislature, failed of their purpose - the conciliation of the opposition. The republicans were glad to get anything they could, but they were not to be satisfied short of everything. A glorious foreign war, especially one against Prussia, would arouse the enthusiasm of the French and the memories of the first Empire, and secure the position of the Napoleonic dynasty for another generation.

488. The Pretext found for War. - When two countries 
are anxious to go to war with one another, an excuse can soon be found, and the ostensible reason for the FrancoPrussian War was a mere excuse. In 1868 the Spanish people, tired of the rule of their Bourbon queen, Isabella, had driven her out by a revolution, and had organized a republic. But Spain was not yet able to govern herself under republican forms, and in a few years they began to look about for some prince, not a Bourbon, who would rule as a constitutional sovereign.

Early in the summer of 1870 , Prince Leopold, of the younger Hohenzollern line, accepted the throne. At once France protested. It could not tolerate the reestablishment of the monarchy of Charles V. in favor of the Hohenzollerns. Prince Leopold withdrew his acceptance. France then demanded of King William an assurance that the crown of Spain should not be accepted at any future time. When this was refused, relations were broken off and the war was begun.

489. France began the War with False Hopes. - France immediately found herself disappointed and deceived in more ways than one. She had expected that Austria and the South German states would join in the war against Prussia, anxious to be revenged for their defeat in the last war. But Austria was held back by Russia, and the South German people proved themselves as enthusiastic and patriotic as those of the north in resisting the hereditary enemy. The German nation was at last united.

France had believed also that everything was well prepared in the way of war material and a well-organized and disciplined army for a rapid advance into German territory. "On to Berlin" was the cry of the multitude. In this she was deceived. Nothing was ready. The German army was larger, in better order, and better handled. It was especially rapid in its attack, and there never was a moment when the French had the least chance of invading German soil.

490. The Course of the War. - Within two months the great French armies which were to capture Berlin had sur-

A revolution in Spain. Müller, Recent Times, 409-417.

France cannot allow a Hohenzollern in Spain.

The declaration of war in Schilling, Quellenbuch, 464 .

Disappointed of allies.

Deceived in regard to her own resources.

Napoleon III. and his 
armies

surrender.

Miiller,

hecent

Iinte's,

$426-4+0$.

The

republic

proclaimed

in P'aris.

Sept. + , I870.

rendered to the enemy. MacMahon was beaten in the great battle of Worth, and later his reorganized army was compelled to surrender at Sedan, where
also the Emperor Napoleon, who had been
present at the battle, sent his sword to
"his brother" King William. Bawas compelled to surrender at Sedan, where
also the Emperor Napoleon, who had been
present at the battle, sent his sword to
"his brother" King William. Bawas compelled to surrender at Sedan, where
also the Emperor Napoleon, who had been
present at the battle, sent his sword to
"his brother" King William. Bawas compelled to surrender at Sedan, where
also the Emperor Napoleon, who had been
present at the battle, sent his sword to
"his brother" King William. Baheld out for a few weeks longer in the fortress of Metz, and then surrendered also.

In Paris on the news of Sedan the republic had been proclaimed and a provisional government of national defence had been organized. After an attempt to negotiate with Bismarck, the new government, which refused to pay the price of the cession of Alsace and Lorraine which was demanded for peace, determined to go on with the war. Before the end of September, hardly more than six weeks after the first fighting, Paris

was completely surrounded by the German lines. 
'The city made a brave defence. It endured a bombardment of three weeks, and attempted in a desperate sortie to break the siege lines. Outside the city also the efforts of the provisional government had no better result. Their armies in the various provinces all met with defeat. Finally further resistance became hopeless, and an armistice was agreed upon at the end of January, 187r. A national assembly was elected which met in Bordeaux to arrange the terms of peace. France was obliged now to accede to Bismarck's demand and give up Alsace and Lorraine, to pay a large war indemnity, and to allow the German troops to hold a part of France until it was paid.

49r. The Empire of Germany. - In demanding the cession of these provinces, Bismarck was hardly true to the principle of nationality to which he owed so much. For that principle had now completely triumphed in Germany. On the i 8th of January, in the hall of Louis XIV.'s palace at Versailles, the German Empire had been proclaimed with William I. as emperor, and all the States united under one government. This triumph of the principle of nationality in Germany carried with it in form the triumph of constitutional government, for the constitution of the Empire was that of a limited monarchy. But in practice the imperial ministries have not been responsible to the legislature, and the German people have still much to gain before they have entirely free government.

492. Alsace-Lorraine and Rome. - In the case of Alsace and Lorraine, the territory had indeed at one time belonged to Germany. It had come into the possession of France at various times and in different ways. Some of it had been conquered by Louis XIV., and a part of this, like Strasburg, by a most violent and brutal disregard of law and right. But it had now become really French, and its representatives in the assembly made solemn protest against the cession. That it may in time become as truly German is likely, but its annexation by (iermany, in which it was organized as a separate imperial territory, can

AlsaceLorraine really a foreign conquest.
William I., emperor of Germany.

See on growth of German unity to the Empire. Bryce, Holy R'oman Empire, 399-445. 
hardly be regarded otherwise than as a conquest of force, like Louis XIV.'s.

Rome the capital of Italy,

The Commune.

The constitution very slowly created. Annals Am. Acad. Pol. and Social Science, Vol. VI., and Supplement, March, 1893.

National unity and constitutional governments.

The war had other consequences than the union of Germany. Napoleon could no longer protect the pope. In September, i 87 o, the Italian troops entered Rome, and that city became the capital of united Italy. In France the results were still more important. The despotism of the second Empire was at an end, and the third Republic was begun.

493. The Third Republic in France. - The way of the new republic was not easy at first. It had many dangers to overcome. The communistic party in Paris, which had aroused so much fear in the middle classes in 1848 , had increased in strength. Now it rose in insurrection again, seized Paris, and held it several weeks, doing enormous damage before it could be subdued.

Throughout the whole of France the republic was hardly desired by the majority of the people, and progress in the formation of a final republican constitution was slow and cattious. It was five years before the legislature contained a republican majority, and it was some years more before the constitution was completed, and the country began to have confidence in the permanence of the government. The third Republic has now, however, passed through several severe crises in safety; its legislatures and cabinets have shown themselves less subject to panic in times of threatened coup d'état than was formerly the case with republican governments in France; and the people seem to have acquired calmness and self-control and to be learning real self-government. We may hope that France has at last obtained a free government by the people in the place of paternal despotism.

494. The Results of the Period in Europe at Large. - By the end of the Franco-Prussian Var, in 1871 , national unity had been secured by Italy and Germany, and all the countries of Europe, except Russia, had gained constitutional government. These governments all follow more or less 
closely the model of limited monarchy created by England, and where they are administered in the same spirit, as is nearly everywhere the case, they make, as the constitution of England does, a virtual republic.

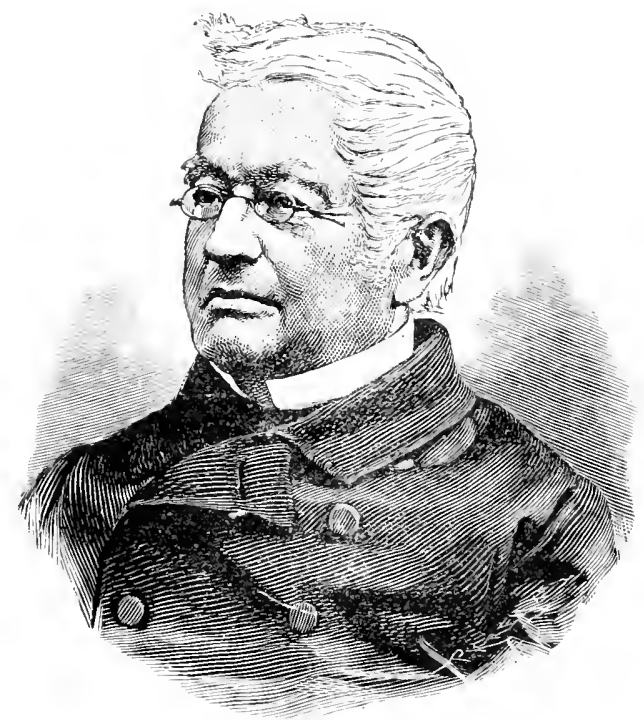

M. THIERS

495. The Eastern Question.-- During the last quarter More than a of the nineteenth century, the great interest of international century old. politics in Europe has been the "Eastern question." 'This question has troubled European diplomacy for more than a hundred years, and seems after all this time no nearer solution than at the beginning. The difficulty has not been to overthrow the Turk, for, if he had been left to himself, The real his dominion would have ended long ago, but it has been to find a disposition of his territories which would satisfy all the interested parties. Russia, Austria, and England, on account of her possession of India, have all had an im- 
mediate concern in the result, and the other states have been indirectly interested not to allow too great an extension of power to any one state.

The results. The impossibility of reaching an agreement among the great powers, except for a small piece at a time, has kept the Turkish Empire a long time dying, and it has exposed the weaker Christian races left under its rule at different times to most barbarous atrocities; but on the other hand, in a part of European Turkey, it has led to a recognition, which would not otherwise have been made, of the principle of local self-government and of race independence.

1:s origin. 496. The First Stages of the Question. - Near the close of See p. 402. the eighteenth century, as we have seen, Catherine II. had a plan for the disposition of European Turkey and thought that she was groing to be able to carry it through with the aid of Austria, but the other powers stepped in and she was not allowed to complete the work. During the first third of the nineteenth century there was a considerable revival of strength in the Turkish Empire due to the vigor

Mabmoud II., $1808-1839$.

The value of reforms. Fyffe,

limpope, $659-672$; Müller, Necent Iime's, $155-159$.

The interference of Russia. and ability of the sultan, Nahmoud II. During his reign occurred the revolt of the (ireeks, lut this woukl probally have been subdued by the Turks if Russia, England, and France had not taken part against them.

497. Rise of Egypt under Mehemet Ali. - At the same time there was in Eygpt a most remarkable revival of Mohammedan power under the pasha, Mehemet Ali, one of the ablest men of his day. He began with well-considered political and military reforms in his own province, and appears to have been anxious to extend the benefit of these measures to the whole Empire, as the first minister of the sultan, with the hope of bringing back the great days of Turkish history.

He was opposed at Constantinople, however, and was at last obliged to make war on the sultan. His troops were at once successful, and conquered all Syria and a large part of Asia Minor. Then Russia interfered, alarmed at his 
growing power. In $1 \$_{33}$ Mehemet $\mathrm{Ali}$ agreed to a peace with Turkey by which he was left in possession of Syria and a small portion of Asia Minor, Russia managing as usual to secure important advantages from the troubles of the successor of the prophet.

The sultan, however, did not propose to allow this arrangement to stand, and six years later he attacked his too ambitious governor. Success was again on the side of Mehemet Ali, and again the intervention of Russia was necessary. But by this time the interest of other powers had been excited, particularly that of England, because she recognized, as Bonaparte had done, that the way of dangerous attack upon India lay through Egypt. Russia had to admit the intervention of England, Austria, and Prussia with her own. The allied powers attacked Syria. Mehemet Ali was of course compelled to submit. His conquests in Asia were taken from him, but he was allowed Egypt as a hereditary possession of his family, with local autonomy but under the suzerainty of Turkey. By another treaty the European powers guaranteed the integrity of the Turkish Empire.

498. The Preliminaries of the Crimean War. - If this arrangement was for the purpose of putting Russia under bonds not to proceed with her designs in regard to Turkey, it had no more effect than such treaties usually do in similar cases. In ten years' time Nicholas I. had resumed his plans, on a scale as extensive as those of Catherine II., and he hoped to succeed in alliance with England, as she had hoped to by the help of Austria and France. Egypt, which Catherine had offered to France, he offered together with Crete to England. He proposed to take the most of European Turkey and Constantinople himself. England refused the offer. Then he demanded of the sultan the protectorate of the Christians in Turkey, which in former times had been conceded to Russia by treaty and subsequently withdrawn. On the refusal to grant this he began war.

Nicholas I. resumes the plans of Catherine II. 
England and France make war on Kussia. Fyffe, Europe,
499. The Crimean War ( $1854-1856$ ). - This was the beginning of the Crimean War. His successes early demanded the attention of England. Nipoleon III. also had reasons of his own for interference, and he was not sorry to have the opportunity for a war. Later the king of Sardinia joined

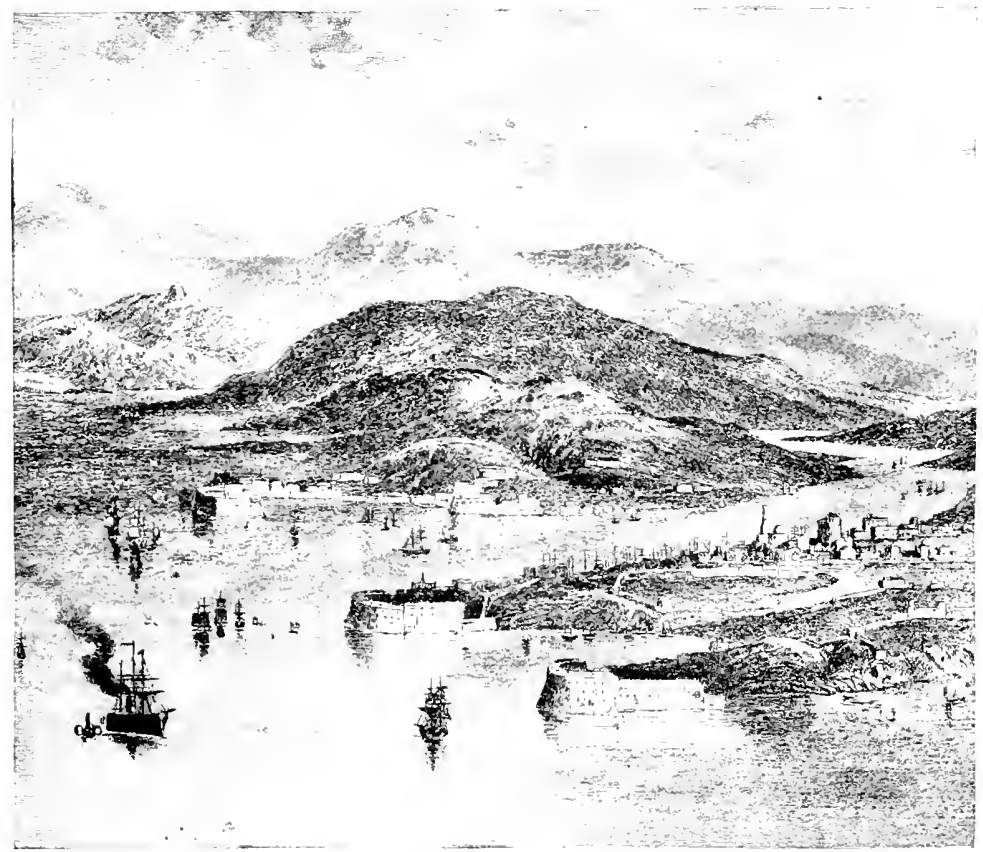

SEIFISTH'11.

Chap. XxI, in the war and sent fifteen thousand men against the Miuller, Recent czar. The allies attacked southern Russia through the Times, Black Sea, and thus forcel the return of the Russian army $253-270$. from beyond the I amube. The chief event of the war was the siege of Sebastopol, which the Russians were finally obliged to yield. In the course of the war Nicholas I. died and the more liberat-minded Alexander II. came to the 
throne. The peace of Paris in 1856 deprived Russia of her right to maintain a fleet on the Black Sea, and of her protectorate of the Danubian principalities, Wallachia and Moldavia. A short time afterwards these principalities were united to form that of Rommania with local independence on the payment of a tribute to Turkey.

The result of the Crimean War was, therefore, the introduction of the practice of forming little independent states out of European Turkey, corresponding to the local division of races, and this practice has since been carried much further. It placed a barrier of independent territory between Russia and the Turkish Empire, and this result was no doubt more desired by the allied powers than any recognition of the principle of nationality; but it is not to be regretted that diplomacy was for once on the side of the people.

500. Russia again attacks Turkey. I877. - Alexander II. set free the serfs of Russia in $196_{3}$, but he had no intention of abandoning the policy of his ancestors for aggrandizement at the expense of Turkey. The Franco-Prussian War gave him an opportunity of which he took advantage to recover the right to keep ships of war on the Black Sea. Soon afterwards insurrections of the Christians began in the Danube valley, which the Turks undertook to repress in their usual style with barbarous cruelties. The Bulgarian massacres so excited the horror of Europe, especially of England, that Russia believed she could venture to interfere.

The Turks made a most vigorous defence, especially at the fortress at Plevna, under Osman Pasha, but he was obliged to surrender in December, 1877 . The Russians now crossed the Balkans, and advanced to the neighborhood of Constantinople. It was the plan of Alexander to form a great state under Russian protection of almost all the European territories of Turkey, and to this the sultan consented in the treaty of San Stefano. This would never do for the interests of Austria and England. Lord Beaconsfield-

The terms of peace.

The principle of nationality recognized.

Alexander II. continues Russia's policy. Fyffe, Europe, Chap. XXV.

The Bulgarian massacres.

Russia defeats the Turks, Müller, Recent Times, 528-544. 
Disraeli - especially protested against it, and by the mediation of Bismarck a congress was called to meet at Berlin and make arrangements satisfactory to all.

In general,

Mülier,

Ricint

rimes,

$5+3+55+$;

Ilcearthy,

Our Oron

Times, II.

Chap. IXV.

Russia.

Austria.

The Balkan

states.

Miller,

The Balkan

State's

(Nations).

Russia not

arirey

sutisfied.
501. The Treaty of Berlin. I 878 . - The treaty of Berlin changed entirely the dispositions of that of San Stefano. Russia gained less, Turkey retained more, and at the same time the small states of the T)anube valley obtained a more independent position. 'To Russia was given a strip of territory at the northwestem corner of the Black Sea, which carried her boundary once more to the northern mouth of the Lanube, and in Asia an addition to her lands south of the Caucasus, including the cities of Kars and Batoum.

Austria was allowed the military occupation and administration of the provinces of Bosnia and Herzegovina, a virtual annexation. England, by an arrangement of its own with the sultan, took possession of Cyprus, engaging to pay over to Turkey the surplus revenue, and hoping to be able from there to watch and check the designs of Russia in western dsia.

Russia's great Bulkan state was cut to pieces. Macedonia went back to lirkey and has remained under the sultan ever since. Bulgaria, between the Danube and the Balkans, was made a principality ilepentent upon Turkey, and the province south of the Balkans was left to Turkey, but was to have an independent alministration under a Christian governor. The sultan agreed to make some small additions to Greece, anıl this was lone a few years later. The older Danubian principalities, Roumania, Servia, and Montenegro, were marle intlependent states.

502. Later History of the Balkan States. - This treaty, the most important step ever taken towards the settlement of the Eastern question, because it proceeled according to national lines, dicl not prove a final settlement because it did not go far enongh. Russia was disappointed of the controlling influence which she hoped to exercise in Bulgaria, a strong party in that state faroring an independent national 


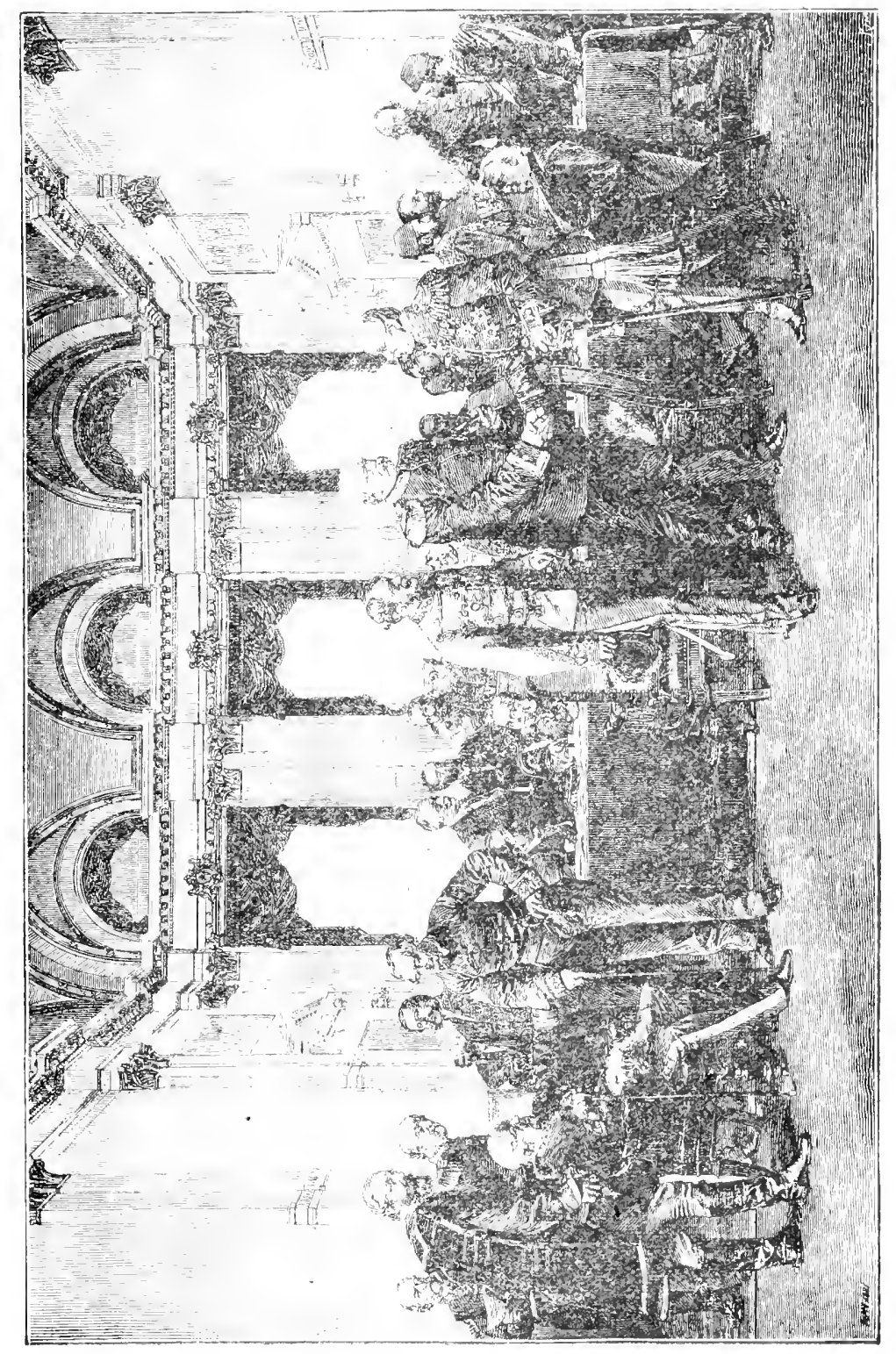

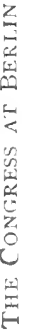


Bulgaria policy. In 1885 the South Balkan province, eastern Rumeadvancing. lia, elected the prince of Bulgaria its governor. This was equivalent to an annexation, and Servia at once took arms to prevent it. But she proved no match in the field for Bulgaria, and was only saved from conquest by the intervention of the great powers. Rumelia has since remained under the prince of Bulgaria.

Bulgaria's independent attitude.

The future of the Danube valley.

The Armenian massacres.
In I 886 the first prince of Bulgaria, Alexander of Battenberg, who proved to incline too much to the national party, was forced by Russian intrigues to abdicate, but Russia was not strong enough to prevent the election of Prince Ferdinand of Saxe-Coburg-Gotha as his successor; he accepted the position without the international sanction required by the treaty of Berlin, but has proved himself able to hold it.

These small Danubian states are constitutional monarchies, modelled on that of England, which are fairly well managed, and are very democratic in spirit. They have an intense national feeling, and are extremely jealous of one another. Each is eagerly hoping for some opportunity for expansion in the dissolution of the Turkish Empire, and each is watching lest some one of the others should gain a premature advantage. What the final outcome will be, still remains as uncertain as ever, but it will hardly be possible for Europe, once having so clearly recognized the principle of nationality, to recede from it in the settlement of the future of European Turkey.

503. Later Phases of the Eastern Question. - After a few years pause, the Eastern question again advanced to a sharp crisis in another part of the Empire. 'Turkish passion - the passion of a dying race taking vengeance upon any of the races that are surplanting it which it still has in its powerbroke out in fearful atrocities against the Christian Armenians of Asia. The material for the history of this period is not yet accessible, but it seems evident that the jealousies of the great powers prevented the adoption of any effective check on the actions of the Turks, until their passion burned itself out. 
Early in 1897 the rather uncalculating anger of the Greek people forced that government into a war with Turkey, which proved in a few weeks disastrous to Greece. Her preparations were insufficient, and her troops though brave were very poorly led. But for the intervention of the great powers she would have been obliged to agree to any conditions of peace demanded, and as it was the war proved a very costly experiment.

The Eastern question seems on the eve of leading to new and decisive events, which no one can foreshadow. But it is only one of the great unsettled problems in the political situation of the world with which the twentieth century will open, and which seem about to bring us very soon to momentous issues.

\section{Topics}

The three lines of important changes in the nineteenth century. The purposes of the Holy Alliance, ostensible and real. The character of the early revolutionary movement. What were the events in Europe which led to the Monroe Doctrine? What led to the "July revolution" in France? Its consequences in Europe. Character of the reign of Louis Philippe. The causes and character of the Revolution of 1848 . The socialistic experiment and its outcome. The revolution in Austria. In Italy. The new policy of the IIouse of Savoy. The movement in Germany. Attitude of the ling of Prussia. Russia's policy towards free government. How was the second Empire established? The union of the cause of free govenment with that of nationality. Treatment of the national iclea by the Congress of Vienna. The Greek war of independence. The independence of Belgium. The failure in $1 S_{4} 8$. The Zollverein. The Italian policy of Cavour. How disl he win France? The formation of the kingdom of Italy. The new policy of Prussia. The attitude of William and Bismarck towards the constitution. Prussia's first step-the quarrel with Denmark. Why was war with Austria necessary? How was it brought about? The character of the war. The new German confederation. Changes produced in the Austrian Empire. What alvantages to the cause of constitutional government in Italy, Austria, and Cermany? Why was Napoleon III. willing for a war with Germany? Why was I'russia also willing? What was the pretext for the war? Ilow was France disappointed? The events of the war. What change of government in 
France? In Germany? The terms of peace. The Alsace-Lorraine question. The constitution and condition of the third Republic in France. In what circumstances dic the Eastern question first arise? What is the real question, and why is it difficult? Mehemet Ali, his plans and their outcome. The plans of Xicholas I. The allies in the Crimean War. The settlement at its close. The war of $1 S_{77}$. The treaty of Berlin. The recent histury of Iiulgaria. The situation at the close of the nineteenth century. What alvantages to the principles of nationality and of free gorernment from the changes in Turkey?

\section{Topics for Assigned Studies}

European politics and the Munroe Doctrine. Fyffe, Europi, Chap. XIV. Müller, Rec'nt Times, 23-62. Am. I Iist. Leaf., No.4. Okl South, No. 50 .

The Bulgarian massacres. Nüller, Recent Time's, 505-517. McCarthy, Ou Ozin Times, II., 591-595. Fyffe, Eurofi, in Chap. XXV. 


\section{CHAPTER VII}

\section{ANGLO-SAYON EXPANSION AND TIE GROITH OF WORLL I'OLITICS}

504. Europe no longer the Stage of History. - Traditionally the politics of the continent of Europe, the international relations of the great powers, are the controlling factors in diplomacy. Men find it still difficult to believe that this is no longer so, but in reality the nineteenth century has wrought a great change. The interest of most nations is now turned far more to other continents than to Europe. The whole world is now the field of active diplomacy, and with the vast improvements in means of intercommunication and the transmission of news, the globe is no larger than the continent of Europe was when the nineteenth century opened. Its remotest inhabited parts are about as easily reached and controlled as the remotest portions of Europe a hundred years ago.

505. The Occupation of the World.-Germany, France, and England have divided Africa between them. Russia has stretched over the whole of central and northern Asia. English territory has been greatly extended in southern Asia. At the eastern end of that continent, Japan has suddenly risen to be a power of the first rank, and there is now as much doubt and eager jealousy over the ultimate disposition to be made of China as there ever was over that of 'Turkey. Off to the south of Asia a new English nation has grown up in Australasia, soon to be of the first rank, and already greatly interested in the settlement of (oriental questions. 
The United

States a

world power.

In America the whole northern continent has become Anglo-Saxon, and in the last half of the century the United States has seemed to be developing a claim to a controlling interest in the South American states which alone would bring it directly into the field of world diplomacy, but by its annexation of Hawaii, and by the results of its successful war with Spain, the United States has definitely taken its place as one of the great powers of the world, and will find in the end its interests immediately involved in the settlement of some of the Oriental problems, both in the disposition of China and in that of the great island region of the south seas.

World politics the work of the AngloSaxon.

Transportation.

Australia then unoccupied. Captain Cook. Story, British Empire, II. 216-222; Cassell's National Librany, No. to.

In this bringing of the world under civilized control, and making it into a closely connected system in which every power must play its part, the Anglo-Saxon race has led. Its expansion began indeed long before the present century and has continued without a check, if we leave the American Revolution out of account, as should be done from the present point of view.

506. Australia the First Step. - It was the loss of the thirteen colonies, indeed, that led immediately to the first step of a new expansion. At the end of the eighteenth century it was still believed that, in practice as well as in theory, the best disposition which could be made of the criminal class was to send them into the colonies to begin life over again. Up to this time England had used the American colonies for this purpose, but she could do so no longer. It was necessary to find a new place of transportation.

For about thirty years both England and France had had Australia in mind. Captain Cook had visited the east shores of the island soon after the conclusion of the Seven Years' War, and had taken possession of the country, which he named New South Wales for England. Neither France nor England had made any actual settlement there, however, up to this time, and it would very likely have remained still longer unoccupied, in the rush of events which followed the French Revolution, if it had not been for this need on the 


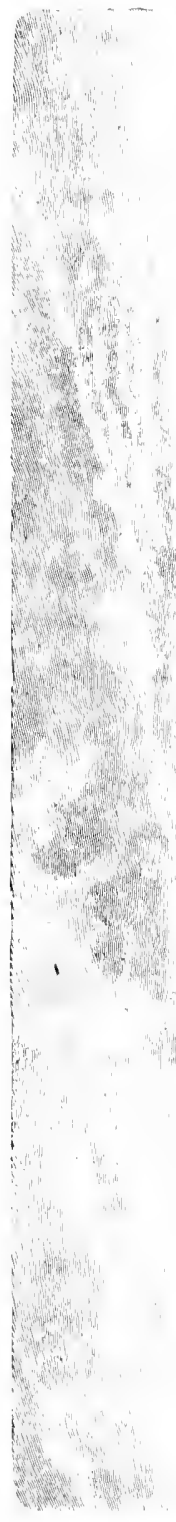

(1)

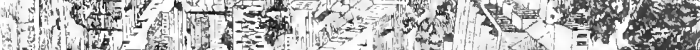
m. 1)

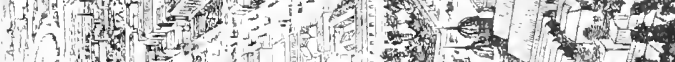

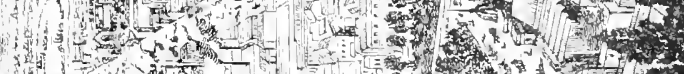
(1)

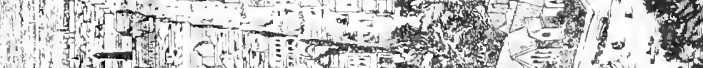
(4)

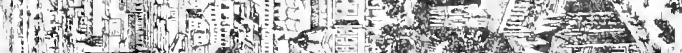

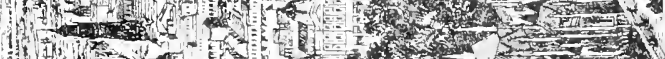

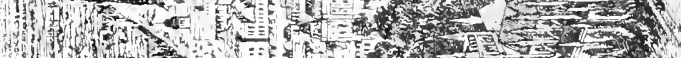

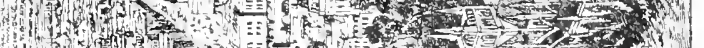

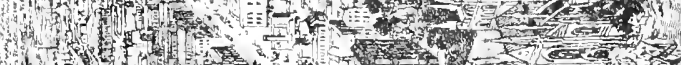

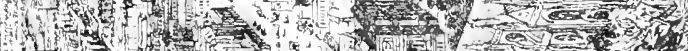
4 .

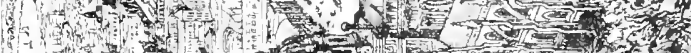

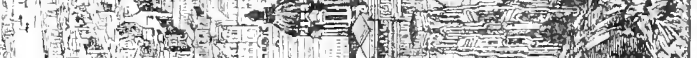
s.

(n)

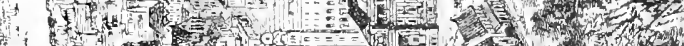

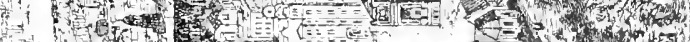

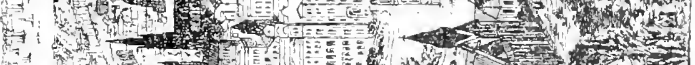

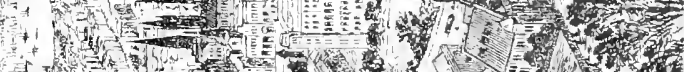
and 19. 3.

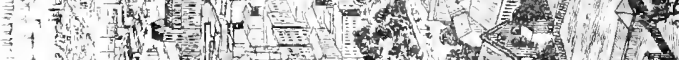

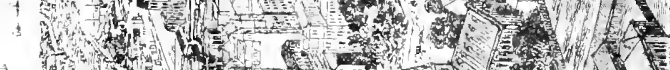
Wh

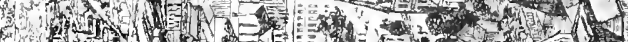

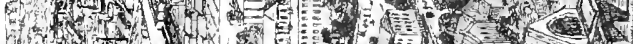

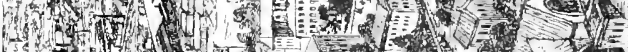
14.5. 
part of England. She determined to found a new penal colony and occupy a new region at the same time.

The settle- 507. Early History of Australia. - Preparations with this ment of Botany Bay. Story, British Empire, II. $223-229$.

lieclie, 1 Filst Itect Finnly' (novel). object in view were almost immediately begun on the conclusion of peace in $i_{7} \delta_{3}$, and the first expedition was sent out in 1787 . This consisted of about a thousand persons, the convicts and their guards included, but there were no real colonists among them. It was several years before the settlement, known as Botany Bay, became anything more than a kind of open-air prison, and certainly those who determined upon the first occupation of Australia had no vision of the unparalleled development of the country in a hundred years.

Expansion in The first step forward was the introduction of grazing, Australia.

Siony, Liritish Empire, Bk. IV., Chap. IV.; Payne, Colonies, $105-176$. especially of sheep raising, about twenty years after the first occupation. This was soon followed by the opening up of the interior, and by the founding of new settlements. Tasmania was occupied in $\mathbf{I} \mathrm{So}_{3}$. Victoria was settled in I $s_{3}+$ and became a part of New South Wales. New Zealand was taken possession of by a free colony from England just as it was on the point of being occupied by the French in 1839 . South Australia was also founded by free settlers from England in ${ }^{8} S_{3} 6$, and West Australia in 1829 .

The place of the thirteen colonies filled. Tregarthen, - Hustrulasia (Nations) ; Jenks, Australian colonies (Cambridge IHist. Series).

Transporlation abandoned.

508. A New English Nation. - Before this last date the great island continent hacl come to take the place once held by the American colonies as a field for emigration, and to be looked upon as a future home of one branch of the English race. About the time of the founding of these last colonies a new method of disposing of the public lands was adopted, by which they were sold at good prices and the proceeds used in bringing out other settlers. This proved for a time very successful, and nearly all the colonies advanced rapidly in population and wealth. By $\mathbf{I} \$_{35}$ they numbered together 80,000 .

As the free settlers became numerous and new ones began to come in large numbers, the colonies very naturally began to object to being used any longer as a clumping- 
ground for English criminals. It was not easy to persuade the home government to give up this practice so useful to the mother country, and language of considerable violence was used in some of the colonies before they accomplished their purpose, but within a few years transportation was given up to all the colonies except to West Australia, which requested that criminals might still be sent on account of the scarcity of laborers. It was finally abandoned there in I 860 .

509. England in the Wars of the French Revolution. Scarcely had the occupation of Australia begun when England was led into the wars which grew out of the French Revolution. For her these wars, as all wars had now been for a hundred years, were chiefly colonial and commercial wars. There was some real ground for fearing that the new enthusiasm of the French nation might lead them to try to reconstruct their naval power and their colonial empire. This became especially the case when in 1795 Holland was practically absorbed in the French republic. This would give them at once a considerable reënforcement of their navy and a most valuable foundation of empire in the East Indies. England at once blockaded the Dutch fleet, and with quick blows took possession of most of the Dutch and French colonies, including the Cape of Good Hope and Ceylon.

The danger became still more acute on Bonaparte's occupation of Egypt. Could he succeed in establishing a strong French power there, England's hold upon India would be at once shaken. But the fatal weakness of his plans was that he could not command the sea. Nelson's victory in the battle of the Nile shut him up as closely as if he were on an island, and it was by good fortune only that he got back to France at all. The war in India in which he had hoped that Tippoo Sahib with French aid would overthrow the English was not successful, though it was no easy task to bring it to an end. It served rather to extend the British dominion. Here it was that Wellington as a young officer served Bonaparte in Egypt.

his apprenticeship in the art of war. In a series of wars

Expansion in India. Story, British Empire, 11. $2+2-253$. 
before the fall of Napoleon the strong Mahratta tribes of south central India were subdued and the Empire greatly enlarged and strengthened.

England's conquests surrendered.

Napoleon saw the importance of colonial power.

Napoleon determines to occupy Louisiana and the Northwest. Adams, History Cinited State's (Scribner), I., Chaps. XIV.-XVII.

'The Louisiana purchase, I803.
In the peace of Amiens, in 1802, England showed that she had looked upon the war as chiefly a defensive one, for of all her extensive conquests, of which she could have kept anything that she pleased, she retained only Ceylon from Holland, and the West India island of Trinidad from Spain.

510. Napoleon's Attempt at Colonial Empire. - Napoleon appears to have realized that France could become permanently the leader of the world only by a reconstruction of her colonial empire. He realized also that the greatest obstacle in the way was the power of England. England, on her side, saw the great danger with which she was threatened by the genius of Napoleon. As a natural result they were irreconcilable enemies. When the war opened once more, in less than two years after the peace of Amiens, it never paused again between them though all other nations made peace.

The second attempt which Napoleon made in the direction of colonial dominion, immediately after this peace of Amiens was concluded, was a most promising one, and it threatened the American half of the Anglo-Saxon race with as serious a danger as the English. His recovery of Louisiana from Spain, and his attempt to obtain in San Domingo a base of operations for its occupation and colonization, seemed about to be successful. But the first expedition was fatally weakened by the yellow fever, and the immediate breaking out of the European war prevented any renewal of the attempt. It led, however, indirectly, to one of the greatest extensions of Anglo-Saxon territory made during the century.

5II. The Expansion of the United States. - The United States was more immediately interested in the growth of a great French dominion west of the Mississippi than England even. Before the practical failure of the attempt was known. the plans of Bonaparte had aroused some excitement, and 
steps to protect American interests had been determined upon. Bonaparte seems to have known, however, that to keep this territory in the hands of France after the war began was simply to make a present of it to England, since there was no French naval force to protect it, and consequently the American envoys to Paris found him willing to sell it all to the United States as if he supposed her to be as great an enemy of England as himself. The bargain was soon made. The enormous advantages offered, and the inborn Anglo-Saxon trait of acquisitiveness overruled the constitutional objection of no power expressly granted the general government to make annexations, although the party of strict construction was in power, and the area of the United States was doubled.

Already the United States had become a great colonizing nation. Settlement after settlement had been made in the region beyond the Alleghanies. In the northwest ordinance of $\mathrm{I}_{7} 87$, for the government of territories and their admission into the Union on the same footing as the original states, a most wise arrangement had been alopted for the management of colonies and the securing of their allegiance to the home country. Already by the time of the Louisiana purchase, four new states had come into the Union and others rapidly followed. Not long afterwards a second important annexation was made in the purchase of Florida from Spain, a sale to which Spain was practically forced by methods of a somewhat unneighborly character.

512. The English Empire in the Napoleonic Period. - In the war which began in $180_{3}$ between England and Napoleon, the occurrences of the earlier war were repeated. England took possession of the French and Dutch colonies, and maintained an indisputable command of all oceans. The short and indecisive war which was fought during this period between The colonization of the west.

Florida, I819. England and the United States, growing out of the harshness with which England, exercised the rights which she claimed over neutral commerce and to the compulsory service of her own seamen wherever found, though it showed the

England supreme on the sea.

The War of 1812 . 
American nary to be worthy of its parentage, served only to perpetuate and intensify the bitterness of feeling between the two nations. In this respect the United States was serving well the purposes of Napoleon.

English At the close of the war, England retained in addition to annexations her annexations at the peace of Amiens, the Cape of Gool in 1815 . Hope, a part of Dutch Giluma, and a few small French

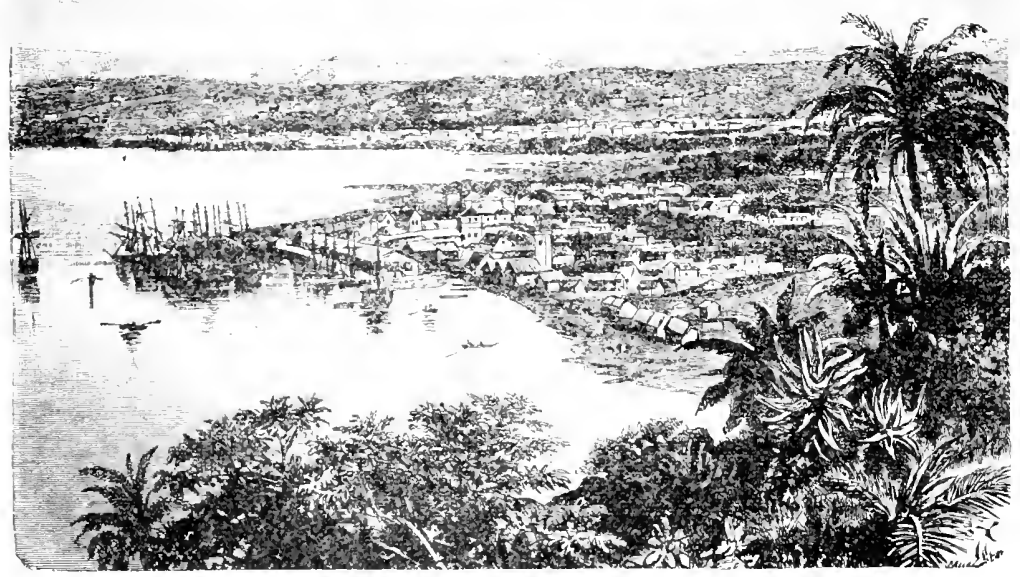

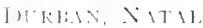

Surv, islanls. For the territories taken from Holland, England iritist/2 I:Hpur, II., $304-317$.

The importance of the Cape Colony. Incas, Historical marle a large payment in compensation.

(of all the gains of England since the occupation of Australia, the Cape Colony was by far the most important. Holking a strategic position unequalled by any other land in the workl, commanding the passage from the Atlantic to the Indian Ocean, a vitally necessary connecting link in a workl empire, a halfway house between England and both India 
and Australia most conveniently situated for supplying and refitting ships, and, finally but by no means the least important, an opening which would render easy the occupation of the best portions of the continent behind it, the colony was of far greater value than its area indicated or its stage of development at the time.

513. The Expansion of Canada. - During these years the population of Canada had steadily increased, though not with the phenomenal rapidity of Australia or the United States. As a result of the American Revolution there was a large immigration of families clevoted to the old government, known at the time as United Empire Loyalists. Slowly, also, Canada began to attract immigrants from Great Britain, and these were usually of a very good class. By I I $5_{5}$ there was a European population in British North America of about half a million.

As the English population and the wealth of the country increased an agitation began to secure more complete selfgovernment. A constitution hal been granted Canada in I 79 I by the ministry of the younger Pitt which was based on the English constitution of the time. In imitation of the monarchical and aristocratic elements in the government of England, which were then in supreme control, the power in Canada was placed in the hands of the governor sent by the cabinet in London and in an appointive upper house. As the English at home were at this time hardly conscious of the principle of ministerial responsibility to Parliament, as they came to be fifty years hater, there was no suggestion made that this practice should be allowed in Canada.

The lebate in Parliament upon the grant shows that it was the conscions intention of everybody to create an aristocratic government for these colonies, and this the bill certainly did. There was clear evidence in the history of the earlier English colonies in America to show that such a government would result in serious discontent and strife. But those who framed and discussed this hill do not seem to have thought of referring to colonial experience for instruction.

The government of Canada. Roberts, History of Cinadu (Lamson), $210-213$.

An aristocratic government. 
A thirty years' conflict. Roberts, Canada, Chaps.

IVIII and XIX.

The English government afraid of the consequences.

The Canadians win their causc by gradua! steps.

Roberts. Camada. Chap. XX.
5I4. The Struggle for Self-government. - The conflict to secure a change began in less than twenty years after the framing of the government, and it continued for thirty years before it was successful. The ultimate object aimed at was the control of the government by the lower house of the legislature, the immediate representatives of the people. In character it resembles in an interesting way the much longer struggle in the old country to secure the same result, and also that in both earlier and later English colonies where the same thing had to be done. The chief weapon employed until near the close of the conflict was the old constitutional expedient of withholding the supplies, and trying to coerce the government through its financial needs.

The government in England, whether the Tory party or the Whig was in office, was extremely reluctant to make the changes desired. 'The first effect of the American Revolution upon the ruling class in England had been to create a fear of independence in the case of their other colonies, and to lead to a resolve to hold them in, politically, with as tight a rein as possible. As the agitation in Canada increased, this fear was repeatedly expressed by the leaders of both parties. To yield to their demands would, it was thought, only lead to other clemands and to final independence. There was at that time very little understanding in England, even among the officers directly connected with the colonial department, of the conditions or feelings of the colonists, and in view of this ignorance their fear of the result of yielding was not unnatural.

5I5. Canada opens the Way for Colonial Self-government. - In ${ }^{2} S_{37}$ came the appeal of a part of the Canadians to arms. The rebellion was soon put down, but it made an impression in England. In the next year Lord Durham was sent out to make a careful examination of the situation. His report was published early in 1839 , and is a most remarkable document. It had a large share in bringing about the great revolution in English public opinion regarding the colonies which takes place in the next twenty years. By $S_{4}$ o the home government had become con- 
vinced that the effect of granting concessions could not be worse than that of withholding them, and concessions accordingly began. These led in a few years to full ministerial responsibility and to all the colonists had desired, and England quickly discovered that instead of independence there resulted a deeper and truer loyalty.

516. A Great Change in English Methods of Colonial Government. - This was the beginning of a great revolution in English colonial government which is one of the most remarkable facts of the history of the nineteenth century. The revolution was not wrought at once. Ten years later the Australian colonies found some of the old difficulties in the way of their securing full self-government, but they were far more easily overcome. Ten years later still the change was complete. Since then England has cordially granted complete local independence to every colony when it reaches a stage of development in which it can wisely exercise it. The Australian colonies and New Zealand, Cape Colony and the Dominion of Canada, are, for almost all purposes, as independent as the United States. Their subjection to the home government in foreign affairs, the chief item in which they are not independent, has been of great advantage to them both in actual protection and in saving the cost of preparations for national defence.

The causes of this important revolution are more than one. It has been erroneously attributed to the influence of the American Revolution, but a study of the Canadian struggle shows clearly that the effect of the independence of the thirteen colonies was rather the opposite. The chief cause was no doubt the discovery that the grant of local selfgovernment did not result in independence, but rather in strengthening the real bonds of connection. This cause was greatly aided by the adoption of free trade in commerce, by the rapid growth of democratic sentiment, by a more general popular interest in colonial affairs and understanding of them, and finally after the change had begun by a more correct reasoning about the American Revolution.

Complete local independence in the great colonies. Lucas, Introduction, I 18 -I37.

The causes of this change. Adams, Rept. Am. Hist. Assn., I896, I., $373-389$. 
lexis and tlie Mexican War.

One-third the United States annexed, $18+8$.

The discoveries of sold, I $8+8-1851$. Story, British Empire, Bk. IV., Chap. VII.
5I7. A Second Great Annexation by the United States.-At just about the time when this change began in England's method of governing her colonies, when the Canadian people secured control of their government, the United States made a second great annexation of territory. The Mexican state of Texas had received a considerable immigration from the neighboring states of the Union. In I 835 it declared its independence of Mexico and was soon after admitted into the Union. Then arose the question of the correct boundary line between Texas and Mexico, and this disagreement was pushed on rapidly to open war, as we now know, with deliberate intention on the part of the American leaders in the hope of conquest.

The war was soon decided. Mexico had no power of resistance either in army or resources. In the end she ceded to the United States her northern territories, down to the mouth of the Rio (irande and to the head of the Gulf of California, an area, if 'Texas be included, equal to one-third the present United States. The result was no doubt of the greatest value to the territories in question and to civilization in general, but it should be remembered that the process did not differ materially from that which we are disposed to criticise when employed by other strong peoples in absorbing the lands of their weaker neighbors.

518. Gold in California and Australia. - Hardly was the Mexican War concluded, and this great territory transferred from the Iatin to the Anglo-Saxon race, when there came the rich discoveries of gold in California in $1 \$_{4} 8$. These were followed three years later still by similar discoveries in Australia. The result in both countries was the same, - an era of enormously rapid increase of population and of wealth, - for although many of the miners returned to their old homes taking their gold with them, a large proportion remained in the country and aided in its development in other directions with the products of their mining.

The propulation of Victoria, in which the best mines were situated, more than loubled in two years, and was multiplied 
by four in four years. In California the same increase took Unparalleled place, and, though this rate could not be maintained, the next thirty year's saw a development of population and wealth in the western regions of the Union and in Anstralasia umparalleled increase of population and wealth. in history. In 1861 Australasia had a population of thirteen

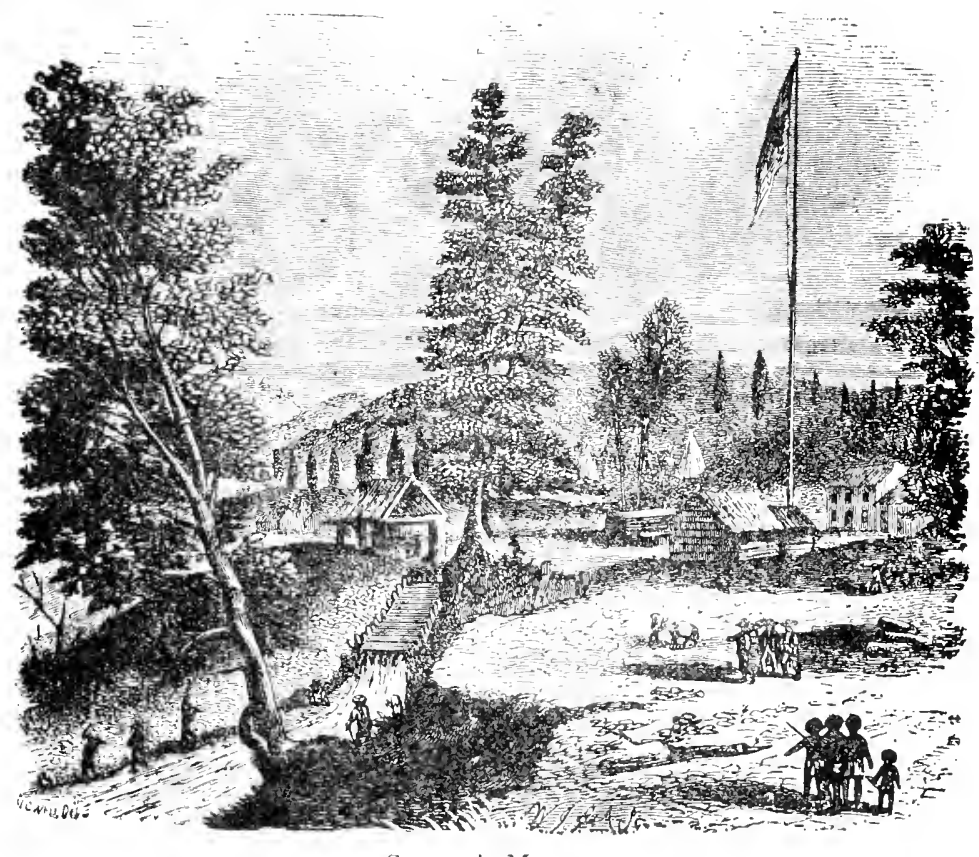

SUTTER'S MIII

Where gold was first discovered in California

hundred thousand. In 189 I this had grown to almost four millions. Since I $S_{9}$ I both these countries have suffered from financial depression and growth has been more slow. As the century closes signs are evident of returning prosperity.

519. A Theory of Imperial Dissolution. - About the year I 8 ; 0 a new era opened in the history of the British Empire. At that time a movement towards imperial ferleration began

The argument for dissolution 
leads to the idea of federation.

The

Manchester school. Cobden, rfeeches, I., $+35$.

Goldwin smith, The Empire (Lond.).

The Liberals rather disposed to hasten the dissolution, I860. which has not as yet led to the exact result intended, but has led to others of hardly less importance. It began as a reaction against theories of a contrary sort. The generation of English statesmen, who then had charge of public affairs, had been brought up in the idea that all the colonies were destined to eventual independence, and could only be retained by England up to a certain stage of development. The growth of this idea had been much encouraged by the teachings of the Manchester school of political economists, under the lead of Richard Cobden.

The fundamental principle of this school was complete freedom from government interference in every direction. As applied to the colonies this meant liberty to sever their connection with England whenever they should think their interests demanded the separation, with no resistance or objection on the part of the home government. Cobden had taught, indeed, that the care of the colonies was far too expensive a burden to be borne, and that whatever advantage was derived from them would not be lost when England's active assistance was withdrawn from them. This teaching was greatly reënforced about s \$60, and extended to an argument for the breaking of all political comnection by a series of most vigorous and effective letters to a London daily paper from Professor Goldwin Smith of Oxford, immediately collected into a book.

520. Gladstone's Ministry ready to let the Colonies go. - These ideas had an especial influence upon the leaders of the Liberal party who were in power under Mr. Gladstone from i 868 on. Their practical effect was to make the government entirely indifferent to a breaking off of the political connection between the mother country and the colonies, if not willing to bring it about. This feeling was plainly enough indicated by the ministry to New Zealand, South Africa, and Canada. On the other hand, the colonies were not in the least disposed to seek independence or to be forced into it, and some of them threatened to seek the protection of the United States, should England refuse hers. 
The feeling of the colonies was, however, speedily reflected by the feeling in England, and the mass of the people soon made it evident that the current theories no more represented their opinion than they did colonial opinion. There was no desire on the part of the nation to force the colonies into an unwilling independence; the desire was rather to draw the bonds of union closer if this could be done in any wise way. The government reversed its action as soon as the nature of public opinion became evident, and the crisis, which had been sharp for a few weeks, was over.

52 I. The Imperial Federation Movement. - Out of the feeling excited at this time grew the Imperial Federation Movement. The first definite proposal of such an organization for the Empire was made early in $\mathrm{x} 87 \mathrm{o}$, just as the ministry was changing its policy. The progress of the movement was at first slow. It was five years before the idea was taken up by any statesman of prominence. Abont I 880 it began to make converts more rapidly, owing to a variety of disasters which seemed to be threatening the English dominion in different parts of the world.

In 1884 the Imperial Federation League was organized in England, having among its officers and members many of the leaders of both political parties, and for its purpose the promotion of such a mion of the mother country and her colonies. After attracting wide attention to the subject, and publishing a considerable literature in its favor, the League was disbanded in $\mathrm{r} 893$ in favor of other methods of advancing the cause.

In the colonies the movement never has found even so much support as at home, and the practical objections to any actual imperial federation seem at present insuperable. But there has undoubtedly resulted a much greater general interest in the imperial connection, and a far better understanding at home of the colonial feeling and in the colonies of the home feeling. The bond of connection is known to be much stronger than was once believed, and no one now looks forward to a time of certain colonial independence.

Results of the movement.

See leader, London Spectater, May 2I, I870.

First definite proposal. See Contenporary Reritio', Jan. and Apr:, I87o.

The

Imperial Federation League. 
The occupation of Asia and Africa.

Gradual expansion in India.

Frazer, British India (Nations).

The Sepoy mutiny, I8 57 . Steel.

On the Face of the

it aters: ( hesney,

The

Dilimma (novels).

The

"scientific frontier."

On the whole in the native interest. Frazer, British India, Chap. XVI.
522. Expansion of English Dominion in India. - While these events were taking place in the purely Anglo-Saxon world, the two largest of continents, which until the nineteenth century had lain nearly always outside the current of history, had been opened up to European enterprise, and almost entirely seized upon by the different European states in their rivalry for colonial empire.

The occupation of Asia was the first to begin. At the opening of the century England already had the possession of India well begun, and Russia had Siberia in the north. After the conquests made during the Napoleonic wars, small additions continued to be made to British territory in India, the most important being that of the Punjaub just before the middle of the century. In $S_{57}$ came the great Sepoy mutiny in north central India, due partly to dislike of the British rule, of whose good effects the natives were as yet hardly conscions, and which was incleed often unnecessarily harsh, partly to superstitious dislike of the greasy cartridges served to the troops and partly to ambitious intrigues of rulers not reconciled to the luss of irresponsible power. The early stages of the mutiny, before the linglish could organize defence or attack, are filled with horrors; but it was overcome in a few months after the first surprise had passed.

In more recent times the fear occasioned by the steady advance of the Rusians in central Asia, has led to a gradual extension of the English occupation to the north and west, in the search for a "scientific frontier," that is one which will achit of easy lefence against attack. To protect the exposed westem lank, the large territory of Baluchistan has been occupied, so that now England controls all central Asia south of Persia. Af ghanistan, and China.

\section{The Character of the English Government of India. -} The British rule in India, though marked by cases of extreme selfishness and of harsh and overbearing conduct on the part of individuals, especially in its earlier periods, is on the whole and in its general results the most remarkable case in modern history, if not in the whole history of the 
world, of the wise and considerate administration of a subject country in the best interests of the native population. The most intelligent of the natives are coming to recognize this more and more, and there is now forming in India a feeling of patriotism and loyalty to the Empire which promises the most happy results, if the swift progress of events allows it time to strengthen itself as it should.

524. Russian Expansion in Asia. - From very early times the Russians have possessed dominion over the north of Asia. Siberia formed a part of the empire of Peter the Great, and his plans of conquest included Asia. The Russian advance has been steady for two centuries, though much more rapid in recent times. Even before the time of Napoleon the Russians began to consider the possibility of striking England a hard blow through India, in case of a war between the two countries, and twice during the Napoleonic wars the project was seriously discussed, and once an army was actually started to begin the invasion.

Although the Russian occupation of central Asia seems on the surface to have been often the result of accident, and of the irresponsible action of military officers, there is perfectly evident behind all the systematic purpose of the gorermment. The action of the officer in the field may he disavowerl. but the annexation which he makes is always preserved. Very possibly the desire of conquest has had less to do with this than two other reasons, - the natural tendency of every great empire to expand, and the military purpose of getting within striking distance of India. With the authorities in the field and in the government directly concerned with the administration of Asia, this last has probably been the most influential motive.

525. The Results in Asia. - All central and northern Asia is now Russian. China, Afghanistan, and Persia are the only independent territories remaining between the two European empires. Since the recent annexation of the Pamir district by Russia, there is at that point only a very narrow strip of neutral land, which belongs to Afghanistan, between the

Early plans against Indiil.

The methods of Russian advance. Curzon, K'ussia in Central Asia (Longmars).

The Russian and English empires near together. 
rival frontiers. The struggle of these great powers in Asia threatens the continued existence of Persia and Afghanistan, and even of China, as the most recent events show.

The problem now more complicated.

The work of twenty years. Keltie, The Partition of Africa (Lond.).

Explorations.

The Congo Free State. Keltie, Partition, Chap. XIV. France.
The entry of other European nations into the rivalry in the further Orient, like France and Germany, and the sudden rise of Japan to a position of the first rank, with especial interest in the solution which is to be found for this far Eastern question, are only likely to push events with greater rapidity, and to lead to less satisfactory and less permanent results than would be produced by a more moderate procedure.

526. The Occupation of Africa. - In the occupation of Africa the rivals of the English have been the Germans and the French, and the greater part of the process has taken less than twenty years. Neither the conquest of the Cape Colony at the beginning of the century, nor that of Algiers by the French about thirty years later, was followed by any noteworthy expansion. In the third quarter of the century general interest in the "dark continent" was aroused by numerous expeditions for scientific explorations, for which the name of Livingstone especially stands ; but these led to no further results until Stanley's famous journey across the continent from east to west, which laid open the course of the Congo River as a great highway into the interior. This awakened the eager desire of several European states to get possession of the commercial advantages which the control of this river would insure, and finally, as a kind of compromise, to the organization of the Congo Free State, open to the commerce of the world, but under the sovereignty of the king of the Belgians.

527. The General Scramble. - This was in the year 1884 , but in the meantime the general scramble had begun. France made the first move in the expedition of De Brazza in 1880 and $188 \mathrm{r}$, by which a large territory on the north bank of the Congo was taken possession of so effectively that it was recognized as French when the Congo Free State was organized. Germany followed immediately the example thus set. In 1883 some Germans who were nominally 
private adventurers seized a portion of the coast in southwestern Africa, and this was in a few months developed into a German protectorate over an extensive territory in that region. This part of Africa had always been regarded by the English colonists of the Cape as within their proper control, but the home government had steadily refused the requests of the colony to annex it formally, and now proved unwilling to sustain the colonists against the claims of Germany.

These cases illustrate the methods followed by all the nations of Europe from this time on. Germany settled in the same way upon several points of the coast, on both the east and west sides of the continent. France formed and has steadily followed the plan of connecting her various colonies by means of annexations in the interior. England pushed rapidly north from the Cape Colony until she now has possession of all the best portions of the interior, and she also considerably enlarged both her west and east African territories. Italy saw with jealousy but was not able to prevent the French occupation of Tunis, and has tried with but little success to found a colonial dominion of her own in eastern Africa in the neighborhood of Abyssinia. Portugal and Spain, whose African possessions date from a much earlier period, have been left behind by the rush of these events and have now no opportmity for expansion.

528. The English Occupation of Egypt. - In Egypt the extravagance of the khedive, Ismail Pasha, especially after the opening of the Suez Canal in r 869 , threw the finances of the country into disorder, and gave an opportunity for the joint interference of France and England in $18_{79}$ in the interest of the holders of the debt. There was much opposition in the country, however, to this arrangement, and in I 882 an insurrection broke out under Arabi Pasha. The French government sent orders to their fleet not to interfere, but the English bombarded Alexandria and put down the insurrection. Since that time England has had virtual possession of the country, though her position is not formally recognized by

Africa now nearly all occupied.

A joint administration by England and France. McCarthy, Our Time's from 1880 (Harper), Chap. Vl.

England alone. 
the European powers. Her rule has been of the greatest benefit to the population and is rapidly developing the resources of the State.

A Noham- 529. The Insurrection of the Mahdi. - At about the same medan time with the insurrection of Arabi Pasha, the equatorial or revival. upper Nile provinces of Egypt were swejt by a flool of

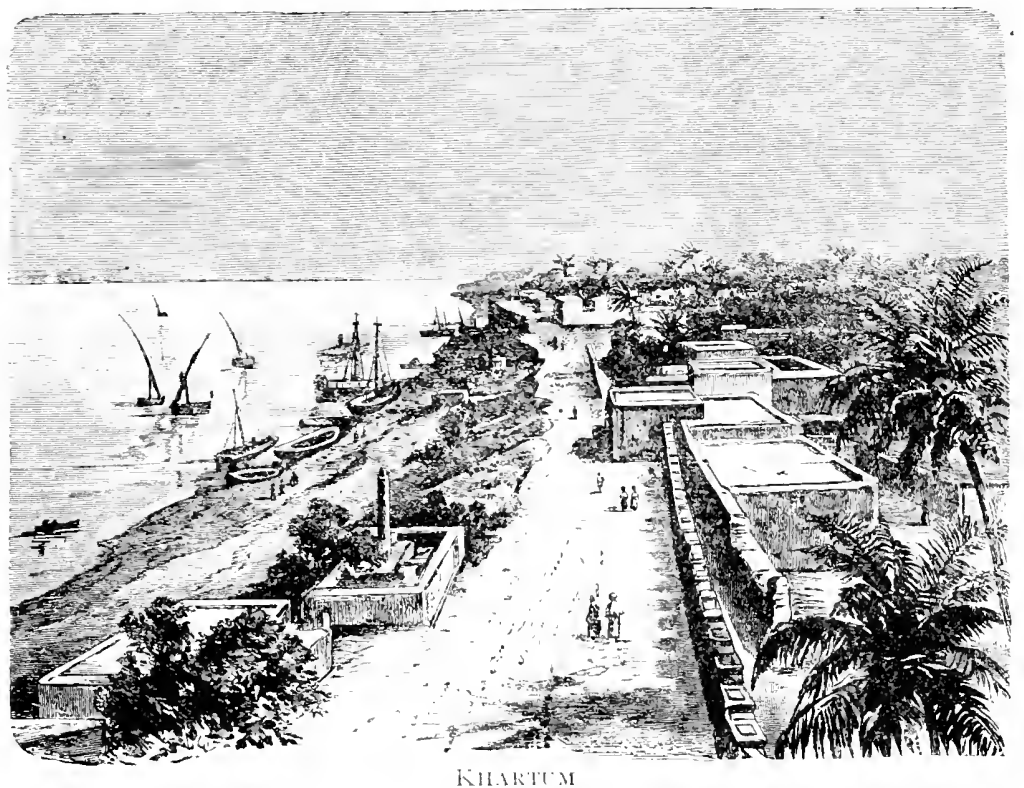

McCarthy, fanatical Mohammedanism, a revival of primitive religious Our Time enthusiasm led by the Mahdi, or the prophet. General from 1 sitis, $\mathrm{I} 3+\mathrm{ff}$. (iordon attempted to check its advance at Khartum, but was killed in $\mathrm{r} 885$, and the Egyptian Sondan became independent. The early attempts of the English to recorer possession of the provinces were unsuccessful, and only in $1 \$ 97$ did their real reoccupation legin, completed in the following year by the capture of Khartum.

The reconquest of the sumlan was no donbt stimulated 
somewhat by the movements of the French towards the upper Nile from the western Soudan, which appeared to be directed to the establishment of a connection between the French possessions in West and those in East Africa. These movements threatened the connection on their side which the English had long been planning to bring about through the centre of Africa between the Cape Colony and Egypt.

In area the French possess by far the largest share of Africa, but neither their possessions nor those of the Germans equal those of the English in resources or in adaptability to European colonization.

530. The Anglo-Saxon Race in the World. - The position which the Anglo-Saxon race now occupies in the world, if its two halves be taken together, is one which no other race has ever held before or holds at present. Of the five continents, it possesses the whole of one, North America, all the portions best suited to European residents of another, Africa, and exceedingly rich and populous portions of a third, Asia, and in addition the whole of a great island continent, Australia, which is as thoroughly Anglo-Saxon as England itself. It holds one-fifth the area, one-fourth the population, and one-third the wealth of the whole globe. It is externally in every sense of the word a world empire, and internally it represents the highest point yet reached by mankind in political and civil liberty and economic freedom.

This proud position which our race occupies has excited the jealousy of more than one of the others, and within recent years signs have been multiplying that some of them at least are only awaiting a favorable opportunity to attempt the dismemberment of the Anglo-Saxon Empire. With the race united in a common policy of defence, it would seem certain that no combination of other nations likely ever to be formed against it could surceed in destroying, or even in dividing, its empire. That the Anglo-Saxon race has a heritage from the past in its system of free government worth defending wherever it exists, and a civilization worth pre-

England has the best of Africa.

The greatest world empire of history.

General

sketch,

Lucas, Introduction,

IOI-IO7 :

Adams,

Atliantic

Monthly,

Apr. 1897.

The future of the race demands its union in policy. Green, English People, IV., 266-27I. 
serving for the future, are conclusions to which the study of our history can hardly fail to lead us.

\section{Topics}

What led to the occupation of Australia? How was it changed into a colony proper? Its early growth. How was the French Revolution dangerous to the English empire? What were Bonaparte's ideas of colonial empire? How illustrated in Egypt? In America? What was the final result in both cases? England's colonial gains from the Napoleonic wars. The importance of the Cape Coluny. Pitt's Canadian government. Canada's struggle for self-government. Of what value to the other colonies. England's present method of governing great colonies. The second great annexation by the United States. Results of the gold discoveries. Theory about the Empire held in England between i $S_{5} \mathrm{O}$ and I 570 . IIow did this lead to the imperial federation idea? English expansion in India. Character of the Inclian government. Russian advance in central Asia. What awakened the first interest of Europe in Africa? The Congo Free State. The beginning of the scramble. The present occupation of Africa. England in Egypt. The question of the upper Nile.

\section{Topics for Assigned Studies}

The Sepoy mutiny. Frazer, British India, Chap. XIV. McCarthy. Our Ou'n Times, II., Chaps. XXXII.-XXXV. Malleson, The Indian .Mutiny. (Scribner.)

Present government of English colonies. Payne, Colonies and Dependencies. (English Citizen Series. Macmillan.) Canada. Text of Act of Parliament, IS67. Roberts, Canada, 443-476.

\section{Important Dates for Review}

European Politics

I789. Estates general meet in France.

I804. Napoleon I., emperor.

18I5. Holy Alliance.

I821. The Greek insurrection.

I83o. The July revolution in Paris.
ANGla-Saxon Expansion

1787. Australia occupied.

I803. Louisiana purchase.

I815. Cape Colony annexed. I8I9. Florida purchase.

1823. The Monroe Doctrine. 
European Politics

I848. Revolutions throughout Europe.

1851. Napoleon III., emperor.

I854. Crimean Wrar.

186. I Kingdom of Italy formed.

I William I., king of Prussia.

186. War with Denmark.

1866. War between Prussia and Austria.

1870. Franco-Prussian IVar.

1877. War between Russia and Turkey.
Anglo-Saxon Expansion

18fo. Change of government in Canada.

18.8. Annexations of Mexican territories.

I $84^{8}$ to 1851 . Discoveries of gold.

I857. Sepoy mutiny.

I867. Alaska purchase.

1870. Imperial Federation Movement begun.

1879. Egypt occupied by France and England.

I880-I883. Sicramble for Africa begins. 


\section{CHAPTER VIII}

\section{THE GROWTH OF THE ENGISISH AND AMERICAN CON- STITUIIONS 1}

\section{Books for Reference and Further Reading}

Medley, Manual of English Constitutional History. (Macmillan; $\$ 3.25$.

Taswell-Langmead, Enstish (onstitutional Ifistory. Ashworth's edition. (Houghton; \$6.0o.)

Nuntague, Elenents of Engrish Constitutional History. (Longmans; \$1.25.) A very interesting an l successful elementary book.

Hannis Taylur, Origin and Growth of the Enstish Constitution. 2 vols. (1loughton: \$o.oo.) With especial reference to the American constitution. A rery suggestive introduction opens Vol. I.

IIallam, (institutional Ifistory of Engkand. (Many editions, usually in 3 vols.) (bl, but still valuable.

Buyle, Selections from Clarenán. (Clarendon; \$2.oo.)

On the present English constitution see:

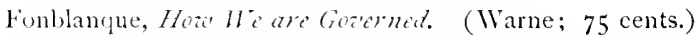

Volumes in English ("itizen Siries. (Nacmillan; \$1.oo each.)

Macy. The Enstish (onstitution. (Macmillan; \$2.0o.)

Bageliot, 7he Enstish constitution. (Appleton; \$2.0o.)

And compare on the Anerican:

Bryce, The American Commoniecalth. 2 rols. (Macmillan; \$4.00; or abrielged, \$1.75.)

Wilsun, (angressional (iverenment. (IIonghton; \$1.25.)

In comnection with this chapter there should be a review of the facts of linglish political history. The study of constitutional history, though of the sreatest importance, is always more difficult than that of narrative history. the separate treatment of this subject, which the facts readily allow, will premit the teacher to omit it entirely with less arlvanced classes, if desired, and in the case of the more advanced to give it more careful attention than would be possible if combined with the political history. 
531. The Importance of the History of our Institutions. - Throughout all its vast empire the Anglo-Saxon race has carried liberty and free self-government. Other nations have found by experience, also, that the Anglo-Saxon institutions are the best adapted to secure freedom ancl the most likely to be permanent of any that are now known, and therefore all civilized nations that try to have a free government at all have adopted some form of ours; if they are monarchies taking the English form with such modifications as their circumstances seem to require; and if they are republics, either following this model still, as in the case of France, or following more closely the special forms of the United States. It seems almost certain, so far as any prediction is possible, that the final free institutions of the world are to be built on the foundation which the English people has laid down. This fact, in addition to the circumstance that they are our own, makes the history of the way in which these institutions were formed of very great interest and importance.

532. The Absolutism of the First Norman Kings. - The William I. English constitution begins with an absolute monarchy. After William the Norman had conquered England in 1066 , he ruled as a very strong king. Every important question of government which came up he was able to decide by his own will alone, and there was no machinery known at the time by which the will of the people or even of their leaders, the great barons, conld be made to decide a question in opposition to the king's will. William II. ruled in the same way, but he was an even more arbitrary man than his father, and he did a great many things which the barons and the Church believed were contrary to the principles of the feudal law.

The feudal system, as it existed in the duchy of Normandy, was brought into England as a result of the conquest of IVilliam. In the theory of the time the fundamental idea of the feudal relation was that it was a contract of mutual service and obligation between the lord and his vassal. This being

They are becoming the institutions of the world.

William II.

William II. pushes his feudal rights to the point of tyranny. Stubbs, Cons. Hist., I., Sec. 106. 
the case, the lord had no more right to demand additional services from his vassal, which the contract did not call for, than one of us would have to change for his own advarntage the terms of a written bargain, which he had made, without the consent of the other party. William II., however, in his anxiety to obtain money, seems to have pressed some of his feudal rights to an extreme point, like wardship and marriage, and to have applied them to the lands held by the bishops and abbots in a way that the Church did not think was right. While he reigned, however, he was so powerful that nothing could be done about it.

The Charter of Henry I., I IOO.

TaswellLangmead, Cons. Hist., $65-67$;

Text, stublss, 99; Penn. I., No. 6 .

The promises of Stephen. Stubbs, II9: Penn. I., No. 6.

What if the king does not keep his promises?
533. Our First Constitutional Document. - On William's death his brother Henry hastened to secure the crown to the exclusion of their elder brother Robert, and as he needed the support of every one whom he could secure, the barons and bishops made him sign and seal a written agreement, specifying many of the things which William had done and solemnly promising that he would not do them. This is the Charter of Henry I., and is the first document in English constitutional history. It is in principle and character, as stating the rights which have been violated and insisting that they must be respected, very similar to the Declaration of Independence of 1776 , and we may rightly call it the earliest ancestor from which that document descends.

534. Progress under a Bad King. - Henry I. was a strong and a fairly good king, and no attempt was made to force him to a strict keeping of his promises. When Stephen tried to make himself king in the place of his cousin Matilda, he had to purchase support, as Henry I. had done, and to make written promises again; indeed, he made several sets of promises to different parties, - to the Church, to London, to some of the great barons, and to the whole kingdom.

Now Stephen proved to be a very bad king, and the people who were interested had to decide what they would do with a king who did not keep his promises. They probably did not think about it and all its consequences very clearly or consciously, but this is certainly what they did. They tried 
to depose him and put Matilda in his place. But Stephen always had a party on his side, and Matilda showed herself just as bad a ruler, so that the attempt did not come to any satisfactory conclusion. It is interesting as the first trace we have of the idea that the people may try to force the king by civil war to keep his promises.

535. Absolute Kings again. - After Stephen came Henry II., the great Angevin king. At the beginning of his reign he issued a charter in which he promised to regard the good laws of his grandfather and discontinue all evil customs ; but he and his sons were the most absolute of English kings, and we may almost say of them that their will was law, certainly it was for everything not already settled by custom, and for all questions of government policy. 'Their hand and will kept the government machine going, and in a very true sense in their time the king was the State.

536. The Beginning of our Judicial Institutions. - Although there was not much progress in the reign of Henry Il. towards constitutional liberty, there was begin a very important development of one set of public institutions, which help to secure our freedom, - the law courts. In order to be sure to get all the money which was due him, and to compel the sheriffs to perform all their administrative duties faithfully, Henry determined to send down into the counties, where they could get at all the evidence easily, members of the king's court, or curia regis, the body to which the sheriffs were responsible and to which they made their reports.

These members of the king's court were supposed to represent the king himself, and were charged to look carefully after all his dues and rights, and to inquire how the sheriff had conducted his office in each county. In order to get the evidence which they needed, they had the right to summon men from each locality and put them on their oath to tell them all they knew about these facts. This was the origin of our jury.

These new officers, called itinerant justices, were also allowed to hear and decide cases at law in the different coun-

IIenry II., kichard I., and John.
Law courts and the jury. Documents in Stubbs, I $35 \mathrm{ff}$, and especially, $25^{8}$; Penn. I., No. 6: Henderson, I I-2O.

The chief work of the itinerant justices. See account of Charlemagne's Missi, p. 169. They also tried cases. 
ties which might otherwise have come before the king's The jury. court at Westminster. In trying these cases, to decide Stubbs, Cons. Hest., I., Sec. 164 . questions of fact which might arise, they were allowed to make use of the jury, which was considered to be an institution belonging especially to the king, and primarily to be used only in his business. This judicial side of their business grew much more rapilly than the other, and by degrees, as new methods of looking after the financial interests of the government were introduced, it came to occupy almost their whole attention. This was the beginning of our circuit court system, which we think of usually as nothing but judicial : but when one of our judges instructs the grand jury to look into the way in which the sheriff has kept the jail since the last meeting of the court, he is doing just what his office was originally invented to accomplish.

The question of taxation at the foundiation of the English constitution. stubles, 14 , I59, 283 , and Cins. Hist., I., Sec. I6I.

537. King John's Arbitrary Taxation. - Henry II. did not serionsly interfere with those rights of the people which were secured by the law, but Richarl I. did many very arbitrary things, and John was a thoroughly bad king. He was indeed bad in more ways than one, but the particular line of badness which had the greatest influence on the growth of the constitution was with reference to taxation. John is not to be blamed for trying to increase the income of the State. The necessities of the government, owing to the rapidly increasing business which it had to attend to, har grown so much greater than they formerly had been that the old fendal revennes were entirely inadequate. But in trying to establish a regular system of taxes, by simply ordering feudal dnes to be paid at his own arbitrary will, without regard to the circumstances which gave him a right to take them by law, John had certainly violated the principles of the feudal contract.

John is forced to grant a full and specific charter. Text and

538. The Magna Charta. - When the opposition to John became so strong that he was forced to yield, in I 2 I 5 , the barons, with the advice of Stephen Langton, archbishop of Canterbury, drew up a new charter, the Magna Charta, which was based on the Charter of Henry I. but which was 
much more full and specific. This charter covered, besides its provisions in regard to taxes, many other points of feudal law. Some were points which had arisen in the working of the new itinerant courts; some regarded questions of administration; others related to the royal forests; and others still to matters in which the interests of the Church were involved.

In latter English history it came to be believed that the Magna Charta secured the right of Parliament to vote all the taxes, and the right of every freeman to a jury trial, and to the writ of habeas corpus. As a matter of historical fact, these things were not in the Magna Charta as its framers unclerstool it, but there were clauses which naturally seemed to imply them, and, when they had once been established as the great safeguards of liberty, the anthority of the Magna Charta helped to give them a sacred character.

539. The Right of Civil War. - Without much question the most important clauses of the Magna Charta, in their influence on the actual work of making the English constitution, are these at the end which state the means of compelling the king to keep his promises. These state that if he fails in any of his obligations "the community of the whole kingdom may distress and distrain [him] in all the ways in which they shall be able" till the grievance is redressed.

This was the logical conclusion of the practice begun with Henry I. of extorting from the king lefinite and specific promises to be faithful to the law; but this conclusion, of which no one had been conscious in Henry's time, and which was first thought of in the case of Stephen, was now much more clearly and conscionsly drawn than it had been before. From this time on it became, we may say, legal and constitutional to raise civil war against the king, if he violated the legal rights of the people.

540. The Right of Insurrection Applied. - On this principle the nation acted as long as it was necessary. When John deposed. John attempted to throw off the engagements made in the

Civil war a constitutional expedient.
Taswell-

Langmead, Cons. Hist., Chap. IV.; Text, Stubbs, 296;

Old South,

No. 5;

Penn. I.,

No. 6;

Lieber, Civil

Liberty:

Henderson,

135 .

The Magna Charta takes on later an even wider meaning. Adams, Civilization, $3+3-3+5$. The Magna Charta to be enforced by war on the king. . 
Charter, and got the pope to release him from them, the barons declared him deposed and proclaimed Prince Louis of France king in his place. A change of dynasty might have taken place at this time if John's death in the midst of the conflict had not saved the throne to his son.

Henry III.

Huton,

Wisrule of

Henry ill.

(Contemporaries).

Stubbs, 378 .

The Baron's

IVar.

Hutton,

Simon $d c^{2}$

llontfort

(Contempo-

raries);

Matthew

Paris (Bohn),

I1 1., 3+4-356;

Matthew of

Westminster

(Bohn), Il.,

+12-ttI ;

Stubbs, fog.

The right to restrain a bad king.

The growth of a national party.

Richardson, National Morement in keign of Henry lll (Macmillan).

When that son, Henry III., came of age, he proved to be a weak and extravagant king, who was continually disregarding the rights of his subjects. At one time the barons threatened to choose another king in his place if he did not dismiss one of his favorite ministers. Later they compelled him to give up practically the whole government of England into the hands of a commission which they had chosen, and to which the officers of the State were made responsible. This was the arrangement called the Provisions of Oxford.

Later still they made open war on the king. At first they were successful and obtained a confimation of the charters from Henry, in which he distinctly recognized their right to rise in insurrection against him if he violated the agreement. Afterwards they were defeated by Prince Edward, and Simon de Montfort, their leader, was killed; but the most of the principles for which they had been contending were adopted, through the wisdom of Prince Edward, and made into laws.

54I. The Idea of a Limited Monarchy. - Besides carrying on this principle of rightful resistance to the king, the reign of Henry III. was one of the greatest periods of constitutional growth in English history. It was a time during which the idea of a limited monarchy, of controlling the king, putting him under restraints, and guiding him by the national will took very rapid shape. This was partly due to the personal character of the king, which was so weak that it did not command the respect of any one, so that nearly every one was ready and willing to oppose him. In part it was due to the fact that there was throughout his reign a constant conflict between the native English and parties of foreign favorites of the king's, who were using their position to gain everything which they could for themselves, so that there was always a good reason for opposition. We cannot 
say that a limited monarchy yet existed or any definite machinery for expressing the national will, but the beginnings of both date from this reign.

542. The Origin of Representative Institutions. -. The greatest advance of all during the reign was in the taking of the first steps towards the formation of Parliament and the introduction of the representative system. The first full and regular Parliament, in the legal sense, the so-called model Parliament, was called together by Erlward I. in I 295, but it was during the reign of his father that the preliminary steps were taken which made the assembling of the full Parliament seem to every one a perfectly natural thing.

These steps consisted, first, in employing representatives of the counties in national business; second, in summoning them to meet with the Great Council, which was composed of the barons and prelates and served as the king's council and court, to act for their counties and make known to the council the local opinion; and, finally, in adding to these representatives of the counties other representatives from certain of the more important towns.

543. Representatives of the Counties brought into the Great Council. - The representatives of the counties were known as knights of the shire. That is, they were members of the lower ranks of the land-holding aristocracy, who had no noble titles but were persons of great influence in their localities. They had first begun to be employed in public business in connection with the itinerant justice courts in which they chose and, so far as their numbers went, formed the juries.

Their use in this way undoubtedly suggested their employment in business more directly concerning the government when the need for it arose. In r 220 two knights were chosen in the county courts to assess and collect a land tax. In 1225 four knights were elected from each bundred to assess and collect a tax on personal property granted the king by the Great Council. In s 226 four knights were summoned to go to the king from each of eight comnties to re-

The steps which led to Parliament. Medley, Manual, Sec. 20; TaswellLangmead, Cons. Hist. 191-197; Social

England, I. 396-403.

The knights of the shire. Stubbs, 259.

The knights employed in public business. Stubbs, 357. 
port on the conduct of the sheriffs. Other cases of the same sort follow.

In the Great In $r 254$ occurs the first case of the knights meeting with Council.

Stubbs,

375 , and cins. Hist.,

11., Sec. $2 \mathbf{I} 4$. the Great Council, summoned thither by the king from each county to aid in granting him a new tax. They were summoned again in 1261 , in 1264 , and in 1265 . From this time on their membership may be said to be a regular feature of the Great Council, which was now beginning to be called Parliament.

Simon de Montfort's Parliament. TaswellLangmead, Cons. Hist., 197-200.
The "model Parliament," 1295.

'TaswellLangmead, cons. Hist., 2OI-208. IVilts of summons.

- Subbs, too, 49 , and 482 ; Penn. I., No. 0.

Parliamentary control of tixation.

544. The First Case of Town Representation. - The representation of the towns was introduced more suddenly, and in a revolutionary way, by Simon de Mlontfort in the Parliament which he called to meet in January, i 265 , while the king was a prisoner in his hands, but it does not seem to have been thought at the time a very strange step. In fact, the towns had been regularly represented for a long time in the county courts, and as they seemed to be a somewhat different class from that directly represented by the knights of the shire, the idea was sure to occur to some one before long that they should be represented in the Parliament also. This step, which Simon de Montfort took to strengthen himself, was not followed, in anything which we can call a full Parliament in the later sense, for thirty years. In the interval, the practice shows a very great variety and uncertainty both in the composition and in the method of operation of the Parliament, which means of course that the institution was still in the process of formation, and that neither its make up nor its functions were yet fixed. We can, indeed, scarcely detect any drift towards regularity, but when all the elements were once more brought together in a regular assembly summoned by the king, in 1295 , this became immediately the standard form.

545. Further Progress in the Thirteenth Century. - Besides determining the composition of Parliament, the reign of Edward I. decided the first great point in the conflict between Parliament and the king, and laid the foundation for the final victory of Parliament. This was the establishment 
of the right of Parliament to vote the taxes. In principle this was the same as the provision of the Magna Charta with regard to extraordinary feudal taxes, but during the century there had been very great progress in two directions which decidedly changed the application of the principle.

In the first place, since the granting of the Magna Charta, a system of taxes, more regular in character and more like modern taxes than the feudal levies, had been growing up. Taxation meant something different in 1295 from anything it had meant in I2 I5. Extraordinary taxes, voted by the Parliament, were at the close of the century a much heavier and nore frequent burden on the nation than at the beginning, and they were much more the dependence of the government, in fact without them government was no longer possible.

In the second place the body giving consent to taxation, called in the Magna Charta the Common Council of the kingdom, and which we have called the Great Council, had now decidedly changed in character. It was no longer, as it had been then, an assembly of the king's vassals only, the barons and prelates of the realm, but it was an assembly containing representatives of all the chief classes of the nation becoming conscious of standing in the place of the community and watchful of its interests.

546. The King recognizes the Right of Parliament to control Taxation. - Consequently, when in I297, after a struggle with regard to arbitrary taxation, Edward was forced to issue a new agreement to conform to the charters, it contained a much more full and specific promise than ever before not to take any taxes "but by the common assent of the realm." It was intended to make this declaration so full as to cover all kinds of taxes. Ancl, indeed, though later kings at different times were able to invent means of dodging the prohibition and violating the spirit of the law if not its form, they were never able to deny the principle nor to recover the ground which had been lost in the thirteenth century. 
The king forced by his need of money to make reforms. Stubbs, Cons. Hist., II., Sec. 289.

The Hundred Years' Var under Edward 11I. gives an opportunity. Medley, Mamual,

Sec. 33 ; Montague, Elements, 73-89:

Taswell-

Langmead, Cons. Hist., 226-24.

The right to make specific appropriations.

Stubbs, Cons. Hist., II., Secs. $237-288$.

547. Parliament immediately takes a New Step. - Upon the foundation thus laid down Parliament steadily proceeded through the whole fourteenth century to increase its power in the State, and to acquire a more complete control over the king. The first step in this advance was taken early in the reign of Edward II., when Parliament asserted a right to use the financial necessities of the gorernment to compel the king to agree to reforms which they demanded. This was done by granting the tax asked for on the condition that the reforms were made. In the next reign Parliament met the tendency of the king to promise the reform, and when he had got the money to fail to carry it out, by insisting that the changes be accomplished before their grant was made.

548. Another Most Important Right Gained. - Hardly had Parliament made sure of this new weapon against the king, when they proceeded to put into use another and still more effective one. The demands of the king for money were frequent beyond all precedent during the long war with France in the fourteenth century, and this made the Parliament more than usually interested in the public expenses. Almost at the beginning of the war they began to make inquiry into the methods of collection and to examine the accounts of the collectors. By the middle of the century they began to grant taxes to be applied to the purposes of the war only.

These were but preliminaries to holding the government to a strict accountability for the expenditure of its income. In the reign of Richard II. this advance was made, and the treasurers were required to make in writing a full statement of the income and expenses of the State. From this was developed the parliamentary right of strict appropriations of money for government use, so strongly insisted upon as a means of controlling the executive in all the Anglo-Saxon constitutions that, though the treasury may be full to overflowing, and the needs of the government never so pressing, not a penny can be userl withont a specific vote of the representatives of the people. 
Of course when this practice should be put into complete operation it would mean a very effective control by Parliament over the whole policy of the government. The right to withhold the money for the necessary expenses would make it possible for Parliament to prevent any action on the part of the State of which it did not approve. In the end the English government did come to be subject to the control of the legislature, even to as great an extent as this. But the right of appropriating the supplies was not the only means which led to this result.

549. A Third Great Gain of Parliament's. - At exactly the same time that Parliament was securing this right, it was creating another equally effective. This was the right of impeaching the king's ministers. In ${ }_{1} 3^{6} 7$ was the first case of impeachment, and in 1386 the second and still more important case which fully established the right. In these cases the House of Commons formally accused the ministers before the House of Lords of misconduct in office. The Lords put them upon trial, found them guilty, and passed sentence of punishment upon them.

The right of impeachment, when it was put into its final form, meant far more than the power of Parliament to punish an unpopular minister. It meant that the king would find it impossible to get any minister who would be willing to carry out a policy known to be opposed by the Parliament or by the public sentiment of the nation. It meant, in other words, a shifting of the responsibility, and so in the end of the control of the government's policy from the king personally, or acting of his absolute will, as Henry II. had done, to the minister.

The great advantage of this change was in the fact that while a king could never be held to any real accountability without civil war and revolution, ministers could easily be held strictly answerable for all the acts of the government without revolution, unless the king insisted, as Charles I. finally did, on assuming the responsibility himself.

To carry out fully this application of impeachment, Parlia-

This would mean a control of the whole government policy.

The right of impeachment.
The minister responsible in place of the king.
A substitute for revolution. 
The fuil development of the right comes later.

Statutes i's. ordinances. Stubbs,

ions. Hist., II., Sec. 292 ; Nedley, Hanual, Sec. $3+$.

The power of Parliament meant the power of the House of Commons.

ment in the end refused to allow the minister to plead the orders of the king in his defence, since that would make the king responsible, or to stop the trial before its conclusion by getting the king to grant him a pardon. These points were not secured, and the full meaning of impeachment was not understood, however, at first. They were a part of the more perfect statement and understanding of the English constitution which resulted from the struggles of the seventeenth century with the Stuart kings.

550. The Exclusive Right to Legislate. - In the fourteenth century Parliament took still another step towards the enlargement of its power at the expense of the king. This was in opening the struggle between laws, or statutes, regularly passed by both Houses of Parliament and assented to by the king, and ordinances made by the king and his council, either the king's permanent council or the great council, now practically the same as the House of Lords. This last had been the method of legislation of feuclal times, in so far as there was any at all, and it survived alongside the new method of legislation in Parliament for some time, and traces of it remained in the constitution much longer. The rivalry between ordinances and statutes was like that between the old feudal and the new parliamentary taxes which runs through the thirteenth century, and, like that, it was in the end settled entirely in favor of Parliament.

55I. The Rise of the House of Commons. - We have been speaking all along of the increase of the power of Parliament, but it must be noticed that Parliament really means the House of Commons added to the old Great Council, or to the barons and prelates of the realm. Consequently the increase of the power of Parliament really means the rise in infuence and to control over public business of the House of Commons. Before the middle of the fourteenth century the Commons had withdrawn from the Lords and organized themselves as a distinct body, thus completing the form of Parliament; and all the advances made in this century are really for the benefit of the lower House. 
552. Summary of Results. - If we put these all to- England gether, we can see that by the close of the fourteenth century we have a right to speak of the English monarchy as already a limited or constitutional monarchy sustained, if king and Parliament came to a square issue, by the right of deposing the king. The monarchy had lost, either completely or to all practical intents, two rights essential to an absolutism: the right of providing a revenue, and the right of making laws without the consent of the nation; and another right of the same kind had so far slipped out of its hands that it was henceforward exercised by kings in exceptional circumstances only, that of determining the policy of the government without consulting the nation. Just the opposite process was going on in this century in France, and by the close of the next the king of that country had made hinıself the most absolute monarch of the Christian world by getting possession of all these three rights so that he could exercise them without any check.

553. The First Dangerous Attack on the Constitution. - This young constitution was brought to a sharp test, which reveals its character and its strength, in the reign of Richard II. Just what kind of a man Richard II. was, and just what he intended to do, we cannot say with any certainty. But this makes very little difference with the result. Whatever his purpose may have been, if he had been allowed to go on and to complete the process he had begun, he would have restored the monarchy of the Angevin kings, where the sovereign's will decided everything. He was getting an independent revenue, and, by a roundabout method, the right to make such laws as he pleased, and he was assuming the power to suspend statutes passed by Parliament and to inflict heavy penalties by a royal order.

That the personal cause of Henry of Lancaster was bound up with that of the nation does not make the revolution of I 399 any the less one in defence of the constitution, or any the less a perfect precedent to apply to a king like James II.

already a limited monarchy.

The contrast in France.

The tyranny of Richard II. TaswellLangmead, Cons. Hist., $255 \mathrm{ff}$.

The first constitutional revolution, I399. 
Stubbs,

Cons. Hist., Secs.

268-269.

The right of deposition clearly: established.

Parliament passes over the heirs by blood.

A new kind of title to the throne created-the parliamentary title. TaswellLangmead, $173^{-1} 7^{6 .}$

Parliament was perfectly conscious of its rights in the case. Much earlier in Richard's reign, when he showed a disposition to resist the right of the legislature to control his ministers, Parliament called his attention in a formal address to their right to depose the king and to the exercise of this right in the case of Edward II.

554. The Deposition of Edward II. 1327. - The case of Edward II. was not so clear a case by any means of constitutional deposition as that of Richard II. The personal element entered into it much more as a controlling influence than in the later case. But in form Edward was deposed distinctly on the ground that he was a thoroughly bad king. But even without this precedent there conld be no question but that the principle had been clearly established, in the still earlier cases of John and Henry III., that the people had the right to make war upon the king to force him to better gorernment, and this logically involved the right of deposition or it could not be really effective. There was abundant sanction in the past, explicit and implied, for the deposing of Richard II., and it was clearly necessary to save the constitution.

555. The Right of Parliament to control the Succession. - In the revolution of I 399 , however, the Parliament besides establishing the clearest precedent yet made for the exercise of this right of deposition went a step further and put into operation another right, logically involved in the first, but never before acted upon and not even then fully understood in all that it was to lead to. This they did by passing over the nearest heirs to the throne and placing upon it a man who could never have reached it by the ordinary rule of succession.

No doubt they did this with no thought of enlarging their own power. Henry was the only one who was competent to be king at the time. But it is equally true that by this act they dis establish the principle that the nation acting through Parliament has the right in exceptional cases to set aside the regular line and to give a legitimate title to the 
throne to a new line whose only right, strictly speaking, is derived from the choice of the nation.

'This right was confirmed during the reign of Henry IV. by acts of Parliament fixing the line of succession in the family of the king, and Parliament very soon became clearly conscious of the gain which it had made. When in 1460 , victorious in the field, Richard duke of York advanced in the House of Lords his better hereditary title to the throne than that of the house of Lancaster, and demanded recognition of it, one point of the reply to him was that the title of the house of Lancaster by statute was better than any other kind of title. When Richard accepted the compromise which Parliament proposed, he practically recognized this fact. The right of the Parliament to do all that it did when it deposed James II. and set aside the rightful line of the Stuarts in favor of the house of Hanover, was fully established by the precedents of 1399 .

556. The Progress of the Fourteenth Century. - The fifteenth century is one of far less activity in constitution making than either the twelfth or the thirteenth. The position of Henry IV. made him dependent upon Parliament, and he reigned in many respects almost like a modern constitutional monarch, and this had an effect to secure all that had been already gained and fix it in the familiar habits of the nation. In many minor details Parliament enlarged or defined its rights during the period.

'The House of Commons secured the right to originate all bills relating to money; the principle was established that the wording of acts of Parliament once passed should not afterwards be changed ; the dangerous power was assumed of punishing great opponents, not by impeachment, but by bill of attainder, an act of Parliament declaring a person guilty and fixing his punishment without trial : a most dangerous power of which the Congress of the United States has been wisely deprived, and which will never again be exercised in England so long as the cabinet system of government lasts. The right Nany minor rights secured.

to determine upon regencies was repeatedly exercised and

Cons. of U.S., I. ix. 3 .
The question between the houses of York and Lancaster. Stubbs, Cons. Hist., III., Sec. 677.

Constitutional government becomes habitual. 
Freedom of debate. Mediey, Manual, viec. 37 ; Tasivelil, angmead, cons. Hist., 263-272.

An evidence of the progress already made. See passage from Fortesque, TaswellLangmead, cons. Hist., $301-303$.

$A$ tine of danger to the constitution.

Tendency of the Yorkist kings to independence. insisted upon; the freedom of speech of members, the right not to be called in question elsewhere for things said in debate, and their freedom from arrest during the sessions of Parliament were established in principle, though not always afterwards perfectly respected; and finally the decision of disputed election cases and the fixing of the qualifications for exercising the right of suffrage, and for membership in the House of Commons were assumed by Parliament.

None of these points is of particular importance in itself, but taken all together they form a considerable body of privilege, and coming all within a short period of less than fifty years they show us what extensive powers Parliament must alrealy have gained to occupy itself during a time particularly favorable to its pretensions with such relatively unimportant matters only.

557. The Yorkist Period. - The last half of the fifteenth century was filled with the Wars of the Roses, a time unfarorable to large constitutional growth. Indeed, the period when the Yorkist kings were in power was a time of no small danger to Parliament and the constitution. The fact that their case required them to insist on the superior right of a hereditary title to the throne brought them into collision with one of the powers which Parliament had acquired which was most essential to the life of the constitution, the power of determining who shonld be king.

The Yorkist kings also show a decided tendency to seek for an independent revenue, and, so far as circumstances would allow, to rule without Parliament. Yet on the whole the constitution lost nothing. Richard III. was compelled to some dependence on Parliament for his title, and the power of the House of Commons was revealed at times by the anxiety of the government to get it packed with its own supporters. Still more decisive was the fact that the period was too short and too tumultuous to allow an absolutism to become fixed in the government.

The battle of Bosworth Field and the accession of Henry VII. were incidents in the Wars of the Roses, and yet the 
overthrow of Richard III. was a revolution which protected the constitution as truly as did that of 1399 , though from a less immediate danger. Edward IV.and Richard III. were abler sovereigns than any that have followed them in English history with the exception, perhaps, of Elizabeth and William III. ; but a constitutional monarchy has no place for able sovereigns. They are always a dangerons menace or a nuisance, and the Jorkist kings were plainly tending to a policy langerous to the constitution.

558. The Tudor Period. - The Tudor period is commonly called that of the absolute monarchy in English history. And it certainly is so in a sense. 'The sovereigns showed tendencies decidedly like those of the Yorkist kings. The constitution was severely strained and in some points even broken. Many times the monarch imposed his will on a nation, reluctant, to say the least. But the absolute power of the Tudors was as far asunder as possible from that absolutism, with no institutions to check or limit it, which was exercised during the same time by the king of France. Certain peculiar circumstances of the historical situation, partly affecting the sovereigns and partly affecting the nation, preserved the underlying principles of the constitution uninjured, and kept the monarch and the Parliament from ever coming into direct collision with one another.

559. The Peculiar Circumstances of the Tudor Age. There were three of these circumstances most important to notice. First was the question of title to the throne, affecting all but Henry VIII. and Edward VI., and compelling a recognition of the supreme authority of Parliament on this most fundamental matter. Indeed, the two kings named are not real exceptions, because the reign of Edward was practically all a minority under a regency deriving its authority from Parliament, and Henry VIII. was compelled by his own situation to recognize the supreme authority of Parliament in this particular, and did so when he allowed it to confer on him the right to fix the order of succession among his heirs. 
The growth of a close community of nations.

The rise of religious strife.

Enough to make a practical absolutism. TaswellLangmead, Cons. Hist., Chap. X.

Prothero, I $18-126$.

The turn of the current.
The second was the rapid development of international politics, which created a great community of the European states, and bound them in a close and intricate struggle for leadership, so that questions of foreign policy now began to influence the conduct of domestic affairs in a way they had never done before. This was intimately connected at first with the question of the succession, and in the last part of the period with the third of these circumstances.

This third was the general condition produced by the great revolution which swept over all Europe in the reformation of Luther, creating new and more intense issues, and dividing almost every nation into two bitterly hostile parties. For England this quickly became a question of national independence, and made the country willing to support the cautious and carefully balanced policy of Elizabeth, even at the cost of orerlooking some disregard of the constitution, of which, however, they were perfectly conscicus.

560. Details of Tudor Action. - The special details of the unconstitutional action of the Tudors are not so many in number as they are grave in principle. Forced loans and other illegal means of aroiding a financial dependence on the legislature, and at times long intervals between Parliaments ; arbitrary methods of trial by a sort of royal prerogative in the court of the Star Chamber, and equally arbitrary arrests and imprisonments both of which tended to destroy the safeguards of individual liberty existing in the ordinary courts ; interference with the freedom of debate, going so far even as the imprisonment of members of the House of Commons in the Tower ; and the insisting that royal proclamations should have the force of statute law, a claim which for a few years and in special cases received the sanction of Parliament. Taken together these principles and practices would constitute a very strong arbitrary government.

The dangers which had induced the nation to submit began to lessen in the last years of Elizabeth, and many signs began to appear which made it evident that Parliament would 
not much longer endure the practical control of everything by the sovereign's will. But one not insignificant result of the trend of things during this period was a theoretical acceptance and defence by some of the doctrine of a divine right in kings of which they cannot be deprived, the source of a supreme power in government. This doctrine in a more developed form was to play a great part in the constitutional history of the next century.

56I. Institutional Character of the Tudor Rule. - In general we may say of the Tudors that theirs was an absolutism exercised not so much through institutions proper to a despotic monarchy, as by imposing their will on the nation through the existing institutions of the State. The nation submitted because in a grave crisis of its existence the sovereign's policy seemed wise and had the support of public opinion, while to resist too far the sovereign's method would only increase the most serious danger of the time, the constantly threatened civil war.

The royal exercise of power was not unlike that of an American "boss," who decides all questions of policy by his irresponsible will, but without any visible change of the constitution. Perhaps a still better parallel would be the present government of Germany, because there the supremacy of the sovereign's will is accompanied with some departure from the constitution, and because intelligent Germans justify the nation's submission on similar grounds of expediency. For England the method of the Tudor absolutism meant that all constitutional rights were still in existence, ready to be put into force when the nation should judge that the time had come.

562. The Constitutional Change in the Position of the Church. - In one particular there had been a great constitutional change during the age of the Tudors. Whatever one may think of the method by which the Church of England had been made independent of the pope, constitutionally the result had been to put the Church completely under the control of the nation. What the fourteenth century had Modern instances.

The "boss."

Germany.

No real absolutist institution. Hallam, Cons. Hist., I., last pages of Chap. V.

The Church made subject to Parliament. See Gee and Hardy, 477. 
done in subjecting the monarchy to Parliament, the sixteenth did on the ecclesiastical side of public affairs in subjecting the Church to Parliament. The supremacy of the king as the head of the Church was in many respects real during the Tudor period, but when Parliament had once recovered its place this function of the sovereign like every other was under national control.

The opening of a new era.

The attitude of the kings,

\section{Personal} characteristics.

563. Character of the Stuart Period. - With the accession of James I., the first of the Stuart kings, there opened a new age in the history of the English constitution. The period of the suspension of parliamentary control had come to an end. The time of national danger, when it was necessary that the strength of the State should be directed by a single will, and when civil strife was more dangerous than temporary submission to arbitrary government, was now past. Parliament was ready to resume its direction of the nation's policy, and to begin once more the steady building up of the constitution.

These intentions of Parliament came by degrees, however, into direct collision with the intentions of the kings. The Stuart kings were by no means disposed to surrender the influence over public affairs which the Tudor kings had exercised.

564. Reasons for the Attitude of the Kings. - The attitude of the kings was partly due to the personal characteristics of the Stuart family. Nearly all its members were men of small intellectual gifts, of little political insight, shortsighted and of poor judgment, but with the highest ideas of their own rights, and with that determined obstinacy of purpose which often accompanies these other characteristics.

Ihe question The attitude of James I. to the constitution was also of title. Hallam, Cons. Hist., I., first pages of Chap. VI. ; Prothero, 250. partly due to the fact that by the parliamentary arrangement of the succession, made in the reign of Henry VIII., his title to the throne had been postponed to that of the descendants of Henry's younger sister, Mary. It is evident that on the death of Elizabeth, the will of the nation was entirely 
In favor of the accession of the king of Scotland. There was, in fact, no real opposition to it. But the existence of this legal defect in his title seems to have disposed James to emphasize the indefeasible right of hereditary succession and to have prepared the way for a union, which was indeed an entirely natural one between the Stuart kings and the growing party of those who held to the doctrine of divine right.

\section{A Third Reason of Strife, the Religious Parties. -} One further reason of the fact that the constitutional history of England in the seventeenth century passes through a great civil war, is to be found in the gradual separation of the nation into two great parties on religious questions. One of these, while desiring to free the national Church from the government of the pope, and to change the most distinctive of the Roman Catholic doctrines, like that of trans-substantiation, was disposed to retain just as much as possible of the old church both in organization and in forms, and was unwilling to take formal sides on minor points of doctrine with any of the sects which were arising in the Protestant world.

On the other hand a large and increasing body in the nation was determined to carry the reformation further, both The Puritan party. in doctrines and in forms, and in the matter of organization wished to give the national Church a constiution which would make it republican in government, or even democratic. The fact that this body was strongly inclined to the spirit and teachings of Calvinism, which was a fighting faith, made it ready to take up arms and enter upon a civil war in defence of what it believed to be the right. Each of these two parties found itself to a considerable extent in a natural alliance: the one with the idea of the divine right of kings to govern, and the other with that of parliamentary supremacy.

566. Slow Advance towards War. - During the reign of James I. there was a growing opposition between the king and the Parliament, a growing determination on the part of

The conservative party.
Nearly a half century of disagreement. 
James l., TaswellLangmead, Cons. Hist., $405-444$; Montague, Ele'ments, II 5-II8.

The Petition of Right, 1628.

Text and comment.

Tasweli-

Langmead, Cons. Hist., 4+4-461:

text,

Gardiner, I ; Old South, 23; Lieber, Cavil Liberty'; Stubbs, 5I5.

The difficulty of a revenue. Montague,

Elements,

I $20 \mathrm{ff}$. :

Gardiner,

5. I6, I7.

Ship-money. Taswell-

Langmead, cons. Hist., $+67-47^{6}$; Gardmer, 37-54; Old South, 60.

The Scottish war. each to insist on what it believed to be constitutionally right ; but there was no open breach between them and no irreconcilable conflict. In the reign of Charles I. matters by degrees progressed to a square issue between king and Parliament.

567. The Second Great Constitutional Document. - Very soon after the accession of Charles, Parliament drew up the second in the series of great constitutional documents which declare and confirm our liberties, the Magna Charta being counted the first. This is called the Petition of Right, and it was made a statute law with the consent of the king in I628. It is exactly similar in spirit and character with the line of great documents already referred to, for its purpose is to state the rights of all citizens which have been infringed by the action of the king, and to secure them from such infringement in the future. But though he had consented to this statute, Charles had no intention of abandoning what he regarded as his rightful prerogatives, and before many months this Parliament was dissolved by the king in anger at its insistance upon its own will.

568. The Period of Rule without Parliament. - The king now resolved to rule without a Parliament and was able to do so for eleren years. The greatest difficulty of such a method of government was to provide a sufficient revenue, for all the usual sources of income were now dependent on the consent of Parliament. The ingenuity of one of the king's ministers revived an old form of taxation, called "ship-money," by which the king had apparently the right to require the different cities and counties to furnish ships for the defence of the kingdom, and this was used to obtain money ostensibly for the strengthening of the navy, but really for the ordinary expenses of the State. The refusal of Hampden to pay this tax led to a trial of the case in the courts, and though the judges decided in favor of the king, the nation was aroused to a consciousness of the danger.

Just at this moment the king had involved himself in a war with the scottish people by attempting to force them to 
use a liturgy in church services to which they were bitterly opposed. They drew up in consequence the famous "Covenant," and took arms in its defence. The expense of this war could not be met without more regular sources of income, and Charles was forced to call a Parliament, which met in April, I640, but remained in session only three weeks. No agreement could be reached about the ship-money, and the king again dissolved the Parliament in anger.

569. Charles forced to a Temporary Submission. - For a few months Charles managed to sustain himself by even more arbitrary methods than before, but the failure of his campaign against the Scots turned the feeling of the army against him, and he was forced to yield. In November Parliament met again, a Parliament which was to continue in existence until after the death of the king, and which is known as the Long Parliament. At the begimning of this Parliament the popular or constitutional party was very strong, and its spirit was one of most determined opposition to the arbitrary govermment of the king.

Its first act was to impeach the earl of Strafford, the king's minister, of treason. The feeling was especially bitter against him because he had been earlier one of the leaders of the popular party, but had now gone completely over to the king. When it was found that under the statute of treason he could not be proved guilty of that crime, Parliament accomplished its purpose by passing a bill of attainder, that is, a special law declaring him guilty, and sentencing him to death by act of Parliament. Strafford hoped to the last that the king would save him, but Charles was not yet ready to accept the full personal responsibility of his conduct by coming to an open breach with Parliament, and preferred to sacrifice his minister.

570. Further Concessions of the King. - Parliament then proceeded to strike at the measures of the king. Shipmoney and the Star Chamber tribunal were declared illegal, and an act was passed to enable Parliament to meet without

The

"Covenant."

Text in

Gardiner, 54 :

Old South,

25.

The meeting of the Long

Parliament, Nov. $3,1640$. Tasuell-

Langmead, Cons. Hist.,

602 , and reference there to Clarendon.

Parliament holds the king's minister responsible. Boyle, Charendon, $63-78$; Gardiner, 85 ; Old South, $6 \mathbf{I}$.

Really enough to restore the constitution. Gardiner, 7f, 88-122. 
the sanction of the king, if he should allow three years to pass without calling it together. To these and other demands Charles seemed readily to give way, and if his concessions had been honest and the Parliament could have had confidence that his future conduct would have been in accord with them, the English constitution would have been preserved without any violent or unconstitutional measures.

The king not trusted.

The party of moderate royalists growing.

The Grand Remonstrance.

Boyle, clarendon. 82-85; text, Gardiner, I27; Old South, 24.

The case of the five nembers. TaswellLangmead, 496-503; Boyle, Clarendon, 88-94.
It was perfectly evident, however, that the king regarded these concessions as only temporary, and that, as soon as circumstances enabled him to do so, he would declare them void because they had been extorted from him by force. This made the most earnest defenders of the constitution very suspicious and watchful, and disposed to more extreme measures.

On the other hand many, who up to this time had been acting with the opposition to the king, began now to think that enough had been demanded of him, and that further concessions would reduce the royal power to a shadow. As a result, the constitutional party in Parliament began to decrease in numbers and the moderate supporters of the king to grow more numerous.

57r. The King determines to resist. - In these circumstances, at the opening of the second session of the Long Parliament, the popular party proposed the adoption by the Commons of the Grand Remonstrance, a formal declaration of their position, and to appeal to the support of the nation. This they were able to carry by only a small majority. Now Charles determined to abandon the policy of concession and to adopt that of resistance.

His first step was to lay before the House of Lords an impeachment of treason of five members of the Commons, including Hampden and Pym, the leaders of the constitutional party. This was an illegal step on the part of the king, since he had no right to make use of an impeachment trial, but only of a jury trial in the ordinary courts. A still greater violation of right was his invasion in person of the House of Commons to try to arrest the five members. The 
attempt was a failure, and the incilent served only to embitter both sides and to aid in convincing them both that an appeal to force would ultimately be necessary.

The open issue came on a struggle between the king and the parliamentary party for the control of the militia in the counties on which much would depend if civil strife should begin. The Parliament was successful in this because the popular sympathy was on its side, but Charles would not give his consent to their arrangements, and on the $22 \mathrm{~d}$ of August raised his standard at Nottingham and began the civil war.

572. The Constitutional Character of the Commonwealth. - IVe are not concerned here with the details of the "Great Rebellion." The governments of the Commonwealth and of the Protectorate are hardly in line with the special, or perhaps it would be more accurate to say with the contemporary, development of the English constitution. But they are in harmony with the deeper spirit of that development which was already at that time showing itself, as it has since continued to do, in the wider Anglo-Saxon world beyond the seas, and which has come into control in England also, in reality if not in form, in the last part of the nineteenth century.

Before the organization of the commonwealth, the Puritan party had founded in New England a series of republics with a strong ultimate tendency towards democracy, and the other colonies in America, as all later English colonies have been, were virtual republics, with the same democratic tendency more or less perfectly realized according to circumstances.

The constitutional documents of the commonwealth period have an especial interest for us because of a certain resemblance in some of the innovations which they made, which were to pass out of use immediately in England, with expedients which the framers of the Constitution of the United States afterwards adopted. The written constitution itself is one of these which has never been adopted in England. But the monarchical drift was too strong in

The war begun. Gardiner, $16+-182$.

Not in the direct line of English development.

The English republics in America.

A slight foreshadowing of American institutions. See Gardiner, 270 and 314 Old South, 26 and 27. 
The commonwealth becomes a monarchy.

Charles II. lioyle, clirendon, 286-290.

James II.

His arbitrary acts.

Taswell-

Langmead, Cons. Hist., 530-538; Montague, Elements, I $44-146$.

William of Orange invised to England.

England in the seventeenth century. Few of the Puritans themselves were out-and-out republicans. Very likely also the situation really demanded a king, and the commonwealth passed into what was really a strong monarchy under the Protectorate.

573. The Later Stuarts. - The Restoration in 1660 brought the Stuarts back in the person of Charles II. He had learned some wisdom from the past, and was careful not to allow himself to come to an open breach with the Parliament, though in the last years of his reign he showed a decided tendency to arbitrary methods, and seemed to be preparing the way for an absolutism.

\section{prepang the way for an ablis}

His brother, James II., had the Stuart characteristics in their worst form. He was extremely short-sighted, obstinate, and determined to rule by his own will; and his attack on the constitution was nearly as thorough-going as that of Richard II., though it never had any chance of success. He ordered the illegal collection of taxes; gathered a standing army of unusual size with which he hoped to overawe opposition; forced the judges to support his policy; and with their aid exercised the right which he claimed of suspending the operation of laws. So rapid was the development of the king's purposes, and so great the fear of the Roman Catholic religion, which he openly professed, that all parties were united in a determination to protect the constitution.

574. The Revolution of $\mathbf{r} 688$. - The crisis was brought on by the birth of the Primce of Wales. Till that event, the Princess Mary, wife of William of Orange, had been the heir of the throne, and the nation had had reason to expect a change on the death of James. Now this hope was destroyed, and revolution seemed the only recourse. An invitation was at once sent to William by leaders of both parties, and on the 5 th of November, 1688 , he landed in England with a small force. James' power immediately crumbled in his hands. His supporters abandoned him, and in six weeks he was a fugitive in France. 
With the expulsion of James II. the last attempt failed which any English sovereign has made to throw off the bonds which the gradual growth of the constitution had placed on the exercise of an arbitrary authority. Some later kings have attempted to influence the policy of the State according to their own ideas, but never to the extent of an open breach with the constitution.

575. The Results of the Revolution. - The convention Parliament, which assembled soon after the flight of James, drew up a formal statement of the arbitrary acts of the king and declared them illegal, and it was on the condition of accepting this declaration that William and Mary obtained the throne. This declaration was soon afterwards embodied in a regular statute, called the Bill of Rights, and takes its place among the great constitutional documents of our history. Some of its clauses are closely copied in the Constitution of the United States.

So far as the larger principles of the constitution are concerned, the revolution of I688 did no more than to restore what already existed under the Lancastrian kings in the fifteenth century, but these principles were now defined in the clearest way and rendered safe from any future attack. The attempt of the Stuart kings to free themselves from restraint had led to a more definite understanding of the constitution, and this was a gain of the greatest importance.

In minor points some positive advance had been made: in establishing the independence of the judges, so that in the future they could not be used as the tools of the executive; in placing the army more completely under the control of the legislature; and in protecting the citizen more perfectly from arbitrary arrest and unfair trial.

576. Constitutional Questions in the Colonies. - In the meantime the English colonies in America had so increased in population and strength that they had become themselves interested in constitutional questions, and that the government at home had begun to look upon their virtual indepen-

No revolution again necessary in England. Medley, Mamual. Secs. 45 and 46 .

The Bill of Rights.

Text, Old South, I9; Stubbs, 523; Lieber, Civ'il Liberty'; TaswellLangmead, Cons. Hist., 5.43 .

A clearer understanding of the constitution.

In some details a real advance.

Growing in interest and importance. 
The government of Andros.

Struggle to subject the executive to the legislature.

Perfection of details.

Acl of Settlement. Montague, Elements, 153-156; text, Stubbs, 528 ;

TaswellLangmead, Cons. Hlist., $55^{\mathrm{I}}$.

Growth of cabinet system. Montague, Elements, 163-173.

Difference in executive dence with some suspicion. The last two Stuarts included a consolidation and increase of the royal authority in America among their plans, and towards the close of the reign of Charles I. the charter of Massachusetts was annulled.

Soon after Sir Edmund Andros was made governor of all the northern colonies and established a " tyranny "in America similar to that of James II. in England, but on the news of the revolution in the mother country he was at once deprived of power and thrown into prison.

In most of the colonies the history of the eighteenth century is the story of a struggle between the appointed royal governors and the elected legislatures, in which the legislatures were winning more and more power by taking advantage of the financial necessities of the executives, a process which is closely like in detail, and entirely so in principle, to that by which the Parliament in England had established its power over the king.

577. Progress in the Eighteenth Century in England. The constitutional history of the eighteenth century in England continues that of the revolution. Some of the great principles were more clearly defined, some minor advances made, and some better government machinery devised. The Act of Settlement, by which the throne was secured to the house of Hanover, proclaimed in the clearest way the right of Parliament to declare who should be king, and to give a title to the crown better than all others. The civil liberty of the citizen received further protection - in the perfection of the jury trial, for instance, and the prohibition of general warrants - and the development of the modern cabinet system provided more simple machinery for the control of the policy of the government by Parliament, though the perfection of this new device came only in the nineteenth century.

578. The Constitution of the United States. - We have already seen how one result of the struggle between England and France for colonial empire was the independence of the thirteen colonies. When the Americans came to frame their Constitution, the fact that they wished to create a republic 
instead of a monarchy led to some changes of form from the English constitution. The most important of these changes from the constitution as it then existed in England was the fact that both the executive and the upper house of the national legislature were made elective, and both these institutions were given such a place in the government that in the hundred years since their founding both have gained in power rather than lost it, as in England.

The difference in form which seems to us now the most striking is that in the relation of the cabinet to the lower house, but it must be remembered that at the close of the eighteenth century statesmen even in England did not realize that relation clearly. It is the experience of the nineteenth century which has brought the forms under which the House of Commons now controls the cabinet to their full perfection.

In the English system the prime minister is the real executive, and not the sovereign. He forms his cabinet of the other leaders of his party, and they hold office so long as the measures which they propose command the support of a majority of the House of Commons. When one of their measures is defeated, either the cabinet resigns and the leader of the opposite party forms a new one, or the Parliament is dissolved and the voters of the nation are asked to decide between the two lines of policy advocated by the opposing parties. The election determines at once whether the old cabinet shall go on or a new one be formed from the other party.

579. Tendency towards Democracy. - Though differing in this way in form, still in principle and in almost all minor details, the Constitution of the United States is thoroughly Engtish. Other differences than those of form are chiefly more rapid advances along the road which the race had long been following, and in which England herself was to advance more slowly. This is especially true of the most important of these differences - the more democratic cast of our government. The colonies had always been demo-

The English cabinet system. Medley, Manual, Secs. I6-17; TaswellLangmead, Cons. Hist., $55^{6-57 \text { I ; }}$ Montague, Eleme'nts, 2I 5-222.

Democracy adopled first in America. 
More

gradually adopted in England.

Videly adopted throughout the world. cratic in spirit, and though democracy was not perfectly realized in practice at the time the Constitution was adopted, still the drift in that direction was so strong and so thoroughly in harmony with all the tendencies of the race that this realization was not long delayed in America.

In England the first steps towards a more democratic government would undoubtedly have been taken before the close of the eighteenth century had it not been for the French Revolution, which naturally, but somewhat needlessly, alarmed the property classes. As it was, the first step was postponed a generation, and was finally taken in the first Reform Bill which was adopted in $\mathrm{I}_{3} \mathbf{3}_{2}$. Since then, by a series of such bills at intervals, the qualifications required of the voter have been gradually reduced until now there is hardly a man in England who cannot become a voter if he cares to be one.

580. Anglo-Saxon Institutions in Other States. - In the past hundred years the Anglo-Saxon constitutions have been widely adopted throughout the worl, almost every civilized nation of the present time having imitated more or less closely some of our institutions. As most of these states retain monarchical forms, and desire a constitution which will be at once monarchical in name and republican in fact, the English constitution has been rather more extensively imitated than the American. Even the French republic follows the English molel, and it must be admitted that the English cabinet system secures to a democracy, more perfectly than the American, a control over the government policy. It is, however, open to question whether this will be considered in the long run an advantage, and whether the American cabinet system, combined with a stronger executive, does not furnish a check to hasty action very necessary in a thoroughly democratic state - a need which England is more likely to feel in the twentieth century than she has in the nineteenth.

58I. The Common Work of England and America.Besides furnishing an example for the imitation of other 
states, each of the two great Anglo-Saxon nations has had its own special mission. That of the United States has been to establish these principles of liberty throughout an empire nearly twice the extent of the Roman, and to absorb into the race and train in self-governing freedom millions of aliens who have come to them from other nations. England's has been to establish the same liberty throughout vast regions of the world, on every continent and in great island states, and to undertake the gigantic task, greater even than America's, of training up to freedom millions upon millions of alien and uneducated races. These are, in truth, but different phases of the same task, and together in this common mission, in harmony for the political freedom and best good of all the world, our race ought to be able, both by its example and by its power to protect the right, to prevent any further extension of tyranny and by degrees even to banish despotism from the world.
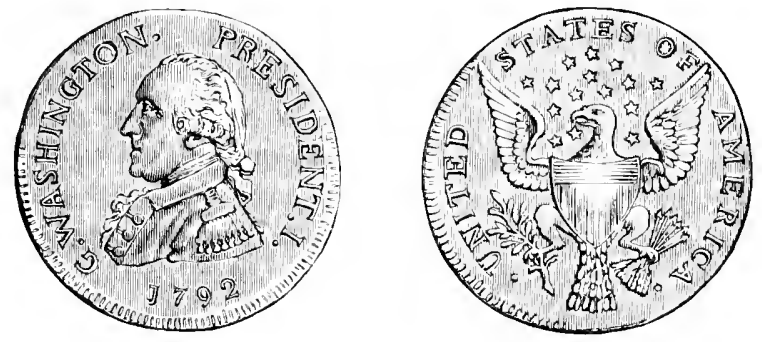

\section{Topics}

Why is the study of Anglo-Saxon institutions especially important? The government of the first Norman kings. What led to the charter of Henry I.? The character of this charter. How was the principle involved in the charter extended under Stephen? The government of the first Angevin lings. I escribe the judicial system organized by Henry II. What do we derive from it? Why was King John involved in special difficulties about taxation? How did this lead to the Magna Charta? The contents and meaning of the Magna Charta. Its special importance in the growth of the constitution. How was the right of 
insurrection used under John and under Henry III.? The beginning of the idea of a limited monarchy. The steps which led to the formation of Parliament. What were knights of the shire? What led to their use as county representatives? The first town representation. The " model Parliament." Just what was the institutional change which created Parliament? How did Parliament secure finally the right to control taxation? State the four great rights established by Parliament in the fourteenth century, and how each was gained. In how far was England then a limited monarchy? What was involved in the revolution of I 399 ? How was the right of deposition established, and of what earlier right was it the logical outcome? How was this right carried still further in I 399 ? Later development of this right. The progress of the Lancastrian period. The constitution in the Yorkist period. The institutional character of Tudor absolutism. What circumstances of the time made a strong government necessary ? Specific instances of Tudor arbitrary rule. Change in the constitutional position of the Church. In what respects was the situation changed at the accession of the Stuarts? Reasons for the attitude of the kings. Parties in England. Character of the Petition of Right. The steps which led to civil war. What constitutional rights were involved? Construct Charles I.'s argument for his case. The relation of the commonwealth to the growth of the constitution. The policy of the later Stuarts. Compare the revolution of 1685 with that of 1399 . The Bill of Rights. What did the revolution of I $6 S S$ accomplish? How were the colonies involved in the Stuart troubles? What were their own constitutional problems? The eighteenth century in England. Why was not the American Constitution exactly like the English? What are the chief differences? Explain the English cabinet system. The difference in the two states in the progress towards democracy. Anglo-Saxon institutions in other states. The special missions and the common work of England and America.

\section{Topics for Assigned Studies}

The judicial system of Henry II. Medley, Mamual, Secs. 51 and 52 . Taswell-Langmead, Cons. Ifist., 1 29-143. Montague, Elements, 31-33, 47-50; Social England, I., 2S5-29S; Penn. I., No. 6, $2 \mathrm{~d}$ ed.

Compare the Declaration of Independence and the Constitution of the United States, especially Amendments I.-VIII., with the Bill of Rights.

The reform bills. Nontague, Elements, 206-2I2. Medley, Manual, Sec. 32. Taswell-Langmead, Cons. Hist., 606-610. Speech of Macaulay on first reform bill, in Adams, British Orations, III., 62, and in Political Orations (Camelot Series), 295. 
Important Dates for Review

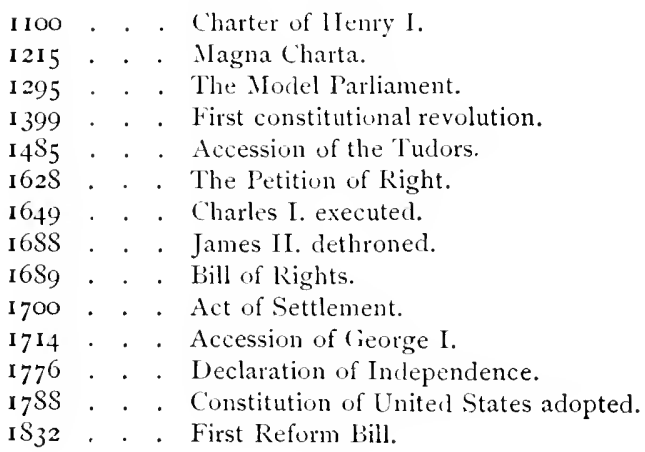




\title{
CHAPTER IX
}

\author{
SCIENTIFIC AND ECONOMIC ADTANCE SINCE THE \\ RENAISSANCE 1
}

\section{Books for Reference and Further Reading}

Meyer, History of (timistry. (Macmillan ; \$4.50.)

Sachs, History of Botanl. (Clarenton; \$2.50.)

Clerke, History of Astrommy during the rinetenth Century. (Nacmillan; \$4.00.)

Lubbock, Fifty lears of Situce. (Macmillan.)

Cunningham, Growth of English Industry and Commeres in .Modern

Times. (Macmillan; $\$ 4.50$.

Traill, Sockil Englunt. Vols. III. to VI. (Putnam; \$3.50 per vol.)

The First (intury of the Refublic. (IIarper.)

Kambaul, Histoire de la ("iritisution Contemporaine en France. (Paris: Colin.; 5 francs.)

Escott, Social Transformations of the Tiatorian Age. (Scribner; \$2.00.)

Wallace. The Wondergl Century. (Dodu, Mead \& Co. ; \$2.50.)

Rugers, Six cinturies of IVork and Wages. (Putnam ; \$3.0o.)

In the first part of the sixteenth century.
582. The Close of the Renaissance. - As we have already seen, the first great intellectual age of modern times, and the first agre of great economic changes was the fifteenth century, the age of the revival of learning with the invention of printing, and of the oceanic discoveries, east and west, with their commercial and economic consequences. We have also seen how this age came to a rather sudden close, involved in the equally great revolutionary age which

It is probable that this chapter, like the preceding, will be found to have its greatest value for advanced classes.

Much of the history, which is covered in outline by this chapter, has still to be written, and as a consequence both the bibliography of the chapter and the specific references are incomplete. 
followed the teaching of luther, in the European wars and the ciril wars which fillerl the whole remaining part of the sixteenth century. The result was that science, which had male so good a beginning in the work of Copernicus, took no further step in alvance in the century, and even classical learning, which might rightfully claim the highest achievements of the fifteenth century, passed into a new age of scholasticism, dominatel hy the rules of a barren style, and with a new dictitor in Cicero, as absolute as Aristotle had been in the earlier scholasticism.

583. The Great Age of English Literature. - With the closing years of the sixteenth century there begin to be sigus of a new age of intellectual activity. This is particularly true of England in the field of literature, as if the stimulus of the great struggle for life and death with Spain had been immediately felt. This was a conflict, indeed, well calculated to guicken mind, fought as so much of it was in the waters of the new work, in the mirlst of strange and thrilling scenes, and with all the enthusiasm awakened by desperate odhs and the most invincible conrage.

The finest products of the age of Elizabeth were in the form of dramas. This would naturally be the case. An age of great achievement is an age which delights in storytelling, and the romances and novels of a time when books were expensive and little general reading was done, were most easily published upon the stage. The greatest of the dramatists was Shakespeare, but the fact that in the mind of to-day he seems to stand almost alone for the whole age, should not make us overlook the very rich product of the minor dramatists, especially of Ben Jonson, Marlowe, and Beamont and Fletcher.

584. A Greai Age of Scientific Work. - The great work of the seventeenth century, however. greater even than its literature, was to be its science. A connecting link between the two forms of intellectual activity in England was Francis Bacon, whose Essays were a permanent contribution to Dramatic literalure. literature and his Adiedncement of Learning to looth. He

Lord Bacon. Wright's Bacon's Adianciment of Learning (Clarendon). 
attacked with vigor the scholasticism of his day, and proclaimed in language eloquent and convincing the necessity of observation and experiment and of the inductive method. If Bacon's services in the actual and practical development of modern science would not now be estimated so highly as formerly, he at least influenced individual students and in the right direction.

Already, independently of any influence of Bacon's, the science of the seventeenth century, probably the greatest age of modern science considered in its relative accomplish-

Kepler and Galileo.

Sir Isaac Newton.

Great pogress during this age. ment, had begun in the work of Kepler and Galileo. On the basis of the Copernican theory of the solar system, Kepler explained more accurately the orbits of the planets and stated the three fundamental laws of their motions. At the same time Galileo in Italy placed the truth of the Copernican explanation of the solar universe beyond all doubt by discovering the moons of Jupiter and the fact that Venus shows the same phases as our moon.

585. The Law of Gravitation. - These great discoveries formed the foundation for much detailed work of value in the years that followed. Before the century closed, its marvellous progress towards a right understanding of the universe was completel by the discovery of the law of gravitation by Sir Isaac Newton. This discovery, agreeing with the laws of Kepler and with the known facts of observation, and tending to take the place of the somewhat speculative theories of Descartes in regard to the physical constitution of the universe, which nevertheless harl been of service in the progress of science, completed the mathematical and practical demonstration of the new astronomy, and placed the science on the most solid foundation.

Comparing what was known in this field in the year 1600 , with what was known at the death of Newton, we are forcerl to say that even the nineteenth century has not broadened the field of human knowlerlge more than did the earlier age, nor in any more important respects has it given us new or more accurate conceptions of the physical universe. 
586. The International Character of Science. - In a very interesting way this earlier progress of astronomy illustrates one feature of all motern scientific study - its international character. The first step, the statement of the heliocentric theory, was taken by Copernicus in Poland. This theory was definitely proved by Galileo in Italy, lut his work was rendered possible only by the hint, at least, of the telescope which came to him from Holland. The demonstration was completed by Kepler in Germany, but his work was based upon data fumished by the observations of Tycho Brahe, the Dane. The final step was taken by Newton in England in the establishment of the law of gravitation, but in order to complete his proof he was obliged to wait for the correct measurement of a degree of latitude by the Frenchman l'icard. Almost every people of Europe had its share in this great building.

587. Advance in Other Sciences. - No other science of the seventeenth century was so far advanced as astronomy, but in several preliminary work of great importance was done, and in some advances were made almost as revolutionary in character as those in astronomy. Galileo's discoveries in physics rank second only to those already mentioned. In mathematics the introduction of logarithms by Napier, and in medicine the discovery of the circulation of the blood by Harrey, both coming in the early years of the century, imparted a new impetus to the progress of these sciences.

588. The Idea of the Reign of Law. - Taken altogether, so great was the progress of science in this age that sometime before its close we notice one result of it on men's general ways of thinking which had important consequences far outside the field of science proper. This was in the conception of law and its operation in the nuiverse, which, in the way in which we hold it to-day, now comes into general thinking for the first time. It was, of course, in the fiell of science a most fruitful idea, but more interesting results for us lay in other directions.

A result of the progress of science. 
The philosophy of Locke.

Attack on the idea of a divine revelation.

Infuence on Christian liwught.

Influence on the age of revolution.

Voltaire and Montesquieu.
Upon this idea, as its fundamental conception, was based a school of empirical or sensational philosophical teaching, whose most famous learler was Locke. He developed the new philosophy in most interesting ways in psychology, education, and the science of government, with results, in this last direction at least, which were long and widely felt in France and America.

589. The English Deists. - A still further manifestation of this belief in the reign of law was the party of the English I leists, who failed to reconcile in their own minds this new idea with the older one of miracles, and a supernatural govermment of the world, especially as related to a divine revelation. Their exceedingly vigorons attack upon these notions forced the leaders of Christian thought to a review of their position, and to much clearer conception and sharper definition than ever before of their religious ideas, especially those concerning the method and plan of revelation: and thongh these have been in turn superseded in many most essential points by the still clearer thinking of the nineteenth century, they nevertheless represent a great arlvance in our understanding of the dealings of Providence with mankind.

Ijut the influence of this school of thinkers upon the religious ideas of the world does not exhaust its historical importance. Through them the scientific morement of the seventeenth century and the intellectual changes which resulted had their influence on the great revolutionary movement which was to be characteristic of the eighteenth century.

590. Leaders of French Thought in England. - Early in that century there came to England refugees from the persecution which too bold thinking entailed in France. The most famous of these were Voltaire and Montesquieu. In England they came in contact with three clifferent lines of influence, which affecter in a marked degree their later efforts for reform: English civil liberty, which, though not as complete as in the nineteenth century, was far in 
advance of anything in France; the political philosophy of Locke; and the ideas of the Deists, especially the idea of bringing old beliefs to a searching, critical examination. Their English training and observation clarified and fixed their ideas, and gave definite aim and purpose to the strong demand for reform to which they had already given voice - a demand which had not unnaturally made itself felt under the absolutism of the French kings and the abuses of all sorts which accompanied it. They returned to france and carried on the attack with new ammunition and redoubled energy, imparting to the nation the conceptions of government and of freelom, intellectual and political, which they had gained.

The influence of these ideas in preparing the way for the French Rerolution we have already seen. But their influence was not confined to France. Through France they spread to all Europe, and, though checked in their immediate operation by the fears which the Revolution excited in the European govermments, they have, reënforced by other influences, brought forth abundant fruit in the nineteenth century.

59I. French Intellectual and Social Leadership. - France exercised in the eighteenth century a kind of despotic sway over the minds of men. Her great power under Louis XIV, and long and fairly successful struggle against almost all Europe ; the brilliance of that age in literature: the great age of the French drama, of Cumeille, Moliere, and Racine; the refinement of the lirench language, as compared with most other European tongues; and the grace and elegance of French fashionable life,--ali these had combined to give to France an intellectual and social influence over the entire continent which made her a leader and teacher through the whole eighteenth century, so powerful an influence indeed that some traces of it remain even at the present time under wholly changed conditions. French became a kind of universal language, and to imitate Versailles and the French court a sort of religion.

Imitated by all the continent.
Through France they influence Europe.
Influenced by English icleas. Norley, Ioltaire (Ma'millan), 94 . 
Reform by paternal governments. Stephens, Piriods, 4-5.

An age of preparation. 'Taine, Ancie'llt Risime, I $70-174$.

592. The Benevolent Despots. - The works of the reformers, which were rather the fashion in France, notwithstanding their attacks on Church and State, were eagerly sought for everywhere and carefully studied by statesmen and sovereigns. One interesting result was the attempts which were made by the so-callerl benerolent despots, especially by Joseph Il. of Austria, but even by Frederick the Great and Catherine II. of Russia, and by statesmen like Pombal in Portugal, to introdnce refurms by paternal methods. These attempts all came to failure, as it was perhaps inevitable that they shoull, based as they were on pure theory and carried out uniler the direction of absolute govermments; but they serve to show us clearly how strong the belief in the necessity of reform had come to be, even among the highest classes, and this was one of the most important conditions of the success of the Revolution. For this belief on the part of those most interested to preserve the old abuses undermined their power of resistance when the people began the attack.

593. Character of Eighteenth Century Science. - In regard to its larger intellectual features we may say of the eighteenth century that it was, on the whole, an age of destruction rather than of construction, and yet the work which it did in the alvancement of science was of the utmost importance. It may be called a great age of observation and experiment, of the collection and clissification of facts, rather than of the discovery of new laws or of great advances in the understanding of the universe as the seventeenth century had been. It wals a time of bringing the old theories to the test of scientific criticism, of becoming conscious of their clefects, and of preparing for new and letter explanations by the careful marshalling of related facts. There were some by no means slight advances made, but the great work of the eighteenth century in science was to make the necessary preparation for the progress of the following age. The wonderful scientific discoveries of the nineteenth century were possible because the eighteenth had cleared the way and provided the means. 



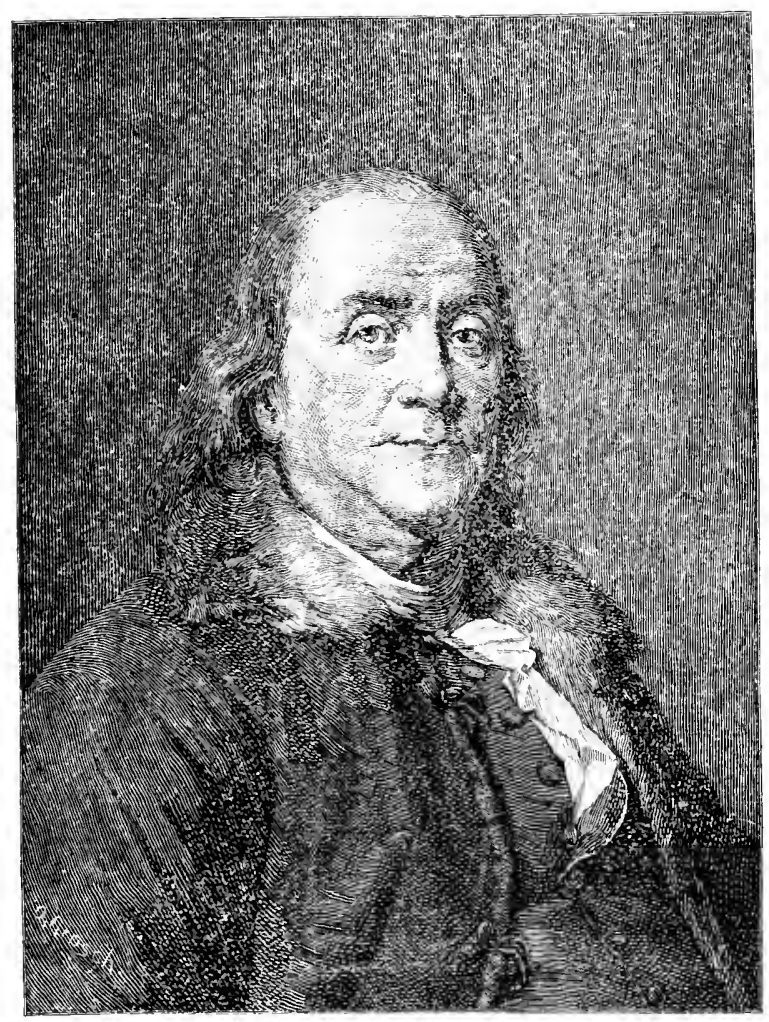

BLNTMIN FRBNKLIN 
594. Positive advances in Science. - Two particularly important advances of the eighteenth century must not be overlooked. One was the discovery of oxygen and the understanding of the true nature of combustion which followed, overthrowing the old theory of phlogiston which had been the ruling explanation for nearly a hundred years. The other was the work of Laplace in astronomy, published just at the end of the century, which put the knowledge of the time into still more scientific form, and made a most valuable slygestion for the future in the statement of the nebular hypothesis. In the natural sciences much better methods of classification were introduced than ever before, in botany by the work of Linneus, and in zoölogy by that of liuffon and later of Cuvier. The stuly of these sciences advanced so far, indeed, as to afford some foregleams of the grealt discovery of the nineteenth century, - the theory of evolution, - of especial interest in the case of the elder I)arwin, grandfather of the author of the "Origin of Species." In medicine the introduction of inoculation for the small-pox must not be forgotten, the first step towards the wonderful immunity from certain especially dangerous diseases which we are now on the ere of acquiring, nor in physics the beginning of the scientific study of electricity in the work of Volta, Galvini, and Franklin.

595. A New Science. - One new science, which in our own time has reached most important conclusions, dates its beginning from the eighteenth century, - the science of political economy. Colbert at the close of the seventeenth century had held certain theories, chiefly concerning government supervision of industry and commerce; but thinking in regard to the production and distribution of wealth had never taken any organized form until the rise of the school of the Physiocrats in France. Quesnay may be called the funder of the science. The new ideas were enlarged by (iournay and later still by 'lurgot, but the work which gave the new science its definite form was Adam Smith's "Wealth of Nitions," published in Scotland in 1776.

Botany and zoülogy.

Darwin, (1)igin of Species. Pieface to Am. edition.

Iolitical economy. 
A succession of inventions. Cunningham, Industry and Commerier, Wodern, $4+7-+75$; Firsi Century of Ripublic, Chap. II.

596. The Age of Machinery Begins. - In one direction the eighteenth century brought about as revolutionary changes as any produced ly the nineteenth, in the introduction of the great age of machinery in manufacturing. between 1760 and 1800 a series of most remarkable inventions and improvements followed one another with unheard of rapidity. The steam-engine was so greatly improved that it could be put to practical use for the first time, and we are in the habit of saying that it was then invented. A

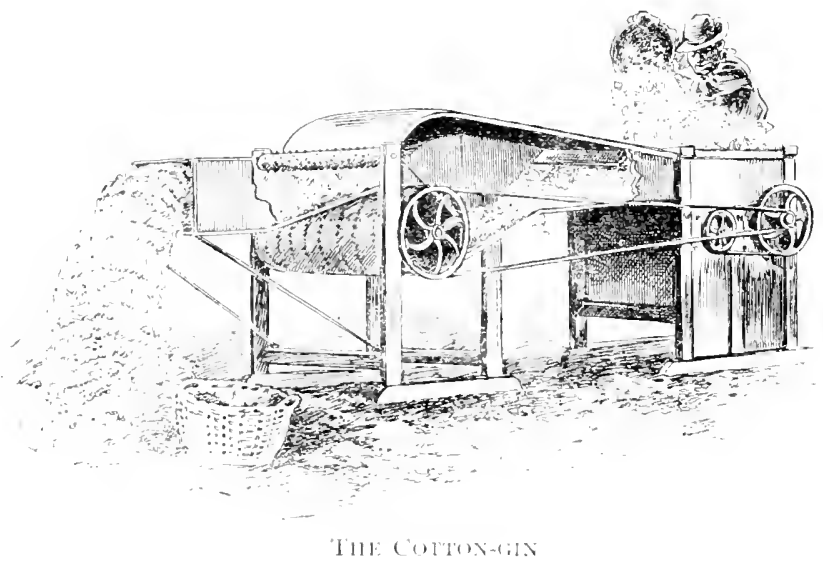

succession of insentions of machinery for spinning and wearing, by Hargreaves, Arkwright, Compton, and Cartwright, revolutionized the making of cloth. At the same time improvements in the mining of coal began to furnish a sufficient smply of fuel for these new demands, and by leading to new processes in the manufacture of iron and steel met in another direction an equally strong demand of the age of machinery. Finally the invention of the cottongin, by Whitney in America, enabled the producers of the raw material to keep pace with the manufacturers, and to share in the benefits of the new era.

597. The Effect upon Manufacturing. - It was a new era 
indeed, and its results touched almost every side of life. In manufacturing there was a complete transformation. $\mathrm{Up}$ to this time everything had been upon a small scale and The fictory system made necessary. entirely unorganized. In the making of cloth of all kinds, for example, the most important industry before the nineteenth century, nearly everything was done by inclividual effort and in the houses of the workmen. Now not merely was there an opportunity for the employment of capital on a lirger scale, but there was a necessity for it if the new machinery was to be properly housed and operated. This was the heginning of the factory system. It meant the collection and careful organization of all parts of the process in one concern, and the employment of larger and larger amounts of capital until the enormous enterprises of the present dily were reached.

598. The Effect upon Labor. - The transformation of the laboring class was just as great. The factory system brought the workmen together, and put them by hundreds into the employ of a single concern to which they lookerl, not merely for payment, but for the direction and supervision of their labor. 'The workman was no longer, as he had been, his own employer, working when and how he pleased, and disposing of the product of his labor to the workman of the next stage for whose labor it was the raw material, and in the mean time living in a little viliage or even on a small farm which he also tilled. Now what he sold was not the product of his work, but his work itself under fixed rules and conditions, and he must live with all the other employees of the concern in the immediate neighhorhood of the factory.

The making of this transformation by the laboring class was a very painful process, and the first results seemed to be disastrous. Olu-firshioned labor could not easily adapt itself to the rhange, and thousands found themselves deprived of their means of sustenance. Jack of experience led to many evil consequences from the crowding together of the workmen in the new towns, and the same reason put them at first rather at the mercy of their employers. The

The workman sells liabor instead of the products of labor.
The first effect disadvantageous to labor. 
result was both a great increase of poverty and suffering among the laborers, and the growth of a bitter feeling of Craik, hostility towards the capitalist who seemed to be reaping the Folun Halifiri, Gentleman (novel). only benefits from these changes and towards the new machines which had brought them about. Frequent machinebreaking riots gave expression to both these feelings. Ex-

But later, beneficial.

Whe fide of Jubor greatly expanded. cimninghim,

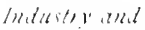
rimmencié, Hodern, $607-65 x$

Great increase of generial intelligence and comfort.

Rogers, $\rightarrow r$ Cintu$\because i 2,1)+97$. perience by degrees brought about a better condition of things, and the operation of natural laws and of the continued cheapening of manufacturing processes has tended to reluce the proportionate returns of the capitalist and to increase the real wages of the workman.

599. The Final Effect. - In other ways also the workman has greatly benefited from the results of this revolution. The introduction of machinery speedily gave rise to new inclustries. Some of these soon passed in importance the great cloth-making industry of the eighteenth century, and in the nineteenth century the field of labor expanded enormously. The necessiary cost of living has been greatly reduced, and comforts and luxuries undreamed of in the eighteenth century have been brought within easy reach of the laborer's family, while progress in sanitary science has rendered their lives more secure.

As a result, directly or in lirectly, of these things, there has been a great arlvance of intelligence, and a clearer and better umlerstunling of their true interests by the laboring class. Great trale organizations have been formed to look after the interests and, where they have been wisely directed, as they have increasingly been among Anglo-Saxon workmen with the growth of experience, many alvantages have resulted. Relatively speaking, the artisin class has gained more from the new age thai the capitalist class. The rich man has been always able to buy what comforts and luxuries he pleased, and the millionaire of to-day can neither purchase nor enjoy many more of these than his predecessor of the end of the eighteenth century; but the wildest prophet of that time would never have ventures to foresee the present improverl condition of the intelligent laborer. 
600. Political Results. - Politically the effect of these Advance of changes has been as marked as economically, especially in England. At first the midllle class rose to a new social and political importance. The centre of power began to shift from the country, and the land-owning class, where it had always been, to the new towns and the new wealthy manufacturers and merchants. Conscious of their power, they began to insist upon the reform of the system of parliamentary representation; and the result was the first reform bill of $I_{3}$, which gave representation for the first time to the great manufacturing towns. The process did not stop at this point, but by successive stages the State became more and more democratic, until it was practically under the control of the mass of the people. The United States began with a more democratic theory, but at first this was not perfectly realized in practice, and the tendency has been in the same direction as in England, though less noticeable and more quickly and more completely accomplished. This tendency has been perhaps still more marked in the Australian colonies, where many measures of an extreme democratic, almost of a socialistic, stamp have been adopted, apparently to the satisfaction of the public, though we should look upon their operation with dread.

601 . The Accumulation of Wealth. - Upon the accumulation of wealth, both by individuals and by the community in general, the economic revolution of the end of the eighteenth century had naturally a profound influence. The introduction of machinery was like the opening of numberless mines of gold. At first the great profits derived from the new methods of work were chiefly absorbed by the capitalist class. But they had their burdens to bear in return, for it was this rapid production of wealth that enabled England to endure the long strain of the Napoleonic wars without ruin. Later the products of industry have leen more fairly divided, and the statistics of the income tax and of savings banks seem to indicate that the middle and working classes have gained relatively more than the

the middle clatss.

Monlague, Elements, I 9 I-I 93 .

Then a democratic tendency.

Vistiy inreared hodaction of wealth. Escott, Sircial Trans formations, $13-3^{8}$. 
rich, notwithstanding the building up of enormous individual fortunes.

Wealth in the AngloSaxon world.

Of great

variety.

First Cientury of the

kepublic, Chap. XI.

Political applications of science.

'Transportation.

Applications of electricity.
Wealth in the Anglo-Saxon world has increased more rapidly than population even, and now comprises one-third of that of the whole globe. It has been said that the amount saved and added to capital in England between I 860 and i 870 was enough to purchase the whole kingdom as it existed in $\mathrm{I}_{\mathrm{I}_{5}}$, and the census of I 880 showed the United States to be the richest nation of the world. In the expansion of the race, these facts have been of great importance. While England has formed and administered the largest empire of history, and has had innumerable frontier wars to pay for, and a great fleet to maintain, her national debt has been reduced since i $\&$ i 5 by a thousand million dollars, and is now, in proportion to the wealth of the nation as compared with that of the earlier date, almost insignificant.

602. Nineteenth-century Science. - The scientific work of the nineteenth century has covered such a wide variety of subjects, and made such a multitude of discoveries, that any brief statement of its results is impossible. Only the general characteristics and the most important advances of the age can be pointed out.

'Two marked traits characterize throughout the science of the century. One of these is the rapid application of discoveries in pure science to practical purposes in improved economic appliances or in increasing the conveniences and comforts of men. This began in the opening of the great age of machinery and has continued ever since.

The nineteenth century was only well under way when the application of the steam-engine to transportation, in the railway and in the steamboat, revolutionized commerce, and enabled it to keep pace in the distribution of goods with the enormous output resulting from the new processes of manufacture. Since that time the most interesting and even startling of these applications of science have been in the field of electricity, the telegraph, the telephone, electric 
lighting, and electric motive power. These are almost efualled in interest by lucifer matches and photography, both now so familiar that the first impression made by their introduction is forgotten; and in the field of surgery and medicine by anæsthetics, antiseptic surgery, and the new methods of meeting and overcoming diseases which are due Other practical results of science. to germs. But these together are only a very few from the long list of such applications of science, and one may perhaps gain some idea of their influence upon our lives by imagining ourselves deprived of all such applications and inventions of the last hundred years.

603. Advances in Pure Science. -- Another chief characteristic of the science of the nineteenth century is its wonderful progress in the discovery of the laws of nature in every department of nature's activity. 'The careful study of the facts during the previous century had prepared the way for great advances in the understanding of the forces behind the facts, and these the next age made.

In this case, also, our list must be a very brief one and of the most important advances only: the conservation of energy, the theories of the molecular structure of matter, of organic evolution, of the cell structure of living organisms with the resulting science of embryology, and the germ theory of diseases. It is difficult to find anything in the history of the past with which to compare these, in their influence upon our understanding of nature, unless it be Newton's theory of gravitation alone, but discoveries only less in importance to these have affected every branch of knowledge.

If it is possible that the seventeenth century made a greater relative progress in science, that is a greater progress considering the point at which it began, it is hardly too much to say of the nineteenth that its absolute progress is as great as that of all preceding time. We may now almost renture to look forward to a time, not very distant in the future, when all natural forces will have been brought into The most important discoveries. covery of natural laws.

The greatest age of the world's scientific history. Wallace, llonderful Century, Chap. XV. the service of man, and when nearly all the suffering, danger, 
and lisease due to our ignorance of nature's ways or to our inability to foresee or control her operations will have disappearen.

\section{Topics}

In what way dill the age of the revival of learning cluse? The limt great age of English literature. The work of Lorl Bacon. Progrens in astronmy in the seventeenth century. The law of gravitation. The intermational character of modem science. The scientific work of the serenteenth century as a whole. The idlea of natural law. The i.leas of the Deists. English influence upon French writers. How dil these ilteas become European? Attempted reforms by governments. The character of eighteenth century science. Alrances in various sciences. The beginning of political economy. Inventions of ma. chinery at the close of the eighteenth century. The effects of the use of machnery upon labor, manufacturing, pulitical reform, and the proluction of wealth. Two chief characteristics of nineteenth-century science. Examples of the practical applications of science. Examples of important discoveries of natural laws.

\section{Topics for Assigned Studies}

The invention of the cuttun-gin. Amerian Histurial Rezieat, Vol. Ill., plp. 90-127.

The weneral character of the nineteenth century. Wallace, The $\mathrm{W}$ onderful contury, chap. XV.

\section{Topics for Studies in Review}

IIow hal the (ierman-Roman Empire become so weak in 1648 ?

Put together the facts which mark the decline of spain.

The steps in the rise of Englaml.

The rasons why France failed to secure a colonial empire.

The steps in the arlvance of Russia.

The share of the Ameran colonists in the struggle with France for colonial empire.

Steps in the alvance of l'russia.

Make an wntline of the history of the "Eastern Question" from the beginning of the reign of ( atherine II.

The relation of the wars of Frederick the Great to the colonial struggle hetween France and Englanrl. 


\section{ABBREVIATIONS}

Am. IIist. Leaf. American IJintory leallets. I'rolessors Alloert Bushnell Hart anel Eilwarl (haming. (A. Lovell A C C..; ro cents each. )

buhn. Bohn's Jilraries. (The Macmillan (ir)

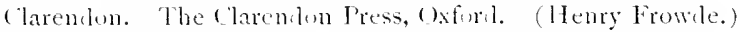

Cuntemporaries. linglish Ilistory ly Contemporary Writers Sieries. (l'utnam.)

Ciscéanl. Choix de Textes pour servir a l’Étude des Institutions de la France. (Paris ; Welatin.)

Epochs. The Eprehs of I Iistory series. (lungmans or Scribner.)

Epochs Ch. 11int. The Epochs of (hureh llistury Series. (Longmans.)

ling, stulies. stulies in European listory. Professor fred larrow Fling. I. (ireek an! Roman Civilization ; II. Nedieval llistory. (J. II. Miller, Lincoln, Xel.; single Stualies, 5 cents. The lound volume, 55 cents.)

Gardiner. Constitutional bocuments of the Puritan Revolution. (Clarendon ; \$2.25.)

Gee and Hardy. Imecuments illustrative of English Church llistory. (Macmillan ; \$2.60.)

llemierson. Historical Documents of the Mirldle Ages. (Irohn; $\$ 1.50$.

lerwes. Heroes of the Nations Series. (Tutnam.)

Inliana. Extracts from the Surces. Professors Samuel P. Ilarding and L. (3. Weatherby. University of lntiana. (Bloomington. 5 cents each.)

Mathews. Select Melieval Wocuments. (Boston ; Silver.)

Natims. Story of the Nations Series. (Putman.)

(1).l south. Olil south Ieallets. (l)irectors of the Old South Work. IBustom ; 5 cents each.)

l'enn. Translations and Reprints frum the Grivinal Sources of European llistury. (Department of IIistory, Lniversity of Pennsylvania. Io to 25 cents each: l,uml volumes $\$$ I.5O.)

Perioli. P'eriols of Eurupan ITistory series. (Nacmillan.)

l'rothero. Statutes and cimstitutional locuments, 1559-1625. (Clarentul ; \$2.60.)

Putger. IJistorischer Sinul-atlas. (I,eijzig; Velhagen ; 2 marks.) 
Schilling. Quellenbuch zur Geschichte der Neuzeit. (Ierlin ; Gaertner.)

S. P. C. K. Suciety for I'romoting Christian Knowledge. (Toung.)

Stubbs. Select charters illustrative of English Constitutional IIistory. (Clarendon; \$3.10.)

Zeller. L'Histoire le France racontée par les Contemporains. I 7 vols. published as $\mathbf{I} 6$. (I Taris: Hachette; I franc each.) Translated into French. I. Gaul and the Invasions; II. The Merovingians; III. Charlemagne and his Successors; IV. Advent of the Capetians, I'hilip Augustus ; Y. St. Louis, Philip the Fair ; VI. Philip VI., Juhn the Gook ; VII. Charles V., Du Guesclin ; VIII. Charles VI.; IX. Charles VII., Louis XI. ; X. Charles VIII.; XI. Louis XII.; XII. and XIII. Francis I.; XIX. Henry II.; XV. Francis II., Charles IX.; XVI. Henry III., The League; XVII. IIenry IV. 


\section{LIST OF BOOKS}

REFERRED TO MORE THAN ONCE, EXCEPT THOSE COVERED BY THE LIST OF ABBREVIATIONS, WITI THE PAGE ON WHICH THE NAME OF THE I'UB-

\section{LISHER IS GIVEN}

Mams, C. K., Demowity and llonarity in France, 452.

Mhame, (i. B., Cintizathe duringr the llutdle liser, 173; The (is didth

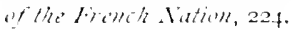

Aily, lours $1 / 1:, 370$.

Allen, (Kristann lustututions, $\mathbf{2} 20$.

Aluog, (hurch Histom, ror.

Archer and Kingstord, Kinsteme of ferustitem, 200.

Ashley, Enolish Fionomic Histery, 223.

Baird, Hensy of Viatere, 3+4; Kise of the llusuents, $34^{2}$.

Boyle, (Marndin, 350 .

Bradley, The (roths, 157 .

Bryce, Fhe Holy liwan Empire, 173.

Bury, Later Roman Empere, 101.

Capes, The the of the Antwints, II3; The Early fimpter, noo.

Carr, The Charih and the Koman EMstre, 122.

Church, llemy l:, 232; storles of the lict, I.

Cox, Jhe (ingides, 200.

cieighten, Fllatbeth, 334.

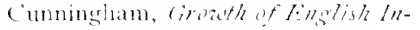
duter and timmerec un ledern fimes, $5+4$.

Cuntius, thatery of Breces, 17.

l odge, Mlammbal, ize.

Du Chailin, The litems lse, 1 .

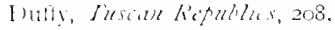

Emeton, Hediatal Rarefe, 173.

20 $5^{6 \mathrm{I}}$
Fither, 7he liegrimnins of Christinnit', 120; Ihstory of the (") lsturn ihurh, ror; The lieformatull, 257.

Fiske, Miscon'e's of merich, 282.

Frazer, lintish linda, 502.

Freman, Histurial lisals, I37; sicill', 70.

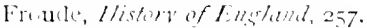

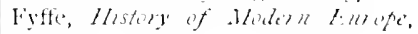
$+52$.

Gairdner, Homl, l\%, 213; lamcister and bork, 242.

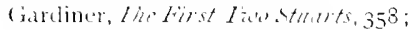

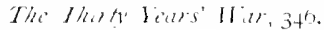

Giblon, Lectene alld fiall of the Komath timfire, IOI.

Gindely, the Thirty liats llitr. $34^{5 .}$

Gieen, cinumest of fintremd, I84: History of the Engtish licofle' 173; Mutins of Engthel, I5I.

Green, Mrs., lemin /I, 226.

Gote, lhstery of Gricice, 17.

Hadley, Intraductum to lioman Lane, $15 \mathrm{I}$.

Ilallam, constifutiund llistury of Enshland, 5 Io.

Hassall, lomis $17 l$, 3 tiq.

Hateh, Orathizathen of the Ravly (Wristim (km)her, Izo.

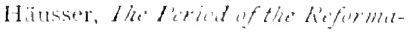
tim), 257.

llenderson, Hastory fie'many, I-3. 
Hodgkin, Ehters the (j)at, I52; linaty of themderins, I32; Itall alld her Incidelers, IOI ; Iheodurli the Goth, 145 .

Hoim, History of Girece', I7.

How and Leigh, History of $h$ ome, 53.

Hutton, I'hlif Alsustus, 227.

thne, History of tiome. 53.

Johnson, The Normans in Europe, I 80 .

Keary, rikings in II estern (hrostinthim, I 80 .

Kelite, The Furtition of Ifrian, 504.

Kitchin, thistery of France, 173 .

Küstin, Life' Lither, 25\%.

Lacky, Ilistery of Engriend in the Eighte'nth (intury, for.

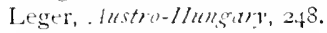

Lewis, Hostery of (it)malm, 248.

lieber, (in'il liberty, 452 .

Longman, Friderith the Grath, 393.

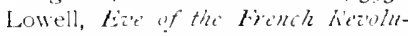
timll, 423.

Lucas, Hestorical (jeographly of the Firitish refonies, Introluction, for.

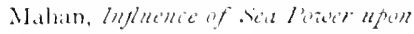
Hetery, 400.

Mason, Homalis shene' in frimitia'c ( 'ulture', I.

Maspero, thain of Cailladion, I ; Lifi in Ancient Eslpt and . Issyma, I.

Masson, Medicéal Findie', 233.

Maurice, bohemia, $2+8$.

Mclartly, (me Times from 1580, 505.

Mediter, llammal of Enstish Comstitutumal Iltstey, 510.

Merivale, homains ander the Empire, IOI.

Nombert, Charles the Great, I64.

Mommsen, History of Rome, 53 .

Montague, Elements of Enstish Constututwhal llistery, 5 io.

Morris, tse of Anne, 377 ; Napolem, $45 \mathrm{I}$.

Motley, The Jutch liefublic, 332.

Nüller, Political Itisterl of heicht fintes, 452.

Oman, Art of $\| T_{i n}$ in the Mithlle Ases, 209; Bysantine Emfire, I I8.
I'aliman, Half icntury of Conflict. Montialm and li olfe, 400 .

P'astor, Histery of the Hopes, 257.

Payne, History of Eurpean Colonies, tob.

reals, The loall of canstantinofle, 209.

Perkins, Framie matr Louis $\mathrm{Il}$. to6; France under the Regency. $3^{8} 5$.

Poole, $11 \mathrm{j}$ cliffe, 230.

Preseott, Philip II., 335.

Rambaut, Histey of K'ussia, 337.

Kamsay, Laniaster and Furk, 230.

Ranke, History of the l'opes, 307

Roberts, History of Cimada, 495.

Rogers, Six cinturies of llorti and II ixsers, 2.45 .

Selnitf, History of the Christion (huth, IOI.

Seebolm, Fic Pootestant Rerolutum, 3 I6.

Seeley, Roman lmferialism, 92.

sergeant, Thi Franks, I37; IIjoliffe, 2.45 .

Sloane, Sapoleon, 45 I.

Siteplens, Fremch Rerolution, 45 r fortusial, 282, speeches of the' Fincth Rewlution, 45 I.

Story, Limling of the British EMnire, to6.

Stublu, Constitutronal History of England, 236 ; The llantagents, 237 .

symonds, The Ke'maissanie' in Italy, 257.

laine, sucient Re'sime, 429.

laswell-1 angmead, Emgrlish Comstitutiollal thistory, 5 IO.

Tout, Ediidz) l., 2.40.

Traill, Social Emshland, I73.

Tuttle, History tof I'russia, 392.

Uhlluorn, Comflict of Christianty ainth Heathe'mism, I20.

Wallace, The IIonderful Century, $5+4$.

NTarburton, Edrathl /II., 230.

Ward, The Cinter Reformation, 320 .

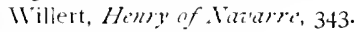

Zimmern, Ilansa, 2 I7. 


\section{INDEX}

Abbassides, the dynasty of, 158,160 .

Abyssinia, 505 .

Acadia, tio.

Achaean league, 48 .

Acre, siege of, 214 .

Actium, battle of, 98, I05.

Act of Siettlement, the, $53^{8}$.

Act of supremacy, the. 3 I8.

Act of Union, $38+$.

Elfred the Great, I82.

Equians, the, 6 .

Eschylus, 32.

Fithelred, 183 .

Aëtius, 134.

Ainlian League, 73 .

Afghanistan, $40,503,504$.

Alruci, 504, 5, 5; conquests of, IO3,

145, 157. Siec Cippe Coleny, Es stpt, etc.

Agincourt, battle of, 232 .

Agricola, II3.

Agrippina, I Io.

Aix-la-Chapelle, treaty of, $37 \mathrm{I}$; peace of, 395,418 .

Alais, edict of, 349 .

Alaric, I02, I22-I34.

Alligense's, $175,207,228$.

Alluquerque, 407 .

Alcibiades, 35-37.

Alcuin, I69.

Alemanni, the, II $6,3^{1}, 13^{8}, I_{4}$, I 93.

Alexander I., C.utr of Russia, 456 , $46 \mathrm{I} ; 11 .,+80,+8 \mathrm{I}$.

Alexamiler the Great, $19,42,44^{-4}$, 68 ; influence on civilization of, 48 , 50,5 I.

Alexandria, in Egrpt, fomminis of

45. 123; bombatiment of, 505 .

Algiers, 5 o4.
Ali, the Caliph, 158 .

Alliance, the Triple, $37 \mathrm{I},+13$.

Asace-Lorraine, 775 .

Alva, duke of, 336 .

Amenemhat 111., 8.

Amenca, discovery of, 277 ; English colomes in, +II-4I5; Revolution in, 422; Anglo-Saxon expansion in, 488 .

Amiens, peace of, $4+4 .+92$.

Amphictyonic Cuuncil, +3 .

Anabasis, the. 39 .

Andros, Sir Edmund, 538 .

Angevin empire, 226 .

Anglo-Saxons, 103, I48-150, 488, 507 .

Anjou, county of, 188 .

Anne of Beraljen, 2 io.

Anne of England, $3^{30}, 3^{3} 4$.

Antalcirlas, peace of, $4 \circ$.

Antioch, 123, 212.

Antiochus, king of Syria, 55, 79.

Antonines, Rome under the, II3.

Antonilis, Mareus, 98.

Antony of Nivarre, $3 t^{2}$.

Appius Clandius, decemvir, 64.

Aqua Sextia, battle of, 87 .

Aquinas, 'Thomas, 263.

Aquitaine, duchy of, 188.

Aralua, 155-157; science of, 158 .

Arabi l'ahla, 505 .

Arabs, 150, 157; in Spain, 104, 157.

Arloela, bastle of, 45 .

Arcadia, yo.

Areadius, I32.

Archangel, 390.

Areopagus, 26.

Areinuse, battle of, 36 .

Aigivi: 24.

Alluns, I3j.

Ariostu, 282. 
Arioristus, 129.

Aristides the Just, $3^{\circ}, 3^{1}$.

Arius, 138.

Armacha, the Invincible, 3 to.

Arminius, or Hermann, rog; the theologian, $33^{8}$.

Amulf, I93.

Armult of Metz, I53.

Arthur of Brittany, 225.

Artois, count of, 455 .

Aryan nations, 14 .

Aryans, 4, I5.

Asia, 45, 5,2-504.

Assignat, French, 437 .

Assvria, Io.

Asti, siegre of, 133 .

Athenian constitution, 27 .

Athenian Empire, $3^{1}$; fall of, $3^{8}$.

Athens, 24, 32, 34-38, 43, 4t.

Attica, 24, 23.

Attila, I3t. I fo.

Angshure, Confession of, $3 \mathrm{I}+$; peace of, $325,330,345$; league of, $37 \%$.

Augustus ( exar, Ion-1 Io.

Anerustus II., king of Poland, 300; IlI. $+\infty 0$.

Aurelian, emperer of Rome, nes.

Aurelius, Narcus, I07, II3, I14, I22.

Austerinta, battle of $+t^{6}$.

Austribinta, fisy.

Australin, 48-490, 497.

Alutratiat, 152, 153, 499 .

Austria, 248, 353, 305, 394-399, 470; in the seven Wleeks War, $470-472$.

Anstrian Succession, Whar of the 395.

Avignon, 258, 283, 373 .

Alof, $36,3 \%$.

Iabyion, $45,4^{5}$.

IBabyloni.zn history, $\mathrm{I}$.

Pracon, Jancis, $5+5$.

Ihagdad, I58, 2 IO.

Inilboa, 277 .

Baldw in of Jlanders, 215.

Balkan states, 482 .

Balliol, efo.

Baltic provinces, 250, for.

B.zuchistan, 502 .

Barcelona, 300: treatr of 311 .

Baste conncil of, 283 .

Iastilie, taking of the, $43+$.
Bavaria, Joseph of, 377 .

Bavarians, the, $164,193,345$.

Bayard, Chevalier, 3 Io.

Becket, Thomas, 238.

Belgium, $\mathbf{1 7 8}, 464$.

Belisarius, I 45 .

Berlin, treaty of, 482

Bill of Rights, 376 .

Bismarck, Otto von, 467,470 .

Bithynia, 8o.

Black Death, the, 23I, 242.

Black Prince, 23 I.

Boethius, 14 .

Ijueotia, 43 .

Bohemia, 248, 258, 286, 287, 346, 378, $459.47 \mathrm{I}$

Bonaparte, Napoleon, $4+\mathrm{I}-4+4 \mathrm{~m}$, fi.

Borgia, Caesar, 295.

Bosphorus, 1 I6, 117 .

IBosworth Field, battle of, $24+, 526$.

lothwell, earl of, 338 .

bourhon, house of, $342,3+3$.

bourges, Pragmatic Sanction of, 288 , $30 \mathbf{I}$.

Bumines, battle of, zto.

boyne, battle of the, 377 .

liaddock, General, +18.

liranclenburg, elector of, 392 .

lisella, compromise of, 337 .

breslau, peace of, 395 .

Bretigny, treaty of, 231 .

Britain, 95, I13, 148.

British empire, expansion of, 487-503: in Africa, 504; in Canada, 495 ; in Intlia, 502.

Bruce, Robert, 240, 24I.

Brunswick, house of, 206. See //an(n)

Brutus, 48 .

Buffon, $55 \mathrm{I}$.

Bulgaria, 482,484 ; massacres in, $48 \mathrm{I}$.

Burgundians, I 33, I39, It2.

Burgundy, luchy of, $173,188,234$; duke of, 232.

Burschenschaft, 454 .

Cabot, fio.

Ciesar, Augustus, emperor of Rome, iof-I Io.

l'ast, lulius, emperor of Rome, $45-98$ 
('ilus, 1 IO.

('alais, 233, 334, 370.

Caligula, emperor of Rome, I Io.

Caliphate, the, I58, I60, 2 I0.

Civin, Jolnn, 259, 3 I9.

Calvinism, 319, 329, 333, 338, 3+I.

Cambray, league of, 298 ; iatus l'ealce of, 3 II.

( amlyses, if.

Campo Formio, treaty of, $t^{+2}$.

Canala, 4I5, 418, 4I9, $420,495,407$.

Cimne, battle of, 72 .

Cianossit, 203.

Canterbury, 238.

Cape Colony, 409, 450, 491, 494, 497. 504. 505.507 .

Cipetian kings of France, I74, I88, I96, 224, 225, 227, 236.

Сариа, 6I, 66, 73 .

Cirloomari, 454.

Carlowitz, preace of, 390.

Carmot, 44 I.

Carolingian house, $152,160,174,181$, I93. Ig6.

Citlliage, I3, 54, 60-74, I 34.

Cimllage, New, m Spain, 54, 72.

Cassius, 98.

Cussius, spurins, 63.

Cistile and Aragon, 252.

Catherine of Arigon, 293.

Catluerine II. the Great, of R Iisia, $320-404,478$.

Ciatloilic League, the 345 .

Citu, 8 I.

Civaliers, 360.

Civour, Count, $4^{6} 5$.

Celts, I48, I5o.

Censors, Roman, 64.

Ceylon, 49 I.

Chreronea, battle of, 4.4 .

Chaldean civilization, I I.

Chîlons-sur-Marne, I3-1.

Chambord, eomte de, -150 .

Charlemagne, I03, Iof 171, I74; the empite of, 168,176 .

i harles Alleet, king of Siardinia, 460 .

Charles V., emperor of Germany, $250,298-300,329-333$; V'I., 394 .

Charles the Pold, 233, 293.

Charles the Fat, I79, 103-I95.

Charles the Simple, 195.
(Charles 1., king of lingland, 358,360 ,

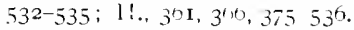

Charies V., king of Fance, 231 ; V'. 23I; Vll., 232; V'lll., 234, 295 297.

Charles XII., king of Siveden, 390.

Chartes of Bourbon, Constable of France, 308,3 ro.

Charles MIartel, I53, I57, I62.

Chancer, $242,304$.

Cheops, 8.

China, 48, 502-504.

Christiznity and the C.luuch at the d.ath of Christ, Ioo; causes of early persecution of, I $2 \mathrm{I}, \mathrm{I} 22$; rapiti spread of, I2x-I25; under Constintine, I02, I24; Chureh government, I22; under Julian, I26; unfer Jovian, r29; Arian a's. Catholic, 138; reforms of Cluny, 200; the crusades and their results, $209^{-}$ 223; Hussites, 249, 286; religious revolution attempted, 283-288; reformation of I,uther, 303-322; in England, $333,340,357$ in France, 34 ; Edict of Nantes, 34.

(icene, 95,08 .

Cimbir, 87.

Cinnil, 92.

Civilis, I 3 .

Clatulius, I I0, I I 3 .

("eisthencs, reforms of, 27.

Cleopatra, 98.

Clelmont, comneil of, zio.

Clive, Rolert, I, ond, 4 Iy.

Cloaca, Naxima, 58 .

Clotilda, 138.

Clovis, Io3, IO4, I37-I40.

Cluny, reforms of, 200.

Cnut, I74, I83.

Coblem, Richard, 500.

Colluert, 368-370, 374, 4I5.

Colet, 270.

Coligny, Adminal de, 343 .

Colonial wars, 4I5, 425 .

Colonies, (ireck, 58; Roman, 68; Northmen, I\&I; lierm,un, 250; modern, 407; Englis?, 4II, 4I5418, 494-407, to0 502; French $360,370,374,525,492$.

Columbus, 2\%o. 
Comitia, centuriata, 59; curiata, 59 ; tributa, $63-64,65$.

Commolus, emperor of Rome, $1_{3}$.

Commons, House of, 359. 360 ; origin and growth of, $517,522,525$. See I'urliumint.

Commonwealth, Englis!l, the, $3^{60,}$ $361,535$.

Conde, piince of 353,372 .

Congo free state, the, 504 .

Cunrad, of Franconia, 193; 11, 'mperor of the Hoy Roman Empite, $195 ; 111 ., 214$.

Constance peace of, 206 ; colncil of, 2.49.

Constuntine the Great, 102, ri 7,120 , I 22-125 126 .

Constantinnple, 117, 157, 215, 253.

Constitumt Asemby, in France, $43^{5}$, $+3^{8}$; in Germany, $t^{5}$.

Constitutions of England aml the Lnited states, 510-57 : Chatter of Henry 1., 512; besinmeng of the judiciary 5i3; the Magna Chutu, 51.4-5Is, 5Iy; the provisions of Oxford, 5 is: the origin at repuesentative institutions, 517 ; 1'arliament, 518-530; House of Commons, 350, 350,521-525; thxation by, 5 to-525; the Yorkist period. 526; the Tudor period, 527 ; the Stuart period, 530; Petition of Right, 532; Cirand Remonstances, 534; Bill of Rights, 537 ; colonial questions, 537 : Reform l3ills, 540.

Consuls, of Rome, 60 ; of liance, +13 .

Convention, the, of the Commune, $+39-4+1$.

Copernicus, 238, 279, 545, 547

('orinth, 3+, 80.

comeile, 549 .

('oralca, $54,72$.

Corter, tor.

council, He Great, 517 .

Coup l'état, the, $f^{62}$.

"Covenumt," the, 533 .

Crassus, the triumvir, 95 .

Crecs, hatte of, 231 .

Crespy, treaty of, 320.

Crimeal to2.

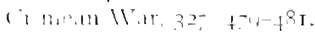

Crinatio. 29.

Crommeil, Oliver, 360-36r, +13.

Crusites, age of, $74,209,212,217$; first, 210; second and third, 214 ; liater, 215 .

(ial)a, $27 \%$.

Cinneifurm inscriptions, II.

Curier. 551 .

Cinucephatie, hattle of, 79 .

Cyms the vounger, 39 .

Ciar, the name, 106 .

D.goluert, 1.42, 152, 161 .

1)amaselus, 138,214 .

1).mes, 180; in England, 18 I.

D.ante, 200.

1).anton, +3 .

1).mulice, states of the, $482,4^{8}+$.

1), nius 1., king of Persia, 14, 15, 29, $3 \circ,+5$.

b.rmin, 551 .

1) will, king of the llebrews, 11 .

Hecomvirs, Roman, 63 .

Decius, $116,131$.

Dechuration of Independence, +23 . 5 I2.

Deinte, Erench, 427, English, $54^{8}$.

1)e'or, 13,31 .

1). phiti, 43 .

lenmalk, fros. $^{6}$

Descartis. $5+6$

1) sederius, king of I ombards, 165.

1)iaz, 275.

1)i.titur at Rome, 97.

I) iretetian, Roman emperor, I02, I16. $117,123,126$.

binracli, i, ord Beaconsfield, +82.

l)ive Kiglit of Kings, doctrine of the, 357 .

1)omithan, Roman emperor, II I, 113 .

1)rinus, the, 18, o; migrations of, 2 I.

Drace, latus of, 26

lirenden, peace of, 395 .

J)msus, 87.

lounbar, hattle of, 361 .

1)mpleix, +17, +19.

I hutch Ropublic, See Votherlands.

1 watch war in reign of ( harles 11., +13.

Eadmund Ironside, $183,196$. 
Fatward the Confessot, 183, Iyth, litasnms, 258, 270.

I97.

Fintern limpire, IU3, I31, I 4 t, I $4^{\mathrm{t}}$.

liastem Question, the, $327,402,477$, $4^{8}+$.

Last lndia Company, 359, +o9, +12.

Ecbatania, 45.

Legberht of Wessex, 182

Eck, Dr., 306.

Lilessa, 2 Iq.

Edict of Restitution, $3+7 \cdot 3+9$.

Elwarcl 1., king of England, 229 , 240,$517 ; 11 ., 241,520,524 ; 111 .$, 230,$242 ; 11 ., 244 ; 11,318,527$.

ligypt, 7-IO, 45, 48, 58, I57, 158,252 , $253,266-272,+43,+78,491,505$.

Eisenach, 308.

Elagabalus, i 6 .

Elba, $4+7-4+9$.

Eleanor of Aquitaine, 226.

Elector, the Great, of Brandenturg, 351, 392, 393. 412; of Bavaria, 395 ; of the Palatinate, $345,358,3^{8}+$ : of Saxony, 329, 352-395.

Elizabeth of York, 293.

Elizabeth of England, 318, 325, 334 . 337-341, 527; literature of the age of, $5+5$.

Elizabeth of Russia, 397, 399.

Emigrés, $438,45^{6}$.

Empire and papacy, 202-207.

England, Saxons in, $1 f^{8}$; under Eltred, I82; invasions of, $174,18 \mathrm{I}$, 182; Norman conquest of, I96; at war with France, 231, 242, 383 . 4I5. 445. 449, 49I; Norman kings of, 237,511; Angevin kings of, 226, $237^{-2}+2,512,513$; in Wars of the Roses, 242-24t, 292, 526; the Reformation in, $285,317,318,333,334$. $33^{8-3+1}$; Tudor rule in, 3I8, 333. 339, 527-530; Stuart kings of, 355$351,375,384,530-53^{5}$; Revolution in, 350, 535; Commonwealtle of, $3^{\text {no }}$; nse of, $3^{8 \mathrm{I}}$, fog; colonife of, 4II-425, 488, 494, 407, 500-502; constitutional lustory of $510-5+0$; Magn. Charta, 5It; Parliment (i), $517-52 t$.

Eichumondas, to, 42 .

6)irms, 51, 58, 132.
Estate, the 'I hird, +32 .

listate, general, 220, $231,233,24^{\text {n, }}$

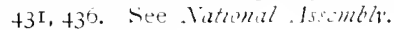

Ethandun, 182.

Etruscans, 58, 67.

Eucles, king of France, 105.

lingene of savoy, 380.

Europe, reorganization of, $4+4,45^{\circ}$ since $1815,452-485$.

Fabius Maximus, the Delayer, 72 .

Ferdinand of Aragon, 25I, 291; emperor of Germany, 330.

Feudalism, the rise of 185 ; the system of, 186, 187, 511; in France, 188; the sert class under, I89-191: classes of, 189 ; permanent influence of, 220, $51 \mathrm{I}$; causes of dreay, $22 \mathrm{I}$; results of, $22 \mathrm{I}$.

Flanders, 188, 409.

Flavian dynasty in Rome, II I.

Florence, the city, 25I, 245 .

Florida, purchase of, 493 .

Fontenay, battle of, 177 .

Fontenoy, lattle of, 395 .

Fort Duquesne, 48 .

Fouquet, 368.

France, under the feudal system, I88; beginning in, I95; Capetian kings of I74, I88, Igt, 22.4-22\%, 236; the Valois in, 230, 343; in the 'Thirty Years' Wir, $34+-353$;

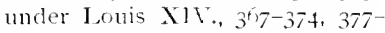
$331,+13-415$; intellectual chatacter of $+27-429$; financial conchtion of, $+30,+35$; revolutions in, +32 $439,+5^{6-45^{8}}, 4^{6}+$ : the Republic in, $43^{8}-4+5,458,476$; the Emjire, $4+5$, f52; lourbon restoration, $477,4,4$. the war with Prussia, 472-45, in the Crimean War, 479 ; colnowies of, $369,+15,492$.

liranche-Comté, 365, 371-373.

Francis I., king of France, 308; II., $33^{8}, 34^{2}$.

Francis of Guise, $3+2,+73$.

liancis Joseph, emperor of Austria, 459 .

Francis of Lorraine, emperor of Aus. tria, 395 . 
Franco-Prussian War, 327, $472-475$. Franklin, 55 I.

Iranks, the, I03, 137-1 $43,157,102$.

Frederiek William, the Great Elector (of Branclenburg), 351, 386, 392, $393,412$.

Frederick the Wise of Saxony, 300.

Frederick II. (the Great), 393-395. 398- 701 .

Frederick 1., emperor of the Germans, 20.4, 214; II., 204, 207-215.

Frederick of the Palatinate, 345,358 , $3^{3}+$.

Frederick William 1., king of Prussia, 393; 11., 403; 1V., $46 \mathrm{I}$.

Freclerickshall, siege of, 391.

French and Indian Wir, 397.

Fiench Revolution, the, $327,+32-+39$.

rronde, wats of the, 367 .

Gialba, emperor of Rome, III.

(i.liles, $5 t^{6}, 5+7$.

Garibaldi, th7.

(i.lul, 45, 103, 106.

fienevil, 319.

(jerman nation, beginnings of, 103 . 109, I35, I92, 193; the Holy Roman Imprise of the, r94; in conflict with the papacy, 100-207, 247 ; in the crusades, $21+-210$; the Great Interregnum, 247; the Reformation of Luther, 303-315; the religious wars, $329-357 ;$ the Thirty Years' War, $3+t^{-}-3+6,351^{--}$ 355; end of the Empile, 35t; rine of the Hohenzollern in, 391-39.4; the Seren Years' IVar, 398, t7o42 : the Zollverein, $f^{65}, t^{68}$; the New Confederation, $47 \mathrm{I}$; the New Empire, +75 .

George I., king of England, 384 ; III., $+20-+22$.

Ghibellines, 206.

Gibraltar, $3^{8} \mathbf{r}$.

Gironlists, the, 439,40 .

Gladstone, 5 oo.

Gold, discovery of, +98 .

Gordon, General, 506.

Goths, 131, 132.

Gracchi, reforms of the, 55,82 .

Gracchus, Cuius, $83-85$.
Gracchus, liberius, 83 .

Grimalli, 291, 292.

Grand Allinance, the, 379 .

Granicus, hattle of the, 45 .

Great Seal of England, $3^{5} 5$.

Greco-Persian War, 29, 30 .

Greco-Turkish War, 485 .

(ireece, influence of physical charaeteristics on the people, 19, 20; in the Homeric age, 21; invasions of, by Persians, 29, 30; contest for the beadship of, $3 t^{-38}$; conquest of, by Philip. $43,4+$; after the death of Alexinder, $t^{8}$; eommerce of, +8; independence of, t53.

Greek Empire. Sere Eitstern Empre?. Greek cities of Asia Minor, 29.

Greeks, 6 ; divisions of, $18,20-26$; legendary history of, 20 ; typlicill constitutions of, 27 ; civilization of, $\left.t^{6}\right)$; intellectual rank of, 32, 49; relation of komatns to, 5 ; ; revival of the leaming of $258,21-263$.

Ginegory. Shee molder lipis.

(iregory of loms, $\mathrm{I}_{3}$.

(irimoald, 152, Ini.

(iluelfs, 206.

Ginise, the family of $3+2$.

Guntavers Adolphus, 347, 351 .

Gitenberg, 268.

I Iaclian, emperor of Rome, I I3-II5.

Ifamilear, 72 .

Hamplen, $359,360,532$.

Ilannibal, $5+, 72,7+, 76,70$.

Hanover, 20t5; the house of, $3^{8}+, 525$ $53^{8}$.

Hanseatic League, 223.

l fapshurg, house of, $248,290,292$, $328,33+, 3+9,3^{65}, 3^{32}$.

HAarold I., king of England, 197.

Itasdrubal, $5+, 73,7.4$.

Ilastings, battle of, 197 .

Hawaii, $f 88$.

Hebrews, the, II-I3.

Itegira, 156.

IItelena, St., +t9.

II ellas, 20.

Hellenes, 20.

Hellespont, +5, 90 .

Heluts, 24. 
Henty 1., emperor of Germany, 103 : 11.. 195, 199; Ill., 195, 201, 202: IV., 202; V., 203; Vl., 202, 204, 206.

Henry 1., ling of England, 237 ; Charter of, 512, 515:11., of Anjou, $226,237,521$; 1II., 228, 240, 516; IV., 523-525; V., 23I, 242; V'l., 232,243 ; VII., 244,526 ; VIII., $292,298,300,308,317,357,527,530$.

tlenry 11., king of liance, 329,330 , $3+2 ; 111 ., 3+3 ; 11$. , of Navarre, $3+3,3+4$.

Henry the Lion, 206.

Henry the Navigator, 275.

Heptarchy, the, It9.

Heraclea, battle of, 68.

Herculaneum, II .

Hermann, Iog.

Hieroglyphics, 9 .

lliers, king of Syracuse, $70,71,73$.

Hipparchus, 27.

Hippias, 27 .

Historic races, succession of, 5 .

History, fiekd of, I; eariiest records of, 5 .

Hohenstaufen, the house of, $174,204^{-}$ 206, 25 I.

Hohenzollern, the house of, 250,326 , $392,461,+73$.

Holbein, 282.

Holland, I78, 409; at war wiih France, $366,371,413,457,491$.

I Iolstein, 468 .

Holy Nlliance, the, $+5 t^{-}+56$.

Holy League, 293.

Holy Roman Empire, the, I69; economic condlitious of, 176 ; its contest with the papacy, 199-207; renewed by Otto the Great, I74. 194; effects of the renewal of, 194; diminished by the treaty of Westphalia, 326 ; end of, $35+$.

Honorius, emperor of Rome, 132.

Horace, 107.

Hubertsburg, peace of, 399 .

Iudson Bay territory, $3^{82}$.

Huguenots, $3 t^{2}-3+t, 3 t^{8}, 3 \overrightarrow{7}+$.

Hundreel liays, the, $4+9$.

Ilundred Years' IVar, the, $1 / 5,230-$ $233,242,290$.
Hungarians, the, 174, 180, 193, 463 .

Hungary, 459, for, 472 .

Huns, the, 102, I29, I $3^{1-1} 35,144$.

Huss, John, $249,25^{8}, 286$.

Hussites, 249, 286.

Hyksos, 8.

Illyricum, 132 .

Imperial Federation league, 501.

Independents, English, $360,+11$.

India, $f^{6}, 273,+16,+17,+19,+43,491$, 502,503 .

Indulgences, 303 .

Indus, the, $4^{6}$.

Interregnum, the Great, 247.

Ionians, the, 18, 20, 29.

I reland, 237, 361, 377 .

lsabella of Bourbon, 473 .

Isabella of Castile, 25I, 252.

Ismail Pasha, 505.

Issus, battle of, 45 .

Italian city-states, 205, 206, 25I, 29.4.

ltalian Renaissance, 255.

Italy, geography and peoples of, 57 . 58; contrasted with Greece, 57; reorganization of, $88,+49,463$; cities of, 205, 206, 251, 294: Renaissance in, 265; the invasions of, 296-300, 310, 3II ; revolutions in, 455, 459,460 ; growth of the spirit of nationality in, +65 ; united, $460 .+6 \%$; in the seven Weeks' IVar, $47^{0-}+7 \mathrm{I}$.

lvan the Great, 388 .

Jacobins, $+3^{6},+3^{8}, 439,4+40,+4^{2}$.

James 1., king of England, 358; 11 , $376,377,3^{80}, 3^{8}+, 53^{6}, 537,53^{8}$; III., 379 .

James I1.. king of Scotland, $3^{8} 4$.

Janissaries, 352 .

Japan, 50.4.

Jaxaltes, 46.

Jena, battle of $+t^{6}$.

Jerome of Prague, 287.

Jerusalem, IO-13; taken by Titus, III; by the Turks, 210, 213; by the crusaders, 21t: latin kingdom of, 2It; taken by Saladin, 21.4 .

Jesuits, the order of, 321 . 
Jeus, insurrection of, II 2 ; expulsion ' Iepidus, the trimmir, 98.

from Spain of the, 292 .

Joan of Are, 232.

John, king of Enghand, I7t, 226, 239 ; grant of Nlagna Charta by, 239,240 , $51+516$.

John, king of Jiance, 231 .

Josephine, $+4^{5}$.

Juseph of Bavaria, 377 .

fovian, 129.

Jugurtha, 86.

Iulian the Ipostate, 126, 129,131 .

Japiter Ammon, shrine of, 45 .

Iuntinian, 103, I I5, 14.4-145, 219.

Jutes, the, It8, I 49 .

Kiaba, the, 155 .

Kepler, $54^{\circ}, 5+7$.

Khadijah, 155 .

Khartum, 500.

kinox, John, 338.

Königgratz, battle of, 47 I.

koreishites, $155,15^{\circ}$

Koscinsk', fo3.

konsuth, 439

Kंufu I., 8.

Lacedamon. Ster Giath.

I at. yyette, $43+, 43^{\circ}, 45^{\text {n. }}$

Lanciater, house of, $242,244,286$, 523-525.

langton, Stephen, 514.

J.aphace, $55 \mathrm{I}$.

Lit Rerchelle, $3+9$.

I attin cities, leagrate of $58,59,61$; revolt of, ot).

latin eolonies, 08.

Jatin Empire, 215.

1,aucl, William, 35\%.

l.aw, folin, 43 .

Jaw, Romm, I I4-1I0, 200, 219.

J aystach, congress of 4,55 .

1,eczmonki, stanislatus, 390.

1, equhtive Assembly, tyo.

Legnano, battle of, 206.

Leipzig, battle of $4+7$.

Leon, 252 .

Jeonarde d. V'inci, 28 I.

Jeenulas, 30.

J eopoli $11 .$, king w Austria, foz.

Leopuld, Prince, 473 .
I, ew is I., Carolingian king, 177,179 .

J ex Hortensia, 65.

Licinian Rogations, 64.

I inneus, $55^{\mathrm{I}}$.

Lishon, 275, 277.

Litelature, Egyptian, 9: Chaldean, II ; Greck, 20, 32; of the Renaissance, 279, 28I, 282.

Livia, I Io.

Livy, 107.

Locke, Joln, $5+9$.

Loire, the, $157,227$.

Lollards, the, 280.

lombard Leagne, the, 205.

Lombards, the, I03, I04, If6, I6I, I62, I05.

Long I'ails of Athens, $3^{3}, 4^{\circ}$

Lorraine, $210,+75$.

Lothair, emperor, 177,178 .

Lnuisturg, +18.

I ouisiana purchase, the, 493 .

I ouik, prinee of Condé, 353, 372.

Lnui, V., king of Fruner, ig6; VI., 224, 225; VII., 2L4, VIII., 228; IX., 215, 228; XI., 233, 2yo, 291; Xill., 297-300: NIIl., 344, 347, 349, XIV., 366-383.+13; XY.. 383. 4 3 ; XVI., +3I, +30, +39, t+o; XVII., 48 ; XVIll., $+47,4+9,45 \%$

I ouis Napoleon, $459, f^{6}-47^{6}$.

Lonis l'hilippe, $4.36,45^{3}$.

law Comntales. See Nefherlands.

lewola, lgnatius, 322.

lilcan, IIo.

Lndovico the Moor, 205-297.

Luther, Martin, 258, 271, 303-315. posts his theses, 304 ; lum the the papal bull, 307 ; edict against, of the Diet of Worms, 307, 308; 1p)posed to fanaticism, 312 , and to tivil war, 3 It.

Litzen, lattle of, 35I.

Luxemburg, the family of, $2+8$.

Lycurgus, 2r.

Iacedonia, tributary to Darius, It; rise to power of, $18,+2,5+$; at war "ith Rome, 73.70; alter the death of Alex.muler, 48 ; end of, 80.

Iachiavelli, 282, 294. 
Machinery, the age of, 552; its effect Mhan, I3 I, 133, 205, 25T, 205, 300, on manutacturing and tatur, 5.53 .

Maclrid, treaty of, 310.

Nagdeburg, siege of, $329,35 \mathrm{~T}$.

Nagellan, 277.

$+1.2$.

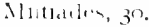

Minorcia, $3^{8} \mathrm{I}, 4^{2}-1$.

Misaturatu, $432-43^{2}$.

Magna Clatrta, the, 240, 5I.t-5IO, $519,532$.

Mehmoud II., sultan of Turkey, 478 .

Maintenon, Nme., 37t.

Mamertines, the, 70 .

Marathon, I5, 18, 29.

Mardonius, 30.

Maria Louisa, empress of France, 46.

Maria Theresa of Austria, 394-399, for.

Marie Antoinette, 430.

Marignano, battle of, 300 .

Marius, Catus, 87, 89-92.

Narlborough, duke of. 380 .

Mary de' Nedici, $3+t$.

Mary of Burgundy, 293.

Mary, queen of England, wife of W'illiam 111., 376,536 .

Mary Stuart, queen of Scots, 334 . $33^{8}-340,3+2,355,35^{\circ}$.

Misse dominue, 10u, 170.

Mithrilates, 89, 90, 92.

Nohammerl, I55, 150 .

Mohammedanism, doctrines of, 155 , spread of, 156 ; decline of, 160 .

Molière, 5.49 .

Money, effects of an increased une of, 220 ,

Nonroe Doetrine, the, 455 .

Montaigne, 282.

Montesquieu, $428,5+8$.

Montfort, simon de, 228, 516, 518 .

Noors of Granada, 292.

Nore, Sir Thomas, $270,27 \mathrm{I}$.

Moseow, burning of, +47 .

"Mountain," the, 439 .

Mozambique, 275 .

Miihlberg, 329.

Nycale, 30 .

Mary Tudor, queen of England, 3 I 8 , 333 .

Massinissa, 86.

Matilda, 237, 5 I 2, 5 I3.

Milurice of Saxony, 329 .

Maximilian 1., emperor of Germany, $23+, 293$.

Mazarin, 299, $349,367,370,374,377$.

Mazeppa, 391.

Mazzini, 460.

Mecca, I55, 156.

Nedes, ro, II.

Medici, family of, 251, 295, 296, 316; Catherine de', 275, 3.22; Lorenzo de', 280; Mary de', 34t

Medina, 155 .

Neluemet $\mathrm{Ali},+73$.

Memplis, 7 .

Menes, king of Egypt, 7 .

Nercia, I $49, \mathrm{I} 8 \mathrm{I}$.

Messana, $70,7 \mathrm{I}$.

Mettemicl, $+54,+59,+89$.

Met $z, 330$; toitress of, $47+4$.

Nexito, conquered ly Cortez, to .

Michael Angelo, 281 .

Nantes, the edict of, $3+4,3+9$; 1evocation of, 374 .

Naples, 295, 297, $38 \mathrm{I}$.

Napoleon 111., f'52, t72.

Naselsy, 360.

National Assemlyly, lirench, $432-436$ $439,4+\%$.

National Guard, $43+4-43^{6}, 45^{6}$.

Navarre, 25I, 291.

Navigation Act, +13.

Nebuchadnezzar, Iо.

Necker, +3I, +33, +3.4.

Nelson, $4+3,+4+491$.

Nero, emperor of Rome, I 10, III, I2I.

Nerva, emperor of Rome, irz.

Netherlands, 286, 293; under Chartes. V., 335; revolt of the, 328,336 ; Union of Utrecht, 337 ; cerled to Austria, 337 ; to France, 355 .

Netherlands, the New, tog.

Neustria, I53.

Newfoundland, 4 I6.

Newtin, sir Isaac, $5.6,547$.

Niciea, 124.

Nicholas I., czar of Russia, $4^{61}, 4^{6}+4$. 479,480 . 
Nicias, the peace of, 35 .

Nile, the valley of, 5 ; delta of, 7 ; the battle of, $43,49 \mathrm{I}$.

Nimegnen, treaty of, 373 .

Nineteenth century, 452 .

Norfolk, I 49 .

Normandy, I8I, 195. 51 1 .

Normans, 169, 196; in Italy, 204; conquest of England by, 196; in the crusates, 2 Io.

Northmen, 174, I80, 181 .

Northumberland, I+9.

Norwegians, 180.

Nottingham, 30 r.

Novi Sicotia, + Io.

Numantia, 80 .

Numidir, 86.

Nuremberg, peace of, $3^{15}$.

Octurius, the tribune, $8_{3}$.

Octavius, the tritumvir, 48 ; emperor of Rome, 105, 109.

Odovakar, 103, 135.

Oivmpian Leus, by Phiclias, 28.

Oiynthian Confederacy, the, 43 .

Olynthus, 43 .

Otimiats, the, 153 .

Orange, 11 illiam of $3-6-3^{80}, 53^{6}$, 537 .

Oriental nations, 5, 15.

Orleans, the siegre of, 232 .

Ormanlis, the, 252.

Osman Pasha, $8 \mathbf{r}$.

Ostracism, 27 .

Ostrogoths, IO3, I3I, I.7O-It4.

Utho, emperor of Rome, in

Otto I., the Great, emperor of Germany, 174, I93; 11, I94; II1, 194; IV., 206, $207,240$.

Ottokar II., king of Bohemia, 248 .

Uttoman Empire, the. See under Turks.

Ovid, I07.

Oxford Lniversitr, 270.

Palatinate, $345,354,377$.

Palmyra, tall of, i 1 o.

Papacy, the "temporal power" of, 103, I02; its growtly, Ioy, InI ; in conflict with the Empire, ros, 202207,247 ; at the height of the power of, 206, 207; theory of papal supremacy, 199; reforms of Cluny. 200 ; removal of the papal chair to Avignon, 258, 283-235; the great schism, 284; the papal states, 295 ; deprived of power in England, 3 I7, in Italy, 460 .

Papal states, the, 295.

l'atis, peace of $\left(17^{6} 3\right), 397$; peace of $(1856), 48 \mathrm{I}$.

Parbiament, English, 495; the first, $517 ;$ growth of power of, 5 18-523. 525-529; rise of House of Commons in, 522, 539; rights of, 358, $515,5^{19-522,524 ;}$ attacks on, $35^{8}$, 359, 523, 532-535; Charles I. and the, $358,532-535$; the Long, 359 , 533; the "Rump," 359,361 ; the contention, 537 ; union of scotch with the, $33_{4}$.

Pathians, 48 , I 2 .

l'atricians, in carly Rome, 59.

Pavia, 3 Io.

l'easants' Niar, $30 \mathrm{r}$.

Peirieus, $30,31,38$.

Pelusgut, the, 20 .

Peloponnestian War, the, 18, 34 .

P'ericles, $18,32$.

Periued, the, s.4.

Persepolis, 45 .

Perseus, king of Macedon, 80.

Persia, conquest of, by Alexander, 45; by saracens, 157; modern, 502-504.

Persian Empire, established by Cyrus It; history of, $\mathrm{I}_{4}-\mathrm{I}_{5}$; government of 15 ; revived, 144 .

Persians, religion of, $1_{5}$.

Persian wars, with Greece, I4, I8, 29. 44. 45; with Rome, i Ió.

Peter the Great, $383-391$; 111., 398.

Peter the Hermit, 2 ro.

Petition of Right, 358.

Petrarch, 266, 267, 282.

Pharsalia, battle of, 96 .

Phiclias, 32.

Philip Augustus, king of France, I75, $2 \mathrm{I} 4$.

lhilip If., king of fiance, 224, 226228, 240; IV., the Fall, 229, 230 , $2.40,283 ; \mathrm{V} 1$, of Valuis, 230 . 
Plilip II., king of Sp.un, 3I8, 325, l'rotestants, the name, 259, 3 I 2 . $33 \mathrm{I}-33^{8}, 34^{\circ} ; 1 \mathrm{~V} .37^{\circ}$; V., ol An- Protestant Union, the, 345 . jol1, 379,380 .

Whilip of llesse, $329,33^{\circ}$.

Philip of Macedon, $+2-44$; in the third century $1 . C ., 73,79$.

Ihilippi, battle of, 98 .

Illocians, the, 43 .

Ihunicians, the, I3; the services to civilization of, 13 .

Physiocrats, the, in France, 55I.

I'icard, $5+7$.

l'ippin of Landen, $5_{52 .}$

['ippin of Heristal, I 53.

l'ippin the Short, 104, I57, 162.

I'sa, council of, $258,285$.

l'isistratus, 27.

l'itt, William, f2o.

I'izarro, to7.

l'lassy, victory of, + Ig.

l'latica, 30.

Plebeians, the class of, 59; the struggle for their rights, $6 \mathbf{r}-65$.

Plevna, surrender of, $48 \mathrm{I}$.

I'oitiers, I57, 231.

Poland, 392 ; partitions of, 400,403 ; revolutions in, 457.

Pomerania, 392.

Pompeii, III.

Pompey, 94-96.

Pontus, 89.

Popes. See Pafacy. Leo I., I34: Gregory 1., I6I; Stephen I1., I62; Leo IX., 202; Gregory V'll., I74. 202, 283; Urban 11., 210; Adrian IV., 239: Innocent III., 207, 2I5. 283; Boniface VIll., 229, 230, 283; Gregory X1., 234; Urban V1., 284; Gregory Xil., 287; Nexander V'. 285; Nartin V., 287; Nicholas V., 28I; Alexander V1., 295, 32I ; Junius 11., 297; 1.eo X., 306; Clement VIl., 3I i Pius IX., 460.

Portugil, 273, 27+. 353, to7.

l'ragmatic Sanction, 288, 30I, 394.

Plague, peace of, 77 I.

l'retender, the Old, $3^{3}$.

l'retorian guard, Io6, IIO, III.

Pinting, invention of, 258,269 .

Proscriptions, by Suila, 92; incler second triumvirate, 98.

P'rovisions of Oxford, 516.

Irussia, duchy of, 392 ; rise of the kinglom of, $391-394,399,467-472$. Psammetichus I., 8.

I'tolemies, the, 48,49 .

I'uitowa, hattle of, 39 I.

I'unic wars, the, $54,70,8 \mathrm{r}$.

I'unjaub, the, 502 .

Puritans, $3 \nmid \mathrm{I}, 357$.

Pym, 534.

Pyramids, battle of the, $4+3$.

Pyrenees, I33, I57; peace of the, of 1659, 355, 370.

Pyrrbus, king of Epirus, 54, 68.

Quadruple Alliance, the, $3^{8} 3$.

Quebee, 326, fio.

Quesnay, 55I.

Ratbelais, 282.

Races of men, 3 .

Racine, $5+9$.

Radagaisus, I 33 .

Rameses 11., 8.

Ramillies, 380.

Rapliael, $28 \mathrm{I}$.

Ravenna, I03, I 8 , I6I.

Reformation, the, under Luther, 258. 260, 303-3I5; in England, 317319; in France, 320, 3t2; the counter-, 320.

Reform Bill of 1832,540 .

Regulus, 7 I.

Rehoboam, king of the Hebrews, I 2 . Reign of Terror, $327,+40$.

Religious wats, the age of, 328 ; the Schmalkaldic War, 329 ; the Thirty Years' War, 3f+.

Renaissance, the, $258,260,273$; south of the Alps, 265,269 ; noith of the Alps, 270; end of, $279,544$.

Restitution, edict of, $3+7$.

Restoration of the Stuarts, 366,375 . $53^{6 .}$

Revival of learning, 26I-267; in Italy, 265; in England, 270.

Revolution, American, 326, $421-424$, 538,539 ; its influence 424 ; in England, 360; of 1688,376 ; in 
Fance, of $1789-1797.435$; results of, 450,457 ; in France, of 1830 , 450, fot; $m$ Germany, to t, th5; in France, of $18+8,438$; in Hungary, of $18+8, f^{51}$; in Italy, of 1820 , 455 ; of 1830,457 ; of 1848,450 , 461 ; in Poland, of $1830-1832,457$.

Rheims, 232.

Rhine, 102, I03, I33; the League of the, 254 .

Rhodes, 48,21 I.

Richard 1., king of England, 225, 239, $24+$; as a crusader, 24.4 ; II., 242 , $520,523.524 ;$ III., 244. 520.

Richelicu, Cardind1, 325, 347-353.

Rights, fill of, $37^{\circ}$.

Robert alse strong, 195 .

Robespierre, $43^{6}$.

Kollo, I81, I05.

Roman colonial system, 68.

Roman letw, IIf-II6, 205, 2 I9.

Komanutt, house of, 388 .

Romans, b; in relathon to (ineelss, 53. 50 ; religion, 77, 121-125; protincial guvernment, 80-82.

kome, as a city-state, 54, 57, 58; wars of conquest, $57,00,60-68,80$; early constitution, $5 \%$, changes in the constitution of, $59,61-55,80$, $96,47,102,116-118$; period of the kings of, 58 ; taken by Gauls, 6I, 87; Puntc wars, 69-74; the Reputslic, 80-96; the Social wars, 87-93; monarchy under Casar, 95; the triumrirates, 95,98 , the Empire, ro5-132; causes of the fall of the Empire, 127; attacks by the Goths, I3I; division of the Empire, 132; end of the IVestern Empire of, I35; the Eastern Empire of, IO3, I3I, I H+-I+8; the capital of the kinglom of Italy, +76 .

Romulus, $5^{8}$.

Romulus Augustulus, 135 .

Roses, Wars of, 244, 292.

Rosetia Stone, the, o.

Roumania, $48 \mathrm{I}$.

Roussillon, 353 .

Rousseau, +28 .

Rubicon, the, g6.

Rudolph of Hapslurg, 2.78.
Runnymeise, 2 fo.

Ruric, 387 .

Russic1, intueduction of Christianity into, 388 ; Tartar conquest of, 388 , under leter the Great, 388-390; under Elizabeth, 398, 399; under Catherine the Great, 399-404; the partition of Poland, 400-404; invaded by Napoleon, $4+7$; expansicn of, in Asia, 503; Nalooleon, $4+7$; in the Holy Alhance, 45t; at Nar with the Turks in $1770-1774$. to2; in 1828, 404; in $1877-1878$, $48 \mathrm{I}-484 ;$ in the Crimean 11 iar, $479-43 \mathrm{I}$; emancipation of serts in, $48 \mathrm{I}$.

Ryswick, peace of, 377 .

Sabines, 53.

sacred wars, the, 43 .

Sialowa, battle of $47 \mathrm{~T}$.

sit. Augustine, 150, 260, 303 .

st. Bartholomen, $3+3$.

st. (iermain, peace of, $34^{2}$.

st. P'aul, III, I2I.

St. P'eter, III, I2I

st. l'etersburg, 391 .

Salimis, battle of, I8, 30 .

Salic law, 23 o.

Simmites, 58, 6r, 66, 67.

samson, the Hebrew prophet, iI.

San Stefano, treaty of, $7^{8}$ I.

Sin Yuste. 33 I.

Saracens, I57; their service to science, etc., $158,159$.

Sardinia, seized by Rome, 54. 72,80; at war with France, $4+0-4+2,45^{\circ}$; revolution in, 455; wat with Austria, 460 ; in the Cimean War, 4 so.

Sargon, king of Assyria, Io.

Sirssanid dynasty, I29.

Siaturninus, 87.

saul, king of the Hebrews, I I.

Savonarola, 129, 295, 296.

Savoy, $37^{3}$; honse of, $178,4^{50}$.

Saxon-, the, invade Britain, $1+8$; conqueret by Charlemagne, 105 ; conversion of, $149,166$.

Sixony, $35+398,399$.

Scandinavians. See Vorthmen. 
Scandinavian states, 259 .

Schleswig-Holstein, 468.

Schmalkaldic War, 329, 330.

Sclumalkald, league of, 315.

Scholasticism, 263-265.

Science in the nineteenth century, 556,557 .

Scipio, Emilianus, 80; Cneius, 74 ; Publius, 74; P. Comelius (Africanus), 54,74 .

Scotland at war with England, 240, 359-36r.

Sebastopol, siege of, 480 .

Sedan, battle of, 474 .

Sejanus, IIo.

Seleucidie, 48.

Semitic race, 4 .

Seneca, 107, 110.

Separatists, the, 341 .

Sepoy mutiny, 502 .

Serfs, emancipation of Russian, $48 \mathrm{I}$.

Servins 'Tullius, reforms of, 59, wall of, 59 .

Settlement, Act of, $3^{8} 4$.

Seven Weels' IVar, 470, 471 .

Seven Years' Mar, 326, 398.

Sforza, family of, 298.

Shakespeare, 545 .

Shepherd kings of Egypt, 8.

Sicily, made a Roman province, 57. $68,70,72$; the two kingdoms of, $25 \mathrm{I}, 455,460$.

Sigismunl, 249, 250, 287, 392.

Silesia, 395, 398.

Smith, Adam, 557.

Sobjeski, 373 .

Social wars, in Greece, 43 ; in Rome, 87-93.

Siociety of Jesus, 321 .

socrates, 39.

Sioudanese revolt, 506, 507 .

spain, empire of Carthage in, 54: conquest of, by Scipio, $54,57,80$; by the Vandals, 133; the Visigoths, 134; the saracens, 157 ; by Charlemagne, 252; by Ferdinand, 291; union of Castile and Aragon, 252, 291: discoveries and colonies of, $277,423,424$; conquest of Granada, 291; uncler Ferdinand and Isabella, 291, 292; expulsion of Jews and Moors, 292; at war with France, 295-298, 300, 308-3II, 329; empire of, under Charles V. and Philip II., 298-300, 310312 ; in the age of religious wars, $328-337,338,340,34^{6-355}, 408$; rapid decline of, 333,365 ; the Armada, $34^{\circ}$; in the Triple Alhance, 37I; the War of the Succession, $326,377,379-381$; annexed by France, 378,383 ; loss of American colonies, 455,493 .

Spanish Succession, the IV ar of, 326 , $377-3^{8} 3$.

Sparta, the constitution of, 22, 24, 27 ;

a rival to Athens, $3 \mathbf{I}$; at war with Athens, 34-36; supremacy of, 38 ; decline of, 4 .

Spartacus, 94.

Spartans, institutions and training of, 22,24 ; in the Peloponnesian War, 34-36; attack on Persia of, 39.

Speyer, Diet of, 311 .

Spurs, battle of the, 298 .

Star Chamber, 359, 528, 533 .

Stephen, king of England, 237, 512, 513.

Strafford, earl of, 533 .

Strasburg, 373; the Oath of, 177 .

Sitrelitz, the, 389 .

Stuarts, house of, $357,3^{8} 3,522,530-$ $53^{8}$; Chanles 1., $358,360,53^{2-535 \text {; }}$ Charles 11., 361, 366, 375, 536; Henry (Lord Darnley), $33^{8}$; James I., $357,35^{8}, 530,53^{1}$; James II., $376,379,536$; James III., 379 . 384 ; Mary, 334, 338-342, 355, $35^{6}$.

\section{Suevi, 133, 134.}

Suez Canal, the, 505.

Suffolk, 149 .

Sulieman the Magnificent, $3 \mathbf{I} 4$.

Sulla, 89-93, 94.

Sippremacy, Act of, 318.

Susa, 45 .

Sussex, 149.

Sweden, 347; in the 'Thirty Years' War, 351-354; power of, under Charles XII., 390; decline of, 386-388; at war with Russia, 390 ; fall of Charles XII., 391.

Switzerland, $178,250$. 
Syagrius, $13^{8 .}$

Tours, battle of, 157 .

Syracuse, 18, 35. 54, 70; siege of, 75. Tower of London, 24 I.

Syria, 48, 54, I 16, 157.

Trajan, emperor of Rome, 1 r 3 .

Tacitus, I 13 .

Tarentum, 67, 68.

Tarquinius, Priscus. $5^{8}$.

Tarquinius Superbus, 59 .

Tarquins, Rome under the, 58, 59 .

Tartar Avars, I66, 193 .

Tell, William, 25I.

Trasimenus, Lake, battle of, 72 .

Trebia, battle of, 72 .

Trent, council of, $32 \mathrm{r}$.

Tribunes, Roman, 63 ; military, 64 .

Triple Alliance, the, 37 I, 4 I3.

Triumvirate, the First, 95; the Second, 98 .

Templar, a Knight, 2 I5.

Trojan IVar, the, 2 I.

Trov, siege of, 2 I.

Ten thousand Greeks, the expedition of, 39 .

Testry, battie of, ${ }_{53}$.

Tetzel, 304.

Teutoberger Forest, battle of, Iog.

Teutones, the, 87.

Teutonic kinghts, order of, 250.

Teutonic races, 0,270 .

'Thebans, the, 40,4 .

Thebes, to, 42-4t.

Themistocies, 30, $3 \mathbf{I}$.

Theodoric, king of the Visigoths, Ifo, IfI.

Theodosius the Great, 102, 103, 132, I 4 .

Thermopylar, battie of, 18,30 .

Thesens, 2.4.

Thespians, the, 3 .

Thessaly, 43 .

Ihiers, $11 ., 476$.

Tudor, house of, 244, 292; table of kings, 363 .

Tunis, 215,505 .

Turanian peoples, 4.

Turenne, 353, 372 .

'Turgot, 43I, 55 I.

lurks, the Seljuk, 160, 210; capture of Elessa by, 214; Osmanlis, 252; capure Constantinople, 253; the siege of Vienna by the, 314; conquered by Peter the Great, 390 ; at war with Russia, 402 ; the Eastern Question, 453, 477, 484; insurrection of the Greeks, $4^{6} 4^{-478}$; the Crimean IVar, $479-482$; war between Greeks and, 485 .

Tycho Brahe, 547 .

Tyre, ir.

Thiral Estate, the, 218, $432,477$.

Ulfilas, I39.

Uim, bittle of, $44^{6}$.

Ulrich von Hutten, 282.

Thitty Years' Wai, the, $325,329,34^{-}$ 353.

Thothmes II., 8.

Thrace, I4, 43 .

Thuringians, $\mathrm{I}_{4} 2$.

Tiber, thes, 58, 6r.

Tiberius, emperor of Rome, in

Ticinus, 72.

'Tiers Etat. See Third Estate.

Tigris, the, 45 .

Tilly, 346, 347, 35 I.

Tilsit, peace of, $+4^{6}$.

Tippoo Sabib, $4+3,49 \mathrm{I}$.

Titian, $28 \mathrm{r}$.

Titus, emperor of Rome, III, II 2.

Tory party in English politics, 422 , 496.

Umbrians, the, 67 .

United States, the, 422-424; War of 1812, 493; the Monroe Doctrine, 455: expansion of, 492-493, 498; Revolution, influence of, $424,496-$ 498 ; Mexican War, 498; the Constitution of, $535,537-540$.

Universities, in the Middle Ages, 264.

Utraquists, 288.

Utrecht, Union of, 337 ; treaty of, $38 \mathrm{r}$.

Valens, emperor of Rome, 102, 132.

Valerian, emperor of Rome, il6.

Valerian law, the, 62.

Valny, 439.

Valois, house of, France under the, 230,343 . 
Vandals, ro3, I34.

Varus, 109.

Vasco da Gama, 275.

Vassy, massacre of $34^{2}$.

Veii, siegre of, or.

Venetia, 466-47 I.

Venetians, 297.

Venice, in the fourth crusade, 215: among the city-states of Italy, 25I, 295; the centre of the boat trade, 269; revolution in, 459-45r; al part of the kingdom of 1taly, $47 \mathrm{r}$.

vercellae, battle of, 87 .

Verdun, treaty of, 117.353 .

V'erona, Congress of, 455.

V'erres, prosecution of, 95 .

V'ersailles, 475 .

Vespasian, emperor of Rome, III, II2.

Vesuvius, III.

Victor Emmanuel, king of Sardinia, 465-467.

Vienna, Congress of, $327,448,463$, reorganization of Europe by the, 449,450 ; siege of, by Sulieman, 3 I. 4 .

Visigaths, 102, 131, 140, 14I, 145: establish kingdom in Gaul and Spain, 132-134.

Volscians, 6I.

Voltaire, 428,548 .

Wagram, battle of, $44^{6}$.

Wales, conquest, 240 .
Wallenstein, $346,35^{2}$.

Walter the P'enniless, 2 ro.

W'artburg, 307, 312.

Waterloo, $4+9,+54$.

Wat Tyler, 286.

Wellington, duke of, $449,49 \mathrm{I}$.

W'essex, $18 \mathbf{r}$.

Western Empire (Roman), Io3.

Westphalia, treaty of, $326,337,353$.

Whig party in I'nglish polities, 422 , 496.

William I., the Conqueror, king of England, 197, 511; 11., 237, 51 I; III., of Orange, $376,379,384,527$.

W'illiam I., emperor of Germany, $4^{67}$.

Wiiliam 1 , the Silent, $33^{6}$.

Witt, John de, $366,372$.

Wittenbuig, 302.

Wolfe, 4 I9.

Worcester, hattle of, $3^{6 \mathrm{I}}$.

Worms, the Concordat of, 174, 203; the Diet of, 259, 307, 3II.

Würtemburg, 455 .

Wycliffe, $249,258,285,3$ I2.

Xanthippus, 7 r.

Xenophon, 39 .

Xerres, king of Persia, $30,44$.

York, house of, 244 .

Zama, battle of, 74 .

Zurich, treaty of, 466. 



\title{
Students'
}

\section{History of the United States.}

\author{
By EDWARD CHANNING. \\ Professor of Histery in Haraded L 'niciersity. \\ Mitu SilgGiéstuns TU Teachers \\ By ANNA BOYNTON THOMPSON, \\ Thater . Liactemy, seuth braintret, lhess.
}

8vo. Half Leather. Price, \$1.40 net.

This work is intended for une in clasnes in high schools and academies where, the facts and dates of Anerican listory having been learned in the more elementary grades, it is wished to give the student a through knowledge of the comatitutional, the political, and the industrial development of the United States, especially the period since the beginning of the movement which led to the separation from the British Empire and the formation of a republican government under the Constitution.

\section{IMPORTANT FEATURES}

\section{Reproductions of original documents Suggestions to teachers \\ CoIored maps \\ Accurate copies of well known por- traits

Lists of Standard
Works for $\left\{\begin{array}{l}\text { Small Library } \\ \text { Good Library } \\ \text { Very Good Library }\end{array}\right.$ \\ A Perspective of United States History \\ List of books for consultation at the beginning of each chapter \\ Suggestive Questions and Topics at the close of each chapter \\ Table of Important Dates \\ Marginal Notes throughout}

\section{Professor A. A. Freeman, Reviewing this work in The American His- torical Review, says:}

"Decidedly the best nne-volume Anerican history yet puhlished : . In the preface the author has explumed that his purpose in the publication of this work is to provide a text-book suited to the needs of the senior class in high schools and acadenies. He believes that "the serious stuchy of American History more fitly follows than precedes other conntries and belons to the maturer years of school life.' The author assumes a considerable knowledge of American hintory on the part of pupils from the use of more elementary text-books in the lower grades. He accordingly omits all the stock stories and anecdotes which form so large a part of our elementary text-books. . . It is full of suggestiuns for both teachers and pupily. Miss Anna Boynton Thompson, of Thayer Academy, has written a chafter entitled "suggestions to Teachers, in which she has described her own method of teaching These suggestions will be very belpful to the teacher if he accepts them as 'suginestons. and not as rules. . . They should prove of peculiar value in preparing pupils for the new requirements for entrance to college E-specially valuable are the marginal references on everv pace to standard works which contain a fuller accunt of each topic. Each chapter is headed by a lint of books, special accounts, sources and biblingraphy, maps and illustrative material. In the last are found the namesof titles of books of American literature. Everything is done to stimulate and aid a more thorongh investigation by the student. The introduction is a study of the land and its resources and shows the influence of geographical conditions in the development of the country. ... The anthor displays a judicial and impartial spirit in rela. tion to all controverted questions. This is expecially noticeable in the consideration of such topics as the administration of Andros in Mlassachusetts, the persecution of the Quakers at Bnston, the effect of the English navigation laws, the character and and treatment of the Loyalists, and the execution of André. . . There is a gratifying absence of cheap illustrations. The volume contains many excellent portraits. The period since $17 \mathrm{Sg}$ is treated by topics. The old arbitrary division by administrations is properly abandoned and is replaced by the following divisions: Federalist Supremacy, 1789-1800; Jeffersonian Republicans, I80r-18i2; War and Peace, 1812-1829: The National Democracy, $1829^{-1844:}$ : lavery in the Territories, $1844^{-}$ 1859; Secession, 1860-r86r; The (ivil War, 186r-1865; National Development, 1865-1897." 


\section{COMMENTS.}

J. M. Greenwood, Supt. of Schools, Kansas City, Mo.: "1 have just finished reading Channing's Students' History, and $\mathbf{l}$ closed it with the conviction that it is the best single-rulume history of the country that has yet been printed."

Frederic A Vogt. Principal Central High School, Buffalo, N.Y.: "It is a relief to see a history in which the miltary achievements give some space to the victories of peace and the growth of constututional liberty. Mere incidents have been weeded out, and the essential whole has been preserved in a contunous story. There is a breadth of view and loftiness of exposition which is scientific and much more profitable than a mere string of dates and events. The schemes for study, the outlines for reading, and the suggestons to teachers, ought to nake the book very helpful."

Prof Kendric Charles Babcock, University of California: "I have no hesitation in same that 1 an convinced it is the best single-solume students" history of the L nitel atates yet publi-hed. The maps are more perfect and satisfactory than in any other school or students" history known to me. It is scholarly, interesting, and typographically excellent."

Prof. W. C. Wilcox, University of Iowa: " ]t is the most complete history of the United states in one volume for high-schorl use. I shall recommend it to the high schouls in this tate. It ought to be in all the preparatory schools either at a textbook or as a work of reference. It will serve equally well as either. The bookreferences, the topical studies, and the completeness of the treatment especially commend it to me."

Prof. F. H. Hodder, University of Kansas: "Professor Channing's book is in cvery way admirable. I do not believe that any other work gives, in a single volume, no excellent a summary of the whole period if Amencan history. It is a splendid text for high schools, unisersity extension clanes, and general readers."

Prof. Jesse Macy. Iowa College: "It seems to me altogether the best planned and the best executed work on the subject yet prepured for the use of high schools."

Prof. Marshall S. Brown, New York University: "Yrofessor Chaming's name was a guturantee that this bouk would be what is nected in our higher grade of secontiury shouls. 'The book as completed is admirably adapted to the purpose for which it wan written."

Charles H. Keyes. Principal of High School, Holyoke Mass.: "We have at last a text sunted fir high-schoul use and one that will help put the subject in to the

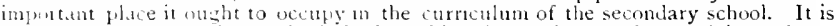
manterty the work of one whe is both an historian and a teacher, and it ought to meet with unprecedented success."

Reuben Post Halleck, Principal of Male High School, Louisville, Ky : "The statements are elear. definte, and interesting. The list of books for consultation is very "wely" selected."

Prof. Edwin A Grosvenor, Amherst College, Mass.: "One can hardly praise it too lighly. It reak like a ronance and puctures like a punorana, while at the same tume accurate and impatial."

Prof. Benjamin G1ll, State College, Pa.: "The brok goes far ahead of any of its pletecennsis. It deils with the suhject unre generously than such hand-books have heen used to de. It m mod in contuely new, its sllu-tratinus, maps, and charts, are abunchut and unlike anything that has freceled them; beaten tlacks have not heen followed; the ath ho has folloned a s li-made pattern: the authorities cited are mont excellent; they ase mostly Amesican, and though quite recent are authortative, such names an Fink, Winmor, Hart, etc. I have been mpressed wath this fact in frarticular - that foum whatever side the student or instructor may approach this book be will find intelligent guilance and stimulus."

E W. Wright, A.M. Harvard, Exammer of Teachers for Essex County, Vt.: "1 1wenty-fise yean in econdary schunl-work leads me unhesitatingly to declare it the schoul histury of our country la braad, phissophical treatment, in the just suborduation of mulitary detals to the real prozress of on people in the al ts of peace, in its true perstecture, and in its fenter. 'callung a spade a spade, it has no roval withon sight. In following ont pultical opinon- trom birth to maturity and in carefully tracing calnes to their effeets 11 surpases even more elaborate works."

\section{THE MACMILLAN COMPANY. \\ NEW YORK. BOSTON.




\title{
The Growth of the French Nation.
}

\author{
BY \\ GEORGE BURTON ADAMS, \\ Professor of History in Iale Lniarersity.
}

Cloth. 12mo. Price, \$1.25.

\section{COMMENTS.}

"The present work is a proof of how much that is Dominant
influences carefully new and striking may be said upon a trite subject. Many books have been written upun French history, traced. but it would be cifficult to specty any in which the dominant forces at work in that history have been so carefully traced." - (1.rford latas daine?

"Mr. Alams has dealt in at fascinating way with the Clear and chief features of the Mhldle Age, and his book is rento the point. dered the more attracuve by some excellent illustrations. He traces the history of Flance from the Conquests of the Romans and lranks down to the presilency of M. Felix Faure, and has always something to say that is clear and to the pont: Mr. Adams

Promise of title seems to us to have seized the salient features of the fulfilled. growth of the French nation, and to have fulfilled the promise of his title." - Educiational Reridiw.

“' 'The History of Institutions,' writes Bishop Stubbs, 'cannot be mastered, can scarcely be approached, Strict fairness without an effort:' and in Mr. Adrms's work we ale and clear, glad to recognize many of the rare qua'ities needed. independent He shows strict taimess with clear and inclependent judgment. judgment, and he tells his story pleasantly. . . The portraits and other illustrations, ali apposite and interesting, lend grace and charm to the book." - Lomdon Academ.'.

\section{THE MACMILLAN COMPANY.}

NEW YORK. BOSTON. CHICAGO. SAN FRANCISCO. 


\section{American History}

\section{TOLD BY CONTEMPORARIES.}

BY

ALBERT BUSHNELL HART,

Harard C'niversity.

Each Volume sold separately. Price, $\$ 2.00$.

VOL. I. Era of Colonization, 1493-1689.

Ready.

VOL. II. Building of the Nation, 1689-1783.

Ready.

VOL. III. National Expansion, 1783-1844.

In Preparation.

VOL. IV. Welding of the Nation, 1845-1897. In Preparation.

Professor 'T'. H. WoOn, of Worcester Academy, Worcester, Mass., says of rolume 1, :-

"The flan and the contents are alike admirahle. The set will be a ncessity for herati's and for teachers of American Hislory."

\section{THE MACMILLAN COMPANY.}

NEW YORK. BOSTON. CHICAGO. SAN FRANCISCO. 




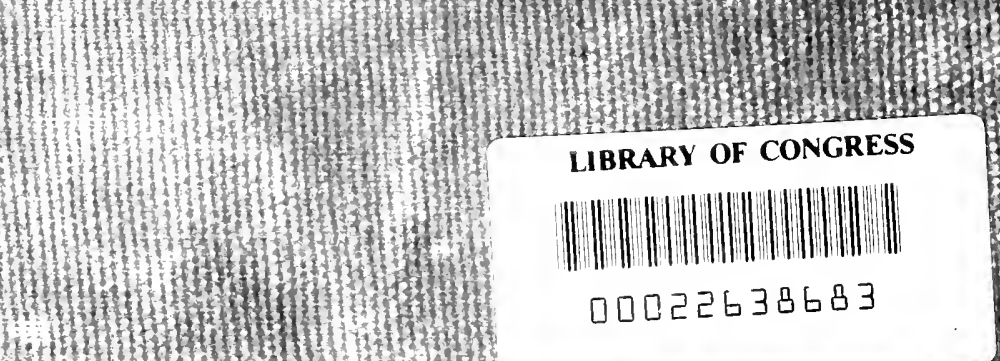

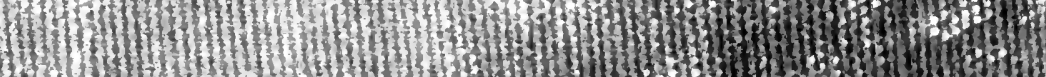

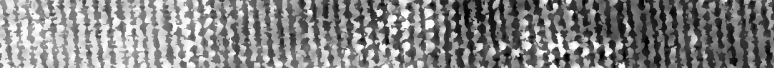

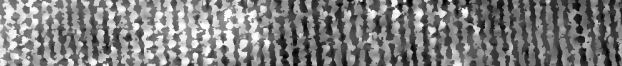
- 1 th

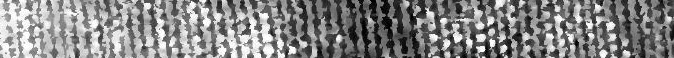

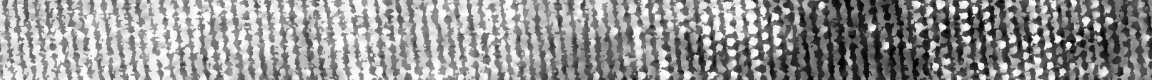

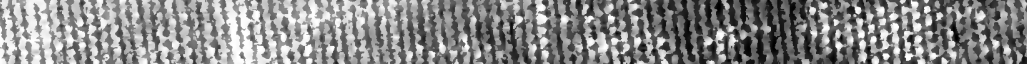

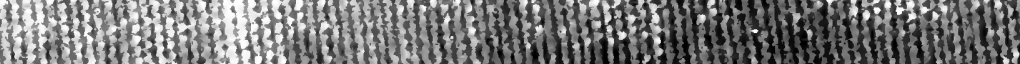

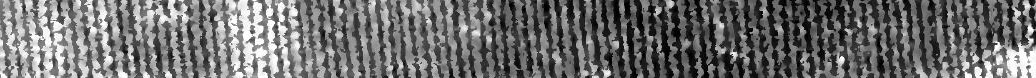

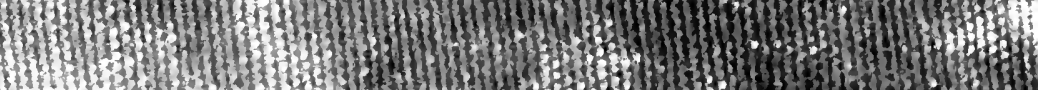

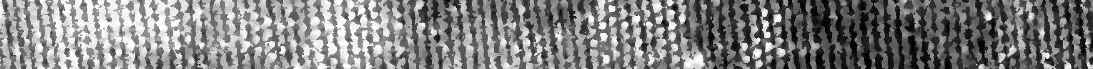
IIth

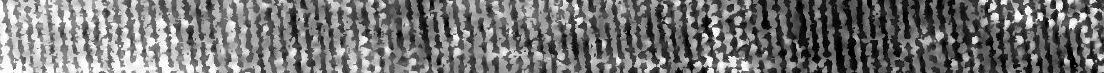

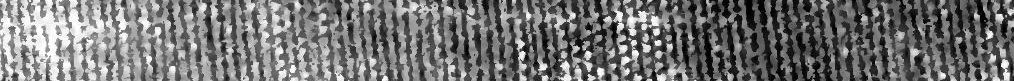

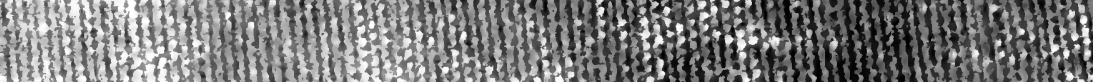
(1)

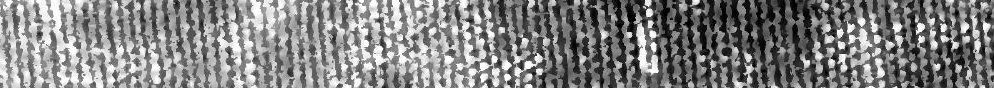

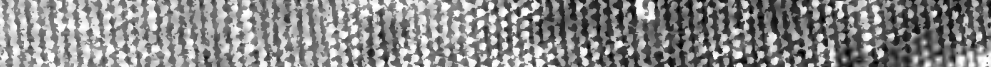

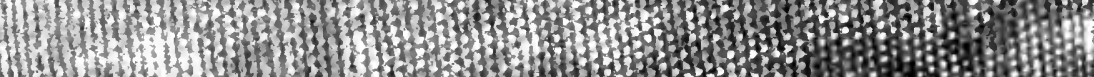
HIt 17 th

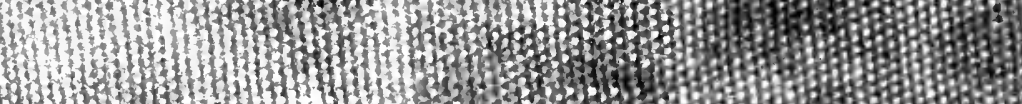
Who

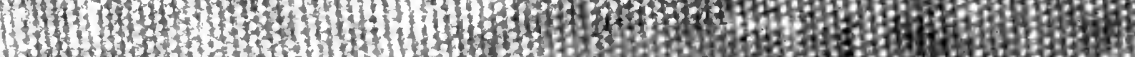

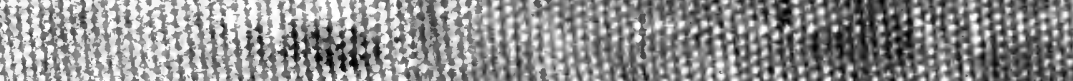

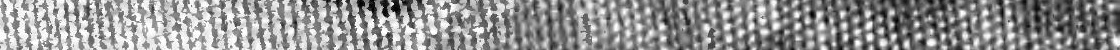

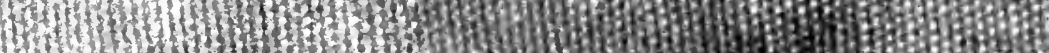

